\title{
Interpretatie van diagnostische gegevens: theoretische en praktische bijdragen aan de diagnostische epidemiologie in de extramurale gezondheidszorg
}

Citation for published version (APA):

Knottnerus, J. A. (1986). Interpretatie van diagnostische gegevens : theoretische en praktische bijdragen aan de diagnostische epidemiologie in de extramurale gezondheidszorg. [, Maastricht University]. Rijksuniversiteit Limburg. https://doi.org/10.26481/dis.19861212jk

Document status and date:

Published: 01/01/1986

DOI:

10.26481/dis.19861212jk

Document Version:

Publisher's PDF, also known as Version of record

Please check the document version of this publication:

- A submitted manuscript is the version of the article upon submission and before peer-review. There can be important differences between the submitted version and the official published version of record. People interested in the research are advised to contact the author for the final version of the publication, or visit the DOI to the publisher's website.

- The final author version and the galley proof are versions of the publication after peer review.

- The final published version features the final layout of the paper including the volume, issue and page numbers.

Link to publication

\footnotetext{
General rights rights.

- You may freely distribute the URL identifying the publication in the public portal. please follow below link for the End User Agreement:

www.umlib.nl/taverne-license

Take down policy

If you believe that this document breaches copyright please contact us at:

repository@maastrichtuniversity.nl

providing details and we will investigate your claim.
}

Copyright and moral rights for the publications made accessible in the public portal are retained by the authors and/or other copyright owners and it is a condition of accessing publications that users recognise and abide by the legal requirements associated with these

- Users may download and print one copy of any publication from the public portal for the purpose of private study or research.

- You may not further distribute the material or use it for any profit-making activity or commercial gain

If the publication is distributed under the terms of Article 25fa of the Dutch Copyright Act, indicated by the "Taverne" license above, 


\section{Interpretatie van diagnostische gegevens}

Theoretische en praktische bijdragen aan de diagnostische epidemiologie in de extramurale gezondheidszorg

\section{Proefschrift}

Ter verkrijging van de graad van doctor in de geneeskunde aan de Rijksuniversiteit Limburg te Maastricht, op gezag van de Rector Magnificus, Prof. Dr. F.I.M. Bonke, volgens het besluit van het College van Dekanen in het openbaar te verdedigen op vrijdag 12 december 1986 om 14.00 uur.

door

André Knottnerus

geboren te

Nieuw-Beerta 


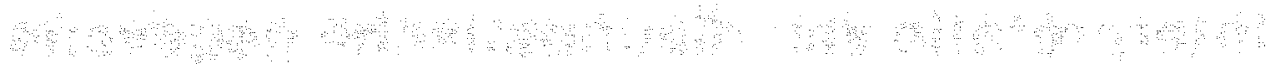

A

:

औ

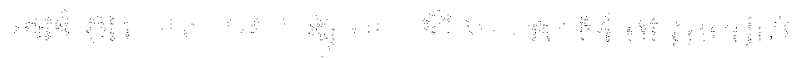

A

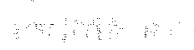

$\therefore \ldots$

. 34

मै।

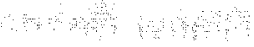




\section{Promotoren: $\quad$ Prof. Dr. P.G. Knipschild Prof. Dr. F. Sturmans}

Referenten: Prof. Dr. C.A. de Geus Prof. Dr. H.G.M. van der Velden

(9 1986: J.A. Knottnerus, Maastricht

Omslagtekening: Bart Knottnerus 


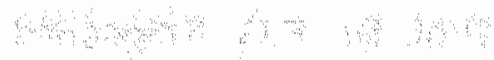

$$
\begin{aligned}
& \text { Bast? }
\end{aligned}
$$

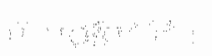

a : क

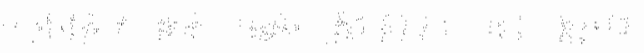

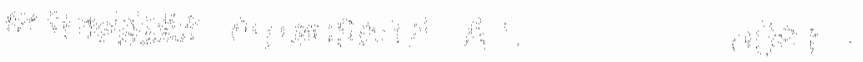

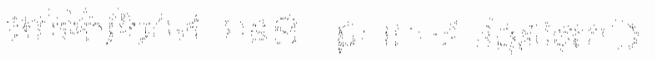


INHOUDSOPGAVE.

pagina

1. Inleiding

Deel I: Interpretatie van diagnostische gegevens en de verschillen tussen eerste- en tweedelijnsgeneeskunde.

2. Interpretatie van diagnostische gegevens, een onontgonnen terrein in de huiartsgeneeskunde.

gepubliceerd in: Huisarts en Wetenschap 1983; 26: 363-368. en in: Journal of the Royal College of General Practitioners $1985 ; 35$ : $270-274$.

3. Symptonatologie en selectiebias. Vertekening van het verband tussen klachten en diagnosen ten gevolge van selectie naar hogere echelons. gepubliceerd in: Huisarts en wetenschap 1985; $28: 325-330$.

Deel II: Enkele observationele onderzoekingen naar het verband tussen klachten en diagnostische bevindingen.

4. Hoofdpijn en hoge bloeddruk. gepubliceerd in: Huisarts en Wetenschap 1984; 27 :441-445.

5. Hemoglobine en "anemische" klachten zoals moeheid. gepubliceerd in: Tijdschrift voor Sociale Gezondheidszorg $1983 ; 61: 788-792$.

6. Onverklaarde moeheid en hemoglobinegehalte; een onderzoek. vanuit de huisartspraktijk.

gepubliceerd in: Nederlands Tijjdschrift voor Geneeskunde 1986; 130 : 402-405.

en, in uitgebreidere vorm, in: The Canadian Family Physician 1986; 32: 1601-1604.

7. Serunferritine bij moeheidspatiënten en gezonde controlepersonen. aanvaard voor publicatie in het Nederlands Tijdschift voor Geneeskunde.

8. Het hemoglobinegehalte van zwangeren en subjectieve klachten.

9. Diagnostische conclusies van de hulsarts naar aanleiding van onverklaarde moeheid. aanvaard voor publicatie in Huisarts en Wetenschap.

10. Klachten op de borst: angaan met onzekerheden. gepubliceerd in: Huisarts en Wetenschap 1985; 28: 159-164. 
Deel III: Medische besliskunde, concepten en toepassingen.

11. Principes van besiliskunde. gepubliceerd in: Nieuw Kampas voor de huisarts juli 1984 II/ $4: 1-15$.

12. De zeeffunctie van de huiarts, het totale plaatje is van 101 belang. gepubliceerd ins The Practitioner (Nederlandse uitgave) 1985; $2: 1251-1254$.

13. Diagnostlek tan de palpabele lymfeklier door huisarts en speciallist, een besliskundige benadering. gepubliceerd in the Practitioner (Meder landse uitgave) $1985 ; 2: 1085-1097$.

14. Diagnostlache hypothesen en a priori kansen in de hulsartsgeneeskunde. gepubliceerd in: Huisarts en Wetenschap 1986; $29 ; 269-273$.

15. Moheid: verschillen in benadering tussen huisartsen en internisten. gepubliceerd in: Medisch Contact 1986; 41: 54-57.

16. Intercollegiale vergelijking. Defenen met hulisartsen in opleiding. gepubliceerd in: Medisch Contact 1986; 41: 574-577.

17. Het belang van therapeutische mogel1 jkheden voor diagnostische beslissingen. gepubliceerd in: The Practitioner (Nederlandse uitgave) 1984; 1 : 769-777.

18. De asymptamatische carotisstenose, wel of niet opereren? Een besiliskunalge benadering. aanvaard voor publicatie in het Nederlands Tijaschrift voor Geneeskunde.

19. Over vertekening van testuitilagen door reeds aanwezlge gepubliceerd In: The Practitioner (Nederlandse uitgave)

Deel IV: Diagnostische testis nader bezien.

20. Dlagnostische tests - Nonmen, referentiewaanden en test-

21. De invioed van verwi jsgedrag op het onderschelidend vermogen van diagnostische tests. 
Deel $V$ : Enkele observationele onderzoekingen naar het verband tussen uitslagen van diagnostische tests en prognose.

22. Henoglobine en zwangerschapsuitkomst.

Een samenvatting van de belangrijkste resultaten van

dit onderzoek verscheen in The Lancet 1986: II: 282.

23. Hemoglobine en hematocriet als risicofactoren voor myocardinfarct, onderzocht in een bedrijfsgeneeskundige setting. aangeboden voor publicatie.

Deel VI : Beschouwing en samenvatting.

24. Beschouwing.

25. Samenvatting.

Sunmary

Dankwoord 
Inleiding:

\section{Motivering.}

Diagnostische gegevens en de wijze waarop zij geinterpreteerd worden zijh van groot belang voor wat ex met patlenten in de gezondheldszorg gebeurt. Mensen kcmen in contact met een arts, al dan niet vamwege bepaalde klachten, en er vinat, al of niet op indicatie, diagnostiek plaats. Op grond daarvan worden mensen "ingedeeld" in bepaalde categorieën, zoals "afwijkend" of 'normaal', 'ziekte $A$ ' en/of 'ziekte $B$ '. Dit leidt weer tot besluitvorming met betrekking tot al of niet, en zo ja hoe, behandelen of vervolgen. In het samenspel tussen de toegenamen bereikbaarheid van medische zorg en de snelle medisch-technologische ontwikkeling is in ait verband de, inmiddels al haast klassieke, vraag op tafel gekomen: hoe kunner artsen en patièten doorzeilen tussen de scylla van het missen van belangriljke diagnosen en behandel ingamogelijkheden en de Charybdis van de medicalisering en de iatrogenese? (1, 2).

Hierbij doen zich onder meer de volgende vragen voor:

1) Hoe informatief zijn anamestische en andere diagnostische gegevens, on de patiént op grond hiervan in de juiste 'categorie' in te delen?

2) Indien men dit niet met zekerheid kan doen, welke kans is er dan op een juiste respectievelijk verkeerde diagnostische conclusie, als men een bepaalde keuze maakt?

3) Wat is de prognostische betekenis van diagnostische informatile?

4) Is de patient gebaat met de resultaten van het diagnostisch proces, in die zin dat zij van belang zifn voor het therapeutlsche beleid en de beinvloeding van de progmose?

In dit proefschrift komen, mede aan de hand van voorbeelden, vooral de vragen 1) tot en met 3) aan de orde. De vierde vraag komt aan bod in het kader van het besliskundige gedeelte.

De genoende vragen bevatten veel aanknopingspunten voor de klinischepidemiologische benadering. In deze benadering staan de klinische (diagnostische, therapeutische en prognostische) aspecten van bepaalde ziekten of gezondheidsproblemen centraal, met gebruikmaking van in- 
zichtien en onderzoeksmethoden uit de epldemiologie, KInisch slaat daarbij niet alleen op de kliniek in de zin van ziekenhuis?, maar betreft ook het vela van de extramurale gezondheidszorg. In dit proefschrift is de klinisch-epidemiologische benadering op verschillende manieren, theoretische en praktische, toegepast. Veel aandacht is besteed aan het belang van de verschillen tussen de situatie van de huisarts en die van de specialist. Immers, vanaf de huisarts naar de specialist vindt een zodanige selectie van patienten plats dat commnicatiestoomissen tussen beider disclplines over het belang van diagnostische gegevens wel haast onvermijdelijk zijn. verheldering van de mechanismen en de konsekwenties van deze selectie ls daarom nodig. voor de eerstelijns geneeskunde is daarbij, naast het optimaliseren van de patientenzorg, ook de ontwikkeling van de eigen identiteit in het geding. Deze laatste opmerking wil ik hiler aankleden met een korte balans van de positie van de huisarts.

2. Speciale aandacht voor de positie van de huisarts.

1) Zoals het rapport 'Hoe helpt de dokter' van het Nederlands Huisartsen Genootschap in 1975 stelde, is de huisarts te localiseren op het kruispunt van twee systemen: de geneeskunde en de eerstelijns hulpverlening (3). Lamberts sprak enige jaren later over de huisartsgeneeskunde 'als leer der kruispunten in de gezondheldszorg' (4). Het staan op een kruispunt betekent voor de huisarts een uitaaging, en wel an de juiste richtingen aan te geven. Maar het is een moliljke, en niet zelden onbevredigende positile. Belde systemen worden steeds ingewikkelder, en minder goed te overzlen. Er zijn dwalsporen te over, on nog maar te zwijgen van de keren dat de huisarts niet zozeer het kruispunt is van twee systemen, maar de plek waar belde met elkaar in botsing konen.

2) Een belangrijk dilemina is dat de huisarts, voorzien van beperkte middelen, met een grote dosis onzekerheld mbet kunnen werken. streeft hij voortdurend naar zekerheld, zoals de speciallst dit naar aanleiding van gerichte vraagstellingen meer zal doen, dan brengt dit een groot risico aan overbelasting en beschadiging van de patient met zich mee.

3) In medische kringen heeft de huisartsgeneeskunde, In haar genera- 
Iime wellicht het mollijkste curatieve specialisme, bij lange na nog niet de wardering gekregen die zij verdient. Dat neent niet weg dat er steeds meer specilalisten te vinden zijn, die inzicht hebben in de specifleke situatie en problematiek van de huisarts.

Een andere kring, namelijjk die van de Medische Tuchtcolleges, heeft hiler soms nog moelte mee. De ophef rond de uitapraak met betrekking tot de beoordeling van een geval van - uiteindelljk - borstkanker heeft dit onderstreept. Zelfs de kundigheld van hulsartsen an een vroumenborst te onderzoeken werd door het tuchtcollege in twijfel getrokken (5).

4) Aan een auidelljker Invalling van de specifieke deskundigheid van de huigarts bestaat in het licht van het voorgaande grote behoefte. Hilerover bestaat inhoudelijk echter nog geen overeensteming onder beroepsgenoten. Wellswaar wordt er veel ontwikkelingswerk verricht, maar de rapporten over de taak- en functie-cmschrijving van de hulsarts aragen nog een globaal en vrijblijwend karakter $(6,7)$. In dit verband is een tendens te bespeuren om terug te keren van al te pretentleuze interpretaties van het begrip integrale zorg naar het tenminste goed beheersen van het 'medisch ambacht' en de 'hierin besloten medische besluitvorming. Hlertoe wordt onder andere gewerkt aan het ontwikkelen van huisartsgeneeskundige strategieën en protocollen $(8,9)$. Een grote moeilijkheid is dat voor de problemen en klachten waamee de huisarts te maken krijgt, de aanpak zoals die tijdens de medische opleiding - grotendeels gedragen door specialistische kennis, ervaring en traditie - wordt onderwezen, onvoldoende houvast bledt. Er dient cen elgen huisartsgeneeskundig kennisgebied ontwikkela te worden.

5) Dit alles gaat gepaard met een crisis van een belangrijke achterban van de hulsartggeneeskunde: de geneeskunde zelf. Wat zifn de opbrengst en de kosten ervan in temen van gezondhelidswinst en levensgeluk? Ten atanzien van cleze kosten kant steeds meer anderzoek van de gnond. Gezlen de eerste resultaten niet ten onrechte. Zo vonden steel c.s. bij onderzoek op een interne afdeling van een Amexikaans universiteitszlekenhuis dat van 815 patienten 368 6en of meer latrogene aandoeningen kreeg (er waren in totaal 497 van dergelijke aandoeningen). Bij 98 waren deze levensbedreigend of invaliderend, en bij $2 \%$ van de patienten droegen ze bij tot het 
overlijden. Geneesmiddelen waren verantwoordelijk woor rulm 200 complicaties (10).

Het probleem van de verwiljzende huisarts is niet alleen meer: hoe breng ik de mensen de hellzame mogelijkheden van de modene geneeskunde, mar ook: hoe voorkom ik dat zilj aan de gevaren ervan worden blootgesteld?

6) $\mathrm{Na}$ de vorige punten is het duidelijk dat wetenschappelijk onderzoek in en vanuit de huisartsgeneeskunde erg belangrijk is. De ontwikkeling ervan gaat echter minder snel dan men zou willen. Zowel de specifleke methodologische problemen dle erbij aan de orde $\mathrm{zl}$ jn, als het ontbreken van de nodige infrastructuur, zijn hier debet aan (11). Wanneer het niettemin mogelijk blijkt on, op grond van onderzoek, algemeen gehanteerde medische kemis-elementen vanuit eerstelijns-optilek te herzien, is te verwachten dat verworvenheden als methodisch werken (12), preventie van samatische fixatle (1, 13) en gezins- en levensloopgeneeskunde (14) meer dan tot nu toe tot hun recht zullen kamen.

\section{Opzet van het proefschrift.}

In de regel beginnen diagnostische activiteiten naar aanleiding van klachten. Aan het verband tussen klachten en diagnostische bevindingen is in het eerste gedeelte van dit proefschrift dan ook veel aandacht. besteed. Eerst worat aan de hand van basisbegrippen uit de klinische epidemiologie een analyse gegeven van de wijze waarop diagnostische gegevens geInterpreteerd kumen worden. Dakma worat aandacht geviaagd vooi de vertekening die kan optreden als men het verband tusigen klachten en diagnostische bevindingen bestudeert in populaties die geselecteerd zijn door hulpuraaggedrag, diagnostische activiteiten en/of verwijzing.

Vervolgens worden in deel II een aental veldstudies beschreven. Daarbij is de vraag gesteld, in hoeverre de vaak gedoceerde verbanden tussen de veelvoorkamende klachten hoofpijn en moeheid enerzijds, en hoge bloeddruk respectlevell jk bloedamoede en $1 \mathrm{jzergebrek}$ anderzi jas op dit moment in onze streken relevant zijh. Deze studies zijn verricht in verschillende settings, te weten de algemene bevolking, het spreekuur van de huisarts, een voor hulsartsen toegarkelijk dilagnos- 
tisch centrum, een polikliniek verlosikunde en enkele eerstelijns verloskundigenpraktijken. Daema wordt wat betreft enkele klachten (moeheid en pijn op de borst) een globale beschrijving gegeven van de diagriostische eindconclusies van huisartsen respectievelijk hum praktisch handelen, mede on een indruk te geven van de mate warin selectile door middel van verwijzing plaatsvindt.

In het derde gedeelte kant de medisch besliskundige benadering aan de orde, en enkele voorbeelden hiervan worden witgewerkt. ook hier wordt aandacht besteed aan verschilien tussen de situaties van huisartsen en speciallsten, wat betreft prevalenties, subjectleve kansschattingen en aan te bevelen strategieën. De nadruk wordt gelegd op de verheldering en de illustratie van algemene concepten. Inzicht in de algemene concepten van de besliskunde is naar mijn mening voor de ontwikkeling van het medisch werk van de diverse disciplines vooralsnog belangrijker dan gedetailleerde cijfermatige analyses.

ondat in de diagnostiek bij voortduring getracht wordt onderscheid te maken tussen "nomale" en 'afwijkende' uitslagen, wordt in het vierde gedeelte geInventariseerd welke betekenissen men kan toekennen aan het begrip 'normaal', en tot welke verschillende wijzen van interpretatie van diagnostische gegevens dit kan leiden. Hierop aansluitend wordt een analyse gegeven van de invloed van selectie door middel van verwijzing op het onderscheidend vermogen van dilagnostische tests.

In deel $V$ wordt veralag gedaan van twee onderzoekingen betreffende de prognostische betekenis van een dilagnostische bevinding. Het gaat hilerbil an het verband tussen:

- het hemoglobinegehalte respectievelijk de hematocriet van zwangeren en de kans op partus prematurus respectievelijk het krijgen van een kind met een laag geboortegewicht:

- het hebben van een (matig) hoog hemoglobinegehalte en de kans op het krijgen van een hertinfarct.

In het zesde en laatste gedeelte wondt het gepresenteerde materiaal geevvalueerd, en worden aabevelingen gedaan met betrekking tot het klinisch-epidemiologisch onderzoek op het gebied van diagnostiek, met bijzondere andacht wor de huisartisgeneeskunde. 
In dit proefschrift is materiaal opgenomen dat reeds in een bepalde vorm is of zal worden gepubliceerd. Dat heeft als voordeel, dat de meeste hoofdstukken als afgerond verhaal zijn te lezen. Daartegenover staat het nadeel dat op enkele plaatsen herhalingen voorkonen. Wij vragen de lezer on dit eerder als een tegemoetkoning te beschouwen dan als hinder: de betreffende passages kunnen wat sneller worden doorgenomen, dan wel als zelf-evaluatie materiaal wonden opgevat.

\section{LITERATUUR.}

1. Huygen FJA. Preventie van somatische flxatie. Huisarts en Wetenschap 1978; $21: 363-365$.

2. Knottnerus JA. Principes van besliskunde. Nieuw Koripas voor de huisarts, 1984, II/4-15.

3. Hoe helpt de dokter? Nederlands Huisartsen Genootschap, Utrecht 1975 .

4. Lamberts H. De huisartsgeneeskunde als leer der kruispunten in de gezondheidszorg. Huisarts en Wetenschap 1978; $21: 465-476$.

5. Centraal Medisch Tuchtcollege. Huisarts berispt na late diagnose manmacarcinoom. Medisch Contact 1982; 37: 250.

6. Commissie Takenpakket Landelijke Huisartsen Vereniging. De taken van de huisarts. Medisch Contact 1977; 32: 765 .

7. Basistakenpakket van de huisarts, Landelijke Huisartsen Vereniging, 1983.

8. Grol R, Mesker P (red.). Huisarts en toetsing. Nijmeegs Universitair Huisartsen Instituut 1984.

9. Sips ABJI. Protocollen voor de huisarts. Medisch Contact 1986; 41: $277-279$.

10. Steel K. Iatrogenic illness on a general medical service at a university hospital. New Engl J Med 1981; 304: 638-642.

11. Touw-otten $F$. Wetenschapsbeoefening en huisartsgeneeskunde, van Loghem Slaterus, Deventer 1981.

12. Holten-Vriesema $J$, Tompot $C_{r}$ van Aalderen $I I$ et al. Methodisch Werken, over een algemene methode van hulpverlening en de opbouw van een functionele relatie, toegespitst op de huisartspraktijk. Huisarts en Wetenschap 1978; 21: 322-335.

13. Grol R (red.). Huisarts en scmatische fixatie. Nijmeegs Universitair Huisartsen Instituut, Nijmegen 1981.

14. Huygen FJA. Family Medicine, the medical life history of families, Dekker \& van de Vegt, Wijmegen 1978. 


\section{as}

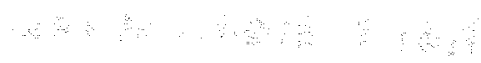

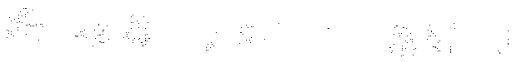

8

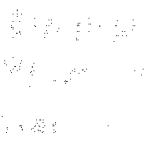

1

the

$+\cdots$

in

$\because \cdots$

$\because \vdots$

\section{क्ष}

अ : : "

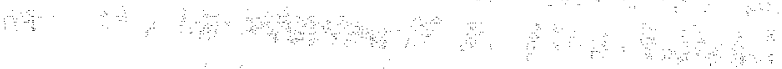

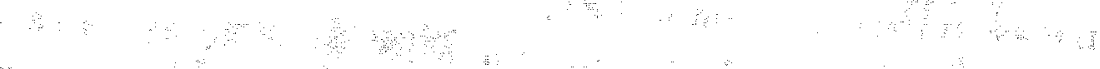

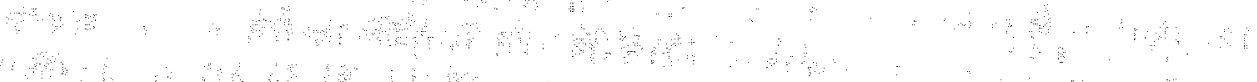

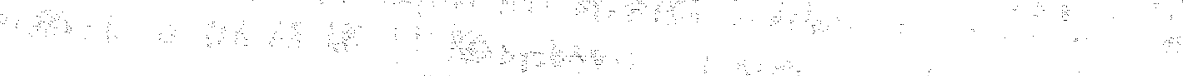

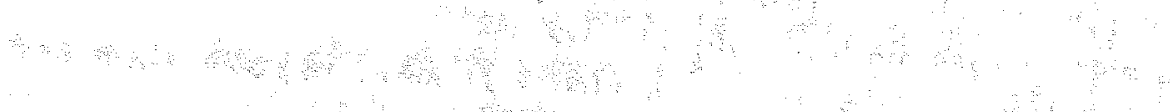

a 
DEEL I

INTERPRETATIE VAN DIAGNOSTISCHE GEGEVENS EN DE

VERSCHILIEN TUSSEN EERSTE- EN TWEEDELIUNSGENEESSKUNDEE. 


\title{
Interpretatie van diagnostische gegevens
}

\author{
Een onontgonnen terrein in de huikartsgeneeskunde
}

\section{J. A. KNOTTNERUS}

Het is al vaak gezegd: de huisarts heeft een werkterrein dat niet door de specialist bestreken kan worden. Huisartsgeneeskunde is een geheel eigen vakge bied, en huisartsgeneeskundige ervaringen en onderzoekingen zijn onmisbaar voor het ontwikkelen van een eigen hulpverleningsstrategie. Dit geldt ook woor de interpretatie van diagnostische gegevens. In dit artikel wordt aan de hand van voorbeelden duidelijk gemaakt. dut hier een terrein braak ligt.

\section{Inleiding}

Ontariges vestiguten Van der Vuthen on

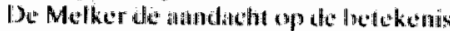
wan de frequentie waturmee andeneningen voorkomen, voor die interpretatic van ditggnostische gegewens. Datarioij werd er op gewezen dat hothitris en specialist te maken hebhen mot versthillende morbiditeitspat ronest. en op grond datirvitm rok andere vorwikhtingen koesteren ten alanzien van eventuelle pathologie. "

Dit artikell sluit hierop atun. Achtereenvolgens zullen worden besproken:

- basishegrippen:

- de verandering van de vourspellendo woorden van een testuitsilag bij werwijzaing:

- de diagnostisthe betekenis van klachten en symptomen:

- de mogelijke vertekening wan do samenthang lusen sympontomen an ficklen ten gevolge vall hed verwijs prouess.

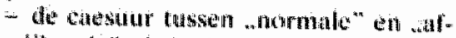
wijkende" uisklagen:

- de invloed wan de inate wan ontwilk keling van het kliniseh heetd op testuritslugen:

\section{Basisbegrippen}

We gatan uit van vrouwen in de leeftijd van 20 lot 30 jaar. bij wite de huisarts oloor middel wan fysikclite cliagnositiek aen palpabele afwijking in de borst whdt. De hiertij getruikte getallen zijn

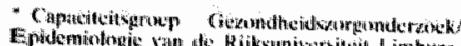

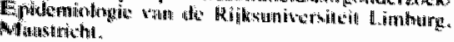

zovel nogelijk gebascerd op de literatum.

Na llact lichamelijk anderzack zijn er fwec contushes mogelijk:

- suspect woor borstkanker (positieve uitslag):

- niet suspect woor borstkanker (negafieve uitsing).

Infigut lis weergegeven hoe de onderzocksresultaten kumnen uitwallen bij $\|$ (kil vrouwen. Er is sprake wan 28 terecht-positiave (TP), $3 k$ fout-positieve (FP). 22 tout-negatieve (FN) en 912 terecht-negatieve (TN) ditslagen.

De huisarts zol nu primair geinteresseerd zijn in de beantwoording van de volgentle vragen:

- Hoe groot is de kans dat vrouwen bij wite ik eem suspect knobbeltije vind, inderdaad borstkanker hebben?'

- Hoe groot is de kans ded roumen bij wie ik het knobbeltje niet suspect wind. geen borstk tinker lachben?

De ecrsto vratag beireft de voonspellende watarde wan de positieve testuitslag $(V W+)$ de tweede vratg de voorspellende watrde van de negatieve testwitslag (VW-).

De testmethode zelf wordt gekenmerkt door:

- De kans dat aanweżge ziektegevalHen door de test worden ontdekt, de sensitiviteilt.

- De kans dat personen zonder de ziekte door de test ook als zodanig worden herkend. de specificititit.

De in figuur I vermelde watarden woor sensitiviteut en specificiteil komen overeen met bevindingen in Nederlands en Amerikaans onderzoek. "4
Uhif figur 1 is woorts de prevalemtie af te kortm: het percentage persinnen in de bestudecrde populatie dat de betreffende ziekte werkelijk theeft, in dit geval 5 procent."

\section{Verandering van voorspellende waarde bij verwijzing}

Sitel dat de huisarts als beleid heeft: - efke vroww met een suspect knobbeltje verwijs ik rechtstreeks nas de chirurg voor biopsie:

- de overige wrouwen met een palpabele shwijiking krijgen een mammografie: als die positief uitvalt (ruimte voor verdenking openlant). verwijs ik alsnog voor hiopsice.

Als we er hierbij van uitgatan dat op indücatie verrichte mammografie een semsitiviteit wan 91 procent en een specifliciteit wan $\$ 4$ procent heeft ${ }^{+?}$, en dat biopsie uiteindelijk de werkelijke toestand onthult, dan is gemakkelijk nate rekstien wall tie verwathiten is. In figwar 2 is dat gedaam.

Het blijkt dat bij de chirurg de prevalen.

Figuar 1. Mogelijke onderzoreksresullawew van fortische diagrasviok bij 1000 "rowtwen mer klachen oner cen knobbel. tice in di" borst. Basisbegrippen.

\begin{tabular}{|c|c|c|c|}
\hline & Barst CA & 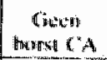 & Tot:at \\
\hline $\begin{array}{l}\text { Onderzoelk } \\
\text { positicf: } \\
\text { suspect }\end{array}$ & $\begin{array}{l}28 \\
\text { TP }\end{array}$ & $\begin{array}{l}38 \\
F P\end{array}$ & 66 \\
\hline $\begin{array}{l}\text { Onderzoek } \\
\text { nezatiaf: } \\
\text { nilet-suspect }\end{array}$ & $\begin{array}{l}22 \\
\text { FN }\end{array}$ & $\begin{array}{l}\text { 412 } \\
\text { TN }\end{array}$ & 93.4 \\
\hline Totatal & 50 & 950 & 10019 \\
\hline
\end{tabular}

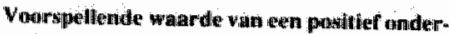
zonthsresultthat:

$W W+=\frac{T P}{T P^{n}}=42 \%$

Vowrspellende warde van ten megutlef on* dernoksiresulfunt:

$W W=\frac{T N}{T N^{n}+F N}=9 x$

Sensiltivitelt van het anderziole:

$$
\frac{T P}{T P+F N}=56 \%
$$

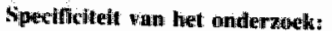

$$
\frac{T N}{T N+F P}=96 \%
$$

Prevalemtie.

$$
\mathrm{TP}^{\mathrm{P}}+\mathrm{FN}
$$

$\mathrm{TP}^{\mathrm{F}}+\mathrm{FN}+\mathrm{PP}+\mathrm{TN}=5 \%$ 
tie wan horstanker 2 l procent Wordt Als de chirurg na, afvorens tor biopsie over te gran, palpacie verwicht (en dat niet beter of sledther doet dan de huisaris dan heef dezer palpatie cen positive woorspellende wardie $(\mathrm{VW}+$ ) van 79 procent en een negatief voorspellende wararde (VW-) van 89 prowent De chi-

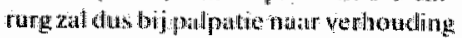
minder foumpositieven winder dan de

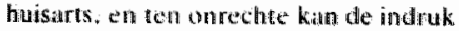
ontstada dat hij dus mok beter palpeert. Ook al zow hij relatef vaker een fout-

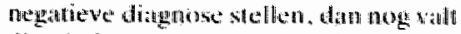
dit minde: nop. datar hij dikwijls wok een biopsic zal doen. Bowendien zal thaif dis meeste vrouwen bij wire gen biopsic wordt gedaan. na korte tijulzelf nog eems. controleren, zodat hij foul-negatieven in treede instamtice loch zal viaden.

De (weinige) fout -negatieven van do diagnostisebe procedure van de huisarts - dus degenen die ten onrechte niet verwezen zijn na een niat verdachte mammografie-tuitslag - zullen voonlopug gerastgesteld zijn en wellicht ook nie: allemal woor controle komen opdagen. Dergelijke gevallen worden later als "gemiste" carcinomen beschouwd, dan wel angemerkt als voobeelden van doctars delay.

Het is duidelijk dat het missen vam een aantal gevallen in eerste instantie alleen woorkomen had kunnen worden, als de huisarts bij alle vrouwen met een palpabele afwijking biopsie had iaten-verrichten. Dat had in dit geval betekend dater 768 extra biopsieen gedaan hadden moeten worden om 2 extra gevallenal in eerste instantie te ontdek ken.

Men kan inzien dat bij de keuze tussen de diverse diagnostische strategièn (al leen verwijhe bij suspecte palpotide de beschreven strategie, of hedere yrouw met kladiter of en knobbeitje verwij zen) van belang is met wetlke preivalen: thes men te maken heef. Als hicwan

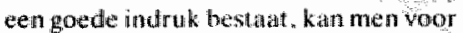
elke strategie en schathing maken van de kans op gemiste carcinomen en de kans op biopsieen bij gezond th vrouWew. Relevante gegevens daarlwij zijn de wetenschap dat wen knoblbet ouderen veel vaker op kanker duid dan bij jongeren." en het feit dat kans op kanker bij mammaklachten in hell alge meen veel klemer is an bij de anwe. zigheid wan cen knobledije.

\section{Voorselectie door de huisarts}

Het bovensitatude resumerend kan gesteld worden: Wanneer de prevalentie toencemt. netrit de voorspellende
Warde van eerpositieve tes fuitslag tow matr word de noorspellende warde van en negatieve toswitslag kleiner of komenminder fout positieve dochneen fout-negatiewe nitsigen. Wametr de prevalentie afneemit, is bet omgekeerde te verwachien: de voorspellende wast. de wan een positieve testuitsiag word

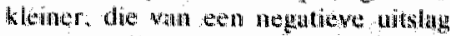
groter: er zijn meer foutpositueve matr mander fout-negatieve uitslagen to ver willthen.

Het feil dat er ean positueve same nhang it fussen de yoorspellende warde van cen positiove istutshag en de prexalen. tic van de andoenting warrop men on. derzoekt, zal niet moeilijk te begrijpen zijn. Lastiger is het zich voor te stelleth dat de voorspellende warde van een ne gatieve uitslag kleiner wordi als de prevalentie coeneemt. Wellicht kan nog

\section{Figaur 2. Mogelijke resulaten wan diagnostixche procedure bif jonge urowwen met} palpabele mamma afwiking:

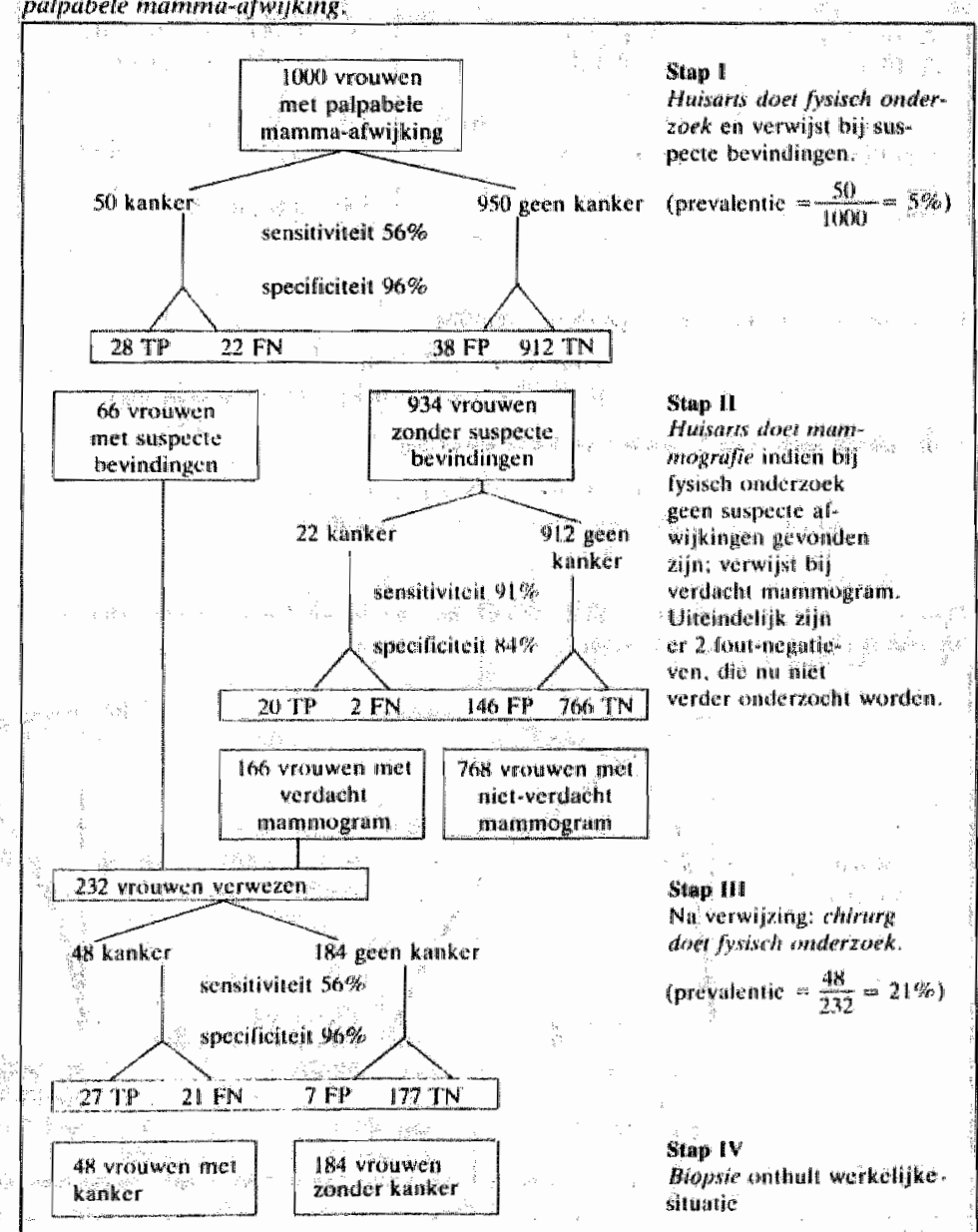

een yoorberid verhelderend werken. Bu een vrou van 25 gar onder klach-

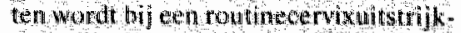
je en an 1 gewonden. De ant al ar

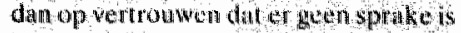
va cenixkanker sid nu dande uirsling Pap 1 ook gegenen wond bij een $40^{\circ}$

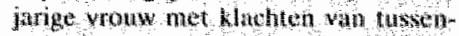
tinds bloedverhas conontobloedngen.

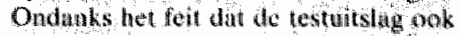

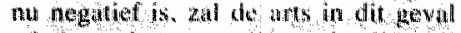
minder zeken van zign rak zijn hij houdt reksuing mett en fout-neguteve uhtslag en toht kanksr nog geensums

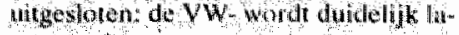
ger geacht.

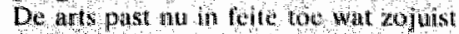
geformuleerd is hij interpeteert de testuitslag wet in the achterhoofd de kennis dat cervixkanker bij vrouwen van 25 jar zonder klauhton zeor weinig 


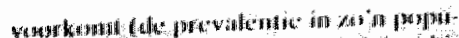

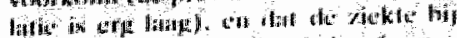

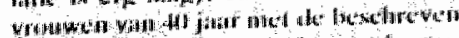

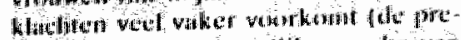

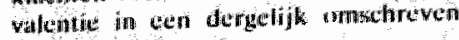

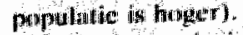

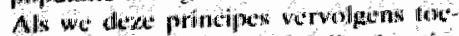

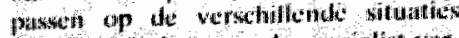
wath de hutiturts en de spectallst wetrkeren zion de volgende condusices te

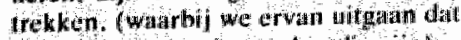

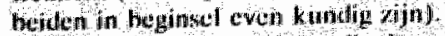

In de populatis patienten die de spe. Galist bezoek is-als gevilg wan de voorselect te door de huisarts - de prevalentie van ennstige ziekten en rain ziekten die specialistische betandeling Mergen groter diun in de paticntenpopu. latie die de huisarns ziict Dat beteken

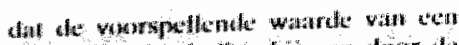

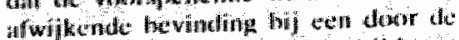

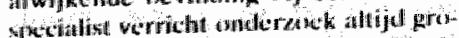

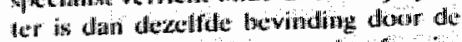
huisarts. Ten anmien van de afwezighed van deze zhelken is do workpellende warde wan en nilet-ef fwilkendk bevinding bij te hisistris juist groter.

- Vow de ziekten die de huisarts valk wet, en de specialist minder vark, getd hel omgekeerde. Voorbeciden hiervan zijin vele minor whwow, exanthenen bij kinderen en dergelijke.

- De voorspellende wande van een positieve uitslag van een specialistisch onderzoek kam relatief groot zin doordat de huiberts voorselecteert. Als de houkarts dit nitet deed, zou veel overtodige dagnositiek en eventuee behande-

Figun 3. De formule van Bayes.

\begin{tabular}{|c|c|c|}
\hline 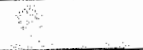 & ztion & Nhetratul : \\
\hline $\begin{array}{l}\text { Tostuitsling } \\
\text { posthicf }\end{array}$ & $\begin{array}{c}\text { TP }=\text { sermativiteit } x \\
\text { prevalumber }\end{array}$ & 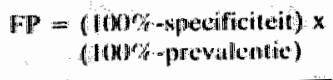 \\
\hline 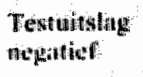 & $F N=\frac{(16) \%-\text { Rensitiviteit }) x}{\text { previlentie }}$ & 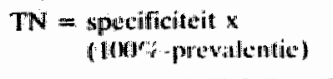 \\
\hline Tounal & provalenuic & I00\%-prewalentie \\
\hline
\end{tabular}

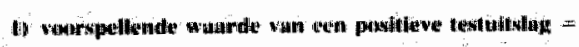

\section{IT}

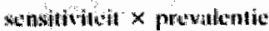

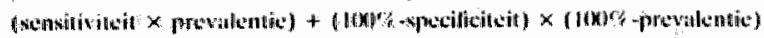

IN

TN + FN

2) de wompellondg wande van wen nequateve llestaitstage $=$

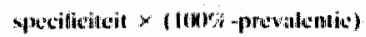

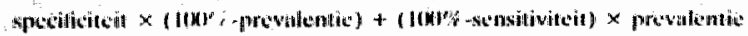

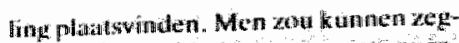

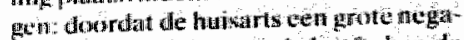

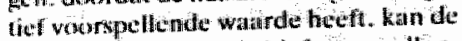
speciulist een hoge posituef voonspellende waardie halen.

Verder specit wok nog cen rol dat de huisarts door muddel van andmateren Hichamelijk onderzoek die patienten selecteer bij wie hij een wenthougde kans op hepabide andoeningen arnwezig

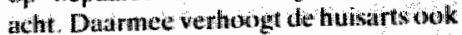
de voorspellende warde van forighende bevindingen bij mader onderzoek dat in eigen beheer plaatswindt.

In figur 3 is thet beschreven verband tussen sensitiviteit, specificiteit, prevalentie en voorspellende warden samengevat in de formule van Bayes. Deze formule is overigens direct af te leiden wit de vierveldentabel en geeft in princilpe ook niet meer informultie dan deze tabel.

Iiv figwiur 4 zijn de verschillende vertianden gratisch weergegeven voor een tweeldil onderzozelken. paspatic en mammograllie.

\section{Betelcenis van klachten en symptomen}

Wiet alleen onderzoeksresulataten: madar ook symptomen en klichten op zich relf hebluen een voorspelliende warde. $Z$ ij zijn in die an nots anders dwin ecn , test" . In het eerste voorbeeld spraken we van de prevalontie van borstkanker in een groep vrouwen met palpabele afwijkingen. We hadden ook kumnen spreken van de woorspellende witarde van een pilpabele af wijking voor het hebben wam borstkanker. Ook

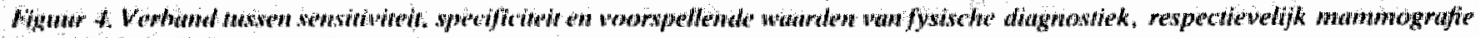

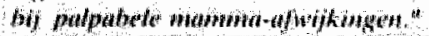

Voirupullend: Watrok $(1)$

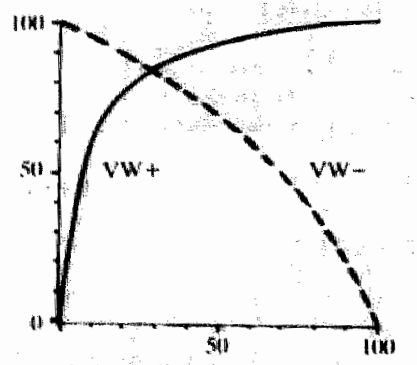

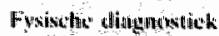
keminfuileit $56 \%$ \% actifitedt
Prevalentiv

anamonusatrinom (\%)

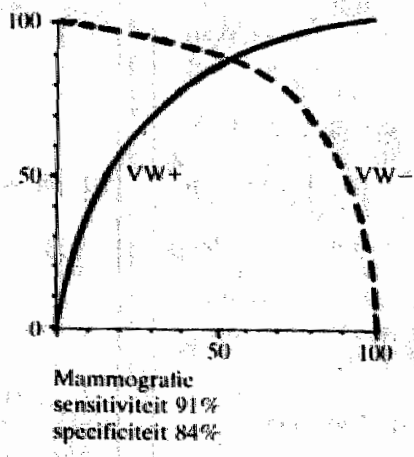

Prevalentic mamouscarcinoon (新)

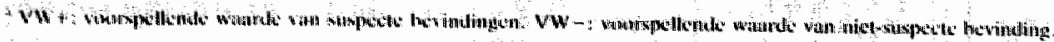




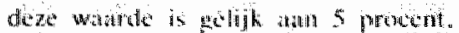
zolkng er mig mu gedifferentiect is

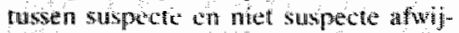

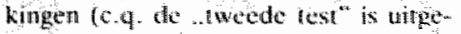
woerd.

Aall da hand van enkele voorbexlden zal nader worden ingegata op de bete. kenis van klachten en symptomen.

Appendicitis acuta en pijn rechts in de onderbuik. Uil morbiditeitsgengevens mogen we concluderen dat appendicit is acuta zich per jaar gemiddeld 4 à 5 kaer voordoet in een praktijk wan 2500 zielen. ${ }^{\text {*in }}$ Bij klinisch onderzoek bleek circa 75 procent wall de patienten met appendicitis acata pijn rechts in de onderbulk te hebhen. De sensitiviteit wan deze klacht is dus 75 procent ten abnzien wan appendicitis.

Als we nu. mede op grond wan klachteryregistraties, schatlen dat zich in een praktijk val genoemude grootte per jaar ongeveer 40 mensen melden met pijn rechts in de onderbuik, kunnen we de $V W+$ van de klacht herekenen. Varn de 4 mensen met appendicitis krijger er 3 (75 procent) pijn rechts in de onderbuik. Total melden zich echter 40 per sonen met die klacht. Aangenomen dat de drie genoemde patienten allen de hulp van de huisarts inroepen, is de $V W+$ van de klwcht slechts $3 / 40=7.5$ procent.

Pijn rechts de onderbuik op zichzelf lijkt hier dus van betrekkeljike waarde bi het voorspellen wen de annwezigheid van appendicitis. Die waarde zou nog geringer worden als we rekening thouden met de mogelijkheid dat de sensitiviteit van de klacht voor de ziekte in de huisartspraktijk geringer is, doordat het beeld wist minder ver oniwikkeld zat zijn dafo in de kiliniek.

Bulfie in de hals, Wannecr én bepiald symptoom kan wijzen op verschillonde aandoeningen is het van belang dat men zich realisert met welle populatic men te maken hecf. Met de populatio lkan immers ook de voorspellende wata" de van dat sympoom varieren. We gewem weer cen vorbeell.

Bij de arts meldt zich een patięnte met wen bulte in de hals, daif natar hatar zeggen reeds enkelle weken anmwezig is. Het is licht drukgewoelig. glad en $0,5 \mathrm{~cm}$ in doorsnede.

Het is duidelijk dat en dargelijke presentatie bij de huisarts een geheel ande. re thetekents hosf tan op het spreekwur wan de ancolong Op grond van exact dezelfde bevindingen all de erste een on tstoken klier thet meest watrehijhlik achten en een afwathlende houding

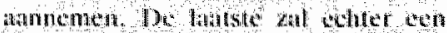
priname malgaitct of netastase wilen wishlitem met behulp van verder onderzoek Menkan zho on woorstellen dat? Wannert beiden een klowache les ower dit symptoom zouden geven, zij thet skek verschillende anbevelingen zoudiev eindigen.

Hemoghobinegehalte en ,anemieklachten". Op grond van onderzouk in de algemone bevolking is het onwaraschinhlik, dat er in onze streken een samenhang bestaat tussen een laag hemoglobinegehalte en de belangrikste klassieke . anemiesynotomen ${ }^{2}$ Huis: artsen hebben echter tijdens hun studie geleerd dat anemic bepaatlde klachten verouraakt en de kans dat zij het hemoglobinegehalte bepalen, is daarom bij aranwezigheid van die kllachten gro. ter dan bij klachten waturan een verband met anemie niet geboekt staat. De kans dat door toeval een laag Hb wordt gevonden, is hij mensen met nanemieklachten" dan ook groter dan bij andere klachteri. Als huisurtsen dan mensen met cen lang Ho warvoor zij geen verklaring of oplossing hebben. natar de specialist verwijzen voor nade onderzoek, zal deze latiste nam verhouding veel patienten zien met een lág $\mathrm{Hb}$ die anemie-klichten" luebben. $\mathrm{De}$ sensitiviteit wan tunemieklachten ten anzien wan de anwezigheid wan een laag Hbzalldan, ook als er geen verband tussen beide is, wril hoog kunnen zijin. De specialist wordt aldus bevestigd in ziji opvatting dat beide verschijnselen same nhangen. In figuiur 5 wordt dit effect gedemonstreerd aan de hamd van cen getallenwoorbeed.

Het is zeer well nogelijk dat dit feno" meen wan warnemerswertekening met betrekking tot de samenhang tussen symptomen en beschreven ziektebeel den wijd verbreid is.

\section{Optimale afkappunten}

Het punt wat men de calesuru liegt tussen een milet-afwijkenda en afwijkende uitslage. is zelden een objectiof gegeven. Meestal gaat het on een wirbi. trair bestuil op grond wan consensus. Mer kan dan spreken van een vastge. steld adfipapunt" voor de beslissing tus sen normal en afwijkend. Voorbeelden zijn: de ondergrens van her $\mathrm{Hb}$, de bovengrens wan de blowdruk leverfuncties of de bloedstiker: de hoogte van het ST-segment op het inspannings. ECG en de hoeveetherd acceptabele mitosen bij pathologisch-anatomisch onderzoek
De sensitiviten on ale spofliciteit yh het onderzod ain whank oligh we do

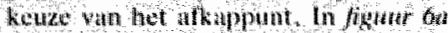
worde dit duidelijk ana de hamd vat de verdelingen yan hemalitcherwhiteden

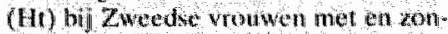
ther if warebrek onby kon de ze onderverdeling ntaken, afpande op de res pons op yjrertoediening by een steek proef van wollwon unt de algemene be volking t.

Te tien is ditt, stls het afkappunt voor ijzergebreksanemie wordt vehthoogd (dus minder stringent wordi) meer ij) zergebreksanemie-patienten worden opgespoord. ternwij! er tegelijkertijd

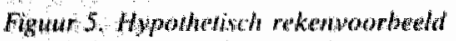

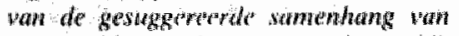

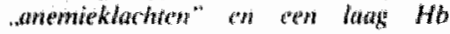

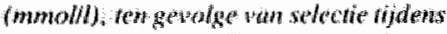

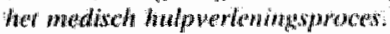

1. In de praktijkpopulatio van de hetisates is de situatic alls wolgh:

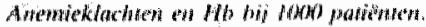

\begin{tabular}{|c|c|c|c|}
\hline $\begin{array}{l}\text { Anemix- } \\
\text { klizithlen }\end{array}$ & $\mathrm{l} \mathrm{Hb}<7.5$ & $11 t_{5}, 7.5$ & Totalal \\
\hline+ & 5 & 45 & 100 \\
\hline- & 45 & 855 & $9(k)$ \\
\hline Totalal & 50 & 6) & IOKIM) \\
\hline
\end{tabular}

Er is geen verband tussen het Ho en do anemicklach tert ; het percentage meinse me met anemieklachtern is bij methen met $\mathrm{Hll}<7,5$ ewen groot uk toij mensicn met Ho $>7,5$ :

$5 / 50=95 / 950=40 \%$.

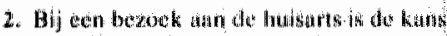

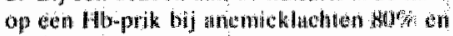
bij andere klaction $5 \%$ :

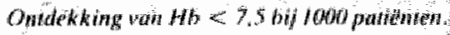

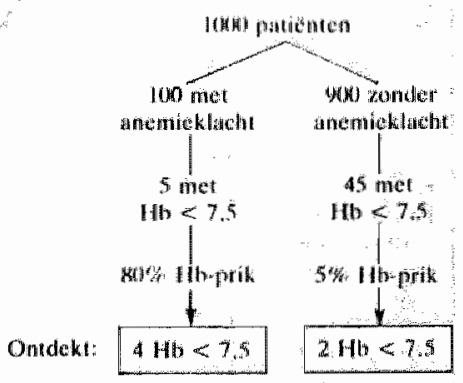

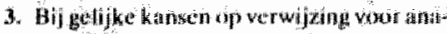

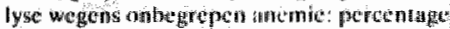

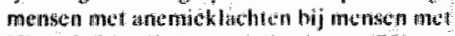

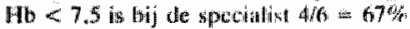




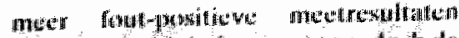

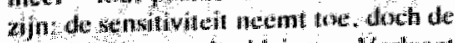
spwesfichteir word hlleuner. Verlidagt men de grenswarde (er wondt dan een

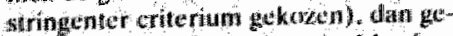

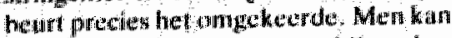

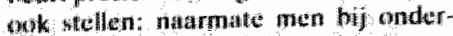
zoek yan en bepalalo pupulatie cen

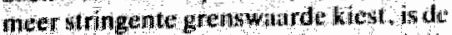
voarspellende ararde wate een alwij kende lestuhtila groter. Bijecen monder strenge norm wordt de vounsullende watrde van een fol werude untslat kleiner.

De wraag ts nut wat is het optingate af Wappunt bij wen tert?

Deze wragg is niet eenvoudig en zaker nict endudig th howowomolen. Ifet thntoord is in de ecers te phats of hanke-

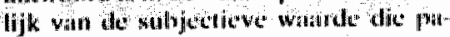

fient en arts fowkentuen ada ken fort-

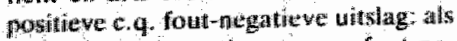
men de consequenties war ed fouthegatieve uitulag ernistiger mind dan die van een fouth-positicve, zal men de nadruk leggem op ten lest met een hoge sernsivinteit. Wordem datatentegen fout powitheven ernstigur ge actht, dan is wen nieter specifieke test extrat belangrijk.

Het wor we lezer wellicht en goede viligeroefiening, eens nat te gaw thoe tit Wat hem of haar betneft ligh voor verwhilende onderzoekingen en andoenimgen op dit moment lijkt het er op. dat fou-negatieve atulagen in het alge. meen enstiger worden gevonden dan foutpositieve, ook indien de laatste

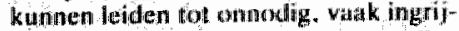
pent vervolgonderzot of overbodige

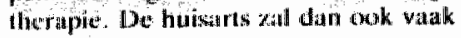

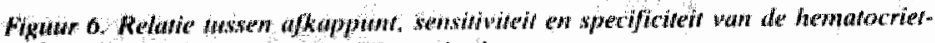

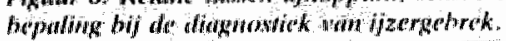

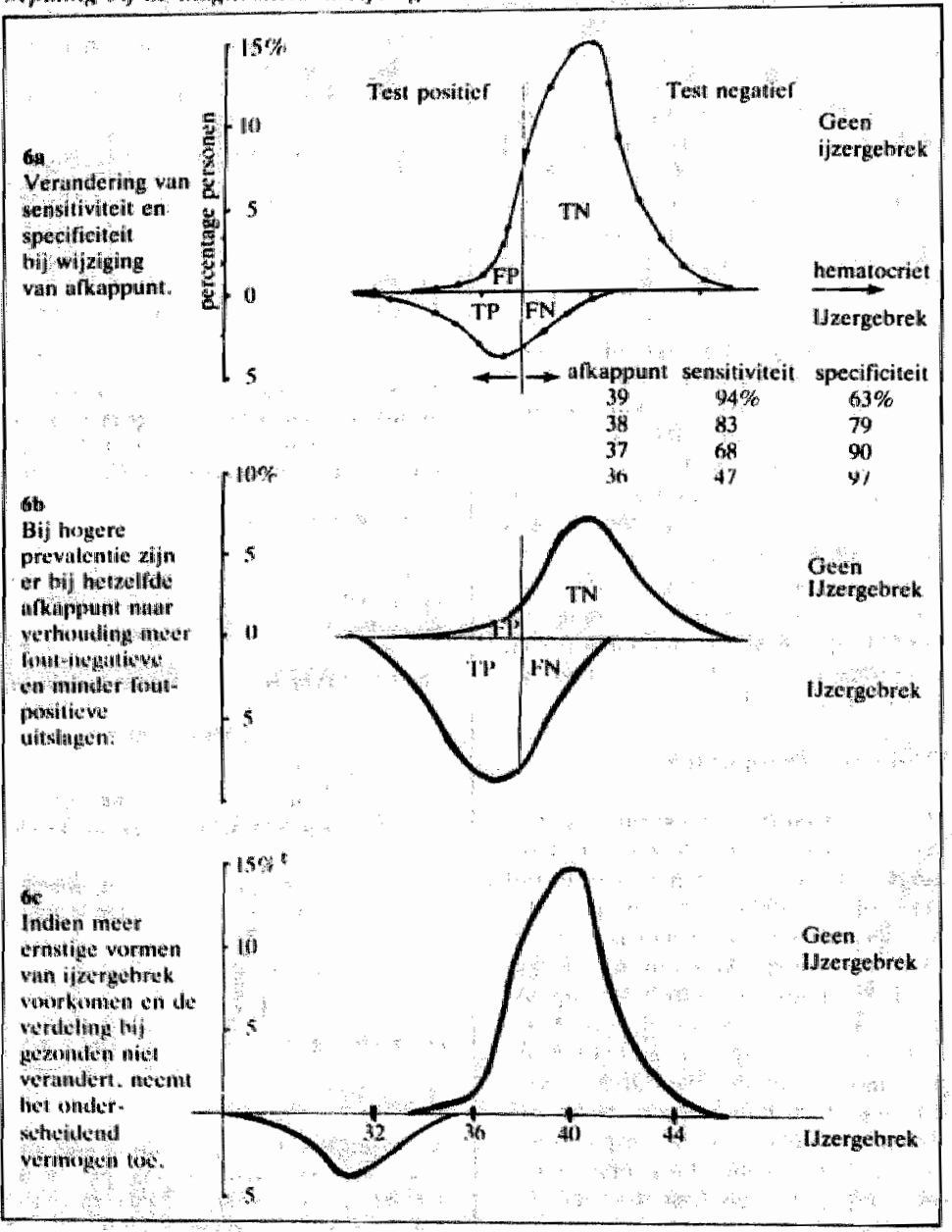

gene igd ain het ankappunt nict te stringen te stellen. Deze beshising impliceert echter een keuze voor een groter antid foutpositieven. met als mogelijk

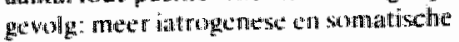
fixullix.

De optmath keuze wan het afkappunt hongt ook af van de prewallente van de mogelijke aandoening zien in figw 6 b: whmeer er meer vrouwen met ijzergebreksanemie in de populatie voorkomen, ijin er bijez zelfde afkappunt meer fout-regatieve uitsla* gen te verwachten. Wil men deze in foom houden, dan zal het afkapmunt minder stringent gekoten moeten worden.

Het is om deze reden niet vanzelfsprekend dat in situatiues war in versichillende prevalenvics alan de orde zijn on bajvoorheeld de sicuatic wan de huisarts in vergelijking tot de situatie van de specialist - slechts én aflkappunt gehanteerd wordt. In het algemeen gebeurt dit echter wel, orndat op de specifieke situatic afigestemde criteria doorgaans ontbreken.

In figuur fa is overigens te zien dat men ook op een andere wijze testuitslagen kan interpreteren dan aan de hand van enketwoudige afkappunten. Bij iedere Ht-warde is namelijk de bijbehorende kans op ijzergebrek aan te geven, als quotient van de hoogte van de curve bij ijzergebrek en de som van de hoogten van beide curves voor de betreffemde Ht-warde. In het voorbeeld is deze kans bij achtereenvolgens de waardent 31 en lager, $33,36,39$ en 41 en hoger: I00. $80,59,9$ en 0 procent. Ook deze kansen zijn echter niet onafhankelijk van de prevalentie.

\section{De ernst van het klinisch beeid}

Len van de belingrijke verschillen in de morbiditeitspat romen, die the huisarts en de specialist onder ogen kriggen. is voorts het ontwikkelingsstadium van het klisish beeld wamme dandoenin. gen zich manifiesteren.

In thet algemeen zullen de verschijuse. lern in de fase watrmee de huisarts er: mee geconfronteerd wordt, minder duidelijk onfwikkeld zijn dan in de fase na eventuele vernwijzing naar de specialist. In de eerste situatie zullhen de zieken minder goed te ontdekken zijn en ook mindler goed wan niet-zieken kunnen worden onderscheiden dan in le twe de situatic. In de huisartsen-fase is het onderscheidend vermogen van onderzoekmethoden dan ook veelal lager dan in de specialisten-fase. Sensitiviteit en - bij juiste keuze wan het afk nappunt - ook 


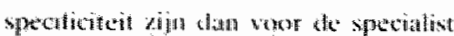
allowill ganstiger.

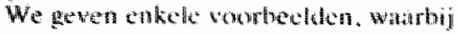

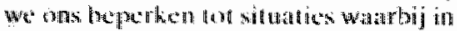
principe ect dichotom andersehed ziekniet-zies to nuken is.

Men kan inzien dat, wanneer men te maken heeft met crnstiger gevallen van jjzergebreksanemic. de verdeling van hematocrietwarden voor "zieken" meer naar links verschoven is figutur $6 c$. Het onderstheidend vermogen van de Ht-bepaling ter opsporing van ijzer. gebrek wordi dan groter ook al blijt de prevalentie onveranderd. Ook kan men zich voorstellen dat het onderscheidend vermogen valu de thermometer in de allereerste fase wn appendicitis acuta nihil is. en dat helzelfde geldo voor leverfunctietests bij beginnende of lichte hepatitis. Terugeripend op het voorbeeld over borikanker. de specialist onderzoekt gemiddeld grotere tumoren dan de huisarts. en deze kunmen beter gevoeld wordwin.

In feile ligt de zank nog gecomplicesder. de specialist zall vaker dan de huis. arts te make hebthen met meer ontwikkelde en dus beter te palperen stadia van borstkanker: de sensitiviteit is groter. Maar fysiologische en bengne borstafwijkingen zijn door mididel van palpatie moeilijk te onderscheiden van kanker ${ }^{13}$. Er worden dardoor ook patienten verwean met een suspect beeld die geem kanker hebben, en ook wat deze gevallen betreft, is er een selectie naar de specialist. .Niet-kanker" is dan ook door de speciallist niet gemakkelijk door middel van palpatie vast te stellen, en wellicht is de specificiteit wan zijn onderzoek zelfs kleiner. Het onderscheidend vermangen van ale specialistiscthe palpatie hat in dat geval niel per se beter te zilin.

In het algemken zou men kumnen zeggen: do zicken in de husartspraktijk lijken meer op geranden (alleen de herkenbare gevallen worden varwezen) en de gezonden in het riek enthuis lijken meer op zieker (anders waren zij niet verwezan). Hutsarts en specialist hebben dus te makun mel ean ander spectrum en aen ind ha re mate van on wikkeling wan klanische beelden bij zowel zieken at ls , nier-zicken". Zij doen in dat opzicht dus ook geheel andere ervaringen op.

Het feit dat de whlditeit wan onderzuekmethoden zom moeten worden wastgesteld in ecen populatie die op relevante punten (zonls die crnst van het kllinisch beeld) representutief is voor de popula tive warop de methode zal worden toegepast, staat in de literatuur pas de liadm

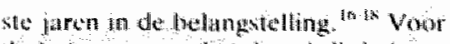
do husartigeneseshonde sal dit belsnu. rujge amplicatios kumbery hebben, data

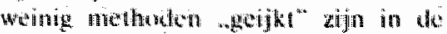
huilsartisensetring:

\section{Behoefte an onderzonek in de huisartspralktijk}

De dlagnostische posities van huisarts en specialist verschillen uiteraard op mear punten dan in het yoorgaande uitgewerkt zin. De huisarts moet meer dan de specialist werken met nog weing uitgekristallisee rde vragstellingen. en

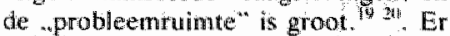
zijin watk meer klachten of problemen tegelijk atan de orde in én hulpwerleningsepisode, en vele verschillende alandoeningen moetem in de hypothesevorming worden betrokken. De huisarts zal meer dan de specialist afhankelijk zijn wan onderzeek methoden die een breed veld van mogelijkheden op nog weinig gerichte wijze kumen .,afgrazen", zoals de hemoglobinsbepaling. de meting wan de hezinkingssiculhelid van de erytrocytan en de meting van de lichaansternperatuur, en in wezen ook de antmnese en het oriënterend lichamelijk onderzoek. Bowendien zatl het valak niet mogelijk of niet zinvol zijn orm tot een deffintieve diagnose te komen.

Aan de andere kant heeft de huisarts weer valak het wordeel. over meer voorkennis over de patiënt te beschikken. Daardoor wordt een betere beroordeling van (extra) risico's mogellijk. Ook van belang is dat de methode van het afwachten wan het natumrlijk beloop een meer gehanteerd en geaccepteerd deel van het diagnostixh repertoire is.

In dit artikel lkwam natr voren dat huissarts cus specialist dow ervaring terun om te gatan met geheel verschillende petronen van vourspellende watarden van kinchten. sympotomen en ondereowsosultaten. De tweode lect de werkwijze die bij zijn situatie past, in het algemeen vanaf de atanvang van de studie: de ecron ste mout later nog veel bijspijkeren. wellicht vatak door schade en schande. De specialist verkeunt verder in een tuatio watrin hij wordt geconfronter met waarnemingen die verbanden kun nen suggereren en bevestigen die er mogelijk miet zijn.

How well men van cillakas ervaringen kan en dien to leren, is het onjuist, cn mogelijik zelfs schadelijk, ats cen vall beiden de ander zijn ervaring, kennise en tworm als matgevend opdring!. Zowel het miskennen van pathologic als het bevorderen van iatrogenese en somatische fixities liguendan op die foct De huis-

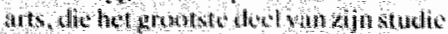

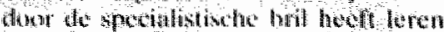

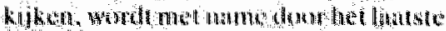
bedreigd.

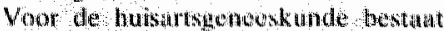
de noodzank, het onmongonnen gebied vin de diagnosthe in kin te brengen. Duarbij moet andath worder besteed usth de voorspellinde watrole van klachten symptomen en testuitslagen, ande besluitvorning over do mate warin bepaalde uitshgen nog on ater meer aceptabel zijn, an het vinden on verbeteren van de diagnost ic die juist voor de thusartspraktijk van belang zijn, en tan het corrigeren yan zichedl bevestigende kinische wertek aningen van de samenhatug tussen symptomen en andoeningen.

"Velden HGM wath ater. Diagnose of pro" gnose. De betekenis vain ate epitemiologito vore het hameten wh to huisarts. Huikiurts en Weterwehan 1083: $26: 125-x$.

De Melken RA. Dhagenostische facilitwien voor de huisarts: wio warett ar beter var?

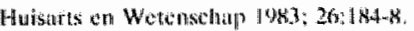

Rombacth ill. Breastl cancer sereening. Results and implications for diagnostic decision making (Dissertantio |: Aiphen a/d Rijn: Stafleu. 19801,

* Grinel PF. Matyeswshi RJ, Mushlin Al. Greenland P. Selection and interpretation of afiagnostics tests and mocedures. Ant Intern Med 1981: 94:527.456.

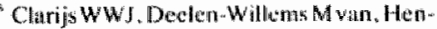
driks JHCL. Lubters EIC. Schmidt WJH. Het occulte manmmancircinom. Ned Tijdschr Geneesto $1977: 121: 526-9$.

"Dronkers DI. De betrouwbathe id wan mammografis. Not Tijdschr Geneeskd 1977: 123:1555.

"Molematir JC. Herder kroma 13 den

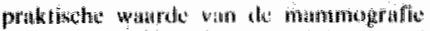

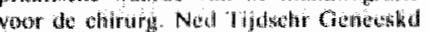
1970: 114:16846.4.

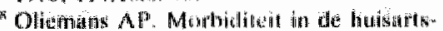

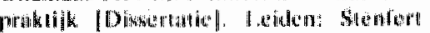
Kroeste, lusto.

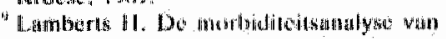

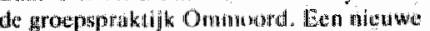

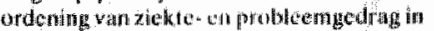

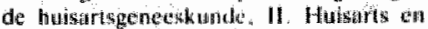
Wetenselsap 1675: 16734 .

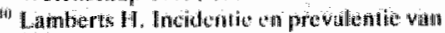
gezondtheidsprotile mon in de huisartsprak-

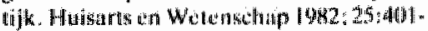
14:

"Domball FT de Actute athominal parith, An O.M.O.E. survey. Stand I Gabtrownerol 1979: 14 (suppt 96029293

1. Ftwood PC. Syrnptome and carculating

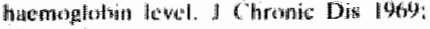
21:61:5-28

Garby L. The nermal hatumgellobin levell.

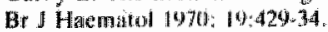




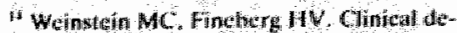

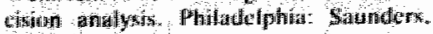
$10 \% 0 \%$.

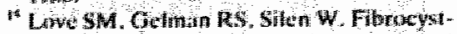

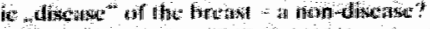

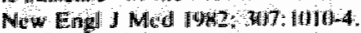

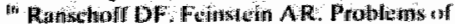

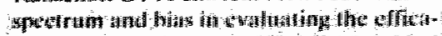

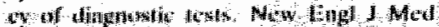
$1074.205260,21$

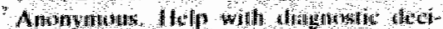
sionis [Ealinoribal] Ann Int Mod 1082 $97,444.5$.

Homke $\ell$ L. Kandichenomgen ower do ger

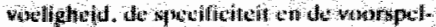

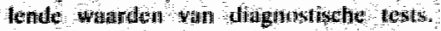
Ned Tidsehr Geneesk 1483, 127,556-16.

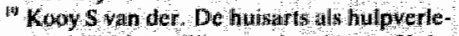
ner bij liehamelitke udindoeningen. Howsaris en Wetensehap 1981, 24:454.8.

weel C vain. Achilles loul bardloper bekeerd. Huistarts on Wetensehap 14t: $24: 417-23$ 


\section{Symptomatologie en selectiebias}

\author{
Vertekening van het verband tussen klachten en duggnosen ten \\ gevolge van selectie naar hogere echelons
}

\section{J. A. KNOTTNERUS, P. G. KNIPSCHILD ENF. STURMANS*}

\begin{abstract}
Waarnemingen ten aanzien van het verband tussen klachten of symptomen enerzijds, en ziekten of diagnostische conclusies anderzijds worden sterk beïnvloed door selectieprocessen. Deze selectie vindt plaats vanaf het niveau van de algemene bevolking. via hulpwraag-gedrag, indicatiestellingen door de huisarts, behandelingsresultaten en eventuele verwijzing. Door selectie kunnen verbanden worden gesuggereerd en gereproduceerd die in werkelijkheild niet bestaan, louter als produkt van aangeleerde indicatiestellingen. Het corrigeren van dergelijke vertekeningen door middel van wetenschappelijk onderzoek vanuit de huisartspraktijk is alleen mogelijk indien men de juiste referentiegroep kiest,
\end{abstract}

\section{Inleiding}

In lhet klinisch epidtmiologisch onderzoek is thet trekken van verkeerde conclusies ten gevolge van zogeheren selecriebias een belangrijke valkuil. Selectiebias is een vertekening van onderzoeksresultatem die veroorzaakt wordt door de wijze warrop de onderzoeksgroepen worden geselecteerd. Berkson vestigde als cerste de aandacht op de vertekening die kan optreden bij onderzoek op basis van ziekenhuispatiënten.' Sindsdien is Berkson's fallacy (admission rate blas) steeds een actued studeonderwerp gebleven (kader op pagina 326i) $2-6$

Met dergelijke selecticbias moet ook rekening worden gehouden bij mogelijke verbanden tussen klachten of symptomen enerzijds, en diagnosen of diagnostische bevindingen anderzijds. Het handelen van de huisarts en verwijzing naar de specilalist kunnen sehijnverbanden introduceren, en verwachtingenten aanzien van verbanden tussen klachten en diagnosen kwnnen zichzelf warmaken. Verbanden kunnen zichelf reproduceren, niet doordat ze werkelijk bestalan, maar doordat men-ten onrechte - geleend heeft dat ze bestan. Het is

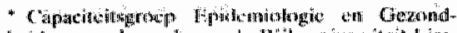

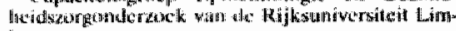
burme.

$\therefore P(X)$ de kans op $X . M=$ Disctse firie:

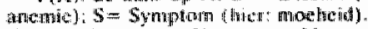

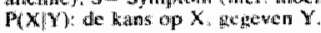

van bijzonder belang dat men zich reali seert als het gatat om de relatie tussen de huisartsgeneeskundige en de specialistische setting. Voor huisartsen is de specialistische geneeskunde immers nog steeds de belangrijkste bron wan kenmis over symptomatologie.

In dit artikel zullen wij deze materie toelichten aan de hand wan een rekenvoorbeeld, waarbij een onderdeel van een worig artikel mader wordt uitgewerkt " Het gekazen woorbeeld heeft betrekking op het verband tussen moeheidsklachten en anemie. Er zijn echter aanwijzingen dat hetzelfoe kan gelden voor andere klachten in melatie tot bepaade ziekten, zoals het verband tussen dyspepsie en galstenen, en tussen boofdpijn en hypertensie. in

\section{Anemie in de algemene bevolking}

Uit diwerse onderzoeken in de algemene bevolking is gebleken. dit er niet of navwelijks een verband bestaat tussen matige anemice ( $\mathrm{c} q$. en hemoglobineconcentratie onder en bepalde waarde) en de ,klassitake" klachten van anemie, zods moeheid, duizeligheid, pijn op de borst en dyspnoe. $13^{12}$

In de leerboeken staat moeheid echter besehreven als cen van de belangrijkste synuptomen wan anemie, en ook in het onderwijw wordt hieratan alandacht besteed. Het ligi dan ook woor de hand dat huizartsen bij mensen met de klacht moeheid relatief vaak het $\mathrm{Hb}$ bepalen.
Uit de gegevens wh het Dhanostisch Centrum Mas astoht blijkt bijvoorbesto dat bij de patienten net ds blacht moeheid die op annvraga wan de huisarts worden onderzocht, in 84 procent van de gevallen en Hb wordt bepaldi. Bij de neeste andere klowten gebeur di veel minder valk. Bjj onderwoek in verband met cen algemerte screening of check up wordt slectuts in 20 procent van de gevallen een Ho ange vratad. (4)

In ons yoobbedd gan we uit van de volgende-genngeerde-basisgegevens: - Dekans op anemie as 5 procent: $(\mathrm{D})$ - S procent.

- De klach "moeheid" komt op een bepaald moment bij 10 procent van de algemene bevolking voor: $P(S)=10$ procent.

- Er is geen verband tussen moeheid en het voorkomen van anemie dde kans op anemic bij patienten met moeheid is even groot als de kans op anemile bij mensen zonder moeheid, en de kans op moeheid bij anemie is evengroot als de kans op moeheid bij afwezigheid wan anemie. Dus:

$$
\begin{aligned}
& P(S \mid D)=P(S \mid D-)=P(S) \\
& P(D \mid S)=P(D \mid S-)=P(D)
\end{aligned}
$$

In label $l$ is de situatie in de algemene bevolking angegeven, omgerekend naar 100.0000 personen.

\section{Bij de huisarts}

Het is aannemelijk dat mensen die moeheidsklachten hebben relatief valak een beroep op de huistrits doen. Stel dat in cen bepaalde periode 20 procent van de menser met moeheidsklachten contact met de huisarts zoekt, en van do overige mensen 10 procent. Het 146 gehalite is niet bekend and de patienten. en is op tichelf geen extru reden om contact met de huisarts zoeken. Daaron blijt het percentage personen met anemie in de groepen mết respectievelijk zonder moeheldskinchten gelijk. Uit tabel 2 blifkt nu dat in de populatis personen die een beroep toen op do huisarts (dle comractpopulatie) moeheid vaker voorkomt dan in de algemene bewolking $(P(S)=18$ procent, in platats van 10 procent). Er is chenternog steeds geen verbavd tussen moeheid en anemie: $P(D \mid s)=P(D \mid S-)=5$ procent. Nu komt er medisch kiandelen in het spel.

Doordat de patienten aum de dokter laten merken dat zij weleens hebben gehoord dat moeheid door bloedamoede kan worden weroorzakt, en de diok- 


\section{Berkson's fallacy}

In het kort komt deze vertekening op het volgende neer.

Men vraagt zich af of factor $F$ een (mede)oorzaak is van ziekte $A$. Om dit te onderzoeken gaat men na, of factor $F$ bij in het ziekenhuis opgenomen patienten met ziekte $A$ vaker wordt aangetroffen dan bij een controlegroep, bestaande uit opgenomen patiënten met ziekte $B$. Het kan nu zijn dat de kans dat patięnten met ziekte $A$ in het ziekenhuis opgenomen worden, positief wordt beinvloed door de aanwezigheid vain factor $F$. Stel dat een dergelijke invloed van factor $F$ veel minder sterk of afwezig is ten atanzien van de kans op opname van patiënten met ziekte B. In dat geval $z a l$ men factor $F_{n}$ alleen al op grond van dit verschil in opnamekansen, vaker kunnen aantreffen bij patiemten met ziekte $A$ dan bij patienten met ziekte B. Een in feite niet aanwezig oorzakelijk verband tussen factor $F$ en ziekte $A$ kan hierdoor worden gesuggereerd of sterker lijken dan het in feite is $O p$ dezelfde wijze kan ook een beschermende werking van een bepaalde factor ten onrechte worden gesuggereerd. Als voorbeeld wan dit laatste noemt Feinstein het onderzoek van Pean uit 1929, die concludeerde dat tuberculose een antagonistische werking heeft ten opzichte van kanker. Hierop volgde een serie pogingen om met behulp van tuberculine kanker te bestrijiden. ${ }^{78}$

- Wer dit bovendien heeft geleurd, zal bij pratięnten met moeheid valak een $\mathrm{Hb}$ worden bepaxald - laten we zeggen: in 80 procent van de gewallen. Bij spreekuurbezoekers zonder moeheid geschied $\mathrm{dit}$ veel minder valak: in ons voorbeeld bij 8 procent van de gevallen.

In tabel 3 zien we wat er nu gebeurt. Hoewel er geen verband is tussen moehelld en anemie, wordt een veel groter deel van de patienten met anemie in de moeheidsgroep "Ontdek" dan in de groep zonder moeheid. Dilt heeft tot gevolg dat van de anemiepatienten die "ontdekt" worden, ruim tweederde dee moeheidsklachten theeft.

Vooral als de huistarts bij het opbouwen van zijn ervaringskennis alleen of hoofdzakelijk afgant op de symptomatologite van ontdekte gevallen, zal een sterk werband tussen afwijking en symptoom worden gesuggereerd. Het verband is echter louter het produkt van de eigen indicatiestelling. Om begrijpellijke redenen zullen negatieve bevindingen in de dagelijkkse praktijk minder aandacht krijgen. Praktijkervaring kan dan bedriegelijk zijn.

\section{Roferientiegroeplen}

Huisartsen die deze walkuil willen ver. mijden, zullen wellicht beswiten tow het verrichten van wen wergelijkend onderzoek. Men moet dan wel een juiste controle- of referentiegroep kiezen.

Stel om te beginnen dal gekozen zou worden voor een vergelijilking wan de ontdekte anemiepatiềnten met een steekproef uilt de overige pattiènten die het spreekuar bezoeken. Bij beide groepen wordt nagegaan hoe vaak er moeheidsklachten zijn gepresenteerd. De indruk zou nu bevestigd worden dat er een sterk verbiand bestal tussen moeheid en anemie: in wergelijking met de anderen "hebben ontdekte anemiepathënten in dit rekenvoorbeeld bijna wiermaal zo vaak moeheidsklachten, namelijk 69 tegenower 18 procent. Dit blijft wrijwel ongewijzigd het geval, als men de referentiegroep als geheell een Hbmonderzoek laat ondergan orn daarmee andere anemiegevallen van de vergelijiking uit te sluiten (controlegroepen a en b in tabel 4 .

Een nog sterkere vertekening is het resultatat als de huisarts besluit om als referentiegroep een random steekproef uit de praktijkpopulatie (c.q. de algemene bevolking, inclusief de nietspreekuurbezoekers) te kiezen, al dan niet met uitsluiting van patiénten met anemie: bij de ontclekte anemiegevillen komt nu bijna zevenmaal zo vaak moeheid voor: 69 tegenover 10 procent (controlegroepen c en $d$ in tabel 4).
Tabell 1. Rekenwoorbeeld over hel vóórkomen van anemie en moefietid in de algemene bewolking.

\begin{tabular}{|c|c|c|c|}
\hline & $\begin{array}{l}\text { Anumbe } \\
\text { (b) }\end{array}$ & $\begin{array}{c}\text { Gieten Antmic } \\
(\mathrm{D}-1)\end{array}$ & Toutaal \\
\hline $\begin{array}{l}\text { Moe (s) } \\
\text { Niet moe }(5-)\end{array}$ & $\begin{array}{r}500 \\
4500\end{array}$ & $\begin{array}{r}9.500 \\
85.500\end{array}$ & $\begin{array}{l}10.000 \\
90.000\end{array}$ \\
\hline Totaral & 5,000 & 95.0000 & 100.000 \\
\hline
\end{tabular}

$P(s)=P(s(b)=P(s) b-)=10 \%$

$P(D)=P(D \mid s)=P(D)-j=s$

Thbel 3. De ondekking van anemie door de huisairts in relavie tor de klach

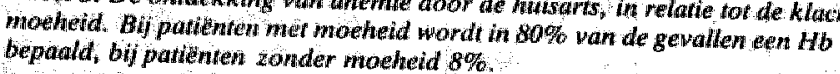

\begin{tabular}{|c|c|c|c|c|}
\hline \multirow{2}{*}{$\begin{array}{r} \\
-\quad 3 \quad \\
\end{array}$} & \multicolumn{2}{|c|}{ M Moe $(S)(n=2000)$} & \multicolumn{2}{|c|}{ Niet moe $(s-)(n=9000)$} \\
\hline & Anewiou (D) & Geen antemie $(\mathrm{D}-)$ & Anemile (D) & Geen anemie $(\mathrm{D}-)$ \\
\hline $\begin{array}{l}\text { Bepaald } \\
\text { Niet bepanald } \\
\text { Totaal }\end{array}$ & $\begin{array}{r}80 \\
20 \\
100 \\
\end{array}$ & $\begin{array}{r}1520 \\
380 \\
1900 \\
\end{array}$ & $\begin{array}{r}36 \\
414 \\
450\end{array}$ & $\begin{array}{r}684 \\
7866 \\
8550 \\
\end{array}$ \\
\hline
\end{tabular}

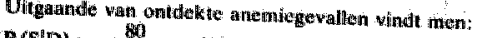

$P(S \mid D)=\frac{80}{80+36}=69$

$$
80+36
$$

Tabel 2. Her vóórkomen wan anemie en moekeid in de populatie personen die de huisarts consulteert.

\begin{tabular}{|c|c|c|c|}
\hline 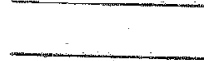 & $\begin{array}{l}\text { Akgsanic: } \\
\text { (D) }\end{array}$ & $\begin{array}{l}\text { Geen Ancinic } \\
(D-1)\end{array}$ & Tôtad \\
\hline $\begin{array}{l}\text { Moe (S) } \\
\text { Niet moe }(S-)\end{array}$ & $\begin{array}{l}100 \\
450\end{array}$ & $\begin{array}{l}1.900 \\
8.550\end{array}$ & $\begin{array}{l}2.000 \\
9.0000\end{array}$ \\
\hline Totaal & 550 & 10.450 & 11.0000 \\
\hline
\end{tabular}

$P(S)=P(S \mid D)=P(S \mid D-)=T$ W

$\mathbb{H}(\mathrm{D})=\mathrm{P}(\mathrm{D} \mid \mathrm{S})=\mathrm{P}(\mathrm{D} \mid \mathrm{S}-\mathrm{S}=\mathrm{s}$.

\section{Toelfchiting}

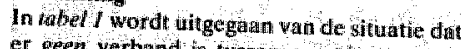
er geen werband is tassem anemule rem mosheid. Het voorbied heeft betrelking op een asmecte steekproef wit de algememe bevol$\operatorname{sing}$

War de mensen met moeheid buzocht 20 procent de husarts, wan de mensen zonder moehet 10 procent. Dit is weergegeven in

Vervolgems wordi bij patienten net moeheid in 80 procent van de gevallen en $\mathrm{Hb}$ be pasid en bij patienaten zowder moeheid in 8 procent van de gewallen fabel 3 j. 
Uirgaande van de oorspronkelijke groep patienten die de huisarts bezoekt en een Hb-onderzoel krijgt, zouden in dit geval twee juiste vergelijkingen zijn te maker (iaber 5 ).

- Her wergelijken van de percentages anemiepatienten vonder de onderzochte pattënten mét respectievelijk zonder moeheidsklachten (beide 5 procent $=$ $8011600=36 / 720$ )

- Het vergelijken van de percentages personen met mocheidsklachten bij onderzochte patiënien met en zonder anemie (beide 69 procent $=80 / 116=1520$ $2204)$.

Het is dudelijk dat het bij deze vergelijkingen om dezulfile subgroepen patienten gaat. dic echter in een andere richting met elkatr worden vergeleken.
Andere benaderingen voot het onderzoeken van het verband tussen de klacht moethed en thet $1 \mathrm{t}$ vanuit de huisartspraktijk zijn:

- Het trekken van een random steekproef van spreekuurbezoers, Bit hen wordt geinformeerd naar eventuele moeherdsklachten en tegelijkertijd wordt thet $\mathrm{Hb}$ bepaals, Op deze wije wordi vermeden dat de indicatiestelling door de arts vertekening veroorzankt. Een beperking van deze methode is dat niet alleen die moeheidsklachten worden gemeld die tot doktersbezoek hebben geleid (iairotrope klachten ${ }^{15}$ ), maar ook allerlei andere wellicht minder ernstige moeheidsklachten. Niet uitgesloten is dat iatrotrope klachten in het algemeen anders van aard zijn dan miet- latrotrope (bijwoorbeeld wa een etique te opgespoorde) khachten, ool wat betreft hur eventuele verband met het $\mathrm{Hb}$. Voor de huisarts aijn met name de ibtro trope klachten van belang als startpount van het handelen.

- Met systematisch bij alle patienten dis met moelieid het spreekun betoe ken. het Hb bepalen en dit ook doen buj een referentiegroep vam willekeurige spreakuturbezokers zondw moeheid, en met klachten of problemen die geacht worden niet met het Ho samen te hangen.

Dit laatste is van belang ondat het goed mogelijk is dat in de groep personen zonder moeheid, matr met een kenne lijke indicatie voor en 1 bb-bepaling. meer anemie voorkom dan bij nnieti:
Tabel 4. Vergetijkend onderzoek wanuit de huisartspraktijk maar hei verhand tussen anemie en her vórkomen wan moeheid, op basis van de gegevens in de wabellen 1 en 2, bij de. keuze van verkeerde referentiegroepen.

\begin{tabular}{lcc}
\hline & $\begin{array}{c}\text { Percentage } \\
\text { moe }\end{array}$ & Berckeningswijze \\
\hline $\begin{array}{l}\text { Door de huisarts } \\
\text { ontdekte } \\
\text {,anemiegevallen. }\end{array}$ & $69,0 \%$ & $\left(=\frac{80}{116}\right)$
\end{tabular}

a Alle

spreekuurbezoekers

exclusief

de ontdekle

anemiegevallen

$$
17,6 \% \quad\left(=\frac{1520+380+20}{11,000-116}\right)
$$

b Alle

spreekuurbezoekers

exclusidef

alle anemiegevallen

$$
18,2 \%\left(=\frac{1520+380}{1.000-(116+434)}\right)
$$

c De praktijkbevolking exclusief de ontidek $\|^{*}$ anemiegevallen

$$
\begin{array}{r}
9.9 \% \quad\left(=\frac{10.000-80}{100.000-116}\right) \\
10,0 \% \quad\left(=\frac{10.000-500}{100.000-5000}\right)
\end{array}
$$

Tabel 5. De correcte vergeliking met betrekking tor het warband iussen moeheid en anemie, uitgaande van de ont. dekne "anemicgevallen" de referentiegroep wordi gevormd door de onderzochte personen met en normaal Hb-gehalte.

\begin{tabular}{lrrr}
\hline & Anemie (D) & Geen anemie (D) & Total \\
\hline Moe (S) & 80 & 1520 & 1600 \\
Niet moe (S-) & 36 & 684 & 720 \\
Total & 116 & 2204 & 2320 \\
\hline
\end{tabular}

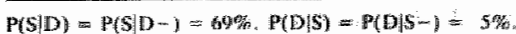

\begin{tabular}{|c|c|c|c|c|c|}
\hline \multirow{2}{*}{$\begin{array}{l}\text { Ho heparald } \\
\text { foor huisurts }\end{array}$} & & \multicolumn{2}{|r|}{ Moe } & \multicolumn{2}{|c|}{ Nien nowo } \\
\hline & & atomise & gecon aneamice & anserbic & perel andentits \\
\hline ia & : & 80) $p$ & 15209 & $36 p$ & 6849 \\
\hline nemen & $\therefore$ & 209 & 3809 & 4149 & 7866 \\
\hline
\end{tabular}

Tabel 6. Berekening wan het pencentage patienten dat moe" heidsklachten heeft in diverse subgroepen van do werwezen patienten.

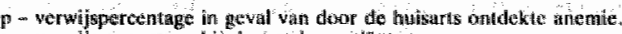
4- - verwijspercentage bij de overige paitienten.

\section{Percentage moeheid in diverse subgroepen}

a Door huisarts ontdekte anemiepatiënten

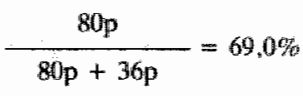

b Overige verwezen patienten

$$
\frac{1920 q}{1920 q+8964 q}=17.6 \%
$$

c Overige verwezen patienten met uitzondering van de na verwijzing nieuw ontdekle anemiepritienten

$$
\frac{1900 q}{1900 q+8550 q}=18,2 \%
$$

d Door huisarts ontdekte aniemiepatienten én de nat verwijzing nieww ontdekte anemiepatienten tezamen

$\frac{80 p+20 q}{116 p+434 q}=\begin{aligned} & \text { afhankelijk van } \\ & \text { verwijstracties } \\ & \text { pen } q\end{aligned}$


gerndiceerden", Een evenueel werschil zou dan kunnen worden verdoezeld. On ruis te voorkomen. zou men de

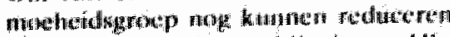

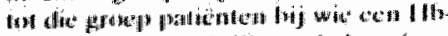

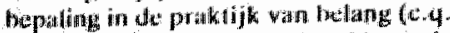
geindiceerdy wordt geacht. Voor we hand liggenue verklatingen vour de

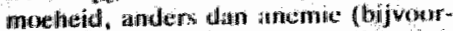
beeld overbelasting) dienen dan eserst vitgesloten te worden.

\section{Verwifling 1}

De huisarts zal vaak prolteren de pa tienten bij wie tunemie is gevonden, te bethandelen, bifvoorbeeld met ijzerthe tapie. Uit onderzoek is echter bekend dat dit in cen aantal gevallen wel het Ho doet stifgen, maar het vertoop wan de moeheidsklachten niet beinvloedt." Stel dat de huisa rts een bepald deel van de patienten met "anemie" verwijst naluar de specialist, bijvoorbeeld de internist. Wij bezien allereerst de - minst redie - situatie, walarin de kans op ver. wijzing alleen wordt beinvloed door de gevonden anemie, en niet door het al dun niet moe zijign.

In deze situatie geldt dat de werhouding moe/niet moe onder de ontdekte anemitugewallen dour verwijuing niset wordt beinwloed. Dus van de door de huisarts ontdekie en verwezen patienten met een onverklaarbare anemie, zall nog steeds ruim tweederde deel moeheidsklachten hebben en het overige eenderde deel niet (a in fabel 6 ). Dit betekent dat de specialist, evenals de huitsarts, afgaande op zijn ervaring dat anemie vaak met hardnekkige moeheid gepaard gaat, gesteund zal worden in de opvatting dat anemie vaak met hardnekkige moeheid gepaand gaat.

Gok de speciallst ka nu door middel van vergeliflkend onderzoek proberen na te gaan, of zijn indruk dat amemiepatienten relatief vakk moe zijn, juist is. Voor de specialist is thet daarbij veell moellijker dan woor de huisarts om wen juiste referentiegroep te vinden. Men zou weer on ste kproaf kummen nemen Bit de lokate algenme hevolking. Omdat histom sluchts 10 procent moeheidsklachten heeft, zal - ten onrechteeen sterk verbund workten gesuggereerd. We beschrowen dize valkuil al then angien van de huisarts. Een lets minder grote vertekening zou optreden, Indien als referentiegroep gekozen wondt voor (een steekproef wit) de overige verwezen patienten, bij wie de huisarts geen anemie lieeft ontdekt en die on andere redenen aijn verwezen. Voor hel gemuk zow men dexe groep kunnem laten repiresenteren dow eén bepaalde

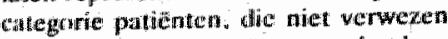

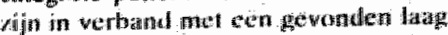

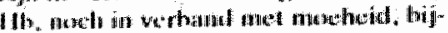
woubetd verwezon patientan die preopeitativer worden onderechl in ver-

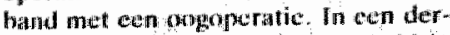
gelijke referentiegroup tall motheid in ongeveer 18 procent van de gevallen woorkomen Daarbil makt het opnieu niet veel ait of de na verwiping bij routine-onderzoek alsinog onitekte anemugevallen wel of niet worden tritgestoten wan de referentikgroep (b en c in tabel 6 .

Dit alles betekent dat er in geval van vergelijking met de verwezen anemiepatienten nog steeds een duidelijik verband tussen anemie en moeheid wordt gevonden.

Juiste benaderingen zouden zijin:

- Teruggaan naar de bron, dat will zeggen opsporen van alle patiënten die bij de huisartsen een Hb-onderzoek kregen ${ }_{n}$ inclusief de niet verwezen patienter. Men zoul nu, indien men het $\mathbb{H b}$ atan het al dewn mitet gepresenteerd hebben van de klacht moeheid koppelt. vabel 5 weer kunnen opstellen.

- Terugprojecteren van de bron. Hiertoe moet men weten of kunnen schatten:

- de fractie van de ontdekte anemiepateenten, die door de huisarts is verwezen (p);

- de fractie van de overige patiënten die is verwezen $(q)$.

Naast de reeds ontdekte anemiepatienten wordien nu door de spectalisten oak de overige verwezen patiënten (of een representatieve steekproef uit die groep) op anemie gescreend, en wan allen wordt genoteerd of de klacht moeheid is gepresenteerd. De pass na verwijzing ontdekte anemiegevallen wordien bij de anemiepatienten gerekend. Met behulp vam de verwijsf tracties en de absolute aantallen verwezen patienten per categorie kan nu een correcte vergetijiking worden ge(re)construeerd tussen alle anemiepatienten en de referentiegroep (tabel 7 ).

- Het vinden vam een (polit)klinische referentiegroep in de naar de specialist verwezen patientenpopulatie die noar aanlealing van de klacht moeheid door de huisarts precies even sterk geselecteerd is, als de door de huisarts ontdekte en yerwezen anemiepatienten.

Het is duidelijk dat deze benaderingen in de praktijk zeer moeilijk en dikwijls. niet uitwoerbaar zullen zijn. Het achter- af terugwindem van de bromi wan $\mathrm{Hb}$ onderzoken verricht door de huisarts met indicaties, kachicen en vitslagen,

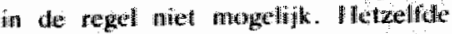

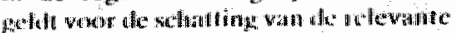
verwijsfraties. Het achtoraf kiezen van ess qua moeheid vergelijkbar gestec-

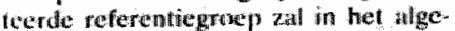

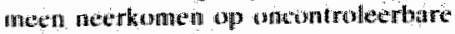
veronderstellingen op dit punte.

Kumen speciallsten vonuit hum situatie dan helemaal geen voor de huisarts relewate warmemingen doen met betrekking tot het verbaind tussen sympionen en axudoeningen?

Dat kan, en daartoe moeten zij uitgaian Van de verwezen patiënten bil wie de huilisarts yoor de werwijzing geen Hb heeft bepaald, en een vergetijking maken tussen de wolgende twee percentages:

- het percentage van de patiënten met anemie dat de klacht moeheid presenteert;

- het overeenkomstige percentage bij de patienten met een normaal $\mathbf{H b}$.

Wit tabel 8 blijkt dat nu inderdaad geen verband tussen moeheid en een la $\mathrm{g} \mathrm{Hb}$ wordt gevonden. Dit komt doordat de groupen die nu met alkar verageleken worden, via verwijzing in gelijke mate ten inanzien wan de klacht moetheid zifin geselecteend (niet beïnvloed door ken" nis over de (Hb-waarde). Voor het kun:nen maken van deze vergelijking is weer nodig dat ook de patiênten die verwezen zijn om andere redenen dan een laag $\mathrm{Hb}$ (of een steekproef waw hen), na verwij. zing een Mbonderzaek krijgen.

Het is tot nog toe niet gebuikelijk om het verband tussen symptomen en diagnosen te onderzoeken bij patiēntem die juist nigt voor de betreffende diagnose. zijn verwezen. Blijkens onze andyse is dit ten onrechte. Op dit gebied zoucten specialisten en ziekenhuizen weleens een belangrijke bijdrage kunnen leveren ana de ontwikkeling van huisartsgeneeskundige kennis inzake het verband tussen klachten en ziekten. De contatpopulatie van de specialist is nu eemmat beter bereikbaar voor wetensehappelij $\mathbf{k}$ ondertoek. De meet- en onderzoeksmetilhoden xijn gemakkelijk te standwardiseren; er is minder interobservervariatie te verwachten, en er zijn organisatorische voordelen. Zelf passen wi deze benadering op dit moment toe in cen onderzoek natr het werband tussen: dyspepsie en galstenen.

Een probleem bij deze methode is, dat valk miet bekend zal zijn of de huisarts vór de verwijzing wel of niet diagnostiek heeft verrichi ten ameien wan de 


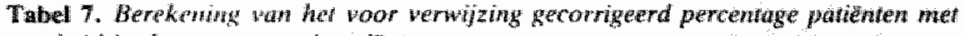

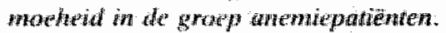

- Stel dat na verwhaing de wolgende verdeling van anemiegevallen in relatie tot moeheid wordt gevonden: Mow Nat

Na verwijzing ontdekte anemie B

C D

- Dan geldt dat de verdeling van de subgroepen spreekurbezoekers van de hutsarts, waaruit deze patienten voortkomen, als volgt is:

Door de huisarts ontdekte anemie

Door de lwisarts niet ontdek te anemie

Moe
$\begin{aligned} & \text { Nipt moe } \\ & \text { C/q }\end{aligned} \quad \mathrm{B} / \mathrm{D} / \mathrm{q}$

- Dan is het percentage moeheidspatienten bij alle patienten met anemie in de oorspronkelijke spreekumpopulatie wan de huisarts (- voor verwijzing gecorrigeerd percentage moeheid bij anemiepatienten):

$$
\frac{A / p+C / q}{A / p+B / p+C / q+D / q}
$$

- In het woorbeeld is dit gelijk aan:

$$
\frac{\frac{80 p}{p}+\frac{20 q}{q}}{\frac{116 p}{p}+\frac{434 q}{q}}+18.2 \%
$$

- Dit is weer gelijk aan het percentage moeheidspatiènten in de categorie owerige werwezen patienten, met uitzondering van na werwijzing nieuw-ontdekte anemiepatienten (zic tabel 6c):

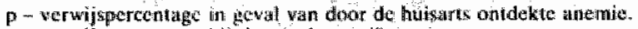

q- werwijspercentage bif idw owerige patienten.

betreffende arodoening (iin ons voorbeeld: het bepalen van het (lb). Wanmeer thet voor yerwijaing reeds verrichte onderzoek met uitslagen, ook als deze megatief zijn, systematisch in verwigsbrieven zou worden vermeld, is dit echter op te lossen. Eventueel kan, in het kader van een onderzoek. additionele informatie betreffende de reeds door de thusarts verrichte diagnostiek worden irigewonnen.

Als de specialist volgens deze benadering te werk zou gan zal het vooral om die ziellegewallin garn. waarbij de huisarts geen indicatie heeft gesteld tot diagnostiek ten thute yan de ziekte. Dit zullen in hel allomeen minder evidente. en minder onnwkkelde gewallen zijn. Het zin juist duze gevallen waraver het minst bekend is, en kenmis hierover is voorall wan belang voor de diag nostiek van de huisarirts.

\section{Verwijzing II}

De tweede verwijssituatie - waarir de kans op verwijzing ook wordt betrwloed door thet hebben wan hardneklkige moeheidsklachten - is het meest rees. omdat hardnekkige moeheid een extra reden kan zijn om iemand met cen laag Ho te verwijzen.

In deae situatic is te verwachten dat er onder anemepatienten naar verhou. ding nog waker moeheid zal worden gevonden. Omdat nu de ontdek king wan anemie en de klacht moeheid een rol spelen bij.j de selectie ten gevolge wan de verwijzing. zijn de in de vorige paragraf beschreven onderzoeksbenaderimgen nog veel moeilijker toe te passen, zowel daor hun complexiteit als door de benodigde gegevens. Zo zal wor elk wan de viet mogelijke combinatie van klachtenparroon (moe/nict moe) en $\mathbf{H b}$ -
Tabel 8. Vergelijking vain her percennage patidnten dat moelnewdsklachnen heof binnen de growe owenge werwezen patienter (met en ander anewio) bij wie vor nerwizing doom alle whisarts geen $H b$ is bepantd regewn antlend an tabe (6).

\begin{tabular}{ccc}
\hline & Antmine & Oeon anemise \\
\hline Moe & $20 \mathrm{q}$ & $380 \mathrm{q}$ \\
Niet moe & $414 \mathrm{q}$ & $7866 \mathrm{q}$ \\
\hline
\end{tabular}

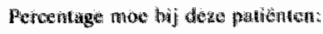

$$
\begin{aligned}
& \text { met anethe } \frac{20}{4340}-46 \% \\
& \text { zomder anemle: } \frac{2804}{82464}=460
\end{aligned}
$$

waarde (wel/niet anemie) een eigen verwijsknns golden.

Ools nu is het echter 20 dat binnende categorie patienten, die niet in verband met anemie verwezen zijn en bij wie voor de verwijzing geen $\mathrm{Hb}$ is bepald, het verband zonder vertekening te bestuderen is. De binnen deze cattegonie alsnog te indentificerten anemiepa tiënten zijn namelijk ten aanzien van moeheid weer even s'terk geselecteerd als de te indentificeran patienten zonder anemie.

In werkelijkheid zijn ar nog meer problemen dan we bespraken. Van de diverse subcategorieàn van de groep „overige" verwezen patienten zullen in de regel geen gegewens bekend zijn over thun specifieke verwijsfracties. Meestal zal men ook te weinig weten over een eventweel verband wan de betreffende diagnosen en thun verwijsfracties enerzijds met het Hb en/of de klacht moeheid anderzijds. Ook de invloed van ernst en de aard van de klacht of het klinisch beold op de werwijizing is onvol. doende bekend. Alleen prospectief onderzoek in samenwerking met huis: artsen, watbij witgegenan word wan de conitactpopulatie van de hussarts, ikan de problemen wat betreft de opgetreden selectie nar de specialist toe definitier oplossen. Zoals gezegd, kan onderzoek bij patienten die werwezen zijn om andiere redenen dan de te bestuderen dia gnose, een arivarabar alternatier bieden:

\section{Beschouwing}

In het voorgatinde is atugetoond dat een bepaald ingeslete of aangeleerd diagnostisch gedrag ten a anzien wan het verband tussen symptomen/k lachten en diagnostische bevindingen ean self-fullfilling prophecy-effect te weeg kan bren * gen. Het betreffende verband kan dan 


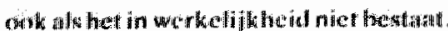

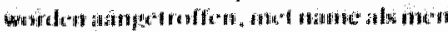

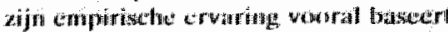
op positieve bevindingen. Im de huistartspraktijk zijn dergelijke indrukken door een goed vergetijkend onderzoek nog wel te worrigeren. Uitgatande van en popullatie verwezen patięntem, is dit veel moeilijker, en vaak onmoge nijk.

Op allerle niveaus kunnen er selectiemechanismen werkzam zijin die schijwerbanden opleveren. Achtereen volgens kan men onderscheiden: de algemene bevolking, bezoek an de huisarts, resultaten van diens handelen, werwijzing naar een (beparald) speciallisme. unterspecialistische verwijzingen (bij) voorbeeld wan kleinere zickenhuizen naar grotere, voorzien van superspecialismen), ziek enhuisopname, bevestiging van diagnosen door middel van pathollo gisch anatomisch onderzoelk of sectie. Bij elk van de tussenstappen wan het ene naar het andere nivea wordt geselecteerd op girond vam betgeen men heeft geleerd.

Sohynverbanden kumnen ook ontstaan ten gevolge wan het publiceren in bekende tijdschriften van rase-reports betreffende bijzondere klinische waarnemingen, zoals een nog niet eerder beschreven combinatie van symptomen. Zo"n ase-report kan atanleiding geven to het verzamelen van alle nieuwe of in thet verleden niet "herkende" gevallien met dit symptomencomplex. Op grond van zo'n patientenserie kan dan cen nieuw syndroom in het llewen worden geroepen. Vaak is de noemer van de epidemialogische breuk watrvan deze serie gevallen de teller is, niet meer bekend of krijgt deze geen aandacht, evenmin als do wijhe vari selectite van deze gevallen. Toovallige combinaties kunnen dan de status van whdroom krijgen, wonden doot alerte warnemers (en wie wil dat niet zijn) daurna waer regelmatig gezien. Het lijkt interessant on vain een anntall beschraven syndromen zonder duidellijke verklaring (zoals de Trias van Suint: galstenten odiverticulosis -hiatus hernia) niti te gaam of een dergelijk meshthisme aan de onde kun zijn. Verlokendle vertwinden kunnen weer viarpalkt woriden in medisch onderwijs, of op Klinische bijeenkomsten als belang. nithe diagnostische anagripingspunten yoor huisartsen nas voren worden gebracht.

Ein zo wordt de cirkel gesloten. Men credert wat men doceert, men doceert wat men creedert.

Het is al met al erg belangrijk dat men tellkens de bevindingen op een bepaald
Forgnivea (echelon) op de juistle wijae

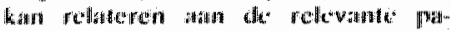

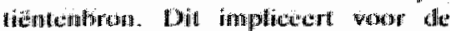
huisartsgeneess kumde:

- het verrichthen wan onderzoek, juist vanaf het niveau van de huisartspraktijk:

- op grond daarvan eventueel het bijstellen wan de onderwezen kennils over bijwoorbeeld symptomatologie;

- het verrichten van onderzoek naar de samenhang van klachten en ziekten bij patiënten die verwez'en zijin om andere redenen dan de betreffende ziekten.

\section{We maken nog enkele algemene opmer- kingen.}

Men kan zeggen: het gaat om het stellen van een diagnose en niet om de precieze weg waarlangss dat gebeurt. Als daarbij gebruilk wordt gemaakt van vertekende verbanden, is dat op zichzelf niet erg. Deze redlenering klopt niet. A Is men het stellen van de diagnose inderdaad relevant windt dient men zich niet te baseren op weinig of niet-informatieve diagnostische gegevens. Als deze gebruikt worden om te selectieren woor nader diagnostisch onderzoek, zullen in elk geval veel diagnosen gemist worden. Men had dan met zo goed een dobbelsteen kunnen opwerpen, of men had Hedereen aan het betreffende onderzoek moeten onderwerpen om het missen van veel diagnosen te vermijden.

Men kan ook zeggen; de verbanden die zich in de loop der jaren in het medisch kennissysteem hebben uitgekristaliseerd, zijn naar woren gekomen vanuit een in oorsprong , blanco" situatie. Dat will zeggen een sutuatie wavrin artsen niet gebiased waren door onderwijs op basis van een vertekende warneming. De verbanden zullen in het algemeen dus wel kloppen. Deze bewering zou opgaran als er in de tijd niets veranderde ten anzien van het verband tussen symptomen en diagnosen. Dit ligt ech. ter niet voor de hand. Ziektebeelden (huin ernst, de wijze waarop ze zich manifesteren en de diagnostische criteria) zijn wel aan veranderingen in een tifd onderhevig, evenals huin verhouding tot andere, deels nieuwe andoeningen en ziektebeelden. Bovendien is symptomatologie, behalve historisch, ook cultureel bepalald: de klachten wermagering en moeheid hebben in Nederland anno 1985 een theel andere betekemis dan in de Derde Wereld, of in Nederland anno 1885.

$\mathrm{Er}$ is ongetwijfeld een zekere tramgheid" in de ontwikkeling van de kemis over symptomatologie. Symptomatologie wit vervlogen tijden kan ons in de han houden en ingesteten routines workellen hatsi per defintic bot sterkst in

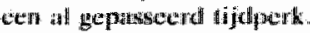

Dat lejdt tot nog een conclusie: het is van belang. van tijd tot tijd bepaalde washeden op het gebied van de symp. tomatologie nog eens te onderzoeken. ook als dit in het verleden reeds correct is gebeurd. Dit onderzoek zou vooral gericht moeten worden op aspecten die gevoelig zijn voor veranderingen in de tijd. De hier beschreven selectiefenomenen gelden bovendien ook in omgekeerde zin: als men bestaande verbanden niet kent, zal men ze ook niet gauw op het spoor komen. De ontdekking van minder sterke verbanden is zeer afhankelijk van de beschikbaarheid van op. lettende waarnemers. Voor de huisartspraktijk kunnen dat alleen huísartsen zijn.

'Berkson J. Limitations to the application of fourfold table analysis to hospital data. Biometrics Bull 1946; 2; 47.54.

2 Rümke Cl, Gevaren woor onjuiste conclusies uit gegewens in ziekenhuisarchieven (Berkson's fallacy). Ned Tijdschr Geneersed 1970; 114: 766-72.

${ }^{3}$ Boydd A V. Testing for association of diseascs. J Chron Dis 1979: 32: 667-72,

4 Sturmans F. Epidemiologie, theorie, methoden en toepassing. Nijmegen: 1982. Dekker \& Van de Vegt.

"Peritz E. Berksons bias revisited. J Chron Dix 1984, 37: 909-16.

" K'leinbaum DG, Kupper LL. Morgenstern H. Epidemiologic research, principles and quantitative methods. Belmont (Ca): Wadsworth, 1982.

${ }^{7}$ Feinstein AR. Clinical biostatistics. Saint Luuis: Mosby. 1977.

"Pearl R. Cancer and tuberculosis. Am J Hyg 1929; 9: 97-159.

"knotherus JA Intorpretatie van diagnostische gegevens. Huisarts en Wetenschap 1983; 26: 363-8.

19 Knipschild PG, Dyspepsite en galstenen Practitioner (Ned uitgave) 1984: 1: 1126-9.

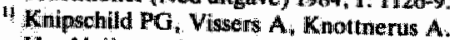
Hoofdpijn hoge bloeddruk. Uitkomsten van een bevolkingsonderzock in Am sterdam. Huisarts en Wetenschap 1984: 27: $441-5$.

"ne Elwood PC. Waters WF, Greene WrW, Sweetnam P. Wood MM. Symptoms and circulating haemoghobin level. I Chron Dis $1969 ; 21 ; 615-28$.

Wood MM, Elwood PC. Symptoms of iron deficiency anemia, a community survey. Br J Prewent Soe Med 1966: 20: 117-21.

"Knotmenas A. Knipsehild PG. Hemoglobine en anaemische" klachten zoals moeheid. Tijdsehr Soc Cezondheidszong 1983; 61: $788-92$.

" Fuinstein AR. Clinûcal juigement. New York: Kruger, 1967. 
DEEEL II

ENKKETE OBSERVATIONETE ONDERZOEKINGEN NAAR HET VERBAND

TUSSEN KIACHTEN EN DIAGNOSTISCHE BEVINDINGEN. 


\section{Hoofdpijn en hoge bloeddruk}

\author{
Uitkomslem wan oen hevalkingsonderoosk in Amsterdam
}

\author{
PAUI. KNIISCIIII.I), AD VISSERS EN ANDRE KNOTTNERUS
}

\begin{abstract}
Het is nog steeds niet duidelijk, of hoofdpijn een woorspellende betekenis heeft voor de aanwezigheid van hoge bloeddruk. In dit artikel wordt, met behulp van de uitkomsten van een bevolkingsonderzock onder 3695 Amsterdammers van 4/-43 jaar, onderzocht of een dergelijk verband hestath. De frequentie en ernst ven de hoofdpijn werden afgemeten an het gebruik van middelen tegen hoofdpijn. Bij de 199 declnemers die deze middelen frequent geloruiklen, was de 1 lowdelruk geniddeld $128 / 81 \mathrm{~mm} \mathrm{H}$. tegen I.3a/RI mm I Ig trij de owerige deelnumers. Een diastolische bloctdruk van $105 \mathrm{~mm}$ Hg en meer werd iets vaker gevonden in the hoofdpijngroep dan in de controlegroep.
\end{abstract}

\section{Inleiding}

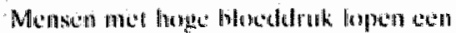
helangrijk risicosom bepatak zitkten he

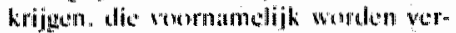
woratak door diun wethelasting end dardow versidechterende functio wan hot

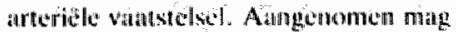
worden dat het risico wordi verkleind doon tijduge opsporing en verlaging van de hoge bloeddirak. Diaturom wordien voortulurend pogingen onderomen on metosen met hoge bloctuluk te nondek-

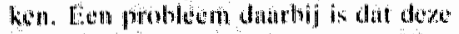

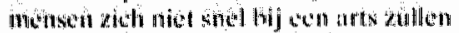

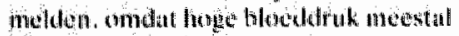

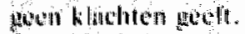

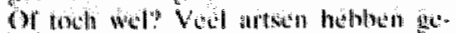

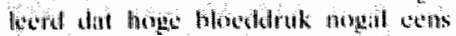

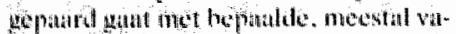

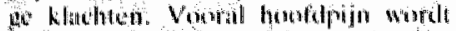

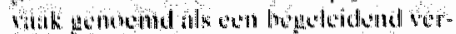

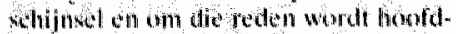

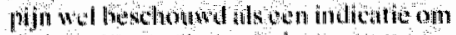

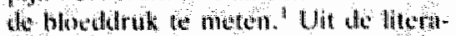
tuiar (knder op phaina 444 ) is civenwel hwit dudelijk op to nokem. of er inder-

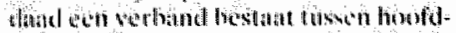

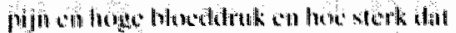

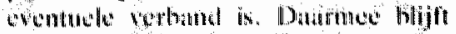

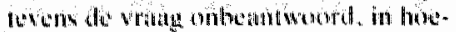

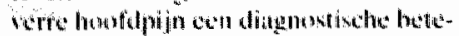

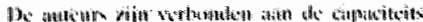

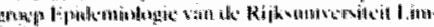
binge. kenis hecf voor het opmoresen wan hoget

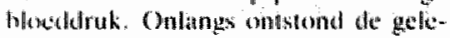

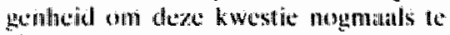
bestaderem

\section{Methode}

De gegewens werden verzaneld in het kader wan een bevolkingsonderzoek ter opsporing van risicofactoren voor hartcn valzieleten in Amstordam, het zogeheten Consultatie Burcenu Project. De afduling Bevolkingregister van de gemeence werdrekte een lijst van alle persumen, woonachtig on Amsterdam en gethoren in 1937 (bowingers van de Wes tolijke nuinsteden $193(6)$. In de periode nowembit 1477 tot september 1980 ontvingevin $2+22$ mannen en 2748 vrouwen.

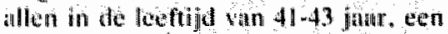

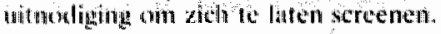

Vun de mannen nam 11 procent en van de vrouwen 4 procent onet aan het onderandek deet, omdat men onlangs delers al geseresnd was op deze nistofactoren (rooral via het commproject in te be (drijuen). Bovendiendeed 3 procent win die matroci en 2 procent valn de vrouwen nut hee. ondat men all onder behandeling wis we gens een hartackte. Tenglotto nam 19 procent won de mannen en t8 procent wan de wrouwen niet and het underzoek deel zonder opgave van redenea. Datrmee bestond de onderzockspopollatic uit 1647 mannen (6x) procent) en 2048 vrouwen ( 75 procent):

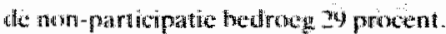

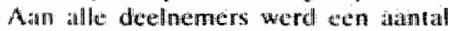
mond linge wragen gesteld, watron enhete andingen waten verricht. Vourde inderhavige vratagstelling waren vooral

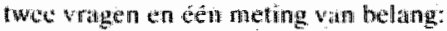
- Mosfipaja ln do vragenlijar was de volgende vrate openenten Gebruikt is wel ens middelen legen hoofdpijn (aspurine of dergelijke)? 20 ja. doet u dit asden. iedere mand, iedere week. iederi dag. in periodes?" Helazs werd miet directer nata hoofdpijnk lachten gemangd. Voor onze anallyse is een driedeling gemalkt. personen die zelden of nooit hoofdpijnmiddelen gebruikteln, persomen die iedtere matind fof in perroden) howdtoijnomiddelen gebruikten en personen dic todere week

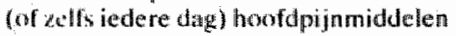
achruikton.

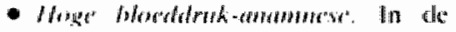

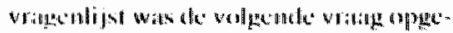
nommen: Is bij th avit cen verhougde

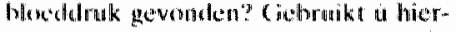

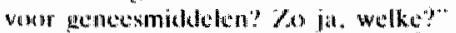
Alus was het mogelijk am de relatio tuscion hoofapijn en hoge houddruk infirlt le besluderen voor persometh mint cull hekende li. on. onbekende hoge blocudruk.

- Bloneddrukmeting. Bij alle deelnemors werd de bloeddruk op gestandatardiscerde wijge gemetern met en gewo$n c^{\circ}$, regelmatig geijkle kwik-minometer. Dit gebeurde terwijl de deenteners gezeten waren, met ontbloot bovenlijf. Indien meer metingen waren verricht, is volor de analyse steeds de eerste meting genomen. Als systolische bloeddruk werd de warde genoteerd. watarbij voror het eerst misch doorgande tow men worden gehoord. Als diastolische bloeddruk werd de warde aangehoudun. Warbiji net geen tonem meer hoorbasti waren. biblialve als de tonen hoorbatat hileven tot $0 \mathrm{~mm} 1 \mathrm{hg}$ of dicht daathij: in dat gevall werd het moment wan diudelifk zachter worden wan de tonen genolecerd.

\section{Resultaten}

Alvorens in te gaan op de vraag of hoofdpijn een voorspellende betek enis. heeft woor de hoogte van de bloeddruk. wond cerst gekeken natr dis mogelijh" heid van iatrogene hoofdpijn.

Uit rabel $I$ blijkt datt 604 van de 3695 deelnemers meldden datil bij hen ooit een verhoogde bloeddruk wiss gewonden. In deze groep gebruikte's procent (24) personen) iedere week middolen leyen hoofupijn en 80 procent $(486$ personen) zalden of nooit. Bij 327 wan do 
6014 deelnerners katn men zich afvragen. of ze wel in du groep met een positieve anammese thuishoren, ondat ze bij meting geen hoge blotddruk (meer) blaken te hebben en wok jeen bloeddrukverlagende medicatit gebrutien. In de groep van 277 persionen met een ..terecht positieve" anamnese gebruikt: eveneens s procent ( 15 pcrsonew) iede. re week middslen tegen hoofdpijn en 79 procent (2 ls personen) zelder of nooit. Indien her hekend a jun net hoge bloed-

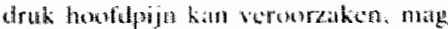
fin de groep met aen negattiove anamoneste

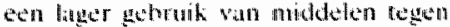
thoofdpijn whorden verwache. Dat blijkt schter niel her gavel. In deze groep wan 3091 deelnemers gebruikte ook 5 procerm ( 170 personen) iedere week middelen tegen howdupin th 79 procent $(2450$ personen) zeldan of noout. Ook in de groep met well atowezige. mata nog niet ondekte hoge bloeddruk 272 persom nen) werden napenoeg dezelfde percerntages gevondem: 6 procent $(15$ personen) gethruikto icchere week middetlen tegen hooldpujin en 82 procent 224 per sonen) zelden of nooit.

Uit label/ komen dus geen aanwijzingen vour een virband oussem een positieve anamnese ten anzien van boge blocddruk en het gebruik wan niddelen tegen hoofopijn. Indien dit gebruik in dicatief is vour de frequentie en ernst wan hoofdpijn. greeft het onderzock dus geen an wijzingen voor thet bestaan wan iatrogene hoofdpija.

Vow het beantwoten wan de vraag. of mensen mer hooldpijn valker hoge

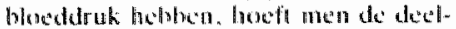

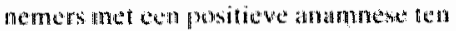
atanzien van hoge bloeddrute dus nitet buiter beschotewing to buten. Cijfers

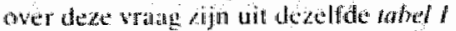
te hallen. door de tahel niet in horizonta-

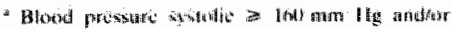
diatsolic $\geqslant 45$ inm il

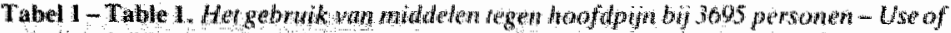
anichphathlgic in 3695 persons

\begin{tabular}{|c|c|c|c|c|c|c|}
\hline \multirow{2}{*}{$\begin{array}{l}\text { Howhry af } \\
\text { bypertensioun }\end{array}$} & \multirow[t]{2}{*}{ Whetgatoh } & \multirow{2}{*}{$\begin{array}{c}\text { Fyperiension } \\
\text { at } \\
\text { exanination: }\end{array}$} & \multicolumn{3}{|c|}{ 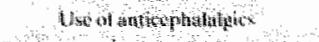 } & \multirow[t]{2}{*}{ Tottil } \\
\hline & & & $\begin{array}{l}\text { soldowa } \\
\text { ntwerer }\end{array}$ & monothety & wewkin & \\
\hline+ & $+\frac{1}{3}$ & + & 59 & 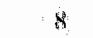 & 7 & 70 \\
\hline+ & + & - & 47 & 17 & 2 & 66 \\
\hline+ & 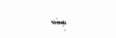 & + & 116 & 19 & 6 & 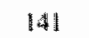 \\
\hline+ & - & - & 268 & 45 & 14 & 327 \\
\hline- & - & + & 234 & 33 & 15 & 272 \\
\hline- & - & - & 2226 & $43 k$ & 155 & 2819 \\
\hline Tural & I & & 2936 & 560 & 199 & 3695 \\
\hline
\end{tabular}

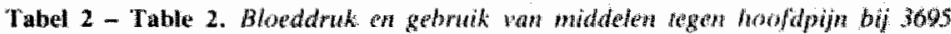
personer Blowd pressure and were of anhicephatalgics in 3695 persons.

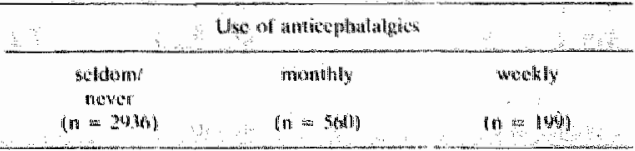

Systotic blood pressine (min Hg)

Mean

129.9

Standard deviation

17.0

$<100$

100.139

$14(1-150$

1601.179

$1.80-1.99$

$\geqslant 200$

$44(1 \%)$
$235(76 \%)$
$473(16 \%)$
$160(5 \%)$
$20(1 \%)$
$4(0 \%)$

$44(1 \%)$

$473(16 \%)$

20) ( $1 \%)$

Diastolic blowd presature (mm $\mathrm{Hg}$ )

Mein

Standert deviation

40.9

11.4

$<60$

(i). $\left.x^{2}\right)$

9i). 94

9.5. 94)

$\|(t) .104$

$105-109$

11ii-1.14

115.119

$\geq 120$
$36(1 \%)$

$2345(80 \%)$

$226(8 \%)$

$136(5 \%)$

$112(4 \%)$

$29(1 \%)$

3 (1) $(1 \%)$

$7(0 \%)$

$14(0 \%)$

128.3
16.4
$6(1 \%)$
$458(82 \%)$
$70(1.3 \%)$
$20(4 \%)$
$4(1 \%)$
$2(0 \%)$

127.8

16.5

$0(0 \%)$

$152(76 \%)$

$37(19 \%)$

$9(5 \%)$

$1(1 \%)$

$0(0 \%)$

\section{Synopsis

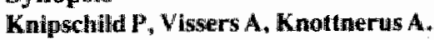 Headache and hypertension. Results of a population studly in Amsterdam. Huisarts en Wetenschap 1984; 27 ; 441 * 5.}

Introduction. The authors discuss the possibility al an association berween headache and hypertension:

Methods. Dat were antalyzed of popilat tion study ancug 3695 in hamitants of $\mathrm{Am}$ sterdam all buing 41 to $\$ 3$ years old. The freculency and severily of headache was mensured through the osse of antioeptialat. gics. Questions wire also ashed alowil a positive history of hypertension. The binod pressure was quasured in wll partotpants. Resulte. Tatole I gives mo indication for an associanton of the use of aniluephalalgics wh thestlive history of hypertonton, on with me asured hypertension. Table 2 how. ever, revoles a rela homship between a fingh diastolic blood proserue ( $205 \mathrm{~mm} / \mathrm{Hg}$ and the ve of antopholighto his pattorn is confrmed in lables 3 and 4
Discussion, This association is statistically

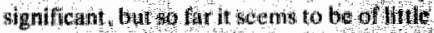
clinctal importance further thvestigat ton is regutired: to what oxtent is umekplained headachs indicative of hypertensions, and What ts the relationshlp bet ween nibgrind and hypertensiond?

Keywords: Heddrethe. Hypentension/ Popalation study.

Addriest of Guthors: Capaciteltsgroep

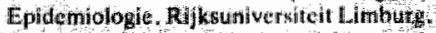
Postbus 616 . 6200 MD Matast rictid. 


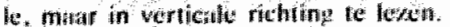

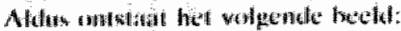

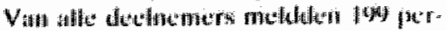

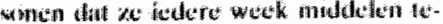

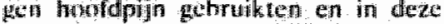

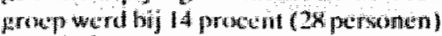

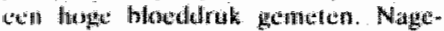
ande dexelfus perentenges werden ge-

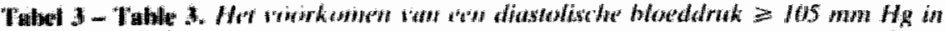

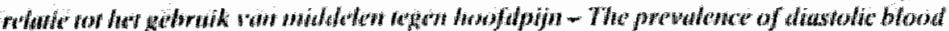

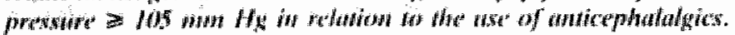

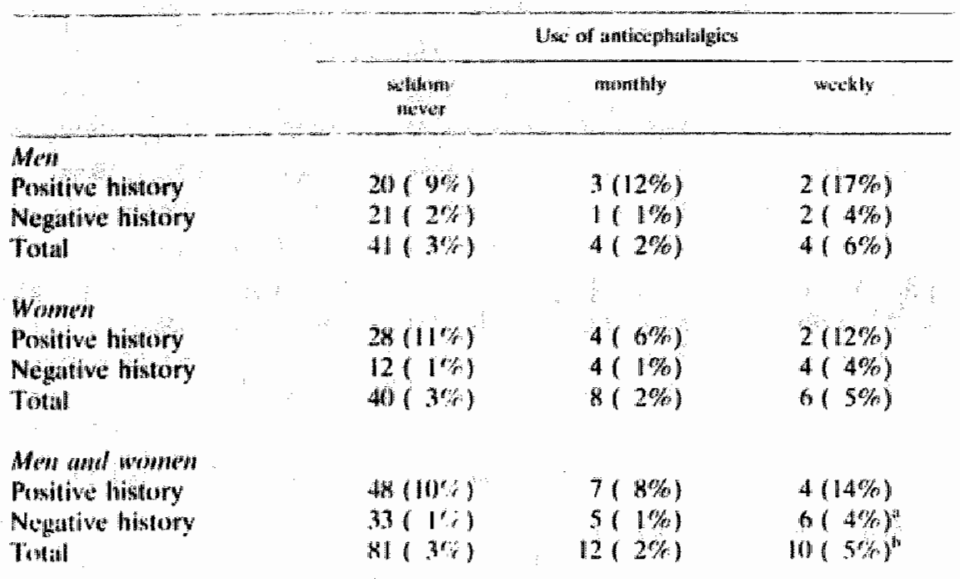

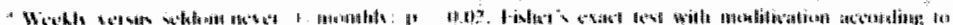
Mentihinin.

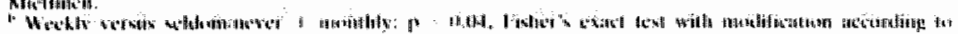
Misulfiulin' il.

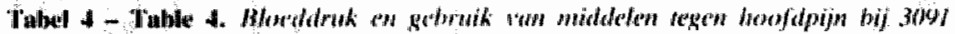

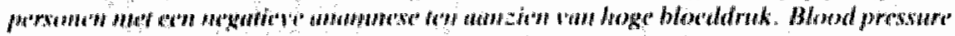

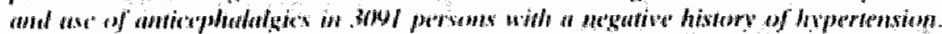

\begin{tabular}{|c|c|c|}
\hline & I the of anticephn & \\
\hline 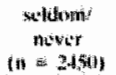 & $\begin{array}{l}\text { minithly } \\
\text { (I) } \approx 47)\end{array}$ & $\begin{array}{l}\text { wivelkly } \\
\text { (n) }=17 \mathrm{w})\end{array}$ \\
\hline
\end{tabular}

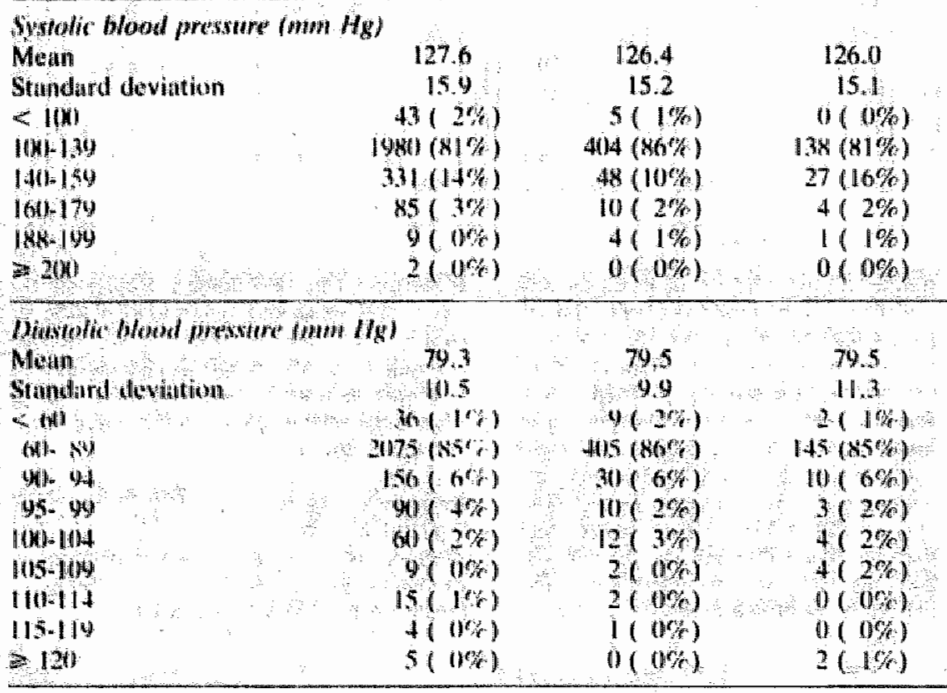

voraden voor de gromep deenemers die iedure matad middeten tegen hoofdpijn

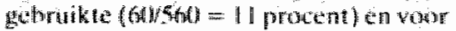
de groep die deza middeten zelden of nomit gebruilete $(395 / 2936=13$ pro(cent)

In wath 2 zijn de gemiddelde bloeddrukwharden genoteerd. Ook dise cijfers geven geen aanwijzingen dat hoofdpijn. atgemeten atm het gebruit wan midde len tegen hoofdpin. eem woorspellende botekenis voor de bloeddruk heeft. Verder blijken zeer hoge systolische bloeddrukken nick waker te worden aange. troffen in de groep die iedere week middelen tegen hoofdpijn gebruiki. Voor de diastolische bloeddruk ligt dat anders. Hoe hoger het afkappunit gekoten wordt, des te meer discriminaent het gobruik van middelen tegen hoofdpijn. Tabel 3 heeft alleen betrekking op de dealnemers met een diastolixche bloeddruk $\geqslant 105 \mathrm{~mm} \mathrm{Hg}$. Van atle 199 personen die wekelijks middelen tegen huofdpijn gebruiken, had 5 procent (10) personen) zo"n thoge bloeddruk. Het overeenkomstige percentage onder de overige declnemers bedritagt bijna ?

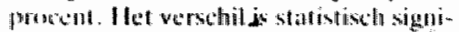

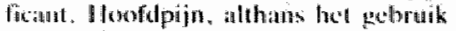
vani aniddelen tusen hoofderijn. lijkt dus cunige voorpellende beteknis te hebben voor de dan wezigheid van een zeer houge diastollishe blowddruk.

Vour we volledigheid rifn in the vabellen I. 3 en took tijfers gegeven worr de

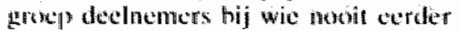
ben verhoogde blocdetra is gevonden. Iloge blowedruk, gedefinieerd als een bloeddruk systolisch $\geqslant 160 \mathrm{en} / \mathrm{of}$ diastolisch $\geqslant 95 \mathrm{~mm} \mathrm{Hg}$. lijkt net vaker voor te komen in de groep die iedere week middelen tegen hoofdpijn gebruike ra. bet 1). Ook de gemiddelde blowddruk is in deze groep niet boger (tabel 4). Wel blijkt nu ook weer dat zeer hoge diastolische bloeddrukken iets vaker in deze groep wordeñ geineten (tribel 3 ).

\section{Beschouwing}

De gegevens waarvan hier gebruik is gemalakt, zijn destigds verzameld met het oog op eer getheel andiere vraagstelhay. bovendien is onze vrat itgstelling pas guformulect. toen de gegevers al binthet waren. We nougen alus anthemen dit het antwoond op de vratas natar heil gebruik van middelen tegen hoofdpizn geen invloed heeft gehad op cle bloeddrukmeting.

Wit onze secundaire analyse kwamen geen annwijzingen dat het bekend raken net hoge bloeddruk hoofdpijn kan veroorzaken. Het onderzoth was echter 
voorit gericht ap de vang of lwage

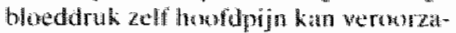

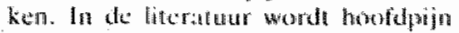

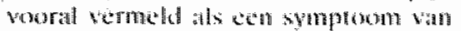

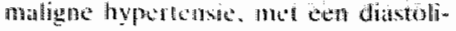
sehe frloeddruk van minstens $120 \mathrm{~mm}$

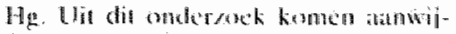

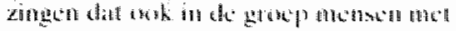

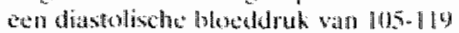
mom Hg utes vaker middelen lowen

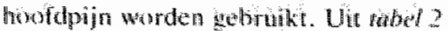
blikk dat 9 procent win de $\$ 6$ personen

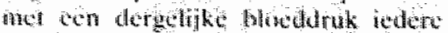

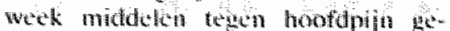

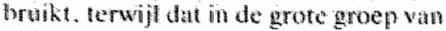
359 personen met cen lagere bloed-

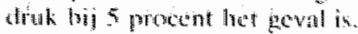

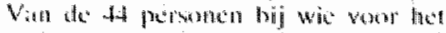

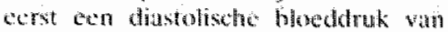
minstens 105 mon 1 lg werd gemweten.

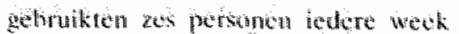

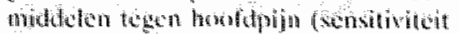

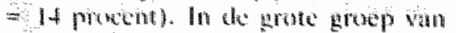

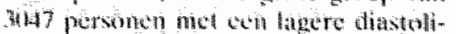

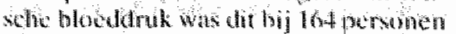

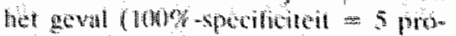
(ent). Het mnthershe iklend wermogen.

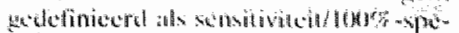

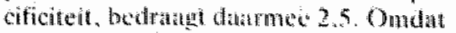

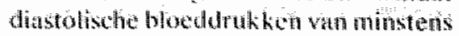

\section{De literaluur:}

De cerste ons lokends publikatio ower het

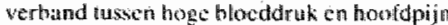

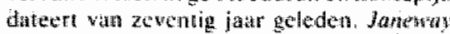

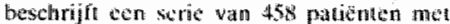
een systolische moetidruk boven 160 mm $\mathrm{Hz}$ ca meld: "Certeral symptoms wiore noto early by many patients. Headacho was the most frequtent (...) So commonty have par

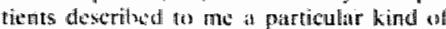
headache that thate almost come to look on

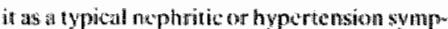
com This headache is one which appesars on awakening. or wates the patient during the earty morning hours, has its greatese intensity before arising. and passes away either imracdighe after breathe or during the course of the morning".

De beschreven hypartensie-hoofdpijn nwerd agigetroffen bij 13 procent wan allo par tien ten. Opvallend darbaj us dat dergellijke hooldpijn reven sakk leck foor te komen in d groep me con systolische blaeddruk wan $165-220 \mathrm{~mm} \mathrm{Hg}$ als in de groep mat eer bogere boto duruk. Het is overigens nog mala de vraag. of bil monsen zonder hoge blood druk defgelijk hosofdpijn veet minder voor

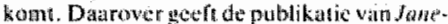

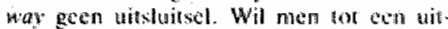
sprak komen oser de reltate thsinen hoold

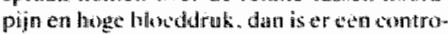

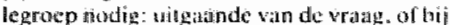

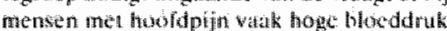
voorkomt, duent men herens de froutemtie

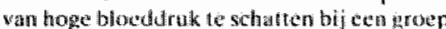
mensen zonder howdpilin. In de ine

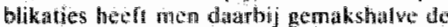
volgarde ongeneerd. Indicn hoofdping een

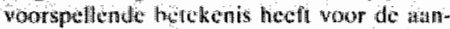

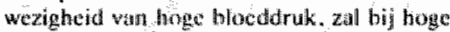
bloeddruk-patichten valk hoofdpijin wordem aangetrotion. Men sulectert ecr groep mensen met hoge bloditruk con en controlegroep zomder hoge bloeddruk on valag natal het opiredery wiln hoofapiju

Howwe de omkering of zichzelf nut lon

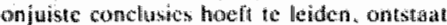
nat wel het gevar van sclectie-bias: niber alle

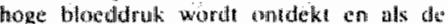

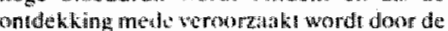

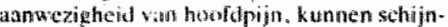

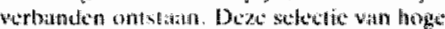

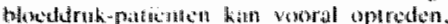

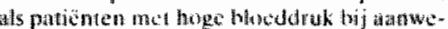

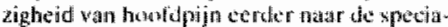

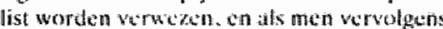
ean growe howe bouddruk-pationten hij de

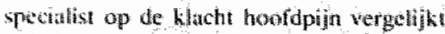
met cen controlegroop zordier hoge bloeddrulk, bijwowbectu in do allemene bevol-

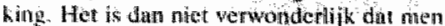
bij putienten mat nicum ontulekte boge

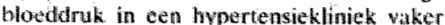
harfdpijn antrelit:"

Bij cen wergetiki onderzocksupzat ontstat

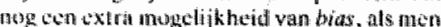

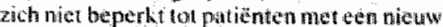

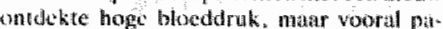

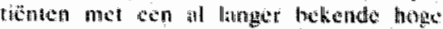

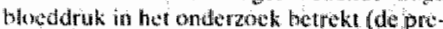

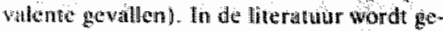
suggereerd dat bekendhe met het heblin vith hoge bloeddruk inwloed heeft op het zich tegevoel. Klachten als hootdpi jn zouden

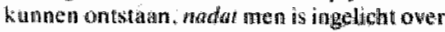
zijn hogu blocddruk en de bublochorende ribj.n cos. Kiest ment nu in het onderrogek wor prevalente gevallin war hoge bloeddruks.

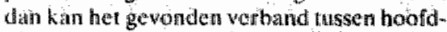
pijo an hoge blioddrul nog cerder 10 ext verkicrdo interpreathe teiden.

De vratis of thoofiapin eon reden is om thu hoge: blazeldruk te denken, kan goed omderzocht worden in de huisurtspriktijk. Tot ofusker zijor hierover twe publikaties verschonen. Walk er onderzocht zijn praktijkpo. pulatic op het vertand tussen migrailne co blowddruk. Her gall dus niet over hoofdpijn

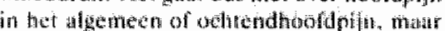

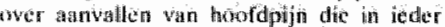

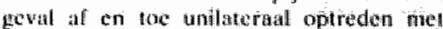

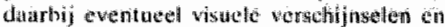

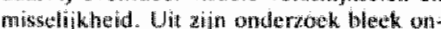

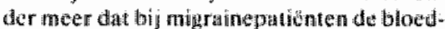

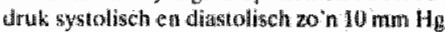

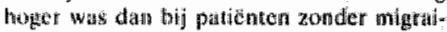

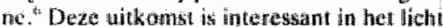

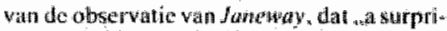
singly large number of these pationts (ntel higge blosddruk cn hoofophin) has been sub ject to migraine throughoul life "

It een ander onderzoek in do hasartsprok. tigk ging het wint om hooldpijn in the algemeen. Vergeklakn werden de frequentix on

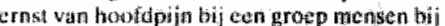

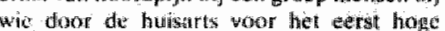

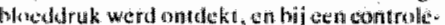

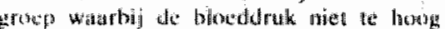

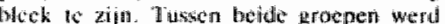

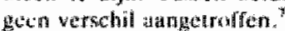

Heldas zifon in dit arike torkele dingem ondindelijk. Hoe kerd the controlegroep gese-

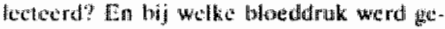

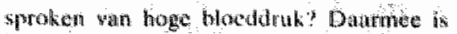

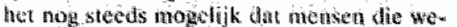

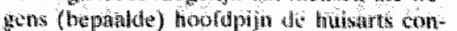

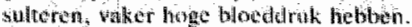

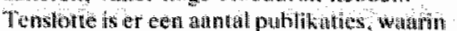
het verband tussen hooldpijn en hoge blowd:

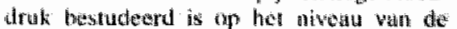

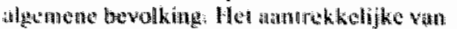

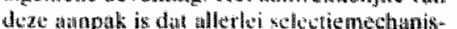

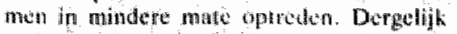

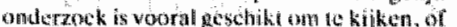
hoofdpin inderdas dect symploum is wat hoge blocddruk. Een fowled van mowrook in de algemene bevolking is dut grote thantal len mensen onderzoch mowter worden on uitspraken te kunmen doen ovet het vertume tussen hoofdpin en zeer hou bloeddiuk

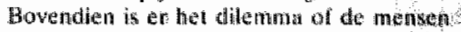

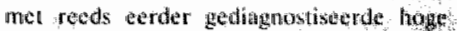
bloeddruk wel of viel in we vergelijhing moeten wordery bolroklken. Doet men dit wel. dain is vertekening de nhath door oven-

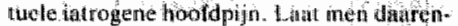
togen alle cerder ontdede ge sallen wate boge

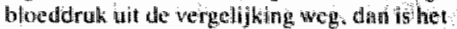
7alfs mogelijk dat now een mogithel (schijn-)

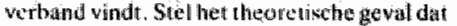
alle mensen me: hourdphin al op hoge bloce.

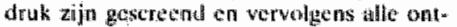

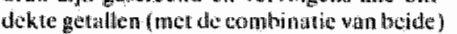
rice mecr mee mogen doert. In dal geval.

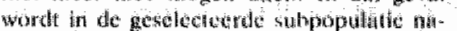

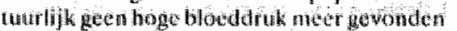

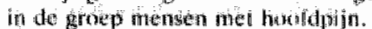

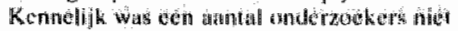

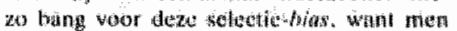

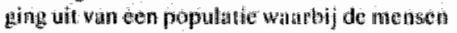

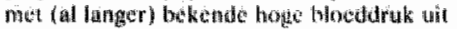

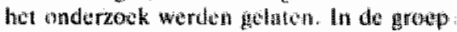

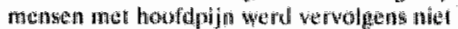

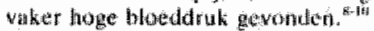

In wee andere publikaties houd men ich

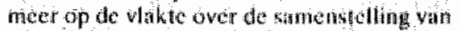

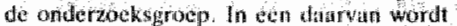
dan dudelijk vorband aromdun tamen

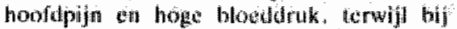

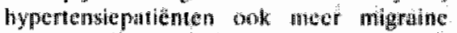
voorkom!." Uil de andere piblikatie komen

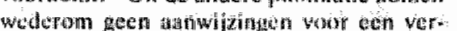

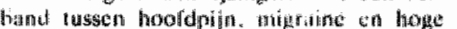

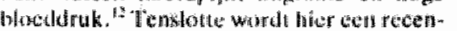

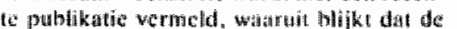

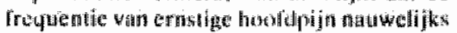

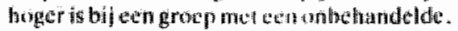

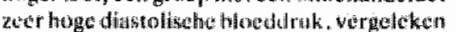

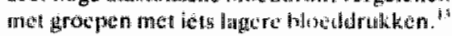




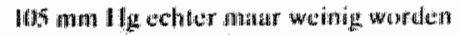

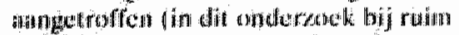

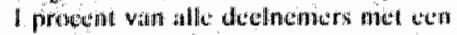

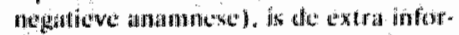

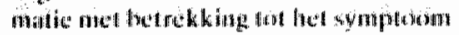

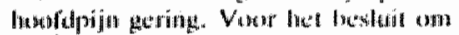

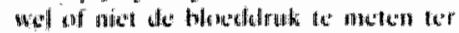

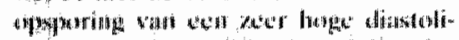

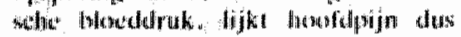

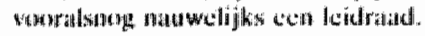

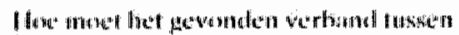

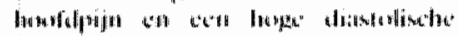

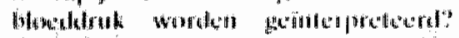

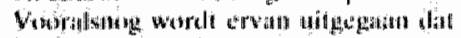

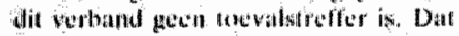

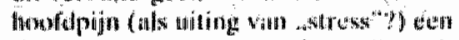

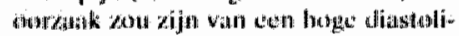

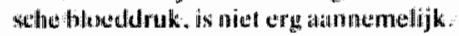
Men zou dan zeker ook cen rebatie met de systolische bllow doruk wawiehten en bowendien is het nog nimar zeer do

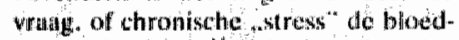
druk dowt stijgen. "Eur is cwenmin reden am te verondorwtelien dant bopalde uniddelon wgen hosfdpijon tphenateti. He) voor het verband verint wowrde tijk aijn. In het beschreven onderzow is niet sevtratgd natr type hoofdpijnmiddel. Analgetica-nefropatheen zijn echter in de algomene bevolking zo zoldzam dat ook alldus geen aldocinde werklaring gegeven kan worden. Veel mest moet datrom gedacht wordicn atan cen meclatsnisme watarbi de hoge diastollsche bloedidruk o via een invloed op ale liquordruk of op de certebrale arteriolen?? hoofdpijn kan veroorzatien. Interessand is dinn hovendien de vrange of bij pat-

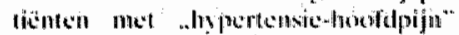
dere klacht minder wondt. als de blocedtArwk serlatigel woirdit.

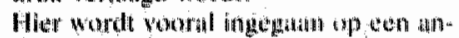

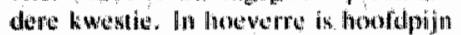

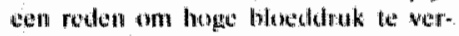

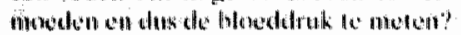

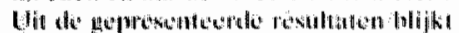

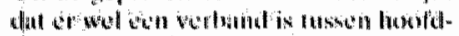
pijn en con (acer) lioge diascolisohe

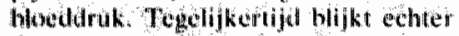
dut het wel of niet heblem vain hoofdpijn. mauwelijks dixcrimine rit tushs hoge elo

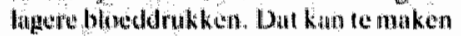

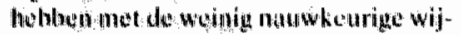

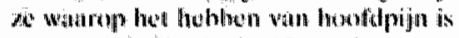

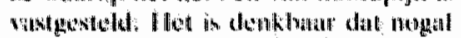

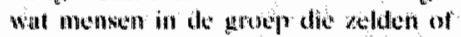

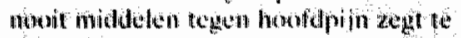
mebraiken: wel fiequent lighen onder erristige hoofdpijin. In dat gevill zullen de wartillen in relatie tor hage bloedJruk in werkelijkhe ul its groter zijn dan un de gepresenterde cijfers bijkk. Vest metr whis" worde mogelijh werarsataki dow een andere onwolkomenheid van dit onderzok fan de messte andere onderataked). Hot is thekend dat weel vormen wan how topijin, geparard galand met frecpuent gebruik wan middekw hicrtegen. nicts te maken hebben net hoge bleceddrak. Heofdpijn hangt

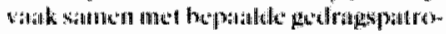

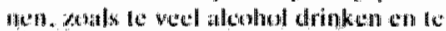

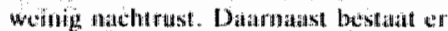

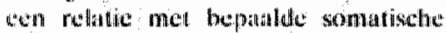
ikind weningen. zouls sinusitis en hersenwhodding. In de gepresenteerdu analy. ne kon helatas de hoofdpijur don aligemean geaccepteerde onranken niet butten beschouwing worden getaten. Het is denkbaar dat onverklaorale hoofdpijn wel duidelijker discrimineert tussen hoge en lagere bloeddrukken.

Nieuw onderzoek is zinvol met als vratagstelling, of onverklatarde hoofdpijn indicatief is voor do anwezhgheid van hoge bloeddruk. Wellicht diemt Aarbij oolk een specificatie gemakt te worden naar de lokatisatic en het tijastip van optreden van de hoofdpijn. Er wordt immers in dw literatua gesuggereerd dat "hypertensic-hoofdpijn" wooral in hes achiterhoofd zit en in de vroege ochtend eptreedt. Ook is hernieuwde andacht gewenst woor het verbotnd tusisen migraine en hoge bloeddruk.

On selectie-bias te vermijulen $k$ an dit omderzok beter nict op specialistisch nivean platitsvindera. Voor de hand ligt on het onderroek sprienw in de algemene bevolking te verrichten, math he? is acker ook dautrekkelijk in de huidantspraktijk. Globual zou dergellijk ondorwok er als volgt kwnmen witzien:

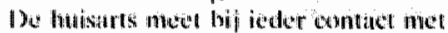
cen pationt meth hovidpijn de hloeddrth op gestanditardisecrate wijze, bij voorkiur met een geblinderorde, randomzero meter. De totale groep onderzochne patienten wordt opgesplitst in pa: tienten met onverklaarde hoofdpinn (ondlerzoeksgroep I) on met migraine (condterzoeksgeroep 2) an do bloeddrulk van deze patienten wordt vergeleken met dis van andere patienden met een guacesptecrde ooratak van de hoofdpijn (controlegiroep 1). Uit hat atanbod van patitutem zonder hoofdpin wordt ew extril controlegroep the gewogd.

\section{Darkbetuiging}

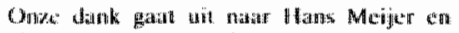

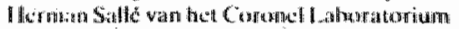

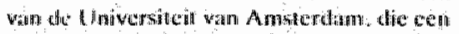

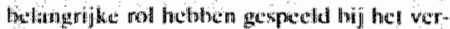

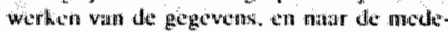

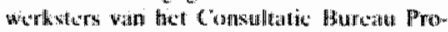

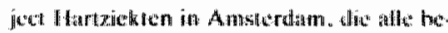

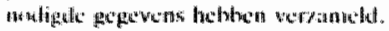

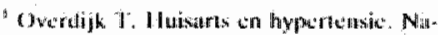

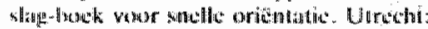

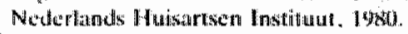
Janeway TC. A clicuical at udy or hyperten-

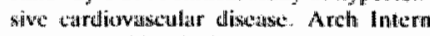
Mod 1413: 12: 755-9\%.

Bulpint CJ. Dollery C". Carnes. Charuge in symptorns of hypertersive patichts after refertal to hospital clinic. Bar Hoar J il976: 3x: $121 \times 8$

"Skewart $1 \mathrm{MG}$. Heddache and hypertension. Lafncet $1953 ; \mathrm{i}=1261+6$.

"Butharan RHA, Weir RJ. Me Cuiness JB. Hypertension and headache. Scott Med J $1970: 15: 48-51$.

"Walkir CH. Migratine and its relationship to hypertension. Br Med I 1959; ii: 1430-3.

Polvinaso JOD. Symptomas and the discov. cry of high blood pressure I Psychosom Re: 1960; 13:157-161.

"Wods NS. Relationship hof high hlood

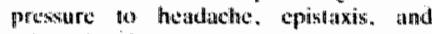
sulected other sympowns: The United Stites Heath Examination Survey of Adults. N Engl Mk M 1972: 237: 631-3.

"Konkw TE. Thumiletho J, Puska P. \$alo" non JT. The relationstap of symptoms and

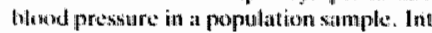

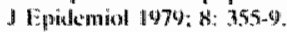

"Keck J van, Diederiks J. Philipsen 11.

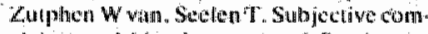
plianes and biond pressure. II Prychosom R4: 1082; 26: 15564.

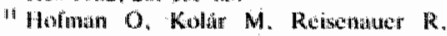

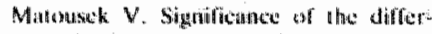

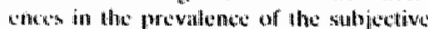

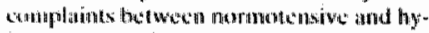
pertensive subjocts. Aethe Univ Carol (Med) (Prahul) 1073: 19: 611-16.

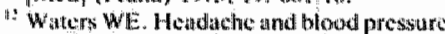
in the communty. Br Med J 1971: $:$ : 142-3.

" Kritus JF. Curts JD, Cuter C: Drugherty SA. Neill KC. Wasketheil-smoller $s$.

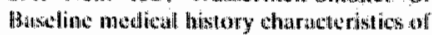
the hypertensive pinfiscipants. Iyperten-

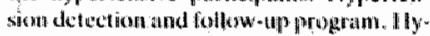

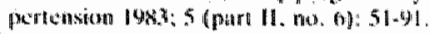

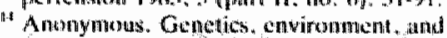
hypertension $\|$ Editoridil\|. Landed 1983 : (n) $1-2$ 


\title{
Hemoglobine en 'anemische' klachten zoals moeheid
}

\author{
A. Knottnerus, dr. P. G. Knipschild'
}

Er zijn veel leemten in kennis over de zin en de betekenis van de zo vertrouwde hemoglobinebepaling, en het belang van het hemoglobinegehalte van het bloed voor de gezondheid. Een oriènterend onderzoek werd verricht naar de hemoglobinewaarden bij patiènten die op verzoek van de huisarts onderzocht waren: patiênten met de hoofdklacht moeheid ( $n=566$ ), en een controlegroep van personen die zonder speciale klacht een algemeen onderzoek ondergaan hadden $(n=112)$.

Er werd geen relevant verschil in hemoglobinewaarden gevonden. Alleen bij oudere mannen was het hemoglobine in de moeheidsgroep iets lager dan in de controlegroep. Ook literatuurgegevens suggereren weinig samenhang tussen hemoglobinegehalte en 'anemische' klachten zoals moeheid. De vraag of in de huisartspraktijk verschillende hemoglobinewaarden gevonden worden bij patiënten met en zonder deze klachten, is echter onvoldoende beantwoord. Omdat de huisarts het hemoglobinegehalte nogal eens bepaalt bij patiënten met moeheid, zal een vergelijkend onderzoek worden gedaan in huisartsenpraktijken naar de relatie tussen moeheid en hemoglobine.

T. Soc. Gezond heidsz. 61 (1983)788-792

\section{Inleiding}

In alle sektoren van de gezondheldszorg wordt vele malen daags de hemoglobinebepaling uitgevoerd. Met name binnen de diagnostiek vande huisarts neemt zijeen bellangrijke plaats in. Vaak wordt de bepaling gebruikt om in twijfelgevallen uit te maken of men aldan niet in somatische richting zall doorzoeken.

Het is echter opmerkelijk hoeveel leemten er bestaan in de kennis over de betekenis wan het he moglobinegehalte in het . bloed (Hb) woor de gezondheid en de gezondheidszorg. Deze leemten betreffen zowel de bijdrage die de Hb-bepaling levert aan de ontdekking van verborgen pathologie en de daarbij te hanteren normaalwaarden, als ook de konsekwenties van een bepaald Hb-gehalte op lange termijn.

"Ants resp sociath geneesikundige, Capacitentsgroep Epidemiologie yan de Rijksuniversiteit Limburg
Vooral dit laatste aspekt is door de epidemiologie nog we: nig bestudeerd. Walers en Elwood (1982) komen op grond wan hun eigen onderzoek tot de konklusie dat weliswaar duidelijk verlaagde $\mathrm{Hb}$-gehaltes gepaard gaan aan een licht verhoogde sterftekans, maar dat een licht verlaagd $\mathrm{Hb}$ mogelijk samenhangt met een lagere noitaliteit aan cardiovasculaire ziekten. Ben aanzienlike stigging van het stertecijfer is waargenomen bij personem met een $\mathrm{Hb}$ hoger dan 15 $\mathrm{g}^{2}$. Deze tendenzen zijn nog onvoldoende onderzocht. Dat gelldt ook voor de mogelijke verklaringen, zoals het frekwenter voorkomen wan coronaire anastomosen bij anemiepatiênten (Zoll e.a. 1951) en de gevonden positieve korrelatie tussen hemoglobinegehalte en cholesterolspiegel (Elwood e.a. 1970).

De normaalwaarden die aningehouden worden voor het $\mathrm{Hb}$ gehalte, geven de arts weinig houvast. In het algemeen zijn zij vastgesteld op statistische en niet op klinische gronden, na onderzoek van klachtenvrije populaties. Zij zeggen dus niets over de gezond heidstoestand. Een probleem hierbij is dat het $\mathrm{Hb}$ een kontimue variabele is en een unimodale, bij benadering normale verdeling volgt. Het kiezen yan een afkappunt als caesuur voor normale respektievelijk afwijkende $\mathrm{Hb}$-waarden is dan een arbitraire zaak. In dit verband is de benadering van Garby (1970) vermeldenswaard. $\mathrm{Hij}$ kon bij een steekproef wan vrouwen uit de bevolking van Uppsala de verdeling van het Hb en de hematocriet ${ }^{3}$ onderscheiden bij vrouwen met en zonder ijzergebrek. Dit geschiedde door middel van het bepalen van de respons op orale ijzertherapie. Met behulp van deze verdelingen werd het mogelijk om voor élke waarde van het $\mathrm{Hb}$ en de hematocriet de bijbehoiende kans op ijzergebrek te berekenen.

Voor de praktizerend atts is het zinvol het probleem van de betekenis van de $\mathrm{Hb}$-bepaling te benaderen vanuit de klachten van de patient. Daarin ligt immers in eerste instantie de indicatie tot het doen van de bepaling. Richtsnoer yoor de arts is daarbij hetgeen deze geleend heeft over de symptomen die kunnen optreden bij een laag hemoglobine gehalte en anemie. Dit antikel is vooral vanuit deze invalshoek geschreven. De centrale vraag daarbiji is:

Hebben mensen met klachten, die per traditie heten samen te hangen met een laag $\mathrm{Hb}$, ook inderdaad lagere $\mathrm{Hb}$-warden dan mensen die deze klachten niet hebben? Met andere woorden: geeft het doen van een Hb-bepaling bil mensen met deze klachten een differentiatie tem opzichte wan hen die ze niet hebben?

\footnotetext{
In de internationale literatun? wordt het $\mathrm{Hb}$ meest hi nog wenmeld in gor. Eeng komt overen met 0.621 mmoll.

De hematocriet is het totale volume van de rode blowdcellen per 100 mll
} bloed 


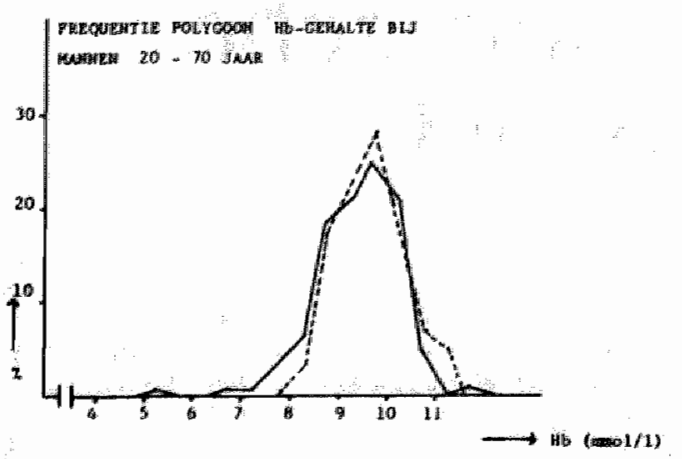

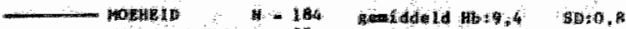

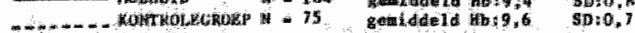

Figuur 1. Frokwontlepolygoon van hemoglobinekonsentratles in het bloed van mannen van 20 -70 fabr, wegons de klacht movheld, reap. In vertasind met een keurling of alkge meen onderzoek (kentrolegroep) onderzocht op hell dingnostlisch centrum Mesastricht

\section{Oriënterend onderzoek}

Moeheid is volgens de gegevens van Lamberts (1982) na hoesten, keelontsteking en nervositeit de meest frekwente nieuwe klacht op het huisartsenspreekuur. Deze klacht staat nog genoteerd voór lage rug en hoofdpijn. Aangezien moeheid yrij algemeen gezien wordt als een belangrijk symptoom van anemie, was onze verwachting dat deze klacht relatief vaak to een $\mathrm{Hb}$-bepaling zou leiden. Ter oriëntatie besloten wij tot een retrospekitief onderzoekje in het databestand van het Diagnostisch Centrum Maastricht:.

\section{Methode}

In het Diagnostisch Centrum wordt op alanvragg van de huisartsen uit de regio Maastricht en omsitreken laboratoriumonderzoek verricht. Op het ianv ratugformulier vermeldt de huisarts de klacht(en) en de reden wan het onderzoek. In 1980 en 1982 werden vom ovaluntiedoeleinden gedurende in torat 6 matanden alle gegevens betreffende anoviragenen uitslagen in de computer ingeyoerd. Daardoor was het mogelijk de Hb-uitslagen over deze maanden te vergelijken voor de volgende groepen:

a) patienten die yoor de eerste keer voor bloedonderzoek waren verwezen wegens de hoofdklacht moeheid (moeheidsgroep).

b) patienten zonder speciale klacht (kontrolegroep). $\mathrm{Zij}$ waren naar het lab verwezen in verband met een keuring of een verzoek om een algemeen onderzoek. Binnen het beschikbare materiaal leek de kans op een van een klachtenvrije populatie afwijkende $\mathrm{H} b \mathrm{~b}$-verdeling bij deze kategorie het geringst:

Alle bepalingen op het laboratorium vonden plats tussen 8.00 uur en 16.00 uur, Eris geen reden om te veronderstellen

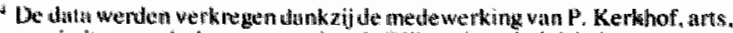
tapacibeitsgroep haisartsgeneeskumbe Rijksuniversiteit Limburg

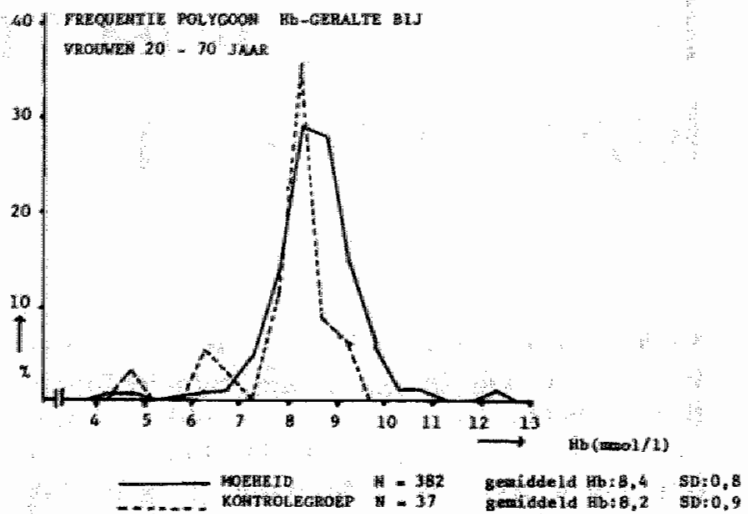

Figutur 2. Frekwentiepolygoon van hemoglobinekonsentraties in hét bloed vami vrouwen van $20-70$ jase, wegens de klacht moehelld, resp. In verbend met een keuring of algemeen onderzoek (kontrotegroep) onderzechl op het diegnostisch centrum Masatricht

dat de bepalingen woor beide groepen op systematisch verschilllende tijdstippen werricht werden.

\section{Resultaten}

De gegevens werden bewerkt voor de leeftijdsgroep van 20 tot en met 69 jaar. Onder de leeftijd van 20 jaar waren bij de mainnen geen kontrolepersonen beschikbaar. Bovendien verandert het $\mathrm{Hb}$ gedurende de eerste 20 levensjaren sterk met de leeftijd, terwijl op zeer hoge leeftijd bij mannen een lichte daling wan het hemoglobinegehalte plaatswindt (Kelly en Munan 1977. Waters en Elwood 1982). Uiteindelijk telde de moeheidsgroep 382 vrouwen en 184 mannen, en de kontrolegroep 37 vrouwen en 75 mannen, die in de genoemde leeftijdskategorie vielen en bij wie een $\mathrm{Hb}$ bepaald was. Daarbij moet opgemerkt worden dat bij de totale groep mensen, die wegens moeheid verwezen waren, in een weel hoger percentage van de gevallen een $\mathrm{Hb}$ bepaald was $(84 \%)$ dan bij de totale groep personen, die onderzocht was wegens een keuring of alge meen onderzoek $(21 \%)$.

In de liguren 1 en 2 tijn de verdelingen gegeven voor beide groepen, voor mannen en vrouwen apart, met gemiddelden en standaardafwijking. Bij mannen is er sprake wan een signifikant verschil tussen de gemiddelden ten nadele van de moeheidsgroep $(\mathrm{p}<.05)$. Echter een versehil tussen de gemiddelden van $0,2 \mathrm{mmol} / 1$, gevonden voor zowel mannen als vrouwen, kan men niet relevant noemen.

Eenaanvullend beeld krijgen we, als we kijken naar tabel ! .

Tabol 1. Cemiddelden en standatanddevlaties van het

hemoglobinegehalte per leeftifds kategorle voior de moohelds groep en de kontrolegroep, mannen on vrouwen van 20-70 /atar, In mmols

\begin{tabular}{|c|c|c|c|c|c|c|}
\hline \multirow[b]{2}{*}{ looftijd } & \multicolumn{3}{|c|}{ MANAWW } & \multicolumn{3}{|c|}{ VAOUWEN } \\
\hline & $\begin{array}{c}\text { moeneid } \\
\mathrm{n} \mathrm{Hb} \pm \mathrm{SA}\end{array}$ & & $\begin{array}{l}\text { kontrole } \\
\mathrm{Hb} \pm \mathrm{SA}\end{array}$ & $\begin{array}{l}\text { moeheid } \\
n \mathrm{Hb} \pm\end{array}$ & & $\begin{array}{l}\text { konitrale } \\
H \mathrm{HB} \pm \text { SA }\end{array}$ \\
\hline $\begin{array}{l}20-29 \\
30-39 \\
40-49 \\
50-59 \\
60-69\end{array}$ & 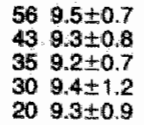 & $\begin{array}{r}4 \\
112 \\
37 \\
15 \\
7\end{array}$ & $\begin{array}{l}9.2 \pm 0.7 \\
9.5 \pm 0.5 \\
9.6 \pm 0.7 \\
9.8 \pm 0.8 \\
9.9 \pm 0.9\end{array}$ & $\begin{array}{rr}109 & 8.5 \pm 0.6 \\
90 & 8.4 \pm 0.6 \\
83 & 8.2 \pm 1.1 \\
54 & 8.6 \pm 0.9 \\
46 & 8.5 \pm 0.8\end{array}$ & $\begin{array}{r}6 \\
10 \\
7 \\
4 \\
10\end{array}$ & $\begin{array}{l}8.5 \pm 0.4 \\
8.2 \pm 0.5 \\
7.8 \pm 1.9 \\
8.5 \pm 2.9 \\
8.2 \pm 0.8\end{array}$ \\
\hline & $49.4 \pm 0$. & 75 & .7 & $828.4+0.8$ & & 82 \\
\hline
\end{tabular}




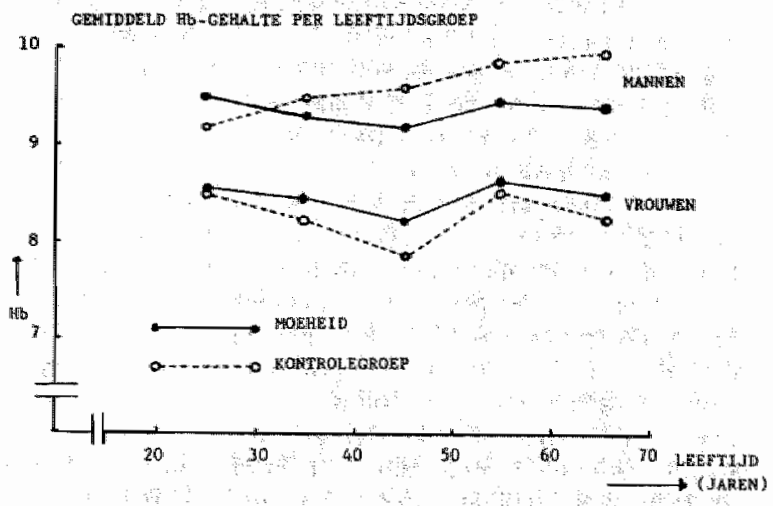

Figuur 3. Gemiddeld hemoglobinegehalte per leeltidskategorie naar geslacht, voor moeheidsgroep en kontrolegroep, in mimolh.

gevisuallseerd in figuur 3 . Het lijkt erop dat bij mannen bij toenemende leeftijd een steeds duidelijker verschil bestat tussen beide groepen ten nadele var de moeheidsgroep. oplopend to $0.6 \mathrm{mmol}$. Anders ge zegal: biloudere mannen lijkt de klacht moeheid samen te heingen met een lager $\mathrm{Hb}$. konform de verwichting. Bij vrouwen daarentegen is het Hb in de kontrolegroep sleeds lets lágerdan in de moeheidsgroep.

Passen we de nombilwaunden wan hel Diagnostisch Centrum toe op de gegevens. dan ontstant tabel 2. Bij mannen ligt een hoger pericentage van de $\mathrm{Hb}^{\circ}$ in de moeheidsgroep onder de norm. Dit beeld is niet terug te vinden bij te vrouwen.

Tabel 2. Aandeel wan de Hb-waarden, dat onder de normaalwaarden vain lhet diagnostissch centrum Maastricht Iigt, in moehaldsgroep on kontrolegroep voor mannen on vrouwem vain 20 - 70 jaar

\begin{tabular}{|c|c|c|c|c|}
\hline \multirow{2}{*}{8} & \multicolumn{2}{|c|}{ MANNEN $(8.6 \mathrm{mmol})$} & \multicolumn{2}{|c|}{ VAOUWEN 7.4 mimolil) } \\
\hline & fraktio & percentagie & fliaktse & percantage \\
\hline $\begin{array}{l}\text { moen } \\
\text { kontr }\end{array}$ & $\begin{array}{c}25 / 184 \\
4 / 75\end{array}$ & $\begin{array}{r}14 \% \\
5 \%\end{array}$ & $\begin{array}{c}20 / 382 \\
3 / 37\end{array}$ & $\begin{array}{l}5 \% \\
6 \%\end{array}$ \\
\hline
\end{tabular}

\section{Bespreking}

In het bescheren onderzok kwamen ma welijk relevande verschillen naw voren in de verdeling wo he moglobineWarden bij memsen die wegens moeheid een bloedonderzoek ondergingen. en degenen zonder deze ktacht die onderzocht werden. Alleen bij oudere mannen kont het resul- tabt overeen met de werwachting.

Direkt moet hierbij worden aangetekend dat het material beperkte warde heeft. Het was niet voor dit doel verzameld, en voor de definiering wan de klicht moeheid bestonden geen werkafspraken. Daamaast is het mogelijk dat eventuele verschillen versluierd $\mathrm{zijn}$, ondat bij de mensien die wegens moeheit nat het diagnostisch centrum verwezen zijn, veel vaker een $\mathrm{Hb}$ geprikt is, dan bij de mensen die gekeurd werden. Als de huisarts speciale - niet vermelde redenen had om bij somnige keuringen wel een $\mathrm{Hb}$ aan te vargen en bij andere niet, kunnen bij de wel op $\mathrm{Hb}$ onderzochten naar verbouting immers meer lage watarden gevonden zijn. We hebben voorts geen informatie over de $\mathrm{Hlb}$ warden wan alle personen die het spree kuurvan de hussarts bezochten wegens moeheid of voor een keuring. dat wil zeggen inklusief deginen die niet natu hel diagnostisch centrum verwezen zijo. Tenslotte getd die he perking, dat in enkele leetrijdsklassen wan de kontrolegroep de auntallen erg klein waren.

Als we kijken naar de literatuur. blijkt dat er weinig onderzoek is gedaan naar de relatie tussen klachten en Hb-gehalte. We moeten ook ver tertggran in de tijd.

Berry en Nash (1954) onderzochten 360 huisvrouwen, die deelnamen wan een routine robntgenborstonderzoek en datirbij vrij bleken wan tubereulose. Gevritigd werd of men zich fit en energiek woelde. vauk nwe was. of kortademig. Tevens werd het Hbbepald. Er werd geen verschil gevonden wat betreft het gemiddelde Hb ussen de vrouwen met en zonder klachten. Evenmin wats er een signifikant verschil in de percentages vrouwen die een Hb hadden onder de $10.8 \mathrm{~g} \%$.

In 1966 gingen Wood en Elwood bij een aleckproet wit do bevolking van Whes (165 mannen, 130 vrouwen) ba "of er een korrelatie bestond tussen kluchten en hemoglobinegehalte. Bif vrouwen werd alleen vool dioor thenzelf opgemerk $(\mathrm{e})$ bleek heid een verthind gevonden met een lager $\mathrm{Hb}$. Bij mannen bleken kortademighelit en pi,n op de borst simen te gatan met den hoger $\mathrm{Hb}$. Woor moeheid, slapte. hartkloppingen. prikkelbathe id en duizeligheid werd geen relatie met de hoogte van het Hb gevonden.

Vanuit hetzelfde gebled en door helzelfide team werden enkele jaren later heuwe resultaten genpporteed (Elwood

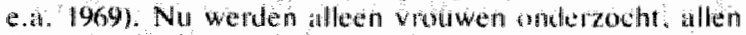

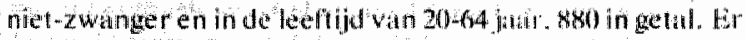
werd gewragd nuar de an nwe zigheld dan wel de graud wan ernst van de volgende klachtent moeheid, prikkelbaarheid. duzeligheid. harkloppingen. kortademigheid en hoofdpijn. en los dwarwan werd ook weer het Hbo beptald. Tussen klachten en Hb werd geen enkel verband gevonde ${ }_{\text {. }}$

In dezelfde publikatie wordt verskig gedkatn wan twee expe. 
rimenten. watrbij het effekt wan ijzertherapie op genoemde klachten is onderzocht, rowes bil vrouwen met een $\mathrm{Hb}$ van $13.5 \mathrm{~g} \%$ of hogger als bij vrouwen met een $\mathrm{Hb}$ tussen 8 en 12 got In beide kattegorieèn werd geen positief effekt van ijzertoediening op de klathten gevonden ten opzichte van de placebogroep. Wel vonder in de kategorie var $8-12 \mathrm{~g} \%$ in de behandelde groep een sterkere $\mathrm{Hb}$-sitjging plaats dan in de placebogroep.

Een boperking vande genoemde studies is dat er te weinig personen gevonden werten mel een /eetlaag Hb (lager dan $8 \mathrm{~g} \%$ ) om een mogelijk weiband tussen klachten en deze lage Hb-waturden upart to onderzoeken. Klinische observaties worden echter juist vask gedtan bij mensen met siterk verlangde Hb-gehaltes, Elwood en Wood (1966) deden wel een onderzoek bij 20 ziekenhuispatienten met Hb"s varierend van 6 tot $10 \mathrm{~g} \%$. mar her gunstige effekt dat ijzer en de gevonden Hb-stijging leken te hebben op hun klachtenpatroon is niet goed te beoordelen bij het ontbreken van een kontrolegroep.

Dawson e.a. (1969) stekden een onderžek in biliziekenhuispatiênten van 50 jaar en ouder. Zij vergeleken bet optreden van klachten bij anemiepaliénten met een $\mathrm{Hb}$ van $8-10 \mathrm{~g} \%$ (n) 70 ) en anemiepatienten met een $\mathrm{Hb}$ lager dan $8 \mathrm{~g} \%$ $(n=63)$. Alleen bleekheid werd frekwenter in de tweede groep gevonden. Voor de overige klachten, zoals moeheid. duizeligheid, hoofdpijn en hurtkloppingen was er geen verschil. Wel kwamen er in ab, olute zin veel klachten yoor. $\mathrm{Z}$ klakgden in beide groepen ongeveer $90 \%$ van de pattienten over moeheid. Helats wordt de geslachtsverdeling niet woor beide groepen tupirt verstrekt. en is op grond van de wegevens ook gee $n$ vergelijking lussen de groepen mogelijk

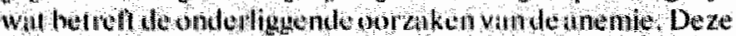
wotiden numelib, onathankelijk van her Illb, genoemde

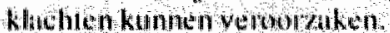

In de huisartsproktijk is nuuwelijks vergelijkend onderzoek

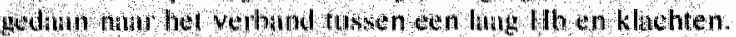

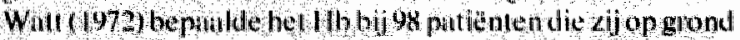
Wan klachten en klinisch beeli verdicht van anemic. Dezelfile bepuling went verricht bij 99 willekentig gekozen

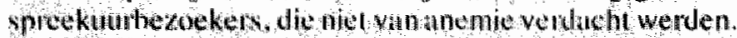
De groepen waren vetgelijktalt wal botleft leefijd en gesheht doch bevitten numwelijk inunuen lobejue groepen word ten even hoog percentage Hh-waturden lager dan 12 g/t gevonden. tehter, alleen in de kontrolegroep kwamen 2 wingeren woor, et wel $16 \mathrm{ingetal}$ Een eventueel verschil zou daradoor kunnen zijn gemaskeerd.

De lauts t tien jaw hebben diverse onderzoekers (Viteri en Turin 1974, Edgerton e. A. 1979, Ohin e.a. 1981 teen posiliof verbund gevonden tumsen Ho gehalte en maximaal arlweidsvermogen. Danthij is mok vastgenteld dat ijzertoedie- ning dit vermogen gunstig beinw loedt bij mensen met ijzergebrek. Gegeven de biologische kernis, dat hemoglobine het transportmiddel is voor zuurstof naar de weefsels, is dit ook te verwachten. De genoemde onderzoekers vergatrden huin gegewens echter in de derde wereld. Het blijft de vraag in hoeverre het gevonden verband voor de medicus practikus in Nederland van belang is bij de diagnostiek. De voedingstoestand is hier veel better en weinig mensen moeten gaan tot het maximum van hun fysieke kunnen. De bevindingen zijn mogelijk valn meerbeling voor de bedrijfsen de sportgeneeskunde. In ieder geval geven zij een extrat dimensie aan de diskussie over normaalwaarden. Viteri en Torún spreken over hematologische normaalwaarden en anemie als 'dynamische konsepten waraij rekening moet worden gehouden met de zuurstofbehoefte van het individu en diens mogelijkheden om daaraan tegemoet te komen". Resumerend kan gesteld worden, dat de vraag of bij mensen, die op het spreekuur komen met "anemische ' klachten zoals moeheid, de hemoglobinebepaling een differentiatie geeft ten opzichte van mensen zonder deze klachten, op grond yan ons orienterend onderzoekje en de literatuur niet afdoende kan worden beantwoord.

Op het niveau van de algemene populatie is er geen onderscheid gemaakt tussen spontaan geuite en door de onderzoekers voorgelegde klachten. Wat de huisartspraktijk betreft, is het onderzoek van Watt onbevredigend opgezet in slechts ến onderzoek. dat van Wood en Elwood (1966) in de algemene populatie, is gelet op eventuelie verschillen tusisen mannem en vrouwen wat betrefi het verband tussen klachten en Hb-gehalte. Het is overigens mogelijk dat een dergelijk verschil, indien het zou bestuan, eerder te maken heef net een ander patloon wan oorzaken van een lager $\mathrm{Hb}$ dan met het lage Ho zolf. Zowel Kirschenteld en Tew 1955

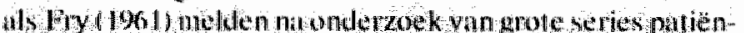
ton in de huisatsprakn $\mathrm{j} k$ dat bij mannen in geval wananemie meestal sprake is van onderliggende ziekteprocessen, terwill bij vrouwen vatu keen andere oorzak wordt gevonden dan overmatig menstrueel bloed verlies, een deficient dieet. of rwangerschap.

\section{Nader onderzoek}

Met nume foor de haisants is het van belang of de $\mathrm{Hb}$ bepuling zinvol is. Veel menven met anemische klachten komen op diens spreekuur. Waak spelen allerlei problemen darbij eer rol - op het gebied wan relaties, gezin of werk die mensen moe, duizelig of geprikkeld kunnen maken of hartkloppingen bezorgen. Als men dan een Hb bepaalt, zou heel wel bij toeval - en hij herhaling - een waarde ktunnen worden gevonden die onder de gehanteerde norm valt. 
Nader onderzoek dreigt dan, tot beenmergpunktie aan toe, vooral als een positieve respons op ijzertheraple uitblijft. Processen als somatische fixatie (Grol, 1981) krijgen aldus een kans. Aan de andere kant weet de huisarts dat ernstige pathologie welis waar zelden voorkomt bij 'anemische' (vage) klachten, maar zich, indien aanwezig, juist vaak aandient met dergelijke klachten. De vraag of en in hoeverre eenvoudige en op zichzelf weinig belastende onderzoekingen zoals het bepalen van het $\mathrm{Hb}$ daarbij in een bepaalde richting kunnen wijzen, wacht nog op antwoord.

Bij het zoeken naar dat antwoord is het van belang zich te realiseren dat woor de huisarts klachtgericht onderzoek meer aansluit op de probleemstellingen vanuit de dagelijkse praktijk dan ziektebeeldgericht onderzoek.

Zelfs als in de algemene populatie geen verband bestaat tussen $\mathrm{Hb}$-gehalte en moeheid, kan dit verband nog wel aanwezig zijn bij patienten die met de klacht moeheid op het spreekuus van de huisarts komen. Door ons wordt een onderzpek ingesteld met ats vraagstelling: vindt de huisarts bij de mensen die hem of haar bezoeken wegens de klacht moeheid een andere verdeling van het $\mathrm{Hb}$-gehalte dan bij overigens vergelijkbare spreekuurpatienten zonder deze klacht?

De onderzoekgroep bestaat uit patienten die de huisarts voor de eerste keer bezoeken met de hoofdklacht moeheid. De kontrolegroep bestaat om redenen van praktische uitvoerbaarheid uit de op de "cases" volgende patiemten zonder deze klacht, in dezelfde leeftijdskategorie en van hetzelfde geslacht. De klacht moeheid wordt daarbij zo gedefiniëerd, dat er voor de huisarts reden is om eventueel aan een verlaagd $\mathrm{Hb}$ te denken $\mathrm{Zo}$ zal direkt voor de hand liggende moeheid - bijvoorbeeld ten gevollge van een week slecht slapen ma echtscheiding of na meer dan gebruikelijke inspanning - moeten worden onderscheiden van moeheid 'e causa ignota" 0 ok zal een schaal naar graden van moeheid gehanteerd worden. In de kontrolegroep mogengeen personen voorkomen met klachten als duizeligheid of hartkloppingen, die natst moeheid geboekt staan als tekenen van een laag $\mathrm{Hb}$.

\section{Summary}

There is incomplete knowle dge about the significance of the measurement of the tylood thaemoghlobin level, and the relevance of this thevel to thealthi. In a retrospective study the haemoglobin levels were companed of patiants examined by the general practitoner because of fatigue $(n-566)$ and a controlgroup of subjects without a special complatint baving a genemal

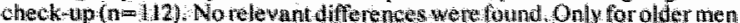
the hae moglobin level was someiwhat lower in the gronp of patients with: fatigue. Litteratune suggesits litule associtation of the "classic synuptoms' of anema and hatmoglobin level It is not olew whether a general phactice different distributions of hatemoghabin levels are found in stubjects wh "anemic" complants such as fatigue and subjects without these complants. A comparative study an the relation of the haenoglobin lewal and the frequently presented sy mptom of fatigute is phanned.

\section{Literaturur}

Berry, W, T. C. \& T. A. Nash, Symptoms as a guide to annaernia. Brit, Med. 1. $1(1954) 918$

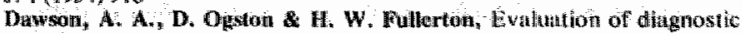
sigmificance of certain symploms and physical signs in anaenio patients. Brit. Med. J, $3(1969) 43$ th 439

Edgenton, V. R., G, W Gardner, Y, Ohlim, K, A. Guanwarticna \& B. Senew rratne, Irom-deficiency andemia and its effect on worker productivity and activity pauterns. Briti. Med., 1.2 (1979) 1546-1549

Elwond, P.C.A.M.M. Wood, Effect of oral hron thernpy on the symptonts of anaemia. Brit, J. Prew . Soc. Med. 20 (1966) 172-175.

Elwood, P. C, W. E. Waters, W. J. W. Greene, P. Sweetnam M. M. Wood, Symptoms and circulliting haemoglobin level. J. Chron, Dis. 21 (1989) 6154628

Fry, J., Clinical putte rns and course of anstemin in general practice, Brit. Med.J. $2(1961) 1732-1736$

Gabby, Lin The normsat hae moglobin level. Brit.J. Hhematol. 19(1970) 429\#34

Grol, $R_{\text {. }}$ (red), Hoisarts en somatische tixatie. Nijmeegs Universitair Huisartsen Instituut Nijmegen 1981

Kelly, A \& Munan, Haematologic profile of natural populations: red cell parameters. Brit. J. Haematol. 35 (1977) $153-160$

Kirschenfeld, J, J. H. H. Tew, Prewallence and significance of anaemia as seen in anural general practice. JAMA 158 (1955) 807-811

Lamberts, $\mathrm{H}_{\text {, }}$, Rede nen or naar de huisarts te gaani. Huisarts \& Wetensch. 25 (1982) $301-310$

Ohira, Y, V. R. Edgerton, G. W. Gardner, K. A. Gunawardena \& B. Senewiratne. S. dkawa, Work capncily after iron treatment as a function of

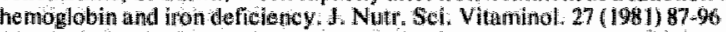

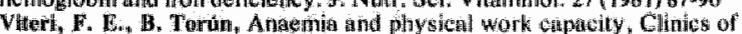
Haermatology. $3(1974) 609-626$

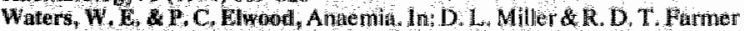

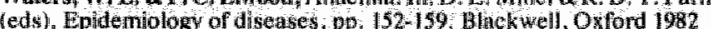

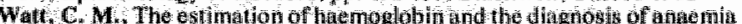
in general proetice, Pritetilionet $209(1972) 218422$

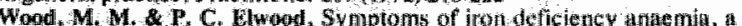
conmunity survey. Brit. Al. Prewent. Soc Medt 20 (1966) 117.121

Zoll, P. M. S Westler \& M. J. Schlesinger, Interurterial cononary andatomoses in the humban theart, with particular reference lo a memia hnd relativo cardiac anoxia, Ciretulation $\| V(1951) 797-8$ is

\section{Correspondentieadiress}

A. Knotinerus, arti, Capaciteitsgroep Lpide mologie, RU Lirrburs, postbus $6: 6,6200$ MD Maxatricht, tel. $043-8848142$ 


\title{
Hoofdstuk 6
}

\section{Onverklaarde moeheid en hemoglobinegehalte; een onderzoek vanuit de huisartsenpraktijk}

\author{
J. A.KNOTTNERUS, P.G.KNIPSCHILD, N.W.J.VAN WEASCHIN A,H.J.SUSTERMANNS
}

Moeheid is en klacht watrmee de huisarts wak te mallen krijgt" Deze wordt daarmee voor een moeilik diagnostisch probleem gesteld. Allerlei psychische of sociale problemen kunnen de oorzak zijn, mar ook een Hichameli ke ziekte. ${ }^{3}$ In het lastste geval zou ditwoeriger diagnostiek meer aanknopingspunten kunnen bieden, terwijl deze in het eerste geval juist mindier gewenst kan zijn wegens de kans op somatische fixatie. Als anamnese en lichamelijk onderzoek onvoldoende aanknopingspunten bieden en als een psychosociale oorzaak niet voor de hand ligt, kan de diagnose bloedarmoede worden overHogen. Hematologisch onderzoek vindt dan vaak plaats, vakk als onderdeel van een batterij van tests. Het jis echter nog maar de vraag of moeheid als klacht die geuit word tegenover de huisants, een relewante indicatie is om dergelijik onderzoek to doen.

Uit de huisomsenpraktijk zijn twe tomderzookingen scpublicest warin het themoglobine(1-1b-)gehalte van pertienten nuet khichten die aan bloedamoede doen denken, werd vergeleken met dat van cen controlegroep zonder deze klachten. In het eerste onderzoek telde de controlegroep echter een atuzienlijk antal zwangeren," wat een eventued versehil kan hebhen gemaskerd Het twede onderdoek had sleohts betrekking op patienten die natar e diagnosisch centrum verwezen waren.

Het hier te beschifjuen onderzoek betreft patienten mat onverklande moeheld". De huisurts had voor hun moeheid bij het eerste consult geen voor de hand liggende verklaring kunnen vinden en achtte datarom een Mblopaling gendiceerd

PATIENTEN HN METHODEN

Het onderzoek werd gedurende thet eerste hall jotar van 1984 verficht, in stmenwerking met negen huisartsen te

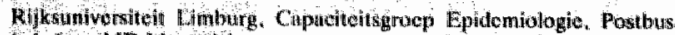

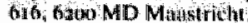

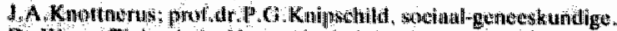

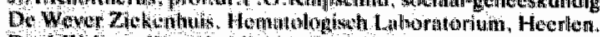

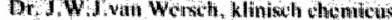

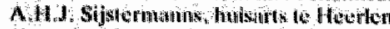

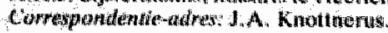

SAMENVATTING

Bif 174 patienten met onwerklaarde moeheid bij wie de huisarts bepaling van het Hbgehalte geindiceerd achtte en bij 48 controlepatienten bij wit dit niet het geval was "werd op gestandaardiseerde wijze hematologisch onde rzoek werricht. In beide groepen werd dezelfde verdeling wan het $\mathrm{Hb}$-gethalte gevonden. Ook de andere hematologische waarden vertoonden geen verband met moeheid. Hb-warden lager dan $7,0 \mathrm{mmol} /$ kwamen niet voor. Als in de haisartsenprialktifk bloedarinoede wordt vermoed alleen op grond van de klacht moeheid "dan zal dit vermoeden slechts zelden worden bevestigd.

Heerlen met een gezamenlijke praktijkonwang van 24.850 personen. Ilet onderzoek werd beperkt tot personen van is jatar en ouder, met uitsluiting wan zwangeren en van patienten die in de twadf mainden voor het consult ijzertherapie hadden gehad.

In de groep patienten met onverklaarde mosheid werden al degenen opgenomen die met moeheid als nieuwe klacht op het spreekuur werschenen en die het spreekuur in de twalf madinden darwoor niet wegens deze klacht hadden bezocht Als eis werd verder gesteld dat anamnese en lichamelijk onderzoek tijdens he teerste consult geen voor de hand liggende verklaring voor de klacht hadden opgeleverd, zoals duidelijke psychosociale problemen, bijwerkingen van geneesniddelen of reeds bekende organische ziekten. Bowendien gold als crite. ritum dat de huisarts bepaling Wan het Hb-gehalte geind: ceerd achtte.

Aan patienten die op het spreekuur na hen kwamen en die van hetzelfide gestacht en ongeveer dezelfode leeftijd als de "moeheidspatienten" waren; werd gevraggd als controlepersonen te fungeren. De controlepersonen had den geen klachten of ziekten die net anemie in verband zouden kunnen staan en zij hadden de huisarts in de voorgaande twaalf maanden ook hiet daarvoor geconsulteerd. Voor de controlepersonen gold werder alls eis dat de huisartis een $\mathrm{Hb}$-bepaling bij hen niet geindiceerd achtte.

Aan beide groepen patiènten werd door de huisarts gevraagd naar moeheid, duizeligheid, hartkloppingen, 


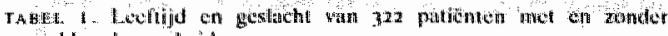

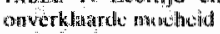

\begin{tabular}{|c|c|c|c|c|}
\hline \multirow{2}{*}{$\begin{array}{l}\text { leefritd } \\
\text { (jarem) }\end{array}$} & \multicolumn{2}{|c|}{ tawsial mamnen } & \multicolumn{2}{|c|}{ 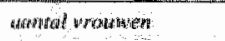 } \\
\hline & moveluetid! & controlegractp & move & cownoleghop \\
\hline $18-39$ & 18 & 25 & 89 & 46 \\
\hline $40-59$ & 18 & 16 & 25 & 33 \\
\hline $60+$ & 6 & 6 & 18 & 22 \\
\hline 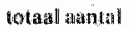 & 42 & $\$ 7$ & 132 & 101 \\
\hline
\end{tabular}

TAB EL 2. Hemoglobinegethalte bij 322 patiênten met en ronder moeheid

\begin{tabular}{|c|c|c|}
\hline \multirow{2}{*}{$\begin{array}{l}\text { hemaglobine. } \\
\text { gehalde (monolin) }\end{array}$} & aunval mosnen (v) & 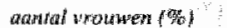 \\
\hline & $\begin{array}{l}\text { mel moueherd controle } \\
(\mathrm{n}=42) \quad \text { persesten } \\
\quad(n=47)\end{array}$ & 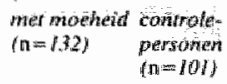 \\
\hline
\end{tabular}

\begin{tabular}{|c|c|c|c|c|c|c|c|c|}
\hline $7.0-7.4$ & - & & - & & - & & 2 & (2) \\
\hline $7.5-7.9$ & 1 & (2) & 1 & (2) & 9) & (7) & 5 & (5) \\
\hline 8.00 .8 .4 & 1 & (2) & - & & 19 & (14) & 10 & 100 \\
\hline $8,5-8.9$ & 4 & $(10)$ & 2 & (4) & 42 & $(32)$ & 37 & ( 37 ) \\
\hline $9,0 \times 9.4$ & 5 & $(02)$ & 10 & (21) & 40 & (30) & 34 & $(34)$ \\
\hline $9,5-9.9$ & 11 & $(26)$ & 19 & $(40)$ & 20 & (15) & 8 & $(8)$ \\
\hline $10,0 \div 10,4$ & 111 & $(26)$ & $\mathbb{1 1}$ & (23) & 1 & (1) & 4 & $(d)$ \\
\hline $10,5 \div 2.0 n$ & 4 & $(\mathrm{~b}(\mathrm{l})$ & 3 & (ii) & ! & (1) & - & 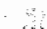 \\
\hline $11,0 \times 41.4$ & 5 & $(12)$ & 1 & (2) & - & & I & (1) \\
\hline
\end{tabular}

gemiddeld

Hb-gehalte"

(standatard.

afwijking

$4,9(0,8)$

$9,7(0,6)$

$8,9(0,6)$

$8,9(0,6)$

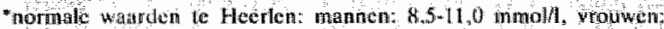
$7,510,0 \mathrm{mmol}$.

kortademigheid en pijn op de borst. In geval van moeheid werd naar de dutur en de ernst ervan gevmagd Voorts werd genotcerd of er sprake was van een bleek geltat of nagelafwijkingen (longitudinaal gegroefde nagels, brokkelige nagels, exn bleek nagelbed, lepeltjesnagels). Tenslotte notecrde do huisarts telkens of hij een laag Hbgehalte alls verklaring wan de klachten a amemelijk vond.

Door de praktikgassistenten werd bij alle personen bloed afgemomen door venapunctie. Het bloed werd opgevangen in EDTA bevattende buizen en onderzocht in een centraal faboratorium (De Wever Zlekenhuis, Heerlen) doorgaans binnen enkele uren na afname. De hematologische wa arden werden machinal bepald mel een H-6owo wnalyzer' (Techicon Instruments).
BESULATHEN

In total werden 32 patuenten yolgens de criteria in het onderzoek betrokken. De tijdstippen wan rop de beide groepen patienten venapunetie ondergingen. waren gelijk over de dag yeadeeld. De verdeling van de patienten nar gestacht, leeftid en categorte wordt gegeven in tabel 1 . Bij vrouwen wan jongere leeftijd waren er meer moeheidspattenten dan controlepersonen. Dit werd niet veroorzakl door weigeringen wan patiénten. matar doordat het in de praktijk niet altijd lukte om consequent het éen-op-én-schema aan te houden bij heit vragen wan controlepersonen ma patienten met moeheid als hootd klacht. Fir is geen reden om an te nemen dat de uitkomsten van ons onderzoek hierdoor zijn beinwloed.

In de tabellen wordt telkens onderscheid gemakt nakr geslacht, omdat het bekend is dat vrouwen een lager Hbugehalte hebben dan mannen. Voor de eernoud is geen onderscheid gemakt naar leeftijd, andat uil ons onderzoek bleek dat leeftijd geen invloed had op de bestudeerde verbanden. (In de onderzochte leeftijdsgroep werd ook geen verband tussen Hbigehalte en leeftijd gevonden.) De verdelingen en de gemuldelden van de $\mathrm{Hb}$-concentraties bleken woor de moeheidsgroep en de controlegroep niet te verschillen (tabel 2). Als we de door het ziekenhuishboratoriun gehanteerde ondergrenzen van de referentiewarden toepassen (mannem. $8.5 \mathrm{mmol} / \mathrm{l}$ en vroumen $7.5 \mathrm{mmol} / \mathrm{l}$ ), dan wallen in de moeheldsgroep bif de mannen slechts twee uitslagen daaronder $(5 \%)$ en bij de vrouwen geen enkele. Ook bij de mannen was er geen uitslig lager dan $7.5 \mathrm{mmol} / \mathrm{h}$. Alleen in de controlegroep bij de vrouwen werden twee uitslagen lager dan 7.5 mimol// gevonden.

De duur en de ernst van de klacht moeheid (beide gemeten opeen driepuntsschal) bleken niet van invloed te zijn. Het maktie ook niet uit of er behatve moelsend nog ed n of meer andere op anemle wijzende klachten of symptomen waren Ook voor de andere hematologische waarden konden geen verschillen worden angetoond tussen patiënten met moeheid als klacht en controlepersonen (tabel 3$)$.

In de subgroep moeheidspatienten bij wie volgens ce husarts een laag $\mathrm{Hb}$-gehalle aannemelijk was, word alleen bij de vrouwen en iets lager gumideld Hbi gehalte gevonden (tabul 4). Meer betekenis zou gehecht kunen worden an de bevinding dat alleen in de groep wrouwen bij wie anemie aannemelijk werd geacht, een auntal wrouwer voorkwam met ben Hbmgehalte lager dan

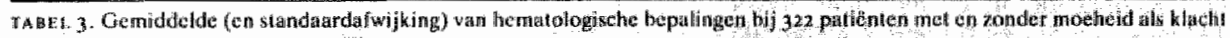

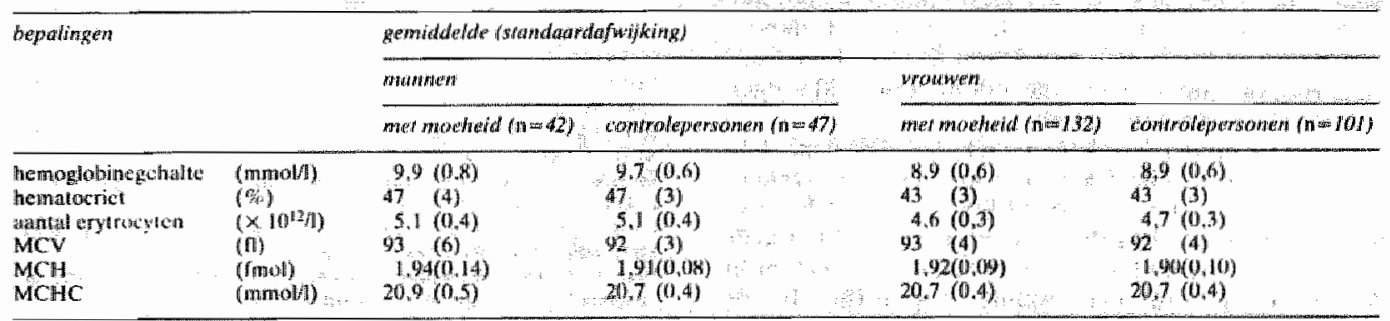




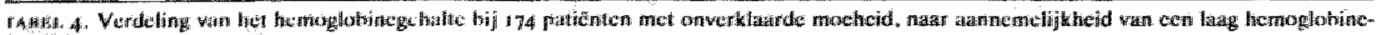
wastithe

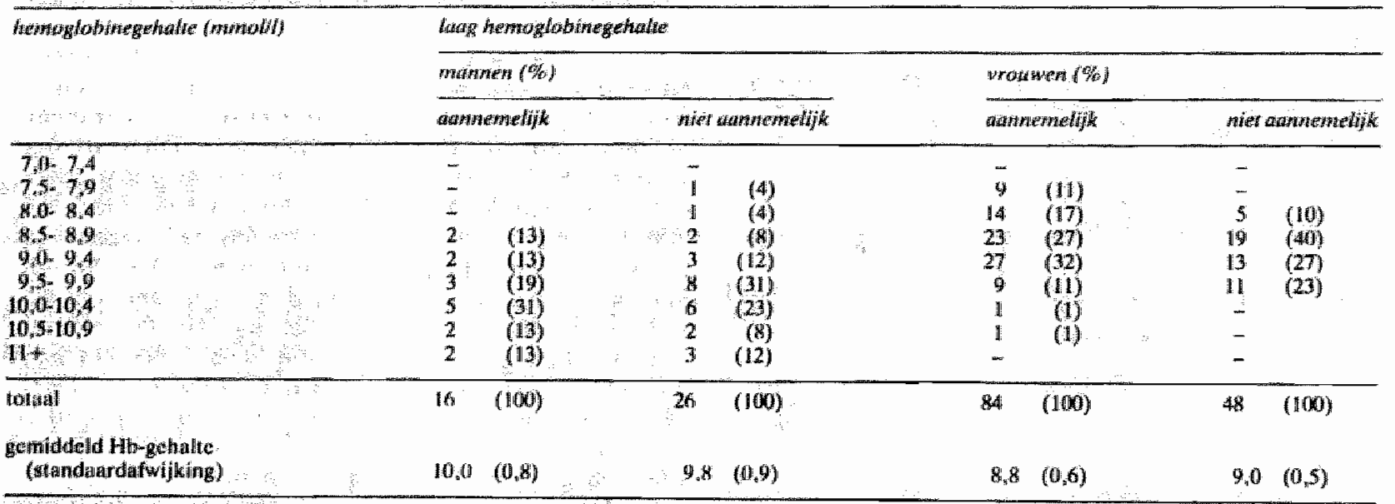

$80 \mathrm{mmol} / \mathrm{(}(1 \%)$ ). Waarden lager dan $7.5 \mathrm{mmol} / 1$ wetden ook hier echter niet gewonden. Beide mannen met een Hbogehalte onder de 8,5 mmol/l behoorden tot de subgroep moeheidspatienten bij wie een laag Hb-gehalte niet aannemelijk werd geacht (zie tabel 4 ).

Het verband hussen cle $k$ lacht moeheid en de hematolo. gitsche uitkomoten werd tenslot te nog onderzocht met multipele lineaire regressic-analyse. De reeds beschreven hewindingen werden hierdoor bevestigd.

\section{BESCHOUWING}

Patiënten consulteren bun huisarts in het allgemeen wegens klachten en symptomen. Als anamnese en lichamellik onderzoek weinig gegevens opleveren, moet de huistarts beslissen of nader onderzoek noodzakelijk is, bijuoorbeeld hematologisch onderzoek ter opsporing van bloedarmoede. Ons onderzoek geeft echter geen aanwizingen voor een verband tussen onverklaarde moeheid en uitslagen van hematologisehe bepalingen zoals van het Hb-gehalte. De voorspellende warde wan de klacht moeheid voor de diagnose bloedarmoede lijkt gering te ain. Het ondarshoidona vermogen wordl er niet beter op, thls tovers de duut en ernst van de klacht of andere "anemische' klachten of vemsehijnselen in de beoordeling worden betrokken, of als de huisarts een laag $\mathrm{Hb}$-gehalte (extra) ananemelijk acht

Het ontboken vam en verband tussen moeheid en Hb-concentratie komt ook nat woren uit onderzoek buiten de huisartsenpraktijk, in de algemene bevol-

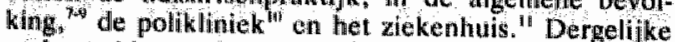
onderzoekingen zijn voor de huisarts echter minder imeressant en bovendien was divarin de mogelijke ruis" alspevolg yan voou do hand liggende andere verklaringen voo moeheid biet uitgesloten.

Onze resultaten betekenen miet dat zeer lage $\mathrm{Hb}$ warden geen moeheidsklechten kunnen veroorzaken. In hiet gebied onder 6,5 mmol/1 lijkt er wel verband te bestan tussen het $\mathrm{Hb}$-getialte en bepaalde klachten zoals moehieid. Extreen lige Hb-wariden worden echter in de huisartsenpraklijk matr weinig tangetroffen. In ons onderzoek werd geen enkele malal een Hb-gehalte onder de $7,0 \mathrm{mmol} / \mathrm{lgevonden.}$

Buj patienten met klachten over moelheid die niet eenvoudig verklaard kan worden door psychosociale of andere oorzaken, denkt de huisarts al snel aan bloedarmoede, Vaak wordt dan hematologisch onderzoek verricht. Gezien onze bevindingen zal het geen verbazing meer wekken dat daarbij het vermoeden van bloedarmoecle slechts zelden wordt bevestigd.

Wij danken P.G.Jvan Aubel, J.P.H.Dolhain. P.Höppener, H.W.M.Logister, A.C.J.Schlöser, G.H.A.Siemons, A.H.J. Sijstermanns, B.T.M.G.van der Werf. F.L.M.Zwanikken, huisartsen te Heerlen. en hun praktijkassistentev woor de patilentengegevens, en A.Vissers, research-assistent yan de Capaciteitsgroep Epidemiologie, die in alle fasen van het onderzoek naw bij de uitwoering betrokken was:

\section{SUMMARY}

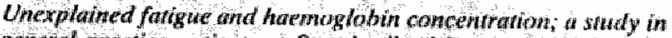
general prochice paveris - Standardzed haematological tests were carried out in 174 patients with unexplained fortigue whose GPs considered determination of the Hib concentration ind cated and in 148 controls wilthout such fotigue in bou groups. the same distribution of haemoglobin walues was found Other ha ematological paramete rs showed no comrelation with fatigue, either $H$ b levels below 7 o mmol/ were not found. If in general practice anaenila is suspected sollely on the bassis of the symptom of fatigue, this suspicion will be confirmed only rarely.

LiTTRATUU

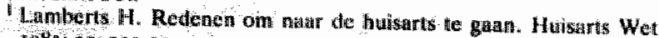
$1982,25.301010$.

2k terndaht DA. Fatigue of uncertain etiology. Family Medieinc Revinw 198,$1 ; 26-38$

Morrison JD. Fatigue as a presenting complatint in fontlly practice.

Fan Pract 1080, 10t: 795-doll

1 Grol $R$, red. Huisarts on somatsohe fixate. Nijmegen Nijmeegs

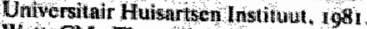

Wait CM, "The cestumathat of hacmoglobin and the ditagnosis of

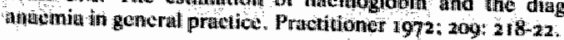




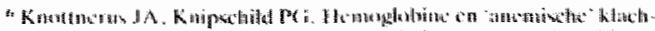

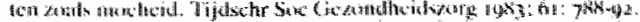

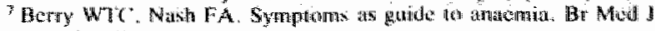
1054; i: $91 \%$.

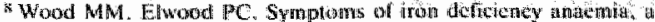

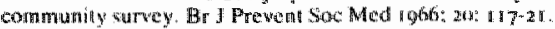

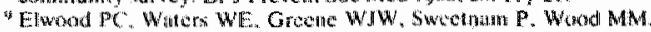

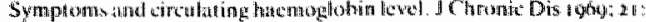
$45-218$

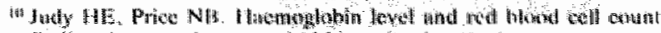

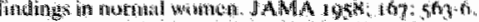

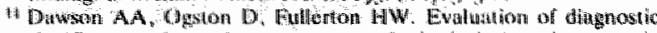

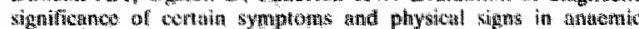

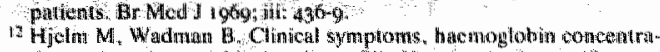

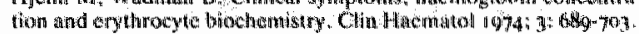


SERUMFERRITIME, BIJ MOEHEIDSPATIBNIEN EN GEZONDE CONTROLEPERSONEN IN

DE HUISARTSPRAKT LJK.

J.A. Knottnerus 1) - P.G. Knipschild 1) - J.W.J. van Wersch 2) A.H.J. Sijatermanns 3)

\section{Samenvatting.}

Bij 174 volwassen patiënten met moheidsklachten die de huisarts bezochten, en bij 148 controlepersonen werd naast de haematologische parameters het serimferritinegehalte bepaald. Er werden geen belangrijke verschillen tussen deze groepen gevonden. Onafhankelijk van de moeheldsklachten werd bij 11 van de onderzochten een serumferritinegehalte van $12 \mathrm{\mu g} / 1$ of lager gemeten. Het serunferritinegehalte bleek toe te nemen met de leeftijd (1.4 $\mu \mathrm{g} / 1$ per jaar) en lager te zijn bij vrouwen dan bij mannen.

Tussen de hematologische parameters enerzijas en het serumferritine anderzijds werden geen significante verbanden gevonden. Moeheidsklachten en het hemoglobinegehalte lijken van beperkte waarde te zijn voor het stellen van de indicatile voor een serunferritinebepaling.

Trefwoorden: serumferrltine/moeheid/huisartspraktijk/hematologie/parameters/

1) Capaciteiltsgroep Epideniologie, Rijksuniversiteit Limburg.

2) Haematologisch Laboratorium, Zlekenhuis de Wever, Heerlen.

3) Hulsarts te Heerlen. 
Inleiding.

In een vorige publicatie berichtten wil geen verband gevonden te hebben tussen onverklaarde moheidsklachten, gepresenteerd bij de huisarts, en het heroglobinegehalte (Hb) (1). Ondat het echter denkbaar is dat de klachten wél samenhangen met een ijzertekort dat zich niet of nog niet heeft geuit in een verlaging van het $H b(2,3)$, bestudeerden wij ook dit alspect.

Als mat voor de ijzervoorraad kozen wij het serumferritine. De beste infomatie over de ijzerreserve krijgt men weliswaar door beennergonderzoek, maar in de huisartspraktijk beperkt men zich bij de evaluatie van de ijzerstatus meestal tot serumbepalingen. Als de meest betrouwbare hiervan wordt tegenwoordig het serumferritine beschouwd. Het zou een gevoelige parameter zijn voor de ijzervoorraad van gezonde personen en personen met een ijzergebreksanemie (4-12). Het senmferritine zou al dalen, vóórdat een daling in serumijzer of hernoglobine worat waargenomen. Aangenomen wordt dat een serum-ferritine concentratie lager dan 10 à $15 \mu g / 1$ altijd op ijjzergebrek wijst (5). Vaak wordt een ondergrens van $12 \mu g / 1$ aangehouden $(7,8)$.

Behalve in het verband tussen moeheldsklachten en het serunferritine gehalte waren wij ook geinteresseerd in de relatie tussen hematologische parameters en het serumferritine. In de praktijk wordt de indicatie tot het bepalen van het serumferritine irmers mede gesteld op geleide van hematologisch onderzoek.

\section{Patiënten en methoden.}

Het onderzoek vond plaats in het kader van het onderzoek naar het verband tussen hemoglobine en onverklaarde moeheld, waarover reeds gerapporteerd is (1). Negen Heerlense huisartsen selecteerden de patiënten gedurende het eerste half jaar van 1984. Uitgesloten werden zwangeren en personen jonger dan 18 jaar.

In de groep moeheidspatiënten werden alle patiënten opgenomen die de huisarts bezochten vanwege de klacht "moeheid", en daarnee in de voorafgaande 12 maanden niet gezien waren. Uitgesloten werden personen die in die periode ijzertherapie hadden gehad en patiënten bij ji wie de moeheld in de loop van het consult te verklaren was door psychosociale 
achtergronden, geneesmiddelengebruik of reeds bekende organische pathologie. Een Hb-bepaling werd in deze groep geindiceerd geacht.

Als controlepersonen werden gevraagd op de meheldspatiênten volgende spreekuurpatiënten, die van hetzelfde geslacht en ongeveer even oud waren geen klachten hadden die in verband zouden kunnen staan met bloedamoede, noch organische pathologie. Bij deze personen werd een Hb door de huisartis niet geindiceerd geacht.

Van alle moeheidspatiënten en controlepersonen werd in zittende positie door mildel van venapumctie bloed afgenomen, en opgevangen in EDTA-vacumbuizen (Becton Dickinson). Daarnaast werd een stolbuis afgenomen voor de bepaling van serumferritine.

De henatologische parameters, werden enkele uren na bloedafname machinaal bepaald (H-6000, Technicon Instruments). Serum werd opgespaard en bi.j $-70{ }^{\circ} \mathrm{C}$ ingevroren. De ferritinebepalingen werden later in serie verricht met een radio immuno assay techniek met behulp van reagentia van Becton b Dilkinson.

De serumferritineconcentratles van beide groepen werden vergeleken na standaardisatie van hum leeftijdsverdeling op die van de Nederlandse bevolking per I januari 1984. Ook werd nagegaan welk gedeelte van de uitslagen per groep $12 \mathrm{\mu g} / 1$ of lager was. Vervolgens werd het verband tussen serumferritine, leeftijd, geslacht en hematologische parameters bestudeerd. Fr werd een multipele lineaire regressie-analyse verricht met de sermferritinecancentratie als afhankelijke varlabele en de hematologische parameters, de leeftljd en het geslacht als onafhankelijke variabelen. Omdat de serumferritine distributie sterkt asymmetrisch was werd deze analyse herhaald na logaritmische transformatie van de serunferritineconcentratie.

\section{Resultaten.}

Er werden 174 patiënten met onverklaarde moeheldsklachten (42 mannen en 132 vrouwen) en 148 controlepersonen (47 mannen en 101 vrouwen) in het onderzoek opgenonen.

In figuur 1 geven wij de voor de leeftijd gestandaardiseerde verdeling van het serumferritline voor vrouwen respectievelijk mannen, onderverdeeld naar moehelds- en controlepatiënten. Behoudens het vóborkomen van wat meer hoge waarden bij de mannen in de moeheidsgroep, zijn er geen relevante verschillen tussen moehelds- en controlepersonen. 


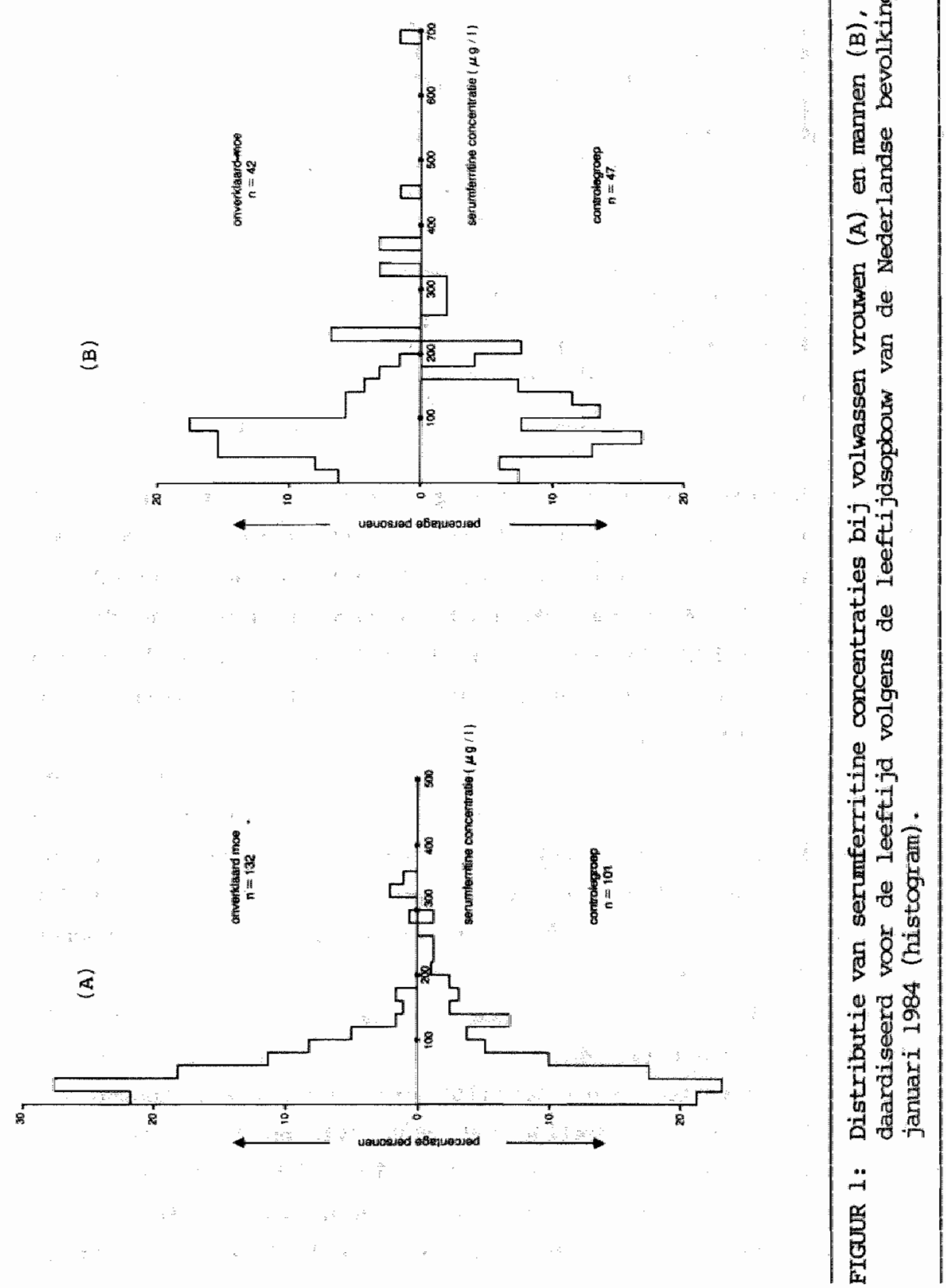


Tabel 1: Distributie van de senumferritine concentratie $(\mu g / 1)$ naar leeftija en geslacht. Range, kwartielen en percentages waarden van $12 \mu g / 1$ of lager.

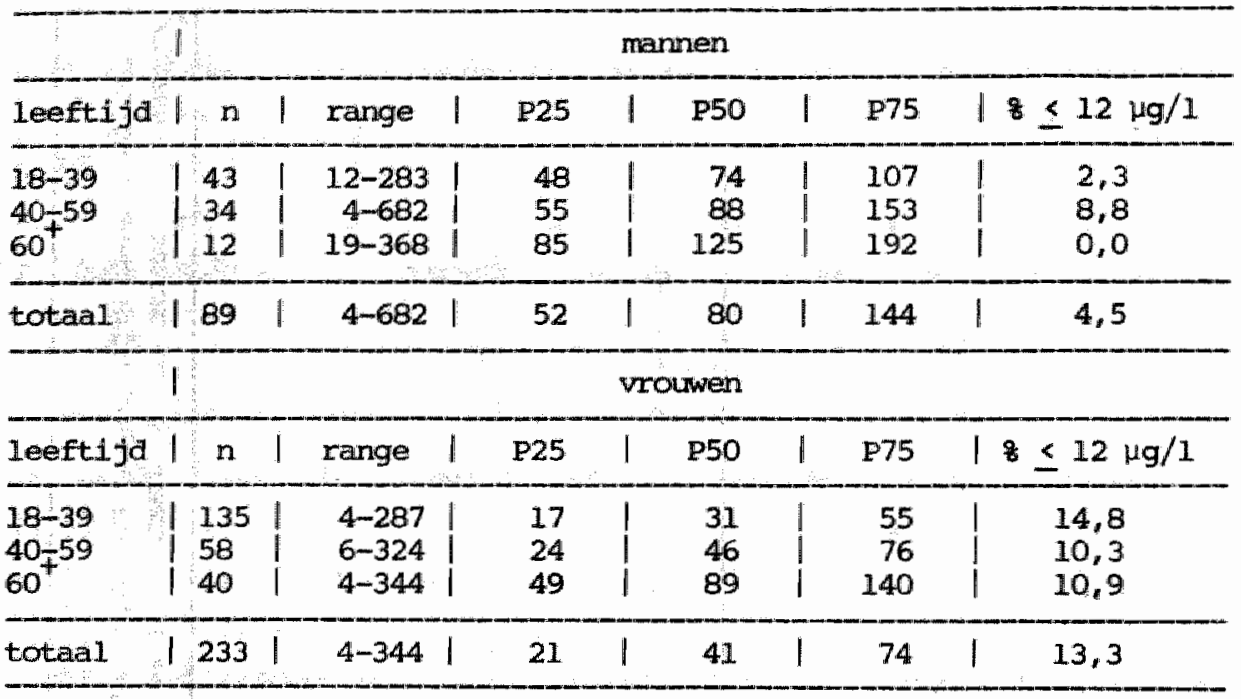

In totaal was zowel in de moehelidsgroep als in de controlegroep 118 van de ultslagen lager dan of gelijk aan $12 \mu \mathrm{g} / 1$. Van de 42 mannen met moeheidsklachten had er één een serumferritine lager dan of gelijk aan $12 \mathrm{~kg} / 1$, en van de 47 mannelijke controlepersonen drie. Van de 132 vrouwen met moeheidsklachten waren or 18 (14\%) met waarden lager dan of gelijk aan $12 \mu \mathrm{g} / 1$, en van de 101 vrouwelijke controlepersonen waren dit er 13 (1398).

andat de moheldsgroep en de controlegroep niet verschilden wat betreft de hematologische variabelen (1) en het serumferritinegehalte presenteren we de verdere beschrijuling voor beide groepen tezamen. Tabel 1 geeft de verdeling naar leeftijd en geslacht. Men kan zien dat de senumferritine-concentratie toeneent met de leeftijd, en bij manmen hoger is dan bij vrouwen.

In figuur 2 wordt gedemonstreerd hoe zwak het verband is tussen de serumferritine-concentratie en het $\mathrm{Hb}$, bij vrouwen respectievelijk mannen. Hetzel fide patroon werd gevonden voor de verbanden tussen het serumferitine en respectievelijk het $\mathrm{MCV}, \mathrm{MCH}$ en MaHC. Een lage serumferritine-concentratie (onder de 10 à $15 \mu \mathrm{g} / \mathrm{ml}$ ) kamt voor zowel bij de hoge als bij de lagere waarden van de hematologische parameters. Uit de multipele regressie-analyse bleek dat alleen de leeftijd 


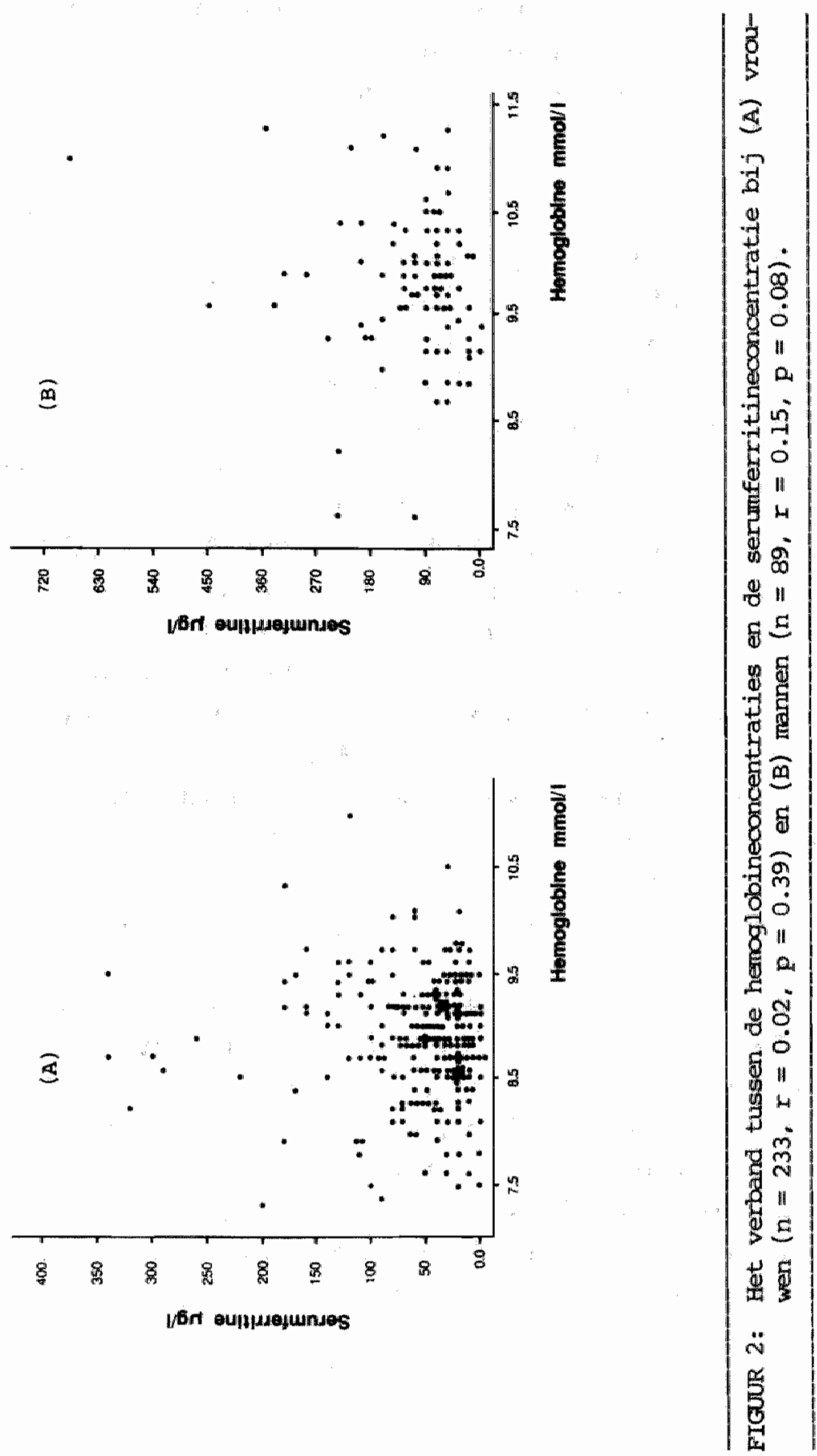


en het geslacht een significante relatie met het serumferritinegehalte vertonen $(P<0.05)$. Per jaar leeftijastoename stijgt het serumferritine gehalte met $1,4 \mathrm{~kg} / 1$, en het serumferritine is bij mannen ongeveer $45 \mathrm{~kg} / \mathrm{i}$ hoger dan bif vrouwen. Herhaling van de analyse met de (nomaal verdeelde) logaritme van de serunferritine-concentratie als athankelijke variabele leverde dezelfae conclusies op.

\section{Discussie.}

Al eerdex bleek dat wij bif volwassenen die zodanige moeheidsklachten hebben dat de huisarts een Hb-bepaling geindiceerd acht, geen lagere waarden van Hb, MCV, MCH en MCHC vonden, dan bij mensen zonder die klachten (1). Nu blijken cok de serumferritine-concentraties niet lager te zijn. Als men uitgaat van de 'spreekuurpopulatie' van de huisarts is er dus welnig aanleiding am bij moeheidspatiènten een duidelijk lager serumferritinegehalte te verwachten dan bij andere patiënten. Rekening houdend met leeftijd en geslacht, konden wij geen relevant verband aantonen tussen de hematologische parameters enerzijds en het sexumferritune anderzijds. De spreiding van het serumferritine rond ledere $\mathrm{Bb}$, MCV-, MCH- en MCHC-waarde is erg groot. Een serumferritine onder de norm blijkt net zo goed te kunnen voorkomen bij personen met een hoog $\mathrm{Hb}$ als bij personen met lagere Hb-waarden. Bij kinderen werd dit patroon al eerder beschreven (13). De leeftijd (oudere mensen hebben een hogere serumferritine-concentratie) en het geslacht (mannen hebben een hogere concentratie dan vrouwen) blijken wel belangrijke determinanten te zijn, zoals ook beschreven is door anderen $(14,15)$.

Een beperking van ons onderzoek is dat Hb-waarden lager dan 7 mol/l niet werden gevonden. Des te opmerkelijker is het, dat er vrij veel serumferritine waarden van $12 \mathrm{\mu g} / 1$ of lager gevonden werden (11\%). Nader onderzoek naar de variatie van serumferritinewaanden bij zeer lage Hb-gehaltes is gewenst. Indien ook daarbij een grote spreiding van de serumferritine-concentratie wordt gevonden, ontvalt de basis aan de strategle on de indicatie tot het bepalen van het serunferritine te stelien naar aamlelding van het vinden van een laag Ho. 
op zichzelf zijn onze bevindingen niet in tegenspraak met de opvatting dat de concentratie van het serumferritine indicatief is voor de ijzervoorraden in het reticulo-endatheliale systeem. Dit is met name beschreven bij gezonde personen en bij patienten met ijzergebrek anemie (6-8). Bij onderliggende ziekten, waarbij sprake is van weefselafbraak of ontsteking, (parenchymateuze leverziekten, leukemie, chronische infecties, rheumatoide arthritis, gemetastaseerde carcinomen) is het serumferritine geen valide index van de ijzervoorraad meer $(6,7,16)$. Dit zet een volgend vraagteken bij de waarde van de bepaling voor de diagnostiek, waarbij men van tevoren nu juist niet weet of de patient gezond is, of een bepaalde aandoening heeft.

De bezwaren die kleven aan de betekenis van het serumijzer en de transferrine-saturatie bij de diagnostiek van ijzergebrek (gevoeligheid voor aspecifieke prikkels, dagschommeling) (17, 18), kunnen aangevuld worden met twijfels ten aanzien van het serumferritinegehalte. Het kan een waarde hebben boven de referentiegrens (12 $\mu \mathrm{g} / 1$ ), niet alleen bij gezonde personen, mar ook bij patiënten met ijzergebrek gepaard aan allerlei ernstige aandoeningen. Ook kunnen blijkens ons onderzoek lage serumferritinewaarden voorkomen bij niet-vermoeide, niet-anemische personen.

Het klachtenpatroon, het hemoglobinegehalte en cok andere hematologische parameters lijken al met al weinig houvast te bieden bij het stellen van de indicatie voor het bepalen van het serumferritine.

\section{LITERATUUR.}

1. Knottnerus JA, Knipschild PG, Van WerBch JWJ, Sijstermans AHJ. Onverklaarde moeheid en hemoglobinegehalte, een onderzoek vanult de huisartspraktijk. Ned Tijdschr Geneesk 1986; 130: 402-405.

2. Jacobs A. Non-haematological effects of iron deficiency. Clinics in Haematology 1982; $11: 353-364$.

3. Waters WE, Elwood PC. Anaemia. In: Miller DL, Farmer RDT (eds.). Epidemiology of diseases. Oxford, Blackwell 1982: 152-159.

4. Eijk HG van, Heul $C$ van der. Enkele facetten van de ijzerstofwisseling. Ned Tijdschr Geneesk 1978; 122: 1759-1765.

5. Zuyderhoudt FMJ. Ferritine in serum. Ned Tijdschr Geneesk 1982; 126: $1733-1736$. 
6. Worwood M. Ferritin in human tissues and serum. Clinics in Haematology 1982; 11: 275-307.

7. Jacobs $\mathbb{A}$, Miller $F$, Worwood $M$ et al. Ferritin in the serum of normal subjects and patients with iron deficlency and iron overload. British medical Journal 1972; 4: 206-208.

8. Jacobs $A$, Worwood $M$. The cilinical use of serum ferritin estination. British Journal of Haenatology 1975; 31: 1-3.

9. Jacobs $A$, Path FRC, Worwood M. ferritin in serum. Clinical and bicmedical Implications. New England Journal of Medicine 1975; 292: $951-956$.

10. Mazza J, Barr RM, MCDorald JED et al. Usefulness of the serunferritin-concentration in the detection of iron deficiency in a general hospital. canadian Medical Association Journal 1978; 119: $884-886$.

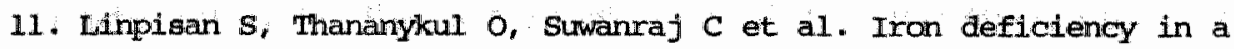
Northern Thai population: the effects of iron supplements studied by means of plasma ferritin estimations. Ann Clin Bloch 1984; 21 : $268-274$.

12. Harju E, Pakarinen A, Larmi T. A ccmparison between serumferritin concentration and the amount of bone marrow stainable iron. Scand J Clin Lab Invest $1984 ; 44: 555-556$.

13. Hershko C, Bar-or D, Gaziel $Y$ et al. Diagnosis of Iron deficiency anemia in a rural population of chilaren. Relative usefulness of serumferritin, red cell protoporphyrin, red cell indices, and transferrin saturation determinations. American Journal of Clinical Nutrition 1981; 34: 1600-1610.

14. Casale G, Bonora $C$, Migliavacce $A$ et al. Serumferritin and ageing. Age and Ageing 1981, 10: 119-122.

15. Rubin C, Wood PJ, Archer T, Rowe DJF. Changes in serumferritin and other 'acute phase' protelns following major surgery. Ann Clin Bioch 1984, 21: 290-294.

16. Rothwell RS, Davis P. Relationship between serumferritin, anemia, and disease activity in acute and chonic rheumatold arthritis. Rheumatology Int 1981, 1: 65-67.

17. Cavill 1. Diagnostic methods. clinics in Haematology 1982; 11 ; $259-273$.

18. Cook JD. Clinical evaluation of iron deficiency. Seminars in Hematology $1982 ; 19: 6-18$. 
HET HEMOGLOBINEGEHALTE VAN ZWANGEREN EN SUBUECTIEVE KLACHIEN.

J.A. Knottnerus 1) - L. Delgado 2) - P.G. Knipschild 2) - G.G.M. Essed 3) - F: Snits 3)

Samenvatting.

Verslag wordt gedaan van een onderzoek naar het verband tussen subjectieve klachten en hematologische parameters bij zwangeren. Door 494 zwangeren werd rond de $30 \mathrm{e}$ zwangerschapsweek een vragenli jst ingevuld. Direct aansluitend werd bloed afgencmen.Met name bij de volgende klachten werden vaker lage $\mathrm{Hb}$ - en/of Ht- waarden gevonden: Moeheid (erger dan voor de zwangerschap), hartkloppingen, kuiltkrampen (vooral als ze 's morgens optreden), en duizeligheld. Reeds onder de afkappunten $7.0 \mathrm{mmol} / 1$ ( $\mathrm{Hb})$ respectievelijk 32 (Ht) is er een toename van deze klachten waar te nemen. Het verband tussen klachten en een laag Hb is vooral duidelijk bij zwangeren met een MCV van 90 of hoger. Slechts 4 o van alle zwangeren heeft geen enkele van de bestudeerde klachten, en ook bij vrouwen met hogere Hb- en Ht- waarden worden vrij vaak klachten gevonden. Door middel van een gemodificeerde stepwise multipele logistische regressie analyse werd nagegaan van welke klachten het aannemelijkheidsquotient ten aanzien van een $\mathrm{Hb}$ en/of Ht onder de gencemde afkappunten significant van 1.0 verschilde na correctie voor de aanwezigheid van eventuele andere klachten. Dit bleek te gelden voor moeheid (erger dan voor de zwangerschap) en hartkloppingen. De aannemelijkkheidsquotienten werden niet wezenlijk beinvloed door leeftija, pariteit en het door een verloskundige of door een gynaecoloog gecontroleerd zijn. Het onderscheidend vermogen van de klachten lijkt evenwel te gering on het controleren van de henatologische parameters louter op geleide van bepaalde klachten plaats te doen vinden. Wel kunnen klachten aanleiding zijn voor een extra bloedcontrole. Nader onderzoek naar het verband tussen foliumzuurgebrek en subjectieve klachten bij zwangeren lijjkt gewenst.

1) Capaciteitsgroep Epidemiologie en Capaciteitsgroep Huisartsgeneeskumale

2) Capaciteitsgroep Epidemíalogie

3) Capaciteitsgroep Verloskunde en Gynaecologie Rijksuniversiteit Limburg 
Inlelding *

Het melden van klachten als moeheid, dwizeligheid en hartkloppingen tijdens de prenatale controle leidt vaak tot extra bloedonderzcek en kan de doorslag geven bij de beslissing on al dan niet over te gaan tot nadere diagnostiek en/of behandeling. Wij konden echter geen onderzoekspublicatie vinden over het verband tussen subjectieve klachten en een laag flo bil zwangeren. Het is nog maar de vraag, in hoeverre subjectieve klachten inderdaad de doorslag zouden moten geven ten aanzien van diagrostiek en/of behandeling van anemie. In het kader van de bestudering van het verband tussen moeheidsklachten en het $\mathrm{Hb}$ in de huisartspraktijk werden zwangere vrouwen van het onderzoek uitgesloten (1). De redenen daarvoor waren dat, ten gevolge van hemodilutie het hb vanaf ongeveer de 6 e zwangerschapsweek met ongeveer $1 \mathrm{mmol}$ $/ 1$ daalt, en dat in de onderzoeksperiode te weinig zwangeren in een vergelijkbare fase van de graviditeit zich bij de deelnemende huisartsen: zouden melden. Daaram besloten wij tot een speciaal onderzoek bij zwangeren. Gekozen werd voor een benadering van het referentiewaarden vxaagstuk, waarbij werden bestudeerd zowel de relatie tussen het filo en de hematocriet (Ft) en subjectieve klachten, als de relatie tusgen het fllo en en de Ht en het verloop en de uitkomst van de zwangerschap.

De resultaten van het onderzoek naar het verband tussen de hematologische parameters en de zwangerschapsuitkomst worden apart beschreven in hoofdstuk 22 . In het nu volgende verslag staat de vraag centraal, of gedurende de zwangerschap bepaalde klachten indicatief zijn voor lage Hib- en/of Ht- concentraties, en, indien dergelijke klachten worden gevonden, onder welke $\mathrm{Hb}$ - en Ht- concentraties deze klachten vaker worden gevonden.

Bij het beantwoonden van deze vraag kozen wij voor het bestuderen van het verband tussen $\mathrm{Hb}$ en $\mathrm{Ht}$ en klachten bij de routinecontrole die rond de dertigste zwangerschapsweek plaatsvindt. Juist bij die controle zou vaak wordien besloten over eventuele ijzersuppletie, en bovendien vindt er na de $32 \mathrm{e}$ week weer een geringe spontane stijging plaats $(2,3)$. 
Methode.

In de periode van 1 juli 1985 tot en met eind april 1986 werd een vragenlijst voorgelegd aan de zwangeren die de polikliniek verloskunde van het Academisch Ziekenhwis Maastricht bezochten in verband met de eerste zwangerschapscontrole na de dertigste week. Gevraagd werd ondermeer naar:

- klachten (die met een laag Hb zouden kunnen samenhangen), waarvan men de voorafgaande week eventueel last had gehad (moeheid, hoofdpijn, duizeligheid, hartkloppingen, kortademigheid, bleekheid, concentratieproblemen, prikkelbaarheid, slaapstoomissen, neerslachtigheid, krani in de kuiten). Over de moeheidsklachten werd gevraagd of deze reeds bij het opstaan aamwezig waren, of ze in de loop van de dag erger werden, en of men er af en toe dan wel dagelijks last van had. cok over een aantal andere klachten werd meer specifieke informatie gevraagd. Dok werd gevraagd of men zelf een verklaring voor de klachten had, en zo ja welke. Door de onderzoekers werden deze verklaringen, zonder voorkennis van het Hb-gehalte, later ingedeeld in warschijnlijk somatische, waarschijnlijk psychosociale en andere verklaringen. Gevraagd werd ook of men nu meer last van de klachten had dan vóór de zwangerschap.

- het gebruik van staaltabletten.

De vragenlijst werd vóór het verlaten van de polikliniek ingelevera. Direct aansluitend werd bloed afgenomen door middel van venapunctie. Het bloed werd opgevangen in EDTA-buizen, en binnen enkele uren werden de hematologische parameters bepald met een SYSMEX Microce11-counter (hematologisch laboratorium Academisch Ziekenhuis Maastricht, Mevrouw Dr. M.S.M. Daniels-Bosman en Dr. G.J.P.C.M. Kok).

De vragenlijst werd cok voorgelegd aan de zwangeren die begeleid werden in twee eerstelijns verloskundige praktijkken, bij de eerste controle ná 30 weken amenorroe in de periode van 1 oktober 1985 tot 1 . februari 1986. Direct aansluitend werd venapunctie verricht in de verloskundige praktijk of op éen van de perifere prikpunten van de Prikdienst van het Academisch Ziekenhuis. Het bloed werd opgevangen in EDTA-buizen, en binnen 24 uur onderzocht in het hematologisch laboratorium van het Academisch Ziekenhuis Maastricht. 
De gegevens werden bewerkt op de VAX-computer van de Rijksuniversiteit Limburg, en geanalyseerd met het BMDP-programa (4).

De statistische analyse werd begonnen met het bestuderen van kruistabellen aangaande de relatie klachten en hematologische parameters. verschillen tussen gemiddelden werden getoetst met behulp van de t-toets voor orgepaarde waarneningen, en verschillen tussen proporties met de chikwadraat toets, of de Fisher exact test indien het verwachte aantal patienten in éen van de cellen 5 of minder bedroeg. Vervolgens werd door midalel van een forward stepwise multiple lineaire regressieanalyse nagegaan welke klachtenset significant samenhing met het Ho-gehalte. Door middel van een forward stepwise logistische regressie-analyse werd nagegaan welke klachten een sterke en significante samenhang vertoonden met een Hb-gehalte lager dan $7.0 \mathrm{mmol} / 1$ en/of een Ht van 32 of lager. Een kenmerk van diagnostiek is dat zij uitgaat van de a priori kans op een bepaalde afwijking (welke vervolgens wordt gemodificeerd door de diagnostische gegevens) en niet van de a posteriori kans, gegeven een negatief resultaat van alle nog te stellen vragen of uit te voeren tests (welke laatstgenoemde kans in het algemeen wordt gepresenteerd in het intercept van de regressiefunctie). Daarom ontwikkelden wij een techniek waarbij het intercept van de logistische regressiefunctie de representatie wordt van de a priori kans in de bestudeerde populatie. Daardoor is het mogelijk rechtstreeks aannemelijkheidsquotienten (1ikelihoodratio's, LR) te bepalen voor de positieve testuitslag of de aanwezigheid van een klacht of symptoom:

sensitiviteit

(1-specificitelt)

en voor de negatieve testuitslag of de afwezigheid van een klacht of symptoom:

\section{(1-sensitiviteit)}

specificiteit

gecorrigeerd voor de invloed van andere tests, symptamen of factoren (zie appendix).

Voorts werd bestudeerd, of de verbanden tussen klachten en hematolo- 
gische parameters verschilden in de subpopulaties begeleid door respectievelijk eerstelijns verloskundigen, verloskundigen op de polikliniek en de gymaecologen. Tenslotte werd nagegaan of de verbanden anders waren bij vrouwen die al dan niet staaltabletten hadden gebruikt en bij vrouwen met een laag of hoger Mean Cellular volum $(\mathrm{MCV})$.

\section{Resultaten.}

Van de zwangeren die via de polikliniek verloskunde benaderd werden, nam 928 deel aan het onderzoek. Redenen voor niet-deelname waren: weigering (4q), taalbarrière $\left.(2)^{\circ}\right)$, niet op de betreffende controle verschijnen (2\%). Van de zwangeren die via de zelfstandig gevestigde verloskundigen benaderd werden, nam $63 \%$ deel; $12 \%$ welgerde, $10 \%$ vond de afstand naar de prikdienst te groot, 8 is werd bij de controle gemist, en bij 7 waren er diverse andere redenen.

voor de analyse zijn beschikbaar de gegevens van 494 vrowwen $(90$ "perifeer" begeleid, en 404 poliklinisch). De leeftijasrange was 18 tot 39 jaar $(P 50=27)$, en 50 z was nullipara. Bij alle deelnemende vrouwen is het $\mathrm{Hb}$ bepaald (gemiddeld $7.3 \mathrm{mmol} / 1$ range $5.6-9.1$, SD: 0.6), bij 968 de hematocriet (gemiddeld 35\%, range 26-44, SD: 3) en bij 918 het $\mathrm{MCV}$ (gemiddeld 91, range 75-114, SD: 5).

In tabel 1 is weergegeven welk percentage van de zwangeren per klasse van de drie hematologische parameters een bepaalde klacht meldde. Veel klachten bleken wat vaker voor te komen bij lagere hemoglobine- en hematocrietwaarden: moeheid, duizeligheid, hartkloppingen, kortademigheid, bleekheid en kuitkrampen. Hoofdpijn werd zowel in de hogere als in de lagere klassen vaker gevonden. De "anemische" klachten moeheid, bleekheid en kortademigheid leken eerder geassocieerd te zijn met een hoger MCV dan met een lager MOV.

over het geheel genomen komen de klachten veel voor, in lédere klasse van de hematologische parameters. Moeheid en kuitkrampen spannen wat dit betreft de kroon: respectievelijk 68 is en 50 van de vrouwen bleek hiervan last te hebben gehad in de week voorafgaande aan het invullen van de vragenlijst. Slechts $4 \%$ van de vrouwen heeft geén enkele van de genoende klachten. 


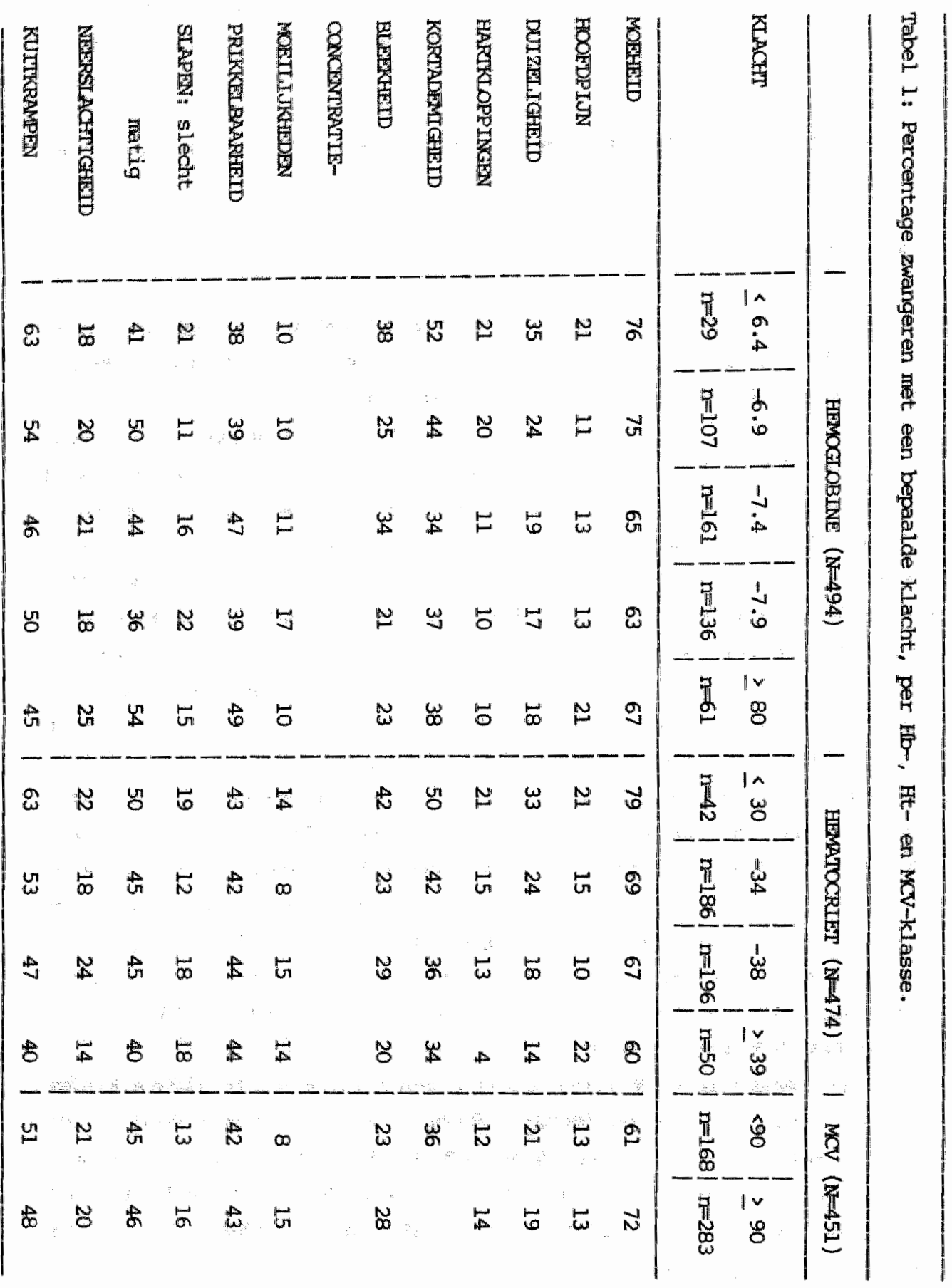




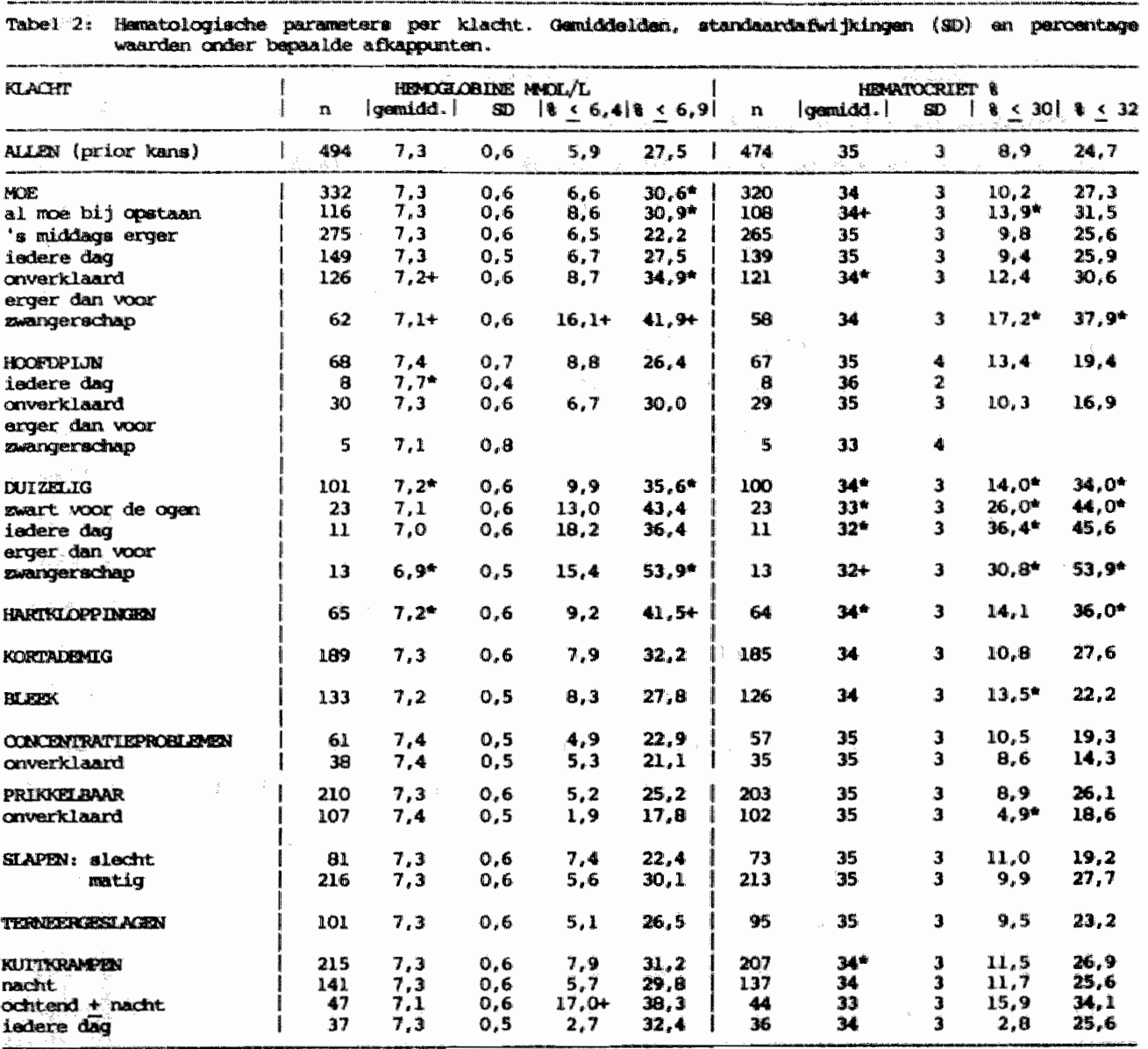

* $p<0,05$

$t p<0,01$

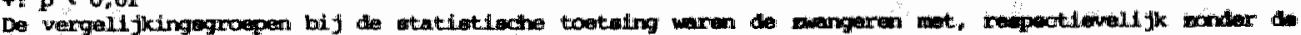

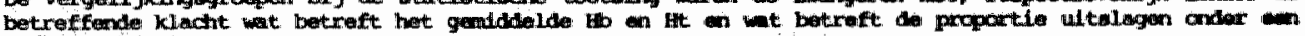
bepainid aftinppumt. 
amiat voor de arts subjectieve klachten als vertrekpunt minsteris wo belangrijk zijn als laboratorüunteslagen, is in tabel 2 voor elke klacht aangegeven, in welke mate deze een indicator is voor een laag Hib respectievelijk Ht. Per klacht is van bepaalde, tevens nagevraagde, nadere kemmerken cok het verband met $\mathrm{Hb}$ en $\mathrm{Ht}$ aangegeven. De klachten 'iedere dag hoofapljn' en 'dulzelig, erger dan vó́r de zwangerschap' bleken gepaard te gaan met een duidelijk hoger, respectievelijk lager gemiddeld $\mathrm{Hb}$ dan dat van de gehele groep. Voor de gemiddelde hematocriet werd een dergelijk (duidelijk negatief) verband alleen gevonden voor duizeligheidsklachten, "iedere dag", en 'erger dan vóbr de zwangerschap". Meer infomatief is het beeld van de "voorspellende waarden" van de klachten ten aanzien van een laag thb of Ht vanaf de afkappunten 6.4 en $6.9 \mathrm{mmol} / 1$, respectievelijk 30 en $32 \%$. Ten behoeve van de duidelijkheid, en ook condat dit op grond van de data te rechtvaardigen is, beperken wij ons in de verdere bespreking tot de afkappunten $6.9 \mathrm{mmol} / 1$ respectievelijk $32 \%$. In tabel 2 is cok de informatie voor de lagere afkappunten beschikbaar. Kijkend naar de afkappunten 6.9 mol $/ 1$ en 32 , blijkt dat de "a posteriori" kansen op lage waarden (d.w.z. de kans hierop; gegeven bepaalde klachten) vooral toenemen ten opzichte van de "a priori kans" (d.w.z. de kans op lage waarden in de gehele groep) bij onverklaarde moheld, "moeheid, erger dan vóbr de zwangerschap", duizeligheid ("zwart voor de ogen", "iedere dag", "erger dan vóór de zwangerschap"), hartkloppingen, kuitkrampen ('s morgens, al dan nilet gepaard aan nachtelijke krampen). Wanneer er sprake is van prikkelbaarheid waarwoor men zelf geen verklaring heeft. lijkt ex juist minder vaak sprake van lage Hb- en Ht-waarden. Daartegenover stat, dat als men wil een verklaring heeft, het th relatief vaak lager dan 7.0 mol/1 1s. Dat geldt vooral voor als "psychosooiaal" geduide verklaringen (14/36, vergus $19 / 107$ in de "geen verklaring" gxoep, $P(0.05)$.

In tabel 3 zijn de lineaire regressiecoêfficienten gegeven van die klachten, die na selectie via een forward stepwise procedure een statistisch significante samenhang blijken te hebben met de hemoglobineconcentratile en/of de hematocriet. Deze invloeden lijken, behoudens voor duizeligheid, gering. Opmerkelijk is weer dat "prikkelbaarheid zonder verklaring" eerder met een hoog dan met een laag Ho/Ht samenhangt. 


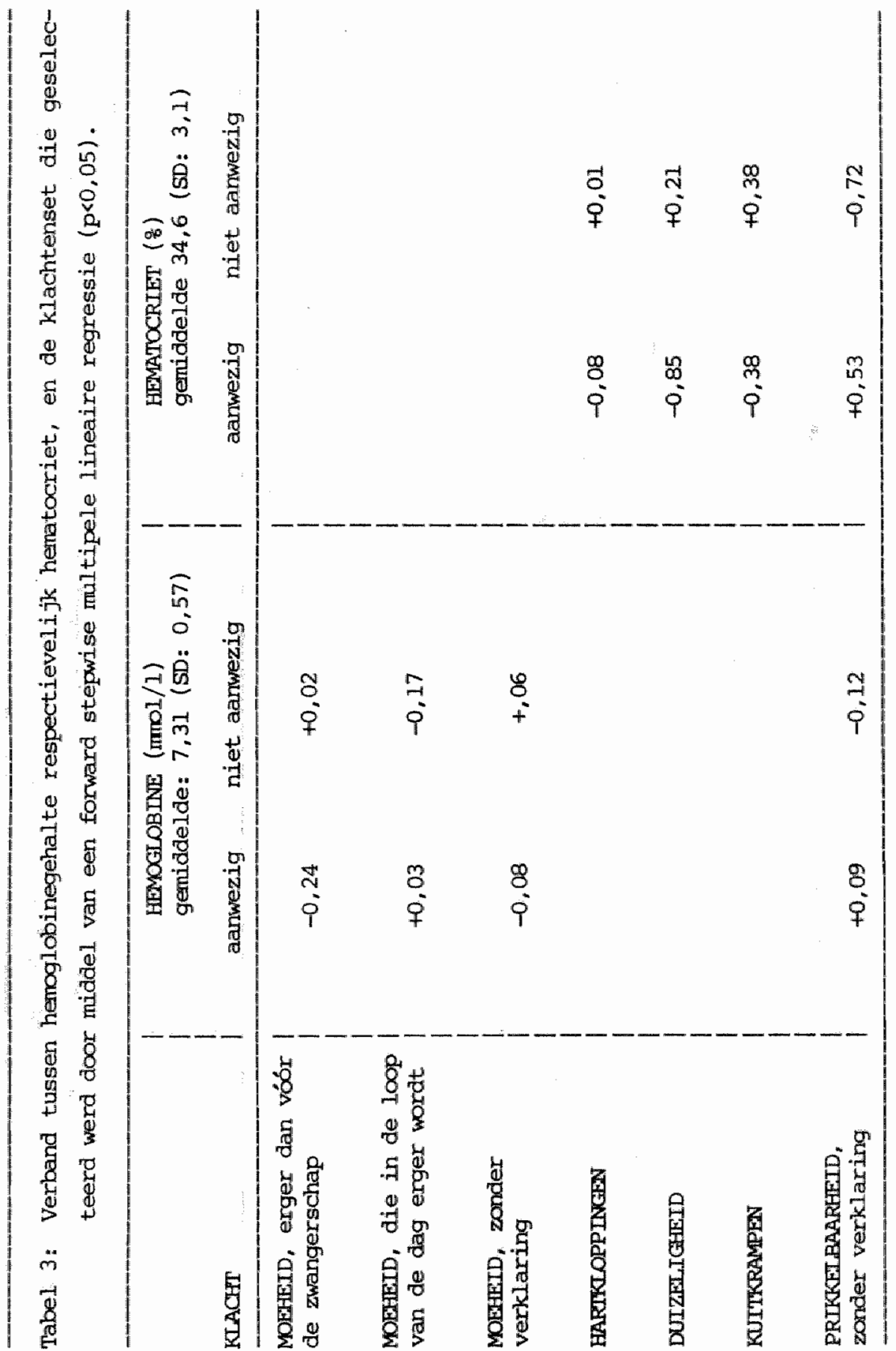




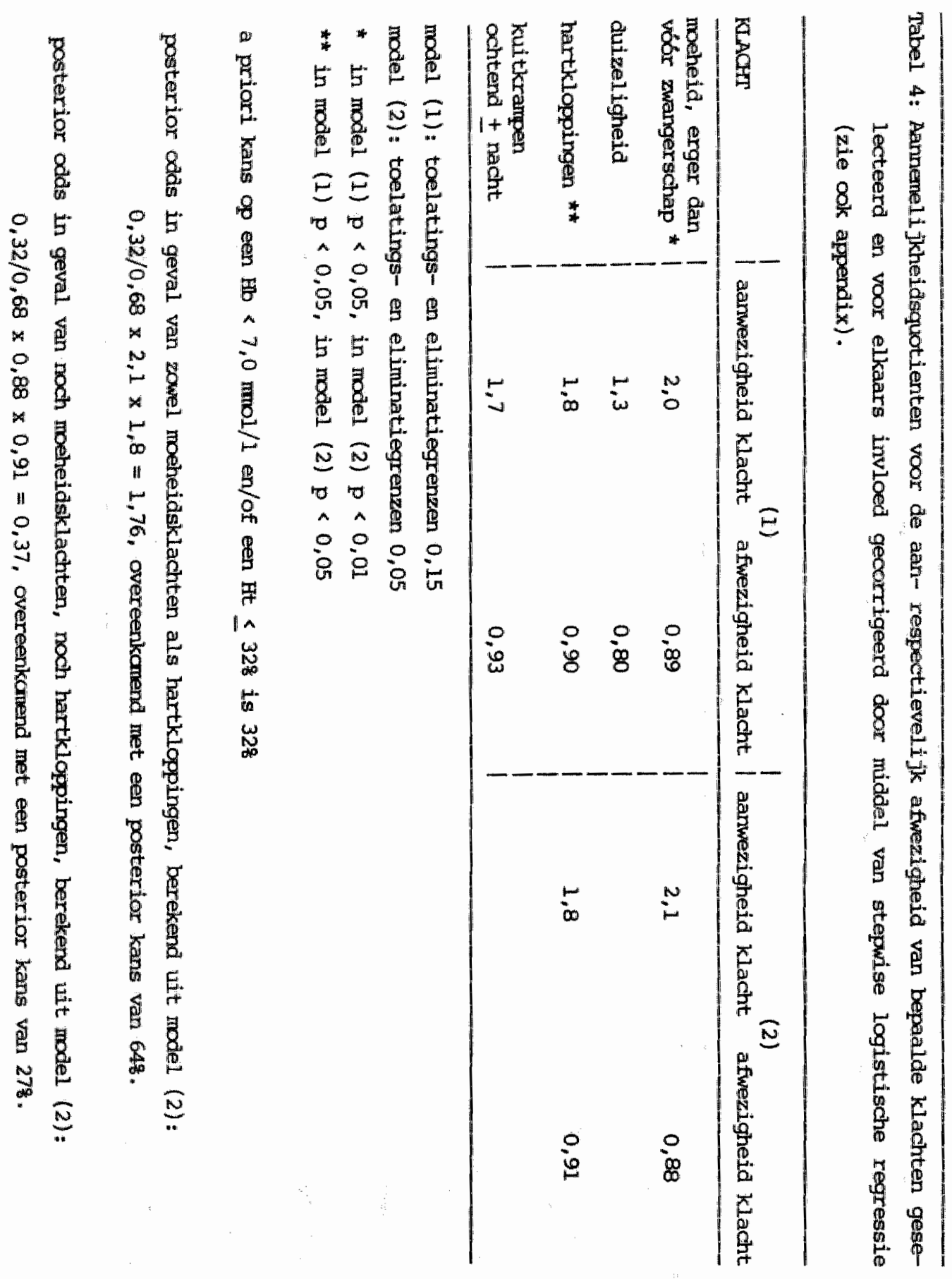


Tabel 4 presenteert de resultaten van de multipele logistische regressie, met afhankelijke variabele: de pasterior odds van een Hb van 6.9 mol/1 of lager en/of een Ht van 32 of lager. Gegeven zijn de aannemelijjkheidsquotiënten van de klachten die geselecteerd werden door middel van een stepwise logistische regressie-analyse. Moeheidsklachten, die erger zijn dan wor de zwangerschap, duizelligheid, hartkloppingen en kuitkrampen, die "s morgens \pm "s nachts optreden, blijken de kans op een Ho en/of Ht onder genoemde greiswaarden, ook los van elkaar, te verhogen. Deze klachtenset is het resultaat van zowel een forward als een backward stepwise procedure, met als toelatings- en eliminatiegrenzen p-waarden van 0.15 . Indien we deze grenzen stringenter maken ( $p=0.05)$, blijven alleen de betreffende moeheidsklachten en hartkloppingen over als indicatoren van lage Ho- en/of Ht- waarden, met aannemelijkheidsquotienten in dezelfde orde van grootte. Als pariteit (al dan niet nullipara) en leeftijd als onafhankelijke variable in het model worden opgenomen, veranderen de uitkonsten niet. Het resultaat van deze multivariabele amalyse impliceert, dat men de diagnostische informatie van de genoemde klachten aan elkaar kan toevoegen (zie appendix). Zo is op grond van de bepaalde waarden van de aannemelijkheidsquotienten te berekenen, dat een zwangere die noch het genoende type moeheidsklachten heeft noch hartkloppingen, nog een kans van $27 \%$ heeft op een Hb en/of Ht onder de gestelde nomen. Heeft men beide klachten wel dan wordt deze kans 64 (zie toelichting tabel 4).

om na te gaan of de bestudeerde relaties anders lagen in de populatile vrouwen die gedurende de gehele zwangerschap door een verloskundige (perifeer of poliklinisch, $n=145$ ) begeleid was, dan in de populatie die primair of secundair door een gynaecoloog begeleid was $(n=349)$, werd voor beide subpopulaties cen aparte regressie-analyse verricht. Moeheid, erger dan vóbr de zwangerschap, en hartkloppingen bleken in beide gevallen weer de belangrijkste predictoren met aannemelijkheldsquotienten die in dezelfde orde wan grootte lagen als in de totale groep.

ondat het op indicatie gebruikt hebben van staaltabletten (43\% gebruikte deze vón de 30 e week) invloed kan hebben op het verband tussen klachten en hemoglobinegehalte, gingen wij na of de bestudeerde relaties veranderden als wij vrouwen dile staal gebrulkt hadden al dan 
niet, c.q. apart, in de analybe betrokken. De richting van de verbanden veranderde niet en de coefficienten bleven weer in dezelfde orde van grootte. Het Hib van de staalgebruiksters was wel iets lager dan dat van de niet-staalgebruiksters $(7.23 \mathrm{mmol} / 1$ (SD: 0.49 ) versus 7.34 mimol/1 (SD: 0.61$)(\mathrm{p}<0.05)$.

om een indruk te krijgen in hoeverre follumzumrtekort een rol zou kunnen spelien, is het verband tussen klachten en $\mathrm{Hb}$ respectievelijk Ht apart bestudeerd voor vrouwen met een MCV lager dan, respectievelijk gelijk aan of groter dan $90 \mathrm{fl}$. Terwijl er bij lagere Mcv- waarden vaker lage Ho- en Ht- concentraties voorkwamen dan bij hoge MCVwaarden, werden moeheid, hartkloppingen en kortademigheid relatief vaak aangetroffen in de groep met zowel een hoger MCV, als een lager Ho (tabel 5). Voor de hematocriet vonden we eenzelfde beeld. Bif de multipele lineaire en logistische regressie konden nu alleen verbanden tussen klachten (de klachtenset moeheid, erger dan vóór de zwangerachap, duizeligheid en kuitkrampen) en Hb- en/of Ht- waarden onder de gehanteerde afkappunten worden aangetoond in de groep vrouwen met een MCV van 90 of hoger.

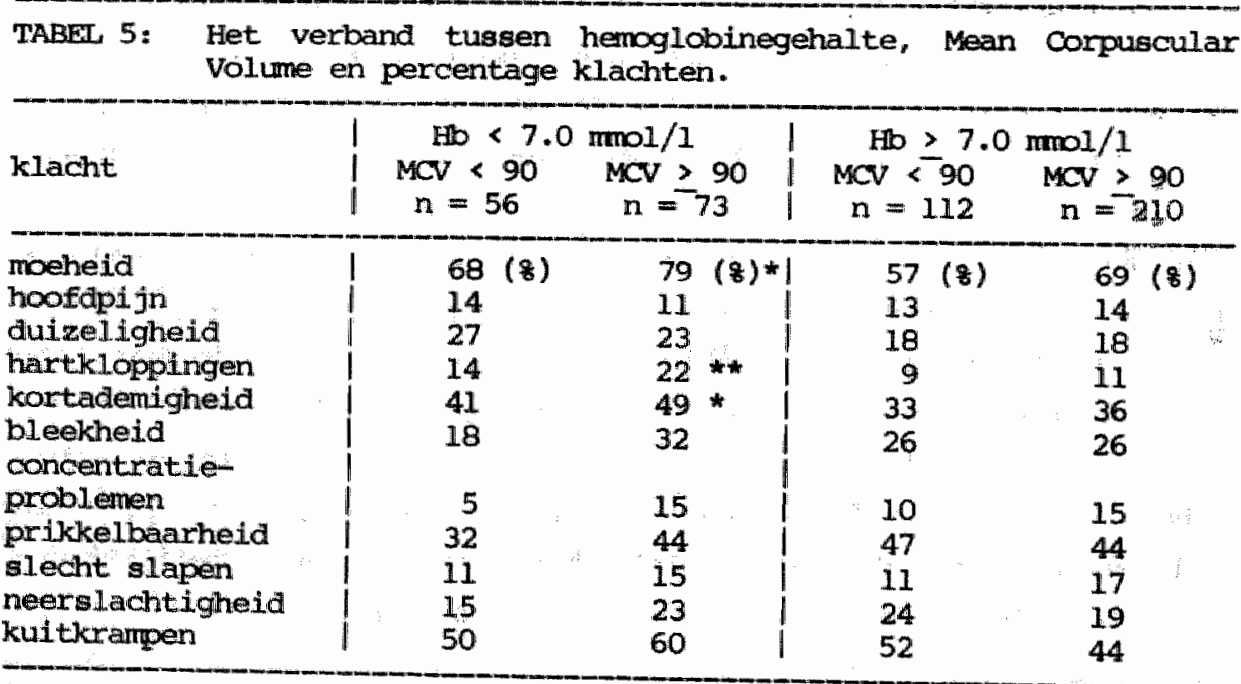

$* p<0.05$
$*: p<0.01$

(Chilkwadraat toets, tweezijdig, voor de vergelijking met de proportie vrouwen met iklachten onder alle overigen). 


\section{Discussie.}

De conclusie van het onderzoek is, dat er bij zwangeren sprake lijkt. te zijn van een verband tussen het voorkomen van bepaalde klachtern en lage $\mathrm{Hb}$ - en Ht-waarden (reeds vanaf $7.0 \mathrm{mmol} / 1$, respectievelijk $32 \%$ ). In ons ondlerzoek kwamen vooral de volgende klachten naar voren: moeheidsklachten (erger dan vóbr de zwangerschap), hartkloppingen, duizeligheid, kuitkrampen vooral als deze in de ochtend optreden. Na opsplitsing van de vrouwen in groepen met hogere respectievelijk lagere MCV- waanden (afkappunt 90 fl), werden verbanden tussen klachten en lage $\mathrm{Hb}$ - en Ht-concentraties alleen aangetoond in de eerste groep. Dit is wellicht een aanwijzing, dat foliumzuurtekort een rol speelt bij het ontstaan van klachten. Sommige klachten lijken (ook) met een hoger $\mathrm{Hb}$ samen te hangen, zoals hoofapijn en onverklaarde prikkelbaarheid. Indien als verklaring voor prikkelbaarheid als psychosociaall gleduide problemen worden aangegeven, dan is er juist meer kans op een laag Ho. De vraag is dan gewettigd, in hoeverre deze prikkelbaarheid werkelijk psychosociaal van aard is.

In tegenstelling tot wat wij verwachtten hangt moeheid die toeneent in de loop van de dag, niet samen met een laag $\mathrm{Hb}$. Waarschijnlijjk is de invloed van de extra belasting in de loop van de dag op zichzelf voldoende verklaring voor deze klachten.

Het feit dat kuitkrampen in de ochtend zo duidelijk verband houden met lage hematologische waarden, werpt een nieuw licht op de genese van deze klachten. Wellicht betreft het hier een ander type klachten, dan de krampen die alleén 's nachts, in horizontale ligging optreden. Het kan zijn dat, als de zwangere 's morgens 'op gang' komt het hemoglobinegehalte net te kort schiet en dat een kortdurende relatieve ischemie ontstaat. cok het feit, dat na lang in horizontale houding liggen een extra hernodilutie optreedt (5), kan hieraan bijaragen.

Klachten, die in meer of mindere mate gerelateerd kunnen worden aan lage Hb-waarden, zijn overigens 'gewoon' tijdens de zwangerschap. Sommige klachten (moeheid, kuitkrampen) komen bij de helft of meer van de vrouwen voor, en slechts zeer weinigen hebiben géen klachten.

Indien ifzertabletten niet of niet alleen routinematig (c.q. at random), maar ook naar aanleiding van klachten zijn gebruikt, is te verwachten, dat de door ons gevonden verbanden sterker zouden zijn 
geweest indien voor de 30 e week in het geheel niet gesuppleerd was. Imers indien vooral vrouwen die tevoren reeds klachten hadden staaltabletten -en daarmee wellicht een hoger Hb- hadden gekregen, dan zou het daarna ontciekken van een verband tussen een laag $\mathrm{Hb}$ en klachten moeilijker zijn. Niettemin vonden wij duidelijke relaties, met en zonder controle voox het gebruikt hebben van staaltabletten.

Is ait alles (toch weer) een pleidool voor, eventueel routinematige, 1 jzersuppletie? Op grond van het hier beschreven onderzoek is die vraag niet te beantwoorden. Weliswaar staat vast, dat ijzersuppletie overigens ook nog bij hoge hlo-watarden - de erythropoiese bevordert (6). Of hiermee ook een gunstig effect op subjectieve klachten bereikt wordt, is voor zover wij weten nog niet onderzocht. Daarnaast is het denkbaar dat met het oog op het verloop van de zwangerschap een matig hoog Hb-gehalte ongunstiger is, dan een matig laag $\mathrm{Hb}(7-10)$. Uit ons onderzoek zou, louter vamuit een oogpunt van subjectieve klachten, een ondergrens van $7.0 \mathrm{mmol} / 1$ voor het $\mathrm{Hb}$, na de fysiologische hemodilutie, kumnen worcen afgeleld. Deze is ieto hoger dan de 6.3 a 6.5 mol/ 1 die 1 s aanbevolen vanuit een oogpunt van een optimale zwangerschapsuitkomst $(7,10)$.

Bespreking behoeft nog de vraag of de hier beschreven bevindingen te rijmen zijn met de resultaten van ons onderzoek bij niet-zwangeren in de huisartspraktijk, waarbij géen verbanden tussen klachten en het Hb werden gevonden(1). Men zou kunnen wijzen op het verschil in de gehanteerde methoden. Bij het huisartsenonderzoek werden de patienten door de huisarts ondervraagd, terwijl de zwangeren zelf het vragenformulier invulden. Daar in beide gevallen het tho niet bekend was op het moment var de registratie van de klachten is systematische vertekening in beide gevallen echter onwaarschijnlijk. Een aannemelijke verklaring is, dat wij in de huisartspraktijk onder de moeheidspatienten geen $\mathrm{Hb}$ watarden onder de $7.0 \mathrm{mmol} / 1$ vonden. Het $\mathrm{lijkt}$ er $\mathrm{nu}$ op dat, althans bij wangeren, een th lager dan $7.0 \mathrm{mmol} / 1$ wel met klachten samenhangt: Hemodilutie kan dan weliswaar fysiologisch zijn, er treden wel wat meer klachten bij op.

Wij keren tenslotte terug naar de vraag in hoeverre de bepaling van de hematologische parameters gedurende de zwangerschap op geleide van subjectleve klachten kan gegchieden. Wij zouden hierop voorlopig wlllen antwoorden: als men het belangrijk vindt een laag Hb bij zwan- 
geren op te sporen, kan men de bepaling niet alleen op geleide van klachten uitvoeren. De redenen zijn, dat klachten ook bij zwangeren met een hóóg $\mathrm{Hb}$ vrij vaak voorkamen, dat weel vrouwen met een laag Hb toch bepaalde klachten niet hebben, en dat het onderscheldend vermogen van geen van de klachten erg groot is. Omalat, zoals beschreven, bepaalde klachten wel verband houden met een laag Hib of Ht, kunnen deze wel als indicatie gelden voor een extra bepaling, los van de routinematige controles. Het verstrekken van staaltabletten louter naar aanleiding $\operatorname{van}$ klachten, zonder hematologische controle vooraf, lijkkt in elk geval. ongerechtvaardigd gezien de matige voorspellende waarde van klachten.

\section{LITERATUUR.}

1. Knottnerus JA, Knipschild PG, Van Wersch J, Sijstermanns AHJ. onverklaarde moeheid en hemoglobinegehalte, een onderzoek vanult de huisartspraktijk. Ned Tijdschr Geneesk 1986; 130: 402-405.

2. Wintrobe MM (ed.). Clinical Haematology. New York 1981, pp. 549-551.

3. Brockerhoff P, Kurtenbach MI, Stark W, Schiketanz KH, Freidberg V, Rathgen GH. Klinisch-chemische und hëmatologische Parameter im Schwangerschaftsverlauf. Gynäk Rdsch 1981; 21 : 101-123.

4. BMDP Statistical Software, University California Press, Berkely 1983.

5. Kreutzer HH, Pennings AW. Het schamelende Hb-gehalte. Ned Tijjdschr Geneesk 1976; 120: 144-146.

6. Taylor DJ, Lind $T$. Red cell mass during and after pregnancy. British Journal of Obstetrics and Gynaecology 1979; 86; 364-370.

7. Garn SM, Ridella SA, Petzold AS, Falkner F. Maternal hematologic levels and pregnancy outcomes. Seminars in Perinatology 1981; 5: 155-162.

8. Huisjes $\mathrm{H}$. Het hemoglobine-gehalte in de zwangerschap. Ned Tijdschr Geneesk 1985; 129: 1323-1324.

9. Huisman A, Aarnoudse JG. Increased 2nd trimester hemoglobin concentration in pregnancies later camplicated by hypertension and growth retardation. Acta Obstetrica et Gynaecologica Scandinavica. In press.

10. Murphy JF", O'Riordan J, Newcombe RG, Coles EC, Pearson JF. Relation of haemoglobin levels in first and second trimester to outcome of pregnancy. The Lancet 1986; 1: 992-994. 
Appenalix.

Stel: $P\left(D^{+}\right)=$de kans op ziekte $D$ in een bepaalde (onderzoeks) populatie, zonder dat vendere diagnastische gegevens bekend zijn (prior kans).

$P\left(D^{+} \mid X\right)=$ de kans op zlekte $D$ in deze populatile, gegeven het

bekend zijn van testuitslag $\mathrm{X}$ (pasterior kans).

In de logistische regressiefunctie geldt voor het verband tussen $P\left(D^{+} \mid X\right)$ en $X$.

Ln $\frac{P\left(D^{+} \mid X\right)}{1-P\left(D^{+} \mid x\right)}=$ natuurlijke logaritme van de posterior odds $=A+B X$ waarbij $A$ het intercept is en $B$ de logistische regressiecoefficient $\operatorname{van} X$.

on in het intercept de prior kans te verwerken, dient men als nieuw intercept te stellen:

$A^{1}=\operatorname{In} \frac{P\left(D^{+}\right)}{l-P\left(D^{+}\right)}=$matuurlijke logaritme van de prior odds.

De functie zal na de conversie van het intercept dezelfale blijven indien $\mathrm{X}$ wordt vervangen door

$\mathrm{X}^{2}=\mathrm{x}-\frac{\operatorname{Ln}(\text { prior odds })-A}{B}$

Het is nu gemakkelijk in te zien dat indien:

$x=x_{0}=\frac{\operatorname{Lin}(\text { prior odds })-A}{B}$

geldt: posterior odds = prior odds

Dat wil zeggen: het aannemelijkheidsquatiènt van de uitslag met waarde $x_{0}$ is gelijk aan 1.0.

Voor dichotome testvariabelen $k a n x_{0}$ een virtuele waarde van $x$ zijn tussen 0 en 1 . 
De regressievergelijiking wordt dan:

Ln $($ posterior odds $)=\operatorname{Ln}($ prior odds $)+B\left(x-x_{0}\right)$

Dat wil zeggen:

posterior odds $=$ prior odds $* e^{B\left(X-x_{0}\right)}$

Het aannemelijkheidsquotiënt (likelihoodratio, LR) van de testuitslag is dar:

voor de positieve uitslag $(x=1)$ :

$L R+=e^{B\left(1-X_{0}\right)}=e^{B-(A-\operatorname{Ln}(\text { prior odds }))}$

en voor de negatieve testuitslag $(x=0)$

$L R-=e^{-B X_{0}}=e^{A-\operatorname{Ln}(\text { prior odds) }}$

Tevens geldt $\frac{\mathrm{LR} t}{\mathrm{LR}-}=e^{\mathrm{B}}$, dat is: de Odds Ratio

Ofwel: $\frac{\text { posterior odds bij testuitslag } X=1}{\text { posterior odds bij testuitslag } X=0}$

De variabele $\mathrm{X}$ kan behalve een dichotome test ook een test met een uitslag op een continue schaal representeren. In (4) en (5) gaat het dan niet an het aannemelijkheidsquotiënt. van een positleve of negatieve testuitslag, maar on het aannemelijkheidsquotiënt voor de (exacte) warde $X$ *

Door de ad (2) genoemde conversie van de onathankelijke variabele $\mathrm{X}$ te verrichten kan men dus met behulp van logistische regressie-analyse rechtstreeks aannemelijkheidsquotiẻnten bepalen, en wordt het intercept equivalent aan de natuurlijke logaritme van de prilor odds.

Door tijdens de data-analyse eerst voor ledere testvariabele $x$; in een univariate regressie-analyse $x_{i 0}$ te bepalen, en deze vervolgens in de 
multivariabele analyse van $x_{1}$ af te trekken via de transfonmatie $x_{i}=$ $x_{i}-x_{10}$ krijgt men de volgende vergelijking.

$\operatorname{Ln}($ posterior odds $)=A^{1}+B_{1}\left(x_{1}-x_{10}\right)+B_{2}\left(x_{2}-x_{20}\right) \ldots \ldots B_{1}\left(x_{1}-x_{10}\right)$

Waarbij $e^{A^{1}}=$ prior odds

en $e^{B i\left(x_{1}-x_{i 0}\right)}=$ aamemelijkheidsquotiënt voor variabele $x_{1}$

met wararde $\mathrm{X}_{1}$

gecorrigeerd voor de invloed van andere onathankelijke

variabelen.

Aangenomen wordt dan, dat de $x_{0}$ waarden voor de diverse variabelen onafhankelijk van elkaar zijn. Deze aanname kan gecontroleerd worden via het onveranderd blijven van het intercept bij toevoeging van een nieuwe variabele.

Via dit model kan men, aldus, beschikbare diagnostische informatie gebruiken in verschillende combinaties, om uitgaande van de a priori kans de a pasteriori kans te schatten, waarbij de betreffende aanneme1ijkheidsquotiènten gecorrigeerd zijn voor andere onafhankelijke (test) variabelen.

In feite reperesenteert het model een 'probability tree' waarbij men, ultgaande van de prior kans, via toevoeging van een bepaalde set diagnostische infomatie uiteindelijk een bepaalde "path probability" bereikt. 
DIAGNOSTISCHE CONCLUSIES VAN DE HUISARTS NAAR AANLEIDING VAN CNVERKLAARDE MOEHEID.

J.A. Knottnerus - R. Stammans - A. Vissers

\section{Samenvatting.}

In een na-onderzoek, 1 jaar na het eerste contact vanwege moeheidsklachten die in eerste instantie onverklaard bleven, werden via het kaartsysteem en de huisarts zelf geinventariseerd: de diagmostische conclusies van de huisarts naar aamleiding van de moeheidsepisode ( $n=161$ ), alsmede àlle diagnostische conclusies die binnen 1 jaar naar voren kwamen $(\mathrm{N}=166)$. Naar aanleiding van de moeheidseplsode werd in $17 \%$ van de gevallen een somatische diagnose gesteld en bij 168 kwam een psychosociaal probleen naar voren. op hogere leeftija werden vaker scomatische diagnosen gesteld. Bij $70 \%$ van de patiënten werd géen diagnostische conclusie geformuleerd naar aanleiding van de moeheidsepisodie. Bij 558 van de patiënten was ook na verloop van een jaar geen diagnose of probleem vastgesteld.

Capaciteitsgroep Epidemiologie en Capaciteitsgroep Huilsartsgeneeskunde, Rijksuniversiteit Limburg, Maastricht. 
Inteiding.

Als een patiënt met de klacht moeheid de huisarts bezoekt, zal dikwijls al tijdens het eerste consult en voor de hand liggende verklaring voor de klacht worden gevonden. Er blijft echter een groep over, bij wie aan het eind van het consult geen bevredigende conclusie is getrokken. Bij deze groep patiênten met "onverklaarde moeheid" wordt vervolgens vaak aanvillende diagnostiek verricht (1-3). In een eerder onderzoek werd geen verband gevonden tussen onverklaarde moeheid en de waarde van hematologische parameters. Bovendien bleek dat de voorspellende waarde van onverklaarde moeheid ten aanzien van het vóbramen van anemie zeer laag was (4). Op grond van deze resultaten zou men het belang van onverklaarde moeheid a.1s "diagnosticum" kunnen relativeren. Er ontbreekt echter nog een schakel, namelijk die van de - witeinde$1 i j k$ - naar aanleiding van het eerste consult vastgestelde diagnosen of problemen.

Over de diagnostische betekenis van de klacht moeheid zijn tot nu twee huisartsgeneeskundige studies gepubliceerd. Beilde waren retrospectilef: de (ingangs)klacht werd achteraf ontleend aan patiëntenkaarten. Het eerste onderzoek betrof 176 patiënten met een "1solated diagnosis of fatigue" (5), en het tweede 57 patiënten met "fatigue of uncertain etiology", waarbij de corzaak van de klacht onzeker was na anamese en fysisch diagnostisch onderzoek (6). Men kwam in deze studies uiteindew $1 i j k$ in 40 à $50 \%$ van de gevallen tot scmatische diagnosen en eveneens In $40 \%$ a $50 \%$ tot psychische problemen, al dan niet in combinatie. In 10 20\% van de gevallen werd ook na follow-up geen definitieve diagnose gesteld. Gezien het retrospectieve karakter van beide studies moeten selectieve uitval en registratie van patlënten niet uitgesloten worden geacht. Hi.erdoor kan de hoeveelheid achterliggende pathologie zijn beinvloed. Tevens werd de onverklaarde moheid pas - scans geruime tija - achteraf als zodanig gedefinieerd. Bovendien betrof het Amerikaanse onderzoken, en het is bekend dat de Amerikaanse Family Practice niet vergelijkbaar is met de Nederlandse huisartspraktijk.

Wij stelden een na-onderzoek in bij de moeheidspatiënten die in het eerste half jaar van 1984 waren opgenomen in het onderzoek "onverklaarde moeheid en het hemoglobinegehalte" (4). De vraagstelling was 
hoe vaak de huisarts naar aanleiding van in eerste instantie onverklaarde moeheidsklachten uiteindelijk tot diagnostische conclusies komt en wat de aard is van deze conclusies.

Methode.

Met 9 huisartsen werd afgesproken dat gedurende een half jaar alle patiënten in het onderzoek zouden worden opgenomen,

o die moeheidsklachten presenteerden waarvoor de huisarts na anamese en fysische diagnostiek, verricht tijdens het eerste consult, geen verklaring kon vinden;

o die tevoren niet bekend waren met pathologie die in verband kon staan met moeheid of het henoglobinegehalte;

o die in de 12 maanden tevoren geen moeheidsklachten bij de huisarts hadden gepresenteerd;

o bij wie de huisarts een hemoglobinebepaling geindiceerd achtte. Deze toelatingscriteria werden van te voren mondeling doorgenomen en schriftelijk aan de huisartsen ter hand gesteld. Gedurende het onderzoek was er minstens eenmaal in de twee weken contact met de huisartsen over de voortgang van het onderzoek.

Aan de in het onderzoek opgenomen patiënten werd tijdens het eerste contact door de huisarts onder meer gevraagd naar de ernst (gemeten op een driepuntsschaal) en de duur van de klacht.

Van deze patiënten werd op de volgende wijze follow-up informatie verzameld.

o om vast te stellen welke diagnostische conclusie naar aanleiding van de moeheidsepisode getrokken werd, bestudeerden de auteurs eerst van ledere patiënt de patiëntenikaart van de huisarts en eventuele specialistische gegevens, fén jaar na het eerste consult wegens moeheid. Op een standaardformulier werden de uiteindelijke diagnostische conclusies van de huisarts genoteerd. Er werden hierbij geen expliciete diagnostische criteria geformuleerd. Aangesloten werd bij de conclusie van de huisarts. In de regel waren deze direct aan de kaart te ontlenen. De diagnose "ijzergebrek" werd nooit expliciet genoend. Daaran werd tot de diagnostische conclusie "ijzertherapie" besloten als de kaart alleen vermeldde dat ijzermedicatie werd verstrekt. 
- Alle patiërten werden vervolgens met de eigen huisarts besproken. Daarbij werden de gegevens van de patiëntenkaart zonodig aangevuld. voorts werd aan de hulsarts gevraagd of zich bij de patiënten in het jaar na het eerste contact belangrijke nieuwe gezondheidsproblemen hadden voorgedaan, cok los van de moheidsklachten. ook over een aantal patieüten van wie geen patiëntenkaart was aangetroffen, kon de hulsarts deze informatie verstrekken. ondat de relatie tussen eventuele diagnostische conclusies en de moeheidsepisode bij deze (5) patienten niet vi.a de kaart te controleren was, werden zij van dat deel van het onderzoek uitgesloten.

\section{Resultaten.}

In de onderzoekaperiode werden 174 patienten in het onderzoek opgenemen. Van 161 van deze patiënten was het mogelijk on via het kaartsysteem (en de informatie van de huisarts zelf) alle follow-up gegevens te verzamelen. Van 5 andere (vrouwelijke) patiënten was de patielntenkaart niet te vinden, maar van hun toestand na een jaar was de huisarts wel op de hoogte. Van 4 patiënten was bekend dat ze verhuisd waren, en volgens de huisarts had zich bij hen tot het moment van verhuizing geen relevante gezondheidsproblematiek voorgedaan. over 4 patiernten kon noch via de kaart en noch via de huisarts informatie verkregen worden. Onder de $166(161+5)$ patiënten van wie follow-up gegevens werden verkregen waren 39 mannen (gemiddelde leeftijd 41 jaar, range 18-82 jaar) en 127 vrowwen (gemiddelde leeftijd 38 jaar, range $18-79$ jaar).

Gemiddeld hadden de patienten 5.1 contacten met hun huisarts in het follow-up jaar ( $5.5 \mathrm{bij}$ vrouwen en $3.7 \mathrm{bij}$ mannen), waarvan gemiddeld 1.3 aan de moeheidsepisode werd besteed. Bij $13 \%$ van de opgevolgde patiënten was na een jaar de moeheidsklacht nog gteeds aan de orde in het contact met de huisarts.

Diagnostische conclusies naar aanleiding van de moeheidsklachten.

In tabel 1 zijn de conclusies naar aanleiding van de moeheidsepisode vermeld voor de 161 patienten van wie de patientenkaart beschikbaar was, onderverdeeld naar geslacht en leeftija (jonger dan 50 jaar, en 50 jaar en ouder). De conclusies zijn gegroepeerd in scmatische diagnosen en psychosociale problemen (indien er een toestandsbeeld of een concreet probleem werd genoema). 
Tabel 1: Diagnostische conclusies van de huisarts naar aanleiding van in eerste instantie onverklaarde moeheldsklachten.

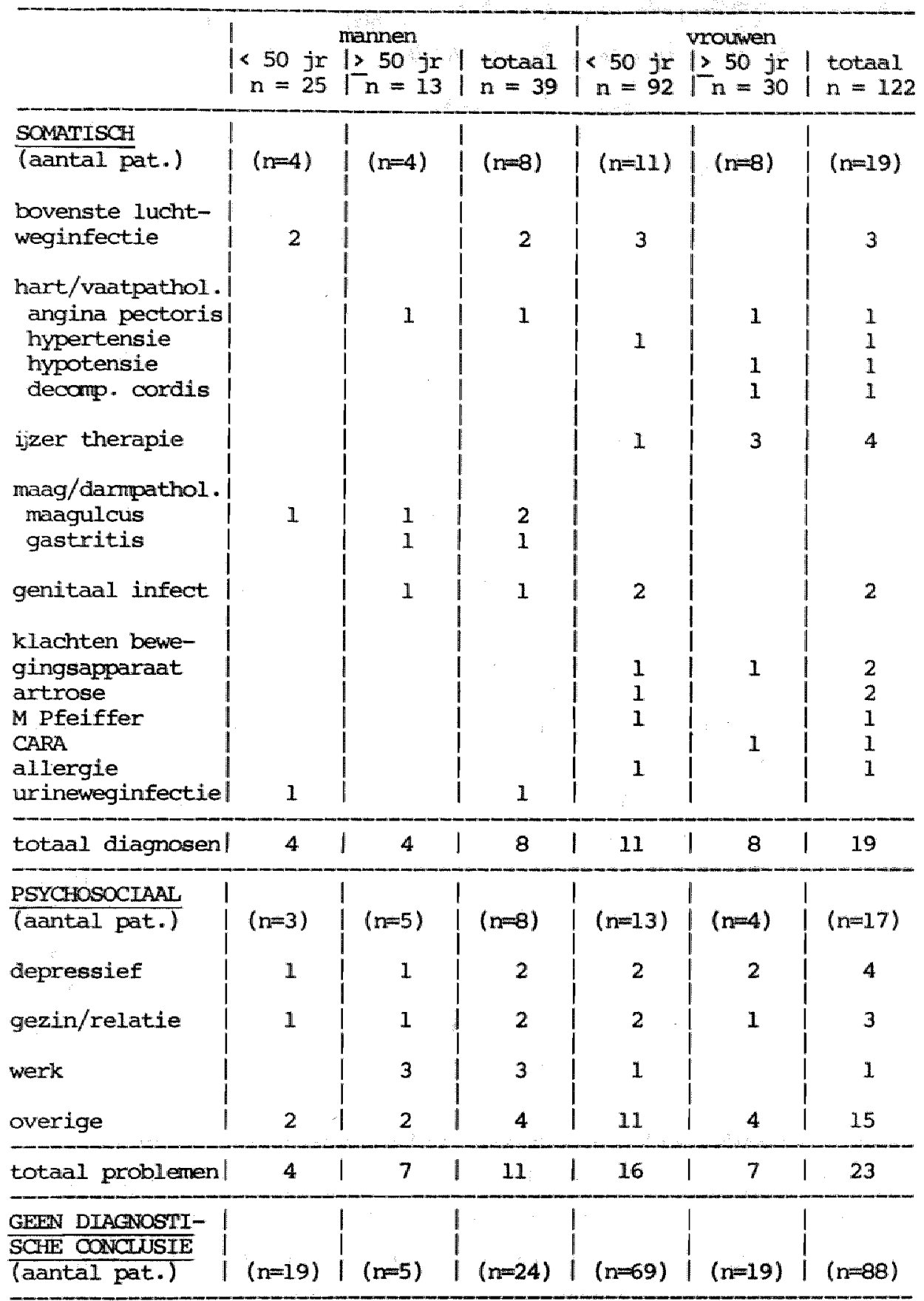


Uit de tabel blijkt dat bilj 178 (n1 $(8+19) / 161)$ van de patiënten scmatische diagnosen gesteld werden. Bij 168 (nI $(8+17) / 161)$ kwam een psychosociaal probleem naar voren. Er werden bij mannen relatief wat vaker somatische diagnosen en psychosociale problemen vastgesteld, maar deze verschillen zijn niet significant (chi-kwadraat toets). De leeftijd is van invloed, zoals ook blijkt wit tabel 2. Bij patienten van 50 jaar en ouder wordt over het geheel genomen ruim tweemaal zo vaak een somatische dlagnose gesteld als bij jongere patiënten ( $p$ * 0.05 , chi-kwadraat toets). Deze tendens doet zich bij psychosociale problemen alleen bij mannen voor.

TABEL 2: Percentage moeheidspatienten bij wie naar aanleiding van de moeheidsepisode een bepaald probleem wordt vastgesteld, naar leeftijd en geslacht.

\begin{tabular}{|c|c|c|c|c|c|c|}
\hline \multirow{2}{*}{ Aard probleem } & \multicolumn{2}{|c|}{ mannen } & \multicolumn{2}{|c|}{ vrouwen } & mannen & \multirow{2}{*}{$\begin{array}{l}\text { en vrouwen } \\
\geq 50 \mathrm{jr} \\
\mathrm{n}=43\end{array}$} \\
\hline & $\begin{array}{l}r 50 j x \\
n=26\end{array}$ & $\frac{\geq 50 j x}{n}=13$ & $\begin{array}{l}40 j x \\
n=92\end{array}$ & $\frac{2}{n}=30 j x$ & $\begin{array}{l}50 \text { jr } \\
n=118\end{array}$ & \\
\hline Somatisch & 158 & 318 & 128 & 278 & 138 & 288 \\
\hline Psycho-socilaal & 1128 & 388 & 148 & 138 & 148 & 218 \\
\hline
\end{tabular}

Gezondheidsproblemen kumnen in cambinatie voorkomen. De grootste groep patiënten bij wie een probleem naar voren komt betreft een geisoleerde somatische diagnose (15\%). Bijj $11 \%$ komt alleen een psychosociaal probleem voor. Cambinaties worden slechts in 5 응 van de gevallen gevonden, terwij1 bij $70 \%$ van de moeheidspatiënten $(112 / 161)$ géen diagnostische conclusie naar voren kont (tabel 1 ).

Wij vonden geen relevant verband tussen de duur van de klachten vóór het eerste contact en de kans op het vinden van een scmatische aandoening of een psychosociaal probleem. ook tussen de gerapporteerde ernst van de moeheid (tamelijk moe, moe, erg moe) en de kans op gezondheldsproblemen vonden wij geen samenhang.

Tot nu toe stonden wij nog niet stil bij de aard van de diagnostische conclusies. Tabel 1 geeft aan dat deze zeer gevarieerd is. Als men de samatische diagnosen hergroepeert in infectieuze en niet-infectieuze aandoeningen, valt op dat de eerste vooral bilj jongeren ( $<50$ jaar) 
woorkomen (608 van de bij hen gestelde somatische diagnosen). Bij de ouderen overheersen meer chromische aandoeningen (92\% van de somatische diagnosen). Bij slechts 4 patiënten (allen vrouw) werd ijzer voorgeschreven. Hierbij kan bedacht worden dat geen van hen bij het eerste consult een Hb lager dan $7.5 \mathrm{mmol} / 1$ had (4).

Naar aanleiding van de ziekte-episode die begon met de presentatie van moeheid werden 20 patiënten (12\%) verwezen naar een medisch specia1ist. De longarts, de internist en de cardioloog namen hiervan driekwart voor hun rekening. Zoals te verwachten wordt in deze groep relatief vaak een samatische diagnose gesteld (bij 12 patiënten. overeenkomend met $60 \%$ van de verwezen gevallen, versus $17 \%$ van de totale groepl. Dit demonstreert dat ten gevolge van selectie specialisten bij patiënten met moeheidsklachten veel vaker somatische diagnosen aantreffen dan huisartsen.

kans op somatische

diagnose $n \cdot a \cdot v \cdot$ moeheidsklachten

(s)
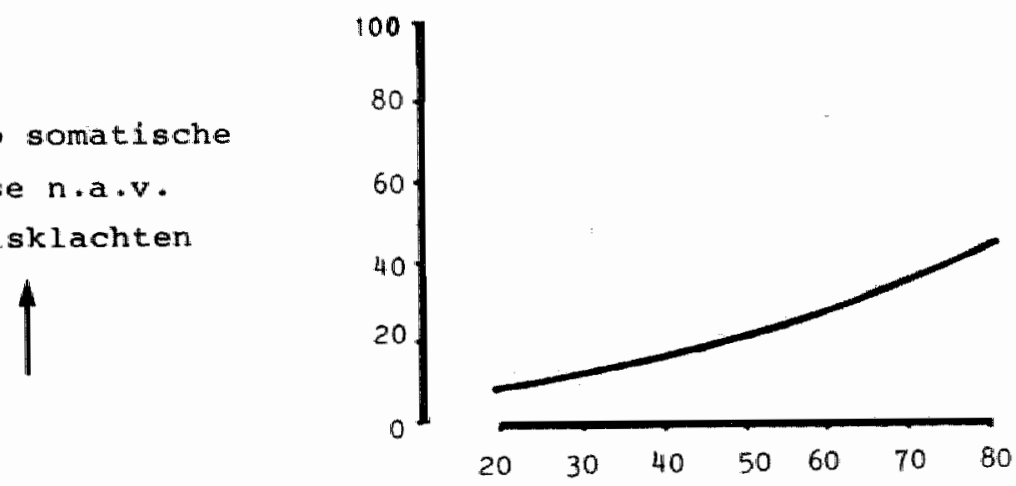

$\longrightarrow \quad$ leeftija (jaren)

Figuur 1: Verband tussen de leeftijd en de kans dat er een scmatische diagnose gesteld wordt in aansluiting op onverklaarde moeheid.

logistische functie:

$\begin{array}{lll}0 \text { intercept } & -3,04 & \text { SE: } 0,61 \\ 0 \text { logistische regressie } & & \end{array}$ coëfficiënt voor leeftijd 0,035 SE: 0,013 
Door middel van een (forward) stepwise multiple logistische regressileanalyse werd onderzocht in hoeverre diverse variabelen de kans beInvloeden dat er een somatische diagnose gesteld wordt. Afhankelijke variabele was de (logit van de) kans op een somatische diagnose. onafhankelijke variabelen waren het geslacht, de leeftijd, de duur van de moeheidsklachten en de gerapporteerde ernst ervan. Behalve de leeftijd bleek in deze analyse geen van de andere variabelen van invloed. In figuur 1 is, op grond van deze analyse, de kans op een scmatische diagnose als functie van de leeftija weergegeven.

Situatie na één jaar follow-up.

In de loop van het jaar na het eerste contact kwamen diverse gezondheidsproblemen naar voren los van de moeheidsepisode. Van de 5 vrouwelijke patienten van wie geen patientenkaart gevonden was (zodat het precieze verband met de moeheidsepisode niet kon worden nagegaan) was bij de huisarts wel follow-up informatie over geconstateerde problemen bekend. Onder de $166(161+5)$ opgevolgde patiënten bleek de groep met een op zich zelf staande somatische diagnose nog steeds de grootste. In totaal werd viteindelijk bij $28 \%$ van de patiënten een scmatische diagnose gesteld en kwam blj 258 een psychosociaal probleem naar voren. Bij 558 (92/166) van de opgevolgde patiënten is ook na verloop van een jaar noch een somatische diagnose noch een psychosociaal probleem vastgesteld.

De meeste van de later gestelde diagnosen betreffen intercurrente 'minor allments' zoals blaasontsteking en huidafwijkingen. Ernstige later gevonden pathologie, die niet in het kader van de moeheidsepisode naar voren was gekomen (maar achteraf mogelijk toch daarmee in verband zou zijn te brengen), wordt gemeld in tabel 3 , onderverdeeld naar leeftijd en geslacht. Deze deed zich vooral voor bij oudere vrouwer. Een patiënte overleed, en bij haar werd bij obductle een genetastaseerd maagcarcinoam gediagnosticeerd. Bij een jongere vrow kwam een mammacarcinoom aan het licht. De invloed van de leeftijd op de kans dat er na 1 jaar een somatische diagnose aan het licht is gekomen, is minder duidelijk dan de overeenkomstige kans naar aanleiding van de moeheidsklachten, en statistisch niet significant. 
TABEL 3: Enstige pathologie die bij follow-up van een jaar werd gevonden, los van de initiële moeheidsklachten.

\begin{tabular}{|c|c|c|c|c|}
\hline & maninen & 1 & vnoux & \\
\hline $\begin{array}{l}50 \text { jaar } \\
\text { geen }\end{array}$ & $\begin{array}{l}250 \text { jaar } \\
\text { CrA bij } \\
\text { diabetes }\end{array}$ & $\begin{array}{l}1 \\
1 \\
1 \\
1 \\
1 \\
1\end{array}$ & $\begin{array}{l}<50 \text { jaar } \\
\text { mammacar- } \\
\text { cinoom } \\
\text { hypertensie } \\
\text { Ig A deficiëntie }\end{array}$ & $\begin{array}{l}\geq 50 \text { jaar } \\
\text { reumatoide } \\
\text { artritis } \\
\text { angina pectoris } \\
\text { nierinsufficiëntie } \\
\text { CARA } \\
\text { gemetastaseerd } \\
\text { maagcarcinoom } t \\
\text { (obductie) }\end{array}$ \\
\hline
\end{tabular}

Discussie.

Evenals Morrison (5) en Katerndahl (6) vonden wij dat naar aanleiding van in eerste instantie (na anamese en fysische diagnostiek) onverklaarde moeheidsklachten een grote variëteit aan somatische en nietsomatische problemen door de huisarts wordt vastgesteld. In onze patiëntengroep werd echter veel minder vaak zo"n probleem gevonden. Bij $70 \%$ van de patiënten kwam voor de moheidsepisode geen verklaring naar voren, en bij 55\% werd in de loop van een jaar follow-up geen diagnose of probleem vastgesteld. Scmatische en niet-scmatische problemen komen bij ongeveer evenveel personen voor, al dan niet in onderlinge combinaties. Het percentage patiënten bij wie ook in tweede Instantie geen verklaring werd gevonden was in onze studie beduldend hoger dan bij Morrison (5) en Katerndahl (6). Dat kan liggen aan verschillen tussen de patiêntenpopulaties, de diagnostische criteria, of tussen de dokters, maar ook aan de onderzoeksmethode of de definitie van onverklaarde moeheid. In onze studle werd op grond van vooraf vastgestelde criteria bepaald welke moeheidspatienten in het onderzoek werden opgenomen, en er was weinig uitval. In de andere onderzoekingen bepalde men achteraf op grond van informatie op de patiëntenkaarten bij wie sprake was geweest van onverklaarde moeheid. De volledigheid van follow-up is mollijk te beoordelen. Onze cijfers 
geven onzes inziens dan ook een betroumbaarder beeld. Daarbij dient bedacht te worden dat onze studie patiënten betrof, bij wie in eerste instantie een verkilaring ontbrak maar wel een hemoglobine bepaling geindiceerd geacht werd.

Whet betreft de aard van de uiteindelijk gestelde scmatische diagnosen vormen, evenals bij de genoemde Amerikaanse auteurs infectieziekten de grootste subgroep. Dok hart-vaataandoeningen leveren een substantiële bijdrage. Ijzertherapie werd in onze patiêntengroep, waarvoor bij het eerste consult een hemoglobinebepaling geindiceerd werd geacht, betrekkelijk zelden voorgeschreven. Er worden 2 maligniteiten gediagnosticeerd in de follow-up periode, waarvan één pas bij obductie.

De kans op het stellen van een somatische diagnose werd duidelijk. beilnvloed door de leeftijd van de patiënt. Het geslacht speelde hierbilj geen rol, evenals de gerapporteerde ernst van de klacht. Bij dit laatste gegeven is uiteraard een zekere subjectiviteit in het spel. Maar ondat op het moment van de beoordeling van de ernst de klacht nog onverklaard was, lijkt systematische vertekening ten aanzien van de kans op een scmatische diagnose onwaarschijnlijk. Wat betreft de duiur van de klacht konden wij niet de bevinding van anderen bevestigen, dat recent ontstane klachten vaker op een scrmatische diagnose wiljzen en langer durende klachten meer in verband staan met psychische en psychosociale problemen. $(5,6)$

Het is natuurlijk mogelijk dat een aantal diagnosen en problemen niet aan de arts worden voorgelegd of door hem niet worden herkend. Daarbilj hoort ook de kanttekening te worden geplaatst, dat de patiënten ná het eerste consult niet aan gestandaardiseerde follow-up diagnostiek werden onderworpen op grond van uniforme criteria. Dit zou gezien de grote variételt van de mogelijke problemen ook nauwelijkks realiseerbaar zijn geweest. Wij achten het evenwel aannemelijk, dat in elk geval de emstlge, medisch relevante problematiek na verloop van een jaar wel bekend is geworden aan de huisarts. De conclusie lijkt gewettigd dat achter moeheidiklachten, waarvoor de huisarts in eerste instantie door middel van anamese, fysische diagnostiek én hematologisch onderzoek geen verklaring vindt, ook later in de meeste gevallen geen ernstige problematiek blijkt schuil te gaan. 


\section{LIITERATUUR.}

1. Berris B, Rachlis A. Investigation of fatigue. Canadian Family Physician 1977; 23: 465-466.

2. Avonts D, Denekens $J$, Hendrikx $K$, Neels $H$. De patiënt die moe is. Nieuw Kompas voor de Huisarts 1983; III/2: 1-9.

3. Solberg L.I. Lassitude, a primary care evaluation. JAMA 1984; 251 : 3272-3276.

4. Knottnerus JA, Knipschild PG, Van Wersch J, Sijstermanns A. Onverklaarde moeheid en het hemoglobinegehalte, een onderzoek in de huisartspraktijk. Nederlands Tijdschrift voor Geneeskunde 1986; 130: $402-405$.

5. Morrison JD. Fatigue as a presenting complaint in family practice. Journal of Family Practice 1980; 10: 795-801.

6. Katerndahl DA. Fatigue of uncertain etiology. Family Medicine Review 1983; $4: 26-38$. 


\title{
Klachten op de borst: omgaan met onzekerheden
}

\author{
J. A. KNOTTNERUS, E. EBBENS, Th. M. E. GOVAERT EN \\ C. A. DE GEUS"
}

In acht huisartspraktijken werden gedurende een half jaar alle patienten die zich met klachten op de borst tot de huisarts wendden, geregistreerd; bovendien werd zes maanden na het eerste consult informatie verzameld over de verdere lotgevallen wan elke patient. Aldus werden gegevens verzameld over ruim 300 personen. Hoewel de huisarts in een kwart van de gevallen rekening hield met de mogelijkheid van een cardiale oorzaak van de klacht, bleek hij sllechts een minderheid van deze patiënten direct te verwijzen; ten tijde wan de follow up was de helft van de verdachte groep nog steeds volledig onder zijn hoede. Op dat moment had hij nog in 8 procent van de gevallen twijfels over de juistheid van de gestelde diagnose.

\section{Inleiding}

De prtient die zich tot de huisarts wend met klachten op dis horst, is watak bang voor een hartkwal en wil sne: weten watar hij ata toe is. De arts will bicrata graig tegemoet komen, mar beseft tevens dtan niet allee hr het miskennen wan

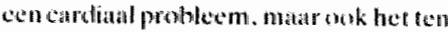
unrechte veronderstellen van zox na pro. blew ingrijpende consequenties kan hebben woor het welzijn van de patiënt. Om hem bij zijn besluilvorming houvast

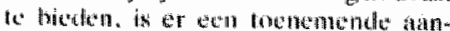
duclut wor de ontwikkelling wan dia. Hoystisteprotocollen. Deze zin echer meestal getasseend op blinusch specialistiwehe ervaling en stechts en enkele

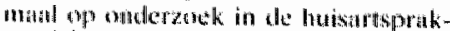
tijk. I Danrnatst hebbuth. ook in dit tijdschrift. de mogelijkheden en beperkingen valu de elektroesurdiognafie in de

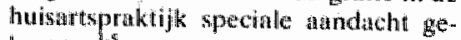
kregen.

Im Mastricht rijn trokete aspecten van de feitulikke hubartsgeneeskundige betrokkenlacid bij klawten op de borst bestudeerd. In dit verslag stratt de vol. genche vribagstelling centraal:

- Wat is het patroon van nicunse kllachten op de borst dat and de haisats wordt gepresenteerd; hoe valk wordt gedacht

\footnotetext{
- De auburs zija wertromalen aun da Capaciteits.

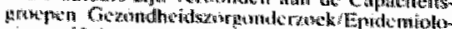

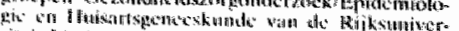

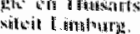

aส n., respectievelijk getwijfeild over een cordiale oorsprong van de klacht; in welle gevallen wordt verwezen, en welk beleid wordt uitgestippeld ten aanzien van nicl verwezen patiènten;

- hoe verhoudt zich de beoordeling vam de huistarts bil het eerste consult tot het oordeel dat hij later velt op grond van hat klinische beloop?

\section{Methoden}

Ain het onderzoek werd declgenomen door ancht thuisartsen in de reging zuidLimburg. verbonden dian het Basispro. ject Registratie en Verslaglegging. Hum geamentijke praktijkpopulatie omvat 17. 0 thot personen.

Het onderack heeft betrek king op de pittienter die zich in de tweede helft van 1983 tot deze huisartsen wenddlen met klachten op de borst. Uitgesloten wer. den patienten met klachten die de huid of de manmae betrotfen of die een direct duidelijke traumatische oorzak hadden. Eveneens uitgesloten werden pationton die de roorgande twaalf manden all eetrder we geras klachten op de borst bij de huisarts waren geweest. en patienten die vanwege dergelijke klachten onder behandeling waren (geweast j van een specialist.

Alle andere patiènten met klachten op de borst werden door de huisarts tijdens of wirect na het eerste combat yeregistrecto op dartoe specianal ontworpen standatadformulieren. De volgende gegevens werden opgetekend:

- busiggegevens als les fujd en geshacht: - de ingangsiklacht en de codering hiervan volgens de Reason For Encounter Claswificatie (RFE-C). latste wersie: - aspecten van het handelen yan de arts met betrekking tot diagrnostiek, therapie, verwijzing en yervolgafspraken:

- de waarschijnlifkheidsdiagnose:

- de mate wan verdenkirig op een cardiale oorsprong van de kiacht. aangegeven op een driepuntsschad (ja, tiwijfel. neen).

Ondat het feiteijik thandelen var: de artsen onderzoctht zou worden, zijn geen afspraken gemakt over de diam gnostische en therapeutische strattegie.

Een balf jaar na het eerste consult werd door de huisartsen over de patienten informatie verzameld vanuat dine bronentern:

- de rapportage wan de specialist, ín geval wan verwijzing:

- de eigen verslaglegging betreffende het klinische beloop:

- speciaal georganiseerde meestal telefonische, contacten met alle in leven zijndc patientions vow: zover bereikbaar; hierbij werd een korte anamnese afgenomen.

Op bigsis van derte informante gaven de huisatisen vervolgens voor alle patientell opnieuw antwoond op de wraag. of de destijds gepresenteerde klacht van cardiale oorsprong was geweest (ja. twijfel, neen).

\section{Resultaten}

Cerste consult

Aan de criteria woldeden 325 patiënten (158 vruuwen en 167 marnen). Van wie 285 op her spreekuur en 40 thutis werden gezien. De gemiddelde leeftijd was 47 jaar (S D. 16 jaar). Een patient over. leed valk voor de komst van de arts. In 92 procent van de gevalllen ging het om pijnklachten, en meestal was die pijn miet nader te specificeren binnen de RFE-C (label l)

De „carriere" van de bestudeende groep tijdens het eerste consult is geschetst in de figuru. Hierbij is uitgegaan van de ingangsk lachten., samengevoegd in drie categorieñ

- klachten mogelijk samenhangend met de circulatie (alle $K$-codes):

- nief mader te specificeren pijn op de borst (A11-code):

- overige klachten.

In 9 procent van de gevallen vermoeddle de huiarts een curdiale oorzaak, terwijl hij bij $\mathbb{\|} 8$ procent twijfel kvesterde. 
Uiterand wonden bijna alle directe verwijzingen plats in deze twee groepen. Omgekeerd werden echter lang niet alle verdachte gevallen verwezen: van de 28 patièten bij wie de hüsarts een cardiale oomak vermoedde, werden er slechits twaalf verwezen.

Warmate de patienten ouder waren. werd waker an een cardiale oorzak gedacht. De gemiddelde leeftijden van de werdachte groep, de twijfelgroep en de niet-werdachte groep waren respecthevelijk 66 (S.D. 14), 55 (S.D. 13) en 43 (S.D. 17) jaar. In de verdachte groep kwamen tweemaal zoveel mannen voor als vrouwen ( 18 versus 10$)$, terwijl in de twijfelgroep de vrouwen oververtegenwoordigd waren ( 24 versus 33 ).

De helft van de deelnemende huisartsen beeft een engen ECC-apparatuut. De keren dat clitect werd verwezen, is geen enkete matall wooraf een ECG gemank Bij 16 procent wan de patienten is na het consult een for gemakd of aangevraagd; in de wajfelgroep was dat percentage zelfs 47 procent.

In die gevallem warin wen cardiale oorsprong werd ove rwogen, matr niet werd verwezen, volstond de huisarts meestal met het geven vin voorlichting en/of medicatie. De nussaste patiënten werden op korte termijn terugbesteld, mar in twaalf gevallen (20) procent wan deze groep) werd hel initiatief aun de patient overgelaten. De helft van deze patiënten had angina pectorís of een ritmestoornis.

\section{Follow-ap aligemeen}

Wan zes patienten zijn geen follow-tup gegewens beschikbatr. Bij slechts en wan then was bij het eerste contact gedach an en mogelijke cardiale oor Zdak, bij de overigen was daran in het geheel miet gedacht. Over de restenende 318 patienten wordt in het volgende geraporteend: met 297: van hen is na eer half jatar persoonlijk comtact geweest:

Als we - met enige overdrijving - de beoordeling bij de follow-up beschouwen als de stancaard, dan zien we in abel 2 het volgende:

- De woorspellende waarde van een duidelijke positieve werdenking bedraagt iets meer dan 50 procent.

- De voorspellende watrde var cen afwezige verdenking bedratagt 97 procent.

- In een kwart van de gevallen waarin de huisarts aanvankelijk twijfelt, blijft die twiffel bestatan.

In totall bestaat na een half jaar nog twijfel bij 8 procent van de gehele on derzockspopulatie; in absolute $z$ in is deze groep vrijwel even groot als de groep patienten bij wie de huisatts zeker is van een cardiale oorzati.

Van de 297 patienten met whe bij de follow phe persoonlijk contact is ge-

Weetst, had 47 procent nogg steeds last van de klachten. Daarlinj makte hat met veel uit, of men op dat monent tor de verdachte groep, de twijfelgroep of de niet-verdachte groep behoorde (per-

Tabel 1 - Table 1. Niewn gepresenteerde klachen op de borst, gevegisireerd volgenw de RFE-classificatie (zes mander, acht huisarispraktiken) - Newly presented chest complaints registered according to the RFE classification fix months, eight general practices).

\begin{tabular}{|c|c|c|}
\hline Reason for cheounter & $\begin{array}{r}\text { Number } \\
(n=125)\end{array}$ & Peinentatio \\
\hline A11 Pain chest, not elsewhere classified & 219 & 67 \\
\hline K10 Pain attributed to heart and circulation & 59 & 18 \\
\hline R10 Pain-respiration & 20 & 6 \\
\hline K27 Fear of disease circulatory system & 9 & 3 \\
\hline K11 Abnotmal/rregular heartbeat/pulse & 4 & 1 \\
\hline A29 Other general symptoms/complaints & 2 & .5 \\
\hline P22 Psychophysiologicall problems & 2 & .5 \\
\hline Other symptoms/complaints (each registered once) & 10 & 3 \\
\hline
\end{tabular}

Figuur 1. Figure 1. War gebeurs er met de patièn die met klachten op de borst de huisars consuliseren in de loop wan het exste consult? - What happens with patients with chest complaints in the coutre of the first encounter with the gencral practitioner?

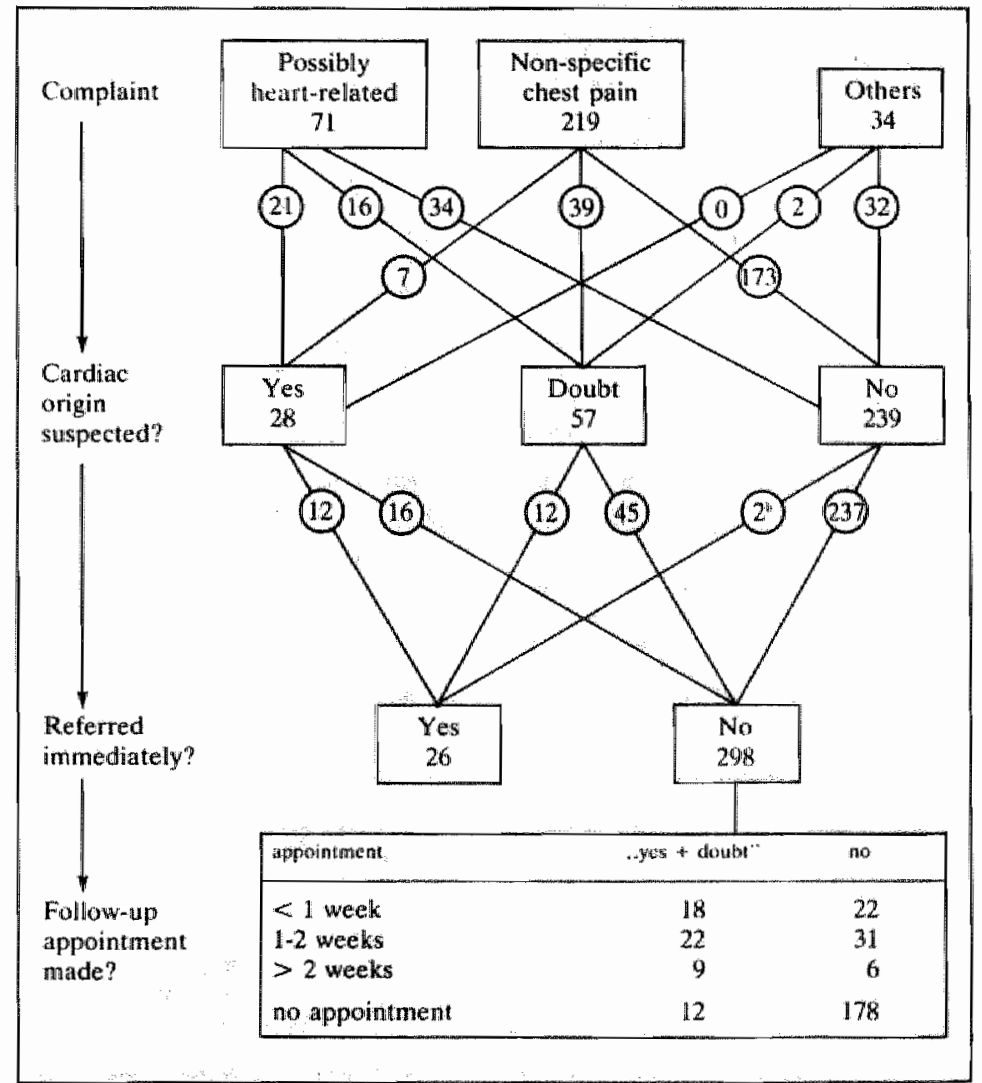

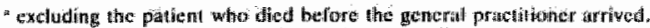

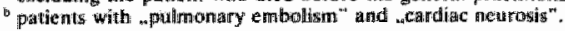


contages patientem mot blathon respece tioveligh 56,55 an 44 procemi. Z Zus

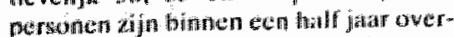
leden (nabel 3). De helft will hen behoorde tot de alanankellik niet-verdachte groep. In de meeste gevallen

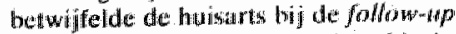

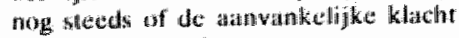
wan cardiale and was gewerest.

\section{Follow-up verwezen patienten}

Uiteindelijk zijn in de loop yan het halfjatar follow-yp nog is patienten wer-
Wezen. Lodat hot totala aantal verwijzingen op $4 /$ komt. Bij vergelijking wan de diagnosen wan de huisarts tigdens het eerste consult mel de conclusies van de specialist bleek, dat wan de zeven vermoede myocardintercten er twee werden bevestigd: in de owisige viff gevallon concludeerde de specialist wel steeds tot ischemische thartziekte c. angina pectoris. Bij de 11 patienten die direct waren verwezen vanwege angina pectoris, concludeerde de specialist slechts drie keer tot ten cardiologische

Tabel 2. Table 2. Het aan wankelijke oordecl over de cardiale oorsprong wan de klachuen en het oordee zes masuden later (percentages) - Initial judgement about the cardias origin of the complaints and judgement six months later (percentages).

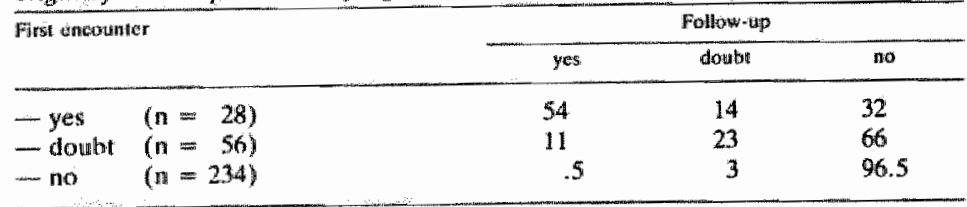

afwijking. Daarnaast werd in de loop van het halve jaar wid de specialist nog twee keer een infarct vastgesteld bij patienten bij wie de huisarts anvanikelijk dacht aan angina pectoris respectiewelijk thyperventulatule (label 4).

Uit tabel 4 blijkt verder dat er nog cnkele mallen een belangrijk verschil was tussen de eerste diagnose van de huisarts en de conclusie van de speciatlist. Hianus hernia en respiratoire infectie tradem op als voorlopers van de coneltw sie angina pectoris. terwijl achter een geval van myalgie een aneurysma dissecans bleek schuil te gaan. Daarbij moet worden a angetekend dat de cerste diagnose van we huisarts en de diagnose van de specialist in de later verwezen groep enige tijd uit elkaar liggen. en dat in die periode thet beeld veranderd kan zijn. In een aantal gevallen liet de huisarts zich niet overtuigen door de diagnose van de specialist:

- Bij 12 patienten concludeerde de spe-

\section{Synopsis:}

Knottnerus: JA, Ebbens E, Gowaert ThME, De Geus CA. Chest problems: coping with uncertainties. Huisarts en Wetenschap 1985; 28: 159-64.

Introdaction. This study concerned some atspects of gemeral practice penformance in relation to chest probteris. The problem definition was:

- What is the pattern of riew chest problewas presented to the general practitioner: how often is a curditac origin of the problem stuspected of doubted; what is the strategy planned with regard (o) unveferned pastients?

- How does the genersial practithmer"s assusument at the first encounter compare with his subsequent issessinient on the basis at the allitical bourse?

Methods. Participantes in the study were eight general pritectutioners with a total practice popultation of 117 . 1 hu persons. The study covered paticats who presented in the latter hall of 1983 with ches probionis. Patients with problems involving the memminty skin or of evidently traumatic origin were excluded. ass were patients who had presented with chest prohlems within the preceding twelwe wronths and thiose who were being (had been) treated by a specinlist in wiew of such problems. All other patients with chest problems were registured by: the general practitioner on special forms during or immediately after the first encounter.

Six moinths after the first encounter the gencral practitioner again collected infor. mation on the patients involved. On the busis of this information the genaral prate-
Witioners then answered the cu|lustion, for all patients, whether the problem originally presented had been of cardiac origin.

Reswilts. The criferia were met by 325 patients. Pain was reported in 92 percent of the cases, and in most cases this pain could not be furthet specificd according to the Reason For Encounter Classification (RFEC) (iable D). In 9 percent of cases the general practitioner suspected a cardiac cawse, and in 18 percent he doubted this. Nearly all immediate referrals were of cowrse made in this group. On the other hand, by no means all suspect cases were referred: of the 28 cases in which the general practitioner suspected a cardiac cause, only 12 were referred (figure).

Accepting the follow-up judgementas cernaim diagnosis. toble 2 can be read as follows

- the predictive value of a distinct positive surspicion anounted to slightly over 50 percent:

- the predictive value ofl an tbsent suspicion amoumted to 97 pencent;

- the general practitioner"s initial doubt persisted in some 25 percent of the cases; - doubl persisted after six months in a total of 2 percent of the study population in absolute terms this group was virturllly ass larige as the group in which the generat practitioner was certain of a cardiac catise. In the end, 15 more patients were referred in the course of the six follow-up months. bringing the total number of referrals up to 41 (twoble 3). About 50 percent of the pathents in whom a possible cardiac origin of the problem was suspected after these six months, were still entirely in the care of the general practitioner at that time.

Table' 4 shows that, in the unveferred group, an initial suspicion of ischememic heart disease/angina pectoris was often subsequentiy doubted. A suspicion that the problems were catased by arthythmias was usually rejected in retrospect. On the other hand, two general practitioners themselves subsequently diagnosed myocardial infarction on the basis of EOC findings.

Disecussion. The predictive walues tisted in vable 2 concur with the general findings of Wright and Kawe, which indicate that in general practice the predictive value of a fowouratle prognosis always exceeds that of a less favourable prognosis. "Morecower; doubl proved to be a factor of importance. to which some predictive walue might also be attached. Various other publications have shown that chest problems, even after detailed diagnostic work, are not always clasisifuable in the long run. A retrospective stiddy in a mumber of general piractices rewealed that 50 percent of the cases of chest puin still had an unproven aetiology after six months ${ }^{7}$; and of a group of patients admitted to an intensive cane whit with problems suggestive of myocandiall infarethon ${ }^{\prime \prime}, 13$ percen were discharged with the diagnosis chess pau of obscure arigin. The study clearly show that generall practitioners regard the guidance of patients whth possible cardiac disorder as par of their task, and accept a degree of uncertainty in these casses.

Keywords: Family practice; Diagnosis; Thoracic diseases.

Address of authors: Capeciteitsgroep Gezondheidszorgonderzoek / Epidemiolo. gie Rilksuniversiteit Limburg, Postbus 616 $6200 \mathrm{MD}$ Maastricht. The Netherlands. 
cilithist tot ischemische hurtziek te (uitgezondend anfareth. Werwigl de huisurts in drie gevallew blatef wijfeter.

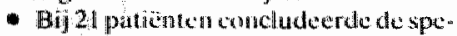
ciallist dat er gees cardiologische afwijking was; ook nu ble ef de huisarts in drie gewallen twijfelen.

- In totalal bleef bij acht patienten (20 procent) twijfel bestaan.
Follow-up niet verwezen pationten Wit whels blijke dat in de nict-wenwezen grow ec a anwankelijke verdernking op ischemische hartzickte/angina pectoris: later vaak werd betwijfeld. Een vermoeden dat de klachten werden veroorzankt door ritmestoomissen, is achteraf meestul verwotpen.

Miertegenover statat. dat twee huis- artstan op hasis van lc (i-bevindingen

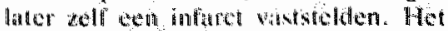
beloop an dere gin vatlen wits gunstig. en deze putienten werden niw werwezen. Het lotate asntal vastgestelde hartip. fareten in het wervolgde cohort kwam hiermec op zes. exclusicf de patient die reeds was owerleden van het erste contact.

Tabel 3-Table 3. Stergevallen, opgetreden in hel cohort waarnan follow-up informatie is werzameld $(n=318)$ - Deahs occurint in the cohorr on which follow up information has been collected $(n=318)$.

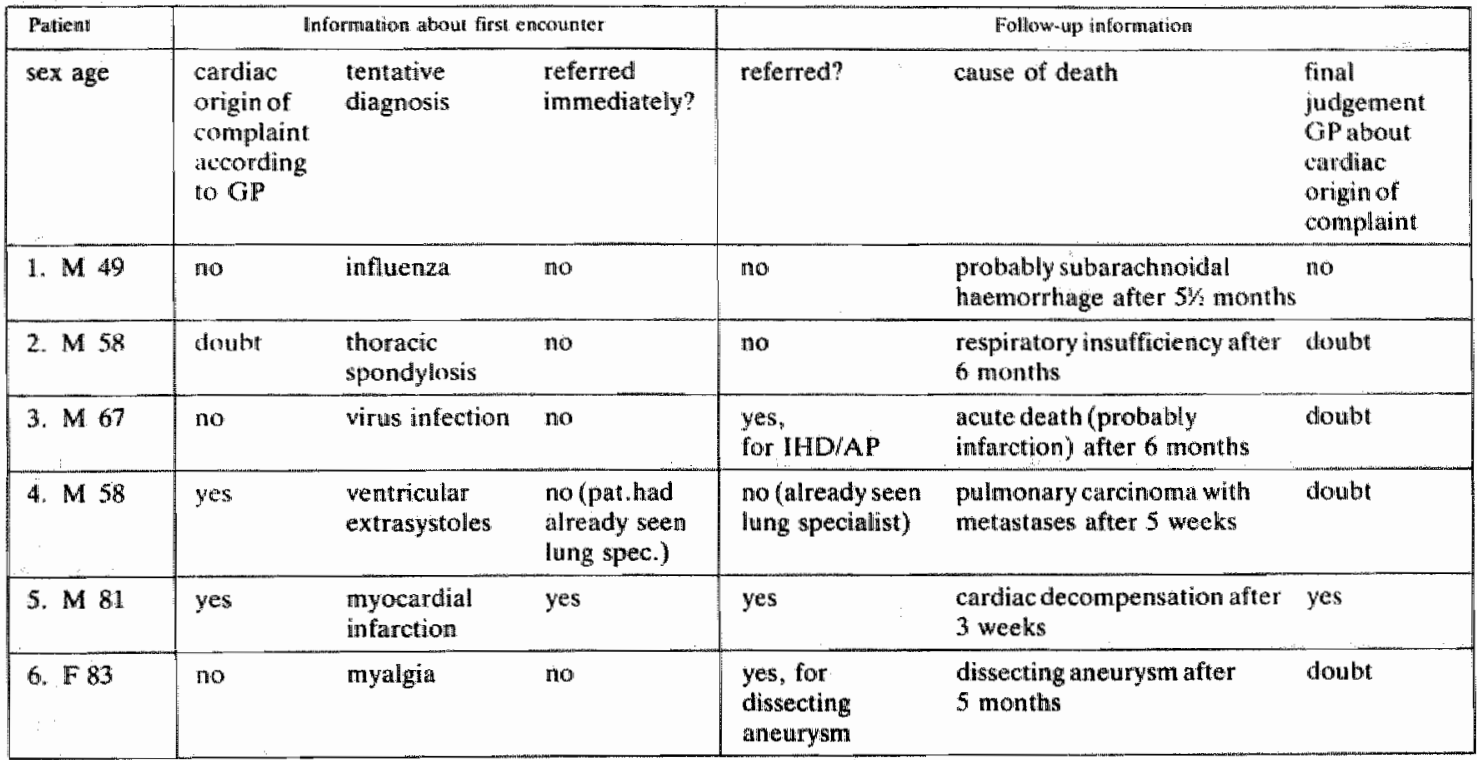

Tabell 4 - Table 4. Waarschijnlijkheidsdiagnosen van de hwisarts bij het eerste consult en de diagnosen wan de specialist $(n=41)$ verwezen patienten) - The general practitioner's tentative diagnoses at the first encounter and the specialist's diagnosesd (in $=41$ referred patiènts)

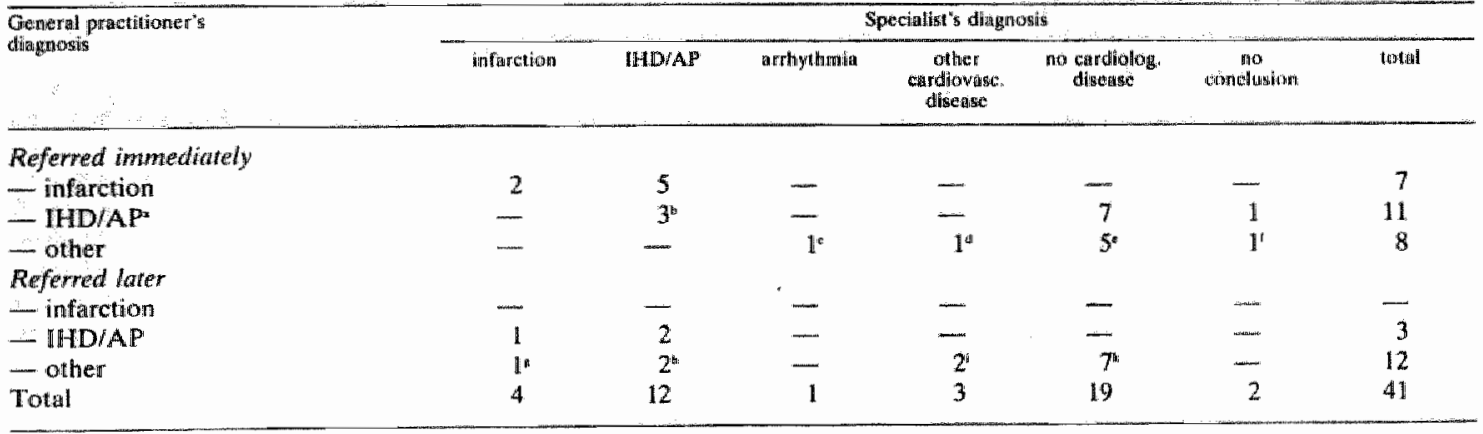

a ischaemic heart discasclaginat pectoris (excluding infarction $)$.

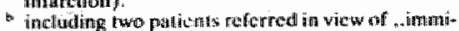
inent infarmiton".

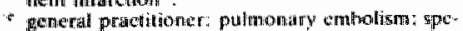

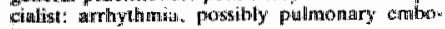

lism.
bovth generall practhitioner and speciallist: pericardiliss.

- Hentative didagnosis by general prachitionet. chest pain of obscuire arigin (fwicey, mayalgia (twiced. hyperventilation syndrome (ance).

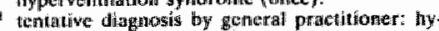
perventilation/cardiac me urosing.

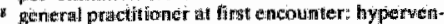

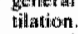

a eneral practitioner's diagnoses at first encoun. ter: 1) histns hernisa, 2) repirtiony inficetion.

1.) general practioner at first encounter: nyalgina speciallst" ditseceting anewrysm.

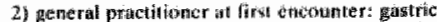

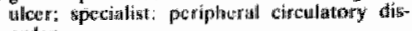
prother.

the gerieral practitionur asually did thot wenture

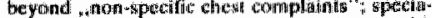

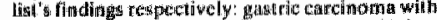

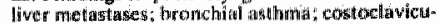

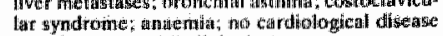
(inot further quallified) (Inwide). 


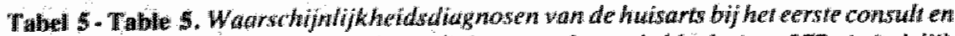

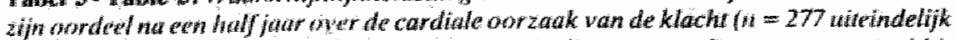

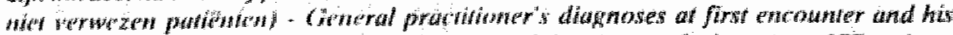

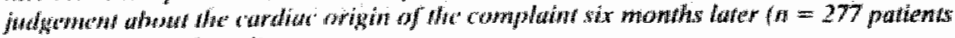
whowaty wow reforred).

\begin{tabular}{|c|c|c|c|c|}
\hline \multirow[t]{2}{*}{ 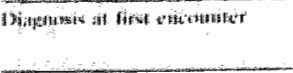 } & \multicolumn{4}{|c|}{ 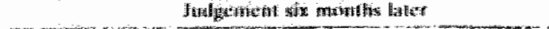 } \\
\hline & Yos: & doutaty & no & notia \\
\hline 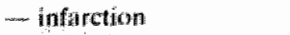 & - & - & - & - \\
\hline$\| I D W P$ & 7 & 6 & 3 & 16 \\
\hline 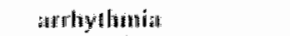 & 1 & 1 & 4 & 6 \\
\hline whest oxmiglunt $c_{.} c$ i. & - & 3 & 40 & 43 \\
\hline - other & - & 6 & 206 & 212 \\
\hline Total & 8 & 16 & 253 & $27 \pi$ \\
\hline
\end{tabular}

In veruit de meeste gevallen watrin de huisarts a anvankelijk een kinchtoliagno. sue of ton met-cardiologische diagnowe had gesteld, verwierp hij uitteindelijk de mogelijkheid warm een cerciologische oorzatak.

Van de patienten mef een angina pecto ris of een bij de follow-up veronderstel de c.q. overwogen cardiale oorzaak. was een half jasr later ongeveer de helft geheef onder de hoede wan de huisarts gebleven.

\section{Beschotuwing}

Het is um te beginner nodig anige kanttokeningen te maken bij lict onderzoek. Nitet uitgestoten is dat het registreren thet tyandelon van de huisar ls heeft beinwhed. Vourts konden het nowteren wan

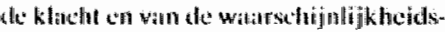

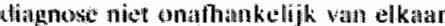
pltalswinden, en hetzelfde gold woor de beowordeling tijders het eerste consult

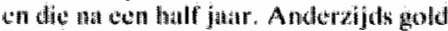

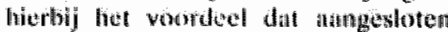
werd bij de normalle gang van zaken. warin het oordecl wain dezelfde huiswarts unor dezelfde putionten wen sntwikikeling doormakat. Dit oordecl is bepalend voor an beleid. Evaluathe vin verschil.

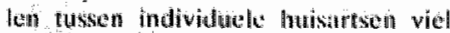
buiten het bestek wan dit onderzoek.

Wat betreft de incidentie wan pijin op de bont komt ons resultant redelijk over

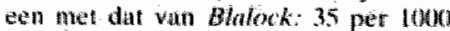
personen uit de batispopulatie per juar. versus 49 pea lomo per jaar. Datarbij moet worden bedicht dit de latstgenocnde situdie ook patienten met duidolike tramuta en not reeds bekende klachten omvarte."

De incidentic van angiha pectoris in onze studie stemde poud overeen met obserwaties wan anderen. men kan erwan uitgakn dat deze 3 tot 5 niew we gevallen per Ithel personen per juar bedriagt. Wh thetreft het myocundinfarct komen wij lager wit: 1 versus 2 a 3 per 1000 per jaar. In onze studie waren echter padioloog en/of reeds kllachten op de borsit hadden., wilgesloten.

De huisarts hield veel patienten zelf onder behandeling. ook als er gedacht werd an angina pectoris. Dit is opmerkelijk, daar in de specialistische literatuur meestal wordt aanbevolen patienten met recent ontstane angina pectoris-klachten snel te verwijzen. Een recent begin wordt namelijk beschouwd als een kenmerk van een instabiele anginat pectoris.

Ellektrocardiografie werd meestal gelyuiki na afloop van het eerste contact. om bij niet-verwezen patiënten bij wie een cardiale oorzaak overwogen word de klachten nader te evalueren. Voor besllutworming in acute situaties is het Ecoi van weinig betekenis. Het is niet erg betrouwbitar bij de wroege diagnostiek van het verse infarct en dient fiet verwijsbeleid bij klinische verdenking hierop niet te bepalen. 12.4

De in rabal 2 vermclde worspellende warden zijh in overeenstemuming met de algemene bevindingen van Wrigdir and Kane, die inhouden dat in de huisartspraktijk de vourspellende warde van aen goede prognowe steids hoger is dan die van een minder goede prognost. ${ }^{\text {t. }}$ Dat ligt overigens voor de hand, ondal goede prognoses in de huisartspraktijk nu eenmatal weel meer voorkomen dan slechte.

Daarnaast blijft twijtel een factor van belang en men zou hieratan eveneens cen voorspellende watarde kunnen toekennen. Uit diverse andere publikaties blijkt dat borstklachten, ook op de lange duar en zelfs na uitwoer dige dianostiek. lang niet altijd in hokjes zhijn te vangen. Een retrospectief onderzoek in enkele hwisartspraktijken leverde op dat 50 procent van de gevallen van pijm op de horst na cen half jaar nog een anprowen ticnten die al bekend waren bij de cur- etiology had ${ }^{3}$ Van een groep patiantef dic wegens ".hartinfarct-suggestieve" klachten op een hartbewakingsafdeling whrer opgenomen. werd 13 procent ontslagen met de diagnose chestpoin? rawse. "its

Veel tackitanden kumuen pijen veroorzas ken die linkt op coronaire pijo: aandow aingen ven de thoraxwand, spondylose. wortelpijn, herpes zoster. hype rventilathe en met name pijn wan oesophageale

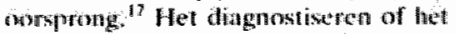
ziou inmkomen wan en infarct blijkt dan ook niet gemakkelijk. Dit kwam al eerder matar voren in de IMIR-studie: door de thuisartsen was anvankelijk de helft varn de infarcten niet herkend.." Ook specialisten kemen dit probleem: blijkens een recente publikatie waren van 100 door middel van autopsie bewezen infarct-gevallen er slechts 53 tewom ren als zodanig gedingmostiseerd, ondanks het gebruik van allerlei diagnostische faciliteiten."

De ontdekking of thet vermoden wan een hartinfarct leidt niet altifd tot verwijzing. In de MMllR-studie werd bijna de helft van de van een unfarct verdachte patienten niet direct verwezen. ${ }^{10}$ Het is inmiddels ten breed aanwarde opwat. ting dat pattenten met een oncompliceend infarct dat reeds meer dan enige uren oud is. in principe niet opgenomen hoeven te worden. ${ }^{2132}$

We weter dat de specialist te maken krijgt met een geselecteerde groep pa. ticuter met klachten op de borst, marar in feite geldt hetzelfde voor de huisarts: Huygen e.a. vonden dat slecthts 10 procent van de mensen met pijn op de borst daurvoor de huisarts ratdple gde. "Het is nog matr de vraage of - ch zo ja, how meer diagnostiek moet worden toegepast op meer mensen. Volgens Todd kumuen alle moderne tests tezamen een klein infarct niet met zekerheid witsluiten. $^{13}$

Overgann tot verregunnde diagnostick. of just een terughoudende opstelling bij aspecifivek borstklachten: de zin van haide beslissingen verdient ewenved studie en overweging. Ongaan mot twijfels en onzekerheden is daarbij niet te ormzeillen.

"Pool J, Van der Does E. Lubsen J. De diangostick war het driegende hartinfarct in de huisartsenprak tijk. Ned Tijoschr Geneeskel $1979 " 123 ; 1457-60$.

¿Puol J. Van der Does E, Luhsen 3. De diagnostiek wan het dreigende hartinfarct in de huisartsenpraktijk. Ned Tijdschr Geneeska. 1979; 123: 1505-8.

"Van Ree JW, De kco-werkgroep Nijme- 
gen. Huasarts an Wercenschap, 1983: 126 : 29.132

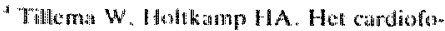

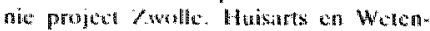
schap 1983: $30: 1325$

- Meytoom WA De beperkingen van caro divfonic. Huwarts cri Wetenschap $n 983$; 26: $136-9$

"Lamberis H. Witarom gaat iema rud naar de husarts? Een internationale studie met de Reason for Encoumer Classification. Huisars en wetersichap 1984:27:23444. "Biatock SM. The symptom af chestpasin in fanily practuce. I Fan Pract 1977 ; 429. 33.

* Lambertw Incidentic en prevalentie van gezondheidsproblemen in de huisartsenpraktijk. Huisarts em Wetenschap 1982 ; 25: 4011.14.

"Coninue Morbiditeingregistratie Nut 1971-197\%. Werkgroep Epidemiologie in de huisartspraktijk. Gewone ziekten. Nijmegen: Nijmange Universituir Huisartsen institum. 1450.

19 Goldman L. Weinberg M, Weisberg M, et al. A computer-derived protocol to aid in the dilagnosis of emergency room patients with acutc chostpain. N Eng J Mcod 1984: 310: $1273-8$.

"Silverman kil. Girnsonan W. Angira pectoris, nathural history and stratggies for evatuation and management. $\mathrm{N}$ Eng J Med $1984: 310: 1712-7$.

12 Smit PTh. Sposedgevalder in een huisartsenprakiigk. $3 c$ dr. Utrecht: Bohn, Sehelternal de Holkema, 1976.

13. Todd JW. Outry cardiac pain. Lancet 1983; i: 3302 .

a De Dombal ET. Exillation of decission nating by humatns and computer in acute abdominal und acute chest poin. Lecture notes in medical Informatics $1983 ; 22: 42$ 53.

His Wright DD. Kane RL. Predicting the outcome of primary care Med Care 1982; 20: $180-7$.

th Whilcox RG. Rouland JM. Hermpton JR. Prognosis of pattande with .chesi pain? cansse". Ar Mtod J 1081:282:431-3

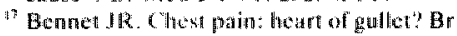
Med I 198. 280: 12912.

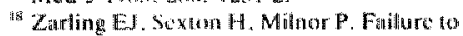
daganose atcute ranyocardial infarction. HAMA, 1983: 251: 1171-81.

"Wan dor Doce E. Lubsen 1. Acute corontry events iry gencral priacice IDissertatie!. Rotucrdam: Ertasmus Universiteit Rontherdam. $107 \%$

") Eggerlsen SC, Herg AO ts il geod practice to trevit patie'sts with uncomplesated myon

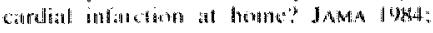
251: $3.49-511$.

7 Junc $K$. Nhescardial infurction and the genteral prasilionot. Practitioner. 1984 : $228: 377.124$

"Do Melker HRA. Thuishohandeling myocalardinfaret? Praciationer (Nederlandse uitgave) $\|$ (4)-1: 1: 959-6nl.

"Huygen FIA, Van den Hoogen H. Moefs WJ. Giczondheid an ziek te: cen onderzock wan dezinnem. Ned Tujuschr Oeneeskd 1983: 127: 16:2-9. 
DEETL, III

MEDISCHE BESLISKTINDE, CONCEPPTEN EN TOEPASSINGEN. 


\section{Principes van besliskunde}

\section{J. A. Knottnerus*}

\section{Inleiding}

Beslissingen moeten juist daar worden genomen waar sprake is van onzekerheden. Voor de huisarts zijn deze aan de orde van de dag. Hij heeft te maken met vele niet uitgekristalliseerde hu!pvragen en problemen en de zich aan hem presenterende ziektebeelden verkeren vaak in nog weinig herkenbare stadia. In bijna ieder arts-patiëntcontact moeten dan ook keuzen worden gemaakt uit alternatieven. Het streven daarbij is door te zeilen tussen de Scylla van het missen van belangrijke diagnosen en behandelingsmogelijkheden en de Charybdis van de somatische fixatie en de iatrogenese. De huisarts, die immers de toegangspoort tot de geneeskunde markeert, heeft hierbij een bijzondere verantwoordelijkheid. Hiermee zij aangegeven dat huisartsgeneeskunde voor een belangrijk deel besliskunde is.

De bedoeling van dit hoofdstuk is om vanuit de nog jonge medische besliskunde enkele basale principes aan te dragen, die van nut kunnen zijn bij het bestuderen en verbeteren van de huisartsgeneeskundige besluitvorming.

\section{Hypothesevorming}

Het meest richtgevende gebeuren in de diagnostiek van de arts is misschien wel de vorming van hypothesen omtrent het gezondheidsprobleem of zicktebeeld dat de patiënt mogelijk parten speelt. Meestal worden dezc bypothesen al vroeg in het consult - soms na enkele seconden - en op grond van luttele informatie opgesteld. ' In de loop van het verdere consult probeert de arts nu door middel van anamnese, onderzoek en eventuele nadere diagnostiek de hypothesen te bevestigen of te verwerpen. Telkens vraagt hij zich af: welke bevindingen zouden zich voordoen als de hypothese waar is? En: hoe waarschijnlijk wordt de hypothese, gegeven deze bevindingen? Deze strategie transformeert de vrijwel onbegrensde, open vraagstelling: wat is er aan de hand met deze patiënt? tot één of meer gesloten vraagstellingen. Is er sprake van galstenen? Ulcus duodeni? Cholecystitis? Of is de patiënt overwerkt? Zo'n set van alternatieven kan getest worden. De arts kan van elk van de hy-

\footnotetext{
- Arts, Capaciteitsgroep Epidemiologie en Gezondheidszorgonderzoek, Rilksuniversiteit Limburg
} 
pothetische eindpunten toewerken naar datgene wat hij bij de patient vindt.

De hypothesen, en hun volgorde van belangrijkheid, worden in het algemeen gebaseerd op cen beoordeling van:

a waarschijnlijkhcden: op welke aandoeningen of gezondheidsproblemen heeft déze patiënt met déze klacht een verhoogde kans, en in welke mate is deze kans verhoogd?

b de mogelijke ernst: zijn de mogelijke aandoeningen dermate ernstig dat meer zekerheid erover gewenst is;

$c$ de therapeutische consequenties: heef het stellen van de mogelijke diagnose zodanige consequenties voor het therapeutisch beleid, dat zij per se moet worden uitgesloten of bevestigd?

Aan de fase van de vroege hypothesevorming naar aanleiding van cen bepaalde klacht wordt in de medische opleiding weinig aandacht besteed. Het betreft echter een cruciale fase in de diagnostiek en fouten die in deze fase worden gemaakt, worden niet gemakkelijk gecorrigeerd.

Zo blijkt dat een eenmaal gevormde hypothese door artsen niet snel wordt verlaten, ook al is zij onjuist en niet in overeenstemming met latere bevindingen. Soms kan men vastraken op een fout spoor: als men eenmaal aan angina pectoris denkt, is het niet gemakkelijk de diagnose hyperventilatie te stellen, en andersom. Een tweede probleem is, dat het testen van een hypothese zelden een $100 \%$-zeker antwoord kan opleveren. Er blijft een bepaalde mate van onzekerheid over en die onzekerheid, hoe gering ook, kan een probleem op zich worden of alsnog aanleiding geven to onnodig handelen en iatrogenese: "dokter, weet u zeker dat ik geen kanker heb?"

Men moet dus goede argumenten hebben om een hypothese te vormen en vervolgens te gaan testen. Dan duikt echter een derde problcem op: het is, zeker op het niveau van de huisarts niet altijd bekend of, en in welke mate, bepaalde klachten samenhangen met bepaalde aandoeningen. Met andere woorden: in hoeverre ecn klacht totéén of meer hypothesen zou moeten leiden is nict duidelijk.

Een voorbeeld: het is cen wijdverbreid gebruik om in geval van rugklachien op een gegeven moment een röntgenfoto te maken van de lumbale wervelkolom. Uit onderzoek komt echter naar voren dat er geen duidelijk verband is tussen lage rugklachten en röntgenologische bevindingen. Zodra men dus bij iemand met lage rugklachten de hypothese van een rugafwijking gaat toetsen door middel van een foto, loopt men een fikse kans (bij ouderen is dic kans tientallen procenten) dat men cen 'afwijking' vindt die niets met de klachten te maken heeft. ${ }^{2}$. De ten onrechte bevestigde hypothese zal dan moeilijk te corrigeren zijn en daarmee ligt voor de onderzochte een verdere carrière als. rugpatient open. Wetenschappelijk onderzoek naar de inhoudelijke aspecten van de hypothesevorming is al met al van groot belang. Het is dan ook verheugend, dat er sinds de eerste aanzetten van Hodgkin ${ }^{4}$ en Morell ${ }^{5}$ steeds meer klachtgericht onderzoek vanuit de huisartspraktijk geëntameerd wordt. Meer dan tot nu toe zouden daarbij vergelijkingen gemaakt moeten worden ten opzichte van personen die de betreffende klacht niet hebben. Immers, allicen als 
mensen met een klacht meer kans op een bepaalde aandoening hebben dan vergelijkbare personen zonder die klacht, heeft de klacht diagnostische betekenis.

\section{Interpretatie van diagnostische gegevens}

Als de huisarts door middel van anamnese en onderzoek hypothesen gaat testen, probeert hij in feite de vooraf ingeschatte kansen te herzien. Bestaande onzekerheden dienen hierdoor te worden verkleind. Dit geeft al direct aan, dat diagnostische procedures (tests) die niet tot een herziening van kansen leiden niet zinvol, en onnodig belastend zijn.

Voor het beoordelen van de vraag in hoeverre een diagnostisch gegeven informatief is, alsmede voor het kritisch interpreteren van zo"n gegeven, is het van belang enkele basisbegrippen te kennen. We bespreken deze aan de hand van een zogenaamde viervelden tabel of beslissingsmatrix (figuur 1 ).

\section{Figutur}

A priori kansen, sensitüwiteit en specificiteit, alsmede voors pellende waarden, zoals gedemonstreerd aan de hand van de vierveldentabet.

\begin{tabular}{|c|c|c|c|}
\hline ; & ziek & niet-ziek & tolaal \\
\hline a fuvijkende uitslag & $T P^{p}$ & $F P$ & $T P+F P$ \\
\hline $\begin{array}{l}\text { niet-afwijkende } \\
\text { uitslag }\end{array}$ & $F N$ & $T N$ & $F N+T N$ \\
\hline lotaal & $T P+F N$ & $F P+T N$ & $T P+F P+T N+F N$ \\
\hline - a priori kans opde de ziekte & \multicolumn{2}{|c|}{$=\frac{T P+F N}{T P+F P+T N+F N}$} & \\
\hline - sensituiviteil van de kest & \multicolumn{2}{|l|}{$=\frac{T P}{T P+F N}$} & \\
\hline - specificiteit van de test & \multicolumn{2}{|l|}{$=\frac{T N}{T N+F P}$} & \\
\hline \multicolumn{3}{|l|}{ - a posterioni-kmsen } & \\
\hline $\begin{array}{l}\text { - warspellende waaxde wan } \\
\text { afwijlende witslag }(W W+)\end{array}$ & $=\frac{T P}{T P+F P}$ & & \\
\hline $\begin{array}{l}\text { - voorspellende warde von } \\
\text { mot-afwijkende uitshlag (VW- }\end{array}$ & $=\frac{T N}{T N+F N}$ & & \\
\hline
\end{tabular}


3-I De 'a priori' kans: de kans op een bepaalde aandoening vóórdat er nader onderzock is gedaan. Men kan deze kans opvatten als het percentage personen dat dic zickte zou hebben in en populatic van personen met dezelfde kenmerken en klachten als de patient die men voor zich heeft. De a priori kans komt dus overeen met de prevalentic in een dergelijke hypothetische populatie. Soms is over deze kans vrij veel bekend, vaak kan zij slechts worden geschat.

Het schatten van a priori kansen is een hoeksteen van het vormen van diagnostische hypothesen.

3-2 De sensitiviteit van de test: de kans dat in aanwezigheid van de ziekte de test ook inderdaad een afwijkende uitslag oplevert. Als men de test zou doen op een groot aantal zieken, dan geldt:

sensitiviteit $=\frac{\text { terecht positieve uitslagen (TP) }}{\text { terecht positieve (TP) }+ \text { fout negatieve (FN) uitslagen }}$

3-3 De specificiteit van de test: de kans dat in afwezigheid van de zickte de test ook werkelijk een niet-afwijkende uitslag oplevert. Als men de test doet op ecn groot aantal niet-zieken geldt:

specificiteit $=\frac{\text { tcrecht negatieve uitslagen (TN) }}{\text { terccht negatieve }(\mathrm{TN})+\text { fout positieve (FP) uitslagen }}$

Sensitiviteit en specificiteit bepalen te zamen de validiteit, of beter, het onderscheidend vermogen van de test. Zij hangen met elkaar samen. Deze samenhang is een functie van het zogenaamde afkappunt: dit is de cesuur tussen wat als afwijkende en niet-afwijkende uitslagen beschouwd wordt. In het algemeen geldt dat, als men door middel van een andere keuze van het alkappunt de sensitiviteit verhoogt, de specificiteit afneemt. En, omgekeerd, wordt de sensitiviteit kleiner als men de specificiteit verhoogt. ${ }^{6}$ Dit wordt duidelijk aan de hand van een voorbeeld. Door middel van het inspannings-elektrocardiogram traclut men een indruk te krijgen over de mate van ischemie van de hartspier, ten cinde besluiten te nemen ten aanzien van nadere diagnostick of therapie. Als men nu de cesuur voor wat men nog een normale sT-depressic vindt legt bij 2 in plaats van I $\mathrm{mm}$, dan zullen meer mensen zonder ischemic ook als zodanig geclassificeerd worden (de specificiteit wordt groter). Van degenen mét ischemie zullen er echter minder worden opgespoord en voor nadere diagnostiek of therapie geselecteerd (sensitiviteit wordt kleiner). Kiest men een geringe ST-depressie als afkappunt, dan wordt de sensitiviteit groter en de specificiteit kleiner. De vraag is nu: wat is het optimale afkappunt bijeen test?

Deze vraag is niet eenvoudig en zeker niet eenduidig te beantwoorden. $\mathrm{Hct}$ antwoord is in de eerste plaats afhankelijk van de subjectieve waarde die patiënt en arts toekennen aan een (fout-)positieve en een (fout-)negatieve uitslag. Als men bijvoorbeeld de consequenties van cen fout-negaticve uitslag 
ernstiger vind dan die van een fout-positieve, zal men de nadruk leggen op een hoge sensitiviteit. Worden daarentegen fout-positieven ernstiger gevonden, dan is een meer specifieke test extra belangrijk. Op dit moment lijkt het erop dat fout-negatieve uitslagen in het algemeen ernstiger worden gevonden dan fout-positieve, ook als de latste leiden tot onnodig, vaak ingrijpend vervolgondercok of zelfs overbodige therapie. De arts zal dan ook geneigd zijn het afkappunt niet te stringent te stellen. Deze beslissing implicert echter een keuze voor meer fout-positieven, met als mogelijk gevolg meer iatrogenese en somatische fixatie. De optimale keuze van het afkappunt hangt ook af van de a priori kans op de aandoening waarop men onderzoekt. Wanneer deze afneemt wordt bij cenzelfde afkappunt de kans op een fout-positieve uitslag groter (zie ook 3-4). Wil men deze in toom houden, dan zal het afkappunt stringenter moeten worden gekozen. Overigens kan men testuitslagen nog op een anderc wijze interpreteren dan aan de hand wan enkelvoudige afkappunten. In principe is er immers sprake van een glijdende schaal: bij iedere waarde van de uitslag is aan te greven wat de kans is op het aan-respectievelijk afwezig zijn van éen of diverse aandoeningen. Intuitief werken artsen al vaak met dit principe. Zo zal men bij een zeer sterk verhoogde bloedsuiker de kans op diabetes mellitus veel hoger (soms zelfs zeker) achten dan in geval van cen licht verhoogde waarde.

Het zal duidelijk zijn dat het onderscheidend vermogen van een test nihi] is wanneer men bij zieken en niet-zieken dezelfde verdeling van afwijkende respectievelijk niet-afwijkende uitslagen vindt. In dat geval kan men in plaats van het doen van de test even goed een munt opgooien. Deze situatie zou wel eens vaker kunnen voorkomen, of benaderd worden, dan men denkt. Helaas is echter van veel tests fook veel gebruikte, zoals de bloedbezinking of leverfunctics) het vermogen om te onderscheiden tussen zieken en niet-zieken op het niveau van de huisarts niet of nauwelijks onderzocht. Meestal werkt men met 'normaalwaarden' dic op statistische gronden zijn vastgesteld na onderzoek van gezonde populaties.

Het onderscheidend vermogen van een test is 'perfect' als de verdelingen bij zieken en niet-zieken elkaar in het geheel niet overlappen. Deze situatie is zeldzaam, zeker bij variabelen die op cen continue schaal gemeten worden (bloeddruk, allerlei laboratoriumbepalingen). Soms echter wordt zij goed benaderd, zoals bij de uitslagen van röntgenfoto's bij fracturen.

34 De woorspellende waarde van de cest: hierbij gat het om de kans dat iemand met een afwijkende uitslag ook werkelijk de betreffende aandoening heef (voorspellende waarde van de afwijkende testuitslag, $v w+$ ) en de kans dat iemand met een nict-afwijkende uitslag de aandoening niet heeft (voorspellende warde van de niet-afwijkende uitslag, $v w-)$. Ofwel:

$$
v w+=\frac{\text { alantal zieken met een afwijkende uitslag (TP) }}{\text { alle personen met cen afwijkende uitslag (TP }+ \text { FP) }}
$$


en: $v w-=\frac{\text { aantal niet-zicken met cen niet-afwijkende uitslag }(\mathrm{TN})}{\text { alle personen met een niet-afwijkende uitslag ( } \mathrm{TN}+\mathrm{FN})}$

De woorspellende waarden noemt men ook wel "a posteriori kansen", dat wil zeggen de kansen op ziekte respectievelijk niet-ziekte, nä het bekend worden van de testuitslag.

Uit de vierveldentabel is gemakkelijk het verband tussen a priori kans, sensitiviteit en specificiteit van de test, alsmede de a posteriori kans af te Iciden. Dit verband staat bekend als de regel van Bayes (zie figuur 2). Het principe is

Figuur 2

De formule van Bayes en haar afleiding.

\begin{tabular}{|c|c|c|}
\hline & ziek & miel-ziek \\
\hline $\begin{array}{l}\text { Lesturitsilag } \\
\text { pasilief }\end{array}$ & $T^{P}=$ sensitivitait $\times$ a priori kams & $\begin{aligned} H P= & (100 \%-s p e c i f i c i t i l) \times(100 \%-0 \\
& \text { priori kann })\end{aligned}$ \\
\hline $\begin{array}{l}\text { terturtalleg } \\
\text { negaltief }\end{array}$ & 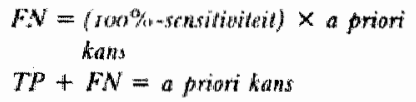 & $\begin{array}{l}T N=\text { specificinat } \times(n o \% \text { a priori } \\
\text { kans) } \\
\mu P+T N=100 \%-a \text { prion kans }\end{array}$ \\
\hline
\end{tabular}

Afleiding formule van Bayes:

* Voorspeliewro waande wan en poritiene testuitslag $=\frac{T P}{T P+F P}$

$=\frac{\text { sensitiziteit } \times \text { a prion kans }}{(\text { sensitiviteil } \times \text { a prioni kans })+(\text { roo\% } \% \text {-sperificiteil }) \times(100 \%-a \text { prioni kans })}$

2 De voarspletlende waardie wan een negatieve testuitslag $=\frac{T N}{T N+F N}$

$=\frac{\text { specificiteit } \times(100 \% \text { a priori kans })}{\text { specifficiteit } \times(100 \%-a \text { priori kans })+(100 \%-\text { sensitiviteit }) \times \text { a priori kans })}$

helder: door het toevoegen wan de informatie die een bepaalde testuitslag in zich draagt aan de a priori kans, verandert deze in de a posteriori kans (voorspellende waarde).

Van groot belang is het inzicht, dat de hoogte van de a priori kans in hoge mate bepalend is voor de voorspellende waarde van de uitkomst. We geven cen voorbecld.

De sensitiviteit en de specificiteit van mammografie bij de opsporing van borstkanker kan men op grond wan publikaties ${ }^{2} 8_{8} 9_{*}$ to stellen op respectievelijk $90 \%$ en $85 \%$. We kunnen het onderzoek nu verrichten bij vrouwen met verschillende a priori kansen op kanker, passend bij: 
a klachtenvrije vrouwen uit de algemene bevolking;

b vrouwen tussen de 20 eni 30 jaar, die de huisarts bezoeken met een knobbelije in de borst;"

c vrouwen tussen de 50 en 60 jaar, die de huisarts bezocken met een knobbeltie in de borst."

Gemakkelijk is nu te berekenen met behulp van een vierveldentabel of de regel van Bayes hoe groot de voorspellende waarden worden. Deze zijn gegeven in tabel 1 . Het blijkt dat de voorspellende waarde van een afwijkend mammogram hoog is, alls ook de a priori kans op kanker hoog is. Men moet echter dan well meer rekening houden met een lagere voorspellende waarde van een niet-afwijkende uitslag, met andere woorden: de kans op een foutnegatieve uitslag wordt groter.

Tabel 1

Voarspellende watden van een afwijkend ( $V W+$ ) en niot-afwijkend ( $V W-$ ) mammogram bij patiëten (lypen) mel verschillende a prion kansen op barsikanker. Rekenvoorbeeld, witgaande van een sensitiviteil en specificiteil van resp. $90 \%$ en $85 \%$.

"type patiënt"

I klachtenvrij, algemene bisolking.

2 2o-zo jaar, met knobbeltje in de borst bij de huisarts

3 50-60 jaar, met knobbeltje in de barst bij de huisarts

* Hierbij is, om didactische redenen, geen rekening gehouden met het feit dat de sensitiviteit en specificiteit in de verschillende situaties enigszins kunnen verschillen (zie blz. $11 / 4-13)$.

Als de a priori kans zeer laag is, blijft de voorspellende waarde van een afwijkende uitslag betrekkelijk laag en zijn er relatief veel fout-positieve uitslagen te verwachten. Men zou kunnen zeggen dat een testuitslag maar een beperkt deel van de informatie is die moet worden beoordeeld. Soms is een reeds bestaande zeer sterke of juist zeer geringe verdenking op grond van de mate van aanwezigheid van risicofactoren of het $k$ linisch beeld, minstens even zwaarwegend.

Nog een voorbeeld. Bij een vrouw van 25 jaar zonder klachten wordt bij een routine-cervixuitstrijkje een Pap I gevonden. De arts zal er dan op vertrouwen dat er geen sprake is van cervixkanker. Stel nu dat de uitslag Pap I ook afgegeven wordt bij een veertig jarige vrouw met klachten van tussentijds bloedverlies en contactbloedingen. Ondanks het feit dat de testuitslag ook nu negatief is, zal de arts in dit geval minder zeker van zijn zaak zijn: hij houdt rekening met een fout-negatieve uitslag en acht kanker nog geenszins uitgesloten. De arts past nu in feite toe wat zojuist geformuleerd is: hij interpreteert 
de testuitslag met in het achterhoofd de kennis dat cerwixkanker bij klachtonvrije vrouwen van 25 jaar erg zeldzaam is (lage a priori kans), maar bij vrouwen van 40 jaar met de beschreven klachten veel vaker voorkont (hogere a priori kans).

Bevolkingsonderzocken zijn crom berucht dat zij zich meestal richten op populaties met dermate geringe a priori kansen dat er veel fout-positieve uitslagen uit de bus rollen. Op het niveau van de huisarts, op wiens spreekuur allerlei ernstige ziekten relatief zeldzaam zijn zou men, weliswaar in mindere mate, hetzelfide kunnen vrezen. Daarom is een kritische instelling ten aanzien van het formuleren van hypothesen, alsmede een goede selectic van patiënten voor nadere diagnostiek, heel belangrijk.

Daarbij geldt natuurlijk dat de vraag van de patiönt de eerste ingang is van de hulpverlening. Het kan dan soms zo uitpakken, dat de arts op aandrang van de patiënt een hypothese gaat testen die hijzelf op goede gronden nooit zou hebben gevormd. Het is dan belangrijk dat de arts zich voor het onderzoek realiseert - en dit ook aan de patient duidelijk maakt - dat de a priori kans erg laag is en dat een afwijkende uitkomst heel wel fout-positief kan zijn.

\section{Beslisbomen}

Huisartsen moeten vaak kiezen uit verschillende diagnostische strategieën. $\mathrm{Zij}$ doen dit op grond van kennis, ervaring en gewoontevorming alsmede aan de hand van wat zij lezen in de vakliteratuur. Nicttemin zijn er veel twijfels en verschillen van opvatting. Het is dan zinvol de diverse alternatieven zo expliciet mogelijk tegen elkaar af te wegen. Hierdoor komt men de meest wezenlijke beslispunten op het spoor en is het mogelijk witte plekken in de bestaande kennis te lokaliseren.

Ećn van de manicren om dit te doen is het ontwerpen van een zogenaamde beslisboom. Daarin worden de diverse mogelijke strategieën op overzichtelijke wijze ondergebracht, te zamen met hun mogelijke uitkomsten. Een en ander wordt dan voor bestudering toegankelijk. Men kan bovendien trachten, met behulp van gegevens in de literatuur eventueel aangevuld door de mening van deskundigen, meer specifieke uitspraken te doen over de meest wenselijke optic. Daarbij moet er rekening mee worden gehouden, dat onder verschillende omstandigheden andere opties de voorkeur kunnen verdienen.

We demonstreren een en ander aan de hand van het voorbeld over het mammaknobbeltie. Men kan stran voor de keuze uit de volgende dric alternatieven:

a directe verwijzing naar de chirurg voor biopsie;

b cerst wordt fysische diagnostiek verricht. Als dezc een voor maligniteit suspecte uitslag oplevert wordt verwezen voor biopsic. Indien het resultaat niet suspect is word mammografie verricht. Is deze afwijkend, dan wordt alsnog verwezen. Anders wondt afgewacht en na enige weken een controle afgesproken; 


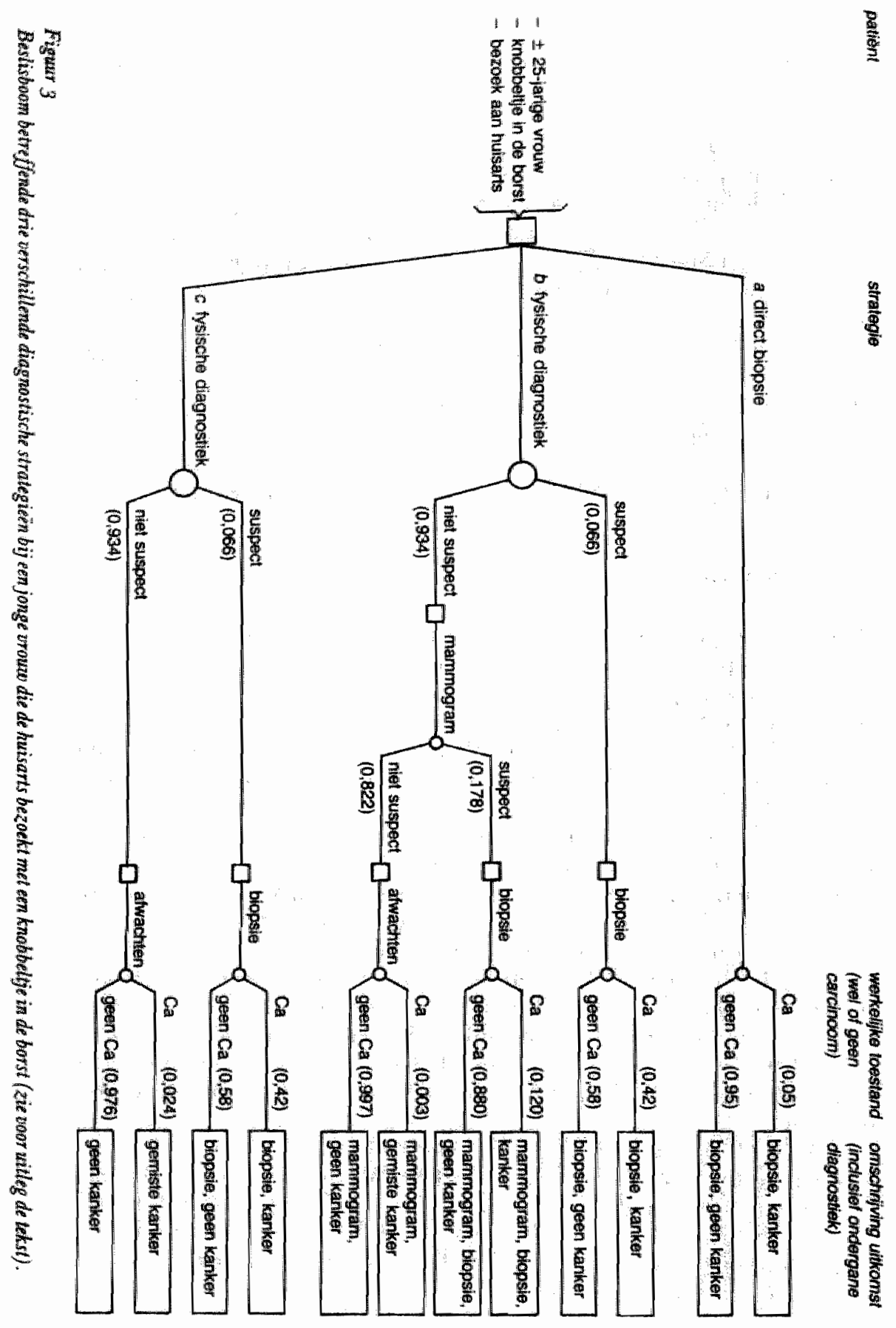


c or word lysische diagnostick verricht. Als hei resultati suspect is, wordt verwezen. In de overige gewallen word afgewacht en een nacontrole afgesproken.

In figuur 3 wordt een beslissing a angegeven met een vickantje (keuzeknoop) en cen uitkomst als en rondje (kansknoop). De laatste vertakking betreft de werkelijke situatic wat betreft de aanwezigheid van kanker. We gaan ervan uit dat biopsic perfecte informatic oplevert. Gcheel rechts zijn de einduitkomsten per tak omschreven.

Met behulp van literatuurgegevens $7,8,9,40,12$ over de sensitivitcit en specificiteit van fysische diagnostiek en mammografie alsmede over de kans op borstkanker bij een jonge vrouw met een knobbeltje in de borst " is het mogelijk de beslisboom van getallen te voorzien: In de beslisboom hebben we in plaats van sensitiviteit en specificiteit de voorspellende waarden van de diverse onderzoeksuitslagen weergegeven. $Z$ ij zijn bij een gegeven a priorikans uit elkaar te berekenen door middel van de formule van Bayes (figuur 2). Wij kozen woor deze weergave omdat zij meer logisch ansluit op de volgorde van het medisch besluitvormingsproces. In dit voorbeeld hebben we alleen gerokend met de gemiddelden van de literatuurgegevens. Op de technicken dic ontwikkeld $z$ ijn om ook de extremen in de analyse (zogenaamde sensitiviteitsanalyse) te betrekken, kunnen we hier niet ingaan (zie hiervoor Weinstein ${ }^{3}$ ).

Bij iedere kansknoop is de som van de mogelijke uitkomsten $100 \%(1,0)$. Men kan de kanswerdeling der verschillende uitkomsten vinden door op weg naar elke uitkomst de achtereenvolgende kansen met elkaar te vermenigvuldigen. Zo kan men nagaan dat de kans dat men bij strategie $b$ een carcinoom in eerste instantie mist, gelljk is aan $0,934 \times 0,822 \times 0,003=0,002 .(=2$ van de $5^{0}$ kankergevallen). Daartegenover staat dat wanneer men 1000 van deze patiënten zou onderzoeken, men bij strategie $b 0,934 \times 0,822 \times 1000=768$ directe verwijzingen voor biopsic zou uitsparen, ten opzichte van strategic $a$.

Indien men zich tot strategie $c$ zou beperken dan zullen op tooo onderzochten $0,934 \times 0,024 \times 1000=22$ van de in totaal 50 kankergevallen worden gemist. Weinigen zullen strategic $c$ nog acceptabel vinden.

Het is cen kwestic van afwoging welke keuze men uiteindelijk makt. Onder meer hangt dit af van het gewicht dat men toekent aan het woordeel van het uitsparen van verwijzingen en biopsieèn, tegenover het niet direct ontdekken van cen klein aantal carcinomen.

Als cen ander type pationt onderzocht wordt kan het becld flink veranderen. Dit kont met name ondat zoals we al eerder zagen, de voorspellende waarden van testuitslagen afhangen van de a priori kans op ziekto. Zo kan men nagaan dat als men strategie $b$ zou kiezen voor vrouwen boven de vijfing die op het spreekuur komen met een knobbeltje in de borst, men weel meer carcinomen zou missen en bovendien veel minder biopsieen zou uitsparen. Strategie a lijkt voor deze vrouwen dus beter. Anderzijds zal men büj klachtenvrije jonge vrouwen bij toepassing van strategie $b$, als vorm van screening, waarschijnlijk relatief zeer veel biopsieën moeten doen om een sporadisch kankergeval te vinden. 
Als de biopsie niet als perfecte test beschouwd wordt, maar - wat niet irreed is - als ecn test die ook foute uitslagen kan opleveren, zou de keuze nog moeilijker worden. Men moet dan niet alleen meer rekening houden met, achteral, onnodige verwijzingen, maar ook met onnodige operaties en anderzijds met ook door biopsic gemiste carcinomen.

\section{Utiliteiten}

In de vorige paragraafis er al op gewezen dat de keuze uit verschillende strategieen mode athangt van de waarden die men aan de mogelijke uitkomsten van olk der strategicën hecht. Deze waarden noemt men ook wel "utiliteiten'. Voor het doorrekenen van beslisbomen is het van belang dat deze utiliteiten in getalsvorm worden uitgedrukt. Soms kan men volstaan met overlevingspercentages. In het algemeen, zeker op het niveau van de huisarts, ligt het echter vecl ingewikkelder. Men moet vragen beantwoorden als:

- welk risico om een appendicitis acuta te missen wil ik nog lopen, ten rinde overbodige buikoperaties te voorkomen?

- hoo belastend is het woor cen patient die uitcindclijk een hyperventilatiesyndroom blijkt te hebben, dat hij bij de cardioloog allerlei diagnostiek heeft mocten ondergaan? En hoe verhoudt zich dit ten opzichte van het achterwege laten var de diagnostiek bij iemand die in feite wël angina pectoris heeft?

- hoo groot is bij de behandeling wan lichte hypertensie de winst van cen wat geringere kans op hersenbloeding of hartinfarct, ten opzichte van de zekerheid van een levensllange antihypertensieve therapic?

- welke kans will ik nog lopen op het missen van cen endometriumcarcinoom als ik het aantal curettages en uterusextirpaties wil terugdringen?

- hoeved beter moct het resultaat van operatie zijn ten opzichte van het naltuurlijk beloop, om de belasting door en rondom cen operatie te compenseren?

Er zijn verschillende methoden ontwikkeld om dergelijke "utiliteitsanalyses' uit te vocren. ${ }^{3}$ Hoewel het hier toch gaat om het uiteindelijk nut van het medisch handelen, staan dexe analyses nog in de kinderschoenen.

In ele individuclo pationtencontacten van de huisarts zal het overleg met en de inbreng van de patiënt van doorslaggevend belang zijn. Een open gesprek over de alternaticven, hun voordelen en hun risico's is daarvoor ecn voorwated Ann de basiskennis en -inzichten waraver de huisarts ten behocve vat zo" 1 communicatic zou mocten kunnen beschikken kan de medische besliskunde in de toekomst cen stecntje bijdragen.

De huisarts zal zich al vroeg in de diagnostische fase moeten bezinnen op de mogelijke uitkomsten. Van belang is dat hij wóór het entameren van een diagnostische procedure zich afvraagt:

" is, of hijn, de aandoening(en) waarop ik wil onderzoeken wel op zinvolle wijze te behandelen? 
$b$ worden beleid en behandeling beïnvloed door de diagnostische informatic die ik nu wil gaan verzamelen of tot de verzameling waarvan ik anderen (bijvoorbeeld specialisten) aanzet?

ad $a$ As het resultat van en behandeling niet beter is dan het natuurlijk beloop, kunnen diagnostische procedures beter achterwege blijven. Men kan denken aan het twijfelachtige nut van het opereren van een bij toeval ontdekte asymptomatische carotisstenose, of an therapeutisch niet of nauwelijks te beïnvloeden maligniteiten.

ad $b$ Voorbeelden zijn het verrichten van een controle-duodenoscopic tijdens of na de behandeling van een al aangetoond ulcus duodeni; of het verrichten van uitvoerige oncologische diagnostiek bij een ernstig zieke patiënt die een intensieve therapie niet meer zou willen of kunnen verdragen.

Deze principes lijken open deuren. Als men zich echter aanwent systematisch vooraf na te denken - en eventueel te overleggen met de patiènt of de specialist - over de verwach te waarde van de extra te vergaren informatie, zal men merken dat er hecl wat diagnostiek achterwege kan blijven.

We merken nog op dat diagnostiek meer doelen kan hebben dan het bereiken van cen beter therapeutisch resultaat, zoals het wegnemen van onzekerheid, of het geruststellen van de patiënt. Dit doet echter niet af aan de geldigheid van de zojuist genoemde twee principevragen.

\section{Enkele verschillen tussen huisarts en specialist}

Na de vorige paragrafen kan een aantal belangrijke verschillen worden aangegeven voor de diagnostische posities waarin huisarts en specialist verkeren.

- In de populatic patiënten die de specialist bezockt, is als gevolg van de voorselcctic van de huisarts de a priori kans op ernstige ziekten en op aandoeningen die specialistische behandeling vergen groter dan in de patiëntenpopulatic die de huisarts ziet. Dat betekent dat de voorspellende waarde van cen afwijkende bevinding bij cen door de specialist verricht onderzock altijd groter is dan de dezelfde bevinding door de huisarts, aannemend dat beiden in principe even kundig zijn. Ten aanzien van de afwezigheid wan deze ziekten is de voorspellende waarde van een niet-afwijkende bevinding bij de huisarts juist groter.

- Voor de ziekten die de huisarts vaak ziet en de specialist minder vaak, geldt het omgekeerde. Voorbeelden hiervan zijn vele minor ailments, exanthemen bij kinderen, enz.

- Men kan stellen dat de voorspellende waarde van een afwijkende uitslag van specialistisch onderzoek relatief groot kan zijn, omdat de huisarts voorselecteert. Als de huisarts dit niet deed, zou vecl overbodige diagnostick en ceenucel behandeling pliatsvinden. Met andere woorden: doordat de huisarts bij lage a priori kansen een grote voorspellende waarde vait normale be- 
vindingen heeft, kan de specialist bij de verwezen gevallen een hoge voorspelllende waarde van afwijkende resultaten bereiken.

Een voorbeeld: bij de arts meldt zich een patiënte met een bultje in de hals. Het is licht drukgevoelig, glad en $0,5 \mathrm{~cm}$ in doorsnede. Het is duidelijk dat een dergelijke presentatie bij de huisarts een geheel andere betekenis heef dan op het spreekuur van de oncoloog. Op grond van dezelfde bevindingen zal de ecrste een ontstoken klier het meest waarschijnlijk achten en een afwachtende houding aannemen. De laatste zal echter een primaire maligniteit of metastase willen uitsluiten met behulp van verder onderzoek. Men kan zich ook voorstellen dat wanneer beiden een klinische les over dit symptoom zouden geven, zij met sterk verschillende aanbevelingen zouden eindigen.

Ook een ander gevolg van verschillende prevalenties (en dus a priori kansen) in de populaties van huisarts en specialist moet in overweging worden genomen. Zoals gezegd hangt de optimale keuze van het afkappunt immers mede af van de prevalentic. Het is dus niet vanzelssprekend dat in situaties waarin verschillende prevalenties - a priori kansen - aan de orde zijn (bijvoorbeeld die van huisarts, respectievelijk specialist) dezelfde afkappunten gehantecrd worden. Dit punt wordt tot nu toe echter in het algemeen niet betrokken bij het vaststellen en toepassen van zogenaamde normaalwaarden.

Een belangrijk verschilpunt in de morbiditeitspatronen die huisarts en specialist onder ogen krijgen, is voorts het ontwikkelingsstadium van het klinisch beeld waarmec aandoeningen zich manifesteren. In het algemeen zuljen de verschijnselen in de fase waarmee de huisarts ermee geconfronteerd wordt, minder cluidelijk ontwikkeld zijn dan in de fase na eventuele verwijzing naar de specialist. In de cerste situatic zullen de zicken minder goed te herkennen zijn en ook minder goed van niet-zieken kunnen worden onderscheiden dan in de tweede situatie. In de huisartsenfase is het onderscheidend vermogen van onderzoekmethoden dan ook veelal lager dan in de specialistenfase. Zo is bijvorbeeld het onderscheidend vermogen van de thermometer in de allereerste fase van appendicitis acuta nihil, hetzelfde geldt voor leverfunctietests bij beginnende of lichte hepatitis. Refererend aan het voorbeeld over borstkanker: de speciallist onderzoekt gemiddeld grotere tumoren en deze kunnen beter gevoeld worden.

In de regel zal dus de sensitiviteit van een onderzoek groter zijn als de aandoeningen die men op het oog heeft verder ontwikkeld zijn. Soms is het zo dat de specificitcit echter tegelijk minder hoog wordt. Bijvoorbeeld als er relatief vecl verdachte gevallen worden verwezen naar de specialist. Zo kan men zich voorstellen dat een chirurg te maken krijgt met een overmaat aan suspect aanvoelende goedaardige tumoren, die heel moeilijk door middel van palpatie van kwaadaardige tumoren zijn te onderscheiden. Algemeen gesteld: zieken in de huisartspraktijk lijken meer op gezonden (alleen de herkenbare gevalIch worden verwezen) en gezonden in het ziekenhuis lijken meer op zieken (anders waren zij niet verwezen). Huisarts en specialist doen met een geheel ander spectrum van ontwikkelingsstadia klinische ervaringen op. Al met al komt de vraag op, of onderzoeksmethoden die 'geijkt' zijn in een 
specialistische populatue, in een huisartsensetting wel zonder meer volgens deaclfde criteria kunnen worden geïnterpreteerd. Recente inzichten steunen de opvatting, dat de validtert van ondersocksmethoden moet worden vastgesteld in cen populatie die op relevante punten representaticf is voor de personen waarop deze methoden zullen worden toegepast. 4 i' 15

Tenslottc: het is mogelijk dat door bepaalde angelecrde of ingesleten diagnostische gewoonten, verbanden tussen klachten en aandoeningen worden gesuggercerd die niet of nauwelijks bestaan. Als huisartsen en specialisten tijdens de opleiding of nascholing een bepaald diagnostisch of verwijs-gedrag krijgen ingegoten, kan dit leiden tot een 'self-fullfilling prophecy' "Daardoor kan de specialist telkens in zijn opvatting worden bevestigd dat een bepaald symptoom samenhangt met een bepaalde aandoening, terwijl dit op het niveau van de huisaris in feite niet zo is. Elders is dit mechanisme nader gedemonstreerd. ${ }^{16}$ Zo bestaat er gerede twijfel of de klacht moeheid en het hemoglobinegchalte ${ }^{17}$, en ook hoofdpijn en hoge bloeddruk ${ }^{18}$, wel een relcvante samenhang met elkaar vertonen. Echter, als huisarıen bij deze klachten relatief vaak het $\mathrm{Hb}$ respectievelijk de bloeddruk meten en als mensen net alwijkende bevindingen worden verwezen, zal de specialist eev verband tussen de betreffende klachten en afwijkingen vinden.

\section{Slot}

In dit hoofdstuk zijn slechts basale notities aangereikt. Kernpunt van de medisch-besliskundige benadering is het kritisch beschouwen van de waarde van diagnostische gegevens, te zamen met het volgens een logische systematiek analyseren van het besluitvormingsproces. Hierdoor kunnen:

- de punten waarop besluiten moeten worden genomen helder worden gelokaliseerd;

- de cventuele consequenties van die besluiten voor het verdere beleid worden bestudecrd:

- diverse strategische opties tegen elkaar worden afgewogen;

- onzekcrheden en manco's in de wetenschappelijke kennis worden opgespoord en voor onderzock tocgankelijk gemaakt;

- vruchtbarc aanknopingspunten worden gevonden voor medisch onderwijs, nascholing en intercollegiale toetsing.

Essentieel is dat men zich steeds de vraag stelt of het besluit dat men overwegt relevante consequenties voor het beleid heeft en of de te verwachten voordelen voor de patiënt opwegen tegen de nadelen.

Het zal lang niet altijd mogelijk zijn op grond van bestaande gegevens een betrouwbare, gekwantificcerde, indruk te krijgen van de waarde van de verschillende opties. Bovendien is de werkelijkheid van elk individucel consult weer zo complex dat nooit alle relevante overwegingen in een algemene analyse kunnen worden betrokken. Een kwalitatieve structurering van het besluit- 
vormingsproces, in bijvoorbecld een beslisboom, kan echter op zichzelf al zeer verbelderend werken.

Pasklare oplossingen moet men van cen besliskundige benadering niet verwachten. Integended: routinematig handelen komt juist ter discussie. De patičnt, dic het cerste en het laatste woord dient te spreken, kan bovendicn een beter inzicht worden verschaft in de implicaties van een bepaalde aanpak.

\section{Litteraturur}

1 Elstein, A. S. L. S. Shulman en S. A. Spratka, Medical Problem Solving an analysis of clinical reasoning. Harvard University Press, Cambridge, Massachusetts 1978.

2 Valkenburg. $\mathrm{H}$. A., Reumatische klachten en aandoeningen in een open Nederlandse bevolkingsgroep (4). Rouma Wereldwijd (1980) 4:1.7.

3 Sanders, H.W. A. Klinische betekenis van degeneratiewe afwijkingen van de lumbale wervelkolom en consequenties van het aantonen ervan. Nederlands Tijdschrift woor Geneeskunde (1983) 127:1374-7

4 Hodgkin, K., Towards eavlier diagnosis in primary care. Londen 1978.

5. Morell, D. C.. Huisartsgeneeskunst. Bunge, Utrecht 1978.

6 Sturmans, F., Epidemiologie, theorie, mothoden en toepassing. Dekker \& v.d. Vegt, Nijmegen 1982 .

7 Dronkers, D. J. De betrouwbaarheid van de mammografie. Nederlands Tijdschrift voor Geneeskunde (1977) 123:955-7.

8 Clarijs, W. W. J., M. van Deelen-Willems, J. H. C. L. Hendriks, E. J. C. Lubbers en W. J. H. Schmidt, Het occulte mammacarcinoom. Nederlands Tijdschrift voor Geneeskunde (1977) 123:526-9.

9 Molenaar, J. C. en B. den Herder-Kroon, De practische waarde van de mammografie voor de chirurg. Nederlands Tijdschrift voor Geneeskunde (1970) 114:1688-90.

10 Grimer, P. F., R. J. Mayewski, A. I. Musklin en P. Greenland, Selection and interpretation of diagnostic tests and procedures. Annais of Internal Medicine (1981) 94:533-96.

11 Velden. H. G. M. van der. Diagnose of prognose. De betekenis van de epidemiologie voor hel handelen van de huisarts. Huisarts en Wetenschap (1983) 26:125-8.

12 Rombach. J. J. Breast cancer screening. Results and implications for diagnostic decision making. Staflev, Alphen aan den Rilin 1980.

13 Weinstein. M. C. en H. V. Fineberg. Clinical decision analysis. Saunders, Philadelphia 1980

14 Ranschoff, D.F. en A. R. Feinstein. Problems of spectrum and bias in evaluating the efficacy of diagnostic tests. New England Journal of Medicine (1978) 299:926-30.

15 Putuke, $C$. L. Kanttekeningen over de gevoeligheild, de specificiteit en de voorspellende waarden van diagnostische tests. Nederlands Tijdschrift voor Geneeskunde
(1983) 127:556-61. 16 Knottherus, J. A. Interpretatio wan diagnastische gegevens. Huisarts en Weten-
schap (1983) 26:363-8.

17. Knottherus: A en P. Knipschild, Hemoglobine en "anemische' klachten zoals moeheid. Tijolschrift woor Sociale Gezondhoidszorg (1983) 61:788-92.

18 Knipschild. P en A. Vissers. Hoofdpin en hoge broedidruk. 1984 (wordt gepubli-
ceerd). 


\title{
Hoofdstuk 12
}

\section{De zeeffunctie van de huisarts}

\section{Het totale plaatje is van belang}

\author{
J. A. KNOTTNERUS

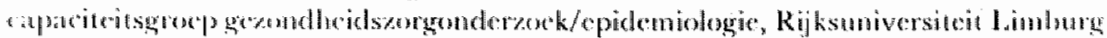

\section{Inlleiding}

Afgaande op het aantal verwijskaarten dat op dit moment aan ziekenfondspatiëntem wordt verstrekı, kan men de indruk krijgen, dat de 'zeel' van de huisarts niet goed functioneert: gemiddeld worden ongeveer 500 verwijskaarten per 1000 ziekenfondsverzekerden per jaar uitgegeven."

Over de achicrgronden van dit cijfer is veel geschreven. Gewezen is op het grote be roep dat op de huisarts gedaan wordt, op de hoogge-

\footnotetext{
Samenvating Hel begrip art senuitstel heeft bijua al een verwijtende betekenis getregen. Men vergeet echler veelal dat de huisarts, wit zijn grool patientenaanbod, een zeer hoog perthlage patiënten weed

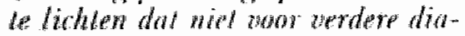

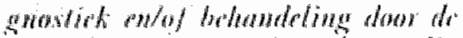
sperialist in anmwerkng kome. Do lijd is een wowne bondgenoot van de hursarts die deze factor wat hanteerl own sijn diagnostiek te ver. diepen en niw primair om verwijzing with th shllen.
}

spannen verwachlingen die patiënten hebben van de specialistische geneeskunde, en op het groelende aandeel van de verwijskaarten dat bijna. autonoom 'wegvloeit' via langdurige poliklinische begeleiding van patiënten. Ook wordt nog al eens als vrees geuit dat een alkalving van de kennis en kunde van de huisarts gaande is, waardoor hij de problemen van patiënten niet meer zell kan alhandelen.

Hoe dit ook zij, gelukkig is het nog steeds zo dat verreweg de meeste huisarts-patiëntcontacten niét tot verwijzing leiden. Uitgaande van 10.000 contacten per jaar in con standaardpraktijk wan 2500 zielen, worden cr gemiddeld zo"n 125 verwijskaten verstrekt op 1000 contacten. 1) at wil zeggen, bij minstens $87.5 \%$ vall do contaten wordil niet verwezen. Minstens, omdat de verstrekking van een grool amtal verwijskaarten zich buiten dc invlocdssfeer van de huisarts. voltrekt.

De zeeflunctie van de huis- arts is er dus nog wel degelijk. De wijze waarop men het liuncioneren van de zed beoordecl, hangt onder meer alf van de positic van waruil men kijkt. Als men wich dit niet, of onvoldoende, realiseert, bestaal hei gevaar van cen verkeerde becldworming. De zecflunctic $k$ an hicrdoor, ten onrechte, nog meer in discrediet geraken dan wellicht al is geschied. Wij illustreren dit met enkele soonten mogelijke beoordelingsfouten op dit gebied.

\section{'De huisarts is altijd te laat'} Een groot deel van de crustige aandoeningen dic legenwoordig veel voorkomen, ontstaat langzaam en is in het beginstadium moeilijk $t^{*}$ onderscheiden van onschuldige andoeningen of congemakken, of van nich-urgutuiscle: problemanick. Maligne aandoeningen bij vourbecld manifesteren zich messtal voor het eerst met een aspeciliek klachtenpatroon, watachter ook allertei levensmocilijkheden schuil kunnor gaan. 
Diarom blijh do kans ep een

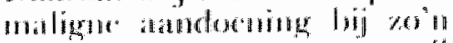

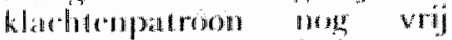
klein. Jo maeste huistrtsen zullen derlalve niet dired het gethele diagnost ische: itsenat willen spentrekkens. bantege

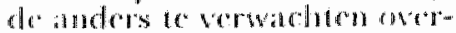

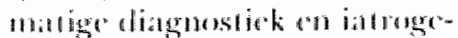
are bedreigingen. Bovendien githle dat lang niet alle consti-

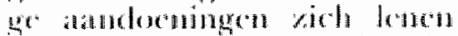
soor (xinvellle) opsposting in

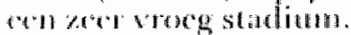

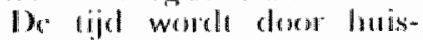
atrien diun orok valak als diar gumsticum gobroikt. Ex zijn

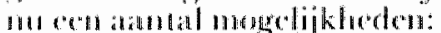

I. do noweste klacheon gatan. over zonder dat or verel an gedlinn hoeft to worden, dikwijls zodls zonder dat an econ diagnestische condusic is getrokkem;

2. in cen adntal gevallen komt cr ma verloop van lijd een problecm of diagnose atan het liche, dic analciding kan xijn tol hot tijdig malisercon van gon behandeling of verwijking;

3. Ac klachl verdwijul soms nice rn leidt onk nited tor econ duidelijke comclusic: men zou hico kumnen spreken vat chronisilhe, vage klachen;

t. in cen relaticl gering annal gevallen kom nil enige tijd con diagnose natr voren, warbij men achteral bezion gratag cerder therapeutisch had willen ingrijpen.

De orste twe situatics zullen wat de inbreng van de huisats beireft zoncler ved complications afuewikkrlel kumnen worlen, en rullen weinig atalleiding vormen voor natdrukkelijke cevaluatie adheraf Hot is immers gegathen $20-$

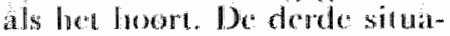
lic leide in het algemern tol langdurige dokseren bij do lunisarts an/ol relders. Federcen \%al het or, wat betredt dow greep pationten, over eens rijn, dith de hulpvertening nied "onvoudige is. In hel viondegesal lige hed weor anders: dlo hutsalts is nu, bij hot utheindelijk stellen van de diagnose" bijna alujd "te latat" in de ogen van vecl betrokkenen. Immers, het is achecral vatalk duidelijk dat de anderening al ved langer bestan mow hebben en dat het klachtonpatroon cr ook bij paste. Voorbeelden zijn pancreascarcinoom on osteosarcoum. Deze tumoren kunnen lange tijd schuilgatan achter do hypothese 'piychogrene: buikklachuen', respecticwelijk '(hardnckkige) spontblessuren'. Bij vod mensun zullen dexe hypollesen nok comrect zijn. Als ye nied correct aijn, omdat er onverwache sprakc blijkt to aijn van én van de genoemde kankervormen, zijn dece laatste toch "typische" gevallen: xij beginnen namelijk bijna altijd sluipend en gaan dan schuil achter andere vermeende, onschuldige, diagmosen. De indruk kan nu ontstaan dat de huisarts doze typischo bocldew onnodig 'gemisi' heef.

Diarenboven is, bij voor- becld bij malligne tumores. valak sprake van cen min of meer expenentiale volumedorneming in de lijd." Daardoor kan de aandoening jarenlang onder de oppervlakie blijuen. Is de dingnose conmal gesteld, dan blijkt het proces verdel bedrekkelijk sucl to were lopen. Als mon op basisi haln dit snelle beloop terugkijki, kan nen de huisares licht 'onkunde" on artsemuitstel tocdichent In klinische lessen kome clan ook voolvaldig bed ecvate vall artsemuitstel van de zijgle van de huisarts an de orde. Men ziet dan ochler alleen cle brelli van het plaatjo.

\section{Het héle plaatje}

fien van de belangrijkste vatardigheden van de: huisarts is het maken van onderscheid tussen patiënten dic nader onderzocht, behandeld of verwezen moclen worden, én patienten bij wic dat niet hocfi to gebeuren.

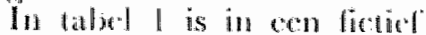
voorbectel werergergeven hase dit seleclieproces kan vitvalfro. We zinn hier dal do huisartsen $90 \%$ van de calcgoric crnstig ricken mei klachtenpatroon $X$. dic specialistisch behandeld moeten worden, inderdaad zonder "tijdverlies" hebben verwezen: de "sensiviviteit' van hun verwijsgedrag is $90 \%$. Daarnaast is ook $10 \%$ van degenen met klachtenpatroon $\mathrm{X}$, die gén specialistische behandeling behocven, desondanks verwezen: de 'specificiteit' van het verwijs- 


\section{TABEL}

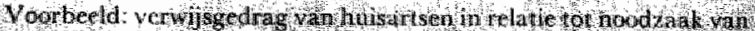

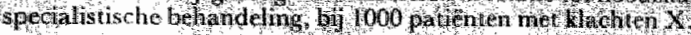

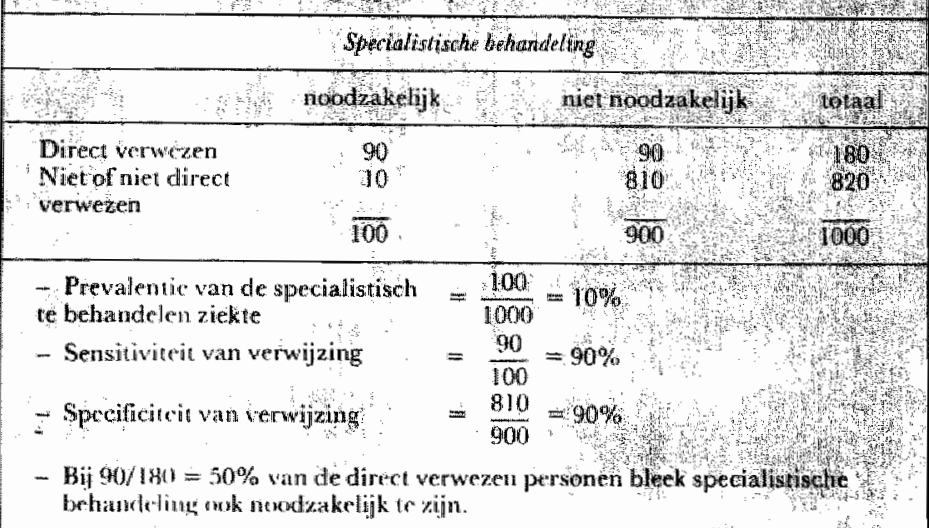

gedrag is $\lim 100 \%-10 \%=$ $90 \%$. Giezinen het lieit dat de betrellonde riekto in deze: grocp pationten met klachenpatroon $X$ in eren klaine nuinderheid wan de erevallen voorkomt (de prevalentic is laag), worden tow vecl 'nict-zicken' verweren. Nicllemin zouden cen scusitivitcil for speciliciteit beide vin $90 \%$ cen redelijke 'vallidicin' van de huisarts betekenen, zeker als mon dece cijfers vergelijkt mot die van menige diagnostische test aloonderlijt:

Het lige nu voor de hand dat veel alandach van sperialisten, die luuisartsen fordback en bijscholing willen geven, zal wigaan naar het wakjo links onder: de tien aanvankelijk gemiste gevallen. Bij de huisartsen zal er op aange- drongen worden zodanig le werk te gaan, dat dit vakjc met zo weinig mogelijk gevallen geveld wordt. Veel minder tandath krijgen de 'terech' on tijdig verwezen patienten (zo hoort het immers), en het aantal verwezen palichnen zónder de zickie (he wordt in hel algemeen minder 'rg gcacht dat een 'mietzicke' verwezen word, dan dat cen zieke niet verwezen wordt).

Holemaal gren aandacht krijgt het vakjo rechtsonder": degenen dic tereche nict verweren werden. \%ij vallen nameliik buiten hed blikveld van de specialist. Juist deze categoric echter gedi ecen becld van de vervulling van ecn kerntaak van de huisarts: het vermijden van overbodige verwijzingen.

Hei kan nu gebeuren dat de beschouwing van het "vakj" links ond $\mathrm{m}^{3}$ zich gatit niten in zeor dringende adviezen aan huisartsen: eerder doorsturen bij klachtenpatroon X cr/of: reeds verwijzing overwegen bij het mindw verdache klachtenpatroon Y. In dat geval kan gebeuren wal in de tabcllen $2+3$ (2ic pag. 1254) wordt getoond.

De sensitiviteit word inderdaad hoger $(95 \%)$ en er worden dus minder zicken gemist. Omdat de verwijsdrempel is verlatagd, is cohter de specilicitei $\mathrm{klcinel}$ geworden: meer mensen dic dr zickte nitet hobben, wordin verwezen voor specialistised onderzock, en de "xcofluntie" ton aanzicn van nict-ricken is achteruit gegaan (fabel 2). Dit kan versterkt worden door het afnemen van de provalenic in de groep dow de huisarts te beoordelen patienten, indien nu reeds bij hel minder verdachte klachtenpatroon $\mathrm{Y}$ verwijzing word overwogen (tailbel 3).

Het proces kan zich voortzetten tot vrijwel geen gevallen meer worden gemist, c.q. niot moer "to laat" worden verweren. Een des gromor aantal nict-zicken zal dan echter óók verwezen worden. Dil latatstc you allicen kunnen worden tegengegatan als, bij cen toeneming van de "sensitiviteit', de "specilicitcit" van de huisarts minstens golijk zou blifven, of liever mog zou verbetcren. 


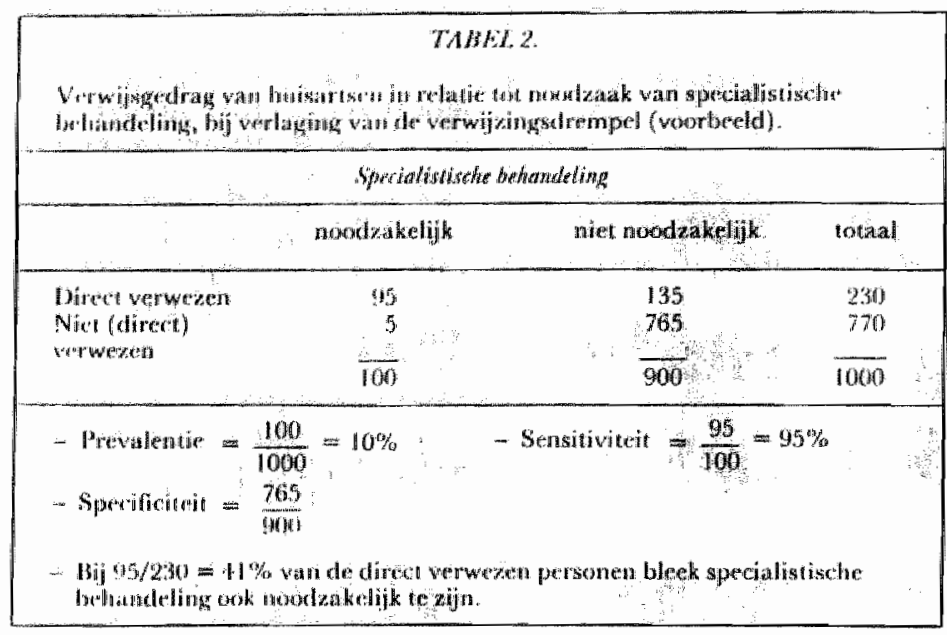

\section{TABEL 3}

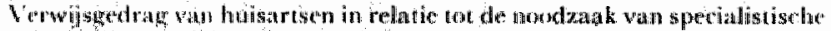

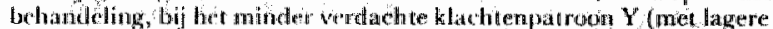
prevaltone) en boxendien on lagerenerwizingadrempel (woonbeld).

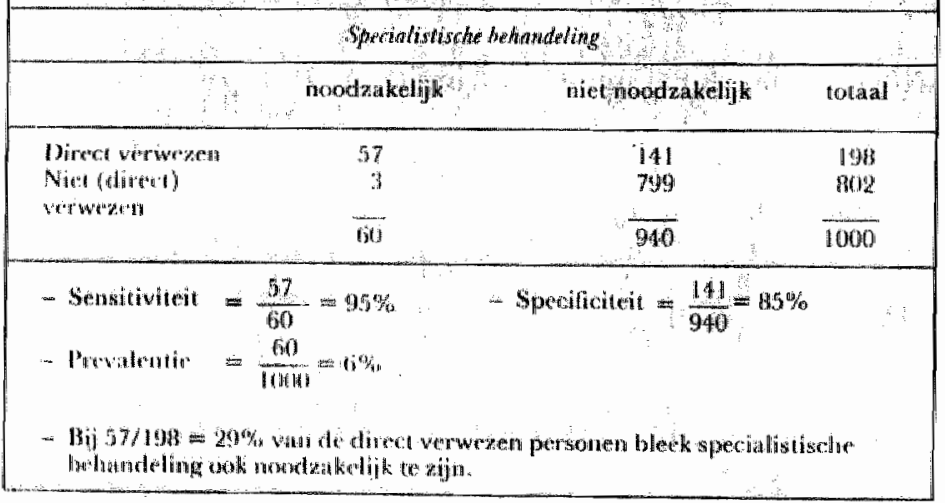

\section{Conclusie}

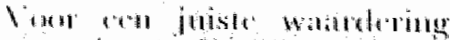

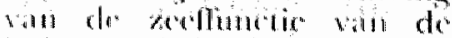

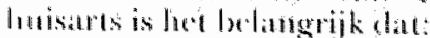

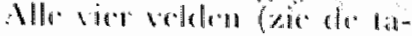

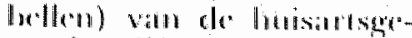

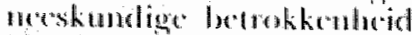
bif de lesthilverming ter andion van verwijhing oncraicu worden.

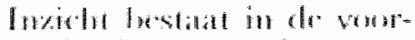
spe-llemle wated wan

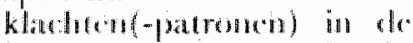
huisurtspraktijk, on dus in de prewalentio van andere-

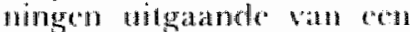
beparilde sympiomatologic.

- De diatarnostiok in de huisartsprakijik gecvaluerd c.e. verbeterd worde wat betreli haar ondersclacidend sermogen. Hicrbij is dan ook het pakket aun diagnostische faciliteiten van de huisurts on dions mogrom lijkluedron ton optimale interpretaltie van ondersockresultaten aan de ordr".

Dere punten onderstrepen laet grote belang vin wetenschappelijk onderzock in $\mathrm{de}$ litisatsprakijk voor het op peil houden, of zo men wil op peil brengen, van de zecfunctie van de huisarts.

\section{Literatuur}

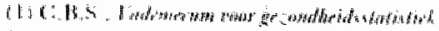

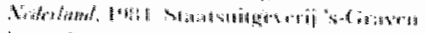

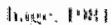

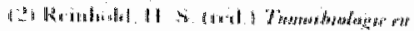

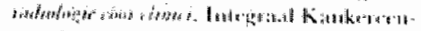

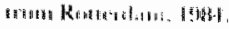

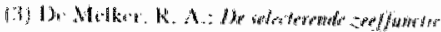

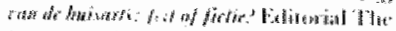

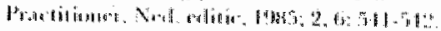




\title{
Diagnostiek van de palpabele lymfeklier
}

\section{door huisarts en specialist, een besliskundige benadering}

\author{
J.A. KNOTINERUS', J. BROEKMAN"EN PTOL Dr. LETURMANS'

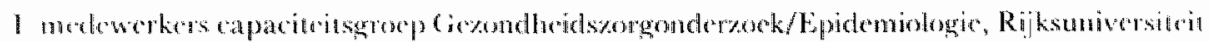 \\ I.intlitirg \\ 2 medewerker capaciteitsgroep Pathologie, Rijksuniversitcit Limburg
}

\section{Inleiding}

Over het diagnostisch beleid dat men zou moeten volgen indien door de patiënt of de arts een 'klier' wordt ontdekt, wordt verschillend gedacht. Sommigen menen dat een afwachicnde houding verantwoord is. Zij zijn vall oorded dat or zelden sprake is van crnstige pathologic. ${ }^{1}$ Anderen propageren ecen mect agressicve aanpak, waarbij in korte tijd do gehele scala van mogelijke onder zorkingen doorlopen moct worden tex de oorzaak gevonden is, ${ }^{2} \mathrm{D}$. vrees cen callamitcit, met mame ren maligne lymfoom of ecen klicrmetastase, over het hoold te zien, specth hierbij cen grote rol. Een problem is dal, voos zover onderzecht, liysisch-diagnostische be-

Samenvatting Geplatst tegemoner het probleem van de vergrole lymfekilieren zal de huisarls zich primair aforagem welke onderzoekmethoden hij moet toepassem om hel benigne of maligne karakier wan de swelling zast le stellen. Op grond van de resultaten zan zijn overwegingen zal hij moelen besluiten of hij de patient al of niet vow verder onderzoek naar de specialist moet venuigjzen. Er zim een viertal strategiemn mogelijk. die de huisarts bij deze beshossingistewze kunnen helpen. vindingen in hel algemeen een gering onderscheidend vermogen luebben, zeker als het gaat om de vroege zicktestadia waarmec de huisarts te maken krijgt. Ook het klachtempatroon van de patiënt biedt vaak geen aanknopingspunt. ${ }^{3}$ De belangrijkste indicatoren lijken noge de lokalisatio vam de klier, en de leefijd van de pattiönt. Tot nu loe, berust helats, vitiwel al het ondersock dat gepublicend is, op gegeveus die verzameld zijn op basis van eliagnostische lymfeklicrliepten bij via verwijzing geselectecrelle populatics. En wordt in deze publicaties bii

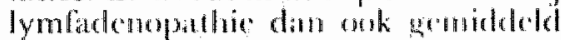
in ongeverer $50 \%$ van olle gevalten 400 maligne abudoening gevondert fan wel een derde hiervan primatiro lymfomen, wee derden metatatasen). $O_{p}$, grond hicervan kan de sugegestic ontstaan dat in het algemern biopsic

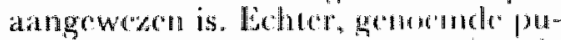
blikatles zeggen niels over de situattio van de huisarts. De kans dat ecol lymfeklierzwelling kwaadaardigy is, is in de huisartspraktijk, afgatand op dit onderzock, waarschijnlijk tientallen malen lager dan in de specrialististh. praktijk. De overgrote mecterbeid van de klicrzwellingen $(70 \%)$ is van infecticuze oorsprong, watabij bijzondere infecties (mononucleosis in- 


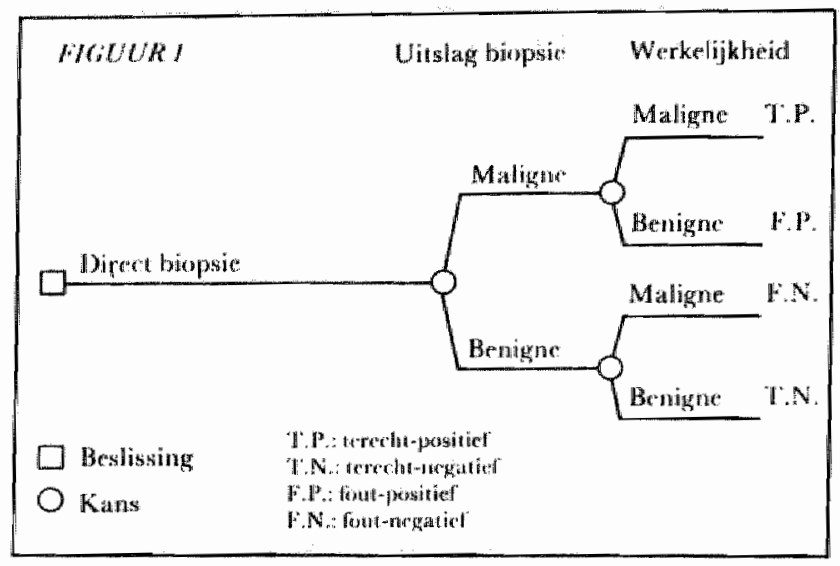

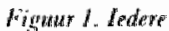

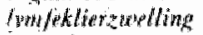
dirnt dited

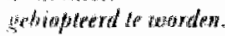

fectiosa, tuberculose) slechts zolden voorkomen.' Zowel bij de huisarts als bij de specialist word in 30 in $40 \%$ van de gevallen geen definitieve diagnose gesteld. Op grond van een eigen proclregistratic gedurende cen maand in negen huisartspraktijken is to verwachten dat een huisarts met en gemiddelde praktijkgrootle per jaar 15 tot 20 mal met het probleem onverklaarde klierzwelling" wordt geconfronicerd. Volgens de gegevens van lamberts ${ }^{3}$ doce dit probleem zich in con normprakiijk van 2500 ziclen 10 à 15 mal per jaar vor.

\section{Diagnostische strategieën}

Wij onderzochton de consequentics van diverse diagnoslische strategien, zoals dic te verwachten zijn op grond van gepublicecrde gegevens voor de huisarts, respecticvelijk de specialist. Daarbij hebben wij ons in hoofdzaak beperkt tot hel onderscheid uussen maligne en nict-maligne, omdat dit de voor de huisants meest wezenlijk vraagstelling betrefi: "Moet ik wel of net verwijzen"? Binnen de groop "malligne" dicuen deor de specialist dan vooral weer onderscheiden te worden primair lymfoom en metastasen van carcinoom. Wij hebben als eindpunt. genomen de al dan niet juiste diagnose "maligne of benigne". De therapeulische consequenties hebben we in dit artikel buiten beschouwing gelaten.

\section{- Siralegiel:}

ledere lymfeklierswelling dient gebiopteerd le worder

We gaan er hicrbij van uit dat biopsic steeds de juiste diagnose oplevert, d.w.\%. dat sensitivitcit en specificitcit steods $100 \%$ zajn. Dit is overigens een voor biopsie gunstige veronderstelling, daar de resultaten van ecn aantal verwolgonderzocken oplewerden dat zich bij circa $25 \%$ van de negatieve biopsieën later alsnog cen maligne lymfoom openbaarde. 7, 8. W Warschijnlijk is dit een gevolg van 'sampling crror": de biopten troffen niet de pathologische lokalisaties. Voorts zijn we uitgegaan van hel optreden van (nict-fatale) complicaties in 2\% van de biopsiecr. Dc tak wan de beslisboom, wat betreft strategic 1 , is wergegeven in $f$ guur I.

- Stralegie 2:

Bij itdere lympekliexzwelling wordt eerst cytologische punctio werrichl 


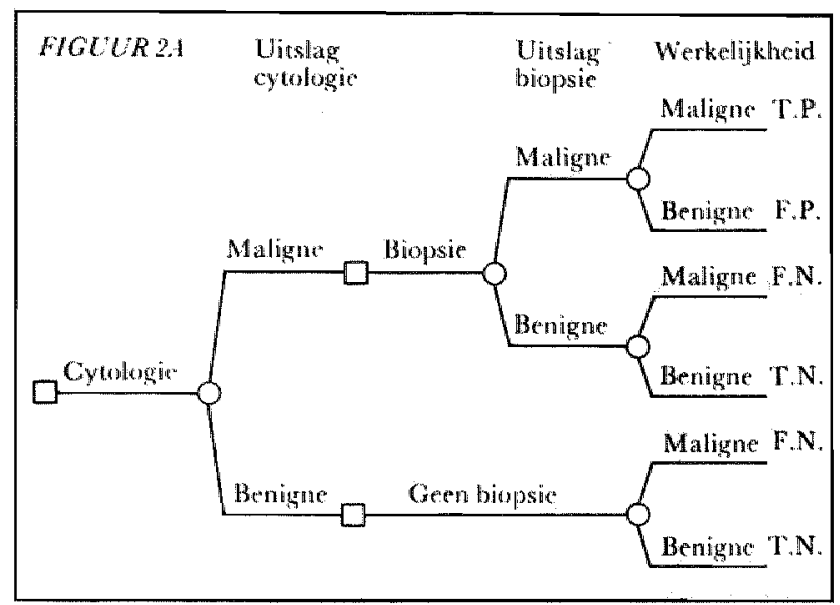

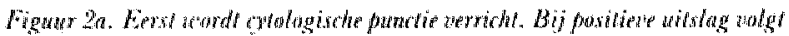
ingovie.

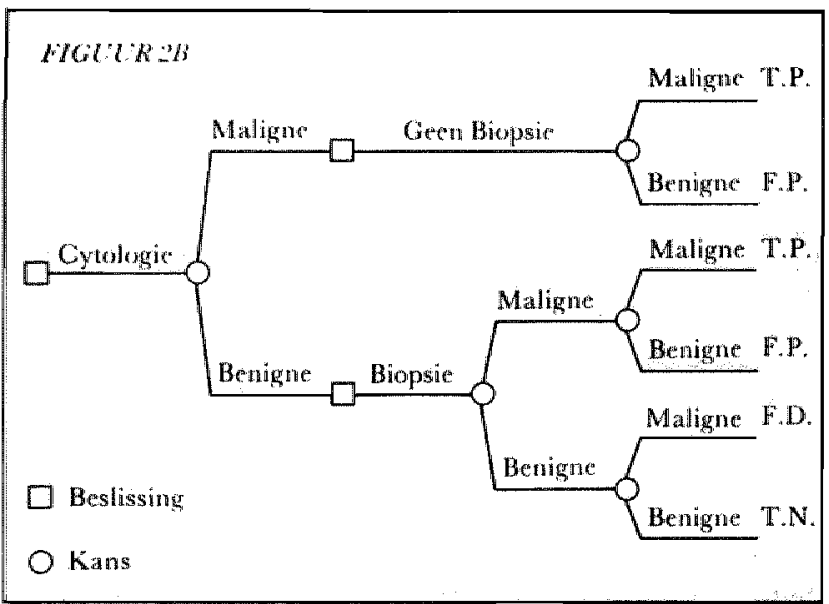

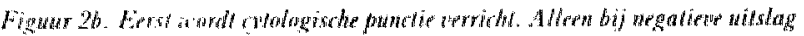

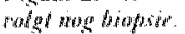

Verwolgens kan gekozen worden tussen de volgende stratcgieën (fig. 2).

$2 \mathrm{a}$ als de cytologische punctic duidt op een maligne standoening, wordt vervolgens an biopsic gedaan. Voor de. huisarts betckent dit cen verwijzing en vaak ecn opneming (cxcisicbiopsic). Bij een negatieve cytologic wordt afgewacht;

$2 \mathrm{~b}$ als de cytologische punctic negatiel is, c.q. nict op maligne tekemen wijst, wordt voor de zekerheid cen biopsie gedatan teneinde geen maligne atondoening te missen. Bij positicue cytologie wordt in principe gehandeld op basis van de uitslag hicrvan, en wordt biopsic 'overgeslagen'. Het 'overslaan' van ecn biopsic. kan van belang zijn, ondal cen antal ingrijpende K.N.O.-opcraties in verband met innwezigheid van maligne alwijkingen (radicalc hallsdisseetic) mocilijke" uitvocrbaar wordt na vooralgaande klictbiopsic.

Het zal niet altijd lukken om biopsic over te slaan, nl. indicn cytologie wel wijst op maligne degeneratie doch geen uitsluitsel geeft over het type. De strategic wordt dan minder efficient, c..q. er vinden mecr biopsieën plaats. In de analyse gaan we uit van hei gunstigsite geval voor deze strategie: ecn positicve cytologic matkt con biopsic overbodig.

Het is duidelijk dall stratcgic $2 b$ 


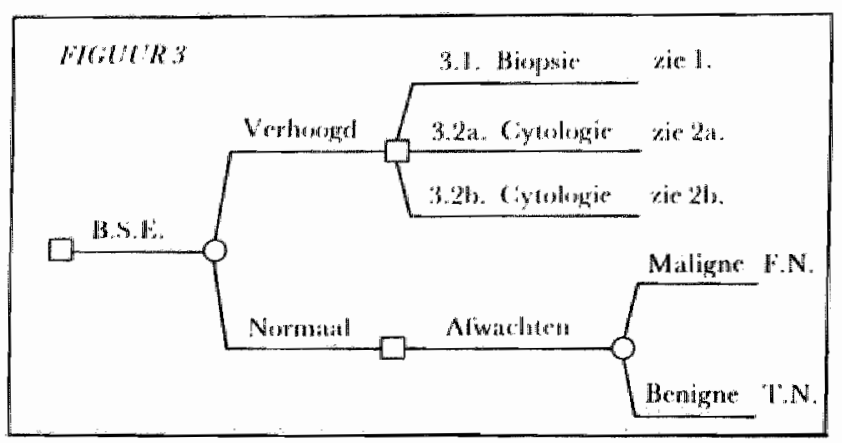

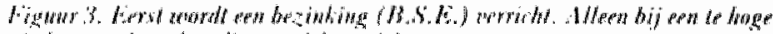

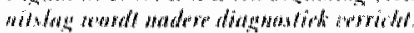

Whill

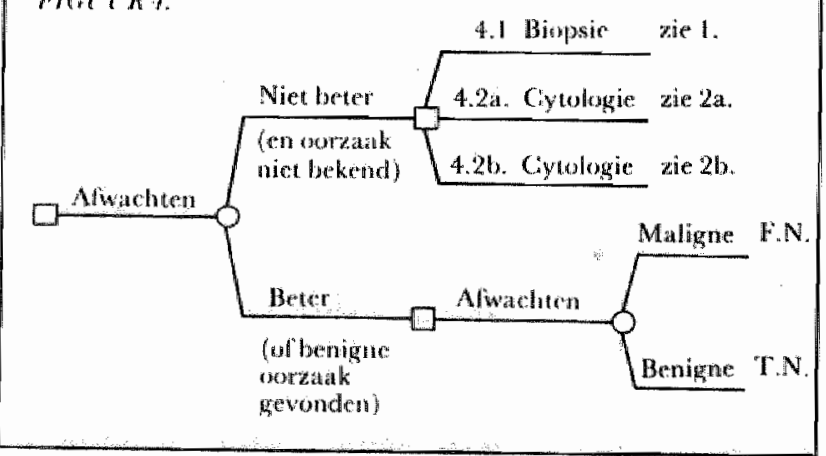

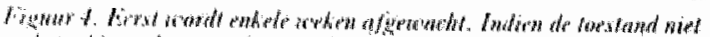

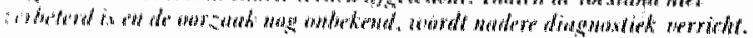

vored de lauisarts stecds verwijaing mal impliceren.

Lir zijin, voonal voor de specialist, mecr variaties in strategicon nat andediding van cylologic mogelijk.

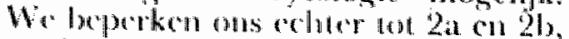
andall droe van het verwijsbeleid van de funisares vall belang rijn. $\mathrm{We}$ sinn er vanuit gewaton, dal de sconsitivileit van cylologer woor cen matigme atandocning $96 \%$ is an de sperificite $98 \%$. Compliratios lreden op bij $0,9^{\%} \%$ wan dio phunclie's.

\section{- Strateguie.}

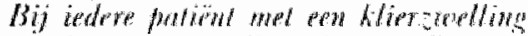
wortl een blow dbezinking (B.S.li.) geprikt

Allecen indion dewe to huege nitvalo. wordt nadere diagnostick verricht. Daarbij katn dan weer gekosen worden tussen strategic 1, 2a cu gh, (lig, 3).

Op grond van liceratuur nemen we aan dat de sensitivitcit van $\mathrm{de}$ B.S.E. ten anriven van maligne afwijkingen gemiddeld 64\%, on de specificiteit $5.5 \%$ is, als we cruan uitgaan dat con warde boven de $20 \mathrm{~mm}$ na con wur te hoog wordt gevonden. 11

- Stralegie 4:

Een afwachtende houding wordt aangenomen. Desgewenst wordt een keclkwook, (streptokokken) en/ol serologic (in het bijzondea mononucleose, cylomegalie, toxoplasmose) verricht. Indien na circa dric woken geon infocticuze sorzatak ontdekt is en de kllicr nog niet verdwenen a. kleiner geworden is, word de kans op cen maligne? andocning uikcraard groler. $\mathrm{br}$ wordt dan gekoren tussen strategic $1.2 \mathrm{a}$ cn $2 \mathrm{~b}$ (lig. 4). Op grond van licraunregevens maken wij con sehating ram de kans dat al- 


\begin{tabular}{|c|c|c|c|}
\hline \multicolumn{4}{|c|}{$\begin{array}{l}\text { THABLA. } \\
\text { Gethantuerde kansero cal veronderstellingen }\end{array}$} \\
\hline 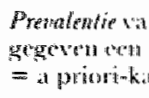 & 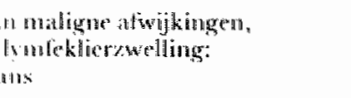 & $\begin{array}{l}\text { huisants: } \\
\text { speciullise: }\end{array}$ & $\begin{array}{l}1 \% \\
50 \%\end{array}$ \\
\hline 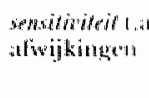 & 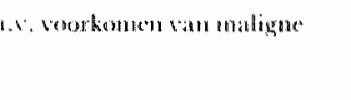 & $\begin{array}{l}\text { biopsie: } \\
\text { cyindongho: } \\
\text { Bis.l:.: }\end{array}$ & $\begin{array}{l}100 \% \\
96 \% \\
61 \% \%\end{array}$ \\
\hline 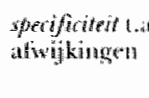 & A. de afwezigheid van maligne & $\begin{array}{l}\text { biopsic: } \\
\text { cytologile: } \\
\text { B.S.E: }\end{array}$ & $\begin{array}{l}100 \% \\
98 \% \\
5 \% \%\end{array}$ \\
\hline romplinaties & & $\begin{array}{l}\text { biopsie: } \\
\text { cytolonge" }\end{array}$ & $\begin{array}{l}2 \% \\
0,9 \%\end{array}$ \\
\hline 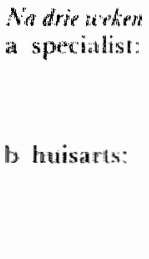 & 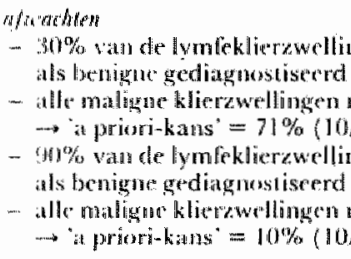 & 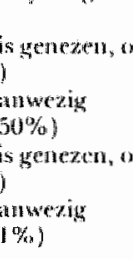 & (terercothe) \\
\hline
\end{tabular}

dus na dric weken nadere diagnoslick gewenst zou zijn, en vain de kans op het bestain van de'n maligne andereneng in de nader onderzoche groep. Wij deden dit voon zowel verweren ${ }^{3}$, als niet-verwezen pationten' (cabel l).

\section{Analyse}

Wij berekenden de resulaaten van de diverse strategiecu voor de siluatic van een specialist (met cen gemiddelde prevalentie van maligne afwijkingen van $50 \%$ bij patiönten van middelbare lectijd met en cen lymfeklicrzwelling bij cen patient van middel- bare leceltijd) en voor en llanisarts (met en overenkomstige prevalenlie van $1 \%$ ). In tabel I zijn de cijlers gegeven die wij bij de andlese haniecrden. Als uilkomsien werden gekozen de antallen verrichingen, hel aantal in cerste instantic "gemiste" maligne andocningen, he greschauc aantal complicaties van biopsic on cytologie on het artsuitsed doctor's delay). Ditarbij word sterels uituegaan van cen "cohort" van 1000 personen met cen lymleklierzwelling. In de appendix is ecn voorbedd gegeven wan de berckening, uitgevoesd voor écn van do strategieën*

\section{Resultaten}

Tabel 2 bovat de resultaten van do analyse. Voor iedere diagnostische stratcgic (1 $\mathrm{U} / \mathrm{m} 4.2 \mathrm{~b}$ ) kan men voor huisarts en spectalist, c.q in situatios mel verschillende prevallentures (a priori-kansen), alzonderlijk on indruk krijgen van de consequenties die to verwachten zijn op grond wan de door ons gebruikte gegevens. Het lijk crop dall de stratcgicen $2 a, 3.1,3.2 a, 3.26$

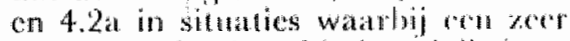
hoge prevalentie geldt (spectitlist) tow cen meer of minder groot andual in cerste instandic gemistc matigne afwijkingen leiden. In de situatio mot de lage prevalentie (huisarts) geld dit voor de stratcgieen 3.1, 3.2a ch 3.2b. Hichaj gaat het on de warg, ol men de door een bepantello strategic uitgespaarde diagnostick vindt opwegen tegen de kans van hel missen van een maligne aickte.

Voorselectie door ecn B.S. I:. -bepa- 


\begin{tabular}{|c|c|c|c|c|c|c|c|c|c|c|c|c|c|c|c|c|}
\hline \multirow[t]{2}{*}{ ther 2} & \multicolumn{8}{|c|}{ 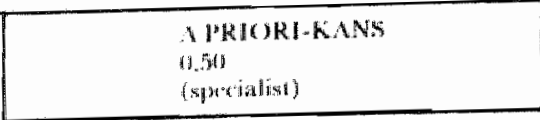 } & \multicolumn{8}{|c|}{ 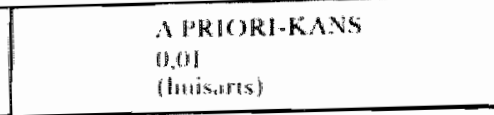 } \\
\hline & $\frac{g}{E}$ & 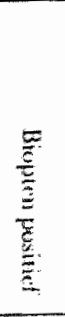 & 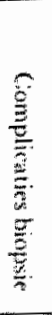 & $\frac{2}{3}$ & $\frac{2}{\frac{2}{2}}$ & $\frac{8}{\frac{8}{3}}$ & 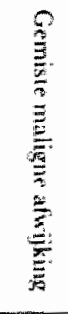 & 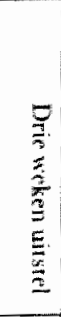 & $\frac{20}{3}$ & 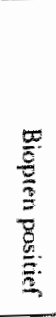 & 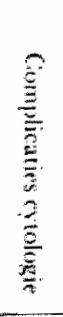 & $\stackrel{\frac{\mathscr{E}}{\bar{E}}}{\frac{0}{9}}$ & $\frac{3}{2}$ & 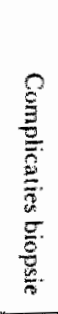 & 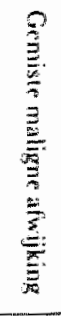 & 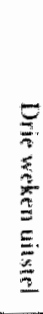 \\
\hline 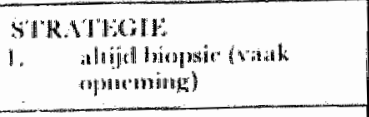 & frobol & 500 & 20 & 0 & 10 & 0 & 0 & 0 & botol & lo & 20 & 0 & 0 & 0 & 0 & 0 \\
\hline 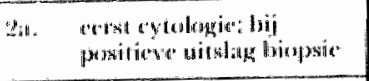 & 40,0 & Hot & IIt & lond & 10 & 9 & 20 & 0 & 30 & 10 & 1 & 1000 & 20 & 9 & 0.1 & 0 \\
\hline 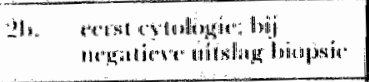 & 510 & 20 & 10 & Hono & 10 & 9 & 0 & (1) & 970 & 11 & 4 & 2unt & 20 & 9 & 0 & i. \\
\hline 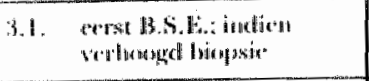 & $5 n$ & $3: 320$ & $n$ & 0 & 0 & i) & 880 & 0 & 552 & 6 & 11 & 0 & i) & 4 & 4 & 0 \\
\hline 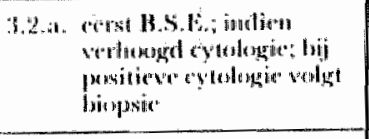 & 312 & 3017 & di & 545 & 5 & 5 & 193 & 0 & 15 & (1) & 0 & 152 & $y$ & 4 & .4 & dy \\
\hline 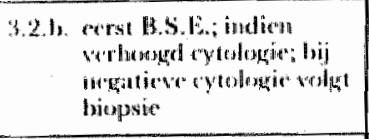 & 233 & $\|: \because$ & $:$ & 3.15 & 5 & 5 & 180 & 0 & 437 & 0 & $y$ & 452 & 9 & 4 & 4 & n \\
\hline 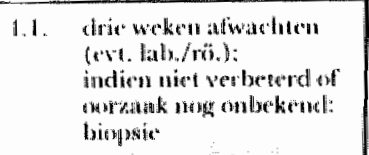 & 700 & $5(0)$ & 11 & 0 & 0 & 0 & 0 & 500 & 100 & 10 & 2 & 0 & 0 & 0 & 0 & 10 \\
\hline 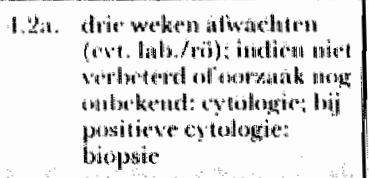 & 14 & 140 & 10 & $7 \mathrm{ino}$ & 4 & 6 & 201 & 齿怙0 & 12 & 10 & 0 & $(x)$ & 2 & 1 & $0-1$ & 10 \\
\hline 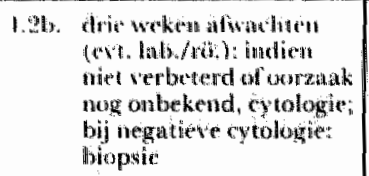 & 216 & 20 & $\sharp$ & $7(x)$ & 4 & 6 & 0 & 5000 & 88 & 0.1 & 2 & 1110 & 2 & $\|$ & 0 & 10 \\
\hline
\end{tabular}




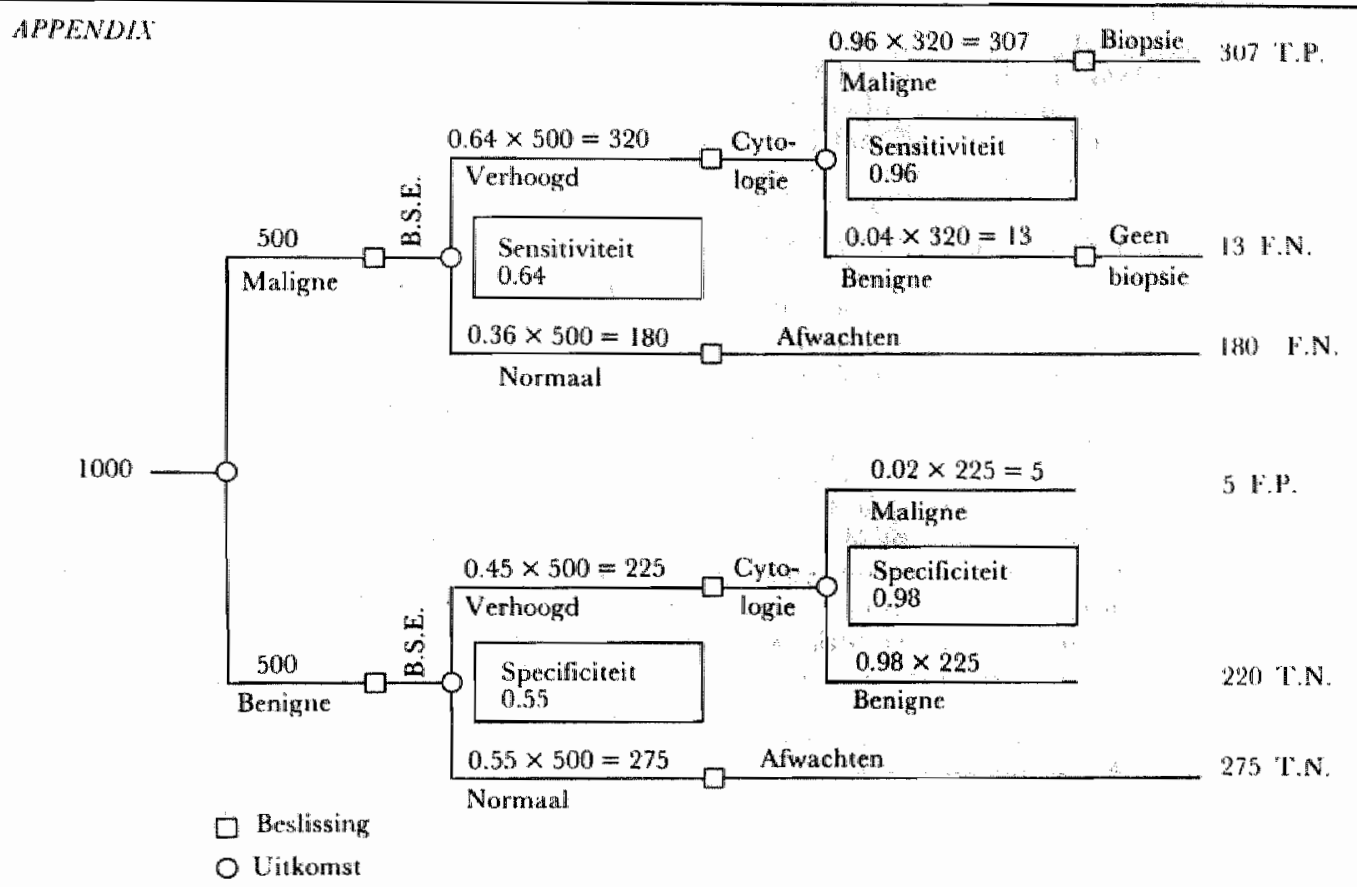

Voorbedid bekening woor strategie. $3.2 a$ buj a priori-kans van 0,50 toegepast op cohort van 1000 personch.

ling leidt telkens tot veel fout-negaticve en ook fout-positicve uitslagen en is dus geen goede strategie.

Cytologie als middel tot voorselectie om daarmee cen aantal biopsieen te omzeilen, is in de situatic met de hoge prevalentie (de specialist) naar ons oordecl alleen zinvol als men de negatieve punctieresultaten niot vertrouwt en in die gevallen nog cen bi- opsic doet (2b, resp. 4.2b). Als men daanaas toch ook nog en biopsic zou mocten doen in een gruot doel van do gevallen met ecu positiof punctieresultaat (ten behone van nadere classificatie), valt het voordecl weg dat veel biopsiec̈n worden omzeild.

Cytologic, tocgepast door of op aanvaag van de huisarts, is juist niet 
rimol als rew megation" uitstag ge-

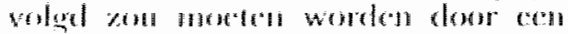

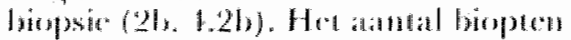
(col verwijeingen) enter niel of nauwelijks doo verminderen. terwijl bovendien tevoren een grom aantal puncties zou moxten worden uitgevocrd. Cytologic zou wöl van betcke-

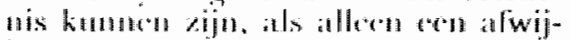

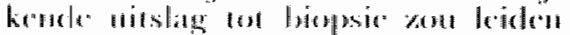

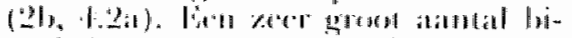

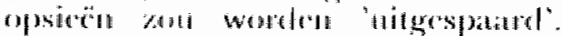

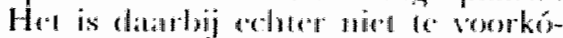
men dinl van de maligne atandomingent in erste instantic $1 \%$ wordt gentist.

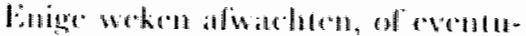

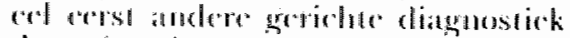

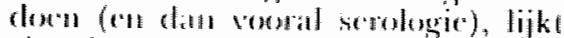

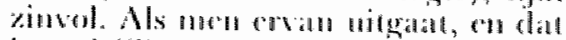
is rodelijk, dat maligno alwijkingern datrbij in de verdathe eatogoric blijven, wombl hum prevalentie in de nat-

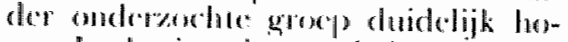

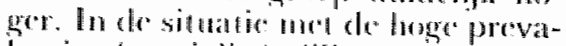
lemie (sperialist) lijken vormed de stratlegicen 4.1 (an t.2b mulig. Daarbij grelle werer dal dil wut van 4.21 ,

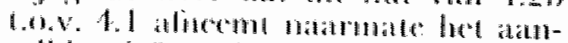
lalbiopsicen onk bij pessitice cytolopüc-uitslag wernemt. Bij lage preva-

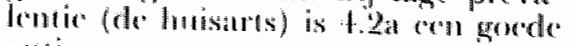
oplic.

\section{Cionclusie}

Ganchuderend kan grocgd worden, dat in situaties mot ero hoge prenatlentic fa priori-kinas). unalls wo" dic

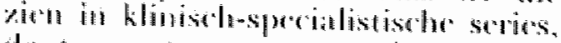

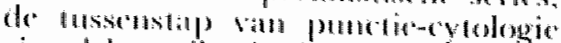
simall kan kiju, indien ern negatieve

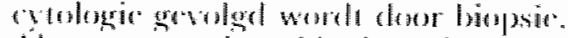
Als veorwaterele gedelt datu, dat pusit-

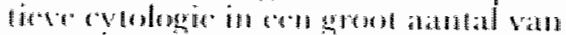

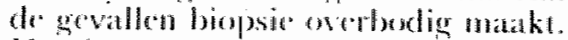
Hel is con kwostio san beroudeling hoeverel uitgesplatalle biopsicen men vind opwegen legen lied altijd verrichten wan etollogisede punctic. Het

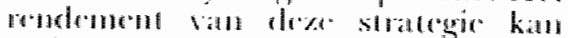

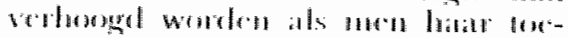

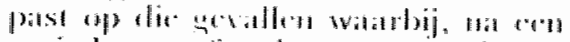

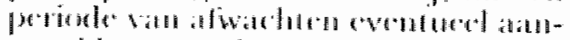

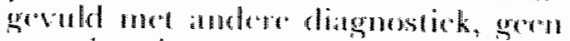

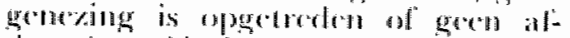
coconde verklatring exenomden is.

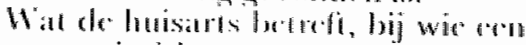

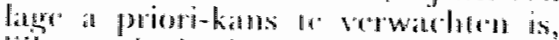

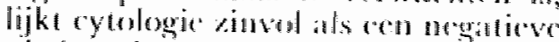

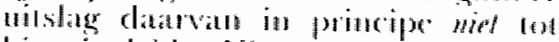

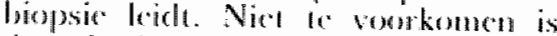
can, dat in cersto instantix econ gering anatal malligno alwijhingen wordt go-

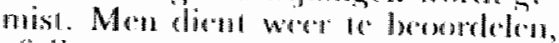
of" die secomponsecend wordl door cen

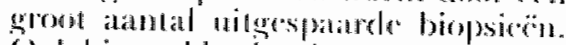

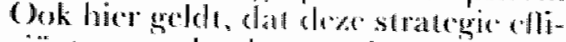
cicher worde als men hatar conden-

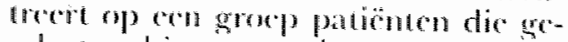

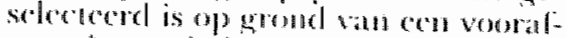

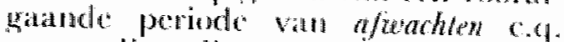
convoudige diagmostick. Fen blocedberinking als medlude van voursolece

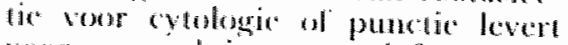
vatar verwachling to ved fout-nogatieven op.

\section{Slotopmerkingen}

Situatios kumen verseluillen, cormals a priori-kansen. Men kan de analyse"

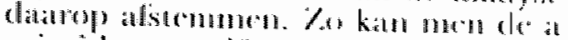
priori-kans varicren al mategelarng de 


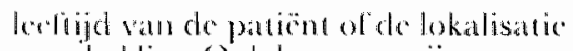
valn cle klicter. Ook kan men zijn verondevstellingen anders stellon. Er is bij vorbecte en publicatic die tot en latgere sensitiviteit $(89 \%) \mathrm{cu}$ con nog hogere speciliciteit $(100 \%)$ voor cytologic komt dan wij hantecrden ${ }^{12} \mathrm{Bij}$ doorrekening van deze cijlers in onze analyse wijzigt het becld in principe niet. Bedacht moet worden dat het verrichuen an cytologishe punctic vatudigheid en ervaring vereist. De schsitiviten zal lager worden als men deze ingreep, bij voorbcold als huisarts, ic weinig verricht. In sommige centra is hel mogentijk om de punctie" alls speciale diagnosisobo verrichoing alan to ragen bij de patholloog-anal(x)III.

Ook kunnen in principe de therapeutische consequenties (verbetering vath prognose; matle van betasting dewer de therapic; bijwerkingen; ten

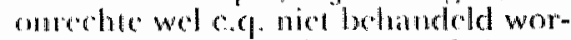
den; de conseguenties van, ankele we-

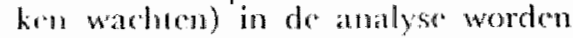
lactrokken.

On tol cen exate alweging te kex nonl, kan ara iedere tinduitkomst con auth de wog watangs dea bereikt is (zoals do hocvedhoid verrichte diagnostick; belaner van "delay") con watude worden toegekend. Per strattogic" kan dan cen verwachle waarde worden berckend. 1) werhouding ussen de verwachte warden van de diverse strategicen kan op hatar stabiliveil getest worden door de veronderstollingen over cen redelijk traject to warieren (sensiliviteilsamalyse).

Do hier gepresentecende klinische uitkomsten kunnen dow de lewer mell wan watarden worden voorxien "u cvenued worden herberekend voor verschillende situaties. De teneur van de conclusies - warbij vooral de consequentics van het verschil tussen de patientenpopulaties van huisarts $\mathrm{cm}$ specialist voorop staan - zal echter duidelijk zijn.

\section{Literatuur}

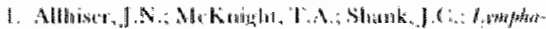

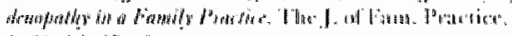
I11611: $12: 29-32$.

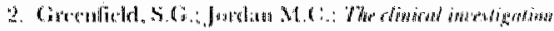

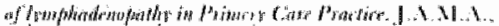

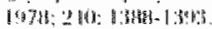

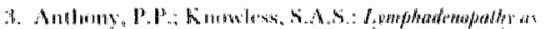

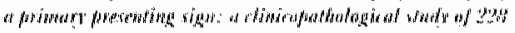

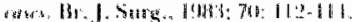

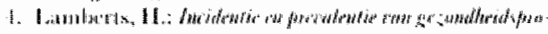

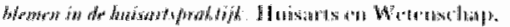

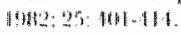

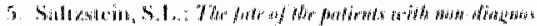

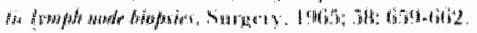

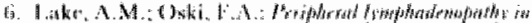

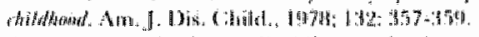

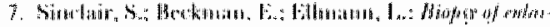

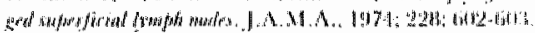

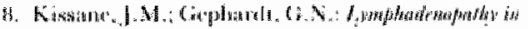

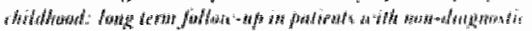

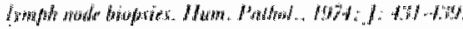

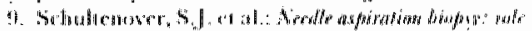

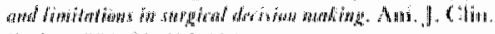

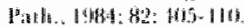

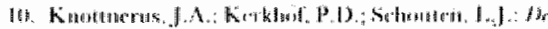

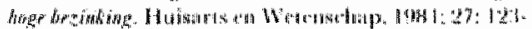
$11: 9$

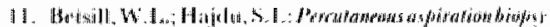

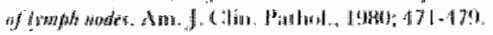




\title{
Diagnostische hypothesen en a priori kansen in de huisartsgeneeskunde
}

\author{
\&. A. KNOTMERUS*
}

In hueverre zajn bepaalde kiachten in symp-

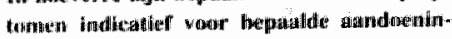

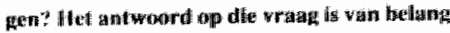

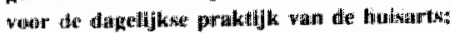

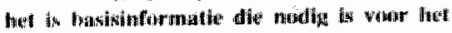

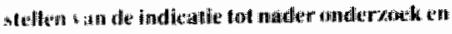
whar het interpseteren wan de witkwnstem wan dat andwrytelk. Moer algumeen pesiproken is dite ind formatle getwernsil water de onderbest wing wean diatganstisctic protocotten en strategiežn. In veruil the meeste gevaltum ontbretk da gewenste informatie echter en valk werk.t de

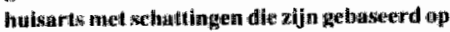
cen speciallistische siffuatle. De bestadande huiksurtsinuregistratie:ystemen kumen echter worden gebrailkt alls gegevenshronnen woor meer op de huisartspriaktijk toegesnedlen schallingetits.

\section{Inleiding}

Wan in de kans dak een 55 -jarige nokende man thet prikkelhoest ex longestrinoom hectl, ton hoe ziet de differentie le diagnosic wan $d e^{*}$ huisarts eruit als zign patient twee weken thees is:" Is bij bloedserbick per anum altijd rectosigmoidoscoybe en exn colonfoto angewezen. lloc mack is eigentijk het verband tussem bepanalde micieklacherm an pros. tusthyportafie?

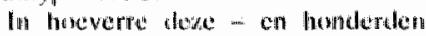

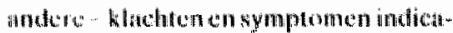

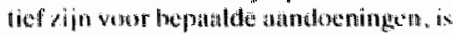

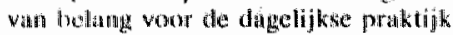
wan de husisats. Het is basisinformathe die modig is voor het stellen van de indichtie tor mader onderzoek on voor het interpreteren wan de resultaten van dat ounderzok. Mcer algemeen gesproken is these informatie gewenst voror de

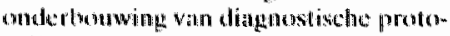
collon on strattegiecern.

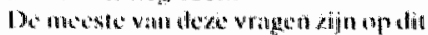

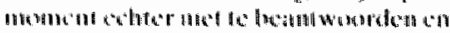

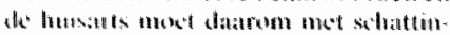

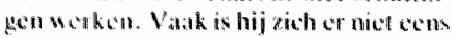

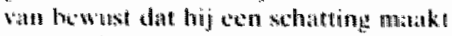
we vath herusten zijo sethatingen op de
- geselecteedde - erwaring van specha-

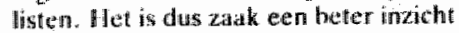
te onthikkelen in de kansen watrmee de huishituts te maken krijgt.

Dit artikel tevert daartoe een aantal houwstenen.

\section{A priori kansen}

De a prori kans op een bepalde aandoeming is de kans op die tatudoening " voordar relevante diagnostische inflormatic bakend is (bijwoorbeeld het antwoord op cen anamnesevrazg of de witsling van een diagnostische test). Anders geformuleerd: de a priori kans op en aaudoening as het percentage personen dat de abndoening heeft in een (cenkbeeklige) populatie van personen met dezelfde kenmerken en klachten als de betreffende patient.

Het schatten van deze a priori kans is Eén van de elementen voor het vormen van diagnostische hypothesen.

In het allgemeen kaf men de patièntenpopulaties Yan respectievelijk huisarts en specialist omschrijven als hun "contactpopulaties": populaties van personen die de huisarts of, na werwijzing, de speciatist consulteren met een vraag of klacht. Hierbij kumen verwollillende putronen wowkomen, die slechts gedeelthelijk athankulijk zijn wan de objec. rieve genondheidstoestand: mensen alie

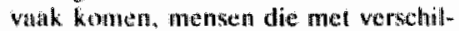
lende kltwhten tegelijk komen, mensem die (tal dan niet gericht) woor controle komer en mensen die nooit komen. Zo bezokt in de loop wan een jaar tijul circa 30 procent van de ingeschreven patientem de huisarts niet, en 30 procemt van de patitinten neemt 80 procent vath de contacten woor aijn rekening."

De "contanctpupulantice betreft het niveau

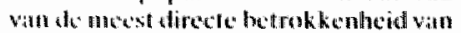

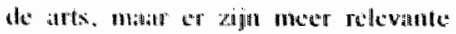
riveatus te onderschetiden:

1. De algemene bevolking. Voor de huisartis is dat de gehele bij hem ingeschreven patientempopulatie.

2. Do deelpopulatie van personen die een hepalde ktacht hebben.
3. De deelpopulatie van personen die ap do intisarts een theroep doen: de huisartecontist populatic

4. De declpopulatio van personen die dit: klach presenteren bij de thuisarts. De a prina hans in deze deelpopulatie, valt samen met de voorspellende waatide van de wllacht zoals gepresenteerd bij de huisarts, mede in thet licht valu de vourkennis wan de haisarts over de pativent.

5. De deelpopulatie van personem die naar aanleiding van de klachl op de ziekte worden onderzocht door de buisarts.

6. De 'contactpopulatie' van de specialist, met woer een eigen a priori kans. Deze a promi kans is gelijk alan de a posteriori karrs dic gepaard gaat aan hell besluit van de huisarts om te verwijzen. 7. De deelpopulatie van personen die door de specialist onderzocht worden vanwege de klacht.

8. De deelpopulatie van patienten die in het zickenhuis wordt opgenomen.

Steeds gaat het om populaties met gemeenschappelijke (diagnostische) kenmerken en een eigen a priori kans. Deze deelpopulaties kunnen elkaar gedeeltelijk overlappen ( 2 en 3) of een deelverzameling van elkaar zijn (4 wan zowel 3 als $2 ; 6$ van 3,8 wan 6,7 van 6,7 van 5,5 van 4) (figur).

Tussen de duclpopulaties kumnen belangrijke versethillen bestaan wat betrefn de a priori kans op ziekte, en bij de overgang van minder natar meer geselecteerde deelpopulaties kunnen allertei

Figuar. Het wetectieproces wan de algemene prakrijkberolking naur de contact. populatie wam de specialist.

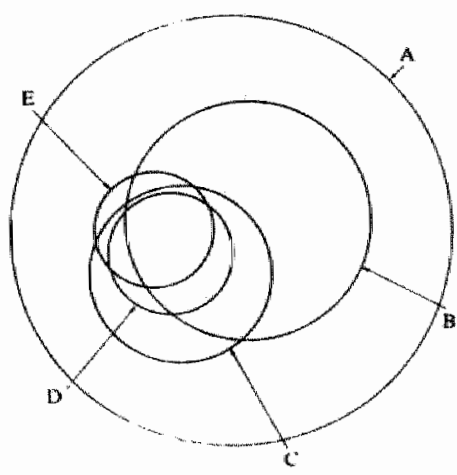

Taellichtim

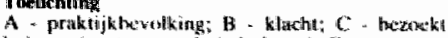

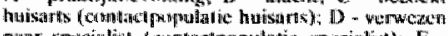

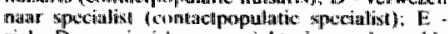

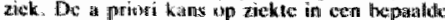

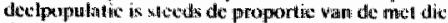
deelpopphatio corresponderende cirkst. die deor

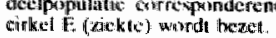


heranderingen optreden in de an te treffen verbandien tussen emerijds klachten (symptomen) of testuitsiggen anderzijds acke ${ }^{2}$ Bowenden zullen de ernst en de prognose wan aandoethin. gen samenhangen met de mate van selecte. Zo blijkt da de kans op latere recidief-convulsics na koortsconwulsies veel kleiner is als men deze baseert op onderzoekingen in de algemene bevolking, dan als men uitgaat wan een populatie kinderen dic bij een specialist of in ziekenhuis onder behandeling is. "Elk miweau van gezondheidszorg krijgt: te maken met sliechts het topje van de ijsberg van het vorige echelon: slechts ongeveer 10 procent wan de gezondheidsklachten leidt tot doktersbe-

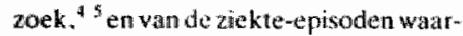
mee de huisarts te maken krijgt, wordi werwolgens matr ongevear 15 procent verwezen (bijlage).

In thet alligemeen geldt dat de a prori kans op ziek te groter word naarmate de selectie natr hogere echelons voortschrijdt. Dit geidt met name woor die atandoeningen warvoor specialistische behandeling wenselijk wordt geacht. 20 zien we in de tatel hoe sterk de a priori kansen op diwerse toestamden kumnen verschillen, ats men wigaat van acute buikpijn en de cijfers wergelijkt woor presentatie in respectievelijk het eerste echellon, op de eerste hulp en op een chirurgische afdeling.

\section{Multipele a priori kansen}

Meestal is er niet slechts ến diagnostische bypothese aan de onde, maar worden wertschillende andowingen overwogen. Dez: kumen tzondertijk, maar ook in combinatic bij ed patient woorkomen. Een wan de hypothesen kn rit yourts zijn: hed niet woorkomen vam ziek te. In schemin kunnern dezte hypothesen. met hur respecteve a priori kansen; als wolgt worden weergegeven:

\begin{tabular}{|c|c|}
\hline Myportiese & A priori kams \\
\hline $\mathrm{D}_{1}$ & $P\left(D_{1}\right)$ \\
\hline $\mathrm{D}_{2}$ & $\mathrm{P}\left(\mathrm{D}_{2}\right)$ \\
\hline$D_{3}$ & $P\left(D_{3}\right)$ \\
\hline Di & $P(D)$ \\
\hline $\mathrm{Di}_{i}, \mathrm{D}_{\mathrm{i}}$ & $\begin{array}{l}P\left(D_{i}, D_{i}\right) \\
:\end{array}$ \\
\hline $\mathbf{D}_{j,} \mathbf{D}_{j, \ldots, \mathrm{D}_{\mathrm{r}}}$ & $\mathbb{P}\left(\mathrm{D}_{\mathrm{i}}, \mathrm{D}_{\mathrm{j}}, \ldots, \mathrm{D}_{\mathrm{k}}\right)$ \\
\hline Geziond (D-) & $P(\mathbb{D})-$ \\
\hline
\end{tabular}

Dit schema is in fieite een weergave van de differentiète diagnose, met de aantekening dat bij de differentielle diagnose

Tabel. Versichillen in het parroon waw aandoenimgen bij patienten mer

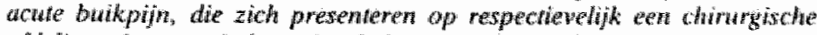
afdeting. de cerste hulp en bij de htutsarts. Percentages.

\begin{tabular}{|c|c|c|c|}
\hline \multirow[t]{2}{*}{ Diagntase } & \multicolumn{3}{|c|}{ Prosentistie hij } \\
\hline & $\begin{array}{l}\text { chthirnurgische } \\
\text { afdeling }\end{array}$ & ecrste hulp & huisuratts: \\
\hline Appendicitis: & 28 & 16 & ) \\
\hline Diverticulitis & 1 & 1 & \\
\hline Perforatie ulcus pepticum & 2 & 2 & 3 \\
\hline Cholecystitis & 9 & 5 & \\
\hline Obstructie & 4 & 3 & \\
\hline Pancreatitis & 2 & 1 & \\
\hline Urologische afwijking & - & 6 & 1 \\
\hline Gymaecologische afwijking & - & 5 & 1 \\
\hline Aspecifieke klachten & 55 & 152 & 95 \\
\hline
\end{tabular}

Brom: Do Dumbal..

niet alleen eien karss-aspect, matr ook nog een waarde-aspect van de betreffende diagnosen aan de orde kan zijn.

De som van deze a priori kansen is 100 procent, indlien alle relevante (combinaties van de diverse) hypothesen worden opgesond. Indien men dit niet doet kan de som hoger dan 100 procent uitkomen, zoals blijki wit het volgende voorbeeld:

Een 54-jarige man bezoekt de huisarts wegens gebrek an eetlust sinds ongeveer vier maanden, en enig gewichtsverlies. Kort nat het eter heeft hil pijn in epigistrio an een brunderig gevoel achter het borstbeen. Als hij gat liggen wordi dit branderige gevoel erger. Hif theeft het erg druk gehad het afgelopen jaar want hij is be noemd tot chef wan het warenhuis watar hij al jaren werkt.

Stel dat woor deze man nu de volgende hypothesen worden overwogen:

- geen aandoening (D-);

- ulcus ventriculi (UV);

- reflux oesphagitis (RO);

- carcinoma ventriculi (CV).

Stel dat verder de volgende a priori kansen gelden:

$\begin{array}{lr}\mathrm{P}(\mathrm{D}-)= & 45 \% \\ \mathrm{P}(\mathrm{UV}+\mathrm{RO})= & 15 \% \\ \mathrm{P}(\mathrm{VV} \text { alleen })= & 10 \% \\ \mathrm{P}(\mathrm{RO} \text { alleen })= & 10 \% \\ \mathrm{P}(\mathrm{UV}+\mathrm{CV})= & 10 \% \\ \mathrm{P}(\mathrm{UV}+\mathrm{CV}+\mathrm{RO})= & 5 \% \\ \mathrm{P}(\mathrm{CV} \text { alleen })= & 5 \% \\ \text { Het totaal bedragt dan } 100 \%\end{array}$

Als men geen rekening houdt met combinaties, krijgt man:

$\begin{array}{lr}P(D)= & 45 \% \\ P(U V)= & 40 \% \\ P(R O)= & 30 \% \\ P(C V)= & 20 \% \\ \text { De som' sow nu zijm: } & 135 \%\end{array}$

Er moet dus rekening worden gehouden met meer of minder witarschijnlijke combinaties van aandereningen the tis daarbij wenselijk alke combinatie van een eigen kansschatting to voorzien. In het voorbeeld zien we ook een demonstratie van het niet van elkat on afhan-

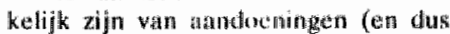
vala a priori kansenj) als king Uat UV en C.V gezamentijk woorkomen, is 15 promcent, terwijl dil bij "onathankelijkheid" slechts 8 procent $20 u$ xin $(40$ procent van 20 procent).

Deze uitweiding aver "multipele" a priori kansen is van loutang. omdat zij aargeeft dat het werkun met én a priori kans op $6 e^{n}$ enkelvoudige ziektetoestand - zoals in de medische beslisk unde valk gebeurt - in feite te eenvoudig is. Een klachtenpatroor of een klinisch beeld lant in het algence on meer dan een diagnostische hypothese toe, en hierop dient men ook terug te komen bij het bepalen van de a posteriori kans (predictie we wararde) op grond wan een testuitslag. Men likan dan voot iedere hypothese apart de a posteriori kans bepalert. Met name in de husiartsensituatic is de probleemruimte nog erg groot en dienen uiteenlopende hypothesen te worden overwogen: 


\section{Verwachle hathisen}

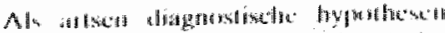

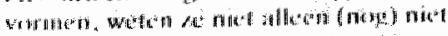

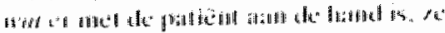

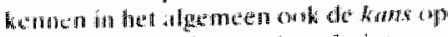

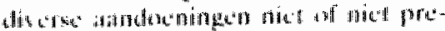

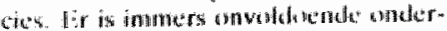

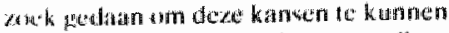

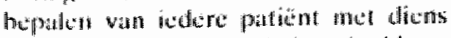

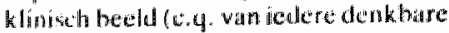
of is y pothetische populdie).

Toh meken artsen zich er weristiclling wa de a priori kans "en zij kunnen

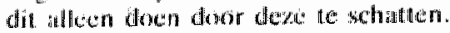

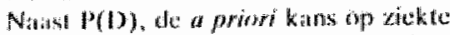

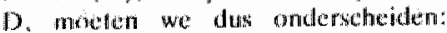

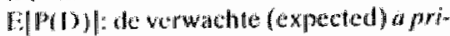

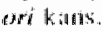

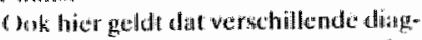
mostistho hypothesen kumera wordan

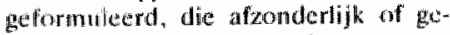
combuacerd hentuen voorkomen. met

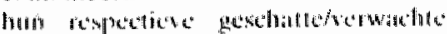

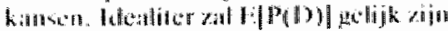

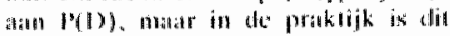

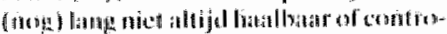

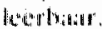

\section{Werkhypothesen}

Fi is can belangrijh wetschil tuskion Whatshijulijklueidsdiagnomen wen werknypoulusen. In watrachijnlijkheidsw dirgentsun kont alleen bet kansiopect nais de onde. In de formulering wath werklupothesen wordt ook een watrdeaspect verwerkt: de consequenties van het atl dan niet stullen van een thepalake diagnosi. I letzaldatrbij woorahganom: - de urnst van de overwogen diagrame (fi):

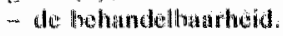

Erratige atandoeningen $z a l$ men net greng willen missen, zeker not als $z$ o goeril to behadelen zijn. Als ze niet zijn

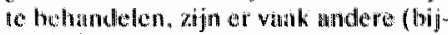
woorbetd sociste) redenen warom het van helong is om ate vast te stallen.

Bij own rokende man vitn 55 jom dis

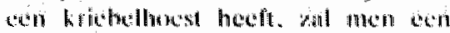

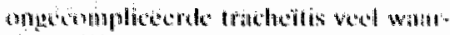

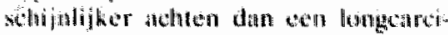

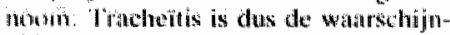
thifherdsdiagnowe. Toch zullen weel atr

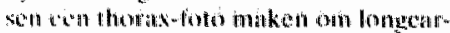

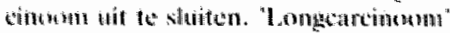

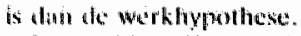

De werk hyponthes is dus de turdrukking vain ten "kinsuspect", en wan ecr "watrille-aspect" (de consequenties be troffond) inf nee precies: eon subjectief geschatro kans E[P(D)| en een subjec-

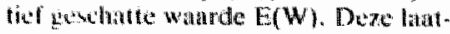
ste in sterk gekleurd dilow de indiriduele withatre, mondall de afweging ombrest de

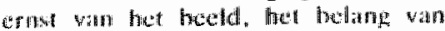

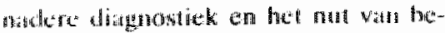

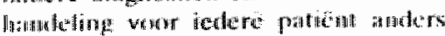

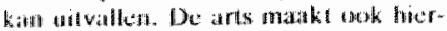
varl bolkurs een beoordeling, in owerlag mot de patient. Het gat ook bier weer om poychologische datawerwerkingsprocessen, die madere hestudering vergetio.

Het light voor de hand dat de vorming wan werkhypothesen afhankelijk is wan de setting waarbinnen men werkt. In hun proefschrift doen Cerritsma en Smal werslag wan han onderavek naur verschillen in werkwije tusion huisartien en internisten. "Wat betreft de vorming van "werkhypothesen" wonden zij dat hinternisten valker werklhypothespen formuleren over ziektebeelden die in de huisartspraktijk weimig woorkomen. Burendien concludecrder zij dat

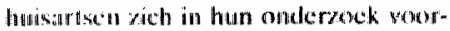

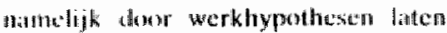
luider terwigl intermisten frequenter getratlik maken van rotatincprocedures. 2owel huisatrtsen als internisten gaven spontata (zonder geheugenstcun) ata $n$ gemiddeld - zes à zeven werkhypoth thser tijdens het consult gehanteerd to hebllyeth.

Een lkanttekening is dat Gerrisma on Smal spreken aver 'werkbypothesen" zonder hierbij anderscheid to maken tusisen het "kansalspect" en 'warde-aspect'. Onlangs konden wij wehter owereenkomstig bevindingen melden met gebruilk wan cen ordening van diagnostische hypothesen alleen malar warkchijnlijkheid. ${ }^{12}$

\section{Brommen woor de schatting van P(D)}

P(D) is mestall onbekend, zeker bij subpopulaties met specificke kennerken en over de a priori kans op in combinatie voorkomende anndoenin. gen is nog minder bekemd. En zelfs at is

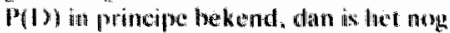
de" vantig in howeverre individuele medici deze kumis op hot juiste moment paraat hobben of snel genoeg kunnen mobiliseren.

Kennis van P(D) - en het bevonderen dat li|P(D)| datarop alansluit $\ldots$ is van wezenlijk helang woor de functic van de huisurts als "porortwachter" van de gezondheidszorg. Bovendien is het kennen van de kansen yan belang, omdat ze uitgangspumat zijn van besliskundige analyses, bijwowrbeeld ten behoeve van protocotorrivikkeling. Datarbij kan het immers nodig zijn om op grond wan de a priomi kans en de sersitiwiteit en de specificite of wan ten test woorspellemde waarden te bepalen. ${ }^{1.3}$

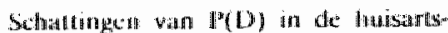
praktik kunnen worden gebaseerd op: 1. Regustruties van klachten, bijwowbeeld mel de Reason For Encounter Chassification ( RFE-C) of de International Classification of Primary Care $(\mathrm{ICPC})^{\text {is- }- \text { If }}$

2. Regwtraties van thet morbiditeitsaldmbod, zoals het Monitoringroject ${ }^{17}$ en de Nijmeegse Continue Morbiditeits Registratie. "Door toepassing wan de MCPC (componenten 1 en 7 ) of een combinatic van RFE-C en ICHPPC-2 kan verder informatic worden verkiregen ower zowel klachten als ged iagnowiseerde dandoeningen. ${ }^{\text {in }}$ at

3. Registratieprojecten ge richt op een beperkik antal aandoeningen. Hertoe hehoren de peilstationprojecten wan NIVEL. Amstcrdam. Den llatag en Rot-

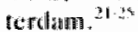

4. Cicrich onderzoek alangainde een

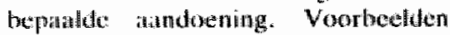
bierwan zijn het IMIR-project (Immneat Myocurdial Infarction Rotterdami) ${ }^{2 n}$ de projecten van de Dombal ower de diagnosilische betekenis wan de "acute buil:" natr het verband tussen onverklaarde mocheidsklachten en thet $\mathrm{Hb}$-gehalte, ${ }^{2}$ en het in Milastricht lopende onderzoek. naar ooraken wan acute diarree in de huisartspraktijk.

De meeste morbiditeitsregistraties zoals bedoeld onder 2 en 3 leveren incidenties en prevalenties op in de totale basispopulatie, inchusicf de gezonden en de niet-spreekuurbezoekers. In dat gevall zijn ze minder geschikt voor schattirngen van a prori kansen in de contactpopula. tie wan de huisarts; en dat geldt zeker woor schattingen van kansen op bastis van bepaaldle klachten an symptomen (P(D|S): de kans op D. gegeven een bepanalde symptomatologie $S$

Cucombine arde registatio van ge presenteds klo kicht(en) en eventuces gestelde diagnosen kan echter wêll de in de praktijk gewenste a prionri kans opleveren. Ciencemom is reeds de koppelling wan de RTE-C: atan de ICHPPC-2. Op dit moment wordt in Matstricht het Registratienet Huisartsemprakujkent ontwikkeld. Door middel van gelijktijdige registratie van subjectieve gegevens en diagnose (met diagnostische criteria) zal ook hier een schatting van P(DIS) bereikbaar zijn. "Ook onder. zoek zoals onder 4 vermeld kan eem schatting van $\mathrm{P}(\mathrm{D} \mid \mathrm{S})$ opleveren. 


\section{Beperkingem}

Dij thet gebruiken wan registratiesystemen als gegevensbron voor de kansen P(D) en P(D/S) bij mensen die de husarts bezoken, doen zich de volgende problemen won:

- Sluitemde, in de tija consistente en generaliseerbare atspraken over de crileria die aangehouden dienen te worden woor het registreren van hepaalde klachton en andoeningen, zijh niet altijd gemak dan well in do praktijk - op controleerbart wijze - na te leven.

- Routinematige - dat wil zeggen voor. af wet op een bepalde vratastelling gerichte - registratie is gebonden aan zodanige praktische beperkingen (uitgebreidheid, buwerkelijkheid, tijd), dat woor de medicus practicus relevante detailleringen van klachten niet of nawwelijks kumen worden a angebracht. $Z$ o wordt in de ICPC wel gesproken over "pain attributed to heart" maar of deze uitstraalt, en zo ja, bij welke gelegenheid en hoe lang ze optreedt, of ze reageert op nitrobaat, dat is niet aan te geven in het kader var dat systeem.

- Hel is wak niet te vermijden dat een probleem onder meer dan ed code geregistreerd zou kumnen worden. en dat een subjectieve keure gemaakt wordt door de arts. Zo is duidelijk dat men sommige klachten van vrouwen zowel onder 'nerveus-functioneel' als onder 'climacterieel' zou kunnen onderbrengen. Dit kan leiden tot onderschatting van het woorkomen wan een bepaalde klacht of klachtengroep.

- Daarnaast kont het voor dat bepaalde kllachten die men geisoleerd zou willen beschouwen, tezamen met andere onder een code worden geplaatst. Zo Worden in de ICPC menorragie en polymenorroe, toch duidelijk verschillende entiteiten, beide onder code $\mathrm{X} 03$ geregi. streerd.

- Registratie geschiedt valak door de onderzoekende (en waarnemende) arts zelf, en we kunnen dan, mede gezien de waak slechts global te maken afspra ken, te maken krijgen mell een aanzientijke inter-en intra-obserwervariarie: als men dezelfde patiènt door meer artser zou laten "scoren" zouden verschillende coderingen kunnen worden gekozen. Een tweede probleem is de detectiebias: men stelt al dan niet een indicatie voor diagnostisch onderzoek en sommige artsen zullen een bepaalde aamdoening eerler opsporen en dus "scoren" dan andere. Bovendien kan (de kennis over) het well respectievelijk niet aamwezig zijm vam een bepaalde klacht leiden tot exn wershillende interwiteit van de diagnostiek gericht op bepaalde aandoeningen, zodat de resulterende informatie over her verband tussen klacht en diagnose vertekend kan zijn. Deze detectiebias zall sterker dreigen, naarmate de kans op geheel of gedeeltelijk sublk linisch werloop van een ziekte groter is. Een voorbeeld kan zijn de opsporing van ritmestoornissen.

\section{Uitdagingen}

Di genoemde problemen vormen evenzovele uitdagingen aar de onderzoekers die bij registratiesystemen be. trokken zijn, om hiervoor oplossingen te zoeken. Zo wordt ar op dit moment op verschillende platatsen in ons land atan gewerkl om diagnostische criteria af te spreken en toe te passen. Speciale studies zijn echter nodig wanneer thet on klachten gat met veel rellevante subdetailleringen (naar aard, lokalisatie begeleidende verschijnselen, voorgeschiedenis en beloop) en on diat gnosen die niet zonder meer op grond vart eenmalig af te spreken, eenduidige en door de huisarts eenvoudig toe te passen criteria te stellen zijn. Dit zal bijwoorbeeld gelden voor beantwoording van de vraag in hoeverre bepaalde pijnklachten indicatief zijn voor het bestaan van asteoporose. Zulke speciale studies dienen te bevatten:

- gedetailleerde afsprakem met betrekking tot de definiëring en precisering van de kacht(en);

- een gestandaardiseerd diagnostisch envof follow-up protocol ter opsporing wan de eventueel atamezige reflevante atandoeningen.

De IMIR-studie, gericht op de dia gnostiek wan her hartinfarct is een goed woorbeeld van eer ondurzoek warin an deze vereisten veel aandacht is besteed. ${ }^{\text {th }}$

What nadeel dat ten aanzien van een onderzoek gericht op én of enkele klachten en/of diagnosen dikwijls wordt. genoemd, is dat bij een "beperkte registratie. de arts te weinig registraticroutine zou krijgen. Hierdoor zou de arts te midden wan de dagelijkse drukte kumnen vergeten patiënten te selecteren voor de studie. Anderzijds zou door concentratie op cen beperkt artal itens ook te veel atandacht naar deze items kunnen uitgaan, met als gevolg overdetectie en overschatting van hun voorkomen.

Juist bij een beperkte opzet kunmen deze bezwaren worden ondervangen door gerichte afspraken en een goede controle hierop.
Welke asmpak op wolk moment het meest geschikt en het meest officis hangt af van het onderwerp en de praktische mogelljkheden. Ragistratie kan affoendie zinn als het gatat on vooraf goed gedefiriende klachten an andoe ningen die wrijwel allijd in korte tijk mamifest worden ien ondubbelzimnnig. zijn wast te stellen. Meor gericht onderzoek is in olk geval wenselijk als het klinisch van belang is meer te weten te komen over de kans op anwezigheid van zitktus, die nued gevarieend en over een lingere puriude werlopen en warvan de diagnostick gepand gat met sterke observerwariatie.

' Van Es JC. Patient cn hưsarts. Een leerboek huisartsenceskende. Utreebt: Oosthoek, Schellema Holkema 1974.

${ }^{2}$ Krottnerus $\mathrm{JA}$, Knipsehild PG, Sturmans F. Symptomarologie en selecticbias. Huis: urts en Wetenschap 1\%85; $28: 325 \% 30$.

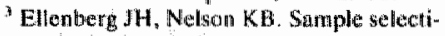
on and the natural history of disteases: studieg of febrile seizures. JAMA 1980; 243: $1337-40$.

- Folmer HR. Huistarts en ijsberg IDisserta" tie]. Utrecht: Rijksumiwersiteit Utrecht, 1968.

"Huygen FJA, Van der lloogen $H$, Neefs WI. Gezondheid en zickle wer onderzoek van gezinnen. Ned Tijdsehr Genecskd $198 \%: 127: 1612-9$

-Van Es JC. Pijlmáa MR. Het verwijzen van ziekenfondspationten in 122 Nederlandse huisartspraklijken. Huisarts $\mathrm{en}$ Wetenschap 1970;13:4,33-49.

- De Dombal FT. Transporting databanks of medical information from one location to another. Effective llealth Care 1983;1: 155-62.

"Elsteir AS shulman IS. Sprafkas SA. Mc. dical problen solving An analysis of ctinicall reasoning Carnbridge (Ma.): Harvurd University Press, 1979.

"Weinstein MC, Findterig HV. Clinicall de. cision analysis "Phitadelphine: Saiunders, 1980.

${ }^{13}$ Knotinerus JA Sturmitins F, Hetl belang van de niet-allwijkende hewinding voor de differentièle disgnosaliuth. Practitioner 1984: 1: 147-51.

"Gerritsma JOM, Smal JA. De werkwijze van huisarts en internist. Een wergeligkend anderzoek met behulp wan sen internction ve patientensimulation Litreshut Bunge. 1982.

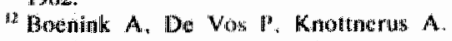
Mencheid: wepschillen tussen huirartsen en intervisten. Med Condact 19k6; 47: 54-7.

18 Knottnerus JA. Princijegs vatn besliskunde. Nieuw kompas woor de huisarts, julli 1984 . $11-4-11-15$.

" Lamberts H. Redenen owa natar de huisarts te gaan. Eerste enwaringen met de Reason for Encounter Clatsification. Huilsarts en Wetenschap 1982; $25: 301-10 \%$

15 Anonymous. Reason For Encounter Clas- 


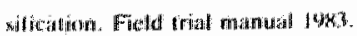

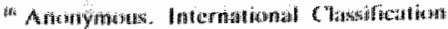

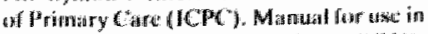

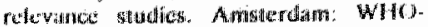
werking forty wh the $\| C P C, 1985$.

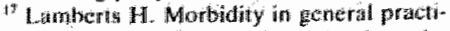

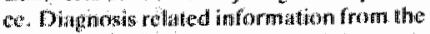

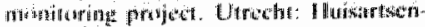
10. $16 \times 4$.

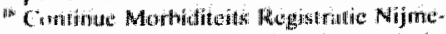

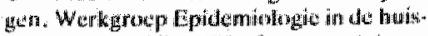

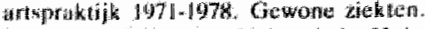

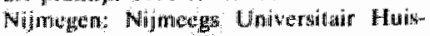
aritent Itwituvit., 1980 .

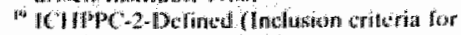
the the of athe rohrick of the Internationat

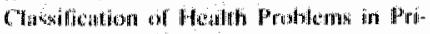
mary (are). Oxford: Oxford Unuversity Potsin, 1983.

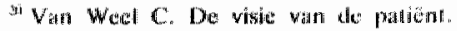

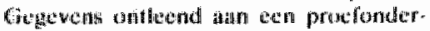

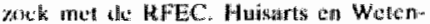

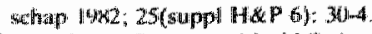

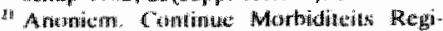

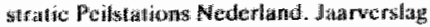
[9x3. Utrecht: Mederlands Fuisartsen inm

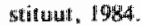

2 Colletre HM, Bijerk H. Viffiten jara poilstations tivederland 1970-1044. Huis arts con Wetcenschap 1985 28: 207-10.

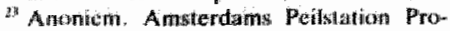
fcet. Jaturverslag 1983. Amsterdam: $\mathrm{GC}$ \& (5D. 1044 .

24 Husartscegstratiesysteom Den Hawg

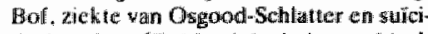
dajal gedrag [Epidemiologische nowities] Huiserts con Wetenschap 1985; $28: 276-8$.

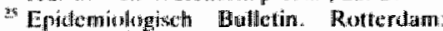

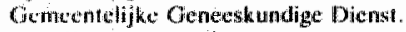

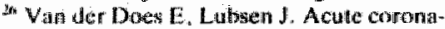
ry awents in general practice. The imminent myocardial infarction Rotterdam study. HDissertitution. Rotterdam: Erasmas Uaiversitcin Rotherdam: 1978.
2 De Dombal FT. Acute abdominat pain. An OMCE murvey. Scand J Gastrocrteral 1979: $14:(\operatorname{supp} 456): 29-43$.

${ }^{2}$ De Dombat FT, Leaper Di, Horrocks $1 C^{*}$ Staniland JR. MeCann AP. Human and compute-aided diagnosis of abdominal pain: lurther reporit with emphasis on performance of clinicians. for wed $\mathrm{J} 1974$;: 37 tho- 40 .

gi notmerus JA, Knipsothind PC, Wan Wersith IWJ. Sijgtermannis AH. Oniver klasarde moeheidsklachten en hemoglohimegeltalte, cen onderzok vanul de husartspraktijk. Ned Tijdsch Genewskd $1986 ;$; 30 - 402-5.

"Van der Hors $F$, Seelen $A$, Visiers F: Plagge H. Van Höfen $\mathbb{R}_{*}$ De Ceasi $C_{\text {. }}$ Kletjen $J$. Rugistratie in de thusisartspraktijk. Over dk betrouwbarartheid, praktiscite hanterbatheid en adequatheud van het RFE-classificatiesysteem: Huisarts en Wetenschap 1985; 28: 229-34.

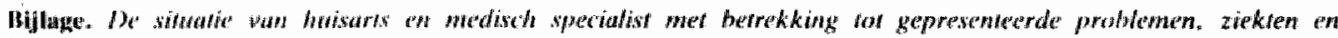

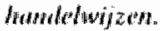

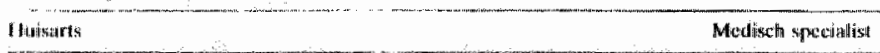

\section{Khathorohleem}

groute probleemruimute

breed scala van problement

somatische, psychische problemen

valkik verschillende problemen per contact

\section{Morbiditeit}

vecl selflimiting diswases

ret minor ailments

vonege stadiat van zicklo

weinig ontwikkelde atypische symptomen

niklaticf weinig ernstige ziekten

vatk niet meer dan symptoon- of klachi-diagnose

\section{Werkwijet}

Wiatik expectittich

problex myicondidnted

tinedische gegevens beperkt tuschikbar

omgatan met onzekerhsid, werken met

wharschijninktheden

\section{Tow trunenten}

kcnnis op athemeem niveat

continue zorg

afwacluten

weinig technologie

weel kemuis ower persoon en soctile omgeving

owerzicht over geticle situatie wan de patient kleine probleemruimte

probleem beperkt tot én discipline, voorgeselecteerd primair somatische problemen

meestal tén probleem per contact

weinig selfimiting diseases

weing minor ailmeints

latere stadia

ontwikkeldle, valk typische symptomen

veel ernstige ziekten

meestal diagnose van ziektebeeld

vaakk snelle diagnostiek

diagnose-georiènteerd

wolledigheid wan medische gegevens wordt nagestreefd weinig onzekerheid, streven naar definitief antwoord

somatische kennis op specialistisch niveau

discontinue zorg

snelle diagnostick

veel technologie

weing kennis over persoon en omgeving

geen overzicht over geheel 


\section{Moeheid: verschillen in benadering tussen huisartsen en internisten}

Tussen de werksituatie van huisartsen en Mternisten bestaan veel verschillen. Een huisarts zall waker patienten zien bijj wie de symplomen (nog) niet duidelijk zijm ontwikkeld. Psychosocialle factoren zullen waker meespelen bij de klacht wan een patiënt. De onderzoekfaciliteiten die een huisarts heeft zullen het miet ailtijd mogelijk maken een specifieke diagnose te glellen en ook zall het stellen van zo'n specifreke diagnose miet alt ijd nodig zijn voor het instellen wan een therapie. De imernist daarentegen ziet patiênten meestal in een later stadium van een zielkte, waarbij de symptomen duidelijker aanwezig kunnen zijn. Hij wordt geconsulteerd vanuit de gedachte, bij pahiènt en verwijzend arts, dat de klachten een organische oorzaak hebber, wasibij het er ook om gaal zeldzame ziekten zoseel mogelijk uit te sluiten. De laboratoriumfaciliteiten van een ziekenhuis bieden daantoe ook veel meer de mogelijkheid.

Gerritsma en Smal veronderstelden dat er onder meer door deze verschillen in wertksituatie ook werschillen in werkwijze ontstaan'. Dit zijn zij door middel van een onderzoek nagegaan. Mogelijk door bovenstaande beschrijving verklaarbaar, is hun bevinding dat internisten bij eenzellde casus vaker da.n huisartsen zeldza. me ziektes onder hun werkhypotheses hadden. Met betrekking tot deze zeldzame ziektebeelden zaten er bij de huisansen waker watkhypotheses over psychosocialle oorzakem. Eistein had al eerder anangetoond dal de eerste probleemformuleringen al vroeg in het contact met de patient ontstaan, soms zelfs al voordat de patient iets heeft gezegd ${ }^{2}$. Gerritsma en Simal hebben ook geanalyseend hoe de werk hypotheses samenhangen met de door artsen gevragade informatie. Zij herkenden drie patronen: de cascade (bij de uitwerking van een werkhypothese komt een nieuwe werkhypothese op, die meteen word getoetst; hiendoor wordt het oude spoor verlaten), de successieve methode (een werkhypothese wordt pas wingediept als de toet sing van de voruge üs afgerond) en de screening (in eerste instantie worden volgens een vast patroon gegevens verzameld, helgeen niet wordt beinvloed door de werkhypothese).

In het kader van het onderwijs an studenten van de Faculteit der Geneeskun-

\section{Annette Boenink, Paulde Vos André Knottnerus}

Verschillen in werksitwatie tussen huisartsen en internisten gaan gepaard met verschillen in werkwijze; dat is uir onderzoek gebleken. Annet te Boenirk, Paul de Vos en André Knottnerus, studeni-assistenten geneeskunde respectievelik arts, we lenschappelijk medewerker capaciteitsgroep EpidemiologielGezondheidszorgonderzoek aan de RU LIMburg, stelden een nader onderzoek in natr de wijze warop huisartsen en internisten omgaan met de Klacht "moeheid" "De huisartsen bleken meer aan een psychosociale oorzaak te denken, de gedachten van de internisten gingen waker in de richting van (ernstige) somatische pathologie. Internisten zouden door de bank genomen meer onderzoek verrichten dan hursartsen. Overigens was binnen beide groepen de onderlinge overeenstemming niet erg groot.

de van de Rijksuniversiteit Limburg hebben wij een klein onderzoek verricht naar de manier waarop huisartsen en internisten omgaan met het probleem "moveheid": aan welke diagnose(groepen) denken zij en wat is hun beleid in eerste aanleg? Zijn hierin verschillen te ontdekken tussen huisartsen en interuisten? Met dït onderzoek wilden wij kijken of de trends die Gerritsma en Smal hebben gevonden ook kunnen worden bevestigd bij een casus over de klacht 'moeheid'.

\section{WERKWIJZE}

Wij hebben een casus met betrekking tot de klacht "moeheid" toegestuurd aan een aantal $Z$ uidlimburgse huisartsen, internisten en arts-assistenten Interne $\mathrm{Ge}$ neeskunde wan het ziekenhuis St. Annadal (hiena te samen aangeduid als: internisten) zonder dot zij wisten dat zij met elkar zouden wordern vergeleken. De casus was zodanig opgesteld dat er allerlei mogelijke oorzaken atan ten grondslag zouden kunnen liggen, van psychische problematiek tot een maligniteit:

Cancins

Meviouw Theunissen. 95 jaar, verthuisde drie jaar geleden wan Roermond nar hior, omda has man een nieuwe baan kreeg bij en plaatselijke bank. Deze baan vizugt nogal veell wan hem. Ze hebben drie kinderen. van wie de jonigste nog thuis woont.

Mevrouw Theunissen komt niet vaak bij de huisants: de lautste keer was enen jatar geleden voor griep. Ze zegt dat ze sillijd goed gezond is geweest, inaar sinds cen pitar maknden voelt zo zith zo versehrikkelijk moe. Het huishouden walt hamer steeds zwasarder. Iti de loop wan de middag is ze zo moe dat ze een half unritje moet gaan zituen. $Z$ e heeft nerge ns meer energie voor. Haar man wond ook dat ze zich maar eens goed moest llaten nakijken, want dit was toch niet normal. Mew rouw vertelt werber in het gesprek dat haar laatsie menstruatie anderhalf jaar geleden was en dat ze de laatste paar maanden een killo is affevallen.

Wij hebben met betrekking tot deze casus twee open vragen gesteld:

1. Aan welke diagnose(groepen) en problemen denkt u (in volgonde wan waatschijnlijkheid)?

2. Wat is in eerste aanleg uw beleid met betrekking tot de diagnostiek ${ }^{\text {dr }}$ ?

Aan de artsen werd verzocht hun antwoorden atan ons lerug le sturen.

Van de 30 benaderde interaisten en arts. assistenten Interne Geneeskunde gaven er 14 gehoor a an ons verzoek ; van de 27 angeschreven huisurtsen reageenden er 19. De antwoonden die zij gaven zijndoor ons in bepaalde categoriedn ingedeeld.

\section{RESULTATEN}

De huisartsen bleken in thet algemeen wat beter overweg te kumnen miel een dergelijk vaag probleem. Wan de 14 intern istem gaven er 2 te kennen dat zij zo weinig gegevens hadiengelkregen dalt ze er nallwelijks iets zimnigs over konden zeggen; 2 andere internisten hebben wel een lijst met diagnosegroepen en problemen gegeven, maar konden niets zeggen over thun bele det betrekking tot diagnos- 
tiek zondw ananullende gegevenis ower ariamnese en lichamelifk onderzoek.

\section{Wharerking wroge !}

Op whatg I werden door de huisartsuen gemiddeld 4,8. diagrosegroepen gerioemd (atandarddeviatie 1.5 ) en door de internisten gemiddeld 5.6 (standáardde viatic 1,6).

Bij de uitwerking val vrabg 1 ( zie $\left./ n b_{k} / I\right)$ is een onderwertleling gemakt in groepen andoeningen; hoe deze grospen preciles zijm samengesteld is te vinden in bujage I. In kolom I van label 1 is vermeld het lotaw aantal keren dat een asandoening wit een bepatde grow werd genoemd door de hujisartsen respectievelijk internisten die deze vraag thebben beantwoord Hierbij is het mogelijk dat een bepailde arts meer aandoeningen uil dezelfde groep noemt (zo kunnen er in eén categorie meer diagnoses zijn genoend dan er artsen zijn). De tweede kollom vermeldt het aantal keren dat een atamdoening uit een be paalde groep als eerste op de lijst van een arts werd genoemd door alc huistrisen respeci hevelijk de inurisnisten.

Kolom 3 geeft een indicalic van het relat tieve gewicht dat an de verschillende groepen wan aandoeningen werd toegekend binnen de huisartsen- respectievetijk finternistengroep. Deze indlicatie hwam tot stand door een bepallde diagnosergroepl/probleem $R$ punten te ge. ven wanneer deze diagnone als eerste werd genoemd. 7 punten als ze op de tivecte plants stond enz. Vervolgens word per dianonegroep het door alle huistartsen respectievelik internisten gegeven anntal punten opgetleld en dararna berekend als peroentage vam het total anntall panticon.

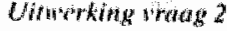

Ook bij de uilwerking van vratag 2 (zic labe/ 2) zijn de ant woonden in bepatalde cattegorie in ingedectd (zic voor de exacle indeling bulage 2).

De huisartsen deden gemiddeld onderzoek op 3,0 gebiedem (standaarddeviatie 1.91 , de internisten op 4.5 gebieden (standrandeviatio 1,5 ). Veel van de ondervruagde artsen (8 internisten en 13 huilsartsent hebben met zoveel woorden gesteld dat er eerst een goede anamnese en een goed lichamelijk onderzoek dient pluals te vinden; dit is verder nieit als zodanig in de tabel opgenomen.

Een aantal artsen (8 van de 12 internisten en: 5 van de 19 huisartsen heeft op eigen

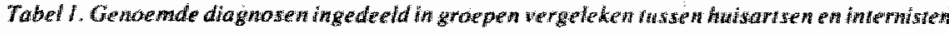

\begin{tabular}{|c|c|c|c|c|c|c|}
\hline & \multicolumn{2}{|c|}{ 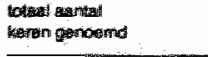 } & \multicolumn{2}{|c|}{ 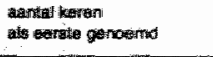 } & \multicolumn{2}{|c|}{ 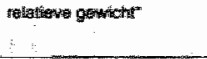 } \\
\hline & 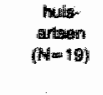 & 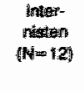 & 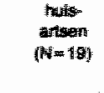 & 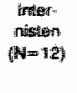 & 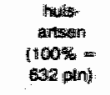 & 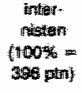 \\
\hline 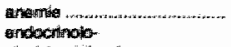 & 16 & 30 & 4 & 6t & $15 \%$ & 2 橉 \\
\hline 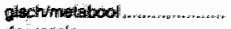 & $12:$ & 11 & a & a & $12 \%$ & $14 \%$ \\
\hline 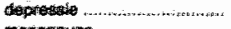 & 18: & 6 & : & 3 & $10 \%$ & $11 \%$ \\
\hline menopiaure & 4 & $y$ & 2. & 1 & 5 & $2 \%$ \\
\hline 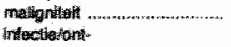 & 9 & 11 & 0 & 1 & 由㬗 & 170 \\
\hline 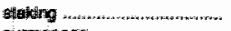 & 5 & 7 & 0 & Q & $15 \%$ & $\%$ \\
\hline 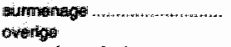 & 5 & 1 & a & a & 5\% & $2 \%$ \\
\hline 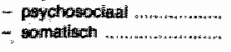 & $\begin{aligned} 6 \\
49\end{aligned}$ & $\begin{array}{c}5 \\
15\end{array}$ & $\begin{array}{l}3 \\
1\end{array}$ & $\begin{array}{l}1 \\
0\end{array}$ & $\begin{array}{r}7 \% \\
24 \%\end{array}$ & $\frac{1 \%}{17 \%}$ \\
\hline 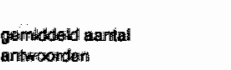 & & & & & $100 \%$ & $100 \%$ \\
\hline 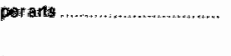 & $\begin{array}{c}4,8 \\
(501,6)\end{array}$ & $\begin{array}{c}5,6 \\
(\mathrm{SD} 1,6)\end{array}$ & & & & \\
\hline 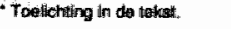 & SO $=$ stannd & Idievialie & & & & \\
\hline
\end{tabular}

initiatief een onderscheid aangebracht tussen wat zij in eerste en in tweede instantie zouden doun. Aangezien de vrangstelling uilging van thet beleid in eerste anteg. is dat wat men zei in tweedo instantic te zullen doen niet meegeteld buj de uitwerking van deze vraag. Onderuan de tabel is aangegeven welk percenlage van de huisartisen onderzoek wil

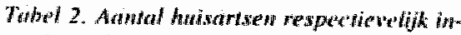

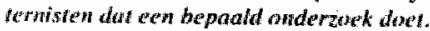

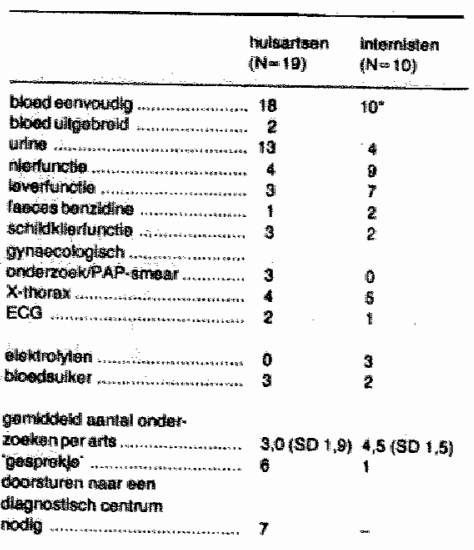

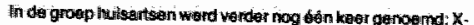

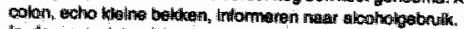

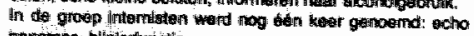

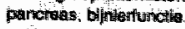

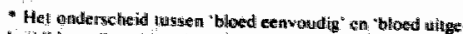

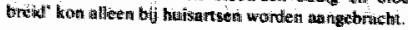

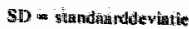

doen warvoor het doorsturen van de patiênt naar een diagnostisch centrum noodzakelijk is.

\section{Discussif:}

Gezien het betrekkelijk geringe antal artsen in ons onderzoek vonden wil het niel zinvol statistische toetsen toe te pissen. Wij richen ons in de nu volgende bespreking op de algernenc trends dic unit het materiatsl natr voren komen.

We kunnen miet uitsluiken dat de geringere respons wan de internisten onze resultaten heef bein wloed. Gezien het feit dat men tevoren niet op de hoogte was van de voorgenomen vergelijking lussen huisartsen en internisten, is het ecthier niet aanne melijk dat de ze invloed sterk is geweest.

De verwachte verschillen in hypothesevorming en beledd ussen huisartsen en internisten tijn inderdaxd gevonden en komen globaal overeen mell wat Gorritsma en Smal hebben gewondien.

Wat de hypothesevorming betneft: hoewel vrijwel alle artisen rowel aan somatische als atan psychosociale oorzaken voor de in de casus geschetste moeheid dachten, zijin er in de volgorde die zij hebben aangebracht duidelijke verschilllen te zien. Internisten zetten waker somatische ziektebeelden op de cerste plats (anemie en maligniteit), de gedachten van de huisartsen gaan eerder in de richting van een depressief beeld. In totaal noemden 7 van de 12 interinisten 
(58\%) een somalische oorzak. tegen 7 wan de 19 huisartsen $(37 \%)$. V rijwel alle intermisten noemen ergens op hun lijst ten maligniteit, tegenover ongeveer de hetit van de huisartsen. Bij "depressie" liggen deze cifers preciles omgekeerd. Internister denken ook wel bijna altijd an een psychosociale oorzaak, maar zij zerien deze lager op hun lijsit en zij doen dat in minder specifieke bewoordingen dan de huisanten. Huisartsen denken vaker aan verschillende vormen van psychosociale problematiek, terwijl intervister deze vaker alle onder één noemer brengen. Een voor de hand liggende verklaring voor deze verschillen op het niveau van de groep is dall de prevalentie van de verschillende oorzaken van moeheid in de interne praktijk anders is dan in de huisartspraktijk.

Hoewel we inderdaad verschillen op groepsniveau hebben gevonden, is ons ook gebleken dat er binnen beide groepem, huisartsen en internisten, maar weïnig overeenstemming bestaal. Die overeensitemming is namelijk kleiner dan de tabel suggereert, aangezien bujvoorbeeld in de groep "endocrinologisch/metabool" zowel de artsen zijn opgenomen die dia. betes mellitus hebben genoemd als degenen die bijvoorbeeld aan hypothyreoìde of bijmierinsufficiëntie dachten. Dit gebrek an onderlinge overeenstemming kan moeilijk worden verklaard uit de verschillen in prevalentic van de diverse oorzaken van moeheid tusser de ene thuisartspraktijk/interne praktijk en de andere. Een verklaring zou kunnen zijn dat. hoewel we natr de volgonde van wasaschijulitkheid heboen gevraagd. sommige tartsen belalve de prewalentic ook de door hen ingeschatte ernst van de mogelijke andoeningen en de noodzaak entof het nut van behandelling ervan een rol hebben latem spelen bij het opstellen van een hypothesemlijsi, daarbij zouden individuele ervaringen van artsen met bepalalde ziekten een rol kunnen spelen.

Naan aanleiding hiervar wijzen wij op het verschill tussen (ons) onderzoek warin naar volgorde wan waarschijnlijkheid wordi gewraagd en ander onderzoek (Gierritsma en Smal) waarin de werkhypothese centraal staat: bij een werkhypothese $z$ zijn ook factoren als de ernst van en andoening betrokken

Wat het beleid betreft valt op dat het "bueleid in eerste aanleg" vooral screenend van aard is: vrijwel alle huisartsen doen bloedonderzoek en de meesten ook urinteonderzoek, de interristen doen een volledig bloedonderzoek en bepalen meestal bovendien de nier- en leverfuncties. Na deze routineonderzoeken volgt nog een lange lijst met meer specifieke onderzoeken die alle slechts doorenkele artsen worden gedaan. Het was met onze werkwijze niet mogelijk een patroon the herkenmen in de werkw ÿze van de artsen (screening, cascade of successieve methode).

Zowel bij de huisartsen als bij de intermisten is de onderlinge overeenstemming ook hier ver te zoeken. Over de helle linie lijken de internisten wel wat meer onderzoek te doen dan de huisartsen; dit werschil is vooral duidelijk bij het klinischchemisch onderzoek (nier-en levertiuncties en elektrolyten). Dit ligt ook wel voor de hand, aangezien internisten over meer faciliteiten beschikken. Bovendien nemen huisartsen en internisten werschillende posities in binnem de gezondheids. zorg: de huisarts velzorgt de eerste opvamg, wanneer het probleem nog erg ongedifferentieerd is; de specialist echter krijgt meer voorgeselecteerde problemen, warbij wam hem of haar een eindoordieel wordt verwacht. Het is gezien onze resultaten aannemelijk dat deze factoren ook bij de beoordeling van een zelfde casus vam invloed zijn.

Tenslotte willen wij nog even stilstalan bij het feit dat tweederde van zowel de huisartsen alls de internisten die wij hebben ondervraagd, heeft aangegeven eerst een goede, uitgebreide anamnese en dito $\|^{i}$ chamelijk onderzoek te willen uitvoeren. Deze - terechte - opmerking geeft de beperkingen aan van dit onderzoek, namelijk dat de artsen gedwongen werden hypotheses en bele id te formuleren op grond van vrij summicre gegevens. Dit is een wat onnattuurlijke situatie, atangezien de artsen in hun praktijk uiteraard wel de mogelijkheid hebben via anammese en lichamelijk onderzoek meer gegevens te verkrijgen. Waar dit met betrekking tot het beleid een vertekening kan inhouden. is deze manier van gegevens verzamelen waar het de eerste gedachten orntrent diagnose(groepen) betreft misschien directer van aard dan de werkwijze die Gerrilsma en Smal bij hun onderzoek hebben gevolgd" zij vroegen pas na de volledige afhandeling van een gehele cal sus nar de werkhy potheses die de artsen vanaf het begin hadden gevormd.

Kijken we naar andere ondenzoelken en andere literaturur ower moeheid, dan is de door ons gevonden diversiteit in denken en voorgenomem handelen niet $z o$ ver" wonderlijk. Zolang er geen andere en concretere aanwijzingen woor pathologie ziju, lijkt moeheid en moeilijk oplosbaar probleem te zijn. In terning van hel begrippenkader van het probleenoplossen kan worden gezegd dat moehe id een grote probleemruimte heeft. Het gedeelte over moeheid in Harrisons "Principles of Internal Medicine' bied weinig concrete handwaten en lijkt sterk gekleurd dool de interesses van de auteur van dat hoofdstuk ${ }^{3}$. De Haan en Mleys merken in de irleiding van hun boek over moebeid op dat het gaat om een onmogelijk te omschrijwen begrip en dat zij daandoor noodgedwongen neer zullem spreken over alles rondom het moeheidsonobleem dian ower het begrip "moeheid" zelf; zij kumnen met de doon" hun voorgestelde benadering vatn de klacht alleen een aantal richtingen (in de zin van emstig-niet ernstig of psychisch-somatischfysiologisch) aange ven en zo de arts enige steun bieden bij het gericht zoeken naar een precieze diagnose".

In het eerste contact wordt wolgens Katermdahl in $15 \%-35 \%$ van de gevallen met anamnese ein lichaneliyk onderzoek geen onderliggende oorzak gevonden". In een tweetal onderzoeken heeft men zich speciaal gericht op de groep patienten met moeheid bij wie de oorzaak atnvankelijk onopgeheldend blijft 5 ; hienuit blijkt dat dit vaak leidt tot het doen van zeer veel onderzoek warvan de zin niet altijd aangetoond is. ln ons onderzoek zijin wij alleen beschrijvend te werk gegaan: wij hebben ruiet de effectiviteit vam het door de artsem woorgestane beleid gemeten.

Wij hopen dat dit onderzoek een bijdrage kan leveren aan de verheldering wan de diverse benaderingen wan hei probleem "moeheid" in de verschillende echelons van de gezond heid szorg.

Met damk aan de interistun, arrismassistenten Interne Geneeskunde wan thet ziekemhuis Sr. Annodal in de Zuidlimburgse huisartsien die an dis onderzoek hebben meegedaan. 


\section{Liteinalygus}

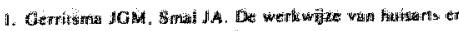

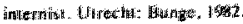

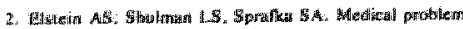

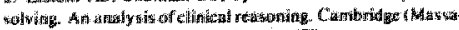

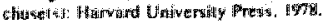

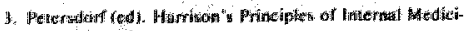

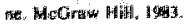

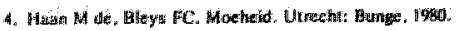

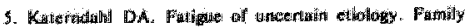

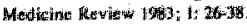

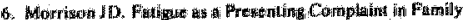

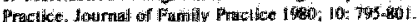

\section{Bijlage I}

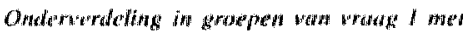

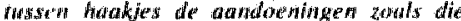
door de artsen zilin opgescheven en door ons in de desterefreffende groep andergebrach"

- anemie: bloedanoede, gastromenteraal blowdverties, fhematologische affi ijk ingen

- endocrinologisch/mitabool: diabetes me! litus, hypertlyyreoldie, hypothyreoüdie. bijnierinsufficientie, Addison, metaboled endocriene pathologie

- depressie: midlife-depressie, neactiewe de pressile, involuticdepressite, climacterium depressie, depresisie door verhwizing. posimenopauze depressie

- menopauze, met titzondering van depressíe (hornonale overgang)

- maligniteil $\mathrm{Ca}$ maligniteit (pancreas?) kanker, malligniteil tractis digestivus, mam (igniteit ovariae)

- infectielontsteking: chronische infectic chronische ontsteking, colitus ullcerosa Crohn, chronische hepatitis, uninewegin- fectie, infectieuze aandoening, prodromen hepatitis

- surmenage: owerbelasting, overspannenheid

- overige psychosocial: anpassingsproblemen, psychosomatiseh, alcoholisme, niet-somatisch, peychisch, gezinsctisils, functioncle moebeid, functioneel syndinom

-- overige somatisch: sarcoidose auto-immuunziekte, elektrolytenstoornis, cardial nierfunctiestoornis, nierinsufficiëntie, systeemalandoening, hypertensie, statische afwijkingen, intoxicaties, neurologische afwilkingen, collageenziekte, pulmonial proces ${ }_{\text {. }}$ hypotensie, Kahler, uremite, diecompensatio condis (zie cardiaal). myoom, colonaf wijkingen

Bijlage 2

Onderwerdeling antwoorden wraag 2

1. bloedonderzoek

a., eenvoudig $\mathrm{Hb}$, BSE diff. (door huisarts te doen)

b. uitgebreid = lenminste een wan de volgende: ery" $s$. Fe, reticulo"s

2. urine (glucose, eiw it, red, , sediment, uricultt)

3. nierfunctie (creatinine ureum)

4. leverfuncties (AFP, GTP, SGOT, GT, cholesterol)

5. faeces benzidine (accult-test)

6. schildklier (T4)

7. gynaecologisch onderzoek (PAP-smear)

8. X-thorax

9. ECG

10. 'gesprekje' (slaapstoornissen, gezinsgesprek, echtpargesprek, psychisch uitdiepen)

11. ellektrollyten

12. bloedsuiker 


\section{Intercollegiale vergelijking}

\section{Oefenen met huisartsen in opleiding}

Een veelhelovend toepassingsgebied wan de medische besliskunde is de intercollegiale toetsing. Echter, bij het ontbreken van criteria kiun in leite niet van toetsing worden gesproken. Een goede werkwijze is dan de intercollegiale wergelijking: thet uitwisselen en bespreken van elkaars üzzichten. werkwijzen en beleidsopties. Als belangrijkste leermomenten zijn in. dit werband te onderscheiden:

1. het werkrijger van inzicht in verschillen van beoordeling bij medische probleemstellingen:

2. het kunnen localiseren van die verschillen binmen het geheel var het beleid,

3. het nagaan van de consequenties vam de verschillen voor het verloop van de hulpverteming;

4. het identificeren van de stappen die moeten worden genomen om tot de formulering wan een optimale strategie te kunnen komen.

Intercollegiale vergelijking is een belangrijk bestanddeel wan het leerproces van huisartsen in opleiding. In het volgende praktijkwoorbes.ld word aan de hand van erwaringen in een bijeenkomst van een groep Maastrichtse thuisartsen in opleiding geillustreerd dat bi zo'n uitwisseling een besliskundig kader als kapsitok kan famgeren. Het ging daarbij voorall om de eerste twee wan de zojuist genoende leermomenten.

\section{MWERR WDZE}

Men is er vanuait gegaan dat thet rendement wan een leer- of uitwisselingssit whthe het grootst is als de deelnemers eígen casuistiek inbrengen en zelf de leerstof (me) ontwhkelen ${ }^{1-2}$.

Naar aanleiding van een rede casus, die behalve aan de inbrenger alan geen van de andere deelnemers te voren bekend is, komen de volgende aspecten aan de orde:

1. Het schatten van de warschijnlijkheid van diverse diagnosem of diagnosecategorieèn (de a priori-kansen);

\section{J. A. Knottnerus \\ Dr. H. K. Muller}

Huisartsen in opleiding kunnen al in én les, aan de hand wan ến enkele casus, kennis maken met de belang. rijkste aspecter wan de medische besluitworming; waaronder het optreden wan verschilen in beoordeling van kansen en het kunnen plaatsen van verschillen in de beoordeling van cen medische probleemstelling in het geheel van het beleid. De artsen J.A. Kwotnerus en Dr. $H, K$. Muller (ROL) beschrijuen za'n les en laten zien hoe intercollegiale vergelijking in de praktijk werkt.

2. de vertaling hiervan in het 'pluis' - of "niet-pluis' -gevoel; en

3. de structuur van het probleem (in de vorm van een beslisboom).

\section{CASUS}

Op een morgen bezoekt een an de arts-assistemil nog niet bekeryde minn wan 64 jaar het spreekuiur met de klacht dat hij de laatste tijd steeds afwalt en daar graag "iets" aan wil heb. ben gedsan. Er zijn verder geen spontane klachen. Bi de wragagerheldering blijkt dat over de vermagering een duidelijke ongerustheid bestaat, zodat wordt bestoten een en ander grondig te onderzoken.

Uil de gegewens op de patièntenkaart (wan de opleider) blijkt het wolgende:

- Acht maanden geleden was er een spreekuurconsult "waarvan de reden miet is genoteerd. Een haemocult-test was $3 \times$ negatief, de BSE bedroeg $40 \mathrm{~mm} / \mathrm{h}$. Er was geen bloedverlies per anum geweest.

- Een maand later was er weer een spreekturbezoek in verband met een vermagering van $8 \mathrm{~kg}$ in eên jaar. Verder waten er geen klachter. Een routine-urineonderzoek levende geen afwijkingen op.

- Weer twee weken later volgde een spreekuarbezoek wegens cen absces aan de stull, dat na verwijzing pollikliniseh door de chirurg werd behandeld. Er waren geven redenen om op dat moncent verder onderzoek te laten doent.

Vandaag vertolt patièntat, die lastste zeven maanden meer dan $\$ \mathrm{~kg}$ tc zi în afgevallen. Bij nawraag blijkt or ook wat breige ontlasting te zijn geweest. Varder zijn er amamnestisch geen aanknopingspunten ter verklaring $v a n$ deze klachten. Bij toutine lichamelijk onderzoek met speciale andacht woot het abdomen worden evenmin ank nopingspunten voor een corzaak wan de klachtendverschijnselen gewonden.

\section{HYPOTHESEN EN PRLIORL-KANSEN}

Nadat de casus tot zover is gepresenteerd, wordt aan de huisartsen in opleiding en hun huisarts-begeleider gevraagd op te schrijuen:

- welke diagnostische hypothese(n) zij op dit moment overwegen:

- hoe groot (in procenten) zij, gegewen de casus, de kans op elk van die diagnose(n) achten; en

- in hoeverre zij het gevoel hebben dat de toestand van de gepresenteerde patient 'pluis" of "miet pluis' is. Dit wordt uitgedrukt in een percentage varierend van $0 \%$ (helemal pluis) tot $100 \%$ (in het getheell niet pluis).

Vervolgens wordt uitgewissesd wat die deelnemers hebben opgeschreven.

Wat de gegeven casus betrefi bleek dal alle deelnemende artsen bij hun eerste diagnostische hypothesen wrij grove categorieen hanteerden. Bovendien bleken zij, onathankelijk van elkaar" guramenlijk slechts een beperkt aantal categorieen nodig te hebben om alle hypothesen te kunnen indeler. De ingevulde kansen. verschilden ewerwel nogal (tabel). De hypothese "carcinoom" (mut name van het colon) werd door alle artsen genoemd, met kansen varierend van $10 \%$ tot $55 \%$. Vooral de termen "vermagering" en "afvallen" hadden gefungeerd als trig" germechanisme voor het opstellen van deze hypothesen. Andere hypothesen werden minder systematisch genoemd. De hypothesen inadequat voedingspa- 


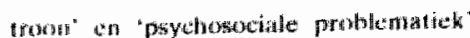

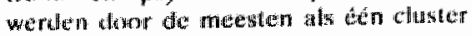

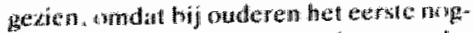

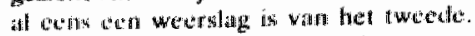
Drie artsen wornden dat in dit cluster verrewegy de meest aannemelijke borzak wan het afvallen gelegen as. Twee artsen overwogen de diagnose "enteritis." terwifl slechts én van de deelnemers de deur nar het alternatief geen afwijkin. gen" duideliyk opentield.

Opvallend is dat de meeste antsen zich wat de kansen betreft uitdruktem in veetwouden van $10 \%$. Slechts een enkeling. geeft een preciszere schatting. Opmerkelijk is ook dat de som van de kansen steeds 100\% is. Blijkbaar acht men de kams dat twee of meer van de onderscheiden cattegoricën tegelijk aan de orde zi jinn , the varwatorloten.

Er zijn dus asmmerkelijke verschillen in beoordeling wat de geschatte wasr schijmlijkheid van de diverse diagnosecategoricen hetreft. Het ligt voor de hand dat dit rich zull weerspiegelen in hel ver-

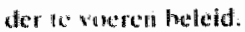

De colgende vratg komt nu natar voren: hoe grout is exiganlijk de kans dat iemand van of jast coloncarcinoom heeft, of licers: hoe groot is deze kans bij een man wan on jaar die sinds een jact afvalt en passsgere klachten van lbloedverlics per anum en dunne ontlasting heeft gehad en nu het spreekuur van de huisarts bezock? Bij pogingen tot besntwoording blijkt dat masarmate men de schatting vian de "a priori-kans" voor meer specifteke situaties wil weten, het des te minder Widarthijnligk is dat deze kans op grond van vertich onderete te bepalen is of ooit procios to bepalen zid zijn. Subjec-

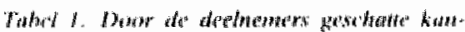

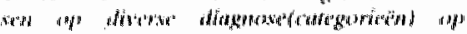

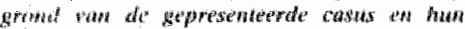

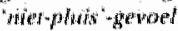

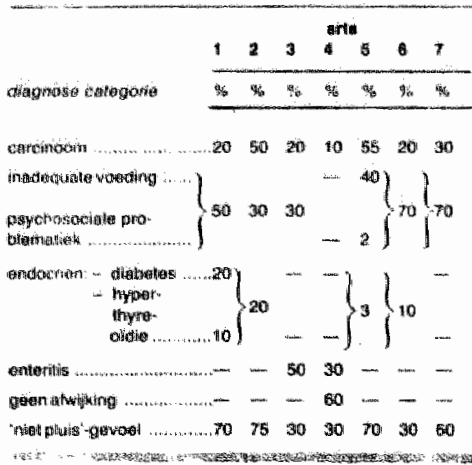

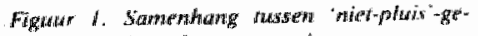

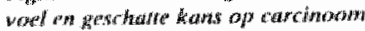

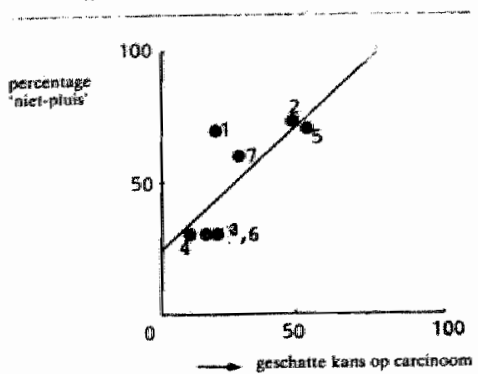

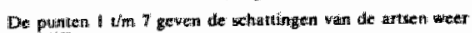

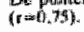

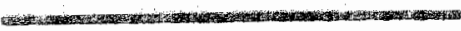

Figutar 2. Samenhang tussen 'mier-plais'-gewoel en geschathe kan op carcinowin of emalo-

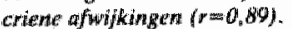

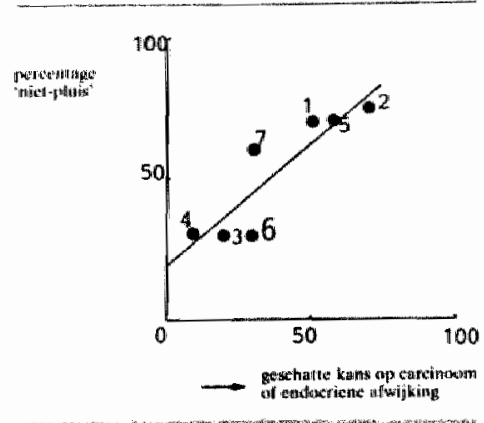

Fighinur 3. Samenhang tussen "wied-plwis"-ge" voet en gercharse kams op wathings- entof

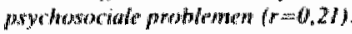

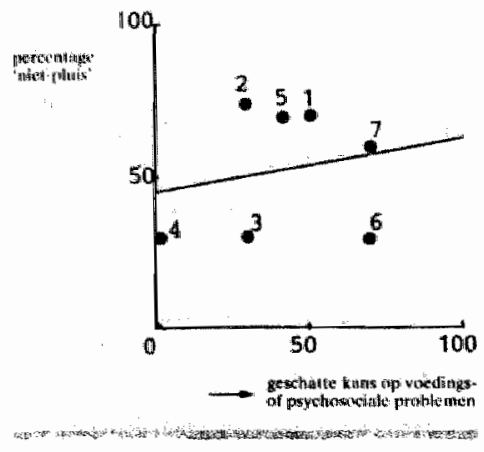

tieve schattingen, op grond van cle eigen ervaring en die van anderen, zullen dan ook in de toekomst het handelen in belangrijke mate blijven sturen. Daarom zal uitwisseling van deze schattingen, en daardoor eventuele onderlinge aanvul- ling of correctie erwan. niet kufmen wor den gemist.

\section{"PLEHS" EN WTET PLUIS:}

Er bleken twee groepen artser herkembaar: een groep die de situatie overwegend als "pluis" ervaarde en een groep die duidelijk neigde nat 'niet-pluis'. Een tussengroep (fifty-fifty') was er in dit ge val rilet (tabel).

Er is cen duidelijk positieve samenhamg tussen het "niet-plutis"-gevoel en de geschatte kans op carcinoon (figutur i) em, nog duidelijker tussen het "niet-plwis"gevoel en de geschatte kans op een carcinoom of een endocriene andoening ofigutr 2). Het "niet-plans"-gevoel hing praktisch niet samen met de geschatte kans op psychosociale problematiek ent of inadequate voeding (figutur 3 ).

Het onderscheid tussen "pluis" en "wietpluis" wordt weel gehanteerd in het kader van de commanicatie over de geschatte ermst wan do situatie. Toch is het miet duidelijk wh hermee pretics word aangegeven en hinc de beoordeling fot stand komt. Opmerkelijk is nu dat veel artsen ook zonder duidelijktheid goed met dit onderscheid uit de voeten lijken te kitum nen in hun communicatie met collega's In de groep kwam wel de vrakg maar voren of het onderscheid niet wath all te globaal was en alanleiding zou kunnen geven tot schijncommunicatie.

\section{STKUCTURERING FROBLEEM}

Gevraagd werd of er deehnemers waren die een bepalat beleid wilden verdedigen. Het wourdel hiervan is dat men uitgesproken voorstanders van verschillende benadetingen met elkaar kan confronteren. Het ping vooral om de eerste stap die zou mostion worden genomen.

Drie strategiec kwanten databil naar voren:

a. Verricht onmiddellijk colononder zoek. Daarbij kan dan worden gekozen tussen een röntgenonderzoek (X-colon) en een coloseopie.

b. Dow eerst een orienterend laborationt"umonderzock (met name BSE, $\mathrm{Hb}_{\text {" }}$ bloedsuiker, faeces). Indlien dit afwijkende warden oplevert kan eventmeel ver. dergaande diagnostiek plaatsvinden.

c. Begin met een nadere anammese wat het woedingspatroon betreft. Levert deze nadere anamnese een verkllaring op voor het afvallen, dan kan de aandacht in eerste instantie worden gericht op vembete. ring van het voedingspatroon. 
Sirrategie $C$ werd angehangen door degenen die de kans op voedingsproblemen hoog inschatten (artsen 1 en 6). Strategie A werd gepropageerd door degenen die coloncarcinoom zo waarschijnijk wonden dat colononderzoek toch zou moeten platsvinden; wat ook de uitslag zou zijn van ander diagnostisch onderzoek (art$\operatorname{sen} 2$ en 5 ).

Die meergave van strategieen is onvolle. dig als nuet duidelijk is welke consequenties die utkomsten van eerdere stappen kumnen hebben voor eventueel te nemen wolgende stappen. Daarom is het vaak nodig eventueel volgende stappen te expliciteren. Het resultaat hiervan kan worden "genotuleerd" in de vorm van het gertamte van een beslisboom waarin de belangrijkste opties zijn weergegeven.

In dit geval ontstond figutur 4. Deze beslisboom bleck nog wrij ingewikkeld.

De wolgende lecrpumten kwamen nu onder meer aan de orde in het kader van de discussile over de meest wensellijke strategie:

- Als een bepaalde diagnose erg waar. schijnlijk is (hoge a priori-kams) zal de negatieve nitslag van een weinig sensitheve test niet gauw geruststellen (bijvoorbeeld een normale BSE of een positieve voedingsanamnese bij een sterke verdenking op coloncarcinoom ${ }^{3}$ ).

- Een test waarvan de uitslag het beleid nulet zal beinvlöeden, kan beter worden owergeslagen (zelfde woorbeelden) ${ }^{4}$.

- Om uit te maken of men uit twee tests die in principe hetrelfde meten er én moet kiezen dan wel beide tegelijk moet doen of eventueel na elkaar (en in welke wolgorde) dient men een juiste indruk te hebben van sensitiviteit en specificiteit wan beide tests. Ook moet men weten hoe sterk de uitstagen van beide tegts met elkaar correleren c.q. van elkar afhanHelijk zujn (bijwoorbeeld X-colon en/of colossopie $)^{3}$.

- Het is van belang overwegingen ten arawzien wan stappen die pas verderop in de beslisboom aan de orde komen naar de primaire besluitwormug terug te koppelen. Bijvoorbedd: als coloscopie een betere test zou zin voor het aantonen of witsluiten van coloncarcinoom dan een $X$-colon, dan pleit dit erwoor het $X$-colon over te slaan en direct coloscopie te verrichten. Het kan echter zijn dat men hiervoot lerugschrikt ondat men dit onderwaek in verhouding tot een $X$-colon 20 bellastend acht dat men het op een strengere indicatie wil laten verrichten: in woorkomende gevallen zal mer dan toch everst een $\mathrm{X}$-collon aanwagen. In plats

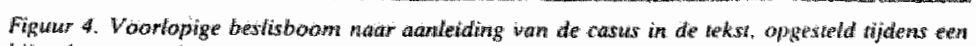

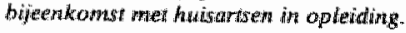

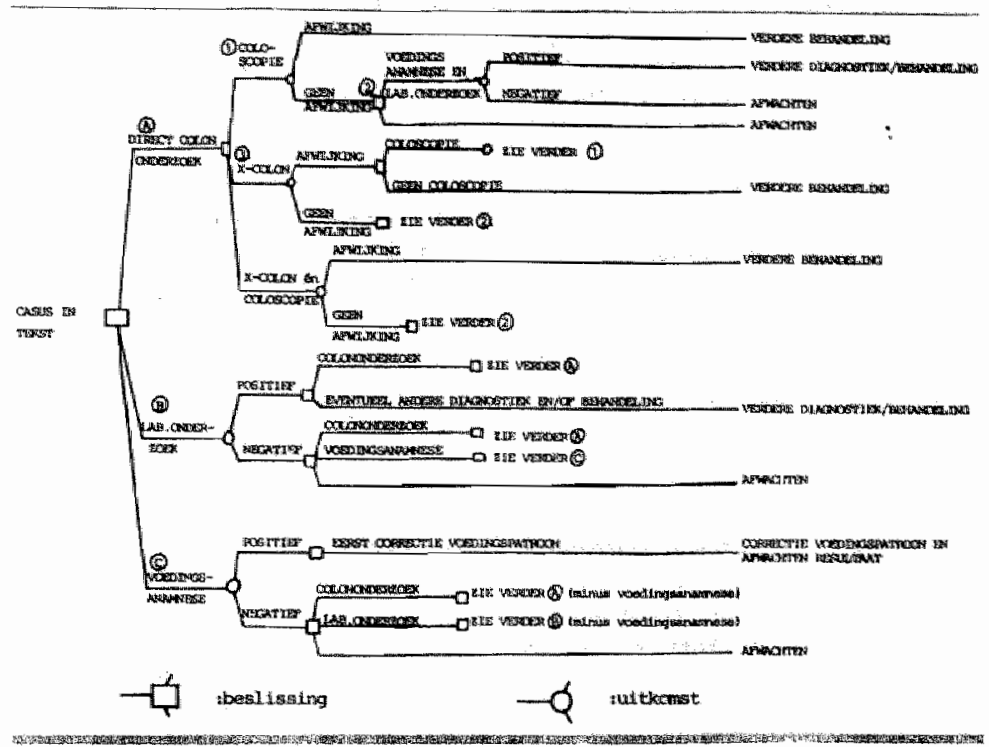

van het aamvragen van een $X$-colon zou men wellicht ook eerst nog een andere optie willen proberen. Dit zou men zekter willen als beide colononderzoeken zo weing valide zijn dat zij zowell veel carcinoomgevallen missen als veel niet-carcinoompatiënten ten onrechte de weg van mog verdergatind ingrijpen opsturen.

Indien er voldioende gegevens voorthanden zijn, zijn deze overwegingen to verwerken door middel van kwantitatieve analyse $c q$. het "doorrekenen" varu de beslisboom. Indien men iedere mogelijke einduitkomst een bepaalde warde (uniliteii) kan toekennem. kan men naguan welke strategie de hoogste wararde bereikt ${ }^{6}$

Dit dwingt ertoe de consequenties van (fout-)positieve en (fout-)negatieve uitslagen tegen elkar af to wegen. Vaak is echter niet aan de voorwasarden woor eem kwanthtatieve analyse voldaan. Door een "Kwalinatieve" analyse van het besluitvormingsproces, waarbil dan wootall de structur van de bes lisboom en de identificatie van cruciale stappen van belang zijn, zal men dan vaak toch een zinwolle evaluatie wan diverse strategieẽn kunnen verrichtem. Ook kan men hieraan aangrijpingspunten woor nadere literatuwrstudie of empirisch onderzoek ontlenen (bijvoorbeld over de relevante an priori-kansen en testëgenschappen). In werwolgbij- eenkomsten kan het probleem dan verder worden uitgewerkt, ook met kwantitatieve gegevens.

\section{SELECTIE CASUISTIEK}

Een punt waaraan meer dan op het noment aandacht moet worden besteed is de selectie van te presenteren casuistiek. Artisen kunnen geneigd zijn voortal succescasus in te brengen. Dat zijn bijwoorbeeld casus die thun woortreffelijk medisch kinnen demonstreren of een gepropageerde boodschap onderstrepen, Casus met cen teleurstellende of beschanmende afloop hebben, athankelijk wan de groep, een minimale of juist overdreven grote kans apontán te worden uitgekozen. Casuristiek watawan men vind dat zij weinig leeraams bevat, hijvoorbeceld omdat zij verwarrend of alledaugs is of een duidelijke afronding mist, wordit, zo leert de ervaring. zelden geselecteend. Het resultat is dat men biil de intercolle giale uitwisseling van ten optichte van de dlagelijkse praktijk sterk vertekend leermateriaal uitgat, wagrin men zich niet meer herkent.

Er is nog en ander nadeel: ondat men achteraf graag de 'clou', de werkelijke affoop. vertelt of wil horcen, krijgt deze de status van thet juiste anthoord; dil kan een ten onrechte normerend effect met zich meebrengen. Ook is vertekening 
Wooraf mogelijk ten gewolge van selectie op onderwerp: in het kadur wan cen wolgens planming te bespreken anderwerp.

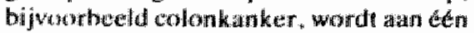

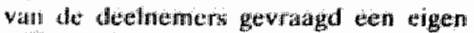
casus voor te bereiden. Het is duidelijk dat whe bespreking in de groep in ditt geval reeds van tevoren gterk is beinvloed, zowel wat de te schatten priori-kansen als de opties ten anzien van het beleid betreft. Men ziel dit watk gebeurer bij themagericht georganiseerde nascholing. In hat beschreven gewal bleek in werkelijkbuid es $X$-colon te zijn vervaardigd, met alls uitslag: coloncarcinoom. Onbekend is evenwell hoe valk bij vermagering een colononderzoek wordit verricht zónder dat kanker of een andere diagnost wordt vastgesteld. Het zou dus onjuist zijn nuar anteiding wan deze casus zonder meer te concluderen dat bij een paltient als in de cassus altijd een colonfoto of coloscopic moet worden gemaakt.

De zin van een casusbespreking is meer gelegen in de onderlinge uitwisseling nair anteiding van de casus dan in de werkelijke afloop van de casus. Het be- kend malken wan de werkelijke afloop kan zelf het leerproces achteraf ondermijnen en zou in principe acchterwege kunnen blifwen.

Wat de selectic ran de te bespreken casuistivek betreft is er veel voor te zeggen dieze at random te ontlenen aan de praktijkervaring van bijwoorbeetl: de afgelopen week. Geen enkel gewal zal daarbij oninteressant blijken, zelfis niet als thet om algemeen ingeslepen routines gat; integendeel: juist dan krijgt men de kans echte blinde whekken op sporen die verscholem liggen in een hele scala wan dergelijte behandelinger..

\section{SAMENWATTING}

Aan de hand van het werloop van een bijeenkomist met huisartsen in opleiding werd beschreven hoe op eenvoudige wijze "reeds in én sessie, belangrijke aspecten wan de medische besluitvorming aan de orde kurmen komen. Deze aspecten betreffen verschillen in beoordeling van kansen, medisch-besliskundige principes en het identificeren van cruciale stap- pen in het beleid, alsmede van angrijpingspunten voor nadere studie hief over. In de bespreking wordt de nadrulk: gelegd op het belang wan een welowerwio gen wijze van selectie van te presentereri casuistiek.

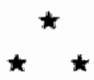

Met dank aan de huisartsen in opleidingr van groep 24, huisartsenberoepsopule. ding Rijkswniversiteil Limburg.

Leringar

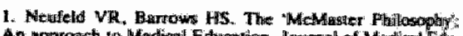

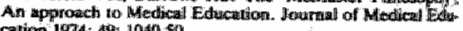
contion 1974; 49: 1024n:

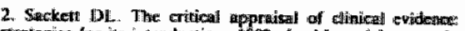

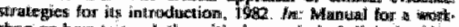

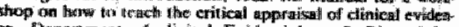

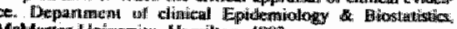

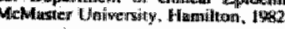

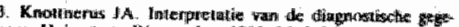

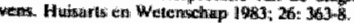

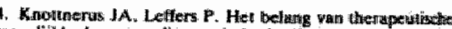

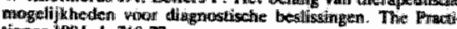
iconer $1084: 1 ; 769-77$.

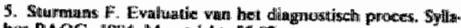

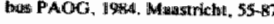

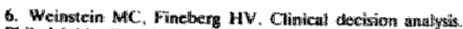

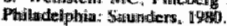




\title{
Het belang van therapeutische mogelijkheden voor diagnostische beslissingen
}

\author{
J. A. KNOTTNERUS EN P. LEFFERS \\ Capaciteitsgroep Epidemiologie/Gezondheidszorgonderzoek, Rijksuniversiteit Limburg, \\ Maastricht
}

$\mathrm{D}$ E VUISTREGEL dat diagnostiek en behandeling niet los van elkaar gezien kunnen worden, is stokoud en tegelijk zeer actucel. Traditioneel bestaat de angst dat te weinig diagnostiek word verricht vóóndat therapeutische beslissingen genomen worden. De laatste jaren is echter ook steeds meer bezorgdheid ontstaan over het tegendeel. De diagnostiek is een eigen leven gaan leiden en is in bepaalde gevallen de therapeutische mogelijkheden bowen het hoolid gegroeid.

Het gaat om twee kanten

Samenvatting Hel handelen van de huisarts berwst in wezen op zen voontdurende wisselwerking tussen zijn diagnoslische activiteiten en de therapeutische overwegingen. Mel een minimum aan feilenmalerical, dat hem ter beschikking staat zonder de palient aan allerlei invasiewe onderzoeken te moeten onderwerpen, zal de hwisarts een aantal factoren legen elkaar afwegen die de verdere gang van zaken sterk kunnen beinviloeden. van dezelfde hulpverleningsmedaille: voor zinvolle behandeling is een optimale diagnostische onderbouwing nodig; en: diagnostiek heeft pas betekenis als haar uitkomsten kunnen bijdragen tot een betere hulpverlening.

\section{De carotissoufle}

Als bij toeval, tijdens een keuring of bij een als routine uitgevoerd uitziftingsonderzoek, een souffle in de hals wordt ontdekt, rijst de verdenking op een stenose van de $\mathrm{A}$. carotis. Uitgaande van de opvatting dat zo'n stenose, ook bij klachtenvrije patiënten, een pathologisch proces inhoudt, ligt het voor de hand nader onderzoek te adviseren. Wellicht kan het euvel exact in kaart worden gebracht, de ernst ervan geschat, en misschien kan het verholpen worden met een operatie. Bovendien is voor de diagnostiek een groeliend aantal middelen beschikbaar: diverse toepassingen van Doppler en ultrageluid, oculoplethysmografie, digitale subtractic-angiografie en de beproefde carotis- angiografie volgens Seldinger, om de belangrijkste te noemen. Men kan deze technicken bij iedere patiënt naast elkaar gebruiken om telkens een zo compleet mogelijk plaatje te krijgen. Van een meer kritische instelling getuigt het, als men te werk gaat volgens een bepaalde systemalick, een strategie, waarbij het beslissingsproces stapsgewijs wordt opgebouwd.

In figuur 1 is schematisch weergegeven hoe zo"n strategie voor het probleem van de asymptomatische carotissouffle er uit kan zien. licrst wordt getracht door middel van nietinvasieve onderzoekmethoden meer te weten te komen over een eventuele lokalle oorzaak van de soufle. Dit wergt in het algemeen een verwijzing. Vervolgens wordt, als er naar alle warschijnlijkheid geen lokale stenose of obstructio is, nagegaan welke andere oorzaken er aan het symptoom ten grondslag kunnen liggen (zoals voortgeleide cardiale souffles of anemie) en aansluitend wordt beoordeeld welke speci- 


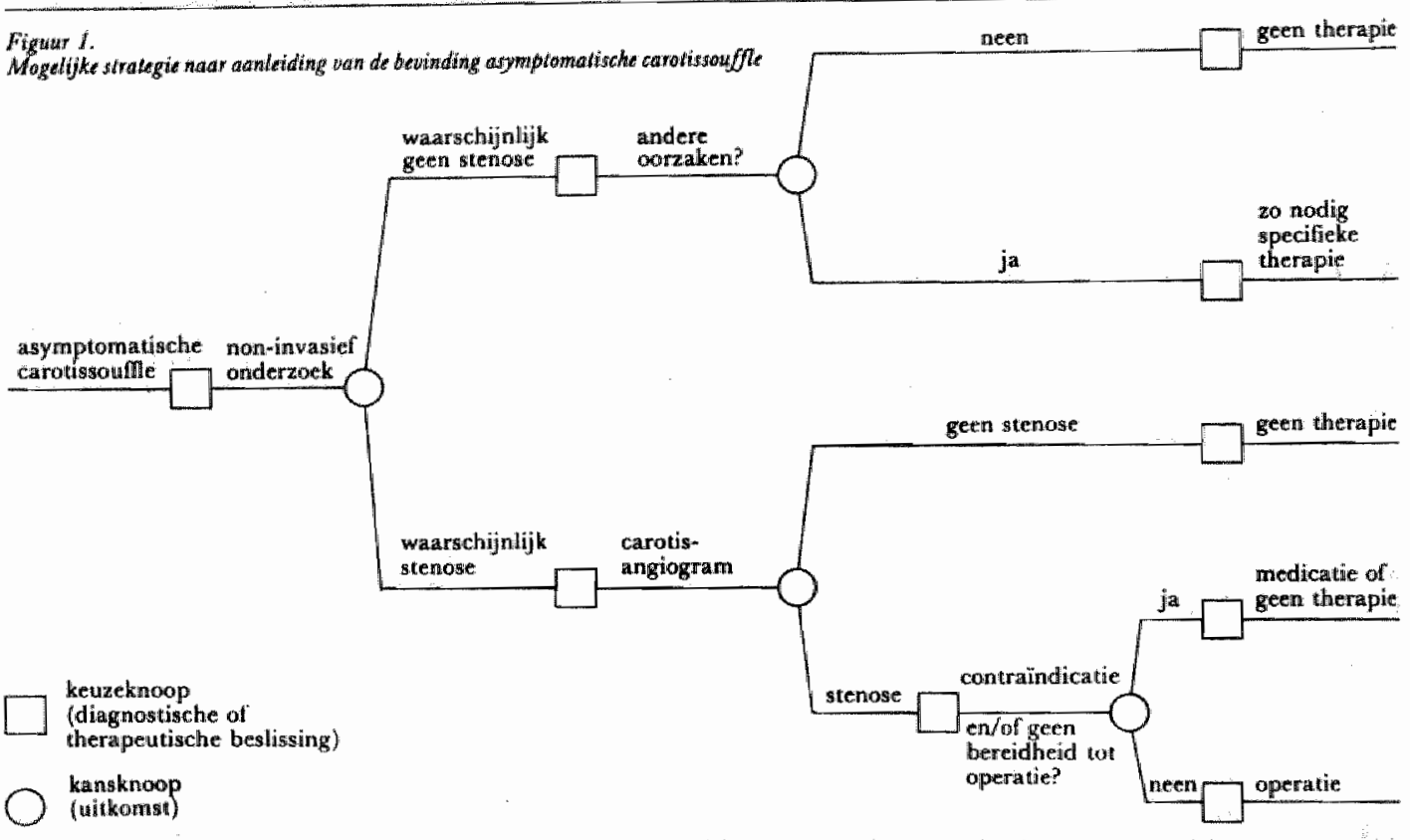

fieke therapeutische mogelijkheden daarvoor zijn. Is er op grond van het nitt-invasieve onderzock wel ecn stemose te verwachten, dan gat men informatic versamelen om tc bcsluiten of er al dan nied geopereerd zou kunnen en moeten worden (endarteriëctomic). Mel angiogralie: kan worden bepaald of er inderdatad een stenose bestaat, of deze operabel is, waar deze precies zit en hoe ernstig xij is. Voorts wordt de vraag gesteld of er sprake is van contra-indicaties voor operatie, bij voorbeeld hoge leeflijd, een belangrijke longzickte of een crnstige inoperabele hartaandoening. Naar aanleiding van de beantwoording hiervan wordt ofwel besloten tot operatic, of wel wordt de voorkeur gegeven an een conservatieve benadering, al dan niet met behulp van trombocyten-aggregatieremmers.

Er is in elk geval sprake van. een complex probleem als men deze aanpak kiest. De gang van zaken kan vereenvoudigd worden, en bepaalde stappen kunnen worden kortgesloten.

- Als men zich all bij het vinden van de eerste symptomien rekenschap geeft van de eventuele contraindicadic aan de orde zijn voor operaticve (of ook medicamenteuze) therapie, zal dikwijls aan invasieve diagnos- 


\section{Figuter 2.}

Aldernatieve sindegie, als men eroan uitgat dat operatie geen cinvoll therapu is.

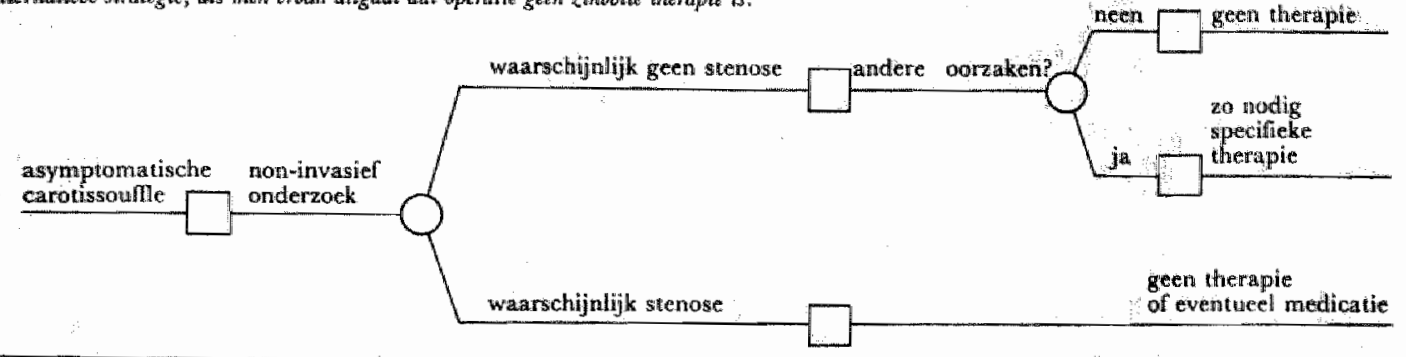

tiek - die alleen nodig is om de operatie-indicatie definitief te stellen - niet meer gedacht hoeven te worden. Men kan zich dan bij veel mensen, bij wie anders wellicht angiografie verricht was, direct beperken tot de behandeling van, vaak al bekende, andere gezondheidsproblemen. Eventueel kan een niet-invasief onderzoek zinvol zijn om de indicatie tot het instellen van medicamenteuze therapie voldoende te documenteren. In andere gevallen, bij voorbeeld bij cen ernstig cardiovasculair lijden waarbij reeds stollingwerende middelen of trombocyten-aggregaticremmers gegeven worden, had men bij wijze van spreken al op voorhand kunnen afzien van auscultatic van de carotiden.

- Bij het bespreken met de pa- tiënt van de betekenis van de bij fysisch onderzoek gevonden souffle, kan al direct duidelijkheid worden verkregen over de vraag of deze überhaupt tot cen eventuele operatie bereid zou zijn. Dit is van groot belang, want als die bereidheid er niet is, kan veel diagnostiek achterwege blijven.

- Een nog sterkere wereenvoudiging kan optreden, als men weet dat het nut van operatie bij asymptomatische ${ }^{2,3}$ en zelfs bij de symptomatische ${ }^{4}$ carotisstenosen nooit afdoende is aangetoond (fig. 2). Als er al enig nut zou zijn, is bijzonder tw wijfelachtig of dit wel opweegt tegen de nadelten en risico"s van invasieve diagnostiek en operatie. En ook de zin van medicinale behandeling staat niet buiten kijf. Als men op dit spoor doordenkt, zou auscultatie van de carotiden alleen zinvol zijn om de patiënt beter te kunnen informeren over zijn of haar toestand. Zelrs dan is nog de vraag of men de patiẽnt goed doet met dergelijke mededelingen.

\section{Wisselwerking diagnostiek- behandelingsplan}

De boodschap is duidelijk: het denken over de (mogelijkheden van) behanding en over de consequenties daarvan voor de mogelijk te vergaren informatie, dient vanaf de aanvang wan de hulpverlening de aandacht te hebben. Het gehele beleid kan dan stap voor stap worden ontwikkeld. Dreigende overmaat kan worden herkend en voorkomen.

Daarbij is sprake van een voortdurende wisselwerking tussen de diagnostische activiteit en therapeutische overwe- 
gingen. Een al to gefasecrde tampak heef gevaren. De houding 'eerst maar eens rustigg de diagnostiek afwerken, de therapie komt daarna aan de beurt" kan, bij voorbeeld, leiden tot myelografieên bij mensen die toch niet aan hum hernia geopereerd hadden willen worden, of tot uilvocrige tumordiagnostick bij patïmton dic al ten dode zijn opgeschreven.

Van iedere beslissing moet dus tevoren het nut voor de patiënt worden beoordeeld. Wat betekenen de mogelijke uitkomsten voor mijn verdere beleid? Brengt de mogelijk uitkomst mij verder dan ik nu ben? Daarbij dienen ook de voorkeuren van de patiënt, diens conditic, en vooral ook de merites van de behandelingsalternatieven in de overweging te worden betrokken.

Kortom: de klachten of symptomen waarmee de patient zich aandient, ${ }_{j}$ eiden tot de vorming yan diagnostische hypothesen. Of en hoe deze getoctst dienen te worden hangt mede al van de therapeutische overwegingen die bij de hypothesen relevant zijn.

In de vroegste fase van de hulpverlening, als er noy weinig of geen medische activiteit in gang is gezet, vinden we de huisartsgeneeskundige betrok- kenheid. Juist de huisarts zal dan ook afwegingen moeten maken, die bepalend zijn voor cle verdere gang var zaken. Dat betekent dat de huisarts, over cen breed terrein, erg goed moet weten wat de geneeskunde wel of niet te bieden heeft. Dat vergt een specifieke deskundigheid die tijdens de oploiding maar mondjesmaal word a angeboden, ch vaak later verworven moet worden. Hier ligt ook een belangrijk aangrijpingspunt voor de ontwikkeling van het overleg tussen huisartsen en specialisten over geneeskurudige thema's of, via consultatic, over concrete gevallen.

Onder dit hoofdje willen we nog wajzen op de gevaren varn diagnostische routinepakketten: "Bij patiënten met die-endie klachicen beginnen we altijd met die-en-die onderzoekingen. Enerzijds kunnen doublures voorkomen, en overmatige belasting van de patiënt. Anderzijds brengt het inwinnen van meer informatie vaak ook en grotere kans op foute of moeilijk te interpreteren gegevens met zich mee. Bovendien verlecrt men door al te routinematig handelen het analytische denken met kritische evaluatie van iedere te nemen of genomen stap.

\section{Kúnnen weten is niet: móeten weten}

Het is nict moeilijk om elk gevoel van onzekerheid om te zetten in cen streven wan maximaal haalbare zekerhcid. Vaak leidt dit echter tot hulpverlening van twijfelachtige kwaliteit. Een veel grotere en meer wezenlijke kundigheid vergt ho" om, nu conmaal licstaande, oncekerheden als nitgangspunt te aanvaarden, en telkens te bezien in hoeverre het zinvol is om tot meer zekerheid te geraken. Zoals Reuben het uitdrukt: 'Ability to know' moet niet verward worden met "need to know'. Vaak is een bescheiden aantal, soms maar één of twee, bevindingeru al zo cruciaal dat additionele informatic er weinig meer toc doct. Zo is bij de klachl pijn op de borst de lokalisatic, het karakter van de pijn en of deze bij inspanning optreedt, al zo essenticel dat bij een op deze punten niet-verdachte anamnese uitvoerig nader onderzoek volgens velen beter achterwegc kan blijwen. ${ }^{B}$ En bij acute pijn in de rechter onderbuik valt het belang van bloedonderzoek zodanig in het niet bij dat van de fysische diagnostick, dat het bestaansrecht ervan in de primaire besluitvorming op xijn minst twijfelachtig is.

Vooral de huisarts is ge- 
wend on met de methode van de 'cruciale' bevindingen te werken, en dit is ook een noodzaak gezien zijn positie in de gezondheidszorg en het klachtenaanbod dat hij ontmoet. Wellicht verdient de verdere ontwikkeling van deze 'methode' in de nabije toekomst minstens zovedl aandacht als het wctcnschappelijk onderzock op het gebicd van de geavanceerde diagnostiek.

Een belangrijke voorwaarde om tot een meer terughoudende geneeskunde te geraken, is dat een dergelijke geneeskunde als goede vorm van beroepsuitoefening a anvaard wordt, $z$ wel binnen de medische wereld als door de patienten. In dit verband is het, bij voorbeeld, tekenend dat op dit moment in de rubricering van de beslissingen van de medische tuchtcolleges door de Geneeskundige Hooldinspectie wél voorkomen: nict of te laat komen op verzoek; onvoldoende zorg; onvoldoende informatie; en niet of te laat verwijzen. En níet de rubricken: ongevraagd of te vecl komen; veel te veel zorg; cen overmaat aan informatie; ten onrechte, te wrocg, of te veel verwijzen; en ten onrechte nie, te laat of te weinig terugwijzen naar de huisarts. En ook het begrip 'kunstfout' is nog eenzijdig gekleurd.

\section{Principes}

Een probleem bij het gebruik van bepaalde diagnostica is, of de te verkrijgen extra informatie opweegt tegen de belasting van de patiënt. Maar ook het steeds minder belastend worden van allerlei diagnostische activiteiten, bij voorbeeld door het vervangen van invasieve door nict-invasieve technieken, kan, hoe prettig dit op zichzelf ook is, een eigen problematiek met zich meebrengen. Men krijgt de neiging ze eerder te gebruiken, ook al is de klinische relevantie van dat gebruik nuet altijd even duidelijk.

Het ontdekt worden van een diagnosticum is soms al voldoende reden om het te gebruiken, en als er één in diskrediet raakt, staan er al nieuwe klaar waarvan gezegd wordt dat de bezwaren niet meer gelden. Er is veel voor te zeggen om voor introductic van diagnostica in dc praktijkwoering een procedure in te voeren die vergelijkbaar is met die welke geldt voor genees middelen. Algemene acceptatie zou pas moeten plaatsvinden als door middel wan goed onderzoek aangetoond is dat datgene wat gepretendeerd wordt ook klopt. Tevens zou de vraag moeten worden beantwoord wat de nieuwe techniek toevoegt aan de bestaande mogelijkheden.
Wij besluiten met het weergeven van enkele basale principes die bij diagnostisch onderzoek van belang zijn, en sluiten ons daarin aan bij Reuben:"

- Als de uitalag van cen onder. zoek een verandering kan opleveren van het therapeutische beleid, dan moet dàt onderzock gedaan worden dat de noodzakelijke informatie oplevert met cen minimum aan belasting en risico's voor de patiënt.

- Een onderzoek kan weliswaar nict van belang zijn voor het bepalen van de therapeutische strategie, doch geîndiceerd zijn om andere redenen: inzicht bieden in de prognose, of ter geruststelling van de patiënt. Ook dan moet men echter positieve argumenten hebben voor het onderzock.

- Men moet onderscheid kunnen maken tussen diagnostiek ten behoeve van de individuele patięnt en diagnostiek ten behoeve van wetenschappelijk onderzoek. Beide hoeven niet samen te vallen. In het tweede geval is op zijn minst een goed research-protocol nodig, alsmede 'informed consent" van de patiënt. 


\section{Literatuur}

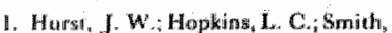

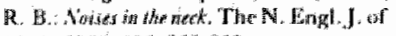

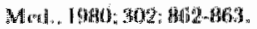

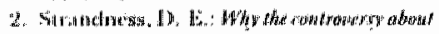

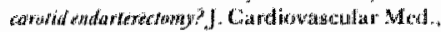
1941; 6: 1067-1068 (Rditorial).

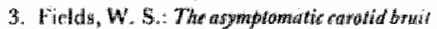

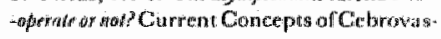

cular diserac Sitrolle, 1978; X111: 1-14.

4. Wartow, C.: Hitransient Ischemic Antack. In: Matthews, W. B.; Gilaser, G. H. Hent

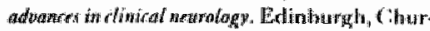
chill livingst one, 1992: 191-214.

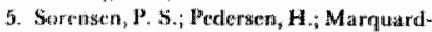
sem, J. ot. all: Acetosalicolic otrid in the prentention of

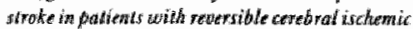

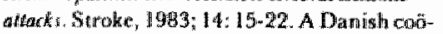

perabovesudy.

6. Knotuerus, J. A., Sturmans, F.: Hed wog-

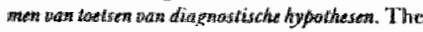
Practitionter, 1684: 1: 277-281.

7. Reuben, 1. B.: Leaming diagnustic restraind.

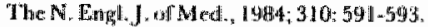
8. Todd, J. W. Quen cartiac pain. The Lan cet 1983; agust 6: 330-332. 
DE ASYMPTOMATISCHE CAROTISSTENOSE;, WEL OF NIET OPERERFN?

In het kader van een algemeen onderzoek ontdekt de huisarts door middel van auscultatie bij een patiënt een souffle over een halsslagader welke mogelijk wordt veroorzaakt door een carotisstenose. Hij wordt nu met enkele belangrijke vragen geconfronteerd. De belangrijkste zijn:

1) heeft de patiënt nu een verhoogd risco op een cerebrovasculailr accident? en:

2) is therapeutisch ingrijpen zinvol?

De eerste vraag kan positief worden beantwoord. Mensen met een carotisstenose hebben een 2 à 3 keer zo grote kans op cerebrovasculaire complicaties in de toekonst. Daarmee is vraag 2 nog niet beantwoord. Juist omdat patiënten met een carotisstenose vaak geen klachten hebben, is de vraag naar de consequenties van deze bevinding extra belangrijk. Wat heeft de literatuur ons hierover te melden? Het mu volgende artikel gaat hierop in. 
DE ASYMPTONATISCHE CAROTISSTENOSE, WEL OF NIET OPEREREN?

- een besliskundige benadering
A. Kinottnerus
1) - p. Leffers
1) - J. Lodder
2) - F. Sturmans
1)

\section{Samervatting.}

Met behulp van besliskundige technieken en gepubliceerde gegevens zijn de te verwachten klinische ultkomsten geëvalueerd van operatieve en conservatieve behandeling van asymptomatische carotisstenose, na respectievelijk 1, 4 en 8 jaar follow-up. Bij conservatieve behandeling is de mortaliteit het laagst, en de kans op TIA het grootst, onafhankelijk van de follow-up duur. De kans op een CVA is na één jaar het laagst bij conservatieve behandeling, doch na 4 en 8 jaar bij operatie. De verwachte utiliteit is steeds hoger voor conservatieve behandeling, en dit resultaat is stabiel over een breed traject van afzonderlijke kansen en utiliteiten.

Het opereren van asymptomatische carotisstenosen kan op grond van de literatuur niet gerechtvaardigd worden.

trefwoorden: asymptomatisch/carotis/stenose/behandeling/besliskunde.

1) capaciteitsgroep Epidemiologie/Gezondheidszorgonderzoek

2) capaciteitsgroep Neurologie

Rijksuniversiteit Limburg, Postbus 616, 6200 MD Maastricht 
Inleiding.

Over het te volgen beleid naar aanleiding van de bevinding "asymptomatische carotissouffle" wordt verschillend gedacht (1). De kernvragen zijn: 1) of endarterectomie in geval van een eventuele carotisstenose de prognose verbetert en dus cok of 2) diagnostiek, gericht op het stellen van een operatie-indicatie, verricht moet worden.

Sommigen menen dat varwege de verhoogde kans op een ischemisch accident een op operatie gericht beleid gewenst is $(2,3)$. Volgens anderen slaat de balans van kosten (directe en indirecte risico's van angiografie en operatie) en baten (verbetering van de prognose door het opheffen van de stenose) door naar de conservatieve benadering $(1,4,5)$. In de twee studies, waarin de klinische resultaten van geopereerden en niet-geopereerden met ellkaar vergeleken werden, Jwamen de geopereerden er beter af $(6,7)$. Echter, de toewijzing van de behandeling gebeurde niet at random, maar werd bepaald door indicaties en contra-indicaties. De prognose van de geopereerden is daardoor waarschijnlijk a priori al gunstiger geweest. Een ander probleem is dat onderzoeksresultaten in zulke uiteenlopende vormen gepresenteerd worden, dat onderlinge vergelijking vaak moeilijk is. Resultaten van studies met een follow-up van 2 tot 15 jaar, en met een follow-up van minstens 6 maanden zijn niet zo maar met elkaar te vergelijken. Uiteindelijk zal de controverse alleen op te lossen zijn door middel van een gecontroleerd experiment op basis van randomisatie $(8,9,10)$. zo'n experiment is tot nu alleen gedaan bij symptamatische patiënten (11).

Inmiddels moeten in de praktijk beslissingen worcien genomen. Het ligt voor de hand dat men zich daarbij mede baseert op gepubliceerde gegevens. In het volgende hebben wij besliskundige technieken gebruikt an beschikbare literatuurgegevens op systematische wijze te verwerken.

Methode.

Structurering van het probleem.

Diagnostiek gericht op het vaststellen van operabele stenosen, heeft alleen zin als operatie van zo'n stenose effectief is. De kern van het 
probleem is daarom de vergelijking van de resultaten van endarterectomie en conservatieve behandeling. Deze is ondergebracht in een besliskoon (figuur 1). Als uitkomsten zijn gekozen: sterfte, cerebrovasculair accident met blijvende gevolgen (CVA), transient ischemic attack (TIA), en de situatie warin geen van deze gebeurtenissen optreedt (status quo).

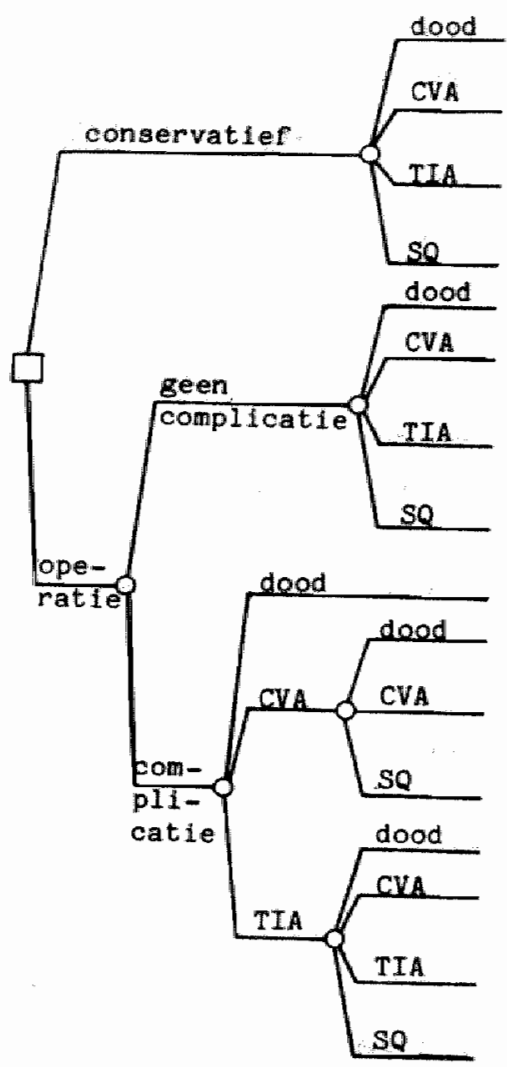

Figuur 1: Beslisboom voor de behandeling van asymptomatische carotisstenose.

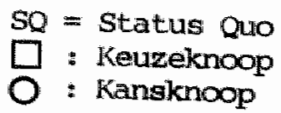


Kansen.

Voor het evalueren van een beslisboom dient men de kansen op de diverse klinische uitkomsten te kumnen berekenen (12). De kansen die in de beslisboam werden gebracht, zijn ontleend aan de literatuur over angiografisch aangetoonde asymptomatische stenosen. Hierbij moet opgemerkt worden dat van de 20 gevonden publicaties over het beloop van asymptomatische stenosen bij conservatief en chirurgische beleid (en perioperatieve complicaties) er 11 afvielen vanwege ontbreken van relevante gegevens of ernstige kwalitatieve tekortkaningen. Wat betreft het beloop nà ongecampliceerde operatie en bij conservatieve behandeling gingen wij er vanuit dat de klinische verwikkellingen gelijkmatig gespreid zijn over de follow-up periode (13-17). De betreffende kansen uit elke daarvoor geschikte studie konden nu worden berekend per tijdseenheid, door het aantal opgetreden klinische verwikkelingen te delen door de som van de follow-up tijd van alle patiënten. Bij gebrek aan gepubliceerde gegevens over het klinisch beloop ná het optreden van niet-fatale operatiecomplicaties, gebruikten wij hiervoor dezelfde kansen als na ongecormliceerde operatie. Dit kan de analyse hebben beinvloed ten voordele van operatie.

Het eventuele effect van trambocyten-aggregatie remers werd buiten beschouwing gelaten ondat hierover geen studies bij asymptamatische patiënten zijn gepubliceerd, en comlat in de meeste patiëntenseries informatie over eventuele medicatie ontbrak. Met geslachtsverschillen hebben wij geen rekening kumnnen houden ondat specifieke cijfers hierover in de literatuur ontbraken. Gezien de gemiddelde leeftijd in de gepubliceerde series mag de analyse van toepassing worden geacht op oudere patiènten. ondat de niet-geopereerde patienten gemiddeld wat jonger waren dan de geopereerden (gemiddeld respectlevelijk 63 en 66 jaar oud) corrigeerden wij het sterftecijfer van de eerste groep net behulp van de leeftijdsspecifieke sterftecijfers van de algemene bevolking (zie appendix).

Bij het doorrekenen van de beslisboom werd uitgegaan van rekenkundige gemiddelden van de aan de diverse publicaties ontleende kansen. Iedere aparte studie kan inmers gezien worden als een een steekproef uit de klinische ervaring ter plaatse, en ex is dan geen reden crn grotere studies een zwaarder gewicht toe te kennen. 
utiliteiten.

Voor een besliskundige analyse is het van belang dat aan iedere mogeWijke klinische uilkomst een waarde wordt toegekend, een zogenaamde utiliteit. Deze warde dient de vermindering van zowel de levensverwachting als de kwaliteit van leven te weerspiegellen. De verwachte warde per strategie wordt dan berekend door de kans op elke uitkamst te vermenigvuldigen met haar utiliteit, en deze producten voor de betreffende strategie bij elkaar op te tellen (18).

Als utiliteiten voor sterfte, CVA, TIA en "status quo" kozen wij in eerste instantie respectievelijk $0.0,0.75,0.95$ en 1.0 . Deze factoren geven aan hoe groot de waarde van het verkeren in de betreffende toestand geacht wordt ten opzichte van gezond zijn. Daarbij gaat het an gemiddelden, waarin bijwoorbeeld voor het CVA zowel zeer ernstige als zeer lichte gevallen zijn verdisconteerd. Omdat deze keuzen arbitrair zijn, pasten wij hierop een sensitiviteitsanalyse toe. Hierbij gingen wij na, in hoeverre het resultaat van de berekening "gevoelig" was voor verandering van de utiliteiten (12).

Lange temijn resultaten.

ondat de gemiddelde follow-up duur van de gebruikte onderzoekingen 4 jaar beciroeg, berekenden wij behalve de resultaten na 1 jaar ook die na 4 jaar follow-up. Voorts werd de toestand na 8 jaar geanalyseerd met behulp van een uitgebreide beslisbocm (figgur 2).

ondat cerebrovasculaire camplicaties zich kunnen herhalen werden hierbij ook gegevens betrokken over de kans op sterfte, CVA en TIA bij patiënter die reeds eerder een CVA en/of TIA hadden grekregen. Voor patiënten die in de eerste periode symptoamvrij bleven werden in de tweede periode van 4 jaar dezelfde kansen gebruikt als in de eerste periode (15). Noor het leeftijdsverschil van 4 jaren ten opzichte van de eerste periode werden de sterftekansen gecorrigeerd (zie appendix). De resultaten van de analyse werden ultgedrukt in "quality Adjusted Life Years" (OUAL's): Deze uitkonstmaat is een aanduiding voor het aantal geleefde jaren, gecorrigeerd voor de "kwaliteit" van de gezondheidstoestand gedurende die jaren $(12,18)$. 


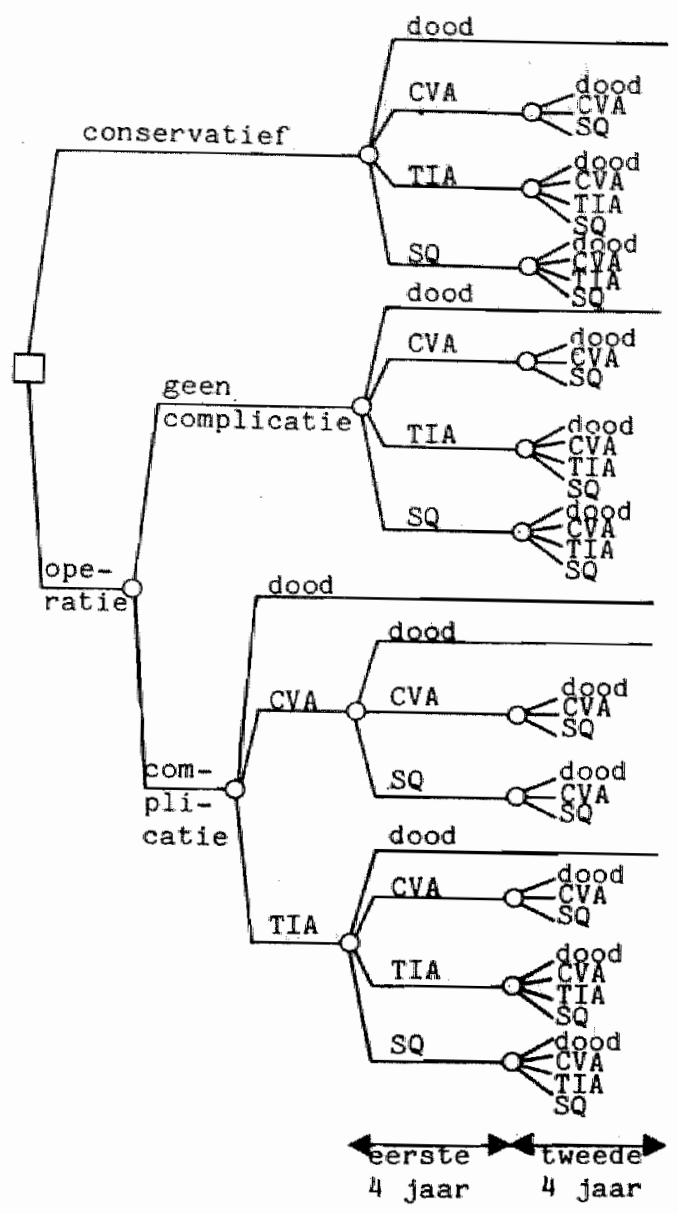

Figuur 2: Beslisboom voor de behandeling van asymptcmatische carotisstenose, voor de analyse van de situatie na 8 jaar followup.

SQ : Status Quo : geen verandering van de situatie.

Voor iedere mogelijke "patiëntencarrière" (overeenkomend met iedere mogelijke route die in de beslisboom is aangegeven) werd het aantal. QUALY"s berekend door het aantal jaren dat men in een bepaalde toestand verkeerde te vermenigvuldigen met de utiliteit van die toestand, en de aldus verkregen producten voor die patièntencarrière bij elkaar op te tellen. Voor de utiliteit van een nieuwe toestand nà een reeds eerder opgetreden verwikkeling is het product van de betrokken utili- 
teiten genomen. Daarbij werd er vanuit gegaan dat perioperatieve complicaties na o jaar optraden, en de latere verwikkelingen gemiddeld halverwege de eerste respectievelijk tweede periode.

Dus voor een patiënt die post-operatief een TIA en vervolgens in de eerste 4 jaar een CVA kreeg, an tenslotte in de tweede 4 jaars-periode te overlijiden wordt in 8 jaren follow-up het volgende aantal QuALY"s geteld:

in de eerste periode van 4 jaar* $(2 \times 0.95)+(2 \times 0.95 \times 0.75)$

in de tweede periode van 4 jaar:

totaal: $\left(2-\frac{x}{4.75} \cdot \frac{95 \times 0.75)}{\text { QUAY }}+\right.$

ondat de lezer zijn eigen oordeel kan hebben over utiliteiten hebben wij ook aangegeven hoe groot de kans is, dat men na een bepaalde periode in een bepaalde toestand verkeert.

\section{Sensitiviteitsanalyse.}

omdat het resultaat van de analyse afhangt van de gehanteerde kansen en utiliteiten, werd de warde van elke strategie herberekend bij andere keuzen voor de kansen en utiliteiten. Hierdoor werd een indruk verkregen van de mate waarin het resultaat gevoelig is voor variatie van kansen en/of utiliteiten (12).

De berekenilngen werden uitgevoerd op een Apple II ${ }^{\mathbf{e}}$ microcomputer, met het programma Decision Maker (19).

\section{Resultaten.}

De resultaten van het literatuuronderzoek zijn gegeven in de tabellen 1 en 2. De uit de verschillende publicaties afgeleide kansen liggen nogal uiteen, hetgeen kan worden toegeschreven aan verschillen wat betreft selectie van patiënten, kwaliteit van zorg en aan het toeval. Ten achuien van het beloop nà ongecompliceerde operatie stemen de diverse studies nog het meest overeen. De resultaten van conservatieve behandeling zijn waarschijnlijk in ongunstige zin beinvloed condat in de meeste onderzoeken uitgegaan is van patiënten die in het verleden een contralaterale endarterectanie hadden moeten ondergaan (tabel 1). 


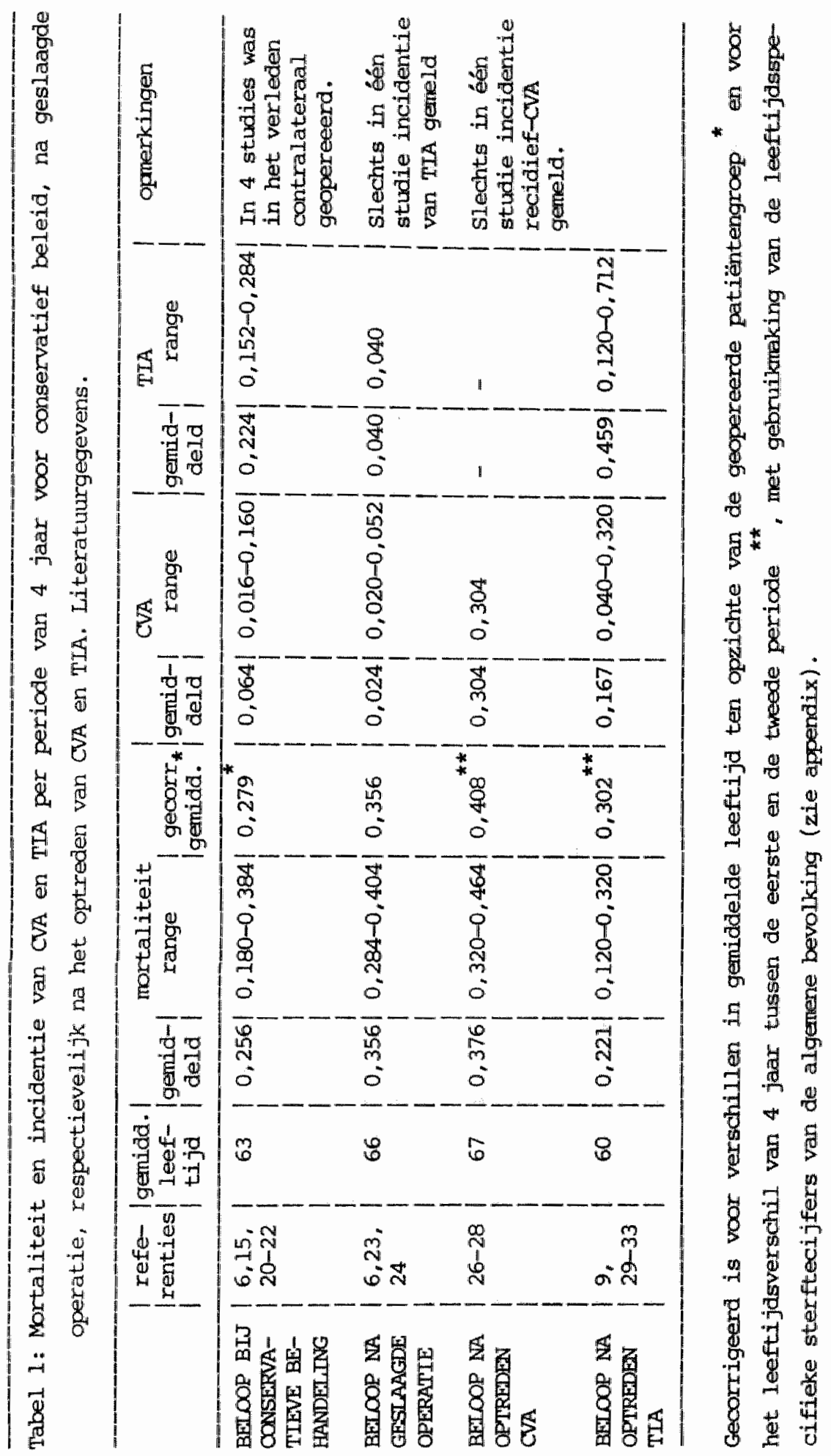


Tabel 2: Peri-operatieve mortaliteit en morblditeit van endarterector mie wegens asymptanatische carotis-stenose, in percentages van het aantal ingrepen.

\begin{tabular}{l|c|c|c|c}
\hline referenties & complicatie & gemiddeld & range \\
\hline $6,17,23-25$ & mortaliteit & $0,3 \%$ & 0 & $-1,5 \%$ \\
$6,17,23-25$ & CVA & $4,5 \%$ & 0 & $-18,28$ \\
$6,17,24$ & TIA & 3,68 & $1,2-7,1 \%$ \\
\hline
\end{tabular}

Tabel 3 bevat de resultaten van de analyse na respectievelijk 1,4 en 8 jaar follow-up. De kans op sterfte is na elke follow-up duur het laagst bij conservatieve behandeling. De kans op een niet-fataal CVA is na 1 jaar het hoogst bij operatieve behandeling, doch na 4 en 8 jaar bij conservatief beleid. De kans op TIA is steeds het laagst bij operatief ingrijpen. De verwachte utiliteit is na elke follow-up periode het hoogst voor conservatieve therapie.

Tabel 3: Berekende kansen op diverse uitkomsten na 1, 4 en 8 jaar follow-up voor de operatleve (LP) en conservatieve (CoNs) strategie, en de te verwachten utiliteiten van beide strategleën.

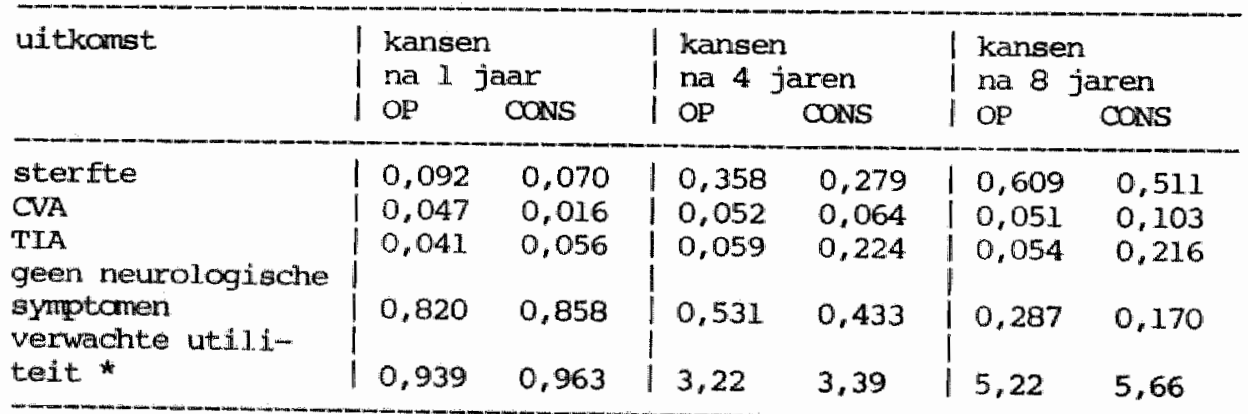

* De utiliteiten zijn uitgedrukt in voor kwaliteit gecorrigeende levensjaren (QUALY's). Eén jaar CVA- respectievelijk TIA-patiënt zijn is equivalent aan 0.75 respectlevelijk 0.95 jaar vrij zijn van neurologische symptomen.

Blijkens de sensitiviteitsanalyse is dit resultaat niet gevoelig voor extreme variatie van de utiliteiten. Of men nu de "utiliteit" van een CVA op 0.0 of 1.0 stelt, de conservatieve behandeling blijft de voorkeur houden (tabel 4). 
Tabel. 4. Verwachte utiliteit $\operatorname{van}$ operatieve (OP) en conservatieve (CONS) strategie na 1,4 en 8 jaren follow-up bij extreme variatie van de utiliteit van het CVA.

\begin{tabular}{|c|c|c|c|c|}
\hline $\begin{array}{l}\text { follow-up } \\
\text { dwur }\end{array}$ & $\left\{\begin{array}{l}\text { utiliteit } \operatorname{van} \\
\text { OP }\end{array}\right.$ & $\begin{array}{c}\text { CVA }=0.00 \\
\text { TIA }=0.95 \\
\text { CONS }\end{array}$ & $\begin{array}{l}\text { utiliteit } \operatorname{van} C \\
\mathrm{OP}\end{array}$ & $\begin{array}{c}\text { CUA }=1.0 \\
\text { TIA }=1.0 \\
\text { CONS }\end{array}$ \\
\hline $\begin{array}{ll}1 & \text { jaar } \\
4 & \text { jaren } \\
8 & \text { jaren }\end{array}$ & $\left\{\begin{array}{l}0,920 \\
3,07 \\
4,92\end{array}\right.$ & $\begin{array}{l}0,954 \\
3,29 \\
5,32\end{array}$ & $\begin{array}{l}0,947 \\
3,32 \\
5,34\end{array}$ & $\begin{array}{l}0,965 \\
3,44 \\
5,86\end{array}$ \\
\hline
\end{tabular}

sterftekans bij conservatieve behandeling.

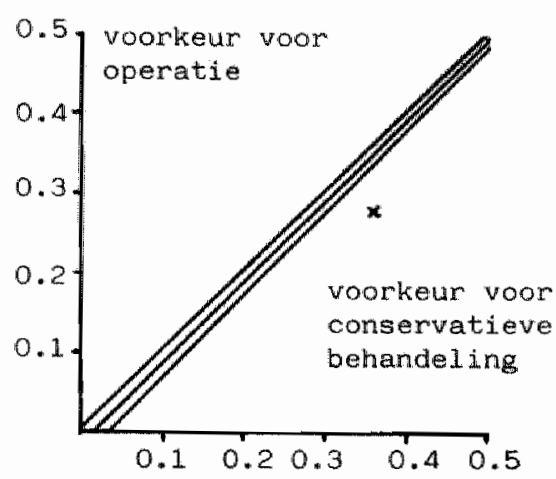

sterftekans na geslaagde operatie

Figuur 3: Sensitiviteitsanalyse met variatie van de sterftecijfers bij conservatieve behandeling en na geslaagde operatie van asymptomatische carotisstenose. Toestand na 8 jaar follow up. De sterftecijfers zijin uitgedrukt als sterftekans per periode van 4 jaar follow-up. De voorkeur voor operatie betreft alle punten (het gebled) boven de lijnen, en de voorkeur voor conservatieve behandeling kornt overeen met het gebied eronder. De lijnen komen overeen met kansen op operatiecomplicaties van respectievelijk $15 \%$ (bovenste 1 ijn), 8.48 (middelste $1 i j n$ ) en 08 (onderste $1 i j n$ ).

$x$ : puntschatting op grond van de literatuur.

Dok wat betreft de gebruikte kansen is het resultaat vxij stabiel. Uit figuur 3 blijkt in hoeverre onze schattingen van de mortaliteit bij conservatieve behandeling, en na ongecampliceerde operatie, onjuist dienen te zijn opdat alsnog de operatieve atrategie de voorkeur zou verdienen. Hiertoe zou de mortalitelt bij conservatieve benadering 
aanzienlijk ongunstiger moeten worden ten opzichte van de mortaliteit na ongecompliceerde operatie, en wel des te meer naarmate de kans op perioperatieve complicaties toeneemt. De figuux betreft de situatie na 8 jaar, maar na 1 en 4 jaar is vijwel hetzelfde beeld te zien. Variatie van andere kansen heeft nog veel minder invloed dan de twee genoemde sterfteci jfers.

\section{Discussie}

op grond van de gepubliceerde gegevens kan blijkens onze analyse een op operatie gericht beleid niet worden verdedigd. Na operatie lijkt de sterfte over de follow-up periode hoger te zijn. Dit wordt, $\infty$ k bij extreme variatie van de utiliteiten van CVA en TIA, niet gecampenseend door een lager risico op CVA en TIA. Deze conclusie kan getrokken worden zonder dat nog rekening gehouden wordt met de eventuele effecten van plaatjesremers.

De mogelijke vertekeningen in de analyse werken vooral ten gunste van operatie, zodat in werkelijkheid het voordeel van de conservatieve strategie wellicht nog groter is. Immers, het ligt voor de hand dat de prognose van geopereerden a priori beter was ondat bij hen geen contra-indicaties voor operatie waren vastgesteld. Bovendien doet het feit, dat in de conservatief behandelde groepen in het verleden vaak wel contralateraal geopereerd was, vermoeden dat het hier ging om patiënten met een vrij uitgebreid $1 i j$ den. Voorts zijn in de analyse de risico's van angiografie buiten beschouwing gelaten. Howwel aangenomen mag worden dat deze risico's tegenwoordig gering $z i j n(3,34,35)$, zullen ze toch vooral op rekening komen van een beleid waarbij operatie wordt overwogen. De belasting ten gevolge van angiografie en operatie op zichzelf, dus los van de eventuele complicaties, zou men nog als extra nadeel aan de operatieve strategie kunnen toevoegen. ook moet men ermee rekening houden, dat onderzoekers liever gunstige dan ongunstige behandelingsresultaten publiceren. Dit laatste kan echter ten aanzien van zowel geopereerden als niet-geopereerden een rol spelen.

Verondersteld mag worden dat de risico's van operatie lager zijn in gespecialiseerde chirurgische centra met veel ervaring. Echter, ook 
als de kans op operatie-complicaties op 0 gesteld wordt, blijuen de resultaten na operatie ongunstiger. In de literatuur varieert het. totale percentage operatiecomplicaties (mortaliteit en morbiditeit tesamen) dat men nog acceptabel acht van 1 tot $38(6,8,36)$. De laatste 10 jaar zijn de operatie-risico's afgenomen als gevolg vari de introductie van nieuwe technieken $(37,38)$. Het is nog de vraag of hilerdoor ook de lange termijnprogmose zal verbeteren. Bovendien worden er nog steeds complicatiepercentages gerapporteerd die hoger liggen dan die welke wij in onze analyse (tabel 3) gebruikten (39).

In de afweging tussen wel en niet opereren hebben wij bij gebrek aan gegevens niet de graad van ernst van de carotisstenose betrokken. In diverse publicaties kon echter geen verband worden gevonden tussen de prognose en de mate van vernauwing $(14,21,40)$. Eocale cerebrale ischemieën lijken eerder te worden veroorzaakt door embolieën dan door een mogelijke hemodynamische consequentie van een aamwezige stenose (41). Bovendien, ook al zou het potentiële voordeel van operatie toenemen bij ernstiger stenosen, de risico's van angiografie en operatie worden dan waarschijnlijk ook groter.

over patiënten met bilaterale stenosen waren te weinig specifieke gegevens voorhanden voor een aparte analyse. In het experiment met syintamatische patiënten leek weliswaar de prognose voor deze groep patiënten te verbeteren na geslaagde operatie, maar dit werd overschaduwd door een overmat aan operatiecorplicaties (11).

Volgens somigen is operatie effectief als $\mathrm{zlj}$ wordt gereserveerd voor patiënten jonger dan 65 jaar zonder risicofactoren als hypertensie, hartinfarct of decompensatio cordis in de anamese $(6,23)$. Dit wordt echter niet ondersteund met empirische gegevens. Het feit dat zulke patiënten er na operatie naar verhouding goed aan toe zijn, is bedrieglijk. Bij gebrek aan een geschikte controlegroep kan het effect van operatie worden verward met een reeds a priori betere prognose.

Bij de beoordeling van de effectiviteit var endarterectamile $z i j n$ ook de volgende overwegingen van belang: 
- patiẻnten met carotisstenosen hebben dikwijls een meer algemeen vaatlijden $(42,43)$. Ook in verband met hun leeftijd zal er relatief vaak sprake zijn van aandoeningen als hypertensie, hartlijden en diabetes. In veel studies kant de meeste sterfte dan ook op rekening van cardiale pathologie $(15,23,44,45)$.

- De localisatie van een souffle of stenose heeft weinig voorspellende waarde voor de localisatie van later optredende accidenten (3, 42, 45).

om deze redenen ligt het voor de hand dat een locale ingreep maar een beperkt effect kan hebben, dat bovendien gemakkelijk te niet wordt gedaan door de risico's van operatie.

- Tenslotte kan er re-stenosering optreden, tot in 3.5\% van de gevallen per jaar na operatie (46-52).

Onze analyse was gericht op angiografisch aangetoonde stenosen. Recent onderzoek met behulp van non-invasieve methoden (Duplex Doppler scan) onclersteunt de opvatting dat een conservatieve benadering van patiënten met een asymptomatische carotissouffle de voorkeur verdient (53, 54).

\section{Conclusie.}

Op grond van de literatuur kan operatieve behandeling van asynptomatische carotisstenosen niet gerechtvaardigd worden. Wij menen dat endarterectomie niet als behandeling van asymptomatische carotisstenose aanvaard kan worden als de effectiviteit ervan niet is aangetoond.

\section{LITEERATUUR.}

1. Lodder $J$, De Krom MCTFM. De consequenties van een toevalsbevinding: de asynptomatische carotissouffle. Ned T Geneesk 1982; 126 : 1220-1225.

2. Thompson JB, Patman RD, Persson AV. Management of asymptcomatic carotid bruits. American surgeon 1978; 42: 77-80.

3. Hurst JW. Noises in the neck. N Engl J Med 1980; 302: 862-863.

4. Strandness DE. Why the controversy about carotid endarterectomy. J Cardiol Med 1981: 6: 1067-1070. 
5. Barnett HM, Plum F, Walton JN. Carotid endarterectomy - an expression of concern. Stroke 1984; 15: 941-943.

6. Thompson JE, Patman FD, Talkington OM. Asymptomatic carotid bruit: longterm outcome of patients having endarterectony compared with. unoperated controls. Ann surg 1978; 188: 308-316.

7. Busuttil RW, Baker JD, Davidson RK, Machleder HI. Carotid artery stenosis - hemodynamic significance and clinical course. JAMA 1981; $245: 1438-1441$.

8. Fields WS. The asymptonatic carotid bruit - operate or not? stroke 1978; 9: 269-271.

9. Mohr JP. Asymptomatic carotid artery disease. stroke 1982; 13: $431-433$.

10. Kuller IH, Sutton KC. Carotid Artery Bruit: is it safe and effective to auscultate the neck. Stroke 1984; 15: 944-947.

11. Fields WS, Maslenikov V, Meyer JS, Hass WK, Remington RD, Mac Donald $M$. Joint study of extracranial arterial occlusion. JAMA $1970 ; 211$ : 1993-2003.

12. Lubsen J, Hunink MGM. Medische besliskunde: een oud probleem in een nieuwe jas. Ned Tijdschr Geneesk 1984; 1.28: 249-257.

13. Hennerici M, Rautenberg W, Mohr S. Stroke risk fram symptomless extracranial arterial disease. Lancet 1982; 1180-1183.

14. Kroener JM, Dorn PL, Schoor PM, Wickbom I, Bernstein EF. Progress of asymptomatic ulcerating carotid lesions. Arch surg 1980; 115: $1387-1392$.

15. Levin SM, Sondheimer FK, Levin JM. The contralateral diseased but asymptomatic carotid artery: to operate or not? An update. Am J Sung 1980; 140: 203-205.

16. Moore WS. Natural history of nonstenotic, asymptomatio ulcerative lesions of the carotid artery. Arch Surg 1978; 113: 1352-1359.

17. Moore WS, Boren C, Malone JM, Goldstone J. Asymptamatic carotid stenosis: inmediate and long term results after prophylactic endarterectcmy. Am J Surg 1979; 138: 228-233.

18. Weinstein MC, Fineberg HV. Clinical Decision Analysis. Saunders, Philadelphia 1980.

19. Pauker SG, Kassiver JP. Deciston Maker. The personal micromcomputer decision analysis, 1982; version 3.0. New England Medical Center, Boston. 
20. Humphries AW, Young JR, Sentilli PH, Beven EG, de Wolfe VG. Unoperated, asymotomatic significant intemal carotid artery stenosis: A review of 182 instances. Surgery 1976; 80: 695-698.

21. Podore EC, De Weese JS, May AG, Rob CG. Asymptomatic contralateral carotid artery stenosis: a five years follow-up study following carotid endarterectany. Surgery 1980; 88:748-752.

22. Durward $Q T$, Ferguson GG, Barr HWK. The natural history of asymptomatic carotid bifurcation plaques. Stroke 1982; 13: 459-464.

23. Javid $\mathrm{HJ}$, Ostermiller WE, Hengesh JW, et al. Carotid endarterectomy for asymptomatic patients. Arch Surg 1971; 102: 389-391.

24. Nunn DB. Carotid endarterectomy: an analysis of 234 operative cases. Ann Surg 1975; 182:733-738.

25. Easton JD, Sheman DG. Stroke and mortality rate in carotid endarterectany: 228 consecutive operations. Stroke 1977; 8: 565-568.

26. Sacco RL, Wolf PA, Kannel WB, McNamara PM. Survival and recurrence following atroke, The Framingham Study. Stroke 1982; 13: 290-295.

27. Solzi P, Rilng $H$, Najenson $T$, Luz $Y$. Hemiplegics after a first stroke: late survival and risk factors. Stroke 1983; 14: 703-709.

28. Garaway WM, Whisnant JP, Drury I. The changing pattern of survival following stroke. Stroke 1983; 14: 699-703.

29. Toole JF, Yuson CP, Janeway R, et al. Transient Ischemic Attacks: A prospective study of 225 patients. Neurology 1978; 28: 746-753.

30. Whisnant JP, Cartlidge NEF; Elveback LR. Carotid and vertebralbasilar transient ischemic attacks; effect of anti-coagulants, hypertension and cardiac disorders an survival and stroke occurrence - a population study. Annals of Neurology 1978; 3: 107-115.

31. Heyden $S$, Heiss $G$, Heyman $A_{4}$ et al. Cardiovascular Mortality in Transient Ischemic Attacks. Stroke 1980; 11: 252-255.

32. Simonsen N, Christiansen D, Heltberg A, Marquardisen J, Pedersen E, Sorensen PS. Long-term prognosis after transient ischemic attacks. Acta Neurol Scandinav 1981; 63: 156-168.

33. Cote $R$, Barnett HJM, Taylor DW. Internal carotid occlusions: a prospective study. Stroke 1983; 14: 898-902.

34. Eisenberg RL, Bank WO, Hedcock MW. Neurologic complications of angilography for cerebrovascular disease. Neurology 1980; 30: 895-897.

35. West $\mathbb{H}$, Burton R, Roon AJ, Malone JM, Goldstone J, Moore WS. Comparative risk of operation and expectant management for carotid artery disease. Stroke 1979; 10: 117-121. 
36. Hass JS. An appraoch to the maximal acceptable complication rate after surgery for Transient Cerebral Ischemia (TIA). Stroke 1979; $10: 84$.

37. Thompson JE, Talkington CM. Carotid endarterectomy. Ann Surg 1976; 184: $1-15$.

38. Thompson JE. Complications of carotid endarterectony and their prevention. World J Surg 1979; 3: 155-163.

39. Brott $T$, Thalinger $\mathrm{K}$. The practice of carotid endarterectomy in a large Metropolitan Area. Stroke 1984; 15: 950-955.

40. Johnson N, Burnham SJ, Flanigan DP, Goodreau JJ, Yao JST, Bergan JJ. Carotid endarterectomy: a follow-up study of the contra-lateral non-operated carotid artery. Ann Surg 1978; 188: 748-752.

41. Fell G, Breslau P, Knox RA, Philips D, Thiele BL, Strandness DE. Importance of non-invasive ultrasonic Doppler testing in the evaluation of patients with asymptomatic carotid bruits. Am Heart J 1981; 102: 21-26.

42. Heyman $A$, Wilkinson WE, Heyden $S$, et al. Risk of stroke in asymptamatic persons with cervical arterial bruits: a population study in Evans County, Georgia. N Engl J Med 1980; 302: 838-841.

43. Levin SM, Sondeimer FK. Stenosis of the contralateral carotid artery - to operate or not? Vasc Surg 1973; 7: 3-13.

44. Kartchner MM, McRae PL. Non-invasive evaluation and management of the "asymptamatic" carotid bruit. Surgery 1977; 82: 840-847.

45. Wolf PA, Kannel WB, Sorlie P, MoNamara P. Asymptamatic carotid bruit and risk of stroke. The Framingham Study. JAMA 1981; 245: $1442-1445$.

46. Callow AD, Matsumoto G, Cossman D, Stein A. Early restenosis after carotid endarterectony. Stroke 1977; 8: 14 .

47. Cantelmo NL, culter BS, Wheeler HB, Herrmann JB, Cardullo PA. Non-invasive detection of carotid stenosis following endarterectoryy. Arch Surg 1981; 116: 1005-1008.

48. Cassman D, Callow AD, Stein A, Matsumoto G. Early restenosis after carotid endarterectomy. Arch Surg 1978; 113: 275-278.

49. Hertzer NR, Martinez BD, Benjamin SP, Beven EG. Recurrent stenosis after carotid endarterectony. Surg Gyn Obstet 1979; 149: 360-364.

50. Kremen JE, Kaupp HA, MCDonald KM. Restenosis or occlusion after carotid endarterectony. Arch Surg 1979; 114: 608-610. 
51. ortega G, Gee W, Kaupp HA, MaDonald KM. Postendarterectorny carotid occlusion. Surgery 1981; 1093-1097.

52. Stoney RJ, String ST. Recurrent carotid stenosis. Surgery 1976; 80: $705-710$.

53. Lees Rs. The natural history of carotid artery disease. Stroke 1984; 15: 603-604.

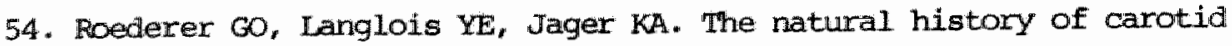
arterial disease in asymptomatic patients with cervical bruits. stroke 1984; 15: 605-613.

\section{APPENDLX}

Leeftijascorxectie voor de sterftekans.

1. ondat de geniddelde leeftijd in de conservatief behandelde patiëntengroepen 63 jaar was en die in de geopereerde groepen 66 jaar, pasten wij een leeftijdscorrectie toe op de sterftekans van de eerste groep.

De 4-jaars sterftekans voor 63-jarigen is 0.256 .

De 4-jaars sterftekans in de algemene bevolking voor 6.3-jarigen is voor manner en vrouwen tezamen: 0.070 .

Het extra sterfterisico ("excess-risk") voor deze patiënten is dan: $0.256-0.070=0.186$.

De 4-jaars sterftekans in de algemene bevolking van 66-jarigen is voor mannen en vrouwen tezamen: 0.093 .

Als de (voor de leeftijd gecorrigeerde) 4-jaars-sterftekans van conservatief behandelde asymptomatische patiënten namen wij nu: "excess-risk" + leeftijdsspecifieke 4-jaars-sterftekans $=0.186+$ $0.093=0.279$.

2. Op dezelfde wijze corrigeerden wij voor leeftijasverschillen de sterftekansen van:

- de conservatief en operatief behandelde patiënten in de tweede 4-jaars-periode. Zij ziju inmers geniddeld 4 jaar ouder.

- de sterftekans na het optreden van CVA en TIA. De gemiddelde leeftijd van deze patiënten in de gepubliceerde series was namelijk 67 respectievelijk 60 jaar, terwijl in de analyse bij het begin van de tweede 4-jaars-periode uitgegaan wordt van een leeftijd van $70(=66+4)$ jaar. 


\title{
Over vertekening van testuitslagen door reeds aanwezige informatie
}

\author{
J A. KNOTTNERUS EN Prof. Dr. F. STURMANS *
}

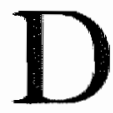
ACELIJJKS worden er door huisartsen en specialisten onderzocken aangevraagd bij 'derden'. Zoals bij alle diagnostische verrichtingen is hierbij de bedoeling, dat vooral ontwikkclde hypothesen, gevormd op grond van anamnese en reeds verricht onderzock, door de uitslag van de aangevraagde lests op hun waarschijnlijkheid getocst worden. Anders gezegd: door de (interpretatie van de) tostuitslag veranderen de 'a priori kansen' op bepaalde aandorningen of toestanden in "a posteriori kansen"

\footnotetext{
Samenvatting Bij het aanyragen van diagnostisch onderzoek wordt dikayijls een korle beschrijving gegeven van het klinisch beeld. Vaak is er oak een gerichle urangstelling. De door de diagnost afgegeven lestwitslag kan dan rechtstreeks beinviloed worden door de sooraf verknegen informatie. Hol onderzoek is dan geen onafhankelij. ke toetssleev meer van de diagnostische bypothesen van de aanuragende arts.
}

(fig. 1). De grootte van die veranderingen zjjn bepalend voor de mate waarin de testuitslag zou mogen bijdragen aan de besluitvorming.

Betekenis van reeds aanwezige informatie ('prior' informatie)

Er zijn verschillende procedures gangbaar wat betreft de aan de te consulteren diagnost tc verstrekken informatie. Bij bloedonderzock worden in het algemeen slechts de naam, de geboortedatum, het adres en het zickenfondsnummer op het anvraaglormulier genoleerd. $\mathrm{Bij}$ andere onderzocken, zoals röntgendiagnostiek, elektrocardiografie, endoscopie, pathologisch-anatomisch onderzoek en dikwijls ook bij microbiologisch onderzoek ligt dit anders. In de regel wordt een korte beschrijuing gegeven van het klinische beeld, gekoppeld aan een differentiële diagnose en/of een gerichte vraagstelling.

Bij bloedonderzoek dat elders verricht wordt, zal het niet vaak voorkomen dat de uitvoering ervan wordt beïnvloed door reeds anwezige informatie, ook al, omdat de aard van de bepalingen zich daarvoor niet leent. In de andere genoemde gevallen echter is te verwachien dat de diagnost terdege mot de vooraf verstrekte informatie rekening houdt.

Dit heeft enerzijds voordelen: de diagnost kan zijn aandacht richten op de vraagstelling, en speciaal letten op aanwijzingen in die richting. Soms ook zall hij crmee rekening houden in verband met de specifieke eisen die gesteld moeten worden aan de te volgen procedures, bij voorbeeld als er bijj microbiologisch onderzoek een specialc voedingsbodem wenselijk is. Ten slotte zal de diagnost, bij het presen teren van de uitslag, het door hem gevonden beeld kunnen interpreteren in het licht van de vooraf reeds bekende gegevens.

\footnotetext{
Arts, resp. hooghlerian epidenvalogie Capacitcitsgroep Epirhemiologie/Gutend. Aneidiszorgonderzock Rajksumbersiteit Limsburn te Malastricht
} 
Anderajds schuill er ean addes onder het gras: watudijik

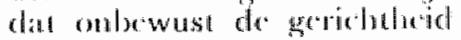
op cou bepanald puont omstidat in kokerrien dat tesiuiblatgen (4) zichyelf nicet onalliankelijk

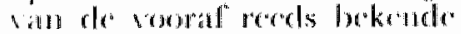

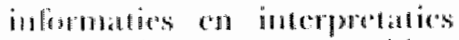

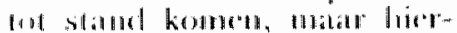

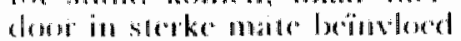
an mogelijk vertokend worden. Dat wil hoggen, ella tesstmitslitg xell werde mede bepitald does de at priori kiuss: daarnaast wordt bij de interpretatic van de vitslay de a priori kans ook weer (en in dit geval (crecht) in beschouwing gonomen, zodtat de a prion infintmatio "dubbel worde geleth. I) e west is dan geen echere rest, in de zin vim ecn onalthankelijks toctssicen, mat

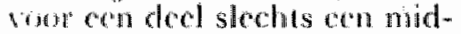
del not "bevestiging" van vermordens (fig. 2). Het gevolig kan tijn diat nu te gemakkolijk ent lepalde diagnose defini-

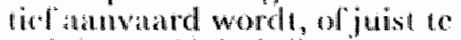
wring andacht krijgt.

\section{Praktische problemen}

As men het principe andvardi dat testuitslag on a priori informatic van elkatronafh.nnke-lijk mocten xijn, dan bijike direce dat dit in de prakaijk nice allajd is rast to houden. Her mest duidelijk is dit, als hypothesevorming en het tilvoeren van tests door cén

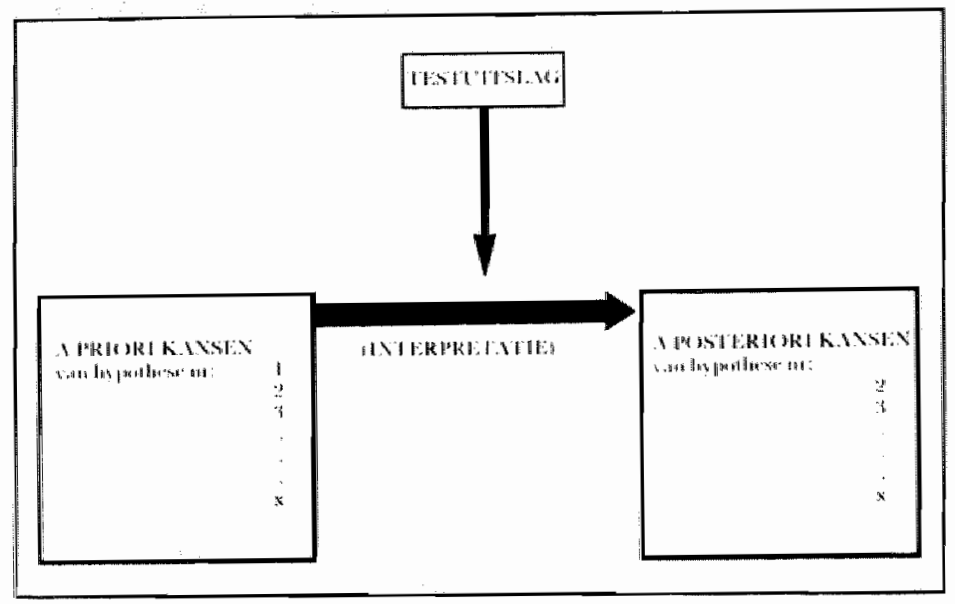

Jigutur 1 .

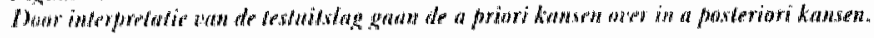

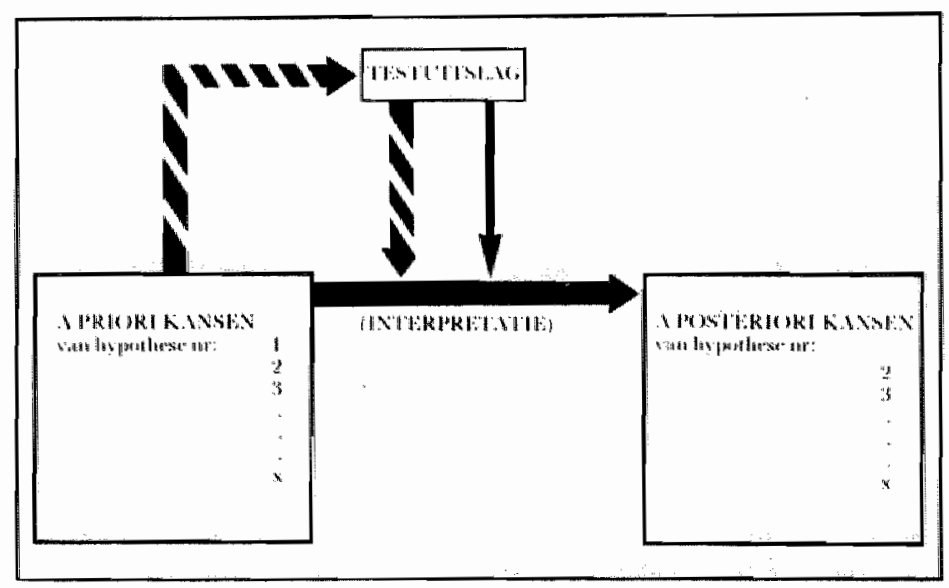

Finume 2

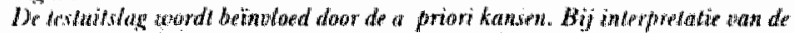

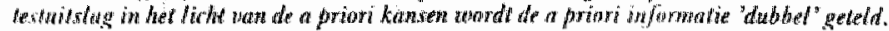


cn dezelfde persoon plaatswinden. Dc arts dic op grond van de anamnese overmatig alcoholgebruit vermoedt, zal vervolgens wellicht de lever eerder palpabel achten dan wanneer ecn dergelijke anamnese zou ontbrition. Ook is denkbaar dat de bloceddrukmeting bij cen wwar rokende, ongezond levende manager naar boven wordt algerond; terwijl bij een sportieve patiènt van wie men weet dat deze een hekel heeft aan medicijnen, het tegenovergestelde kan gebeuren. En denkt u cens aan het aflezen van de kleurnuances van de Sicca-meter bij iemand met onverklaarde moeheidsklachten. In dergelijke gevallen zijn hypothesevorming en diagnostick mocilijk wan elkaar te scheiden. Men kan dan niet veel meer doen dan:

1. toch proberen zo objectief mogelijk te werk te gaan;

2. er rekening mee houden dat de bevindingen beinvloed kunnen zijn door de voorkennis.

Een arts die met een collega samenwerkt kan, als het om voor het beleid cruciale bevindingen gaat, deze vragen het onderzock ook bij dezelfde pittiënt te docn zónder voorafgaande anamnese. De a priori informatic dient dan ank niet op andere subtiele wijzen te worden overgedragen. Beter dan: Zou jij ook even willen voelen of je de lever van meneer A ook vergroot vinde?', is: "Zou jij de buik van meneer $A$ even willen onderzoeken?' Een systematisch buikonderzock is dan wel ecn vereiste.

Terugkerend natar de situatie waarbij onderzoek bij derden wordt ctangevraagd, lijkt het daar allemaal op het cerste gezicht minder moeilijk te liggen. En bij blocdonderzoek is dat ook zo. Maar in andere gevallen, zoals radiodiagnosiiek of pathologisch-anatomisch ondcrzock kan de genoemde 'dubbeltelling' juist extra sterk uitpakken:

- De aanvragende arts verstrekt a priori informatie.

- De diagnost beoordeelt en beschrijft de uitslag in thet licht van de a priori infiormatie.

- De aanwragende arts meent, na ontvangen van de witslag, dat nu eindelijk objectieve gegevens bekend zijn, en op zijn beurt interpreteert hij de beschreven uitslag in het licht van de a priori informatic.

Het moge duidelijk zijn dat op deze wijze de "voorspellende" warden van bij voombeeld cen uitstrijkje of cen mammogram hoger kunnen uitwallen dan zij zouden zijn als de reeds bekencle informatic niet in de uitslag verworkt was. Als mon hierbij voorts het valak kleurrijke, maar nict alijid voor éćn interpretatie valbare taalgebruik van vecl diagnosten in aanmerking necmt, worden de volgende uitslagen begrijpelijk: 'Inderdaad wat grove maagplooien, zoals men dic wel zict bij chronische gastrilis'; 'Op zichzell geen verdacht becld, doch malignitcit niet geheel uit te sluiten'; 'Enige discusversmalling op de niveaus L3-L4-1.5. Gezien de anamnese valt myclografic te overwegen'.

\section{Een voorbeeld: de biopsie}

Het probleem van vecl uitslagen is niet zozeer het feit dat geen volstrekt zekere uitspraak gedaan wordt. Immers, warer zekerlicid niet is to geven, dient deze ook niet gesuggereerd te worden. De moellijkheid is vooral dat de mate van onzekerheid vaak onduidelijk blijft. Dit geldt a fortiori als het gaat om uitslagen, waarbij de grens tussen normaal en abnormaal niet. scherp te trekken is en als er meer dan én diagnostisch allternatief overwogen moet wor. den. Het zijn ook juist dic situaties, waarin de voorkennis cen op zichzelf nict typisch beeld het laatste duwtje kan geven in de enc of de andere richting. Ook ten arazicn van 
pathologisch-anatomisch onderrock dat raik geache wordt de deliniceve arbiurage - de 'gouden standaard" - te yijo, zijon es wat dit betreft mecr dilemma"s dan in het algermeen vermocd wordt. Underwood geeft in zijn 'Introduction to biopsy interpretation and surgical pathallogy' het volgends: voorbecld: een botbiopsic word genomen van een laesic, warvan op $\mathrm{kli}$ nische en radiologische gronden word vermoed dat het con ostcossarcoomn is. I) biopsic laat in werkelijklucil nicts anders zien dan een fractuurcallus. Een patholoog geeft als uilslag: osteosarcoom. Hij maakt deze beoordelingsfout op grond van de a priori informatie en ondat hij weet dat calluswectsel sterk op osteosarcoom kan lijken. Gezien de hem reeds verstrekte informawic neemt hij het zekere voor het onzekere. Hij moel immers van goeden huize komen om de clinicus en de radioloog tot andere gedachten te brengen, en het zal toch maar cens cen osteosarcoom zijn. Een andere patholoog rapportect wel en callusbeeld matar men atht hem weing gelinolwatardig omdat hij bekend staat als ienand die uitslagen afgeeft nonder het röntgenbed gewen te hebben. Fen derde patholoog. die op zich wel ge- loofwaandig wordt geacht, herkent de callusvorming ook. Dewe conclusic is echter nict in overecenstcenming met $\mathrm{dc} \mathrm{kli}$ nische en radiologische bevindingen. De patholoog gaat er vanuit dat dit slechts geaccepteerd wordt als dit gebrek aan overcenstemming expliciet wordt vermeld, met de mogelijke verklaring dat dit kan liggen aan een inadequaal gekozen plek om te biopteren."

Underwood beschrijf voorts alan de hand van velle voorbeelden de: gelleidelijke: overgang van "normaal" naar maligne, en van benigne naar malignc. Vaak zijn goed- en kwaadaardig niet precies te onderscheiden. Er zijn veel geheel of gedecltelijk overlappende morfologische kenmerken, ook als het om andere lacsies dan nieuwvormingen gaat. Weinig beelden zijn pathognomonisch en foutc classilicaties zijn zeer wol mogelijk. Wat betreft de vermelding van uitslagen aan de aanvragers stelt Underwood dat het zinvol is niet alleen te melden dat thet beeld past bij bepaalde afwijkingen, maar ook dat het bij andere alwijkingen niet past. Dii kan helpen relevante diagnosen uit te sluiten. Wat betreft het komen tot meer eensluidende, kwantificerbare uitslagen, wijst hij in navolging van anderen op de mogelijkheid om diagnosen te vermelden met een bepaald betrou whatarheidsinterval.

Hierdoor zou de mate van onzckerheid kunnen worden overgedragen.

\section{De methode-Schwartz}

Een meer precieze, besliskundige benadering is dic van Schwartz et al. ${ }^{2} \mathrm{Zij}$ gaan er daarbij van uit dat diagnostiek, ook de pathologisch-anatomische, gekenmerkt wordt door het werken met onzekerheden en dus kansen. Met hun methode wordt tegemoetgekomen aan de behoefte aan zowell kwantificering van onzekerheden, als aan de noodzaak van het onathankelijk zijn van de testuitslag van de a priori informatic. De methode is als volgt:

1. de behandelende arts stelt op grond van het klinische beeld cen lijst op van aandoeningen en toestanden die in aanmerking komen. Voor zichzelf geeft hij door middel van een numerieke schatting aan hoe watschijnlijk de alternatieven zijn ten opzichte van elkaar (a priori kansen);

2. de patholoog omtvangt bij wijze van vraagstelling de Jijst van alternatieven in willekcurige volgorde, zonder aanduiding van hun 
TABELI.

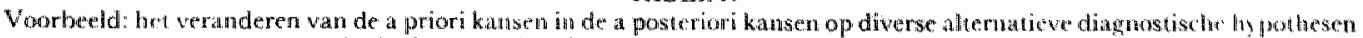
conder invloed wan de infermatie vitu de biopsie (methode sohwart?).

\begin{tabular}{|c|c|c|c|c|}
\hline $\begin{array}{l}\text { Diatgnostische } \\
\text { hyponcese }\end{array}$ & 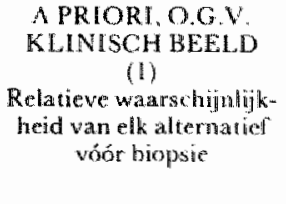 & 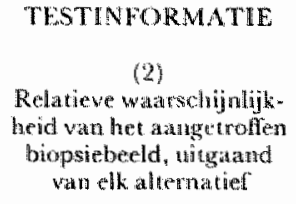 & 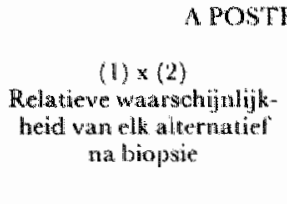 & 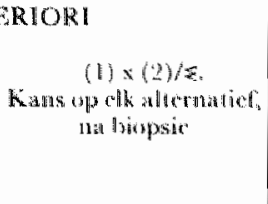 \\
\hline $\begin{array}{l}\text { (Variant wan) normal } \\
\text { Ontsteking } \\
\text { Benigne tunor } \\
\text { Maligne tumor }\end{array}$ & $\begin{array}{r}15 \\
15 \\
5 \\
1\end{array}$ & $\begin{array}{r}1 \\
2 \\
5 \\
15\end{array}$ & $\begin{array}{r}15 \\
30 \\
25 \\
15 \\
-85\end{array}$ & $\begin{array}{l}48 \% \\
35 \% \\
29 \% \\
12 \%\end{array}$ \\
\hline
\end{tabular}

respectire waarschijnlijkheden. Hij bekijkt het preparaat on geeft nu zelf in een numcrieke schatting weer how waarschijnlijk het gevonden morfologische becld is bij elk van de door de aanvager genoemde alternatieven "conditionele" kansen). De patholoog kan hicrbij uitcraard ook alternaticven betrekken die door de aanvragende arts niet waren overwogen;

3. als de patholoog nieuwe mogelijkhoden heeft gonocmd, sordt de aamvrager eerst gevratagd deze alsnog te voorzien van eer a prioni kans, in relatie tot dc andere allernaticen;

4. ten slotie worden de schattingen van de patholoog, op grond van allecen de biopsic, gemeld aan de aamvragende arts. Deze kan ac nu combineren mett de cigen a pritori schattingen, on hieruil volere de a posteriori schatting. Dil gelbeurt, formeel gesprokun, door de a priori wairschijnlijkheden van clk alternatief met de betreffende conditionele kansen fo vermenigvuldi- gen (appendix). In tabel $\mathbb{1}$ is deze benadering aangegeven mel ech voorbecld. In principe is zij dezelfde als die, welke aan de orde was in her eerste artikel in deze rubriek. Het verschil is dat hier uitgegaan worde van relatieve waarschijnlijkheden in plaats van in een percentage uitgedrukte kansen. Het gaal dan om de warschijnlijkheid van respecticvelijk:

- Ecn bepaalde diagnose of loestand op grond van de informatic die voor het doen van de lest over de botrefrende pationt beschikbaar is (kolom 1).

- Hel aangetrolicn beeld, gegeven elk der overwogen alternatieven (kolom 2).

- Elk alternatief na combineren van de informatie van de kolommen 1 en 2. Dit is wecrgegeven in de kolommen onder 'a posteriori', voor respenticvelijk de relaticue watrschijnlijkheden cu de in cen perentage uitgedrukte kansen.

De relaticve warschijnlijkheden zijn relkens witgedrukt als veclvouden van do minst waarschijnlijke mogelijkheid. Dere uitdrukkingsvorm heef praktische voordclen als er veel alternatieven overwogen worden of wanncer sommige alternaticven een $x$ eer lage waarschijnlijkheid hebben. Uit dit voorbeeld blijkt dat, als men de biopsic-informatie combineert met de a priori schattingen, het mogelijk is dat maligniteit uitcindelijk toch nied hed meest waarschijnlijk is. Dit ondanks hot feil dal men dit biopsicbeedd hee merese frequent (dert nied altijd!) aantreft bij malligno uumoren.

Schwarte C.s. vergeleck voor een vicrtal recte casussen met elkaar encrzijds de a posteriori kans op de diverse alternatieven volgens do zojuist beschreven formele methode $10 t$ stand gekomen, met anderzijds de rechtsircekse, meer intuiticve, schatling van de a posteriori kansen dour de patholoog, op grond van zowel de klinische als dr bistologische gegevens. Hierbij bleken grote verschillen naal voren te komen. Zo leidde in ećn gcval de formelle metholk tot ren 
kans op tuberculose wersus dic np salcouldose vath $80 \%: 20 \%$, trewijl de dincete interpretatic door do patholoog de vorhouding 15\%:85\% opleverde.

\section{Conclusies}

Hor is nicet allujd mogelijk, o'n atket nict gebruikelijk, om de uilslags van ecn diagnoslisch undrorack te beschrijuen los van de" receds andowerige klinische vermoedens. Beswendien is mong gewend om vooral thatr con nitslag loc te schrijucen, zonder explicitering van de: kansen dat het gevondene roorkomt bij verschillende alernaticse diagnosen.

Eon bonadering, wats die vall Schwarte c.s., kan edeher vourdelen bieden voor de rapportage en interpretatic van uilslagen van diverse diagnostische technicken. in:

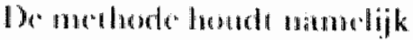

1. on duidelijker scheiding van beschrijuing an interpretatice van de uitslays:

2. geringere afhankelijkheid van de uitslag van reeds bestaande vermoedens:

3. kwantificering van onzekerheden, en daarmee het wegnemen van vod sprakkverwarring;

4. het mogelifk maken van besliskundig-analytische bcnaderingen met voordelen voor onderwijs, cvalluatic

\section{Appendix}

In do benadering van Schwartz c.s. wordt impliciet gewerkt met het begrip "atannemelujkhcidsquotient' (in het Engets: likelibood ratio).

Dit is:

de kars op en bepaalde Icstuitslag bij mensen met oen bepalde zickte

do: Kans op dic willsigg be grezondon

Uit kolom 2 van tabel I is dit quotient voor wh alternatic direct af te

Jewen, thamelijk: voor ontstcking voor benigne lumor voor maligne f umor

$2 / 1=2$

$5 / 1=5$

$15 / 1=15$

Het annemelijkheidsquotican is cen maat vour thet onderscheidend vermogen van de testuitslag. Als hot gaat om ecn situatie waarin slechts sprake is wan de mogelijkheden zick en nict-zick xijn, is het

atanemelijkheidsquotient gelijk aan:

$$
\text { do sensitiviteit }
$$

$100 \%$ - de speciliciteit.

en loetsing;

5. con heldere afbakening wan verantwoordelijkheden van diagnosi an clinicus.

Als literatuargegevens ontbreken voor het onderbouwen van kwantitatieve schattingen $_{n}$ is een zo goed mogelijk subjectieve schatting op grond van de eigen crvaring altijd nog beter dan een mistige en voor velerlei uideg vatbare formulering.

Alspraken tussen curatief en diagnostisch werkzame artsen zijn inmiddels zinvol juist ook voor degenen die van de geschetste formele benadering vooralsnog geen heil verwachten) tencinde te komen tot:

- Niet voor misverstand valbare communicaticvormen.

- Duidelijkheid over de te verstrekken voorinformatie en over de vraag of de integratic van klinische en diagmostische gegevens recds door de diagnost verricht moeten worden. Voorts is het met het oog op de gewenstc onathankelijkheid van kJinische voorinformatie en testuitslag van belang dat diagnostische methoden dic hierop inspringen, aandachi krijgen, zoals: 
- Het gobruik van "randomzero" blocd drukmeters.

- Het volgen van standaardprocedures bij het beoordelen wan foto's en preparaten, los van de aanvraagindicaltic.

Het is nict duidelijk waarom dergelijke 'geblindeerde' beoordelingen in het algemeen stechis torgepast zouden moc- ten worden in het kader van wetenschappelijk onderzoek en niet in her kader van patiëntenzorg. In de gedachtenvorming over vrocgujdige diagrostick van mammacarcinoom worde mede in dit verband onalhankelijke beoorde. ling door meer dan één radioloog resp. patholoog-anatoom overwogen.

\section{Literatuur}

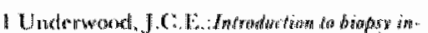

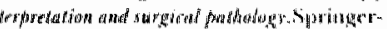

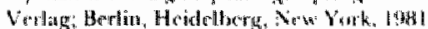

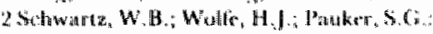

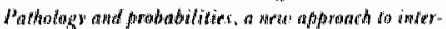

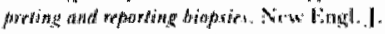

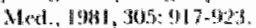

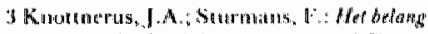

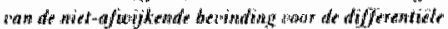

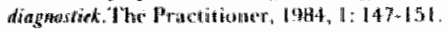


DEEL IV

DIAGNOSTISCHE TESTS NADER BEZIIEN. 
DIAGNOSTISCHE TESTS.

Wormen, referentiewaarden en testkenmerken nader bezien: een inventarisatie.

J.A. Knottnerus 1)

Samerwatting.

In het voorgaande is wat betreft de waarde van diagnostische tests meestal gebruik gemaakt van de temen sensitiviteit en specificiteit. Deze impliceren en bepalde uitwerking van het begrip 'referentiewaarde'. In het nu volgende hoofdstuk wordt dieper op dit begrip ingegaan. Er wordt een inventarisatie gegeven van de verschillende wijzen warop het vraagstuk van de referentiewaarden kan worden benaderd. Aan de orde komen de volgende benaderingen: gebruikelijk bij gezonden; onderscheiding van personen met en zonder bepaalde klachten of ziekten; testuitslag en prognose; testuiltslag en het belang van de uitkansit. In dit kader worden diverse methoden en maten besproken. Het: blijkt, dat referentiewaarden nilet in het algemeen zijn te definieren, maar dat de te kiezen oplossing afhangt van de situatie en het gestelde doel.

1) Capaciteitsgroep Epideniologie en Capaciteitsgroep Huisartsgeneeskunde

Rijksuniversiteit Limburg 
1. Inleiding.

Resultaten van diagnostisch onderzoek ontlenen hun betekenis aan het feit, dat zij iets zeggen over de gezondheidstoestand van mensen, en dat het bekend worden ervan nuttig is voor die gezondheidstoestand of, meer algemeen, het welzijn ten goede kant. In de praktijk kont het er op neer dat men bepaalde resultaten vergelijkt met een nom of referentiewaarde. Uit die vergelijking vloeit een conclusie voort die in de eerste plaats een interpretatie onvat van uitslagen als "normal." (of niet-afwijkend, negatief) of, in meer of mindere mate, afwijkend (positief). In de tweede plaats kan de testuitslag gevolgen impliceren voor de besluitvorming over eventuele verdere stappen op het gebied van diagnostiek en/of therapie.

Vanwege het normatieve aspect van het adjectief 'normaal' de mogelijke verwarring met de 'nomale verdeling' volgens Gauss en tenslotte het besef dat er altijd een arbitrair element kleeft aan nomen, spreekt men heden ten dage liever van referentiewaarden dan van normaalwaarden.

De interpretatie van een uitslag als vallend binnen of buiten het 'referentiegebied' kan op ulteenlopende wijzen tot stand komen, die niet tot dezelfde conclusie hoeven te leiden. Ondat een andere interpretatie van een uitslag kan leiden tot een ander therapeutisch beleid, is het van belang am bij de diverse benaderingen stil te staan. vaak wordt er een onderscheid gemaakt tussen diverse typen parameters, dat voor onze bespreking van belang is, namelijk in:

a) parameters dile slechts aan- of afwezig kunnen zijn, of mar twee waarden kunnen aaremen (dichotome variabellen).

b) parameters die meer dan twee, van elkaar onderscheiden, categorieen kennen. Hierbij kunnen weer worden onderschelden:

1. parameters waarbij aan de verschillende categorieen geen inherente volgorde ten grondslag ligt (nominale variabelen).

2. parameters warbij dit laatste wel het geval is (ordinale variabelen).

c) parameters die op een bepaalde kwantitatieve schaal àlle waarden kunnen aannemen (continue variabelen).

Voorbeelden van a) zijn: koliekpijnen, angina pectoris, een palpabele lever, het al dan niet aanwezig zijn van karker; van b): haarkleur (nominaal), een cervix uitstrijk volgens Papanicolaou (ordinaal) en 
van c): lengte, gewicht, bloeddruk en laboratorium parameters zoals het hemoglobinegehalte en de bezinking.

Men kar er over twisten in hoeverre genoemde onderscheiding opgaat. Bij als dichotoom en ondinaal opgevatte variabelen is bij nadere beschouwing toch vaak sprake van een glijdende schaal, waarbij op een bepald moment een grens wordt overschreden (angina pectoris, een palpabele lever, een afwijkende glucose tolerantietest, overgangen tussen benigne en maligne histologisch beeld). Men kan ordinale en continue variabelen dok kunstmatig dichotamiseren, door één score of waarde te kiezen als grens tussen hoge en lage scores.

Met name het onderscheid tussen de typen $a+b 1$ enerzijds en b2 $+c$ anderzijdis is voor onze bespreking van belang.Men kan bij de eerstgenoemde groep namelijk in de praktijk in het algemeen geen invloed uitoefenen op het positiviteitscriterium (de warde van de testparameter die negatieve en positieve uitslagen scheidt). Bij ordinale en continue variabelen kan dit laatste wel. Er is immers een overgangsgebied tussen hoge en lage waarden en men kan de referentie- of grenswaarden desgewenst manipuleren in eén van beide richtingen.

Murphy onderscheidde zeven betekenissen van het begrip nomaal: een "normale' frequentieverdeling volgens Gauss volgend; representatief voor een groep; gebruikelijk; het meest gunstig ten aanzien van overleving en reproductie; zonder verhoogd risico op gezondheidsschade; bepaalde normen en conventies volgend; ideaal met voorbeeldfunctie (1). De laatste twee laten wij in het kader van de bespreking over diagnostische tests buiten beschouwing. In het vervolg hanteren wij, genumerd volgens de konende paragrafen, de indeling:

2. Nomaal als gebruikelijk .

3. Relatie met klachten.

4. Relatie met ziekte.

4.1. Test en diagnose.

4.1.1. Sensitiviteit en specificiteit.

4.1 .2 . R.O.C. analyse.

4.1.3. Likel ihoodratio en oddsratio.

4.1.4. Maximale toename van zekerheid.

4.2. Test en lange termijn prognose.

5. Relatie met het gewicht (de waarde) van de diverse uitkcansten.

5.1. Dilagnostiek en behandelbaarheid.

5.2. Het optimale afkappunt.

5.3. De optimale teststrategie. 
2. Normaal als gebruikelijk.

Aan deze benadering ligt in beginsel de volgende redenering ten grondslag: in geval van kenmerken of waarden die relatief weinig voorkomen is er sprake van een afwijking van de norm. Dextrocardie, roodharigheid of het hebben van bloedgroep $A B$ zijn dan bijvoorbeeld 'afwijkingen" .

Deze benadering wordt veel toegepast bij laboratoriumparameters, die een continue verdeling volgen. In de rest van deze paragraaf zullen we hierop ingaan.

Men gaat vaak uit van de verdeling van waarden in een gezonde populatie en leidt hieruit af welke grenzen voor het referentiegebied dienen te gelden. Dikwijls postuleert men, al dan niet terecht, een 'normale' verdeling van de variabele of de logaritme ervan, en kiest als grenzen de waarden die 1.96 standaardafwijkingen van het gemiddelde liggen. Acht men een normale verdeling niet van toepassing, dan kan men een grens stelien bij een bepaalde percentiel. In het algemeen definieert men de 'normale' range zodanig dat deze de uitslagen van 958 van de personen in de populatie onvat. "Nommal" is in deze benadering niets anders dan: gebruikelijk bij een gezonde (d.w.z. een niet als ziek te boek staande) populatie.

Een beperking van deze benadering is dat zij op zich zelf niet gerelateerd is aan de gezondheidstoestand van mensen, en daarmee geen aanknopingspunten biedt voor diagnostiek. Immers, de gevonden verdeling wordt niet afgezet tegen warden bij zlieken. Bovendien is er vaak discussie mogelijk over de vraag in hoeverre er sprake is van een "gezonde" populatie. Een voorbeeld: diverse onderzoekers pleiten voor het hanteren van andere normen voor het hemoglobinegehalte van blanken en negers op grond van de waarneming dat de hemoglobine-distributie voor negers in haar geheel $0.5 \mathrm{~g} / \mathrm{dl}$ naar beneden verschoven is ten opzichte van blanken $(2,3)$. Micozzi meent dat de norm voor Aziatische zwangeren éen $g / d 1$ lager mag worden gesteld dan voor Westerse zwangeren (4). Wintrobe, de nestor van de haematologie, ergert zich aan dergelijke benaderingen: "Locally prevalent values must not be equated with normal values. To do so would erronously lead to the conclusion 


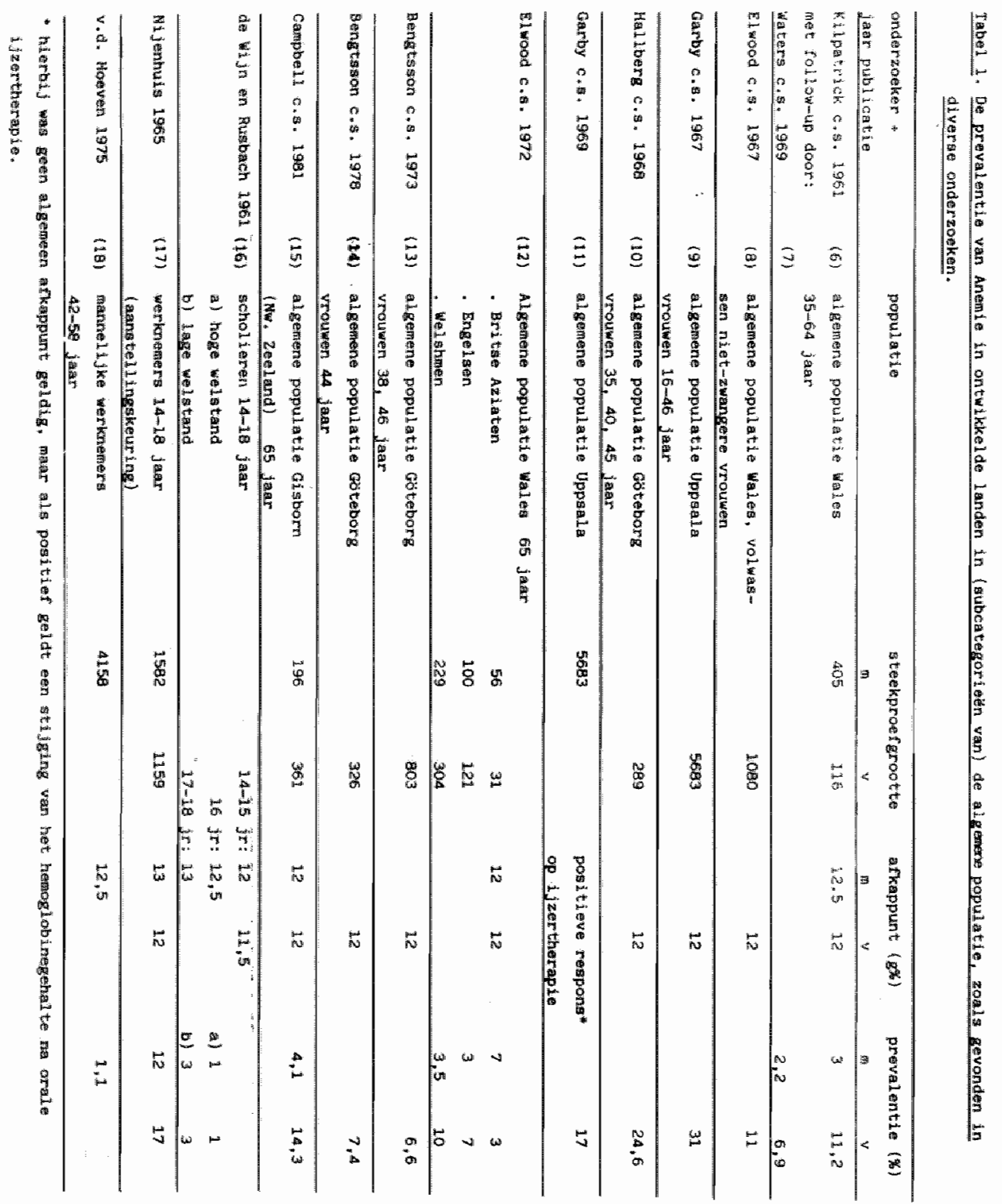


that in a particular subpopulation or geographic region a different lower standard applies. This error has been made in surveys of large populations." Dit, zo meent hij, "is a disservice to patients and misleads physicians" (5). Dat niet alleen tussen westerse en niet-westerse landen verschillen in de hemoglobineverdeling bestaan, en dat het ook niet zo'n vaart loopt met het aanpassen vam normen aan locale stuaties blijkt uit tabel I. Zo vond men eind jaren "60 in Wales bij 11 을 van de vrouwen waarden onder de $12 \mathrm{~g} / \mathrm{dl}$, terwijl in een zweeds onderzoek 25 onder dezelfde nom viel.

Wat betreft de bezinkingssnelheid van de erythrocyten (BSE) zijn er vergelijkbare controversen. Het International Comittee for Standardization in Haematology beveelt expliciet aan on hierbij waarden binnen een range, die 90 of $95 \%$ van de locale gezonde bevolking ormat, als normaal te beschouwen (19). Daarbij moet nog rekening worden gehouden met de methode van bepaling omdat bijvoorbeeld de methode van Westergren bij hoge waarden van de BSE hogere witslagen geeft dan de methode Wintrobe $(20)$. Op grond van deze uitgangspunten stelden Böttiger (21) en Lewis (20) algemene richtlijnen vast, geslacht (vrouwen hebben een hogere BSE) en leeftijd (de BSE stijgt met de leeftijd (22)) in aanmerking nemend. Miller vond hun correctie voor de leeftijd nog onvoldoende - te veel ouderen zouden een te hoge bezinking krijgen toegedicht en stelde de $98^{e}$ percentiel als bovengrens voor (23). Volgens anderen echter leidt correctie voor de leeftijd er toe dat bij ouderen een belangrijk signaal voor de ontdekking van pathologie wordt gemaskeerd $(24,25)$.

De uiteindelijke keuze van een grenswarde kan zeer grote invloed hebben op het percentage afwijkende waarden. In tabel 2 hebben we aangegeven hoe vaak de BSE, zoals gemeten op het Diagnostisch Centrum Maastricht(DCM) in de jaren 1980 en 1982, als 'verhoogd' zou worden beschouwd bij toepassing van 3 verschillende nomen: die van het Diagnostisch Centrum zelf, die volgens Lewis (de British Association of Clinical Pathologists (20)), en die welke recent door Miller zijn voorgesteld (23). De laatste twee benaderingen bevatten zoals gezegd een correctie voor geslacht en leeftijd, de eerste houdt alleen rekening met het geslacht. De verschillen zijn enorm: volgens de DCMnormen is $60 \%$ verhoogd, volgens Lewis $40 \%$ en volgens Miller slechts 15 영. 
Tabe1 2: Percentage verhoogde BSE-waarden van op het Diagnostisch Centrum Maastricht onderzochte bloedmonsters, bij toepassing van arie verschilliende nomen.

\begin{tabular}{|c|c|c|c|c|c|c|c|c|c|}
\hline & \multirow[b]{2}{*}{ anantal. } & \multicolumn{2}{|c|}{$\begin{array}{l}\text { afwijkingen } \\
\text { normen DC }\end{array}$} & \multicolumn{3}{|c|}{$\begin{array}{l}\text { ( afwijkingen } \\
\text { normen Lewis }\end{array}$} & \multicolumn{3}{|c|}{$\mid \begin{array}{l}\text { | afwi jkinger } \\
\text { normen Miller 23) }\end{array}$} \\
\hline & & $\mathrm{n}$ & 8 & 1 & $n$ & 害 & 1 & $\mathrm{n}$ & \& \\
\hline manumen & 13149 & 1804 & 57,3 & I & 1270 & 40,3 & 1 & 471 & 15,0 \\
\hline vrouwen & 1999 & 1296 & 64,8 & 1 & 770 & 38,5 & 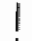 & 301 & 15,1 \\
\hline totaal & | 5148 & 3100 & 60,2 & 1 & 2040 & 39,6 & 1 & 772 & 15,0 \\
\hline
\end{tabular}

Het laatste voorbeeld geeft aan dat het hanteren van verschillende referentiewaarden tot grote spraakverwarringen kan leiden. Om dit te vermijoen kan men voor een bepalde populatie beter opgave doen van de gehele distributie dan van alleen het percentage waarnemingen onder (of boven) een bepaald afkappunt. Dat afkappunt is immers 'nomatief' terwijl de gehele distributie daarvan niet afhankelijk is.

onder het hoofdstuk 'nomal als gebruikelijk' kan tenslotte $\infty$ k nog de 'Individuele' norm worden ondergebracht. Als men uitgaat van een bepaalde gemeten uitgangswaarde voor een individu, kan men latere bepalingen in het licht hiervan interpreteren. Het kan voorkamen, dat ienand weliswaar enkele malen achtereen een uitslag heeft binnen het algemene referentie-gebied, maar dat tussen de afzonderlijke uitslagen grote verschillen bestaan: bijvoorbeeld een daling van het Ho bij een man van $10.5 \mathrm{mmol} / 1$ tot $8.6 \mathrm{mmol} / 1$. Aan de andere kant kan iemand met een lichte teruggang schijnbaar "abrupt" in het afwijkende gebied terecht kamen (bijvoorbeeld bij een Hb-daling van $8.6 \mathrm{~mol} / 1$ tot 8.4 mol $/ 1$ ). Bij de eerate patiênt is er echter meer reden tot ongerustheia dan bij de tweede patiënt. Costongs (26) demonstreerde hoe groot de intra-individuele variatie in de tija kan zijn, ok bij gezonde proefpersonen. Dit kan weliswaar samenhangen met zich ontwikkelende pathollogie, maar ook een gevolg zijn van fysiologische variabiliteit. Daarmaast moet men nog rekening houden met een eventueel beperkte reproduceerbaarheid van de test. Als maat voor het individuele referentilegebled stelde Costongs de "critical difference" voor: dit is de range warbinnen, in een grotere populatie, 95\% van de verschillien tussen twee aparte bepalingen van dezelfde parameter bij eenzelfde 
individu vallen. Deze range is in het algemeen veel smaller dan de $95 \%$ range van de verdeling van de parameter voor alle personen gezamen$1 \mathrm{ijk}$, op één moment in de tija.

\section{Relatie met klachten.}

Klachten kan men in zekere zin "tests' noemen, of soms ook 'ziekte" (als de klacht geheel of gedeeltelijk het gezondheidsprobleem zelf representeert, zoals biji hoofapijn). Vanuit praktisch oogpunt echter is het zinvol apart aandacht te besteden aan het verband tussen subjectieve klachten en testuitslagen. De gedachtengang hierbij is als volgt: bepaalde klachten worden beschouwd als indicatie on een diagnostisch onderzoek te doen, dat dan weer bedoeld is am ziekte op het spoor te komen. Dit heeft meer zin, naamate men in aanwezigheid van de klachten een duidelijker verschil in uitslagen vindt ten opzichte van klachtenvrije personen. Met andere woorden: er moet een verband zijn tussen de klacht en de testuitslag. Vindt men in beide gevallen hetzelfde of nagenoeg hetzelfde patroon, dan moet men overwegen de betreffende klacht als specifieke indicatie voor het doen van de test af te schaffen.

De ingang van de diagnostilek is de klacht, en niet de test. Het gaat dan ook niet zo zeer an de vraag hoe vaak de klacht voorkomt bij mensen met een 'positieve' respectievelijk 'negatieve' testuitslag. Van belang zijn:

a) De kans dat bij personen met de klacht (s+) een bepaalde bevinding $\left(\mathrm{T}^{+}\right)$gedaan wordt, én

b) Hoeveel groter deze kans is, dan bij mensen zónder de klacht.

In feite gaat het hier om de voorspellende warde van de klacht ten aanzien van de diagnostische bevinding: $\mathrm{P}\left(\mathrm{T}^{+} \mid \mathrm{S}^{+}\right)$, respectievelijk het quotiënt van de voorspellende waarden van de aanwezigheid respectievelijk de afwezigheid van de klacht:

$$
\frac{P\left(T^{+} \mid s^{+}\right)}{P\left(T^{+} \mid s^{-}\right)}
$$

om de klacht van betekenis te doen zijn voor de indicatiesteling voor de test is nodig:

- dat het genoemde quotiënt duidelij jk groter is dan 1, én 
- dat de voorspellende waarde van de klacht ook op zich zelf van betekenis is, qua grootte.

Immers aan de eerste voonwaarde kan voldaan $z i j n$, terwijl de voorspellende waarde toch laag blijft. Dit kan gebeuren als de betreffende bevinding zeer weinig voorkamt.

Het verschil met de benadering in de vorige paragraaf is dat nu niet. (alleen) gekeken wordt naar de verdeling van uitslagen en bevindingen in een 'gezonde' populatie, maar dat een vergelijking wordt gemaakt van groepen, op grond van het al dan niet aanwezig zijn van bepaalde klachten *

Men moet hierbij uiteraard rekening houden met de selectiemechanismen die ten aanzien van de klacht, de bevinding en hun onderlinge verband kan zijn opgetreden, en men dient qua selectie vergelijkbare referentiegroepen te kiezen $(27,28)$ (zie hoofdstuk 3).

Voorbeelden van de bestudering van het verband tussen de aamwezigheid van klachten enerzijas en bevindingen anderzijas zijn de door ons ingestelde onderzoekingen naar het verband tussen onverklaarde moeheid en het $\mathrm{Hb}$ (29) en tussen hoofdpijn en hoge bloeddruk (30). Het eerste onderzoek richtte zich op de spreekuurpopulatie van de huisarts, en het tweede vond plaats in de algemene bevolking. In beide gevallen was de voorspellende waarde van de bestudeerde klacht ten aanzien van de bestudeerde parameter erg laag, en waren de verbanden tussen klacht en bevinding afwezig respectievelijk zeer zwak. Deze onderzoeken worden elders in deze bundel beschreven. In een onderzoek bif zwangeren, beschreven in hoofdstuk $B$, vonden wij wel enig onderscheidend vermogen van klachten ten aanzien van een laag $\mathrm{Hb}$.

In dit verband kan ook gewezen worden op ons onderzoek naar het verband tussen 'onverklatirde moeheid' en het serumferritinegehalte in de huisartspraktijk (31). Tussen beide werd geen verband gevonden, en tussen het $\mathrm{Hb}$ - gehalte en het serumferritine evenmin. Bij zowell de personen met moeheidsklachten als de controlepersonen kwam in $11 \%$ van de gevallen een serumferritinegehalte voor van $12 \mu \mathrm{g} / 1$ of lager, dat volgens velen bewijzend zou zijn voor ijzergebrek. Bij een dergelijk hoge schatting van de prevalentie dringt zich de vraag op of screening, los van klachten en Fib-gehalte, geindiceerd zou zijn. Bij het niet bestaan van een verband tussen klachten en diagnostische bevin- 
dingen zijn dus twee elkaax op zich niet-tegensprekende conclusies mogelijk:

- er is géen indicatie voor de test aan te geven op grond van de klachten,

- screening lós van kliachten is noodzakelijk als men eventuele achterliggende bevindingen op het spoor wil kamen.

of men het diagnostisch onderzoek dan niet of juist altija toepast hangt onder andere af van:

- het belang van het op de hoogte zijn van de bevinding op zich, bijwoorbeeld met het oog op de prognose.

- de behandelbaarheid van de eventuele onderliggende pathologie,

- de geschiktheid van de test als screeningsinstrument (ondermeer het niet te belastend $\mathrm{zijn}$ van het onderzoek).

Tussen klachten en bevindingen kan een causale relatie zijn (bijvoorbeeld indien een laag $H b$ moeheid zou veroorzaken, en een hoge bloeddruk hoofdpijn). Dit hoeft echter niet het geval te zijn. Vaak gaat het om "correlaties' ten gevolge van een gemeenschappelijke oorzaak. Bijvoorbeeld de bevinding van een o-top op het ECG en de klacht pijn op de borst kunnen als gemeenschappelijke oorzaak hebben een myocardinfarct.

\section{Relatie met ziekte.}

Uiteindelijk ligt de rechtvaardiging vam diagnostisch onderzoek in de voorspelling van de aarwezigheid van aandoeningen, de prognose, en mate van de behandelbaarheid. In deze paragraaf hanteren wij de volgende tweedeling:

1) diagnostische betekenis van de test

2) prognostische betekenis van de test.

De behandelbaarheid en de relatie tot de "waarde" van de diverse uitkomsten kamen in de volgende paragraaf aan de orde.

\subsection{Test en diagnose.}

Wat betreft de maten voor het verband tussen een testuitslag en de aanwezigheid zlekte ten behoeve van de diagnostiek zijn er diverge opties. We bespreken ze achtereenvolgens. 


\subsubsection{Sensitiviteit en specificiteit.}

Men kan de validiteit van de test uitarukken in de sensitiviteit en specificiteit ten aanzien van de ziekte, en met behulp daarvan, gegeven een bepalalde prevalentile, de voorspellende waarde bepalen van een bepaalde testuitslag voor het al dan niet vórkomen van ziekte. Dit is in hoofdstuk 2 afdoende belicht. Hierbij mot men er op bedacht zijn, dat aensitiviteit en specificiteit afhankelijk kunnen zijn van de kenmerken van de te onderzoeken populatie. In het kader van de verschtllen tussen extra- en intramurale gezondheidszong $z i j n$ belangrijke factoren hierbij:

- de mate van ontwikkeling van het ziektebeeld (hoofdstukken 2 en 21):

- de mate van selectie in relatie tot de uitslag vóóndat men in de te testen onderzoeksgroep terechtkomt (hoofdstuk 21).

Een voorbeela van het laatste geeft de publicatie van Bezemer et al. (32). Zij definieerden als geschikte referentiepopulatie voor patienten die verwezen waren naar de polikliniek of afdeling interne geneeskunde: allle in het recente verleden verwezen patiënten met uitzondering van de patienten bij wie uiteindelijk diagnosen werden gesteld waarvan bekend is dat ze de test variabele kunnen beinvloeden. Hierbij werd, onder andere voor de calciumspiegel, gevonden dat de waarden van cle testvariabelen in de klinische referentiegroep vaak hoger uitvielen dan in de poliklinische referentiegroep. Blijkbaar is er sprake geweest van een selectieproces van perifeer naar ziekenhuis, waarbij personen met hogere uitslagen relatilef vaak opgenomen werden, ook al was er geen sprake van diagnosen die met de betreffende uitslag in verband konden worden gebracht.

In tabel 3 presenterer wij, ter illustratie, gegevens over sensitiviteit en specificiteit van de BSE ten aanzien van verschillende aandoeningen, zoals in diverse onderzoeken vastgesteld. Er blijken tussen gerapporteerde series belangrijke verschillen te bestaan, afhankelijk van de populatie, de aandoening en het gehanteerde afkappunt. In het algemeen gelat dat sensitiviteit en specificiteit telkens verre van 100\% zijn. Dat wil zeggen dat er een grote overlap is van waarden van zieken en niet-zieken, en een grote kans op fout-positieve en foutnegatieve witslagen. 
Tabel 3: Sensitiviteit en specificitelt (percentages) van de BSE-bepaling volgens tien onderzaeken.

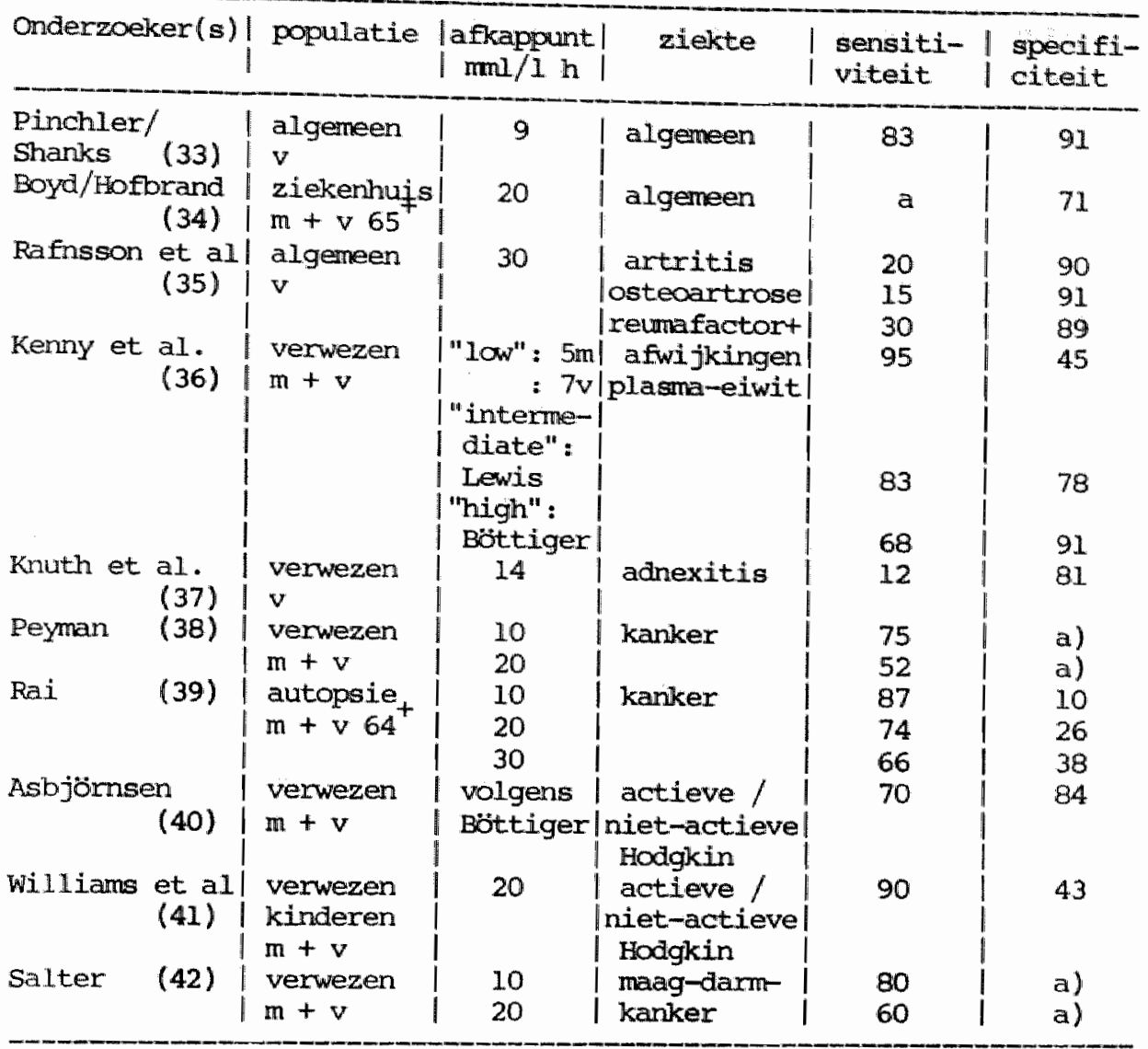

a) op grond van de gepubliceerde gegevens niet te berekenen.

Een test kan voor verschillende aandoeningen een verschillende sensitiviteit en specificiteit hebben. Het is dan handiger niet te spreken van de sensitiviteit maar, neutraler, van de kans op een positieve uitslag bij ziektetoestand $D_{x}$ :

$\mathbb{P}\left(\mathrm{T}^{+} \mid \mathrm{D}_{\mathrm{x}}\right)$

Wat betreft de specificiteit zou verwarring kunnen vöbrkamen tussen de kans op een negatieve uitslag bij personen zonder énige ziekte $\left(P\left(\mathrm{~T}^{-} \mid \mathrm{D}^{-}\right)\right)$, en de kans op een negatieve uitslag bij personen zonder een bepáálde ziekte $\mathrm{D}\left(\mathrm{F}\left(\mathrm{T}^{-} \mid \mathrm{D}_{\mathrm{x}}^{-}\right)\right)$. De tweede groep personen kan immers 
wel degelijk zieken bevatten, namelijk die met àndere aandoeningen dan $\mathrm{D}_{\mathrm{x}}$. Voor het rekenen met kansen ten aanzien van meer dan één toestand (waaronder gezondheid), kan men de respectievelijke kansen op positieve uitslagen bij de diverge toestanden (conditionele kansen) als uitgangspunt nemen. Gegeven een bepaalde a priori verdeling van kansen op een aantal verschillende toestanden, kan men nu met behulp van de conditionele kansen op eenvoudige wijze de a pasteriori kansen op elk van de mogelijke aandoeningen (de voorspellende watarden, $P\left(D_{x} \mid T+\right)$ ) berekenen $(43,44)$.

Bij ordinale en continu verdeelde variabelen kan het afkappunt (dat een kunstmatige dichotomisering van negatieve en positieve uitslagen markeert) gevarieerd worden. Sensitiviteit en specificiteit zullen dan veranderen. We komen hierop in de volgende paragraaf terug. In zo'n geval kan men het optimale afkappunt trachten vast te stellen. Dit kan geschieden volgens verschillende methoden waarop wijj ook terugkanen. Bij onderzoek ter bepaling van de sensitiviteit en specificiteit of, in het algemeen, van $P\left(T+\mid D_{X}\right)$, is van belang dat er duidelijkheid is over een 'gouden standaard' voor het vaststellen van de bestudeende ziekten, onafhankelijk van de testuitslag. Wanneer deze niet beschikbaar is of niet toegepast kan worden (wat vaak in de huisartspraktijk het geval is - bijvoorbeeld PA-onderzoek bij alle mensen met buikklachten is ondenkbaar), zal men benaderingen hiervan moeten zoeken. Gedacht kan worden aan (27):

- consensus-becordeling van de diagnose door een forum van experts die, los van de testuitslag c.q. zonder voorkennis daarover, op grond van het klinisch beeld en zoveel mogelijk op gestandaardiseerde wijze verzamelde aanvuliende gegevens tot een eindoonclusie komen.

- een follow-up studie, an aan de hand van het klinisch beloop de dilagnose definitief te kunnen stellen of wit te sluiten.

\subsubsection{RoC-analyse.}

Reeds eerder $11 s$ gezegd, dat voor tests waarbij de testvariabele gemeten wordt op een continue of ordinale schaal geldt, dat het criterium voor het onderscheid tussen positieve en negatieve uitslagen gevari- 

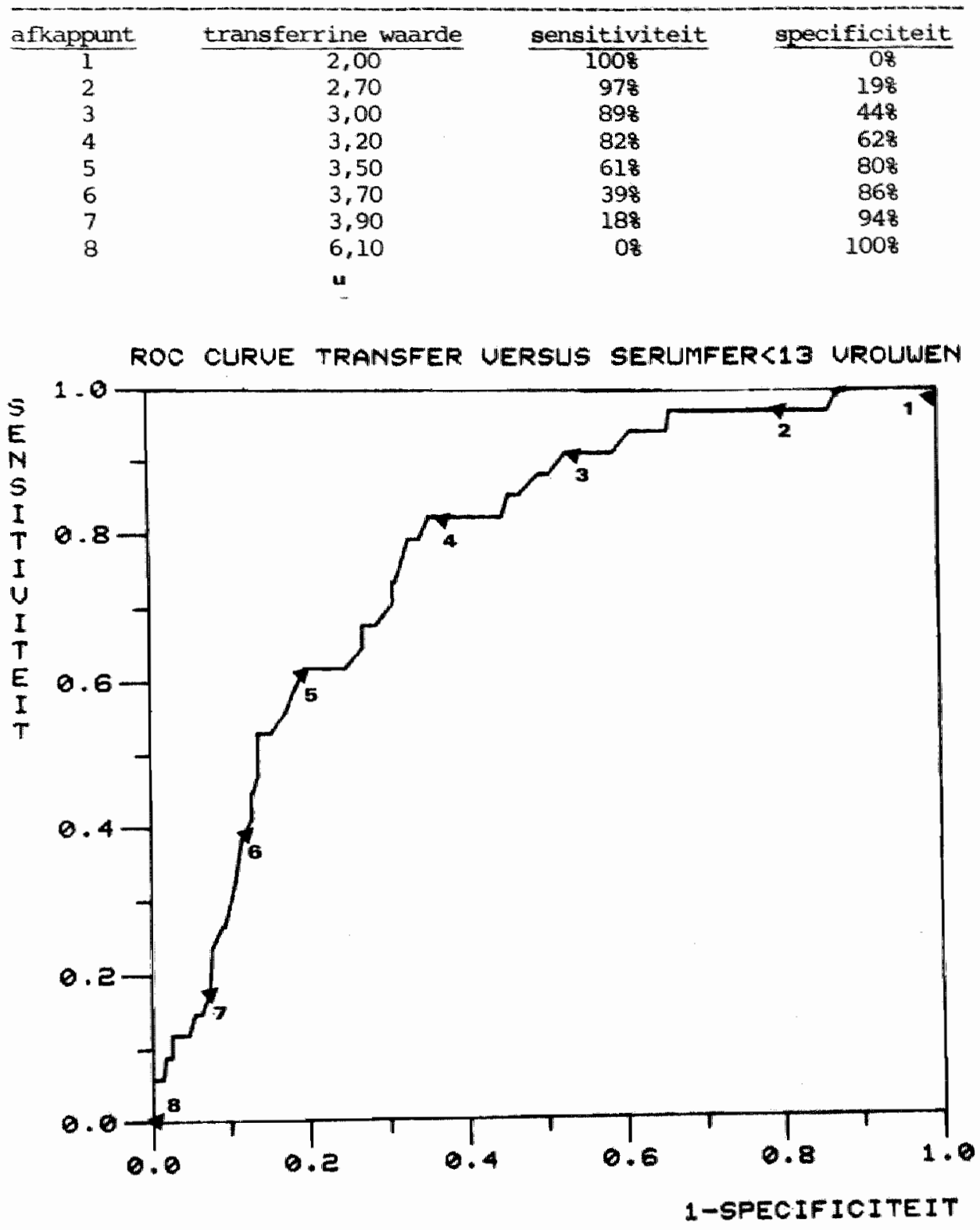

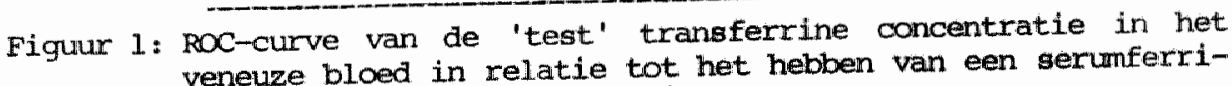
tine concentratie van $12 \mu \mathrm{g} / 1$ of lager. 
eerd kan worden in meer of minder stringente richting. Sensitiviteit en specificiteit zullen hierdoor in onderlinge samenhang en in tegengestelde richting veranderen (45). Het is magelijk an het verloop vansensitiviteit en specificiteit bij een dergelijke variatie van het afkappunt grafisch weer te geven in een zogenaamde Receiver Operating Characteristic (FOC) curve. Daarbij wordt de kans op positieve uitslagen bij zieken (de sensitiviteit) uitgezet tegen de kans op positieve uitslagen bij niet-zieken (100\%-specificiteit). In figuur 1 geven wij een voorbeeld op grond van eigen gegevens over 268 patiënten uit de huisartspraktijk. Bij 34 vrouwen met een serumferritine $\leq 12 \mu \mathrm{g} / 1$ en 234 vrouwen met een serumferritine > $12 \mu \mathrm{g} / 1$ werden de sensitiviteit en specificiteit van het transferrine ten aanzien van 'ijzergebrek" (gedefinieerd door een serumferritinegehalte $\leqslant 12 \mu \mathrm{g} / 1$ ) bepaald voor een serie afkappunten.

Het is gemakkelijjk na te gaan dat naarmate een $\mathrm{ROC}$-curve dichter ligt bij de diagonaal van de grafiek, het onderscheidend vermogen van de test afneemt. Immers als: de sensitiviteit = (100\%-de specificiteit) (en dat gelat voor alle punten op de diagonal), dan is de kans op een positieve uitslag bij zieken even groot als de kans op een (fout-)positieve uitslag bij niet-zieken. Goede tests (met een goed onderscheidend vermogen) kermerken zich door een snel steil oplopende curve die ver van de diagonaal verloopt.

De vorm van ROC-curves van diverse tests kan dus behulpzaam zijn bij het selecteren van tests met het beste discriminerend vermogen, nog los van de keuze van een bepaald afkappunt.

In het kader van ons onderzoek 'onverklaarde moeheld en Hb-gehalte', was het ons mogelijk de ROC-curves op te stellen voor diverse laboratorlumparameters ten aanzien van ijzergebrek, zoals dile gevonden worden in de huisartspraktijk. Voor ijzergebrek werd weer als criterium gedefinieerd een serunferritinegehalte van $12 \mu \mathrm{g} / \mathrm{ml}$ of lager. Voor dit doel werd een computerprogramma geschreven door Drs. S. Roos (Medische Informatica en Statistiek, Rijksuniversiteit Limburg). In figuur 2 zien we het resultaat. De test 'transferrine' heeft het grootste anderscheidend vermogen ten aanzien van de herkenning van vxouwen met een serumferritine concentratie van $12 \mu \mathrm{g} / \mathrm{ml}$ of lager. 


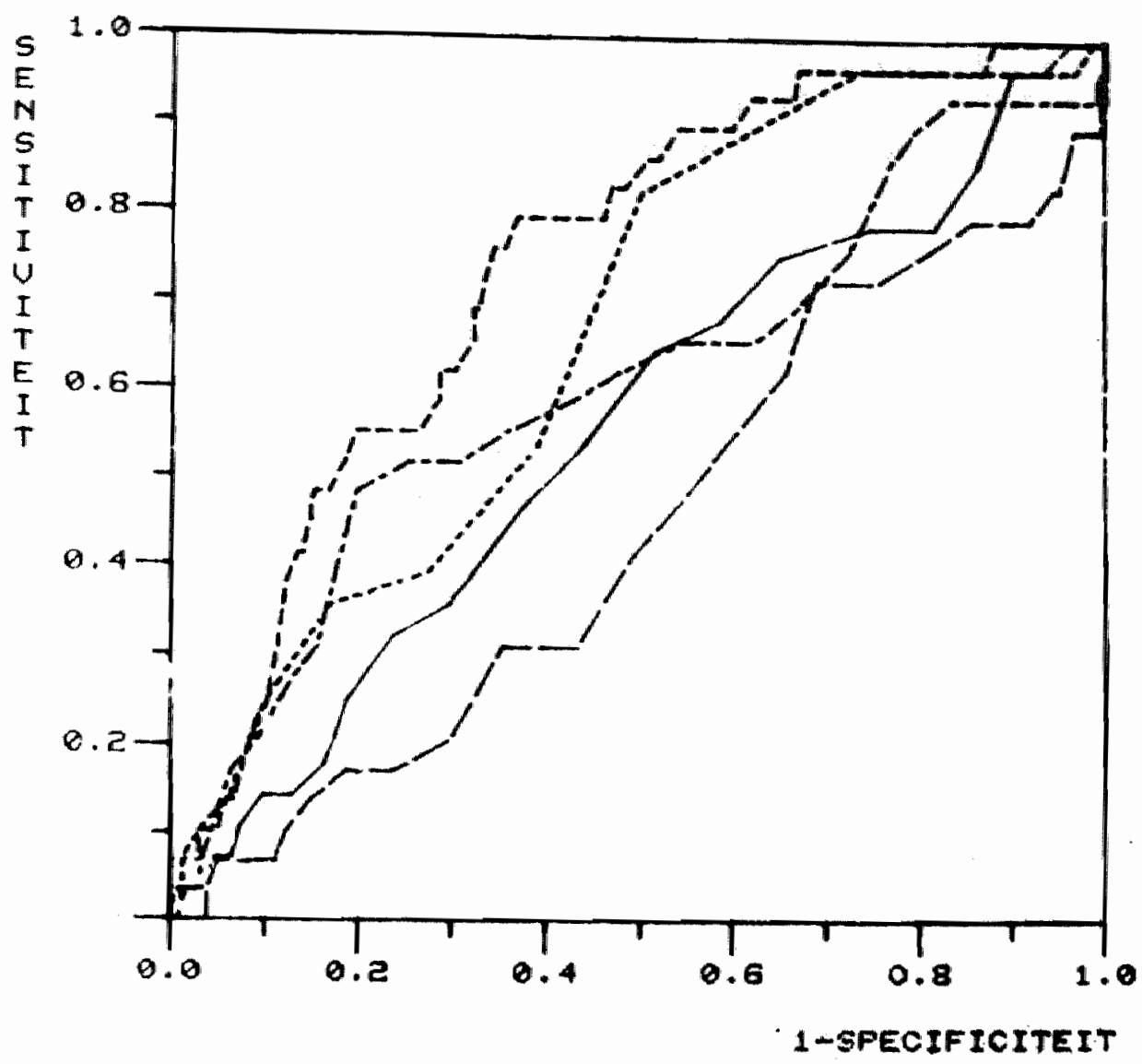

Figuur 2: RoC-curves van diverse laboratoriun parameters ten danzien van de diagnostiek van ijzergebrek $(d, w . z$. een gerunferritine gehalte van $12 \mu \mathrm{g} / 1$ of lager).

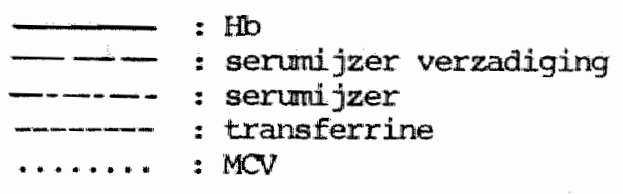

andat sensitiviteit en specificiteit gevoelig kumnen zijn voor verschillen tussen populaties, kan dit cok gelden voor roc-curves. Dat wil zeggen: In de huisartspraktijk kunnen RoC-curves er anders uitzien dan in de contactpopulatie van de specialist. Het is mogelijk de in een verwezen populatie vastgestelde FOC-curve te corrigeren voor het verwijsgedrag indien men een schatting heeft van de prior kans op 
ziekte in de contactpopulatie van de huisarts, en bowendien wordt aangenomen dat bij verwijzing niet dan alleen via de testuitslag op ziekte geselecteerd wordt $(46,47)$. Deze aanname is lang niet altija in overeensteming met de praktijk. In hoofistuk 21 komen wij terug op het effect van verwijzingspatronen op het onderscheidend vermogen van diagnostische tests.

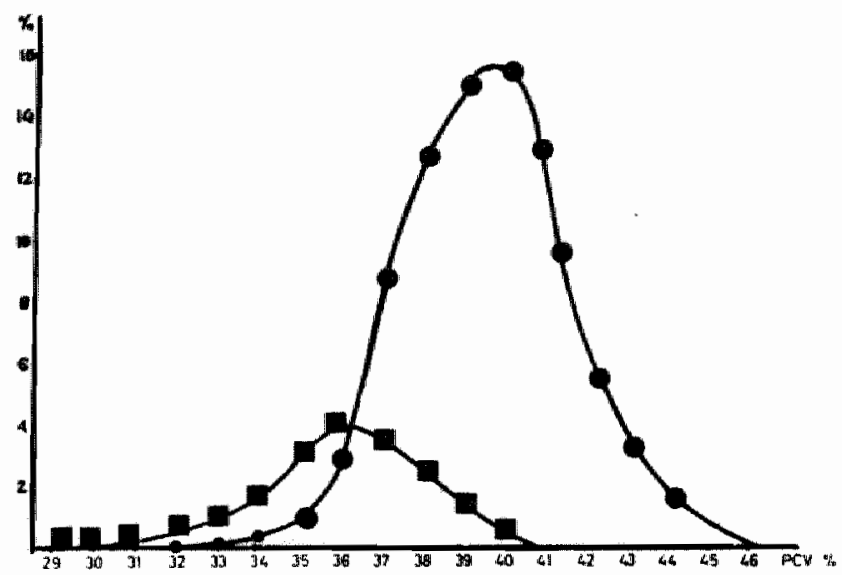

Figuur 3: Verdelling van de hematocriet bij vrouwen met (a) en zonder (-) ijzergebrek (steekproef uit de algemene bevolking).

On informatieverlies te voorkomen kan men ook afzien van het definiëren van én afkappunt, en voor iedere mogelijke waande van de testparameter de kans op zilekte aangeven (zie figuur 3 en tabel 4 met als woorbeeld de hematocriet in relatie tot ijzergebrek, ontleend aan Garby (9)). Deze kans neemt dan in het algemeen toe als de waarde van de paraneter in de 'pathologische' richting verschuift. Cok in de praktijk zall men, vaak reeds inturtief, een bepaalde betekenis toekennen aan de preciéze gemeten waarde: een bloedsuiker van $20 \mathrm{mmol} / \mathrm{l}$ betekent iets anders dan een bloedsuiker van $9.0 \mathrm{mmol} / 1$, hoewel beide als "verhoogd" zijn te beschouwen. Analoog aan wat opgemerkt werd onder paragraaf 2 zou men bij het rapporteren van onderzoekresultaten betreffende de validiteit van tests zich, als het on continue variabelen gaat, niet moeten beperken tot het geven van het percentage waarden 
dat onder respectievelijk boven één bepaald afkappunt valt. De camplete distributies zouden weergegeven moeten worden voor zieken en nietzieken. Een diagnost zou dan, voor een bepaalde geneten waarde zelf, een meer adequate schatting van de kans op ziekte kunnen maken (zie weer het voorbeeld van hematocriet, figurur 3 , en paragraaf 4.1.3.).

Tabel 4: Kans op ijzergebrek bij Zweedse vrouwen (steekproef uit de algemene bevolking) bij bepaalde waarden van de hematocriet (zie ok figuur 3).

\begin{tabular}{|c|c|c|c|}
\hline hematocriet & $\begin{array}{l}\text { verhoud } \\
\text { "ijzergebrek" }\end{array}$ & $\begin{array}{l}\text { Aing } \\
\text { : "geen ijzergebrek" }\end{array}$ & $\begin{array}{c}\text { kans op } \\
\text { ijzergebrek (q) }\end{array}$ \\
\hline $\begin{array}{r}31 \\
32 \\
33 \\
34 \\
35 \\
36 \\
37 \\
38 \\
39 \\
40 \\
>41\end{array}$ & $\begin{array}{l}1 \\
0,51 \\
0,93 \\
1,49 \\
2,79 \\
3,63 \\
3,17 \\
2,33 \\
1,30 \\
0,47 \\
0\end{array}$ & $\begin{array}{ll}: & 0 \\
: & 0,08 \\
: & 0,23 \\
: & 0,46 \\
: & 0,92 \\
: & 2,58 \\
: & 8,07 \\
: & 11,67 \\
: & 13,75 \\
: & 14,21 \\
: & 1\end{array}$ & $\begin{array}{r}100,0 \\
86,4 \\
80,2 \\
76,4 \\
75,2 \\
58,5 \\
28,2 \\
16,6 \\
8,6 \\
3,2 \\
0,0\end{array}$ \\
\hline
\end{tabular}

\subsubsection{Iikelihoodratio (aannemelijkheidsquotiënt) en de oddsratio.}

De likelihoadratio is het quotient van de kans dat een bepald symptoom of een bepaalde testuittslag voorkont bij zieken, en de overeenkonstige kans bij niet-zieken. Men kan haar voor positieve respectievelijk negatieve uitslagen noteren als (48):

$\mathrm{LR}^{+}=\frac{\mathrm{P}\left(\mathrm{T}^{+} \mid \mathrm{D}^{+}\right)}{\mathrm{P}\left(\mathrm{T}^{+} \mid \mathrm{D}^{-}\right)}$, ofwel $: \frac{\text { sensitiviteit }}{100 \mathrm{z}-\text { specificiteit }}$

en:

$L R^{-}=\frac{P\left(T^{-} \mid D^{+}\right)}{P\left(T^{-} \mid D^{-}\right)}$, ofwel: $\frac{100 \%-\text { sensitiviteit }}{\text { gpecificiteit }}$

Uit de definitie en de formules is direct af te leiden dat een likelihoodratio van 1.0 betekent dat de test waardeloos is, c.q. geen onderscheidend vermogen heeft. Hibe meer de LR van 1.0 afwijkt (variërend van 0.0 tot oneindig), des te beter is het onderscheidend vermogen. 


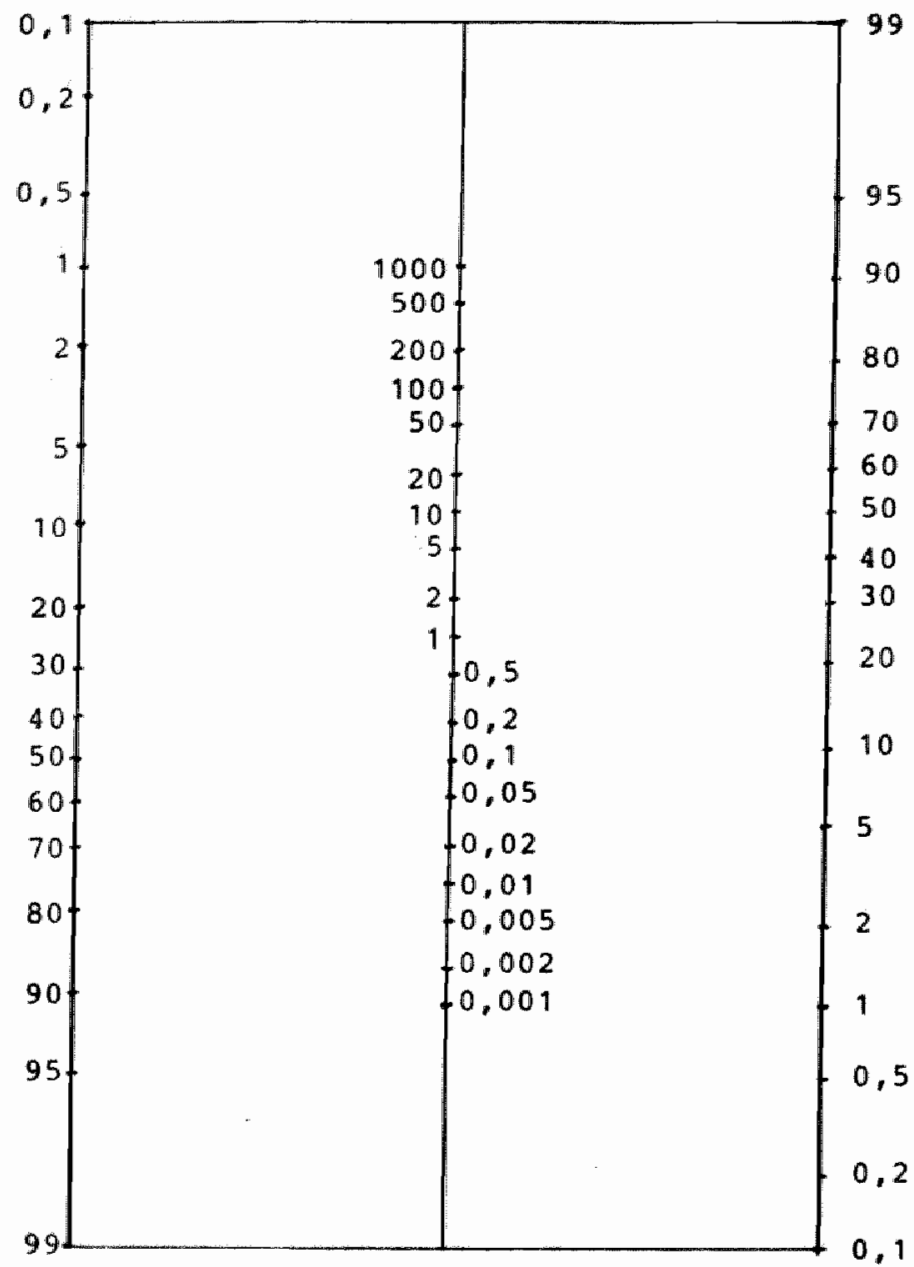

Pre-test walarschiljnlljkheid aannemelljkhelds quotient post-test waarschijnlijkkheid

Eiguur 4: Nomogram voor de relatie tussen prevalentie (a priori kans), aannemelijksheidsquotiënt en a posteriori kans. De a posteriori kans is te vinden door met een liniaal vanaf de betreffende "pre-test waarschijnlijkkheid", via de relevante waarde voor het aannemelijksheidsquotiënt, de as van de "post-test waarschijnlijkheld" te snijden (49). 
In beide maten is de informatie van sensitiviteit en specificiteit samengevat.

De likelihoodratio heeft het voordeel dat $z i j$ rechtstreeks gebruikt kan worden in de berekening van de a posteriori kans, door middel van een bepaalde notatie van de formule van Bayes (48).

$$
\frac{\mathrm{P}\left(\mathrm{D}^{+} \mid \mathrm{T}^{+}\right)}{\mathrm{P}\left(\mathrm{D}^{-} \| \mathrm{T}^{+}\right)}=\mathrm{LR}^{+} \cdot \frac{\mathrm{P}\left(\mathrm{D}^{+}\right)}{\mathrm{P}\left(\mathrm{D}^{-}\right)} \text {ofwel: } \mathrm{P}\left(\mathrm{D}^{+} \mid \mathrm{T}^{+}\right)=\frac{1}{1+\frac{1}{\mathrm{LR}^{+} \times \frac{\mathrm{P}\left(\mathrm{D}^{+}\right)}{1-\mathrm{P}\left(\mathrm{D}^{+}\right)}}}
$$

en:

$$
\frac{P\left(D^{-} \mid T^{-}\right)}{P\left(D^{+} \mid T^{-}\right)}=\frac{1}{L R^{-}} \cdot \frac{P\left(D^{-}\right)}{P\left(D^{+}\right)} \text {, ofwel: } P\left(D^{-} \mid T^{-}\right)=\frac{1}{1+L^{-} \times \frac{P\left(D^{+}\right)}{1-P\left(D^{+}\right)}}
$$

op deze wijze kan men dus, gegeven een bepaalde LR, de a posteriori kans berekenen uit de a priori kans. Men kan ook gebruik maken van een nomogram (49) (figuur 4). Voor diverse symptomen en testuitslagen zijn waarden van likelihoodratio's gepubliceerd, dan wel af te leiden uit gepubliceerde waarden van sensitiviteit en specificiteit (49). In tabel 5 geven wij een aantal likelihoodratio's voor de BSE ten aanzien van diverse ziekten (berekend uit tabel 3) en voor transferrine ten aanzien van ijzergebrek (voor diverse afkappunten). Bij de generalisatie van dergelijke gegevens zij men overigens voorzichtig: het is niet zonder meer te verwachten dat likelihoodratio's stabiel zijn over verschillende populaties. Factoren als de mate van ontwikkeling van de ziekte en de mate van selectie ten gevolge van het verwijegedrag van huisartsen zijn van invloed.

Het is aantrekkeliljk om één samenvattende mat voor het onderscheidend vermogen te hebben, uitgaande van sensitiviteit en specificiteit. Op dit punt aangekanen, blijkt dat wij toch nog met twee maten te maken hebben, namelijk $\mathrm{LR}^{+}$en $\mathrm{LR}^{-}$. Men kan dit oplossen door, als samenvattende mat te kiezen voor het quotient van $\mathrm{LR}^{+}$en $\mathrm{LR}^{-}$. Dilt is de zogenaamde oddisratio (OR), die met name in de etiologische epidemiologie gebruikt wordt. In dit geval kan men haar als volgt definiëren: 


$$
\begin{aligned}
\text { OR } & =\frac{\text { Terecht Positieven }}{\text { Fout Negatieven }} / \frac{\text { Fout Positieven }}{\text { Terecht Negatieven }} \\
& =\frac{\text { gensitiviteit }}{(100 \text { st-sensitiviteit })} \times \frac{\text { specificiteit }}{(100 \text {-specificiteit })}=\frac{\text { LRt }}{L R-}
\end{aligned}
$$

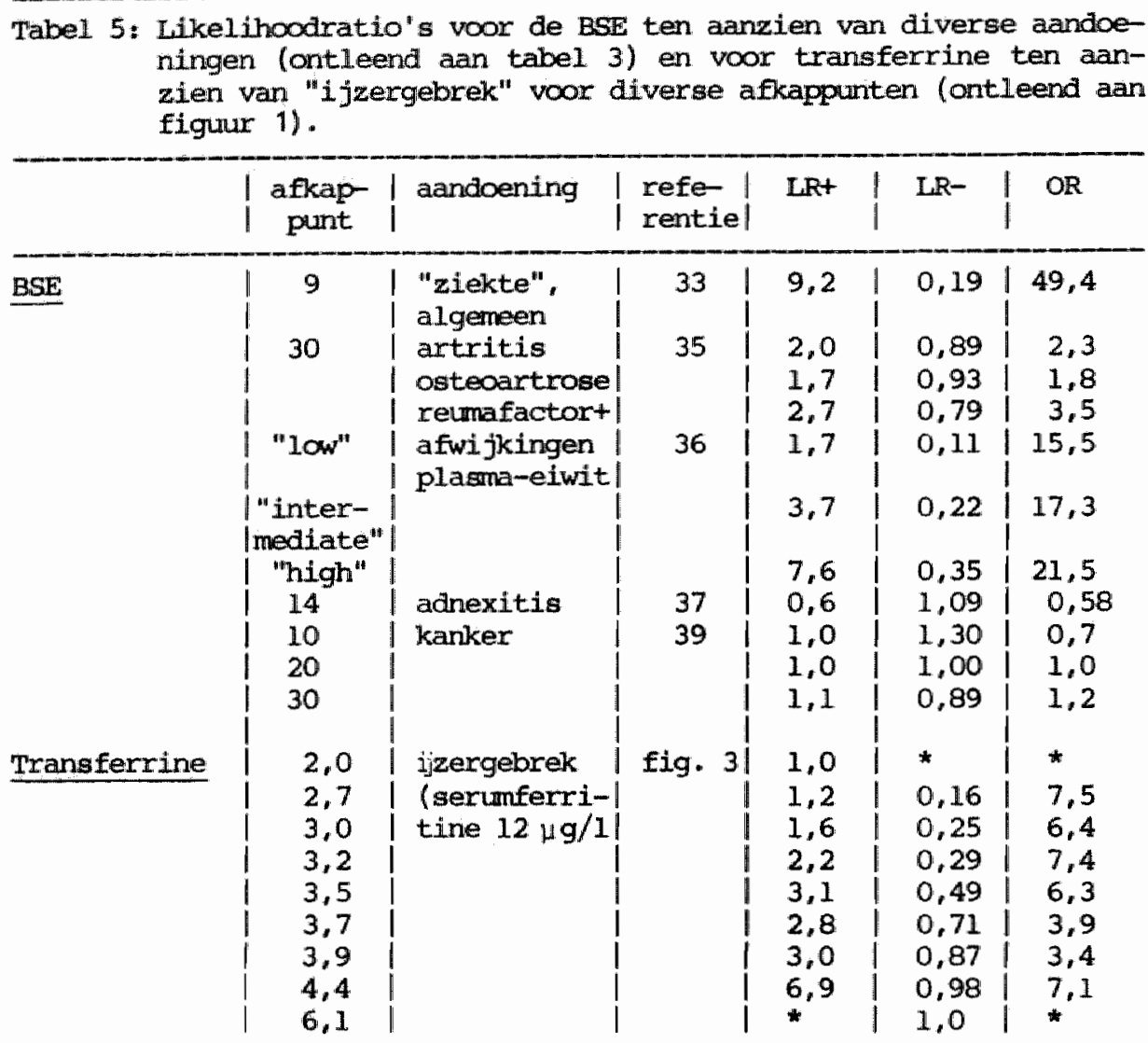

\footnotetext{
niet te berekenen
}

De OR is gelijk aan 1.0 als het diagnosticum geen onderscheidend vermogen heeft en wijkt hiervan sterker af (varièrend van 0 tot oneindig) naarmate het onderscheidend vermogen beter is. In de laatste kolom van tabel 5 is de waarde van de oR ter oriëntatie toegevoega. In het algemeen blijkt dat de OR zeer hoog wordt als men nadert tot de grenzen van het overgangsgebied waarbinnen de test-uitslagen van zieken en niet-zileken elkaar overlappen: de noemer van de breuk nadert dan tot 0 . Onder de ondergrens en boven de bovengrens van dit overlappingsgebied hebben de oR en respectievelijk de $\mathrm{LR}^{-}$en $\mathrm{LR}^{+}$geen betekenis meer, en hebben ook hun functie verloren: er is immers geen overlap meer tussen zieken en niet-zieken en men mag dus zeker van zijn zaak ziljn. 
Over het nut van de odds-ratio als samenvattende maat voor het onderscheidend vermogen kan men van mening verschillen. Het voordeel is de "samenvatting". Het nadeel is, dat men haar niet zonder meer kan gebruiken voor het berekenen van a posteriori kansen. Immers, dezelfde oddsratio kan gelden voor verschillende waarden van sensitiviteit en specificiteit respectievelijk $\mathrm{LR}^{+}$en $\mathrm{LR}^{-}$. $\mathrm{Zij}^{\mathrm{j}}$ is $00 \mathrm{k}$ een functie van de testvariabele zoals in het tweede deel van tabel 5 te zien is. voor dichotame test-variabelen is de interpretatie van de odds-ratio meer eenduidig dan voor continue variabelen, daar er geen afhankelijkheid is van het (immers niet te variëren) afkappunt. In dat geval is zij dan ook meer geschikt als samenvattende mat voor het onderscheidend vermogen.

Voor continue testvariabelen is er nog een andere benadering, die tevens het meest efficiënte gebruik van de diagnostische informatie inhoudt, namelijk: het verstrekken van de likellihoodratio die behoort bij de gemeten (klasse van) warde( $n$ ) van de testuitslag, zonder hierbij dus te hoeven dichotomiseren in negatieve en positieve uitslagen. De likelihoodratio is dan:

$L_{x}=\frac{P\left(T_{x} \mid D^{+}\right)}{P\left(T_{x} \mid D^{-}\right)}=\frac{\text { kans op testuitslag } x \text { bij zieken }}{\text { kans op testuitslag } x \text { bij niet-zieken }}$

Op grond van de a priori kans en $\mathrm{LR}_{\mathrm{x}}$ kan men dan, zoals eerder beschreven, de a posteriori kans berekenen maar nu meer precies, uitgaande van de "exacte' testuitslag $x$.

Tabel 6: Likelihoodratio's van transferrine ten aanzien van ijzergebrek (serumferritine $\leq 12 \mu \mathrm{g} / 1$ ), berekend voor verschilliende klassen van waarden.

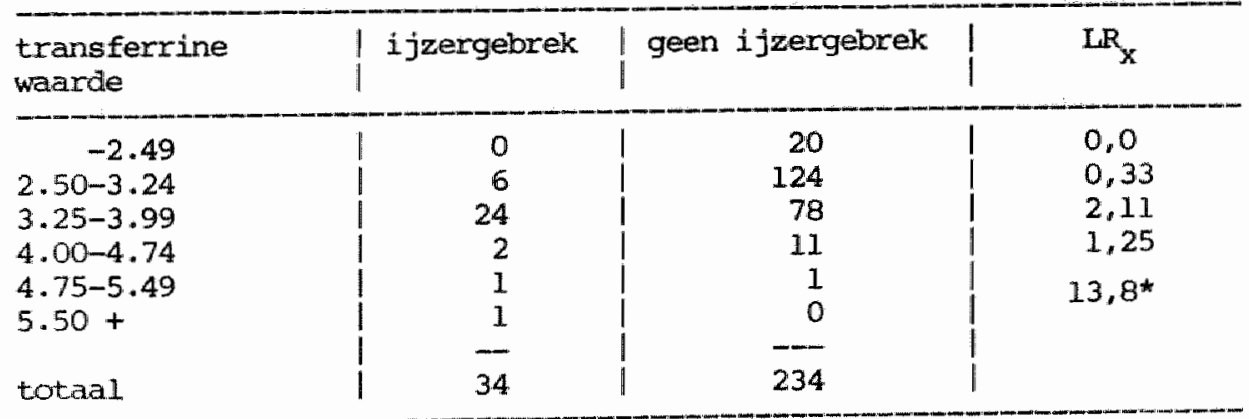

* i.v.m. de kleine aantallen werden deze categorieẹn tezamen genomen. 
In tabel 6 hebben wij, ter illustratie, LR $_{\mathrm{X}}$ van diverse klassen van transfercinewaarden gegeven voor het diagnostiseren van "ijzergebrek" (c.q. een serumferritine waarde onder de nomi). Ondat echter ook een "klasse" nog geen precies gemeten wararde is, is het wenselijk een statistisch model op te stellen, op grond van empirische data, voor $L R_{x}$ als functie van de testvariabelle, waaruit $L R_{x}$ voor iedere waarde volgt. Voor transferrine, dat bij benadering normaal verdeeld is, konden wij dit doen door door middel van logistische regressie, waarbij wij het intercept gelijk maakten aan de natuurlijke antilogaritme van de prior odds. Om dit te bereiken dient men de onafhankelijke variabele $x$ te transformeren tot $x-x_{0}$ " waarbij $x_{0}$ dié warde van $x$ is waarbij de posterior disease-odds gellj $\mathrm{k}$ is aan de prior disease-odds. Met andere woorden: $x_{0}$ is juist die testuitslag die de kans op ziekte niet groter en niet kleiner maakt. Dan geldt immers (zie ook appendix bij hoofdistuk 8):

posterior odds $=e^{a+\beta\left(x-x_{0}\right)}=e^{a} x e^{\beta\left(x-x_{0}\right)}$

en posterior kans $=$

$\frac{1}{1+\frac{1}{e^{a+\beta\left(x-x_{0}\right)}}}$

waarbij: $x_{0}=$ waarde $\operatorname{van} x$ waarbij geldt dat posterior odds $=$ prior odds .

$$
\begin{aligned}
e^{a} & =\text { prior disease-odds. } \\
e^{\beta\left(x-x_{0}\right)} & =L R_{x}
\end{aligned}
$$

Ter illustratie geven wij in tabel 7 het model voor transferrine als test voor ijzergebrek, met de eruit volgende waarden voor LR, de posterior odds, en de posterior kans.

Op grond van het beloop van genoemde functie van $L R_{x}$ over het overlappingstraject kan men het onderscheidend vermogen van de test becordelen zonder de testuitslag te hoeven dichotomiseren (wat bij een ROCcurve wel gebeurt). 
Tabel 7: Iogistisch model voor de berekening van $\operatorname{LR}_{\mathrm{X}^{\prime}}$ de likelihoodratio van bepalde transferxine waarden $x_{\text {ten }}$ aanzien van ijzergebrek, en de hieruit volgende posterior kansen.

\begin{tabular}{ccc} 
model: & coëfficiënt & standard error \\
$\begin{array}{c}\text { intercept } \\
(\text { transferrine } \\
-3.36)\end{array}$ & 1.89 & 0.206 \\
\hline
\end{tabular}

dus: posterior odds $=e^{-1.94+1.89(x-3.36)}$

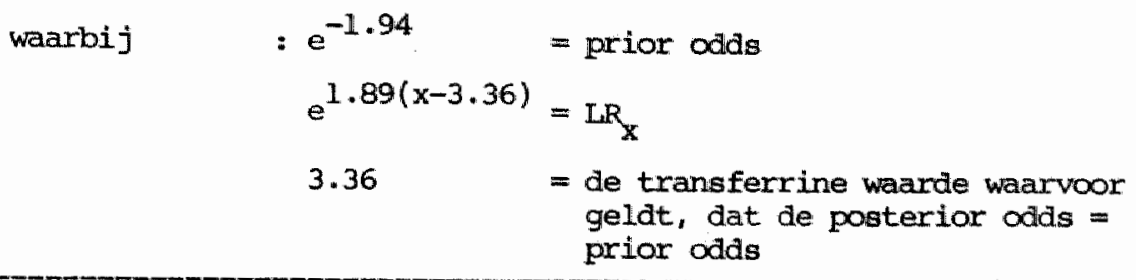

Toepassing:

transferrine waarde $\quad \mathbb{R}_{\mathrm{x}}$ pasterior odds posterior kans

$\begin{array}{lrrr}2.50 & 0.20 & 0.03 & 0.03 \\ 3.00 & 0.51 & 0.07 & 0.07 \\ 3.36 & 1.00 & 0.14 & 0.13 \\ 3.50 & 1.30 & 0.19 & 0.16 \\ 4.00 & 3.35 & 0.48 & 0.33 \\ 4.50 & 5.38 & 0.77 & 0.44 \\ 5.00 & 22.19 & 3.12 & 0.76 \\ 5.50 & 91.57 & 13.16 & 0.93\end{array}$

Er is in de praktijk veel voor te zeggen om bij het zoeken naar normen niet één afkappunt te kiezen, maar twée. Onder het laagste afkappunt (waar de sensitiviteit $=100$ ) ) is de voorspellende waarde ten aanzien van niet-ziekte 1008, en boven het hoogste (waar de specificiteit = 100\%) is de voorspellende waarde ten aanzien van ziekte 100\%. Tusien beide afkappunten zijn we onzeker, en zijn de likelihoodratio, de priar kans en de voorspellende waarde van belang bij het reduceren van de onzekerheid (27). 
4.1.4. Het bepalen van het afkappunt waarbij de te verwachten toegenomen zekerheid van een zlekte als gevolg van de test maximaal 1.5.

De predictieve waarden (a posteriori kansen) $P\left(D^{+} \mid \mathrm{T}^{+}\right)$en $P\left(D^{-} \mid T^{-}\right.$) van een testuitslag op zichzelf zijn onvoldoende am de informativiteit van een test te becordelen. Het gaat om het verschil tussen:

- de a priori kans en de a posteriori kans van een positieve test: $P\left(D^{+} \mid T^{+}\right)$respectieveli jk $P^{p}\left(D^{+}\right)$, en tussen:

- de a priori kans en de a posteriori kans van een negatieve test: $P\left(D^{-} \mid T^{-}\right)$respectievelijik $P\left(D^{-}\right)$.

Men kan cok spreken over de mate van toename in zekerheid dankzij het verrichten van de test. Deze toename kan in diverse 'maten' uitgedrukt worden:

a) netto "toename" :

b) procentuele toename:

(a.ls percentage van de

a priori kans)

c) percentage van maximaal haalbare toename (d.w.z. als percentage van het verschil tussen $100 \%$ zekerheid en de a priori kans)

d) relatieve toename t.o.v. de a priori kans

e) de verhouding tussen: de kans op ziekte en niet-ziekte ná: $\frac{\mathrm{P}\left(\mathrm{D}^{+} \| \mathrm{T}^{+}\right)}{\mathrm{P}\left(\mathrm{D}^{+}\right)}$ resp: $\frac{P\left(D^{-} \mid T^{-}\right)}{P\left(D^{-}\right)}$ resp. v66r toepassing van de test.

$$
\begin{aligned}
& P\left(D^{+} \mid T^{+}\right)-P\left(D^{+}\right) \text {resp: } P\left(D^{-} \| T^{-}\right)-P\left(D^{-}\right) \\
& \frac{P\left(D^{+} \mid T^{+}\right)-P\left(D^{+}\right)}{P\left(D^{+}\right)} \text {resp: } \frac{P\left(D^{-} \mid T^{-}\right)-P\left(D^{-}\right)}{P\left(D^{-}\right)}
\end{aligned}
$$

$$
\frac{P\left(D^{+} \mid T^{+}\right)-P\left(D^{+}\right)}{1-P\left(D^{+}\right)} \operatorname{resp}: \frac{P\left(D^{-} \| T^{-}\right)-P\left(D^{-}\right)}{1-P\left(D^{-}\right)}
$$


De laatstgenoemde maat is onafhankelijk van de a priori kans: zij is namelijk gelijk aan de likelihoodratio van een positieve respectievelijk negatieve test, die we al bespraken.

De eerst vier maten zijn wél afhankelijk van de a priori kans.

Conell en Koepsell behandelen de drie eerste genoende en spreken in dit verband van: 'measures of gain in certainty from a diagnostic test" (50).

Een positieve test en een negatieve test hoeven niet even frequent voor te komen. Het kan zijn, dat in het geval van een positieve uitslag de kans op ziekte sterk toeneemt ten opzichte van de vooraf kans, maar dat de kans op een positieve uitslag in de te testen populatie zeer laag is. Deze laatste kans is mede bepalend voor de te verwachten toename in zekerheid door het uitvoeren van de test. Indien de kans op een positieve respectievelijjk negatieve test vóbr het uitvoeren van de test te voorspellen is, kan men de toename van de zekerheid door de test vooraf wegen voor de kans op een bepaalde uitslag. Aldus kumnen de uitdrukkingen a $t / m$ c worden getransformeerd tot 'measures of expected gain in certainty' ten aanzien van respectievelijk een positieve uitslag, een negatieve uitslag en de gecombineerde informatie van positieve en negatieve uitslagen. Voor een gedetailleerde uitwerking verwijzen we naar conell en Koepsell (50). In het kader van dit hoofdstuk, waarin het gaat an 'nomen' voor testuitslagen, zijn vooral de volgende aspecten van belang.

1) De verwachte absolute toename in zekerheid (certainty) als gevolg van de te verwachten gecombineerde infonnatie van positieve m. negatieve uitslagen is gelijk aan:

$$
\mathrm{E}(\Delta \mathrm{C})=2 \cdot \mathrm{P}\left(\mathrm{D}^{+}\right) \cdot \mathrm{P}\left(\mathrm{D}^{-}\right) \cdot\left\{\mathrm{P}\left(\mathrm{T}^{+} \mid \mathrm{D}^{+}\right)+\mathrm{P}\left(\mathrm{T}^{-} \| \mathrm{D}^{-}\right)-1\right\}
$$

Dit is een functie van $P\left(D^{+}\right)$, de a priori kans op ziekte.

Deze is maximal als: $P\left(D^{+}\right)=0.5$, dat wil zeggen als de a priori kans $50 \%$ is: er is sprake van maximale twijfel, er is een 'fifty-fifty' kans op ziekte. (Zie ook MaNeill et al. (51)).

en minimal als: $\quad P\left(D^{+}\right)$nadert tot 0 of tot 1 . 
Als functie van sensitiviteit $P(T+\mid D+)$ en specificiteit $P(T-\mid D-)$ wordt $E(\Delta C)$ maximal als $P\left(T^{+} \mid D^{+}\right)+P\left(T^{-} \mid D^{-}\right)-1$ maximaal is. Dat betekent dus dat, bij een continu verdeelde testvariabele het afkappunt zo gekozen zou moeten worden dat de som van sensitiviteit en specificiteit maximaal is.

2) De maten voor de verwachte toename in zekerheid, als percentage van de reeds bestaande zekerheid vbor de test $(E(z \Delta c))$ respectievelijk als percentage van de maximaal mogelijke toename ( $($ max $\Delta c)$ ), voor de gecombineerde informatie van postieve on negatieve uitslagen zijn beide gelijk aan:

$$
E(Z \Delta C)=E(\max \Delta C)=P\left(T^{+} \mid D^{+}\right)+P\left(T^{-} \mid D^{-}\right)-1
$$

Deze maten zijn nu dus onafhankelijk van de prevalentie, en weer maximal als de som van de sensitiviteit en de specificiteit maximaal is.

De conclusie is dat, als men streeft naar maximale winst in zekerheid ten gevolge van het uitvoeren van een test, men het afkappunt moet kiezen warvoor geldt dat de som van de sensitiviteit en de specificiteit maximaal is. Op de ROC-curve betreft dit het punt waarop de afstand tot de diagonaal maximaal is (50). Indien de uitslagen bij zieken en niet-zieken een 'nomale' verdeling met gelijke spreiding volgen, is dit het punt warbij sensitiviteit en specificiteit gelijk aan elkaar zijh.

Het opmerkelijke van deze benadering is, dat duidelijk wordt dat een maximale likelihoodratio van een positieve test niet betekent dat de toegenomen zekerheid (op grond van de gecombineerde informatie van positieve en negatieve uitslagen) ten gevolge van de test ook maximaal is. De maximale likelihoodratio vindt men immers als de specificiteit nadert tot 1008: de likelihoodratio nadert dan tot oneindig, ook als de sensitiviteit zeer klein is.

Dk hier geldt overigens weer dat de gebruikte maten afhankelijk zijn van kermerken van de bestudeerde populatie, met name van de mate van 
selectie ten aanzien van de testuitslag en van de mate van ontwikkeling van de ziekte.

\subsection{Test en lange termi jnprognose.}

In het voorgaande is gesproken over het verband tusisen testuitslagen en de aanwezigheid van ziekte op het moment van het uitvoeren van de test. Het is echter ook mogelijk on de testuitslag te gebruiken als voorspeller van toekomstige ontwikkelingen. Bekende voorbeelden zijn de bloeddruk en het cholesterolgehalte. Het hebben van een hoge bloeddruk betekent uiteraard niet dat men een cerebrovasculair accident heeft. Wel kan men er vanuit gaan dat een hoge bloedaruk de kans op het krijgen van een cerebrovasculair accident in de toekomst verhoogt $(52,53)$. Hetzelfde geldt voor het verband tussen het cholesterolgehalte en het myocardinfarct $(52,54,55)$. Men ziet dan een hoge blloeddruk en een hoog cholesterol niet zozeer als diagnostica, maar als risico-indicatoren ten aanzien van bepaalde mogelijke verwikkelingen in de toekomst.

Hierbij zijn de volgende kanttekeningen te maken:

- Een risico-indicator kan al dan niet een causale betekenis hebben. Het hebben van gele vingers heeft, in tegenstelling tot roken, geen causale betekenis ten aanzien van longkanker. Toch kan het, evenals roken, gelden als een risico-indicator. Tests kumnen een prognostische betekenis hebben, ook al komen ze in de corzaak-gevolg keten van de ziekte niet voor.

- Het vinden van een risico-indicator kan, evenals een diagnosticum, aanleiding geven tot interventie. Daarbij kan de risico-indicator zélf het doelwit zijn van de beinvloeding ordat hij geacht wordt een causale rol te spelen én bovendien belnvloedbaar is, (zoals bijvoorbeeld hoge bloeddruk). Vaak echter is de 'test' zelf niet te beinvloeden (zoals de resultaten van genetisch onderzoek, en de rhesusfactor) maar maakt het resultaat ons alert, teneinde eventueel te kunnen anticiperen (amnionpunctie; controlle op rhesusantistoffen). Soms is wel een verhoogd risico vast te stellen, maar kan zal men (vooralsnog) nöch interventie kunnen plegen, nóch hierop kunnen anticiperen. Een voorbeeld zou kunnen zijn het positieve verband tussen een matig hoge hematocriet en de kans op een hartinfarct (56, 57). 
Men zou kunnen spreken van het diagnostiseren van risico's met behulp van-risico-indicatoren, en het behandelen van risico-indicatoren voor zover ze causaal van betekenis zijn.

Een maat an de karakteristieken van de test in prognostische zin te beachrijven is: het relatief risico. Dit kont in het verband van deze bespreking overeen met:

de kans op het krijgen van de aandoening bij 'test-positieven'. in een bepaalde periode

de kans op het krijgen van de aandoening bij 'test-negatieven'. in dezelfale periode.

Zelf verrichtten wij een onderzoek naar de betekenis van het hemoglobinegehalte, c.q. de hematocriet voor het risico op het krijgen van een hartinfarct. Wij maakten hierbij gebruik van een patiënt-controle methode, waarbij het $\mathrm{Hb}_{\mathrm{b}}$ vór het optreden van het infarct werd gemeten. Wij konden de bevindingen van diverse onderzoekers $(56,57)$, dat er sprake is van een verhoogd risico bij een verhoogde hematocriet, bevestigen. Wij vonden, dat in de leeftijdsperiode van 50-60 jaar, mannen die een hematocriet hebben van 46 of hoger, over het geheel genomen een 2.7 maal zo grote kans hebben op het krijgen van een infarct als mannen met een hematocriet lager dan 46 . Er blijft hierover overigens nog een controverse, omdat anderen het verband tussen een matig hoog hemoglobinegehalte of hematocriet en hartinfarct niet of nauwelijks vonden $(58-61)$. In hoofalstuk 23 doen wij verslag van dit onderzoek.

Het relatieve risico heeft als pendant in de diagnostiek: het quotiënt van de voorspelliende waarde van een kenimerk of positieve testuitslag en het complement van de voorspellende waarde van de afwezigheid van het kenmerk of de negatieve uitslag. Het ligt voor de hand: om na te gaan of er anderson ook diagnostische parameters voor de prognostiek bruikbaar zijn, uitgaande van bepaalde risico indicatoren. Hierbij komt in aarmerking de likelihoodratio (LR), hier te benoemen als de prognostische likelihoodratio van een prognostisch kerunerk of een positieve testultslag. Men kan deze bepalen op grond van cohortstudies met een bepaalde follow-up duur $\Delta t$ of op grond van patiënt-controle 
onderzoeken (cumulatieve incidentie-methode). zij is te anschrijven als: de kans dat personen, die de ziekte na een periode $\Delta t$ gekregen hebben, op $t_{o}$ (bij het begin van de follow-up) een positieve uitsiag hadden, gedeelld door de overeenkanstige kans bij personen die na de periode $\Delta t$ de ziekte nilet gekregen hebben. Met behulp van deze ratio kan men de kans berekenen dat personen met een positieve uitslag na een periode $\Delta t$ de ziekte gekregen hebben, indien men tevens beschikt over een schatting van de "a priori kans" dat de zilekte optreedt (de geschatte kans zonder voorkennis over de test-uitslag). Deze a priori kans is gelijk aan de cumulatieve incidentie over de periode $\Delta t$ voor de gehele bestudeerde populatie, dus met de personen met én zonder het kenmerk of de positieve uitslag.

We krijgen dan de volgende vergelijkingen:

$$
\frac{\left(C I_{\Delta t} \mid F+\right)}{\left(1-C I_{\Delta t} \mid F+\right)}=\frac{P_{t}(F+\mid D+)}{P_{t}(F+D-)} \cdot \frac{C I_{\Delta t}}{1-C I_{\Delta t}}
$$

waarbij:

$$
\frac{\mathrm{Cl}_{\Delta t} \mid \mathrm{F}+}{1-\left(\mathrm{CI}_{\Delta t} \mid \mathrm{F}+\right)}=
$$

$\frac{\text { cumulatieve incidentie na periode } \Delta t \text { bij patiënten met kenmerk } F}{1-\text { cumulatieve incidentie na periode } \Delta t \text { bij patiënten met kenmerk } F}$

$P_{t}(F+\mid D+)$ likelihoodratio, bepaald uit een cohort-onderzoek

$\frac{t}{\mathbb{P}_{t}(\mathrm{~F}+\mathrm{D}-)}=$ of patiënt-controle onderzoek na afloop van $\Delta t$.

$$
\frac{C I_{\Delta t}}{1-C I}=\frac{\begin{array}{l}
\text { cumlatieve incidentie voor de gehe- } \\
\text { le patientengroep na afloop van } \Delta t
\end{array}}{\begin{array}{l}
1-\text { cumulatieve incidentie voor de ge- } \\
\text { hele patientengroep na afloop van } \Delta t
\end{array}} \text { ("prior disease-odas ') }
$$

De vergelijiking is equivalent aan:

posterior odds = likelihoodratio $\mathrm{x}$ prior odds

Evenals in de diagnostische situatie, moet de eis worden gesteld dat de 'prognostische likelihoodratio' bepaald is bij zieken en niet-zieken uit een brompopulatie die op relevante kemerken representatief is voor de populatie waarop men de prognostische schatting wil toepassen. 
De patienten-groep en de niet-zieken moeten ook representatief zijn voor de personen die na $\Delta t$ de ziekte wel, respectievelijk niet hadden. Een praktisch probleem dat hierbij kan optreden - en wel des te meer naarmate $\Delta t$ langer is - is selectieve uitval van patiënten en wellicht vooral die patiënten die kenmerk $F$ bezitten. De progmostische likelihoodratlo zal hierdoor anderschat kunnen worden. Dit zou nok gebeurd kunnen zijn ten aanzien van ons patiënt-controle onderzoek naar het verband tussen het optreden van een eerste hartinfarct en de hematocriet respectievelijk het hemoglobinegehalte, waarover wij elders in deze bundel verslag uitbrengen. Met deze kanttekening presenteren wij ter 1llustratie van deze paragraaf het verloop van de progmostische likelihoodratio's van de hematocriet en het hemoglobinegehalte voor mannen van 50-60 jaar, voor diverse afkappunten en precieze waarden, zoals berekend op grond van onze resultaten (ongematchte analyse) (figuur 5). Men ziet dat deze likelihoodratio's vooral gaan stijgen als zij hoger worden dan een hematocriet van 48 en een hemoglobine van $10.0 \mathrm{mmol} / 1$.

Het voordeel van de prognostische likelihoodratio ten opzichte van het relatief risico en de odds-ratio is, dat indien deze likelihoodratio eermaal bekend is (eventueel voor verschillende follow-up duren) men slechts de geschatte a priori kans op het ontwikkelen van de ziekte hoeft aan te passen op grond van het nieuwe diagnostische gegeven. Men hoeft nilet meer uit te gaan van de incidentie bij mensen zonder het kenmerk. Dit is vooral een voordeel bij het formuleren van de prognose van individuele patienten, voor wie vaak uitgegaan wordt van een meer op de persoon afgestende a prtor 1 kans op bepaalde verwikkelingen in de toekonst. Bovendien kan men, vooral bij continue variabelen lang niet altija spreken van personen zonder het kenmerk: iederéén heeft een bloeddruk, een cholesterol- of een hemoglobinewaarde. Het is dan beter om als referentlepunt te kiezen de overall (a priori) kans op ziekte, nog niet rekening houdend met het kenmerk of testuitslag. Verder is een voordeel, dat de LR en de a priori kans op het krijgen van de ziekte in principe van elkaar onathankelijk zijn, terwijl het relatief risico mede beinvloed wordt door de a priori kans: als deze zeer hoog is, dan nadert het relatief risico tot 1.0. Uiteindelijk 
(a)

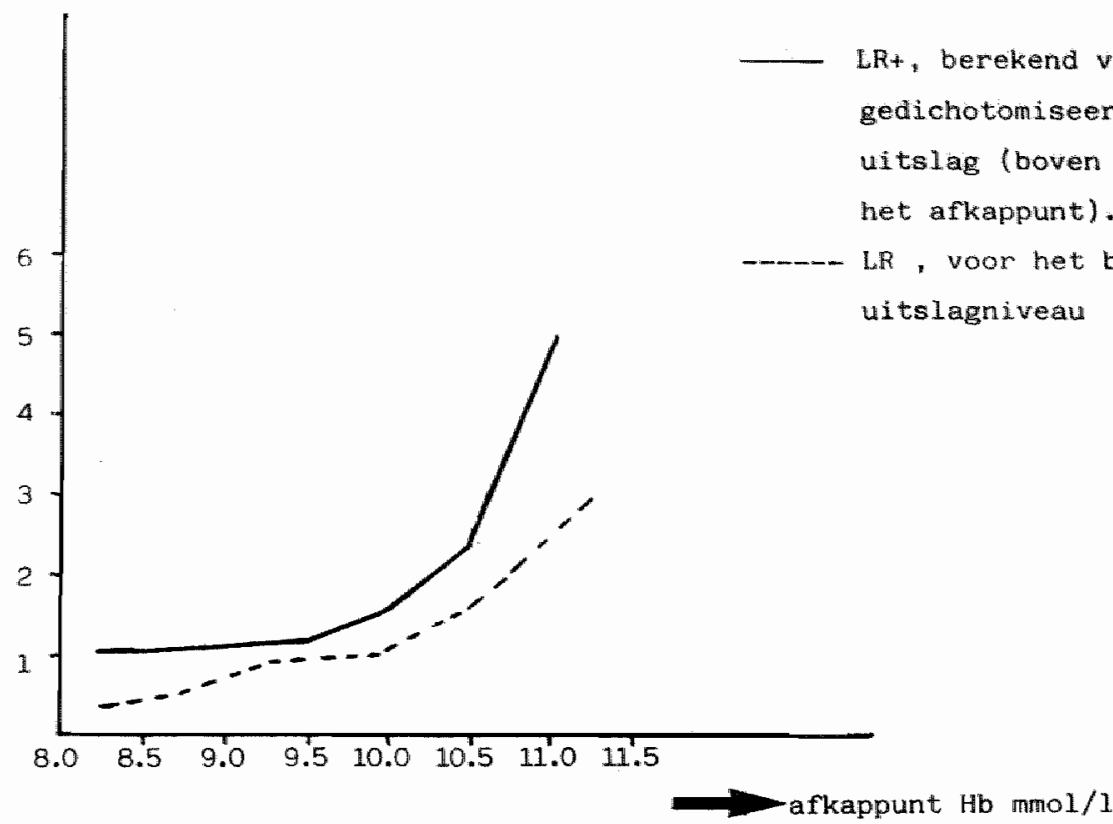

(b)

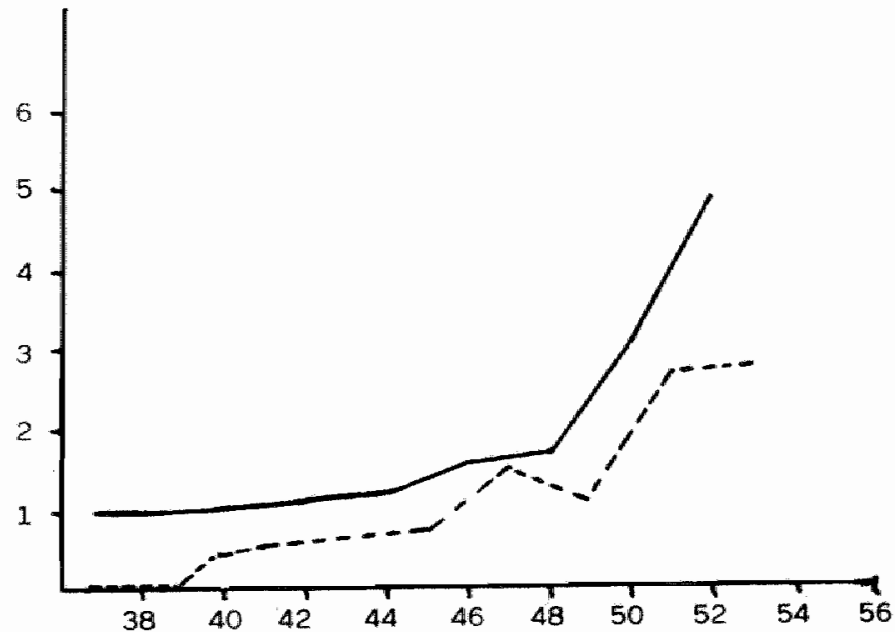

afkappunt $H t(x)$

Figuur 5 Het verband tussen de prognostische likelihoodratio en het Hemoglobinegehalte (Hb) respectievelijk de Hematocriet (Ht) bepaald op grond van een patiënt-oontrole onderzoek naar het - verband tussen het optreden van een eerste hartinfarct en Hb respectievelijk Ht, bij mannen van 50-60 jaar. 
moet op grond van empirische gegevens worden vastgesteld welke mat beter c.q. het meest constant is bij toepassing in verschillende populaties en in relatie tot de follow-up duur. Dit kan voor verschillende kemmerken en aandoeningen anders blijken te liggen.

Het verband tussen de schatting van de kans op het krijgen van de ziekte door middel van de Bayesiaanse methode en de schatting van deze kans met behulp van een logistisch model is eenvoudig. Inmers, het gaat in beide gevallen on dezelfde eindultkanst, namelijk: $C I_{\Delta t} \mid F 4$ Deze is gelijk aan:

$\frac{1}{1+\frac{1}{e^{a+\beta x}}}=$

(volgens het 1ogistische model)
$\frac{1}{1+\frac{1}{\mathrm{LR}_{\mathrm{F}+} \times \text { prior disease-odds }}}\left(=\mathrm{CI}_{\Delta t} \| \mathrm{F}^{+}\right)$

(volgens het Bayesiaanse model)

Zodat:

$a+\beta x=\ln \left(L R_{F+} x\right.$ prior odds $)$

Indien men nu een dichotome onafhankelijke variabele $\mathrm{x}$ transformeert tot $\left(x-x_{0}\right)$, waarbil $x_{0}$ die (virtuele) warde van $x$ is (tussen 0 en 1 ) waarvoor de prior kans gelijk is aan de posterior kans, dan geldt:

$$
\begin{aligned}
& C I_{t} \mid F+=e^{a+B\left(x-x_{0}\right)}=e^{a} \cdot e^{B\left(x-x_{0}\right)} \\
& \text { Hierbif is: } e^{a} \quad=\text { de prior disease odds }\left(x=x_{0}\right) \\
& e^{\beta\left(x-x_{0}\right)}=\text { de prognostische likel ihoodratio } \\
& e^{a-B x_{0}}=\text { de posterior disease-odds bij een negatieve } \\
& \text { test-uitslag of bij afwezigheid van kenmerk } \\
& (x=0) \\
& e^{a+B-\beta_{x}}=\text { de posterior disease-odds bij een pasitieve } \\
& \text { uitslag of bij aanwezigheid van het kenmerk } \\
& (x=1)
\end{aligned}
$$


Bij continue $x$-variabelen is het model op dezelfae wijze toepasbaar. Daarbij kiest men voor $x_{0}$ weer die waarde van $x_{\text {waarbij }}$ de posterior kans gelijk is aan de prior kans (zie ook de appendix bij hoofdstuk 8 en paragraaf 4.1.3. van dit hoofdstuk).

5. Normen in relatie tot het gewicht van de diverse uitkonsten.

Het uiteindelijke doel van het verrichten van diagnostiek is het bijdragen aan de verbetering van de gezondhelidstoestand van de onderzochte. Dit impliceert, dat de beslissing an diagnostiek te doen, en de wijze van interpretatie van de uitslagen in verband moeten worden gebracht met de te verwachten invloed op de gezondheidstoestand. Er zijn diverse manieren on dit gezichtspunt wit te werken.

\subsection{Diagnostiek en behandelbaarheid.}

Diagnostiek wordt gelegitimeerd door haar mogelijk gunstige invloed op de prognose, via een naar aanleiding van de diagnostische resultaten in of bij te stellen behandeling. Men kan hieraan een criteriun ontlenen voor de interpretatie van testuitslagen:

De uitslag van het diagnostisch onderzoek is positief als deze wijst op een behandelbare aandoening of toestand.

De uitslag is negatief uitgevallen warneer deze wijst op géen aandoening of op een aandoening die niet - of niet meer - behandelbaar is. Een voorbeeld is het carotisangiogram. Het kan enerzijds wijzen op operabele stenosen (positief) en anderzijds op afwezigheid van stenosen of op inoperabele stenosen (negatief). Het gaat hilerbij om de klinische relevantie van de uitslag woor het beleid.

Hierbilj is nog onderscheid te maken tussen 'technisch' behandelbaar en vatbaar voor zinvolle interventie. Immers: een carotisangiogram kan wijzen op een op zich operabele stenose, terwijl het nut van endarterectomie voor de prognose nog niet is aangetoond (zie hoofdstuk 18). Het is duidelijk dat een op deze wijze gedefinieerd positiviteitscriterium niet gebaseerd is op de sensitiviteit en specificiteit ten aanzien van de aamwezigheid van ziekte, maar op de sensitiviteit en specificiteit (of voorspellende waarde) ten aanzien van de behandelbaarheid van de ziekte. Dat introductie van het begrip 'behandelbaar' 
tot andere interpretaties kan leiden, blijkt uit het al eerder aangehaalde onderzoek van Garby (9). Door het geven van een proefbehandeling met oraal ijzer kon hij twee subpopulaties onderscheiden in een steekproef van wrouwen wit de algemene bevolking van Zweden: een (grote) aubpopulatie die niet reageerde op ijzertherapie met een stijging van hematocriet en hemoglobine, en een (kleine) subpopulatie die wel reageerde. Hoewel de hematocriet- en hemoglobinewaarden van de whel reagerende groep in het algemeen lager waren dan van de niet-reagerende groep was er een sterke overlap: in beide groepen kwamen veel waarden voor ter weerszijden van het gebruikelijke afkappunt (zie filigur 3 ).

Stel dat men reeds op geleide van de gemeten hematocriet- of hemoglobinewarde (dus zonder ijzer bepalingen te verrichten) zou willen besluiten om al dan niet tot ijzerbehandeling over te gaan (hetgeen in de huisartspraktijk niet ongebruikelijk isi). De vraag, waar men in zo'n geval het afkappunt zou willen aangeven, reikt verder dan het bereiken van een maximaal onderscheidend vermogen. De beantwoording hangt mede af van het gewicht dat men hecht aan:

- het terecht behandelen (terecht-positief)

- het terecht niet behandelen (terecht-negatief)

- het ten onrechte behandelen (fout-positief)

- het ten onrechte niet-behandelen (fout-negatief).

In 5.2. zullen we dit verder uitwerken.

5.2. De bepalling van het optimale afkappunt van een test met een continu (of ordinaal) verdeelde testvariabele, aan de hand van 'utiliteiten'.

Men kan de consequenties van terecht positieve, terecht negatieve, fout-positieve en fout-negatieve uitkomsten uitarukken in warden (utiliteiten), respectievelijk te noemen:

$\mathrm{U}_{\text {'TP' }} \mathrm{U}_{\mathrm{TN}}, \mathrm{U}_{\mathrm{FP}}$ en $\mathrm{U}_{\mathrm{FN}}$ '

Met behulp van een eenvoudige beslisboam, de formule van Bayes en de gelijkstelling van de gezamenlijke warde van alle positieve (TP en FP) aan de gezamenlijke waarde van alle negatieve uitkansten (FN en TP), is de volgende formulle op eenvoudige wijze af te leiden (48). 
$\mathrm{LF}_{\mathrm{X}}=\frac{\mathrm{P}\left(\mathrm{T}>\mathrm{x} \mid \mathrm{D}^{+}\right)}{\mathrm{P}\left(\mathrm{T}>\mathrm{x} \| \mathrm{D}^{-}\right)}=\frac{\mathrm{P}\left(\mathrm{D}^{-}\right)}{\mathrm{P}\left(\mathrm{D}^{+}\right)} \times \frac{\mathrm{U}_{\mathrm{TN}}-\mathrm{U}_{\mathrm{FP}}}{\mathrm{U}_{\mathrm{TP}} \mathrm{U}_{\mathrm{FN}}}$

waarbij $I_{\mathrm{R}}$ staat voor de Iikelihoodratio voor testuitslagen > $\mathrm{x}$, met het optimale afkappunt $\mathrm{x}$ (waarbij de gezamenlijke consequenties van positieve uitslagen even zwaar wegen als die van negatieve uitslagen)

en: $\frac{P\left(D^{-}\right)}{P\left(D^{+}\right)}$de inverse is van de prior odds $(48)$.

Uit de formule blijkt dat de waarde $x$ van het optimale afkappunt (c.q. de optimale likelihoodratio) afhangt van de gekozen utiliteiten van iedere mogelijke testuitkanst. Deze kunnen per arts en/of per patiënt of subgroep van patiënten verschillen.

ook is te zien dat de waarde $x$ van het optimale afkappunt afhangt van de a priori kans: hoe groter de a priori kans, des te kleiner $L_{x}$ (d.w.z. des te minder stringent dient het afkappunt te zijn). Het begrip 'norm' - of grenswaarde verliest nu in feite haar algemeen geldende karakter. Het zal van de specifieke situatie en met name de voorkeuren van de patiënt(en) en de a priori kansen kurnen afhangen welke norm men kiest.

Men kan ook uitgaan van een bepaalde precieze waarde van de testvariabele $\mathrm{T}$. Zonder nu een (geforceerde en inefficiënte) indeling te maken in positieve en negatieve uitslagen $\mathrm{T}^{+}$en $\mathrm{T}^{-}$kan men spreken van $P\left(D^{+} \mid T\right)$ en $P\left(D^{-} \mid T\right)$ : de kans op ziekte, respectievelijk niet-ziekte gegeven de gemeten testuitslag $\mathbb{T}$ (zie ook figuur 3 en 4.1.3.). Voor welke diagnostische conclusie men kiest (wel of niet ziekte constateren, dan wel tot nader onderzoek overgaan) hangt weer mede af van het gewicht van die conclusie voor de diverse classificatie mogeLijkheden van $T\left(U_{T P}, U_{F P^{\prime}}, U_{F N}, U_{T P}\right)$. Voor de precieze gemeten waarde $x$ geldt nu, dat de uitslag zou moten worden beschoumd als wijzend op ziekte als:

$\frac{P\left(D^{+} \mid x\right)}{P\left(D^{-} \mid x\right)}>\frac{U_{T N^{-}}-U_{F P}}{U_{T P^{-}}-U_{F N}}$

en dat de uitslag zou moeten worden beschouwd als wijzend op nietziekte als: 


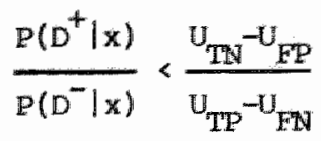

Zijn de twee uiturukkingen gelijk aan elkaar, dan maakt het niet uit welke van de twee conclusies men trekt.

Men kan in platats van $\mathrm{U}_{\mathrm{TP}}, \mathrm{U}_{\mathrm{FP}}, \mathrm{U}_{\mathrm{TN}}$ en $\mathrm{U}_{\mathrm{FN}}$ beter (namelijk neutraler) schrijuen respectievelijk:

$U\left(B^{+} \| D^{+}\right), U\left(B^{+} \mid D^{-}\right), U\left(B^{-} \mid D^{-}\right), U\left(B^{-} \mid D^{+}\right)$.

$\mathrm{B}^{+}$en $\mathrm{B}^{-}$betekenen dan het verder behandelen van patiënten alsof ze ziekte D hebben respectievelijk niet hebben. Dit kan gebeuren in situaties warin men in werkelijkheid wèl, respectievelijk niét, de ziekte DH heeft. In deze uitdrukkingen komt beter tot uiting, dat het gewicht van een uitkonst niet éemmalig wordt vastgesteld, doch in relatie tot de verder te nemen beleidsbeslissingen gezien wordt.

Teruggaand naar figuur 3 betreffende de verdeling van hematocriet waarden bij vrouwen die wel respectievelijk niet reageren op ijzertheraple kunnen we de formule als volgt toepasisen.

Stel: we vinden de waarde van de gezondheidstoestand van iemand die terecht niet behandeld wordt met ijzer $\left.\left(\mathrm{U}^{-\mathrm{B}^{-}} \|^{-}\right)\right)$gelijk aan 1008 . Tevens achten we de schade van onnodige therapie gering: $\mathrm{U}\left(\mathrm{B}^{+} \mid \mathrm{D}^{-}\right)$is bijna even hoog, nl. 958. Ook ten aanzien van de toestand van iemand die terecht met ijzer wordt behandeld zijn we positief gestend: $U\left(B^{+} \mid D^{+}\right)=95 \%$. Het niet behandelen van lemand met ijzergebrek vinden we echter nadelig: $\left.\mathrm{U}^{-\mathrm{B}^{-}} \mid \mathrm{D}^{+}\right)=60 \%$.

We vinden nu: $\frac{U\left(B^{-} \| D^{-}\right)-U\left(B^{+} \| D^{-}\right)}{U\left(B^{+} \mid D^{+}\right)-U\left(B^{-} \| D^{+}\right)}=\frac{(100-95) 8}{(95-60) \%}=\frac{1}{7}$

Dat wil zeggen: $\frac{\mathrm{P}\left(\mathrm{D}^{+} \mid \mathrm{x}\right)}{\mathrm{P}\left(\mathrm{D}^{-} \mid \mathrm{x}\right)}$ dient $>\frac{1}{7}$ te zijm,

tenelnde naar aanleiding van uitslag $x$ tot zinvolle behandeling te kunnen overgaan. Dit betekent dat de gemeten hematocrietwaarde lager dan $38.5(=x)$ dient te zijn (zie figuur 3 ). 
5.3. Het bepalen van de optimale teststrategie, in relatie tot de utiIiteiten van de diverse mogelijke uitkansten.

De vraag wellke normen, of beter handvaten, men moet hanteren bij de interpretatie van diagnostische gegevens kan verbreed worden naar de vraag: in welke situaties is het zinvol on een bepaalde test toe te passen? Naar aanleiding van deze vraagstelling introduceerden Pauker en Kassirer "the treshold approach to clinical decision-making' (62). Door het uitwoeren van diagnostische test wil men de a priori kans $O P$ een aandoening amzetten in een a posteriori kans. Het besluit an naar aanleiding van de testuitslag tot een bepaalde beleidsoptie (bijvoorbeeld therapie) over te gaan hangt af van de vraag of een daardoor bepaalde a posteriori kans kan worden bereikt of overschreden: $\mathrm{P}_{\mathrm{X}}\left(\mathrm{D}^{+} \| \mathrm{T}^{+}\right)$.

Het is duidelijk dat uitvoeren van de test geen zin heeft als:

1) de a priori kans op zichzelf al zoveel hoger is dan $\mathrm{P}_{x}\left(\mathrm{D}^{+} \mid \mathrm{T}^{+}\right)$dat door het uitvoeren van de test de negatief voorspellende waarde niet lager kan komen te liggen dan $\mathrm{P}_{\mathrm{x}}\left(\mathrm{D}^{+} \mid \mathrm{T}^{+}\right)$

2) de a priori kans zo laag is, dat bij een positieve testuitslag de positief voorspellende waarde niet $\mathrm{P}_{\mathrm{x}}\left(\mathrm{D}^{+} \mid \mathrm{T}^{+}\right)$kan bereiken.

Er is dus een bepaalde range van de a priori kans waar binnen het witvoeren van de test zinvol is. Daarboven en daaronder dient men direct te besluiten an wel respectievelijk niet verder te behandelen. Deze range wordt begrensd door twee drempel waarden (tresholds) van de a priori kans.

Indien men van tevoren een idee heeft van de grootte van de a posteriori kans die overschreden moet worden, wil men besluiten tot behandeling of nader onderzoek, dan kan men deze drenqelwaarden berekenen.

Men moet dan wel informatie hebben over de validiteit van de test. Het is mogelijk een nomogram op te stellen, met behulp waarvan deze waarden snel zijn af te lezen. In figuur 6 hebben wij dit aangegeven. Op deze wijze kan men dus een Indruk krijgen van het 'Indicatiegebied' voor toepassing van de test, in termen van de a priori kans. Uitgaande van de validiteit van de test (sensitiviteit en specificiteit) en de met het oog op de nadere diagnostiek te overschrijden posterior kans, kan men dit gebied gemakkelijk berekenen met behulp van een andere schrijfwijze van de formule van Bayes. 


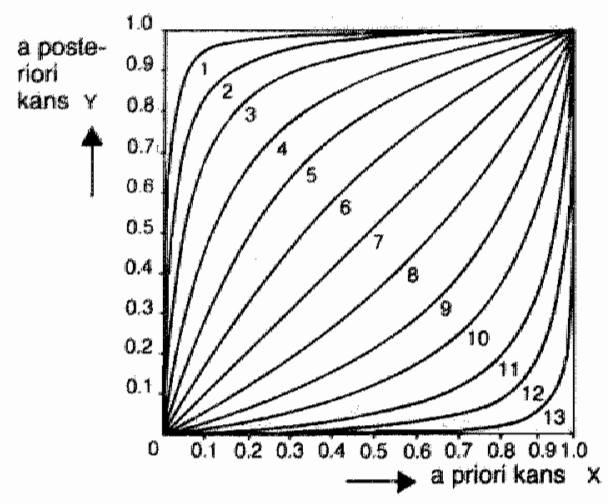

\begin{tabular}{|c|c|c|}
\hline lin & LPt & $\angle R^{-}$ \\
\hline$\overline{1}$ & 200 & \\
\hline 2 & 50 & \\
\hline 3 & 20 & \\
\hline 4 & 8 & \\
\hline 5 & 4 & \\
\hline 6 & 2 & \\
\hline 7 & ข & 1.000 \\
\hline 8 & & 0.500 \\
\hline 9 & & 0.250 \\
\hline 10 & & 0.125 \\
\hline 11 & & 0.050 \\
\hline 12 & & 0.020 \\
\hline 13 & & 0.005 \\
\hline
\end{tabular}

berekening van de lijinen doormiddell van de formules:

$$
\begin{aligned}
& \text { LFt } \quad V=\frac{1}{1+\frac{1}{\operatorname{LAt} \cdot \frac{x}{1-x}}} \\
& L F-Y=1-\left(\frac{1}{1+\operatorname{LF} \cdot \frac{x}{1+\infty} x}\right)
\end{aligned}
$$

Figuur 6: Nomogram voor de bepaling van de a priori kansen waarbij het uitvoeren van de test zinvol is.

Toelichting:

(1) Stel, men heeft een test beschikbaar met sensitiviteit van 56 en een specificiteit van $86 \%$, dat wil zeggen de

$$
\begin{aligned}
L R+ & =\frac{\text { sensitiviteit }}{1-\text { specificiteit }}=4.00 \\
\text { en de } L R- & =\frac{1-\text { sensitiviteit }}{\text { specificiteit }}=0.51
\end{aligned}
$$

(2) Men doet met deze test diagnostiek ten aanzien van ziekte D. Men is wan mening dat behandeling van ziekte $D$ nodig is als na het uitwoeren van de test blijkt dat de kans op de ziekte meer dan 50 o is.

(3) Men kan nu zien dat het doen van de test slechts zinvol is indien de a priori kans tussen circa $20 \%$ en circa $65 \%$ ligt. Dit zijn de snijpunten van de horizontale die de $50 \%$ a posteriori kans markeert, en respectievelijk lijn 5 (behorend bij $L R+=4.0$ ) en 1 ijjn 8 (behorend bij LR- $=0.50$ ).

Indien de a priori kans lager is dan 20\%, dan zal ook bij een positieve uitslag geen a posteriori kans van $50 \%$ bereikt worden. Indien de a priori kans hoger is dan 658, dan zal, $\infty$ k bij een negatieve uitslag, de a posteriori kans toch niet onder de $50 \%$ kunnen kamen. 
Tabel 8: Het indicatiegebied van de hemocculttest in termen van a priori kansen, bij verschillende drempels voor uitgebreidere diagnostiek, voor verschillende waarden van sensitiviteit en specificiteit.

\begin{tabular}{|c|c|c|c|c|}
\hline sensitiviteit & Ispecificiteit & $\begin{array}{c}\text { drempels voor } \\
18 \\
\text { indicatie- } \\
\text { gebied }\end{array}$ & $\mid \begin{array}{c}\text { uitgebreidere } \\
58 \\
\text { indicatie- } \\
\text { gebied }\end{array}$ & $\begin{array}{c}\text { diagnostiek } \\
108 \\
\text { indicatie- } \\
\text { gebied }\end{array}$ \\
\hline 678 & 978 & $0,058-2,98$ & $0,248-13,48$ & $0,50 \%$ \\
\hline 808 & $83 \%$ & $0,218-4,08$ & $1,10 \%-17,9 \%$ & $2,318-31,68$ \\
\hline 908 & 968 & $0,058-8,88$ & $0,238-33,68$ & $0,498-51,68$ \\
\hline 958 & $80 \%$ & $0,218-13,98$ & $1,108-45,7 \%$ & $2,298-64,08$ \\
\hline 958 & 968 & $0,048-16,28$ & $0,228-50,38$ & $0,478-68,18$ \\
\hline
\end{tabular}

Toelichting:

De berekening van de grenzen van het indicatiegebled kan geschieden via de volgende schrijfwijzen van de formule van Bayes, waarbij de drempelwaarde de gewenste voorspellende waarde is.

De kans behorende bij de ondergrens $=$

1

$1+\left(\frac{\text { sensitiviteit }}{1008-\text { specificiteit }}\right) \times\left(\frac{1008-\text { drempelwaarde }}{\text { drempelwaarde }}\right)$

De kans behorendle bij de bovengrens $=$

1

$1+\left(\frac{1008-\text { sensitiviteit }}{\text { specificiteit }}\right) \times\left(\frac{1008-\text { drempelwaarde }}{\text { drempelwarde }}\right)$

Als voorbeeld geven wij in tabel 8 de berekening van het indicatiegebied voor de hemaccult test (op occult bloed in de faeces ter opsporing van dikke darm kanker) voor diverse "drempel kansen' voor nadere diagnostiek (colonfoto en/of coloscopie) en verschillende op grond van de literatuur te beargumenteren waarden van sensitiviteit en specificiteit (deze laatste kunnen variëren met de wijze van uitvoering).

Indien men een opvatting heeft over de waarde (utiliteiten) van de diverse testuitkonsten kan men een stapje verder gaan. De situatie kan dan weer in kaart worden gebracht door middel van een beslisboom (figuur 7). 
DECISION: $\quad$ RESULTS OF TEST: STATE OF PATIENT: OUTCOME:

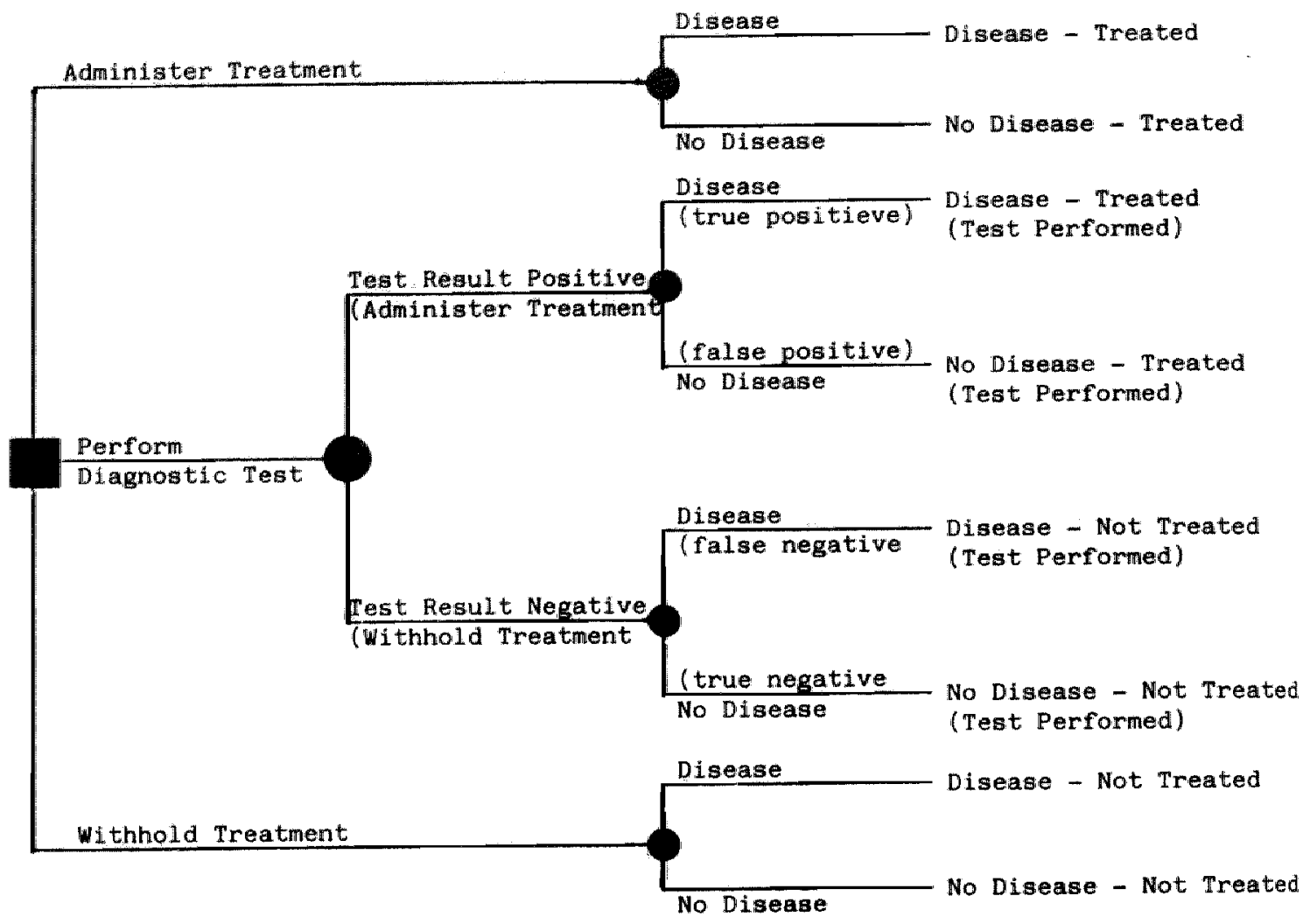

Figuur 7: Beslisboam, ter bepaling van de drempelwaarden van de a priori kans om het toepassen van een test zinvol te doen zijn (62).

Het is duidelijjk dat de drempelwaarden $P_{1}\left(D^{+}\right)$en $P_{2}\left(D^{+}\right)$afhankelijk zijn van het nut van wel en niet behandelen bij zileken en niet-zieken, de risico"s van de test en de validiteit van de test. Gedefiniëerd worden:

- de utiliteit van verdere behandeling bij zieken: $U\left(B^{+} \| D^{+}\right)$

- de utiliteit van verdere behandeling bij niet-zieken: $U\left(B^{+} \mid D^{-}\right)$

- de utiliteit van geen behandeling bij zieken: $U\left(\mathrm{~B}^{-} \mid \mathrm{D}^{+}\right)$

- de utiliteit van geen behandeling bij niet-zieken: $U^{-}\left(B^{-} \mid D^{-}\right)$ 
- de risico"s van het uitwoeren van de test (inclusief de mate van belasting van de test): $R_{t}$

- $P\left(T^{+} \mid D^{+}\right) \quad\left(=1-P\left(T^{-} \mid D^{+}\right):\right.$de sensitiviteit van de test

- $P\left(T^{-} \| D^{-}\right)\left(=1-P\left(T^{+} \| D^{-}\right)\right.$: de specificiteit van de test

- $P\left(D^{+}\right) \quad$ : de a priori kans op D.

De verwachte utiliteit (EU) van de mogelijke diagnostische strategie is nu uit te drukken met behulp van deze symbolen.

(1) EU (niet testen + niet behandelen) = $P\left(D^{+}\right) \cdot U\left(B^{-} \mid D^{+}\right)+\left[1-\mathbb{P}^{+}\left(D^{+}\right)\right] \cdot U\left(B^{-} \mid D^{-}\right)$

(2) EU (testen) $=$ $P\left(T^{+} \| D^{+}\right) \cdot P\left(D^{+}\right) \cdot\left[U\left(B^{+} \mid D^{+}\right)-R_{t}\right]+P\left(T^{-} \mid D^{+}\right) \cdot P\left(D^{+}\right) \cdot\left[U\left(B^{-} \mid D^{+}\right)-R_{t}\right]+$
$P\left(T^{+} \| D^{-}\right) \cdot P\left(D^{-}\right) \cdot\left[U\left(B^{+} \mid D^{-}\right)-R_{t}\right]+P\left(T^{-} \| D^{-}\right) \cdot P\left(D^{-}\right) \cdot\left[U\left(B^{-} \mid D^{-}\right)-R_{t}\right]$

en

(3) EU (niet testen behandelen) = $P\left(D^{+}\right) \cdot U\left(B^{+} \mid D^{+}\right)+\left[1-P\left(D^{+}\right)\right] \cdot U\left(B^{+} \mid D^{-}\right)$.

Hierbij is uitgegaan van de (vereenvoudigde) situatie, dat $\mathbb{R}_{t}$ niet afhankelijk is van de ziekte status.

Voor $\mathbb{P}_{1}\left(D^{+}\right)$, d.w.z. de drempel tussen strategie 1 (niet testen en niet behandelen) en strategie 2 (testen en afhankelijk van de uitslag handelen) geldt dat verwachte utiliteiten van beide strategieën juist aan elkaar gelijk te zijn. Door (1) en (2) aan elkaar gelijkt te stellen kan men de vergelijking dan oplossen voor $P\left(D^{+}\right)$:

$P_{1}\left(D^{+}\right)=$

$\frac{P\left(T^{+} \mid D^{-}\right) \cdot\left[U\left(B^{-} \mid D^{-}\right)-U\left(B^{+} \mid D^{-}\right)\right]+R_{t}}{P\left(T^{+} \mid D^{-}\right) \cdot\left[U\left(B^{-} \| D^{-}\right)-U\left(B^{+} \mid D^{-}\right)\right]+P\left(T^{+} \mid D^{+}\right) \cdot\left[U\left(B^{+} \mid D^{+}\right)-U\left(B^{-} \mid D^{+}\right)\right]}$

Evenzo kan men $\mathrm{P}_{2}\left(\mathrm{D}^{+}\right)$berekenen door $(2)$ en (3) aan elkaar gelijk te stellen: 
$P_{2}\left(D^{t}\right)=$

$\frac{P\left(T^{-} \mid D^{-}\right) \cdot\left[U\left(B^{-} \mid D^{-}\right)-U\left(B^{+} \mid D^{-}\right)\right]-R_{t}}{P\left(T^{-} \mid D^{-}\right) \cdot\left[U\left(B^{-} \mid D^{-}\right)-U\left(B^{+} \mid D^{-}\right)\right]+P\left(T^{-} \mid D^{+}\right) \cdot\left[U\left(B^{+} \mid D^{+}\right)-U\left(B^{-} \mid D^{+}\right)\right]}$

Indien men de testkenmerken, de waarden van de diverse uitkomsten, en de risico"s van de test kent of kan schatten, kan men het verloop van de verwachte utiliteit van de arie strategieën (ten opzichte van elkaar) grafisch weergeven als functies van $P\left(D^{+}\right)$(figur B) (63). De snijpunten tussen de grafieken van $Q$ en $T$ respectievelijk $T$ en $W$ leveren de drempelwaarden $P_{1}\left(D^{+}\right)$en $P_{2}\left(D^{+}\right)$op. Men heeft dan in feite een sensitiviteitsanalyge verricht, waarbij wordt nagegaan hoe de voorkeur voor een bepalde strategie verandert bij variatie van $P\left(D^{+}\right)$. Deze benadering beperkt zich niet tot testen met dichotome (of gedichotomiseerde) uitkomsten. Doubillet (63) heeft de benadering uitgebreid voor tests met een ordinale, respectievelijk een continue testvariabele. In zijn benadering is het mogelijk de optimale strategie te kiezen uitgaande van een bepaalde a priori kans én iedere gemeten testuitkomst $T_{x}$. Het is mogelijk an daarbij een keuze te maken tussen diverse tests of teststrategieên.

In feite kant het erop neer, dat het kiezen van de meest optimale diagnostische strategie een besliskundige probleemstelling is, waarbij naast de structuur van de te nemen beslissing (te representeren in een beslisboom) a priori kansen, conditionele kansen en utiliteiten de pijlers van de optimale besluitvorming zijn.

\section{Conclusie.}

In dit hoofdstuk heblben wij een inventarisatie gegeven van de vragen die aan de orde komen bij het spreken over referentie waanden, en de diverse benaderingen die er zijn voor de beantwoording ervan.

De belangrijkste conclusie is, dat het definieren van een referentiegebied c.q. optimaal 'afkappunt' een probleem is dat niet in het algemeen is op te lossen. De a priori kans, de testkenmerken (c.q. de verdeling van uitslagen bij zieken en niet-zieken) de risico's van de test, en het gewicht van de diverse uitkamsten spelen een grote rol. 


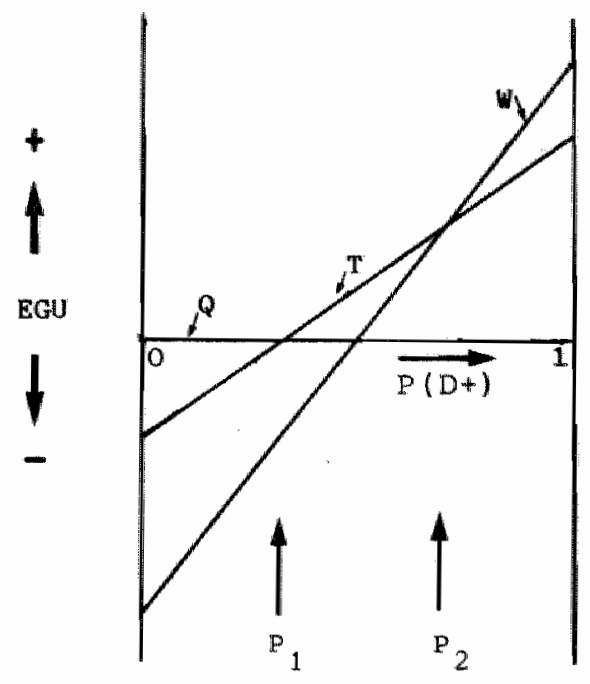

Figuur 8 Grafische weergave van de bepaling van de drempelwaarden van de a priori kans voor het zinvol zijn van het verrichten van een diagnostische test (63).

Toelichting:

$Q=$ niet testen, niet verder behandelen ("njiets doen")

$\mathrm{T}=$ testen en naar aanleiding $\operatorname{van}$ de uitslag handelen ("testen")

$W=$ niet testen, direct verder handelen ("direct behandelen")

EGU = expected gain in utility

$\mathrm{P}_{1}=$ a priori kans, die de drempel vormt tussen "niets doen" en $\mathrm{P}_{2}=$ a priori kans, die de drempel vormut tussen "testen" en "direct behandelen".

In klinische termen: de patiënt, diens probleem en persoonlijke waarderingen van risico's en uitkomsten moeten zo individueel mogelijk benaderd worden. In feite heeft men te maken met een besliskundige probleemstelling, waarbi.j ook de zin van het doen van de test ter discussie staat.

Diagnostische informatie die in principe wel in het algemeen te verschaffen is, betreft de verdelingen van test-uitkansten bij zieken en niet-zieken, liefst voor verschillende zilektetoestanden en verschillende populaties. Deze vormen immers de sleutel voor de testikenmerken, welk afkappunt of methode men ook kiest, en zijn de basis voor ledere 
benadering. De voorkeur verdient hierbij een benadering waarbij, in geval van ordinale of continu-verdeelde testuitkonsten, zoveel moge$\mathbb{l i j k}$ de informatie die vervat is in de precieze waarde van de testuitslag wordt gebruikt in plaats van alle uitkomsten onder te brengen in een kunstmatig gedichotamiseerde schaal.

Een belangrijk uitgangspunt is het doel dat men nastreeft. Of het nu gaat om het beschrijven van de verdeling van meetwaanden in populaties; het bestuderen van het verband tussen testuitslagen, klachten en diagnosen: het selecteren van tests met een groot onderscheidend vermogen; medische besluitvorming met een behoefte aan toename aam zekerheid; prognostische voorspellingen, of on het bepalen van de optimale test-strategie in individuele gevallen; telkens is een op het doel toegesneden benaderingswijze aangewezen.

\section{LITERATUUR.}

1. Murphy EA. "The normal, and the perils of the sylleptic argument. Perspectives in Biology and Medicine 1972; 566-581.

2. Meyers ID, Habicht JP, Johnson CC. Components of the differences in hemoglobin concentrations in blood between black and white women in the United States. Am J Epid 1979; 109: 535-549.

3. Owen GM, Yanochik-owen A. Should there be a different definition of anemia in black and white children? Am J Public Health 1977; 67: $865-866$.

4. Micozzi M. On definition of anemia in pregnancy. Am $I$ Public Health 1978; 68: $907-908$.

5. Wintrobe M. Clinical Haematology. Lea Febiger 1981.

6. Kilpatrick GS. Prevalence of anaemia in the general population. Brit Med J 1961; dec 30: 1736-1738.

7. Waters WE. Ten-year Haematological Follow-up: mortality and haematological changes. British Medical Journal 1969; 4: 761-764.

8. Elwood PC, Waters WE, Greene WJ, wood MM. Evaluation of a screening survey in adult non-pregnant women. Brit Med J 1967; 4 : $714-717$.

9. Garby L, Imell L, Werner I. Acta Soc Med Upsalien 1967; 72: 91. 
10. Hallberg I, Bengtsson C, Garby L, Tibblin E, Lennartson J, Rassander L. An analysis of factors leading to a reduction in iron deficiency in Swedish women. Bulletin wHO 1979; 57: 947-954.

11. Garby L, Irnell $L$, Werner I. Iron deficiency in women of fertile age in a Swedish community. III. Estimation of prevalence based on response to iron supplementation. Acta Med Scand 1969; 185: 113-117.

12. Elwood PC. Nutritional state of elderly Asian and English subjects in Coventry. Lancet 1972; 3 juni: 1224-1227.

13. Bengtsson $C$. The study of women in Gothenburg 1968-1969 - a population study. Acta Med Scand 1973; 193: 311-318.

14. Bengtsson C. The population study of women in Gothenborg 1974-1975 - the second phase of a longitudinal study. Scand J Soc Med 1978; $6: 49-54$.

15. Campbell H. Pilot survey of haemoglobin and plasma urea concentration in a random sample of adults in Wales 1965-1966. Brit J Prev Soc Med 1968; 22: 41-49.

16. De Wijn JF, Rusbach HW. Het hemoglobinegehalte van Nederlandse schoolkinderen en adolescenten. Ned Tijdschr Geneesk 1961; 105: $1028-1035$.

17. Nijenhuis HWA. Pre-employment health conditions among young people. Proefschrift, Amsterdam 1975.

18. Hoeven $J$ van der. Evaluation of a programe of periodic medical examination. Proefschrift, Nijmegen 1971.

19. International Comittee for Standardization in Haematology. Recommendation for measurement of erythrocyte sedimentation rate of human blood. Am J Clin Pathol 1977; : 505-507.

20. Lewis, SM. Erythrocyte Sedimentation Rate and plasma viscosity. Association of Clinical Pathologists Broadsheet $1980 ; 94: 1-7$.

21. Böttiger LE, Svedberg $C A$. Normal erythrocyte sedimentation rate and age. Br Med J 1967: 85-87.

22. Raffnson V, Bengtsson C, Lennartsson J, Noppa H, Tibblin E. ErYthrocyte sedimentation rate in a population sample of women with special reference to its clinical and prognostic significance. Acta Med Scand 1979; 206: 207-214.

23. Miller A, Green M, Robinson D. Simple rule for calculating nomal erythrocyte sedimentation rate. Br Med J 1983; 286: 266. 
24. Eastham pD. Simple rule for calculating normal erythrocyte sedimentation rate (letter to the editor). Brit Med J 1983; 22 jan: $557-558$.

25. Patri B, Margara JP, Loison F, Dubrisay J. Vitesse de sédimentation. Le Concours Medical 1980; 102:4265-4269.

26. Costongs GMPJ. Intra-individual variations and critical differences of clinical laboratory parameters. Proefschrift. Maastricht 1985.

27. Feinstein AR. Clinical Epidemiology, the architecture of clinical research. WB Saunders, Philadelphia

28. Knottnerus JA, Knipschild PG, Sturmans F". Symptomatologie en selectiebias, vertekening van het verband tussen klachten en diagnosen ten gevolge van selectie naar hogere echelons. Huisarts en Wetenschap 1985; 28 : 325-330.

29. Knottnerus JA, Knipschild PG, Wersch JWJ van, Sijstermanns AHJ. onverklaarde moeheid en hemoglobinegehalte, een onderzoek vamuit de huisartspraktijk. Ned Tijdschr Geneesk 1986; 130: 402-405.

30. Knipschild PG, Vissers A, Knottnerus JA. Hoofdpijn en hoge bloeddruk van een bevolkingsonderzoek in Amsterdam. Huisarts en Wetenschap 1984; $27: 441-445$.

31. Knottnerus JA, Knipschild PG, Wersch JWJ van, Sijstermanns AHJ. Serumferritine, bij moeheidspatiënten en gezonde controle personen in de huisartspraktijk. Wordt gepubliceerd in: Ned Tijdschr Geneesk 1986; 130.

32. Bezemer PD, Netelenbos JC, Mulder C, Theune JA, Stamhuls IH, Straub JP. Determining reference ('normal') limits in medicine: an application. Statistics In Medicine 1983; 2: 191-198.

33. Pincherle G, Shanks J. Value of the erythrocyte sedimentation rate as a screening test. Br J Prev Soc Med 1967; $21: 133136$.

34. Boyd $\mathrm{kV}$, Hofforand BI. Erythrocyte sedimentation rate in elderly hospital in-patients. Br Med J 1966; : 901-902.

35. Rafnsson V. Bengtsson $C$, Lurie M. Erythrocyte Sedimentation Rate in women with different manifestations of joint disease. scand $J$ Kheumatol 1982; 11: 87-95.

36. Kenny MW, Worthington DJ, Stuart J, AJ Davies, M Farr, Davey PG, Chughtai MA. Efficiency of haematological screening tests for detecting disease. Clin Lab Haematol 1981; $3: 299-305$. 
37. Knuth UA, Muhlerstedt D, Schneider HPG. Zur effektivitat won Kurszwellenbelastungtests, Blutkorperchen senkungisgeschwindigkeit und leucocytenzahl bei der diagnose der subakuten adnexitis. Geburtshilfe und Frauenheilkunde 1982; 42: 52-55.

38. Peyman MA. The effect of malignant disease on the erythrocyte sedimentation rate. Br J Cancer 1962; 16:56-71.

39. Rai GS. Erythrocyte sedimentation rate and disease in the elderly. I Am Geriatr Soc 1979; 27: 382-383.

40. Asbjörnsen $G$. Serum copper campared to erythrocyte sedimentation rate as indicator of disease activity in Hodgkin's disease. Scand J Haemat $1977 ; 22: 193-196$.

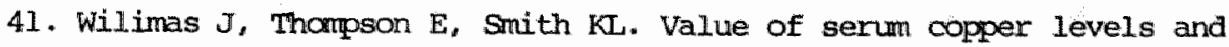
erythrocyte sedimentation rates as indicators of disease activity in children with Hodgkin's disease. Cancer 1978; 42: 1929-1935.

42. Salter RH, Gastrointestinal malignancy and the ESR. Practitioner 1981: $255: 566-568$.

43. Schwartz WB, wolfe HJ, Pauker SG. Pathology and probabilities, a new method to interpreting and reporting biopsies. New Engl J Med $1981 ; 305: 917-923$.

44. Knottnerus JA, Stumans F. Over vertekening van testuitslagen door reeds aanwezige informatie. The Practitioner 1985; 2: 287-295.

45. Stunmans F. Epidemiologie, theorie, methoden en toepassing. Nijmegen 1982. Dekker \& Van der Vegt.

46. Begg $C B$, Greenes RA. Assessment of diagnostic tests when disease verification is subject to selection bias. Biometrics 1983; 39: $207-215$.

47. Gray R, Begg CB, Greenes RA. Construction of Receiver Operating Characteristics when disease verification is subject to selection bias. Med Decis Making 1984; 4:151-164.

48. Weinstein MC, Fineberg HV * Clinical Decision Analysis. Saunders, Philadelphia 1980.

49. Department of Clinical Epidemiology \& Biostatistics. MoMaster University. Manual for a workshop on how to teach the critical appraisal of clinical evidence (Diagnosis Unit). Hamilton 1984.

50. Conell FA, Koepsel1 TD. Measures of gain in certainty from a diagnostic test. Am J Epid 1985; 121: 744-753. 
51. Mckleill BJ, Keeler E, Adelstein SJ. Primer on certain elements of medical decision making. N Eng J Med 1975; 293: 211-215.

52. Dawber TR. The Eramingham Study. Harvard University Press Cambridge, 1980.

53. Herman B, Leyten ACM, Luijck JH van, Frenken GWCM, Op de Coul AAN, Schulte BPM. An evaluation of risk factors for stroke in a Dutch Community. Stroke 1982; 13: 334-339.

54. Tibblin $G$, Wilhemsen $L$, Werkö L. Risk factors for myocardial infarction and death due to ischemic heart disease and other causes. Am J Cardiology 1975; 35: 514-522.

55. Yano K, Reed DM, MoGee DL. Ten-year incidence of coronary heart disease in the Honolulu heart program. Am J Epid 1984; 119: $653-666$.

56. Elwood PC, Waters WE, Benjamin IT, Sweetnam PM. Mortality and anaemia in women. The Lancet 1974; $2: 891-894$.

57. Campbell MJ, Elwood PC, Mackean J, Waters WE. Mortality, haemoglobin level and haematocrit in women. J Chron Dis 38: 881-889.

58. Truett J, Cornfield J, Kannell W. A multivariate analysis of coronary heart disease in Framingham. J Chrom Dis 1967; 20: 511-524.

59. Abu-Zeid HAH. The relation between haemoglobin level and the risk for ischemic heart disease: a prospective study. J Chron Dis 1976; 29: $395-403$.

60. Wilhelmsen $\mathrm{L}$, Wedel $\mathrm{H}$, Tibblin $\mathrm{G}$. Multivariate analysis of risk factors for coronary heart disease. Circulation 1973; 48: 950-958.

61. Brand RJ, Rosenman $\mathbb{R H}$, Sholtz RI, Friedman M. Multivariate prediction of coronary heart disease in the Western Collaborative Group Study compared to the findings of the Framingham Study. Circulation 1976; $53: 348-355$.

62. Pauker SG, Kassirer JP. The treshold approach to clinical decision making. New Eng J Med 1980; 302: 1109-1117.

63. Doubilet P. A mathematical approach to interpretation and selection of diagnostic tests. Med Decis Making 1983; 3: 177-195. 
DE INVLOED VAN VERWIJSGEDRAG OP HET ONDERSCHEIDEND VERMOGEN VAN DIAGNOSTISCHE TESTS.

J.A. Knottnerus ${ }^{1)}-$ P. Leffers 2 )

Samenvatting.

Het onderscheidend vermogen van een diagnostische test, gekarakteriseerd door sensitiviteit, specificiteit, aannemelijkheidsquotient en FOC-curve kan veranderen ten gevolge van verwijspatronen van huisartsen. Vooral de symptamatologie en de de uitslag van de eventueel reeds verxichte test zullen de verwijskans beinvloeden, terwijl de mate van ontwikkeling van het pathologisch proces rechtstreeks de kans op positieve uitslagen beinvloedt. De mogelijke veranderingen worden geanalyseerd met behulp van rekenvoorbeelden, waarbij achtereenvolgens worden bestudeerd: de verwijzing is alleen afhankelijk van de symptomatologie; de verwijzing is afhankelijk van symptomatologie en testuitslag; de verwijzing is alleen afhankelijk van de testuitslag. In het eerste geval blijven de testkenmerken en voorspellende waanden per stratum van de symptomatologie onveranderd, in het laatste geval veranderen alleen de voorspellende waarden niet. Als er een positief verband bestaat tussen de afwijkende testuitslag en de verwijskans, zal overall de sensitiviteit toenemen, de specificiteit afnemen en het aannemelijkheidsquotient van de afwijkende uitslag afnemen. Een algemene representatie wordt gegeven voor de evaluatie van de richting van de de verandering van het aannemelijkheldsquotient.

1) Capaciteitsgroep Huisartsgeneeskunde en Capaciteltsgroep Epidemiologie

2) Capaciteitsgroep Epidemiologie

Rijksuniversiteit Limburg 
Inleiding.

Vaak wordt aangencmen, dat de validiteit van een diagnostische test (in casu de sensitiviteit en specificiteit) een vast gegeven is, onafhankelijk van de populatie wearin men de test toepast. De voorspellende waarde van testuitslagen wordt dan verder alleen bepaald door de prevallentie van de te diagnostiseren ziekte in de te onderzoeken populatie. Naar aanleiding hiervan is erop gewezen dat testuitslagen in de huisartspraktijk een andere woorspellende waarde kunnen hebben dan in de praktijk van de specialist. De prevalenties (a priori kansen) zullen namelijjk in beide situaties dikwijls verschillen (1-4).

In de laatste jaren is benadrukt, dat nilet alleen de voorspellende waarde, maar ook de validitelt van de test zelf niet los te zien is van de populatie die onderzocht wordt $(3,5-8)$. Behalve de aan- of afwezigheld van ziekte (tot uiting komend in de prevalentie) zijn er andere factoren die de testuitslag kurnen beinvloeden, en deze factoren kunnen in verschillende populaties anders verdeeld zijn.

Zo is beschreven, dat de sensitiviteit van reumaserologie ten aanzien van relmatoìde artritis in de algemene bevolking lager is, dan in, door middel van verwijzing naar reumapoliklinieken, geselecteerde populaties (9). En wat betreft de manmografische screening op borstkanker wordt in de algemene bevolking vaak een hogere specificiteit gevonden dar bij vrouwen die voor evaluatie van een knobbeltje naar een chirurgisch centrum zijn verwezen (10). Met dergelijke verschillen moet men rekening houden bij medigch-besliskundige analyses en het op grond daarvan aanbevelen van bepaalde handelswijzen. Vertekeningen, en dus foutieve adviezen kumnen het gevolg zijn van onjuiste schattingen var de validiteit van diagnostische tests.

Vaak zal het niet mogelijk zijn on de benodigde basisinformatie rechtstreeks uit de doelpopulatie te betrekken. Het is bijvoorbeeld nauwelijks denkbaar dat de validiteit van het inspannings-electrocardiogram bij mensen die de huisarts bezoeken met atypische klachten op de borst oolt zal worden vastgesteld door bij een ruime steekproef van deze persomen, naast electrocardiografie, cok nog coronairangiografie te verrichten (11). In dergelijke gevallen zullen gegevens ontleend aan meer of minder geselecteerde groepen het uitgangspunt blijven. an die 
reden is het van belang om tenminste inzicht te hebben in de mechanismen die bij de selectie een rol spelen, teneinde uitspraken te kumen doen over de te verwachten richting en grootte van de vertekening. Selectie-invioeden kunnen een vertekening geven van het onderscheidend vermogen, indien we te maken hebben met een "niet-perfecte test". wanneer er dus een overlap is van uitslagen van zieken en niet-zieken. Dit is in de regel het geval.

Dit artikel is gericht op verschillen die te verwachten zijn tussen de huisartsgeneeskundige en de specialistische praktijk, wat betreft de validiteit - of liever: het onderscheidend vermogen - van diagnostische tests. Besproken wordt het effect van selectie door middiel van verwijzing op diverse parameters waarin men het onderscheidend vermogen kan uitarukken:

- de sensitiviteit en de specificiteit.

- het aannemelijkheidsquotient.

- van de positieve uitslag $=\frac{\text { sensitiviteit }}{1-\text { specificiteit }}$

. van de negatieve uitslag $=\frac{1 \text {-sensitiviteit }}{\text { specificiteit }}$

- de Receiver Operating Characteristic (ROC-curve).

Wij beginnen met een bespreking van enkele factoren die in het kader van het selectieproces belangrijk zijn.

\section{Selectieve invloeden bij verwijzing.}

Verandering van het onderscheidend vermogen van een diagnostische test door verwijzing kan optreden indien er factoren werkzaam zijn, die zowel met de kans op bepaalde (bijvoorbeeld positieve) testuitslagen als met de kans op verwijzing samenhangen. Zulke factoren zijn:

a) het "klinisch beeld": de ontwikkeling van de symptomatologie en emst van de ziekte:

b) de uitslagen van reeds verricht diagnostisch onderzoek. 
- Symptonatologie kan in allerlei gradaties van ontwikkeling voorkomen. Een aandoening kan gepaard gaan met een breed spectrum van kilinische beelden, variêrend van "asyriptamatisch", tot "sterk ontwikkeld"t" of "zeer suspect". Ook bij mensen zónder de te diagnostiseren aandoening kan een meer of minder sterk ontwikkeld beeld voorkomen. Fr kan bijvoorbeeld een palpabele tumor in de mama aanwezig zijn zonder dat er sprake is van kanker.

- Wanneer er sprake is van ziekte, zijn er weer diverse graden van ernst (hier is bedoeld: de ontwikkeling van het pathologisch proces) te onderscheiden. Dit is bijvoorbeeld het geval bij de histologische en klinische ontwikkelings-stadia van veel maligne tumoren. Hoewel zij in geval van ziekte in het algemeen positief samenhangen, dienen de mate van ontwikkeling van de symptamatologie (s) en de ernst van ziekte (D) van elkaar te worden onderscheiden. Immers een ziekte in een vergevorderd stadium $\mathrm{kan}$ nog asymptomatisch $\mathrm{z} i \mathrm{jn}$, terwijl een niet- of niet-ernstig zieke toch een verontrustende symptamatologile kan vertonen. Fr zijn cok situaties waarbij $S$ en D geheel of grotendeels samenvallen, zoals bij allerlei "symptoomdiagnosen" (hoofdpijn, migraine, low back pain, angina pectoris) en in het geval dat de (ernst van de) ziekte (mede) wordt gedefinieerd aan de hand van de symptomatologie (reumatoide artritis, coronair aandoeningen).

- Een diagmostische test ontleent zijn bestaansrecht aan het feit dat de uitslag ervan, en daarmee de kans dat de referentiewaarde wordt overschreden (c.q. de test positlef uiltvalt), afhangt van de aan- of aanwezigheid van (een) bepaalde ziekte( $n)$. De uitslag is in het algemeen ook afhankelij]k van de érnst van de ziekte. Bij ernstige of verder ontwikkelde hepatitis zullen de uitslagen geniddeld hoger uitvallen dan buj lichte hepatitis. En grote levertumoren zullen eerder een afwi jkend echogram opleveren dan kleine.

De ultslag kan voorts samenhangen met de symptamatologie. Voor een deel is dit het gevolg van het verband tussen symptomatologile en de ernst van de ziekte. Deels echter kan de symptomatologie een zelfstandige invloed hebben, zowel bij personen met een bepaalde ziekte als bij personen zonder die ziekte. Sans hangt de symptomatologie dan samen met andere afwijkingen. Zo zijn er bij vrouwen met gave 
mamae minder fout-positieve manmogrammen ten aanzien van carcinoom te verwachten, dan bij vrouwen met palpabele multipele (benigne) tumoren. Ook kan het zijn, dat een maligne tumor minder gemakkelijk wordt gevonden als hij te midden van goedaardige aandoeningen ligt (12-14). De beinvloedingen van de kans op een bepaald test resultaat zijn conplex, en de richting waarin de invloed werkt is niet altijd voorspelbaar.

- De kans dat een patiënt door de huisarts wordt verwezen naar een specialist, wordt onder meer beĩnvloed door:

1) De mate van ontwikkeling van de symptomatologie $s$ (inclusief voorgeschiedenis en anamese). Met name als de ziektestatus nog onbekend is, zal de symptomatologie een belangrijke rechtstreekse invloed op de verwijskans hebben.

2) De ernst van de ziekte. Deze zal, los van de symptonatologie, alleen invloed op de verwijiskans hebben als de huisarts naast de symptomen nog andere (terechte) gronden heeft om aan (een bepaalde graad van ernst van) ziekte $D$ te denken én bij ernstiger vormen van ziekte D relatief vaak verwijzing wenselijk acht. Dok kan het zijn dat de ziekte reeds door de huisarts is vastgesteld. Verwijzing kan dan on therapeutische redenen plaatsvinden, vooral bij ernstiger gevallen.

3) De uitslag van het eventueel door de huisarts verrichte onderzoek T. Een afwijkende uitslag zal in de regel een positieve invloed op de verwijskans hebben, een niet-afwijkende uitslag een negatieve. Dok het tegengestelde is mogelijk, afhankelijk van de zin van verwijzing bij het vermoeden of vastgesteld zijn van (een) bepaalde ziekte( $(n)$. Daamaast zal een aantal patiënten onderzoek. $\mathrm{T}$ niet ondergaan, maar op andere gronden verwezen worden. De uitslag van de test heeft in die gevallen geen rechtstreekse invloed op de verwijskans.

In het algemeen is de kans dat de test iberhaupt wordt uitgevoerd afhankelijk van de symptonatologie. Dit leidt er toe dat van de eventuele afwijkende uitslagen er relatief veel in de meer suspecte groepen worden gevonden, zelfs als er in werkelijkheid géen verband is tussen de testuitslag en de ziekte. Als nu de verwijskans toeneent bij meer suspecte symptomatologie en bij een posi- 
tieve testuitslag, dan zal dit invloed hebben op de validiteit van de test in de via verwijzing geselecteerde populatie. Bij het bestuderen van de invloed van verwijzing op het onderscheidend vermogen van test $T$, is de verwijsikans op grond van de test zelf van belang als de test-uitslagen vobr en ná verwijzing met elkaar samenhangen. Dit is in de regel het geval, en wel via een positieve samenhang.

Ter vereenvoudiging gaan wij er in het volgende vanuit dat een bepaalde testuitslag vớr en ná verwijzing hetzelfaje zal uitvallen. Het gaat dan in de verdere bespreking uiteraard an diagnostische tests, die zowel door de huisarts als de specialist uitgevoerd kunnen worden. Het zijh juilst dergelijke tests waarvoor het van belang is de invloed van selectie op het onderscheldend vermogen te bestuderen.

Verwijzing alleen naar aanleiding van de symptomen.

Aangenomen mag worden dat, indien de diagnose nog niet bekend is, de symptanatologie (bijvoorbeeld de hevigheid van angina pectoris klachten) een rechtstreekse invloed heeft op de verwijskans. De mate van ontwikkeling van het pathologisch proces (bijwoorbeeld de graad van vernauwing van de coronair vaten) heeft in deze situatie vooral een rechtstreekse invloed op de testuitslag (de kans op een afwijkkend inspanningselectrocardiogram).

Ten aanzien van niet-zieken kan men twee situaties onderscheiden:

1) de kans van niet-zieken op een afwijkende uitslag is onafhankelijk van de symptonatologie. Bijvoorbeeld: het inspanningselectrocardiogram van een overigens gezonde man met oesophagus-klachten die op angina pectoris lijken, wordt niet beinvloed door de hevigheid van die kilachten:

2) de kans van niet-zieken op een afwijkende uitslag hangt wel samen met de symptomatologie. Wij noemden in dit verband al de samenhang tussen symptomatologie van (goedaardige) mama-afwijkingen en de validiteit van mamografie. ook is het mogelijk dat de testuitslag vertekend is door voorafkennis over de symptanatologie (15). 
SCHEMA 1: Invloed van verwijzing op de parameters betreffende het verband tussen testuitslag en ziekte, indien er een positieve samenhang is tussen de kans op een positieve testuitslag en de mate van ontwikkeling van de symptomatologie, en indien de verwijskans $V$ groter wordt bij meer ontwikkelde symptomatologie.

Een getallenvoorbeeld.

(a) Verdeling van personen, verwijskansen, en de kans op positieve uitslagen naar symptomatologie en ziekte-status.

Symptonatologie duidelijk ontwikkeld

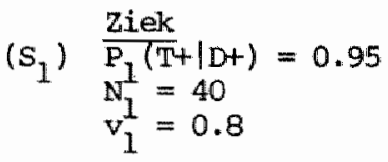

Niet-ziek

$$
\overline{P_{1}(T+\mid D-)}=0.30
$$$$
\mathbb{N}_{3}=40
$$$$
v_{3}^{3}=0.8
$$

minder duidelijk ontwikkeld $\left(S_{2}\right)$

$$
\begin{aligned}
& \mathrm{P}_{2}(T+\mid \mathrm{D}+)=0.60 \\
& \mathrm{~N}_{2}=60 \\
& \mathrm{~V}_{2}^{2}=0.2
\end{aligned}
$$$$
\mathrm{P}_{2}(\mathrm{~T}+\mid \mathrm{D}-)=0.05
$$$$
\mathrm{N}_{4}^{2}=160
$$$$
\begin{aligned}
\mathrm{N}_{4}^{4} & =0.2
\end{aligned}
$$

(b) De parameters van de testuitslag in relatie tot de ziekte vón en ná verwijzing.

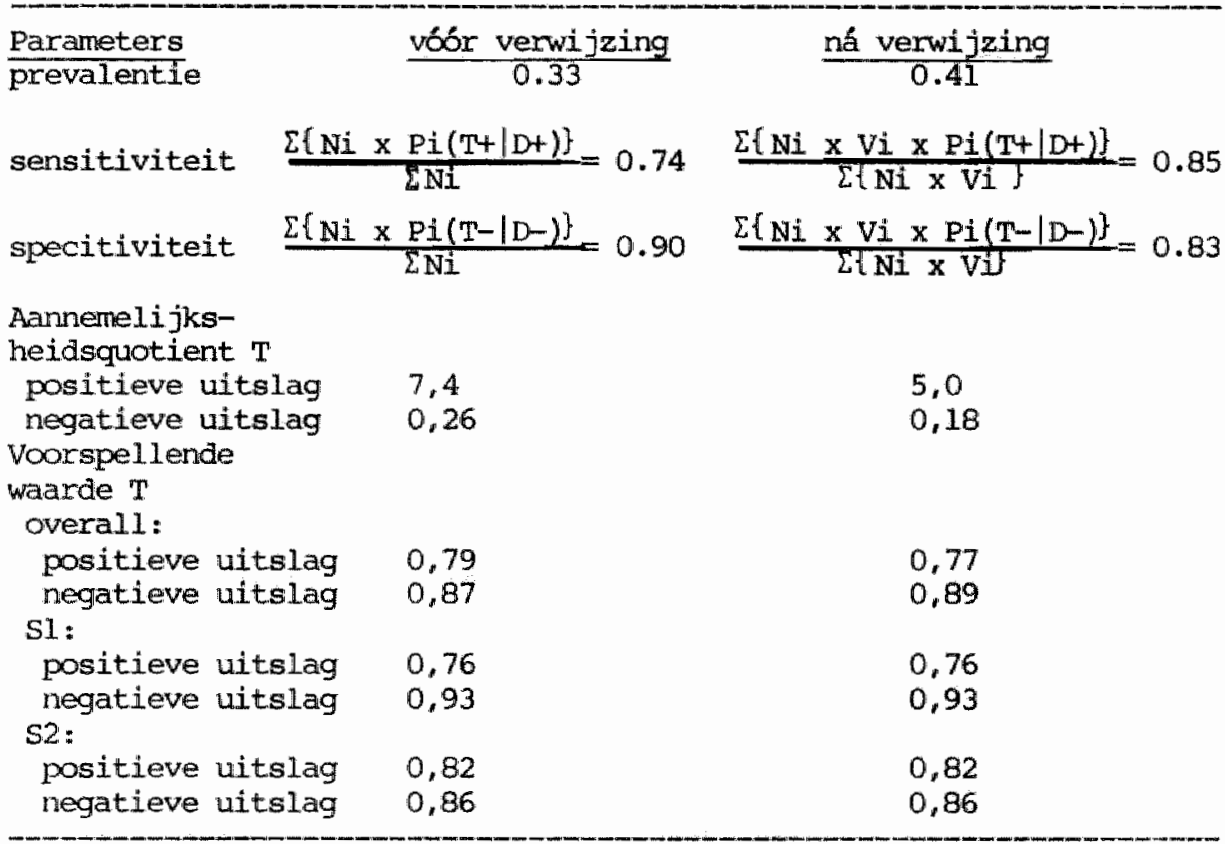

In het voorbeeld in schema 1 zijn wij uitgegaan van een duidelijk en een minder duidelijk ontwikkelde symptomatologie, en een positieve samenhang tussen mate van ontwikkeling van de symptomatologie en de 
ernst van de ziekte. Dit levert een hogere sensitiviteit van de test op bij meer ontwikkelde symptomatologie. Ook voor de niet-zieken in dit voorbeeld gelat dat de kans op positieve witslagen (100\%-specificiteit) groter wordt bij meer ontwikkelde syntomen zoals bijvoorbeeld het geval is bij manmografle in aanwezigheid van benigne tumoren. Als men nu het onderschelidend vermogen van de test evalueert in de door middel van verwijzing geselecteerde populatie, en daarbij uitgaat van een hogere verwijskans bilj meer ontwikkelde symptomatologie, dan blijkt onder meer dat:

1) de overall-sensitivitelt duidelijk toeneent;

2) de overal1-apecificiteit afneemt;

3) het aannemelijkheidsquotiènt van zowel de positieve als de negatieve uitslag afnemen.

cok de andere parameters - de prevalentie en de voorspellende waarden - veranderen. Zoals men verwacht is de prevalentie na verwijzing hoger, maar daarentegen vindt men in dit voorbeeld een lagere voorspellende waarde van de positieve uitslag en een hogere van de negatieve uitslagl De reden hiervoor is dat bij de niet-zieken met een meer ontwikkelde symptomatologie de specificiteit lager is en de verwijskans hoger. Indien zoals in het voorbeeld de verwijskans voor zieken en niet-zieken bif ernstiger synptomatologie met dezelfae factor toeneemt (namelijk $\mathrm{V} / \mathrm{V} 2=\mathrm{V} 3 / \mathrm{V}_{4}$ ), dan is het verband tussen deze factor en de genoemde testkenmerken grafisch eenvoudig weer te geven (figuur 1).

Indien de kans op een positieve uitslag bij niet-zieken niet afhankelijk is van de symptomatologie, zal de specificiteit bij verwijzing alleen op geleide van de symptomatologie nilet veranderen. Het aanneme1ijkheidsquotiënt van een positieve test neemt dan evenredig toe met de sensitiviteit.

Het veelbeschreven patroon, dat door verwijzing de prevalentie en de voorspellende warden van een positieve testuitslag toenemen, wordt in ons voorbeeld matar ten dele bevestigd. De in het algemeen gevolgde redenering dat men de voorspellende warde van een test, na voorselectie via verwijzing, kan berekenen uit de hogere prevalentie bij gelijkblijvende testeigenschappen lijkt te simpel. 
A verband tussen $\frac{\mathrm{V} 1}{\mathrm{~V} 2}$ en de sensitiviteit

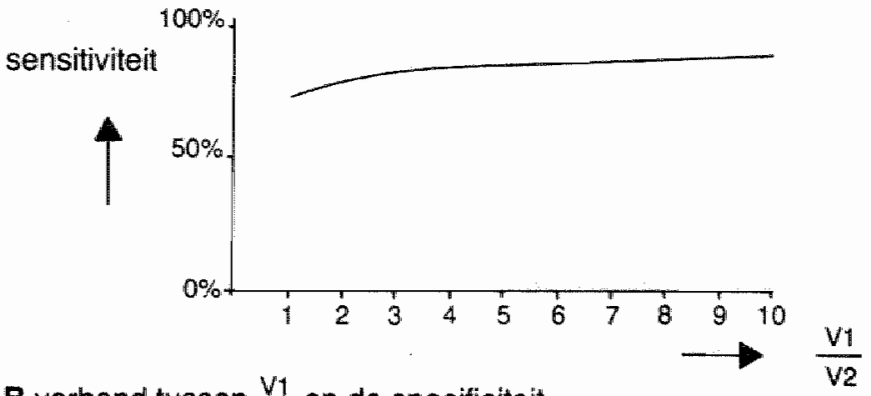

$B$ verband tussen $\frac{V 1}{V_{2}}$ en de specificiteit

$$
\frac{v_{1}}{v_{2}}
$$

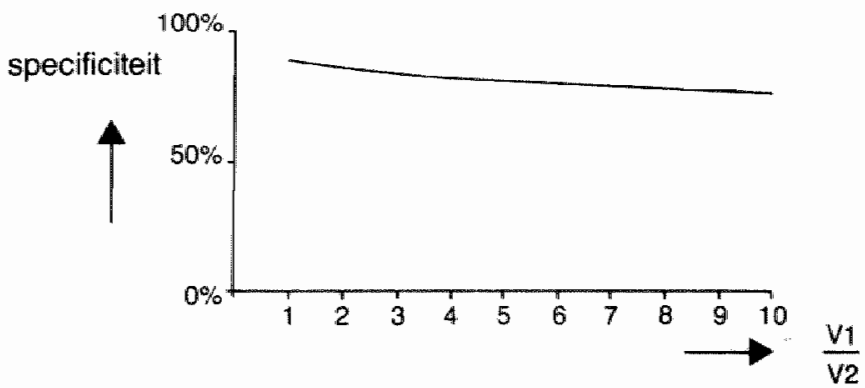

C verband tussen $\frac{V 1}{V_{2}}$ en de aannemelijkheidsquotiëntten

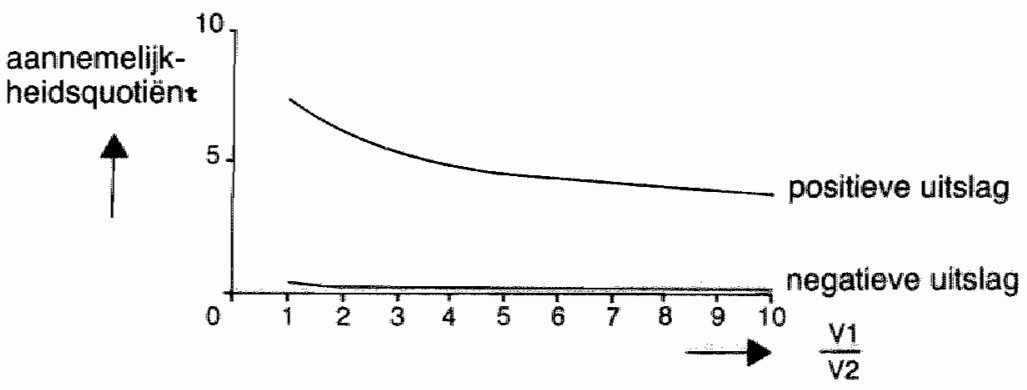

Figuur 1: Grafische weergave van het verband tussen de ratio var de verwijskansen bij ontwikkelde respectievelijjk minder ontwikkelde symptomatologie $\frac{\mathrm{V} 1}{\mathrm{~V} 2}$ en de overall-testkenmerken in de verwezen populatie (Basisinformatie over stratumspecifieke sensitiviteit en specificiteit uit schema 1 ).

Men kan fouten maken als men de sensitiviteit en de specificiteit in een geselecteerde populatie meet, en deze vervolgens toepast op de prevalentie van een ongeselecteerde populatie ter berekening van voor- 
spellende waarden. Aldus zon men, uitgaande van de gegevens in schema 1. de voorspellende warde van de positieve uitslag in de niet-verwezen populatie onderschatten (71) versus 798) en die van de negatieve test overschatten (92\% versus 87\%). Men kan ook, bijwoorbeeld in het kader van een epidemiologische survey, de (door selectie vertekende) sensitiviteit en speciflciteit gebruiken an de prevalentie "exact" te berekenen op grond van het aantal gevonden positieve uitslagen (zie de formule in appendix 1). Zo zou men, bij toepassing op de data van schema 1, een prevalentie vinden van slechts $20 \%$, in plaats van de $33 \%$ die deze in werkelijkheid bedraagt!

Uit schema 1 wordt tenslotte duidelijk, dat men er goed aan doet, om de testeigenschappen en de voorspellende waarden zowel vóbr als ná verwijzing te beschouwen per stratum van ontwikkeling aan de symptomatologie: indien vooral, of, zoals in het voorbeeld, uitsluitend de mate van ontwikkeling van de symptomatologie de verwijskans bepaalt zal er in zo'n stratum weinig of geen verandering van test kenmerken en voorspellende waarden plaatsvinden.

Verwijzing naar aanleliing van symptamen en testuitslag.

In de vorige paragraaf is de situatie besproken waarbij alleen verwezen wordt naar aanleiding van de symptamatologie, en niet rechtstreeks in verband met de testuitslag. Het is echter vaak zo dat zowel de symptomatologie als de, reeds door de huisarts vastgestelde, testuitslag een rol spelen bij de selectie door verwijzing. In appendix 2 zijn formules afgeleid voor het verband tussen de overall-sensitiviteit en specificiteit na de verwijzing, als functie van:

1) de sensitivitelt en specificiteit v6́b de verwijzing, per graad van ontwikkeling van de symptomatologie (twee strata);

2) de verthouding tussen de verwijjskansen bij meer en minder ontwikke1de symptomatologie;

3) de verhouding tussen de verwijskansen van testpositieven en testnegatieven:

4) de verhouding tussen het aantal mensen met meer respectievelijk minder ontwikkelde symptomatologie.

Hierbij is aangenomen dat de invloeden die de symptomatologie en de testuitslag op de verwijskans uitoefenen onathankelijk van elkaar zijn (indien beide elkaar zouden versterken worden de nu te beschrijven trends nog meer uitgesproken). Men kan nu bestuderen hoe de beschreven 
verbanden zich gedragen. We zijn hierbij weer uitgegaan van de situatie in de (ongeselecteerde) populatie uit schema 1.

A

sensitiviteit

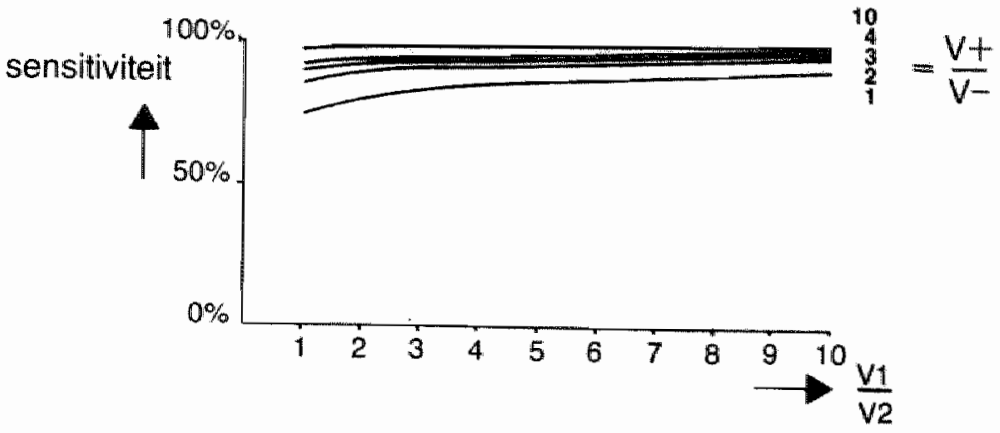

B

specificiteit

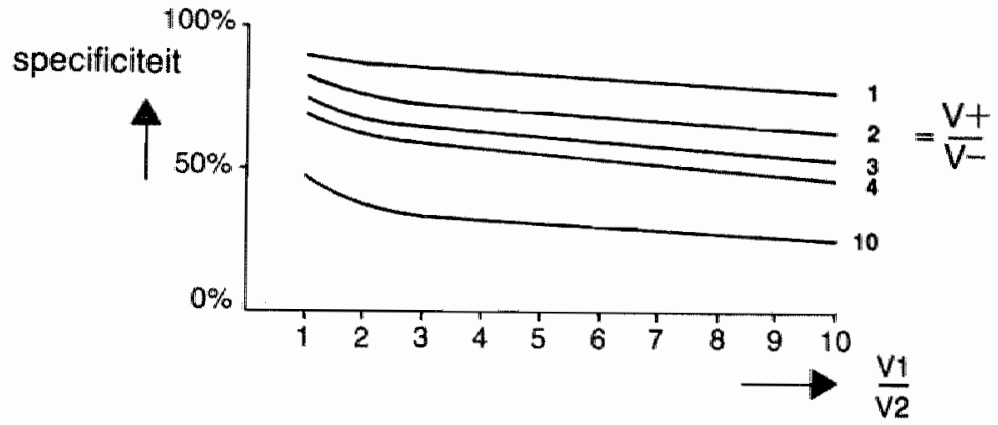

C

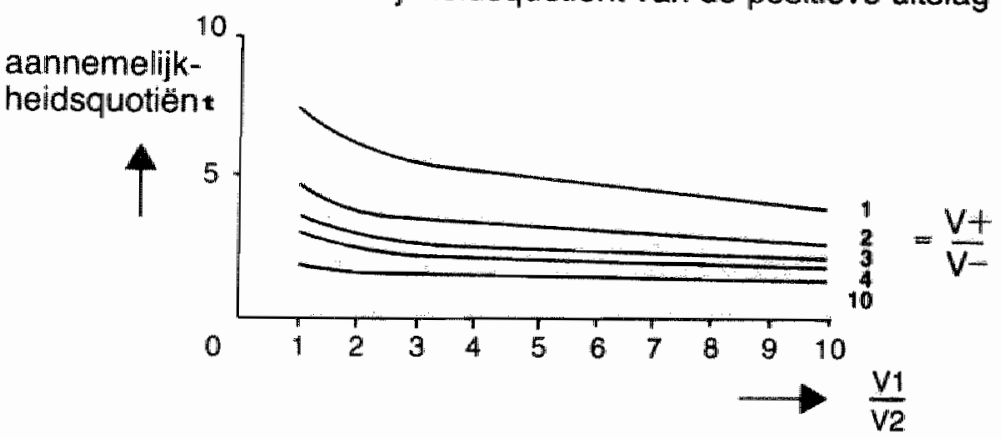

Figuur 2: Grafische weergave van de invloed op de testkenmerken van de ratio van de verwijskansen bij meer ontwikkelde respectieve lijk minder ontwikkelde symptamatologie $\frac{\mathrm{V} 1}{\mathrm{~V} 2}$ en de ratio van de verwijskansen van test-positieven en test-negatieven $\frac{\mathrm{V}+}{\mathrm{V}}$, indien de verwijskansen in verband met de testuitslag en de symptoomstatus onafhankelijk van elkaar ziljn. 
Uit figuur 2 blijkt nu dat, door toevoeging van het element 'selectie naar testuitulag' de trends uit figuur 1 versterkt worden. Bij een toenemende verwijzingskans bij de meer ontwikkelde symptamatologie en poslitieve testuitslagen zien we de sensitiviteit enigszins toenemen, de specificiteit dramatisch afnemen, en de aannemelijkheidsquotiënten sterk afnemen.

Indien alléén ten aarizien van het al dan niet test-positilef zijn wordt geselecteerd, en niet daamaast nog op de symptomatologie - hetgeen voorkomt als men de testuitslag van overheersend belang vindt ten opzichte van de symptamatologie - dan zullen de voorspellende waarden van de testuitslagen door verwijizing niet veranderen. Wel veranderen de sensitiviteit, de specificiteit en de aannemelijkheidsquotiënten

als functie van de verwijskans. Voor het geval dat er een positief verband is tussen test-uitslag en ziekte zijn deze veranderingen aangegeven in figuur 3 . Het blijkt weer, dat bij een positief verband tussen positieve uitslagen en de verwijskans de overall-sensitiviteit toeneent, de specificiteit afneemt, en de aannemelijkheidsquotiènten afnemen.

Het onderscheiden van testkenmerken naar de mate van ontwikkeling van de symptamatologie levert in het geval dat de testuitslag de verwijzing beInvloedt géén 'verwijzings-resistente' testkenmerken per stratum van de symptomatologile op.

\section{Een algemene representatile.}

In algemene termen gesproken hebben we te maken met mogelijk verschillende overall-verwijskansen voor elk van de vier denkbare cambinaties van testuitslag- en ziektestatus. Hiervan uitgaande zijn algemene formiles af te lelden waamee is na te gaan in welke richting de aannemelijkheidsquotienten zullen veranderen bij ledere mogelijke combinatie van die verwijskansen. Dat is gebeurd is appendix 3 . In figurur 4 is het resultaat grafisch weergegeven. Zo is het bijvoorbeeld te zien dat, bij een positief verband tussen afwijkende uitslagen en de verwijskansen on het alleen via de testuitslag beinvloed worden van de verwijskansen ( $a \cdot w \cdot z, a / c=b / d>1)$, de aamnemelijkheidisquotienten na verwijzing altijd afgenomen zijn. 
A

sensitiviteit
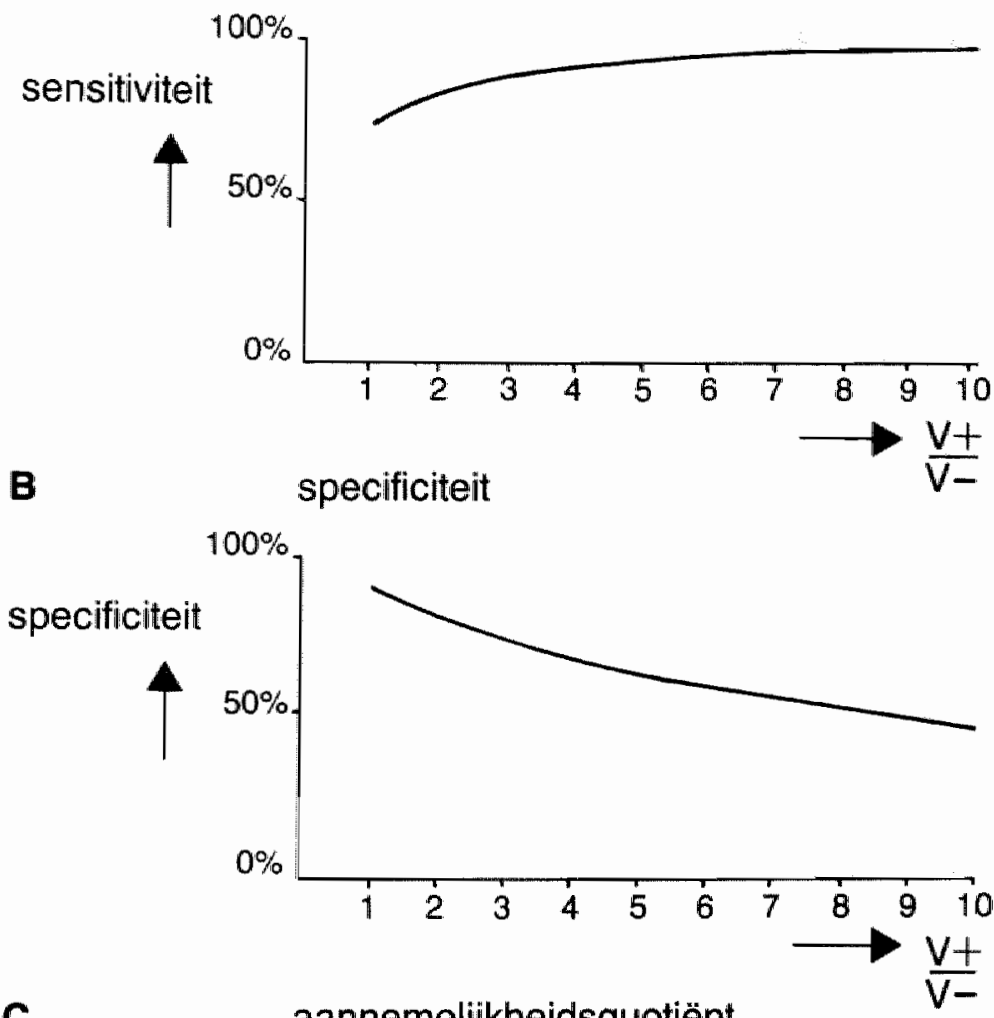

C aannemelijkheidsquotiënt

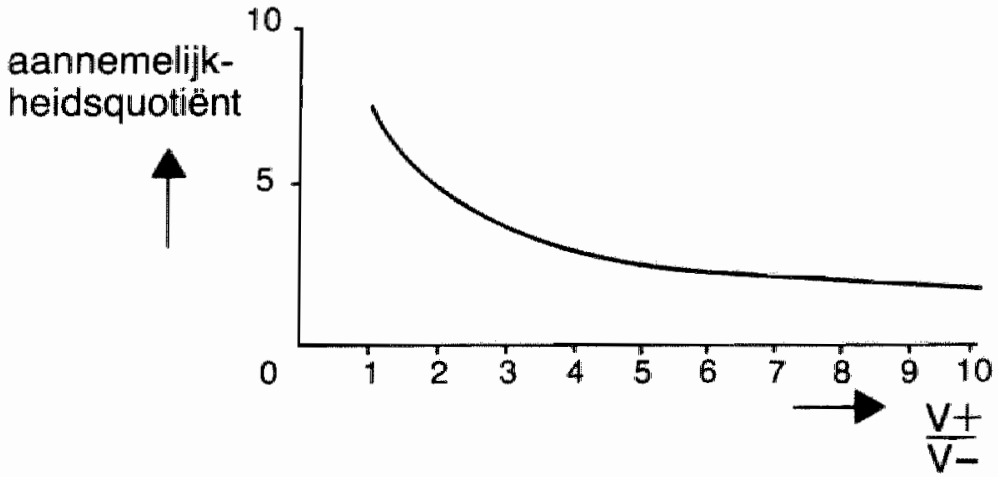

Figuur 3: Grafische weergave van de invloed op de testkenmerken van de ratio van de verwijskansen van test-positieven en test-negatieven $\frac{\mathrm{V} t}{\mathrm{~V}-}$. 
(D)

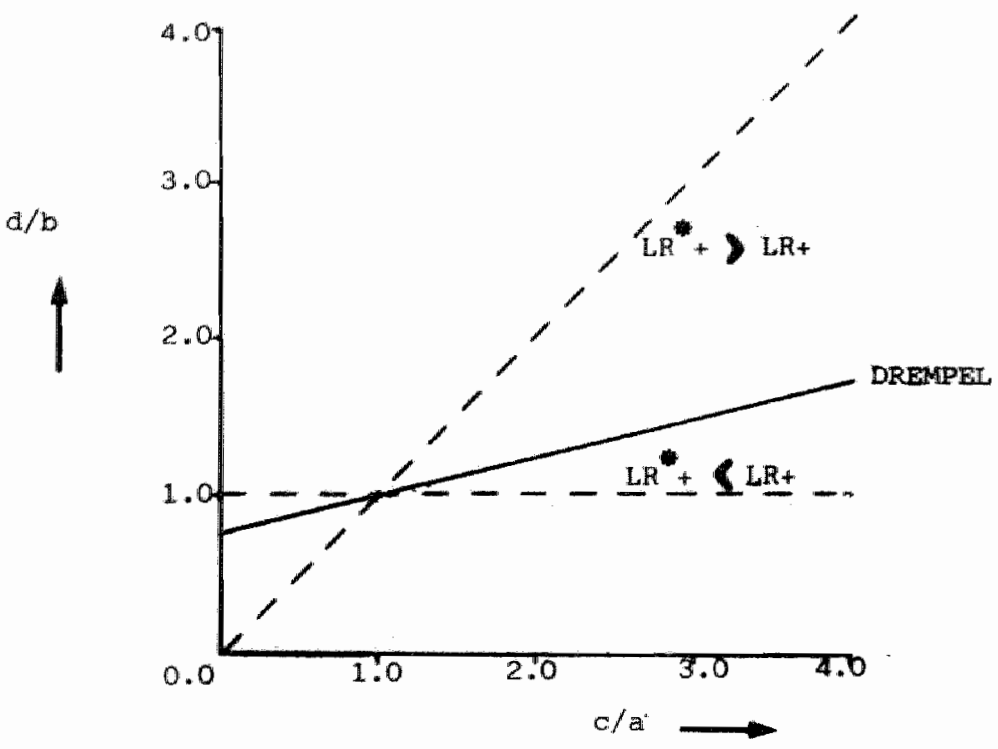

(B)

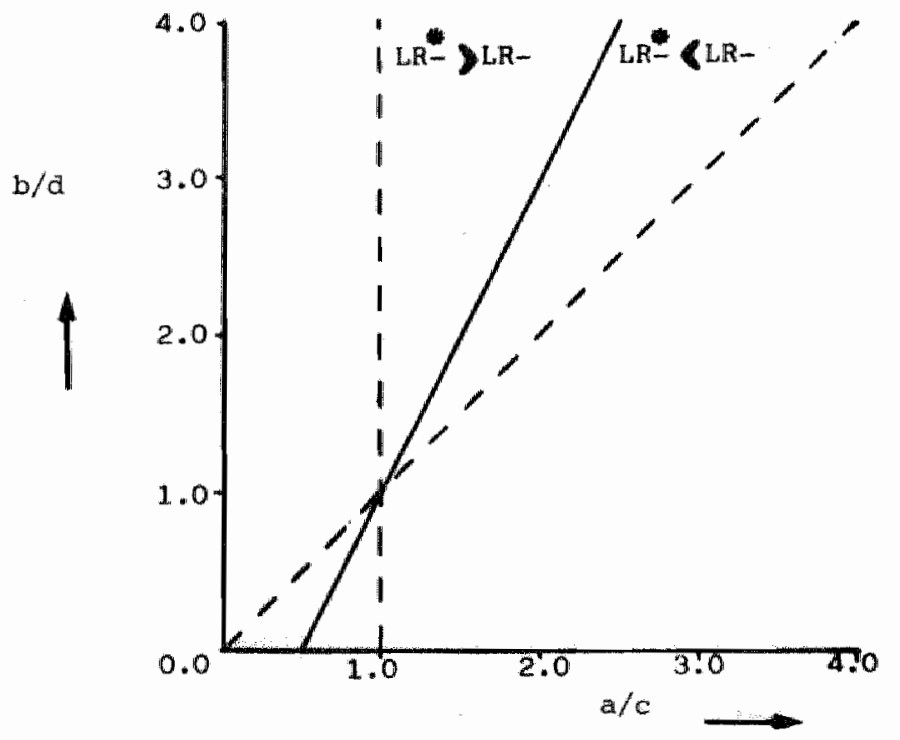

Figuur 4: Relatie tussen overall verwijskansen en de richting van de verandering van de aannemelijkheidsquotiënten $L \mathrm{R}+*$ (A) en $L_{R}-*(B)$, voor een test met in de ongeselecteerde populatie een $L K+=2,0$ en een $L R-=0,25$.

$a, b, c$ en $d z i j n$ de verwijskansen (c.q. selectiekansen) in een vierveldentabel ( $z$ lie appendix 3 ). De gebroken lijnen markeren de nogelijjke range van de drempelfunctie voor andere waarden van LRt en $L R-$. Bij cambinaties van verwijskansen die overeenkonen met punten onder de drempellijinen neent de $L R$ af. Bij punten boven de $I i j n$ neent de $I R$ toe. De 1 ijn representeert de pumten warbij de IR niet verandert. 
Schema 2: Samenhang tussen de mate van ST-depressie op het inspanningselectrocardiogram en het voorkomen van coronaire pathologie $(D+)$ in een (nog) niet, respectievelijk wel door verwijzing geselecteerde populatie. De verwijskans is afhankelijk van de mate van ST-depressie.

(a) Verdeling van patiënten naar mate van ST-depressie vóór en na verwijzing.

\begin{tabular}{|c|c|c|c|c|c|}
\hline \multirow{3}{*}{$\begin{array}{l}\text { ST-depressie } \\
>3.0 \mathrm{~mm}\end{array}$} & \multicolumn{2}{|c|}{ vóór verwijzing } & \multirow[t]{2}{*}{ verwijjkans } & \multicolumn{2}{|c|}{ ná verwijzing } \\
\hline & Dt & $D-$ & & $D^{+}$ & $\mathrm{D}-$ \\
\hline & 31 & 0 & 100\%: & 31 & 0 \\
\hline $2.5=2.9$ & 20 & 0 & 758 & 15 & 0 \\
\hline $2.0-2.4$ & 49 & 13 & 558 & 27 & 7 \\
\hline $1.5-1.9$ & 86 & 23 & $35 \%$ & 30 & 8 \\
\hline $1.0-1.4$ & 160 & 195 & 200 & 32 & 39 \\
\hline $0.5-0.9$ & 120 & 430 & $10 \%$ & 12 & 43 \\
\hline $0.0-0.4$ & 60 & 1060 & 58 & 3 & 53 \\
\hline "TOTAAL. & 526 & 1721 & 138 & 150 & 150 \\
\hline
\end{tabular}

b) Uit (a) berekende testkenmerken, vóór en na verwijzing, naar afkappint.

\begin{tabular}{|c|c|c|c|c|c|c|c|c|c|c|c|}
\hline \multicolumn{3}{|c|}{$\begin{array}{l}\text { Testkenmerken 1) } \\
\text { Afkappunt }\end{array}$} & \multicolumn{5}{|c|}{$\begin{array}{l}\text { Testkermerken 1) } \\
\text { zing }\end{array}$} & \multicolumn{4}{|c|}{ ná verwijzing } \\
\hline \multicolumn{2}{|c|}{ ST-depressie } & \multirow{2}{*}{$\frac{\mathrm{Se}}{0.06}$} & \multirow{2}{*}{$\frac{\mathrm{Sp}}{1.00}$} & \multirow[t]{2}{*}{ LRt } & \multirow{3}{*}{$\frac{L R-}{0.94}$} & \multirow[t]{2}{*}{ LRI } & \multirow{2}{*}{$\frac{\text { Se }}{0.21}$} & \multirow{3}{*}{$\frac{\mathrm{Sp}}{1.00}$} & \multirow[t]{2}{*}{ LRt } & \multirow{2}{*}{$\frac{L R-}{0.79}$} & LRI \\
\hline $3.0 \mathrm{~mm}$ & $(\mathrm{~A})$ & & & & & & & & & & \\
\hline 2.5 & (B) & 0.10 & 1.00 & & & & 0.31 & & & 0.69 & \\
\hline 2.0 & (C) & 0.19 & 0.99 & 25.2 & 0.82 & 12.3 & 0 & 0.95 & 9.8 & 0.54 & 3. \\
\hline 1.5 & (D) & 0.35 & 0.98 & 16.7 & 0.66 & 12.2 & 0.69 & 0.90 & 6.7 & 0.34 & 3 \\
\hline 1.0 & (E) & 0.66 & 0.87 & 5.1 & 0.39 & 2.6 & 0.90 & 0.64 & 2.5 & 0.16 & 0. \\
\hline 0.5 & (F) & 0.89 & 0.62 & 2.3 & 0.18 & 0.9 & 0.98 & 0.35 & 1.5 & 0.06 & 0.3 \\
\hline 0.0 & (G) & 1.00 & 0.00 & 1.0 & - & 0.2 & 1.00 & 0.00 & 1.0 & - & 0.1 \\
\hline
\end{tabular}

1) $\mathrm{se}=$ sensitiviteit, $\mathrm{Sp}=$ specificiteit, $\mathrm{LR}_{\mathrm{R}}=$ aannemelijkheidsquotiënt van een positieve uitslag, LR- = aannemelijkheidaquotiënt van een negatieve uitslag, LRl = aannemelijkheidsquotiënt per niveau van de testuitslag.

Tests met meer dan twee uitslag-niveau's.

In de vorige paragrafen zijn we telkens uitgegaan van een op grond van één gefixeerd afkappunt te maken onderscheiding in positieve en negatieve testuitslagen. Bij veel tests zijn er echter meer dan twee uitslagniveau's mogelijk, en in dat geval kan het afkappunt op verschil- 
lende niveau's gekozen worden. Daamaast kan men ook aan ieder witslagniveau zelf een eigen diagnostische waarde toekennen. Wij zullen naar aanleiding van een uitbreiding van een voorbeeld van Feinstein (8) aandacht besteden aan de mogelijjke effecten van verwijspatronen op het onderscheiderd vermogen van tests warbij meer dan twee klassen van uitslagen worden gehanteerd.

In schema 2 is aangegeven hoe de samenhang kan zijn tussen de mate van ST-depressie op het inspanningselectrocardiogram en het vookcmen van anglografisch aangetoonde coronaire pathologie. Deze gegevens zijn vastgesteld door beide onderzoeken te verrichten bij door middel van verwijzing geselecteerde personen. Het ligt voor de hand dat, zeker indien cok hulisartsen inspannings-EOG's vervaardigen, er een positief verband is tussen de verwijskans en de mate van ST-depressie. Daaran hebben wij aan de hand van een getallen voorbeeld aangegeven hoe de verdeling van uitslagen onder zieken en niet-zieken zou zijn geweest in de bron populatie die de huisarts consulteerde. Tevens hebben wij aangegeven:

- de sensitiviteit, de specificiteit, en de aannemelijkheidsquotiënten voor de diverse afkappunten in de verwezen en de (nog) niet verwezen populatie:

- de aannemelijkheidsquotiënten voor de diverse uitslag-niveau's afzonderlijk.

Tenslotte is de RoC-curve (die de relatile aangeeft tussen de sensitiviteit on de specificiteit bij diverse afkappunten) voor beide situaties getekend (figuur 5 ).

Het blijkt, dat indien de verwijzing positief gerelateend is aan de testuitslag, het patroon van de "dichotone situatie" zich herhaalt: bif elk afkappunt neent de sensitiviteit toe, en de specificiteit neemt af evenals de aannemelijkheldsquotiënten per uitslag-niveau. De bewering van sackett et al (16) dat dergelijke aannemelijkheidsquotilënten ongevoelig zouden zijn voor selectie is dus niet juist.

De ROC-curve is minder gevoelig, althans wat haar vorm betreft. Echter de haar bepalende punten schuiven na verwijzing op: om een vergelijkbaar ondergcheidend vermogen (c.q. aannemelijjkheidsquotient) te krijgen zou men, na werwijzing, een wat hoger afkappunt moeten kiezen, 
bi jvoorbeeld $1.5 \mathrm{~mm}$ in plaats van $1.0 \mathrm{~mm}$. Men moet zich dan wel realiseren dat er meer zieken "gemist" worden. Het minst gevoelig woor selectie, indien deze plaatsvindt vooral of uitsluitend naar aanleiding van het niveau van de uitslag, is weer de voorspellende waarde van een bepaald uitslag niveau: in schema 2 zijn de voorspellende waarden per elevatie-niveau vớor en ná verwijzing gelijk, ondanks de veel hogere overall-prevalentie na verwijzing. Daarbij is wel een voorwaarde, dat na verwijzing de zieken en niet-zieken in de onderzochte groep everredig (op grond van de samenstelling van de verwezen populatie) vertegenwoordigd zilin.

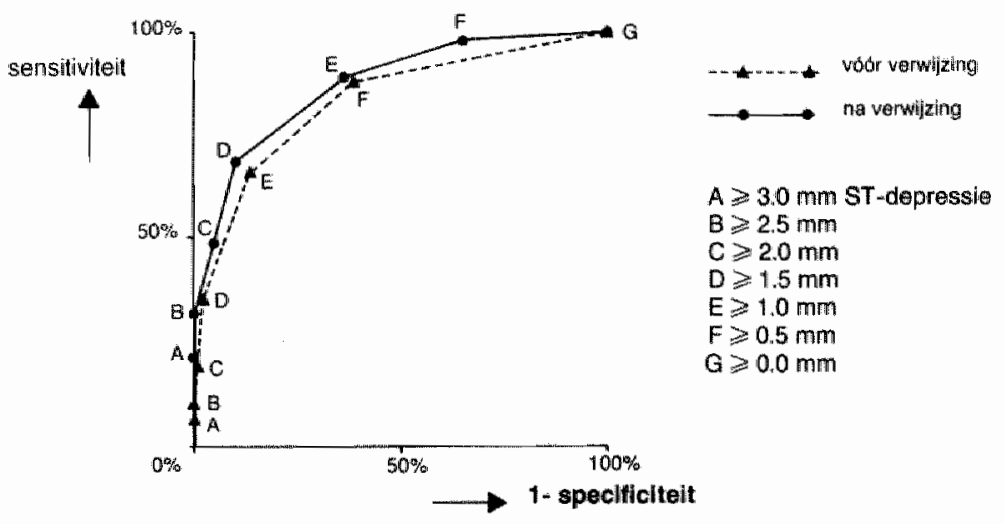

Figuur 5: ROC-curve (Receiver Operating Characteristic) vór (A) en ná (•) verwijzing, uitgaande van de gegevens in schema 2 .

\section{Beschouwing.}

Bij verwijzing door de huisarts naar de specialist moet men niet alleen rekening houden met een veranderende (meestal toenemende) prevalentie. Ondat het verwijsgedrag wordt beitnvloed door de symptornatologie, de ernst van de ziekte en door de uitslagen van diagnostisch onderzoek is ook - een scms aanzienlijke - verandering van de validiteit, c.q. het onderscheidend vermogen van diagnostische tests te verwachten.

Het veel beschreven model, dat voorspellende waarden van testuitslagen 
in een bepalde populatie kumen worden berekend op grond van de (meestal geschatte) prevalentie en de, in andere populaties bepaalde, sensitiviteit en specificiteit, is dan ook te simpel en kan leiden tot vergisisingen.

Over verwijspatronen in relatie tot symptomen, aandoeningen en testresultaten is weinig bekend. Hoe groot de besproken invloeden in de praktijk precies zijn voor diverse diagnostica is dan ook op dit moment niet te zeggen. Er is geen empirisch onderzoek gedaan naar de invloed van verwijsgedrag op de validiteit van diagnostische tests en de daarbij werkzame mechanismen. Een probleem bij onderzoek op dit gebied is dat criteria en standaarden voor klachten, symptomen en diagnosen mellijk zijn te formuleren of op vergelijkbare wijze door verschillende artsen toe te passen. Ingrijpende definitieve diagnostiek in het kader van wetenschappelijk onderzoek is op het niveau van de huisarts in het algemeen niet te effectueren. Wiettemin is, $\infty$ k blijkens het hilervoor besproken, onderzoek naar verwijspatronen zeer relevant.

Wanneer men een indruk heeft van deze verwijspatronen, in relatie tot het klinisch beeld en de resultaten van diagnostische tests, kan men in principe schattingen maken van het onderscheldend vermogen van die tests in (nog) niet door middel van verwijzing geselecteerde populaties. Men doet dan niets anders dan het terugrekenen, witgaandie van de eindtoestand ná selectie, naar de begintoestand vóór selectie. De in appendix 2 gegeven formile geeft een beeld van de variabelen die men voox zo'n schatting in elk geval zou moten kennen. De tot nu toe in de literaturi beschreven methoden zijn in het algemeen echter nog niet toereikend. zij berusten op aannames die niet altijd acceptabel zijn, zoals het alleen beinvloed worden van de verwijskans door testuitslagen en niet ook nog eens door symptomen (17-19). Meer dan een schatting zal een dergelijke berekening bovendien niet kunnen opleveren. Aannames blijven tot op zekere hoogte nodig en bepaalde invloeden worden niet of onvoldoende bekend. Het adagilum dat de validiteit van een test elgenlijk het best bepaald kan worden in eenzelfae type populatie als warin hij toegepast zal worden, blijft dan ook geldig. zolang dit niet of onvoldoende geschiedt, is het van belang om tenminste een inzicht te hebben in de belangrijkste mechanismen van de selectie, en de richting en de mate waarin zij werkt. Wij hebben laten 
zien, dat in de veel voorkomende situatie dat er positieve verbanden bestaan tussen de mate van ontwikkeling van de symptomatologie, de mate van ontwikkeling van de ziekte, het test-positief zijn en de verwijskans, te verwachten is dat:

- de overall-sensitiviteit toeneent;

- de overall-specificiteit afneemt.

Het aannemelijkheidsquotient van de testuitslag kan dan afnemen.

In feite kant het er op neer, dat het onderscheidend vermogen slechts blijft bestaan voor zover er, bij de verwijzing, niet reeds gebruik is gemaakt van de informatie in de testuitslag.

Indien alléén of vooral de symptomatologie de verwijskans bepaalt, kan men de vertekening door selectie voorkanen of reduceren door de testkenmerken (sensitiviteit, specificiteit, aannemelijkheidsquotient) te bepalen per graad var ontwikkeling van de symptomatologie. Indien alléen of vooral het niveau van de testuitslag zélf de verwijskans beïnvloedt, is er veel voor te zeggen an de voorspellende waarde per uitslag-niveau als meeste constante kenmerk te beschouwen.

\section{LITERATUUR.}

1. Sturmans F, Mulder FGH. de betekenis van de prevalentie voor de predictieve waarde van een test. Tijdschr Soc Geneesk 1976; 54: 496-501.

2. Velden HCM van der. Diagnose of prognose: de betekenis van de epidemiologie voor het handelen van de huisarts. Huisarts en Wetenschap 1983; 26: 125-128.

3. Knottnerus JA. Interpretatie van diagnostische gegevens, een onontgonnen terrein in de huisartsgeneeskunde. Huisarts en Wetenschap $1983 ; 26: 363-368$.

4. Baggen J, Leffers $P$, van Leeuwen YD. Het testdiagram; een visueel middel bij de interpretatie van testuitslagen. Ned Tijdschr Geneesk 1984; 128: 1656-1659.

5. Ransohoff DF, Feinstein AR. Problems of spectrum and bilas in evaluating the efficacy of diagnostic tests. New Engl J Med 1978; 299: $926-930$.

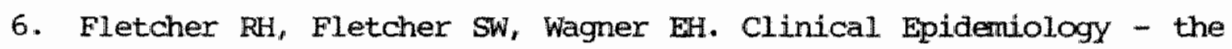
essentials. Williams \& Wilkins, Baltimore 1982: 51-52. 
7. Rtmke CI. Kanttekeningen over de gevoeligheid, de specificiteit en de voorspellende waarden van diagnostische tests. Ned Tijdschr Geneesk 1983; 127: 565-561.

8. Feinstein AR. Clinical Epidemiology. The architecture of clinical Research, WB Saunders, Philadelphia 1985.

9. Ottolander GJH den (red.). Interne Geneeskunde $6^{e}$ druk $1980, p$. 290.

10. Griner PF, Mayewski RJ, Mushlin AI, Greenland P. Selection and interpretation of diagnostic tests and procedures. Ann Intern Med 1981; $94: 533-596$.

11. Green MS. The effect of validation group bias on screeningtests for coronary artery disease. Statistics in Medicine 1985; 4 : $53-61$.

12. Meischke-de Jongh ML, Blonk DI, Gan-Siauw IN, den Hoed-Sijtsema $S$, ter Laag M. Borstklachten en hun betekenis voor de diagnostiek van het marmacarcinoom. Ned Tijdschr Geneesk 1983; 127: 2361-2367.

13. Meischke-de Jongh ML, Gan-Siauw IN, den Hoed-Sijtsema S, Blonk DI, Fitskie-de Ronde EHCM, ter Laag M. De waarde van echografie bij het marma-onderzoek. Ned Tijidschr Geneesk 1985; 1.29: 1339-1347.

14. Dronkers DJ. Marmografisch accult carcinocm. Ned Tijdschr Geneesk $1985 ; 129: 1632-1635$.

15. Knottnerus A, Sturmans F. Over vertekening van test-uitslagen door reeds aanwezige informatie. The Practitioner 1985; 3: 287-295.

16. Department of Clinical Epidemiology \& Biostatistics, Manual for a workshop on how to teach the critical appraisal of clinical evidence. Hamilton ontario, 1984.

17. Dawid AP. Proporties of diagnostic data distributions. Bicmetrics $1983 ; 39: 207-216$.

18. Begg CB, Greenes RA. Assessment of diagnostic tests when discase verification is subject to selection bias. Bicmetrics 1983; 39 : 207-216.

19. Gray R, Begg CB, Greenes RA. Construction of Receiver Operating characteristic curves when disease verification is subject to selection bias. Med Decis Making 1984; 4: 151-163. 


\section{Appendix 1.}

Berekening van de prevalentie uit het percentage afwijkende uitsiagen in een onderzochte populatie.

We gaan uit van de situatie, zoals weergegeven in de volgende viervelden tabel:

\begin{tabular}{|c|c|c|c|}
\hline & I ziek & I niet-ziek & 1 \\
\hline $\begin{array}{l}\text { positieve } \\
\text { testuitslag }\end{array}$ & $\mid \begin{array}{l}\text { sensitiviteit } \\
\mathrm{x} \text { prevalentie }\end{array}$ & $\mid \begin{array}{l}\text { (1-specificiteit) } \\
\mathrm{x} \text { (1-prevalentie) }\end{array}$ & $\mathrm{P}\left(\mathrm{T}^{+}\right)$ \\
\hline $\begin{array}{l}\text { negatieve } \\
\text { testuitslag }\end{array}$ & $\mid \begin{array}{l}\text { (1-sensitiviteit) } \\
x \text { prevalentie }\end{array}$ & $\left\{\begin{array}{l}\text { specificiteit } \\
x(1-\text { prevalentie })\end{array}\right.$ & $\mathrm{P}\left(\mathrm{T}^{-}\right)$ \\
\hline
\end{tabular}

Nu geldt:

$P\left(\mathrm{~T}^{+}\right)=($sensitiviteitprevalentie $)+(1$-specficiteit $) *(1-$ prevalentie)

hieruit volgt:

Prevalentie $=\frac{\mathrm{P}(\mathrm{T}+) * \text { specificiteit-1 }}{\text { sensitiviteit }+ \text { specificiteit-1 }}$ 


\section{Appendix 2:}

De overall-sensitiviteit, -specificiteit, en -aannemelijkheidsquotiènten kumnen worden uitgedrukt als fumctie van

- de testkenmerken (sensitiviteit en specificiteit) per stratum van ontwikkeling van de symptomatologie $\mathbf{S}$.

- de verwijskans van test-positieven en test-negatieven.

- de verwijskans bij een meer ontwikkelde en bij een minder ontwikkelde symptomatologie.

- de verhouding van het aantal personen met meer, respectievelijk minder ontwikkelde symptomatologie in de (nog) niet-verwezen populatie.

We gaan uit van de volgende situatie in de corspronkelijke populatie:

Graad van ontwikkeling van de symptomatologie $S_{1}$

$\mathrm{S}_{2}$ $S_{1}$

waarin:
Ziekte status

\begin{tabular}{|c|c|}
\hline ziek & Niet-ziek \\
\hline $\operatorname{Se}_{\text {(nsitiviteit) }}$ & $\operatorname{sp}_{(e c i f i c i t e i t)}$ \\
\hline $\mathrm{N}_{1}$ & $\mathrm{~N}_{3}$ \\
\hline$v_{1+}$ & $v_{3+}$ \\
\hline$v_{1-}$ & $v_{3-}$ \\
\hline $\left.\operatorname{Se}_{(n s i t i v i t e i t}\right)_{2}$ & $\operatorname{sp}($ ecificiteit) 2 \\
\hline $\mathbf{N}_{2}$ & $\mathbf{N}_{4}$ \\
\hline$v_{2+}$ & $v_{4+}$ \\
\hline$v_{2-}$ & $v_{4-}$ \\
\hline
\end{tabular}

\footnotetext{
sensitiviteit $t_{i}=$ sensitiviteit bij symotamatologie-status $s_{i}\left(S e_{i}\right)$ specificiteit ${ }_{1}=$ specificiteit bij symptomatologie-status $s_{i}\left(S_{i}\right)$

$\mathrm{N}_{\mathbf{i}} \quad$ het aantal personen met een bepalide symptomatologieen ziekte-status

$\mathrm{V}_{1+} \quad=$ de verwijskans van testpositieven met symptamatologie- en ziekte-status i

$v_{i-} \quad=$ de verwijskans van testnegatieven met een bepaalde symptamatologie- en ziekte-status
} 
Nu geldt:

. A de sensitiviteit in de door verwijzing geselecteerde populatie, sensitiviteit.'

$$
\begin{aligned}
& =\frac{\left(\mathrm{Se}_{1} \cdot \mathrm{N}_{1} \cdot \mathrm{V}_{1+}\right)+\left(\mathrm{Se}_{2} \cdot \mathrm{N}_{2} \cdot \mathrm{V}_{2+}\right)}{\left(\mathrm{Se}_{1} \cdot \mathrm{N}_{1} \cdot \mathrm{V}_{1+}\right)+\left(\mathrm{Se}_{2} \cdot \mathrm{N}_{2} \cdot \mathrm{V}_{2+}\right)+\left(1-\mathrm{Se}_{1}\right) \cdot \mathrm{N}_{1} \cdot \mathrm{V}_{1-}\left(+\left(1-\mathrm{Se}_{2}\right) \cdot \mathrm{N}_{2} \cdot \mathrm{V}_{2-}\right)} \\
& =\frac{1}{1+\frac{\left(1-\mathrm{Se}_{1}\right) \cdot \mathrm{N}_{1} \cdot \mathrm{V}_{1-}+\left(1-\mathrm{Se}_{2}\right) \cdot \mathrm{N}_{2} \cdot \mathrm{V}_{2-}}{\mathrm{Se}_{1} \cdot \mathrm{N}_{1} \cdot \mathrm{V}_{1+}+\mathrm{Se}_{2} \cdot \mathrm{N}_{2} \cdot \mathrm{V}_{2+}}}
\end{aligned}
$$

Indien de verwijskansen in verband met de testuitslag en de symptoonstatus onafhankelijk van elkaar zijn, dan geldt:

$\frac{\mathrm{V} 1}{\mathrm{~V} 1} \pm=\frac{\mathrm{V} 2 \pm}{\mathrm{V} 2}=\mathrm{Cl}$ en: $\frac{\mathrm{V} 1 \pm}{\mathrm{V} 2}=\frac{\mathrm{V} 1-}{\mathrm{V} 2}==\mathrm{C} 2$

de formule (2) is nu te herleiden tot:

$$
\text { sensitiviteit }{ }^{\prime}=\frac{1}{1+\frac{1}{C 1} \cdot \frac{\left(1-S_{1}\right)+\left(1-S_{2}\right) / C 2 \cdot q}{{S e_{1}}_{1}+S e_{2} / C 2 \cdot q}}
$$

waarbij $C_{1}=$ de ratio van de verwijskansen van test-positieve en testnegatieve zieken

$\mathrm{C}_{2}=$ de ratio van de verwijskansen van zieken met een meer ontwikkelde resp. een minder ontwikkelde symptomatologie

en $q=$ de ratio van het corspronkelijke aantal zieken met symptoom status $\mathrm{s}_{1}$ en het aantal zieken met synptoomstatus $\mathrm{S}_{2}$.

-B op analoge wijze is af te leiden, dat de specificiteit in de door verwijzing geselecteerde populatie, specificitelt'

$$
=\frac{1}{1+\frac{\left(1-\mathrm{Sp}_{1}\right) \mathrm{N}_{3} \cdot \mathrm{V}_{3+}+\left(1-\mathrm{Sp}_{2}\right) \mathrm{N}_{4} \cdot \mathrm{V}_{4+}}{\left(\mathrm{Sp}_{1} \cdot \mathrm{N}_{3} \cdot \mathrm{V}_{3-}\right)+\left(\mathrm{Sp}_{2} \cdot \mathrm{N}_{4} \cdot \mathrm{V}_{4-}\right)}}
$$

Indien de werwijzing in verband met de testultslag en de symptocmstatus onafhankelijk van elkaar zijn, dan geldt weer: 
$\frac{V 3 t}{V 3-}=\frac{V 4 t}{V 4-}=C_{3} \quad$ en $\frac{V 3 t}{V 4 t}=\frac{V 3-}{V 4-}=C_{4}$

formule (4) vereenwoudigt dan tot:

$=\frac{1}{1+\mathrm{c} 3 \cdot \frac{\left(1-S p_{1}\right)+\left(1-5 p_{2}\right) / C 4 . r}{S p_{1}+S p_{2} / c 4 . r}}$

waarbij: $c 3=$ de ratio van de verwijskans van test-positieve en testnegatieve niet-zieken

$C 4=$ de ratio van de verwijskans van niet-zieken met een meer resp. minder ontwilkkelde symptomatologie.

en $r=$ de ratio van het oorspronkelijke aantal niet-zieken met symptocnstatus $s_{1}$ en het aantal niet-zieken met symptoomstatus $\mathrm{S}_{2}$.

Indien de werkelijke ziektestatus vóór verwijjzing nog niet bekend is, is het aannemelijk dat:

$\mathrm{cl}=\mathrm{C} 3=\frac{\mathrm{V}+}{\mathrm{V}-}$ en $\mathrm{C} 2=\mathrm{C} 4=\frac{\mathrm{V}}{\mathrm{V} 2}$

.C Het aannemelijkheidsquotiënt van de positieve uitslag na verwijzing is nu:

$\frac{\text { Sensitiviteit" }}{1-\text { Specificiteit }}$

en van een negatieve uitslag: $\frac{1-\text { Sensitiviteit" }}{\text { Specificiteit }}$ 


\section{Appendix 3}

Stel, voor de testpositieve zieken, de testpositieve niet-zieken, de testnegatieve zieken en de testnegatieve niet-zieken gelden respectievelijk de verwijskansen $a, b, c$, en $d$.

Als we de sensitiviteit en de specificiteit in de ongeselecteerde populatie se respectievelijk sp noemen, geldt:

$L R+*=L R+\cdot \frac{(1-S p)+S p \cdot d / b}{(S e+(1-S e) \cdot c / a}$

en:

$L R-^{*}=L R-\cdot \frac{(l-S p) \cdot b / d+S p}{S e \cdot a / c+(1-S e)}$

waarbij LRT en LUR- de aannemelijkheidsquotiënten, respectieveli.jk voor de positieve en de negatieve uitslag, in de ongeselecteende populatie representeren, en

LR+* en LR-* de overeenkanstige quotiënten in de door middel van verwijzing geselecteerde populatie.

Als we als maat voor de vertekening van het aannemelijkheidsquotiënt ten gevolge van verwijzing nemen de verhouding tussen het aannemelijkheidsquotiënt in de gesellecteerde en de ongeselecteerde populatie, dan geldt:

$\frac{\mathbb{L} R+*}{L R+}=\frac{(1-S p)+S p \cdot d / b}{S e+(1-S e) \cdot c / a}$

on, in algemene termen, de richting van de vertekening te beschrijven, kunnen wij, als functie van de verwijskansen, de drempel (treshold) functie afleiden door LRt ${ }^{*}=$ LRt te stellen. Na het vervangen van de linkerterm van (3) door 1.0 en onder witvoering van enkele eervoudige algebraĩsche substituties, blijkt deze functie equivalent aan:

$$
(\hat{d} / \hat{b}-1)=L R-\cdot(\hat{c} / \hat{a}-1)
$$

waarbij $a, \hat{b}, \hat{c}$ en $\hat{a}$ die realisaties van de verwijskansen zijn waarvoor LRt* = LRt, c.q. waarbij er geen vertekening optreedt. 
Op analoge wijze bilijkt de dxempelfunctie van LR-* en LR- te zijn:

$(b / a-1)=L R+\cdot(a / c-1)$

waarbij er voor de realisaties $b, a$, $a$ en $d$ geen vertekening van $L R-$ * ten opzichte van LR- optreedt.

(4) en (5) drukken de arermels uit als lineaire relaties tussen respectievelijk $(\vec{a} / \hat{b}-1)$ en $(\hat{C} / \hat{a}-1)$ en tussen $(\dot{b} / \vec{a}-1)$ en $(\ddot{a} / \ddot{c}-1)$, gecentreend op punt $(1,1)$ met als linaire regressiecoëfficiënten respectievelijk LR- en LRt.

Met behulp van figuur 4 kunnen we de richting van de vertekening nu gemakkelijk evalueren, als we uitgaande van de originele aamemelijkheidsquotiënten LR- en LRT de grafiek door $(1,1)$ tekenen en hierin de (waarschijnlijke) schattingen van de verwijskansen voor elk van de categorieèn inbrengen. In geval van een werkelijke of geschatte cambinatie van $a, b, c$ en $d$ welke een punt boven de rechte representeert, is het aannemelijkheidsquotiënt na verwijzing groter geworden. Voor punten onder de rechte geldt dat het aannemelijkheidsquotiënt na verwijzing kleiner is geworden. 
DEEL $\mathrm{V}$

ENKELE OBSERVATIONETE ONDERZOEETINGEN NAAR HET VERBAND

TUSSEN UITSLAGEN VAN DIAGNOSTISCHE TESTS EN PROGNOSE. 


\section{HFNOGLOBINE EN ZWAMGERSCHAPSUITKOMST:}

J.A. Knottnerus 1) - L. Delgado 2) - P.G. Knipschild 2) - G.G.M. Essed 3) - E. Smits 3)

\section{Samerivatting:}

Beschreven wordt een onderzoek naar het verband tussen de waarden van haematologische parameters tijdens de zwangerschap, het geboortegewicht en de zwangerschapsduur.

Bij 494 zwangeren werden rond de $30 \mathrm{e}$ zwangerschapsweek de haematologische parameters bepaald, en werd door middel van een vragenlijst informatie ingewonnen over rookgedrag, alcoholgebruik, en gebruik van staaltabletten. Gevonden werd een verband tussen enerzijds een hemoglobinegehalte (Hb) $\operatorname{van} 8.0 \mathrm{mmol} / 1$ en hoger en een hematocriet (Ht) van $39 \%$ en hoger, en anderzijds de kans op een laag geboortegewicht en prematuritas. Dit verband bleef aanwezig indien gecorrigeend werd voor roken, alcoholgebruik, pariteit en het gebruik van staaltabletten. Voor $\mathrm{Hb}$ - en Ht-waarden gemeten vobr de $16 \mathrm{e}$ zwangerschapsweek kon geen duideli.jk verband worden gevonden. De mate van hemodilutie hangt sterk samen met de uitgangswaarde. De resultaten zijn in overeensteming met de hypothese dat een te geringe mate van hemodilutie, oq. het niet bereiken van de optimale range, een ongunstige invloed heeft op de placenta-doorbloeding.

1) Capaciteitsgroep Epidemiologie en Capaciteitsgroep Huisartsgeneeskunde

2) Capaciteitsgroep Epidemiologie

3) Capaciteitsgroep Verloskunde en Gynaecologie

Rijksuniversiteit Limburg 
Inleiding.

In hoofdstuk 8 is verslag gedaan van een onderzoek naar het verband tussen hemoglobinegehalte (Hb) van zwangeren gemeten rond de dertigste zwangerschapsweek, en subjectieve klachten. Het bleek dat bij hemoglobine waarden van $7.0 \mathrm{~mol} / 1$ of lager bepaalde klachten vaker voorkwamen dan bij hogere Hb-waarden. De hiervan af te leiden (algemene) ondergrens voor het Hb-gehalte tijjens de hemodilutiefase van de zwangerschap is hoger dan die welke op grond van een optimaal verloop van de zwangerschap wordt aanbevolen $(1,2)$. Daamaast is er de laatste jaren toenemende aandacht gekomen voor de mogelijke nadelen van een (te) hoog Hlo-gehalte $(1-6)$, casu quo een te geringe mate van plasma volume toename en hemodilutie $(7$ - 10) tijdens de zwangerschap. De zone waarbinnen het. Hb-gehalte optimaal zou zijn, wordt daamee tot een betrekkelijk smal gebied beperkt. Inmiddels zijn er nog kanttekeningen te maken bij het onderzoek naar de relatie hoog Hb - zwangerschapsuitkomst. De meeste studies betroffen erg kleine en geselecteerde groepen $(5-9)$ en slechts enkele onderzoekers hielden rekening met de mogelijke invloed van verstorende variabelen, zoals roken $(1,4)$ of bloeddruk (4). Bij het grote onderzoek van Garn (1), die een U-vormig verband vond tussen Ho en hematocriet (Ht) enerzijds en de ongunstige vitkomst anderzijals, is bovendien enige selectiebias niet uitgesloten. Men hield geen rekening met het aantal weken amenorroe waarbij het $\mathrm{Hb}$ bepaald werd. Dit kan bijvoorbeeld betekenen dat men bij een partus immaturus een Hib-waarde wit de vroege fase van zwangerschap in de analyse betrokken heeft. Ondat het $\mathrm{Eb}$ dan nog weinig gedaald hoeft te zijn, kan er een schijnassociatie optreden tussen een hoog Ho en een ongunstige uitkomst.

In het volgende doen wij verslag van een onderzoek naar de invloed van hoge $\mathrm{Hb}$ - en Ht (henatocriet) -waarden, vastgesteld bij de zwangerschapscontrolie rond dertig weken, op de zwangerschapsuitkomst, rekening houdend met de mogelijke irvloeden van roken, alcoholgebruik, bloeddruk, pariteit en het gebruik van staaltabletten.

Methode.

In de periode van 1 juli 1985 tot en met eind april 1986 werd een vragenlijst voorgelegd aan de zwargeren die de polikliniek verloskunde 
van het Academisch Zlekenhuls Maastricht bezochten in verband met de eerste zwangerschapscontrole na de dertigste week. Gevraagd werd onder meer naar roken en alcoholgebruik gedurende respectievelijk de eerste drie mander, de tweede drie maanden en de voorafgaarde weken, en naar het gebruik van staaltabletten. De vragenlijst werd vór het verlaten van de polikliniek ingeleverd. Direct aansluitend werd bloed afgenomen door middel van venapunctie. Het bloed werd opgevangen in EDTA-buizen, en binnen enkele uren werden de haenatologische parameters bepaald met een SYSMEX Microcel1-counter (haematologisch laboratorium Academisch ziekenhuis Maastricht). Na afloop van de zwangerschap werden, op een standaardformulier, uit de status gegevens genoteerd over het verloop van de zwangerschap (onder andere bloeddruk, het wel of niet aanwezig zijn van een primaire of secundaire medische indicatie, de pariteit) en de uitkanst (uiteindelijke zwangerschapsduur en geboortegewicht). De vrageniljst werd ook voorgelegd aan de zwangeren die begeleid werden in twee perifere verloskundige praktijken, bij de eerste controle ná 30 weken amenorroe in de periode van 1 oktober 1985 tot 1 februari 1986. Direct aansluitend werd venapunctie verricht in de verloskundige praktijk of op één van de perifere prikpunten van de Prikdienst van het Academisch Zi.kenhuis Maastricht. Dok van deze groep zwangeren werden post partum gegevens verzameld over het verdere verloop van de zwangerschap. De geboortegewichten op de verloskamer werden vastgestela met een speciaal geijkte electronische weegschaal (Berkel) terwijl de zelfstandig gevestigde verloskundigen het geboortegewicht bepaalden met, wederom speciaal geijkte, veer-weegschalen van het type Unster. In beide gevallen werden dezelf fie ijkgewichten gebruikt.

De gegevens werden bewerkt op de vax-computer van de Rijksuniversilteit Limburg en geanalyseerd met het BMDP-programma.

In de analyse zijn betrokken de bloeddrukwaarden bij de hoogst gemeten diastolische bloeddruk. Deze werd in $90 \%$ van de gevallen in het derde trimester vastgestela.

De statistische analyse vond als volgt plaats. Eerst werden de verbanden tussen de hematologische parameters, geboortegewicht en zwangerschapsduur bestudeerd met behulp van kruistabellen, puntendiagrarmen en univarlate lineaire regressie analyse.

ook werden onderzocht de verbanden tussen roken, alcoholgebruik, pariteit en diastolische bloeddruk enerzijds en hematologische parameters, geboortegewicht en zwangerschapsduur anderzijas. Op grond van de 
bevindingen werden multipele regressie modellen opgesteld, met een laag geboortegewicht en/of vroeggeboorte als onafhankelijke variabelen. Omdat vooral bij hoge waarden van Hb en Ht een verband met de uitkonstparameters werd gevonden en op grond van de literatuur, werd een kwadratisch model ontworpen dat gebaseerd is op het in principe bestaan van een U-vormig verband tussen de hematologische parameters en de uitkanstparameters. Hierbij is het $\mathrm{Ho}$, respectievelijk het $\mathrm{Ht}$, getransformeerd door er de waarde van af te trekken waarbilj op grond van de data het laagste punt van de "U" wordt verondersteld. Voor het HD is dit de waarde $7.9 \mathrm{~mol} / 1$ en voor de hematocriet $37 \%$. Als men in het model een kwadratische term voor het $\mathrm{Hb}$, respectievelijk de Ht toevoegt, ontstal een U-vormige functie.

Voorts werd nagegaan in hoeverre het al dan niet gebruikt hebben van staaltabletten van invloed was en of er verschillen waren tussen de diverse bestudeerde subpopulaties. Tenslotte werd de samenhang tussen de hematologische uitslagen bij de eerste en de dertig-weken controle bestudeerd, in relatie tot de zwangerschapsuitkonst.

Resultaten.

Van de zwangeren die via de polikliniek verloskunde benaderd werden, nam 92\% deel aan het onderzoek. Redenen voor niet-deelname waren: weigering (48), taalbarrière $(2 \%)$, het niet op de betreffende controle verschijnen $(2 \%)$. Van de zwangeren die via de zelfstandig gevestigde verloskundigen benaderd werden nam $63 \%$ deel; 128 weigerde, $10 \%$ vond de afstand naar de prikdienst te groot, $8 \%$ werd bij de controle gemist, en bij $7 \%$ waren er diverse andere redenen.

voor de analyse in het kader van dit proefschrift waren beschikbaar de gegevens van 494 zwangeren (90 "perifeer" begeleid, en 404 poliklinisch). De leeftijdsrange was 18 tot 39 jaar $(P 50=27)$, en 508 was nullipara. Bij alle deelnemende vrouwen is het th bepaald (geniddeld $7.3 \mathrm{mmol} / 1$, SD: 0.6 ), bij 968 de hematocriet (gemiddeld 35\%, SD: 3) en bij 918 het MCV (gemiddeld 91, SD: 5).

ondat de non-respons bij zwangeren die via de vijgevestigde verloskundigen benaderd werden, vrij hoog was (378), gingen wij na of er sprake was van selectieve uitval ten aanzien van zwangerschapsduur en/of geboortegewicht. Daarvoor konden wij geen aanwijzingen vinden. Het gemiddelde geboortegewicht in de non-respons groep was 3328 gram 
(SD: 564 gram) versus 3316 gram (SD: 494 gram) in de deelnemende groep. voor de zwangerschapsdiur waren de overeenkomstige cijfers 39 weken en 4 dagen (SD: 1 week en 5 dagen) respectievelijk 39 weken en 4 dagen (SD: 1 week en 4 dagen).

Tabel 1. Hemoglobinegehalte tussen 30 en 32 weken amenorroeduur, zwangerschapsuitkonst en bloeddruk.

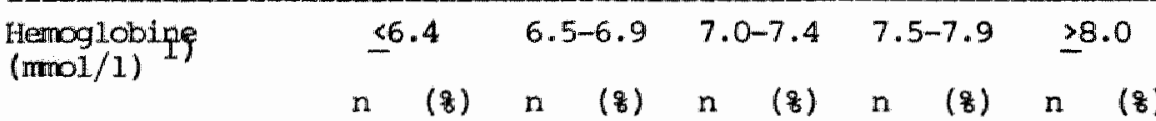

geboortegewicht

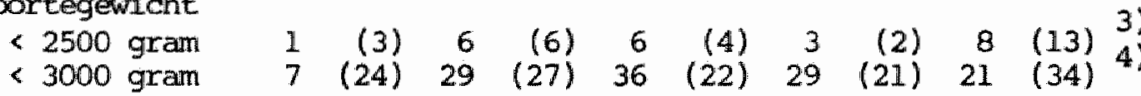

vroeggeboorte

( $<37$ weken)

$1 \quad(3) \quad 3 \quad(3)$

(3) 9

(6) 1

(3) $6(10)$

hoge bloedaruk

2)

totaal

$29(100) 107$ (100) $161(100) 135$ (100) 62 (100)

1) $1 \mathrm{mmol} / 1=1.61 \mathrm{~g} / \mathrm{dl}$.

2) diastollische druk > $90 \mathrm{mmHg}$ en/of systolische druk > $140 \mathrm{~mm}$ ilg bij gelegenheid van de hoogst gemeten diastolische bloeddruk tijdens de prenatale zorg.

3) $\mathrm{p}<0.01$ (de hoogste categorie vergeleken met de rest).

4) $p<0.05$ (de hoogste categorie vergeleken met de rest).

(Bij de statistische analyse werd de chilkwadraat toets gebruikt, of de Fisher exact test als het verwachte aantal patiënten in én van de (vier) cellen 5 of lager bedroeg).

In de tabelien 1 en 2 worden de relaties tussen 10 en Ht enerzijds en geboortegewlcht, zwangerschapsduur en bloeddruk anderzijads gepresenteerd. Het is duidelijk dat hoge Hb- en Ht-waarden ( $\ 8.0 \mathrm{mmol} / 1$ respectievelijk $\geq 398$ ) samenhangen met een laag geboortegwicht en prematuritas. Een hogere bloedaruk vinden we al boven een Hb van 7.5 mol $/ 1$ en een $H$ t van $35 \%$.

Voor lage $\mathrm{Hb}$ - en $\mathrm{Ht}$-waarden vonden wij geen duidelijke verschillen, mogelijk comdat erg lage waarden zeldzaam waren. Voor het MCV (Mean Corpuscular volume) vonden wij geen relevante invloed op de zwangerschapsuitkomst. Blijkbaar is het erythrocytengetal sterker van invloed dan het celvolume. 
Tabel 2. Hematocriet tussen 30 en 32 weken amenorroeduur, zwangerschapsulitkonst en bloedaruk.

Hematocriet $(z)$

$$
\leq 30
$$

$31-34$

$35-38$

$\geq 39$

$\mathrm{n}$ (8) n (8) $\mathrm{n} \quad(8) \quad \mathrm{n}$

(8)

geboortegewicht

$\begin{array}{rrrr}<2500 \text { gram } & 2 & (5) & 10 \\ <3000 \text { gram } & 10 & (24) & 41\end{array}$

(22)

$\begin{array}{rrr}4 & (2) & 7 \\ 51 & (26) & 14\end{array}$

7 (14)

2)

< 3000 gram

vroeggeboorte

( $<37$ weken)

1 (2)

9

3

5 (10)

3)

\begin{tabular}{|c|c|c|c|c|c|c|c|c|}
\hline hoge bloeddruk ${ }^{1)}$ & 4 & $(10)$ & 15 & (8) & 27 & (14) & 29 & (18) \\
\hline totaal & 42 & $(100)$ & 186 & $(100)$ & 196 & $(100)$ & 51 & $(100)$ \\
\hline
\end{tabular}

1) diastolische druk > $90 \mathrm{mmHg}$ en/of systolische druk > $140 \mathrm{mmig}$ bij gelegenheld van de hoogst gemeten diastolische bloeddruk tijdens de prenatale zorg.

2) $\mathrm{p}<0.01$ (de hoogste categorie vergelieken met de rest).

3) $\mathrm{p}<0.05$ (de hoogste categorie vergeleken met de rest).

(Bij de statistische analyse werd de chilkwadraat toets gebruikt, of de Fisher exact test als het verwachte aantal patiënten in éen van de (vier) cellen 5 of lager bedroeg).

Roken had een sterke negatieve invloed op het geboortegewicht, waarbij in tweërlei zin sprake was van een cosis-respons relatie: naarmate men later in de zwangerschap nog rookt, en naarmate men mér sigaretten rookt is het effect sterker. Van wie rond de dertigste week nog rookte, bleek het kind per gerookte sigaret per dag een verlies van 24 gram geboortegewicht ten opzichte van niet (inclusief ex-)rokenden te hebben. Bij rooksters werd ook vaker vroeggeboorte gevonden: bij $6 \%$ van hen duurde de zwangerschap korter dan 37 weken versus 3\% bij niet-rooksters $(p=0.08)$. Het verband tussen $\mathrm{Hb}$ en Ht en zwangerschapsuitkanst kon niet door roken verklaard worden: onafhankelijjk van de hoogte van het $\mathbb{H b}$ en de Ht rookte 35\% van de zwangeren rond de dertigste week. Alcoholgebruik vertoonde evemin verband met de hematologische parameters en wij konden ook geen systematische invloed ervan op de uitkanstparameters vaststellen.

opmerkelijk is, dat er geen duidelijke verbanden konden worden gevonden tussen de hoogst gemeten diastolische bloeddruk enerzijds, en het geboortegewicht en de zwangerschapsduur anderzijds. Een mogelijjke verklaring zou zijn, dat bij de prenatale controle direct wordt inge- 
speeld op verhoogde bloeddruk, zodat ongunstilge effecten later moeilijk te meten zijn.

Bij hogere pariteit werd vaker een laag $\mathrm{Hb}$ aangetroffen: van de nulliparae, primiparae en de multiparae had respectievelijk 48 (10/238), 68 $(11 / 181)$ en $11 \%(8 / 75)$ een Hb lager dan $6.5 \mathrm{mmol} / 1$. Het gemidaelde geboortegewicht nam in deze groepen toe: respectievelijk 3249 gram (SD:497), 3352 gram (SD: 480), 3440 gram (SD: 495), zonder dat er verschillen in zwangerschapsduur werden waargencren.

Vrouwen die staaltabletten gebruikten of hadden gebruikt, hadden rond de dertigste zwangerschapsweek een iets lager Hb dan de anderen 17.2 mol/1 versus $7.3 \mathrm{mmol} / 1$ ), doch de geboortegewichten en zwangerschapsduren verschilden niet duidelijk. Overigens bleek bij de wrouten die staal gebrulkten, het gemiddelde $\mathrm{Hb}$ bij de éérste zwangerschapscontrole relatief nog lager te zijn geweest $(7.8$ versus $8.2 \mathrm{mmol} / 1$, $p$ < $0.001)$. Blijkbaar is er in het verloop van de zwangerschap niet alleen routinematig, maar zeker ook op indicatie, ijzer verstrekt.

In tabel 3 worden de resultaten van de multipele regressie-analyse weergegeven. Afhankelijke variabele is de kans op een geboortegewicht lager dan $2500 \mathrm{~g}$ en/of een zwangerschapsduur van minder dan 37 weken. Het blijkt dat roken en hematocriet ook na correctie voor de invloed van de andere variabelen, een duidelijke invloed hebben. De invloed van het $\mathrm{Hb}$ bereikt de statistische significantie drempel ( $p<0.05$ ) niet. Dit is wel het geval als men de analyse beperkt tot de zwangeren die géen staal gebruikt hebben. De reden hiervoor kan zijn dat onder vrotwen die staal gebruikt hebben, minder vaak hoge Hb-waarden worden aangetroffer.

Het verband tussen de zwangerschapsuitkonist en de hematologische parameters verandert niet Indien men de analyse apart verricht voor vrouwen die primair door verloskundigen begeleid zijn en voor vrouwer die vanaf het begin door de gymaecoloog zijn begeleid.

De kans op het krijgen van een secundaire medische indicatie voor de bevalling stijgt met het hoger wonden van het $\mathrm{Hb}$ en de Ht. Dit is vooral duidelijk in de hoogste Flo- en Hit-klassen (tabel 4). 


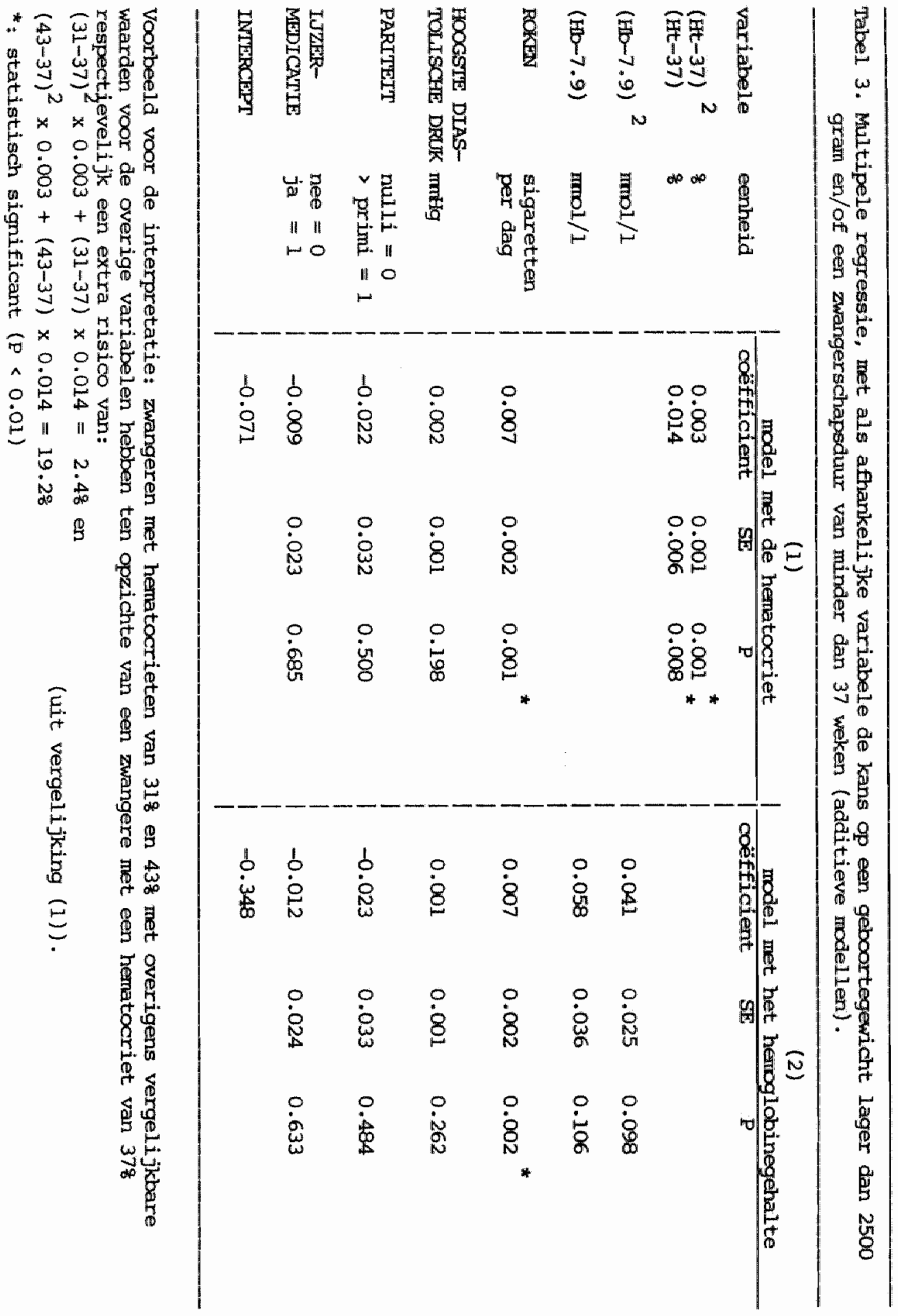


Tabel 4. Het Hb-gehalte en de Ht rond de dertigste zwangerschapsweek in relatie tot een primaire respectievelijk secundaire medische indicatie. Er is horlzontaal gepercenteerd.

\begin{tabular}{|c|c|c|c|c|}
\hline tho $(\mathrm{mol} / 1)$ & $\begin{array}{l}\text { geen } \\
\text { medische } \\
\text { indicat } 1 \text { e }\end{array}$ & $\begin{array}{l}\text { primaire } \\
\text { medische } \\
\text { indicatie }\end{array}$ & $\begin{array}{l}\text { secundaire } \\
\text { medische * } \\
\text { indicatie }\end{array}$ & $\begin{array}{c}\text { totaal } \\
n\end{array}$ \\
\hline $\begin{array}{l}-6.4 \\
6.5-6.9 \\
7.0-7.4 \\
7.5-7.9 \\
8.0-8.4 \\
8.5+ \\
\text { totaal }\end{array}$ & $\begin{array}{r}358 \\
278 \\
348 \\
308 \\
338 \\
\frac{08}{318}\end{array}$ & $\begin{array}{l}528 \\
548 \\
428 \\
448 \\
448 \\
438 \\
468\end{array}$ & $\begin{array}{l}148 \\
198 \\
248 \\
268 \\
248 \\
578 \\
239\end{array}$ & $\begin{array}{r}29 \\
107 \\
160 \\
136 \\
55 \\
794\end{array}$ \\
\hline He (8) & & & & \\
\hline $\begin{array}{l}-30 \\
31-32 \\
33-34 \\
35-36 \\
37-38 \\
39-40 \\
41+ \\
\text { totaal }\end{array}$ & $\begin{array}{l}298 \\
328 \\
258 \\
368 \\
318 \\
308 \\
\frac{188}{318}\end{array}$ & $\begin{array}{l}558 \\
518 \\
538 \\
398 \\
438 \\
438 \\
\frac{468}{478}\end{array}$ & $\begin{array}{l}178 \\
178 \\
228 \\
258 \\
268 \\
288 \\
368 \\
238\end{array}$ & $\begin{array}{r}42 \\
75 \\
111 \\
124 \\
72 \\
40 \\
11 \\
475\end{array}$ \\
\hline
\end{tabular}

* De lineaire regressiecoëficiënten van het $\mathrm{Hb}$ en de Ht voor de kans op een secundaire medische indicatie als afharkelijke variabele $z i j n$ respectievelijk 0.09 (SE: 0.033 ) en 0.012 (SE: 0.06 ).

Voor de vrouwen die aanvankelijk door perifere verloskundigen begeleid waren, ontbrak een gestandaardiseerde meting van de aanvangs $\mathrm{Hb}$ - en Ht-waarden. Daarom bestudeerden wij alleen voor de geheel poliklinisch begelelde wangeren (door de poliklinisch werkzame verloskundigen en/of de gynaecologen), of het negatileve verband tussen de hoogte van de hematologische parameters en het geboortegewicht respectievelijk de zwangerschapsduur ook al aan te tonen was wat betreft het $\mathrm{Hb}$ en $\mathrm{Ht}$, gemeten bij de érste zwangerschapscontrole (bij een mediane amenorroeduur van 9 weken; vrouwen die nà de zestiende week voor het eerst op controle kwamen werden van deze analyse witgesloten). Dergelijke verbanden werden voor de hematocriet niet gevonden. Voor het thb werden evenmin statistisch significante verbanden gevonden, maar was er wel een zwakke U-vormige trend te bespeuren wat betreft de kans op een geboortegewicht onder de 2500 gram (tabel 5). Hoewel de aantallen te klein zijn voor een definitief oordeel, lijkt de conclusie voorlopig gewettigd, dat de eventuele invloed van het $\mathrm{Hib}$ em de Ht bij de eerste zwangerschapscontrole in elk geval minder uitgesproken is dan de invloed van deze parameters bij 30 weken. 

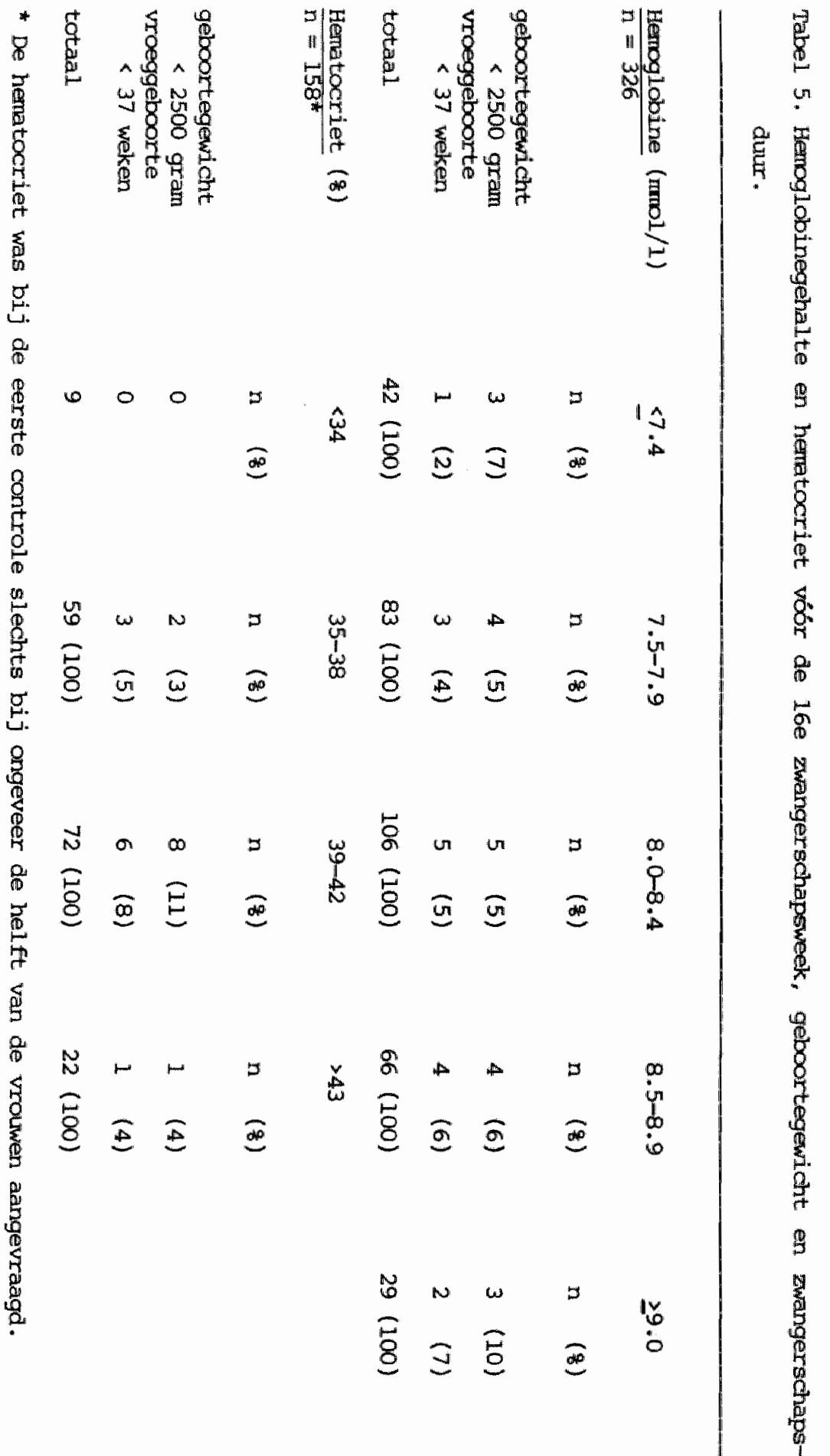

$\begin{array}{lllllll} & \\ 0\end{array}$

营

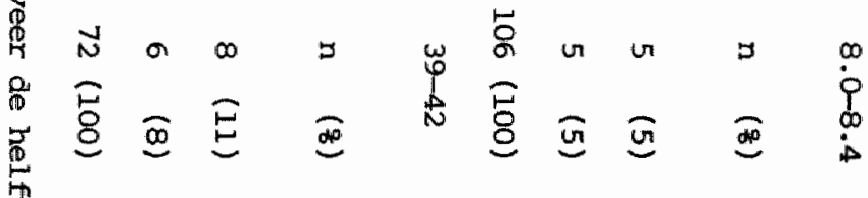
7

ฐ

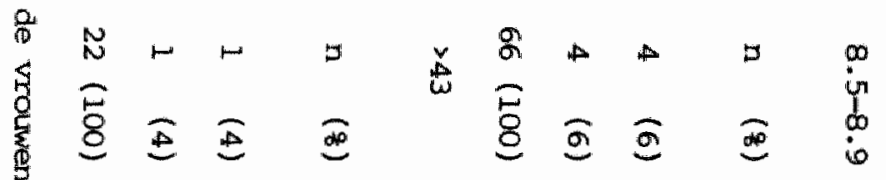

है

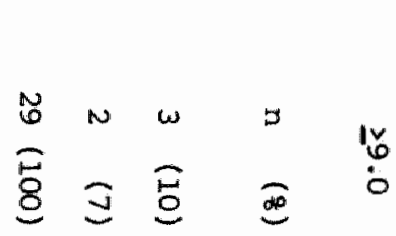




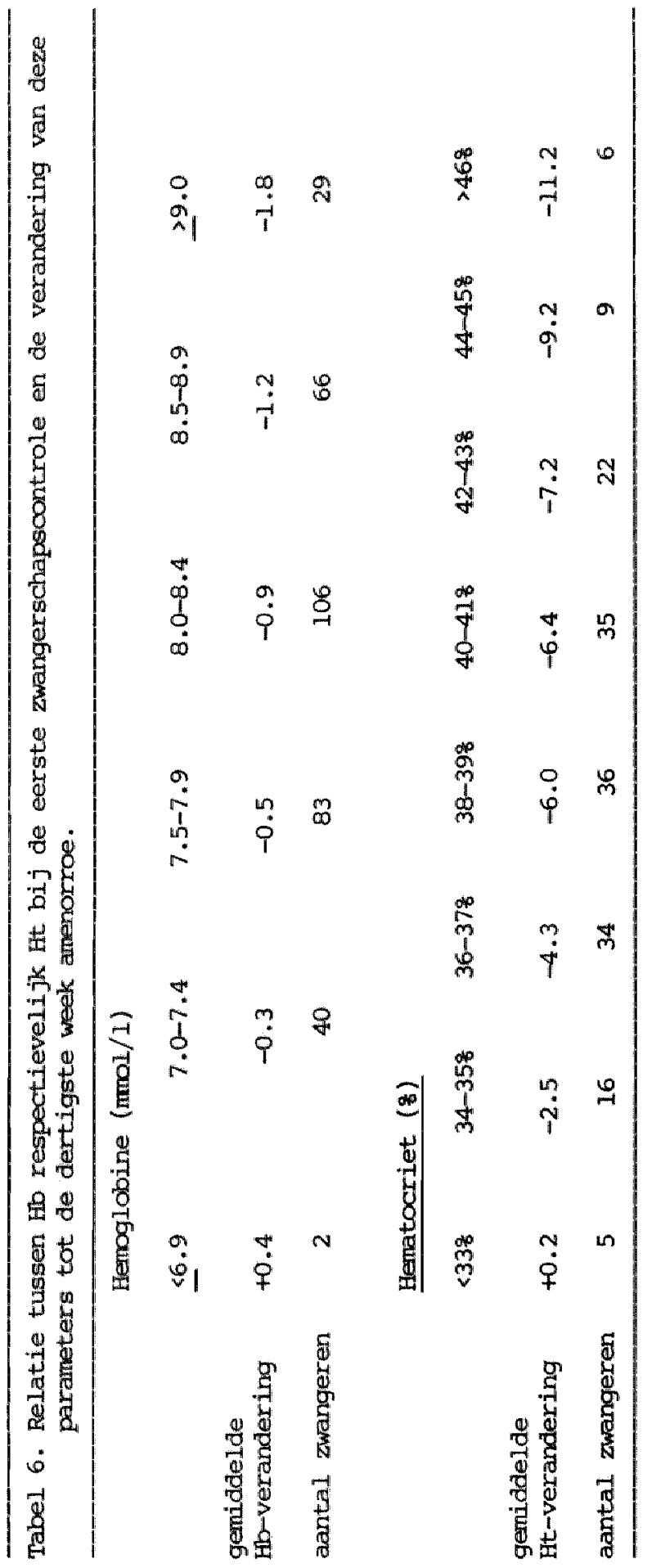


De mate en de richting van de verandering van tio en Ht gedurende de zwangerschap hingen sterk samen met de aanvangswaardien (tabel 6).

Dit patroon bestond zowel bij de vrouwen die staaltabletten kregen als bij degenen die deze niet hadden gekregen, hoewel in de eerste groepen de stijging in de groep met zeer lage uitgangswaarden meer ultgesproken was.

Beschouwing.

In ons onderzoek werd een samenhang gevonden tussen enerzijds een hoog hemoglobinegehalte $(8.0 \mathrm{mmol} / \mathrm{l}$ en hoger) en een hoge hematocriet (398 en hoger) gemeten bij dertig weken amenorroe en anderzijas e@n laag geboortegewicht en een korte zwangerschapsduur. Dit verband blijft aarwezig, als gecorrigeerd wordt voor het (aanzienlijke) effect van roken, de (geringe) invloed van pariteit en bloeddruk, en het gebruik van staaltabletten. Het verband is aanwezig in zowel de populatie zwangeren die primair door verloskundigen worden begeleid als onder degenen die vanaf het begin door de gynaecoloog worden gecontroleerd. Een verband tussen het Hb en de Ht bij de eerste controle en de zwangerschapsuitkomst was niet duidelijk. Wel bleek dat de mate van verandering van fib en Ht sterk samenhangt met de eerst gemeten waarde. Het lijkt er daarbij op dat het lichaam streeft naar een hernoglobine gehalte van rond 7.2 à $7.3 \mathrm{mmol} / 1$ en een hematocriet tussen rond de 33 à $34 \%$, later in de zwangerschap. Een dergelijke streefwaarde sluit goed aan bij de bevindingen van de hier gerapporteerde studie en ander onderzoek $(1,2)$. Inmers, vanaf circa $8.0 \mathrm{mmol} / 1$ respectievelijjk 398 is er meer kans op prematuritas en een laag geboortegwicht en op een secundaire medische indicatie. Bij Hb-waarden onder circa 7.0 mol/1 is er een (bescheiden) samenhang met enkele subjectieve klachten zoals moeheid - erger dan vóbr de zwangerschap - en hartkloppingen (hoofdstuik 8 ).

Over het algemeen stemmen onze bevindingen overeen met de conclusies van anderen: een niet optimale hemodilutie is een risicofactor voor een minder gunstig zwangerschapsbeloop (1 - 10). In onze studie hebben wij kunnen aantonen dat de invloed van deze factor, gemeten via de hematocriet, cok na controle voor een serie relevante, deels met de hematologische parameters en/of zwangerschapsultkomst geasisocieerde, covariabelen aantoonbaar blijft. Het is dan ook niet waarschijnlijk, 
dat het pathogenetisch mechanisme door de samerhang met de bloeddruk wordt verklaard, zoals Murphy et al. suggereren (2). Wat roken betreft: ook anderen constateerden, dat het verband tussen hematologische parameters en zwangerschapsuitkanst bij rooksters en niet-rooksters op dezelfde wijze was terug te vinden $(1,2,4)$. Het is daarbij wel zo, dat een zwangere die rookt én een hoog Ho heeft een dubbel extra risioo loopt.

In tegenstelling tot Murphy et a.l. (2) vinden wij het verband dat bij dertig weken wordt waargenomen, niet duidelijk terug woor de hematologische bepalingen bij de éerste zwangerschapscontrole. Onze data pleiten voor de hypothese dat niet zozeer de beginwaarden van belang zijn, maar de vraag of men een optimaal traject bereikt. In combinatie met de waameming van diverse andere groepen dat de verbanden reeds in het tweede trimester duidelijk zijn $(4,5)$, zou dit optimale traject bij voorkeur al vij spoedig bereikt moten zijn.

Het feit dat het verband duidelijker is wat betreft de hematocriet dan wat betreft het hemoglobine, is in overeensteming met het door Huisman veronderstelde pathofysiologische mechanisme: een hogere viscositelt van het bloed brengt een minder goede placenta-doorbloeding met zich mee $(11,12)$, en het is dan van belang dat het bloed zich in voldoende mate verdunt. Omdat roken, hoge bloeddruk, alcoholgebruik en pariteit de samenhang tussen hoge Ht- en Hlb-waarden en een ongunstige uitkomst niet verklaren, meigen wij ertoe am aan een te geringe hemodilutie een directe causale invloed toe te schrijwen. Het ligt voor de hand dat de medicus practicus bij de hematologische controle van de zwangere de Ht altijd (mee)bepaalt. Dit zou, eventueel in samenhang met de bepaling van de bloedviscositeit (11) eenvoudige infonmatie kunnen geven over de kans op intra-uteriene groelvertraging c.q. aanleiding kunnen zijn an te waken voor (verdere) hemoconcentratie (6). Mede op grond van het optreden van "anemische" klachten zou de optimale range (zie hoofdstuk 8) tussen de 32 en 38 o gesitueerd zou kunnen worden. Voor routinematige ijzersuppletie én voor routinematig niét suppleren lijjkt geen grond te bestaan.

In een nader onderzoek bij nog eens 400 zwangeren zullen de hier beschreven resultaten worden getoetst. Tevens zal de totale groep dan groot genoeg zijn an meer duidelijkheid te verkrijgen over de invloed van de $\mathrm{Hb}$ - en Hit- waarden bij de eerste zwangerschapscontrole. 


\section{LITERATUUR.}

1. Garn SM, Ridella SA, Petzold AS, Falkner F. Maternal hematologic levels and pregnancy outoomes. Seminars in perinatology 1981; 5 : 155-162.

2. Murphy JF, O'Riordan J, Newcombe RG, Coles EC, Pearson JF. Rellation of haemoglobin levels in first and second trimester to outcome of pregnancy. The Lancet 1986; 1: 992-994.

3. Huisjes $\mathrm{H}$. Het hemoglobinegehalte in de zwangerschap. Nederlands Tijdschrift voor Geneeskunde 1985; 129: 1323-1324.

4. Huisman A, Aarnoudse JG. Increased 2nd trimester hemoglobin concentration in pregnancies later complicated by hypertension and growth retardation. Acta Obstetrica et Gymaecologica Scandinavica. In press.

5. Koller O, Sagen N, Ulstein M, Vaula D. Fetal growth retardation associated with inadequate haemodilution in otherwise uncomplicated pregnancy. Acta Obstetrica et Gynaecologica Scandinavica 1979; 58: $9-13$.

6. Koller $O$, Sandvei $R$, Sagen $N$. High hemoglobin levels during pregnancy and fetal risk. International Journal of Gynaecology and Obstetrics 1980; 18: 53-56.

7. Hytten FE, Paintin DB. Increase in plasma volume during nomal pregmancy. The Journal of Obstetrics and Gynaecology of the British Commonwealth 1963; 70: 402-407.

8. Gibson HM. Plasma Volume and glomerular filtration rate in pregnancy and their relation to differences in fetal growth. The Journal of Obstetrics and Gynaecology of the British Conmonwealth $1973 ; 80: 1067-1074$.

9. Pirani BBK, Campbe11 DM, MacGililivray I. Plasma volume in nomal first pregmancy. The Journal of Obstetrics and Gynaecology of the British Cormonwealth 1973; 80: 884-887.

10. Gallery EDM, Hunyor SN, Györy. Plasma volume concentration: a significant factor in both pregnancy-associated hypertension (pre-ecclampsia) and chronic hypertension in pregnancy. guarterly Journal of Medicine 1979; XLVIII; 192: 593-602.

11. Huisman A. De veranderingen in de viscositeit van bloed bij zwangeren met intra-uteriene groeivertraging, Groningen 1983.

12. Huisman A. Haemorheological changes during pregnancy. Thesis, R.U. Groningen 1986. 
HEMOGIOBINE EN HEMATOCRIET ALS RISICOEACTOREN VOOR HET KRIJGEN VAN EEN MYOCARDINEARCT.

- een studie in een arbeidsgeneeskundige setting.

J.A. Knottnerus 1) - G.M.H. Swaen 2) - J.J.M. Slangen 2) - A. Volovics 3) - J. Durinck 4).

\section{Samenvatting.}

De vraag, in hoeverre verhoogde hemoglobine- (Ho-) en hematocriet (Ht-) waarden risicofactoren zijn voor het krijgen van een hartinfarct, is nog niet beantwoord. Met behulp van de gegevens van het Algemeen Perlodiek onderzoek (APO) van Philips" Gloeilampenfabriek werd een patient-controle onderzoek verricht. Patienten waren manne1ijke werknemers van 50 tot 60 jaar oud, die (gemiddeld 16 maanden) wb6r het krijgen van een eerste infarct een APO hadden ondergaan $(n=104)$. Per patient werden twee gezonde mannelijke contralepersonen getrokken uit de lijst van APO-deelnemers, gematcht op leeftijd. Van patienten en controlepergonen werden de APO-gegevens genoteerd betreffende Hb, Ht, rookgedrag, bloeddruk, cholesterol, polsfrequentie, gewicht, lengte, longfunctie $\left(\mathrm{FEV}_{5}\right)$ en het gebruik van antihypertensieve geneesmiddelen. Na het dichotomizeren van het tib en de Ht op hun gemiddelde waarden (respectievelijk $9.7 \mathrm{mmol} / 1$ en $46 \%$ ) werden ruwe odds ratio's gevonden $\operatorname{van} 2.1$ (958 betrouwbaarheldsinterval $1.2-3.6$ ) en 2.7 (1.6 - 4.6) voor respectievelijk hoge Hb- en Ht-waarden. De verbanden tussen tho en $H t$ en het optreden van eer myocardinfarct waren ook duidelijk na correctle voor mogelijke verstorende factoren door middel van multipele logistische regressie. Onze resultaten zijn in overeensteming met de hypothese dat matig hoge Ht- en, in mindere mate, Hb-waarden risicofactoren zijn voor het krijgen van een hartinfarct.

1) Capaciteitsgroep Epidemiologie, Rijksuniversiteit Limburg

2) Capaciteitsgroep Arbeidsgeneeskunde, Rijksuniversitelt Limburg

3) Capaciteitsgroep Medische Informatica en Statistiek, Rijksuniversiteit Limburg

4) Philips Medische Dienst, Eindhoven. 
Inleiding "

In de medische praktijk worden dagelijks hemoglobine (Hb) bepalingen verricht. Men is daarbij meestal geinteresseerd in zeer lage waarden, en sams in zeer hoge waarden, als indicatoren van pathologische verwikkelingen. Veel minder aandacht is er voor minder extreme uitslagen. In dit artikel gaat het on de vraag of er een verband is tussen matig hoge Ib- en hematocriet (Ht)- waarden en de kans op het krijgen van een eerste hartinfarct.

De literatuur geeft over deze vraag geen uitsluitsel.

In een aantal prospectieve cohortstudies met lange follow-up perioden werd geen relevant verband gevonden tussen Hb $(1-4)$, Ht $(3,5-8)$ en coronaire hartziekten. In andere studies kwam een dergelijk verband echter wel naar voren, vooral met betrekking tot cardiovasculaire sterfte onder vrouwen (9-13).

Enkele transversale onderzoekingen lieten een hogere hematocriet zien bij patienten met een hartinfarct (14-16) of andere coronaire hartziekten (16), dan bij controlepatienten. Hoewel deze resultaten niet werden gereproduceerd in twee andere studies $(17,18)$ werden, meer recent, wederom hogere $\mathrm{Ht}$ - waarden gevonden bij patienten met angina pectoris (19) en vernauwingen van de coronalre arteriën (20).

Een nadeel van de transversale methode is dat geen informatie wordt verkregen over de vraag of een hoge Ht voorafgaat aan het infarct of daarvan het gevolg is. Dit laatste zou een uiting kunnen zijn van een compensatiemechanisme, teneinde het ischemische hart van extra zuurstof te kunnen voorzien (3). Voorts is de mogelifkheid geopperd, dat de resultaten van patient-controle onderzoekingen in ziekenhuizen vertekend zijn, omdat een verschillende duur van imobilisatie van patienten en controlepersonen op zichzelf verschillende waarden van de hematologische parameters tot gevolg kan hebben (18).

In een patient-controle onderzoek bestudeerden wij het verband tussen routinematig bepaalde $\mathrm{HB}$ - en $\mathrm{Ht}$ - waarden van mannelijke werknemers zonder voorgeschiedenis van coronaire hartzlekte en het later optreden van een eerste hartinfarct, rekening houdend met andere bekende risicofactoren. 
Methoden.

Gegevens bestand.

Alle werknemers van Philips" Gloeilampenfabriek in Eindhoven worden, vanaf de leeftlja van 50 jaar, elke twee jaar vitgenodigd voor een Algemeen Periodiek Onderzoek (APO). Van 1977 tot 1984 hebben ongeveer 10.000 mannneli.jke werknemers deelgenamen, genulddeld 3 keer per persoon. Het jaarlijkse responspercentage lag rond de 90\%. Alle Afo-resultaten zijn opgeslagen in een gecomputeriseerd gegevensbestand.

Het APO bestaat uit:

- een standaardvragenlijst over de gezondheidstoestand, de medische consumptie en het gezondheidsgedrag;

- metiling van gewicht, lengte en bloeddruk;

- bloedonderzoek;

- (rust) electrocardiografie en longfunctie-onderzoek.

Observaties.

De vragenlijsten zijn routinematig afgenomen door speciaal getrainde assistenten. Gevraagd is naar roken ( op het moment en in het verleden), de aanwezigheid van cardiovasculaire klachten of afwijkingen, en het gebruik van antihypertensleve geneesmiddelen.

De bloeddruk is gemeten met eer kwik sphygmomanometer met een standaardmanchet om de linkeram van de onderzochte, in rustig zittende positie. Voor de diastolische bloedaruk is het Korotkov-IV criterium gebruikt.

Lengte en gewilcht zijn gerieten nadat schoenen en jasje waren uitgetrokken, en tijdens het tellen van de polsfrequentie lag de onderzochte in rugligging.

Het bloed is afgenomen via venapunctie. In een deel ervan zijn, na behandeling met EDTA, onmiddellijk de hematologische parameters (Bb, Ht, erythrocytengetal (ery's)) bepaald met een TOA-counter CClOB. Het cholesterol is bepaald met een Cobas Bio analyzer (Roche), met behulp van cholesteroloxidase en -esterase.

van iedere werknemer is een drie-kanaals rust-electrocardiogram ver 
vaardigd, en dit is blind beoordeeld door een ervaren cardioloog op yrond van algemeen aanvaarde criteria voor het vaststellen van hartinfarct (typische infarct-Q-top en ST- en T-afwijkingen). De longfunctie is bepaald met een droge spirometer (Vica-test), bij geforceerde expiratie. Voor de analyse is de $\mathrm{FEV}_{5}$ ( 5 seconden warde) gebruikt, als de hoogste waarde van drile opeenvolgende metingen.

Selectie van patienten en controlepersonen.

Uit het gegevensbestand werden die mannelijke werknemers geselecteerd die in het kader van het APO hadden gemeld dat zij voor het eerst hartinfarct hadden gehad. Selectiecriteria waren voorts:

- dat minstens éérmaal eerdex een APO was bezocht;

- dat bij vorig(e) bezoek(en) noch anamnestische, noch electrocardiografische aanwijzingen voor coronaire hartziekte waren gevonden;

- dat het infarct bevestigd werd door vergelijking van de electrocardiogramen vóór en na het melden van het infarct en/of door informatie van het ziekenhuis waar de patient behandeld was. Deze laatste infomatie werd verkregen via de aan het bedrijf verbonden verzekeringsgeneeskundige.

voor iedere patient werden als controlepersonen at random twee mannelijke werknemers getrokken wit de APO-deelnemerslijst van dezelfde dag dat de patient het infarct meldde, gematcht op geboortejaar. Als sen controlepersoon klinisch relevante veranderingen op het ECG had, of geen vorig APO bezocht had, werd hij vervangen door een andere op dezelfale wijze geselecteerde controlepersoon.

Na selectie van patienten en controlepersonen werd op een standaandformulier informatie genoteerd over de hematologische parameters (Hb, Ht, ery's), andere mogelijke deteminanten van hartziekte (roken, cholesterol, bloedaruk, polsfrequentie, gewicht, lengte, $\mathrm{FEV}_{5}$ ) en eventueel gebruik van antihypertensieve geneesmiddelen. Deze infonmatie werd voor de hartinfarctpatienten ontleend aan het laatste APO vón het infarct, en woor de controlepersonen werd het daamee oorresponderende APO genomen. In de analyse werd betrokken het rookgedrag (al dan niet roken) ten tijde van dit voorgaande APO. 
Statistische analyse.

Ruwe verbanden, niet gecomigeerd voor de invloed van covariabelen, werden berekend als odds-ratio's met behulp van Schlesselman's methode voor gematchte tripletten (21). odds-ratilo's voor continue variabelen, werden berekend na dichotanizering in "lage" (lager dan of gelijk aan het gemiddelde) en "hoge" (hoger dan het gemiddelde) waarden. Vijfennegentig procents betrouwbaarheidsintervallen werden berekend, ook volgens Schlesselunan (21).

on te controleren voor de andere risico-factoren werd en conditionele logistische regressie-analyse voor gematchte gegevens uitgevoerd volgens Breslow and Day, met het programa PASCAL van het. IARC te Lyon (22). De gematchte factoren waren, zoals beschreven, het APO en de leeftija. De matching ratio was $1: 2$. In deze analyse werden de continue variabelen met hun gemeten waarde opgencmen, gecentreerd door subtractie van de gemiddelden.

Bij het fitten van het logistisch regressiemodel werd de volgende strategie gevolgd:

1) Alle hoofd-effecten werden in het model opgencmen.

2) Alle mogelijke producttennen (interacties) van de eerste orde werden gescreend door middel van en voorwaartse selectieprocedure waarbij voorrang werd gegeven aan interacties met de primair bestudeerde risicofactoren ( $\mathrm{Hb}$, $\mathrm{Ht}$, en ery" $\mathrm{s}$ ). Hierbij werd een $5 \%$ significantiedrempel gehanteerd.

3) Niet-significante hoofd-effecten, die niet betrokken waren in interacties werden geèlimineerd onder behoud van de validiteit, dat wil zeggen dat de cöefficiënten van de termen die in het model bleven niet substantieel veranderden in waande en/of teken. Eir was sprake van multicollinearitelt tussen $t$, Ht en ery"s. Daarom werd voor lk van deze factoren een apart model opgesteld volgens de beschreven strategie. 

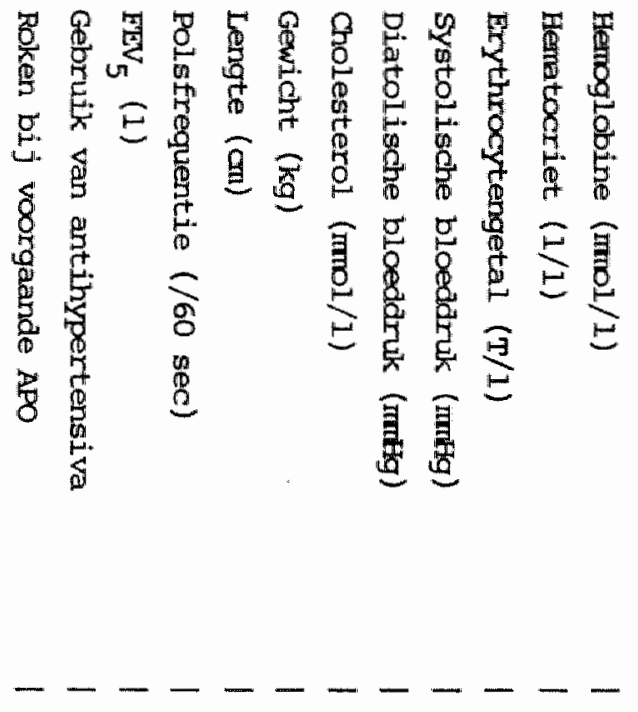

$\mathbb{N}_{\mathrm{N} N} N$

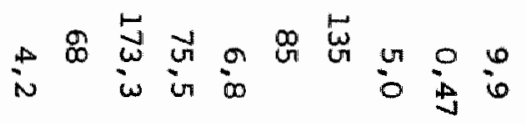

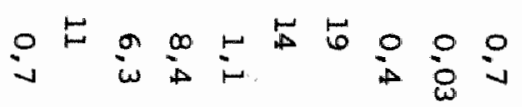

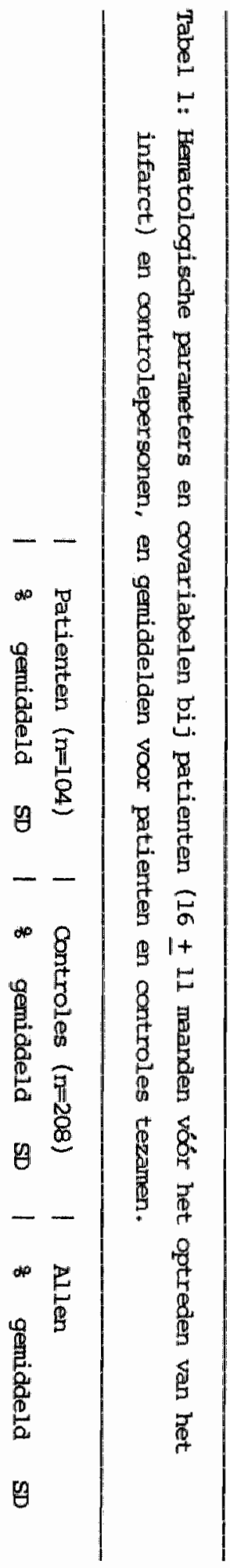


Resultaten.

Honderdvier hartinfarctpatienten en 208 controlepersonen voldeden aan de criteria. de gemiddelde leeftija van beide groepen was 53 jaar, met een range var 50 tot 60 jaar. De gemiddelde periode tussen het APO watbij de patienten en controles geselecteerd werden en het voorgaamde APO was 31 maanden (SD:13) voor de patienten en 29 maanden (SD:10) voor de controles. De patienten kregen hun infarct gemiddeld 16 maanden na het voorgaande APO met een range van 1 tot 48 maanden.

Tabel 1 geeft informatie over de waarden van hematologische parameters en covariabelen ten tijde van het voorgaande APO. Hartinfarctpatienten $1 i j k e n$ wat hogere $\mathrm{Hb}$ - en $\mathrm{Ht}$ - waarden te hebben gehad dan de controles, wat nog duidelijker gedemonstreerd wordt in tabel 2, waarin de verdelingen van het $\mathrm{Hb}$ en de $\mathrm{Ht}$ in beide groepen worden gegeven.

Tabel 2: Distributie van hemoglobine en hematocriet bij patienten (vóbr het optreden van het infarct) en controles.

\begin{tabular}{|c|c|c|c|c|c|c|c|c|c|c|c|}
\hline \multicolumn{6}{|c|}{ HEMOGLOBINE } & \multicolumn{6}{|c|}{ | HEMATOCRIET" } \\
\hline \multirow{2}{*}{\multicolumn{2}{|c|}{$\begin{array}{l}\mathrm{Hb} \\
(\mathrm{mmol} / 1)\end{array}$}} & \multicolumn{2}{|c|}{ Patienten } & \multicolumn{2}{|c|}{ Controles } & \multirow{2}{*}{\multicolumn{2}{|c|}{$\begin{array}{l} \\
\mathrm{Ht} \\
(\mathrm{z})\end{array}$}} & \multicolumn{2}{|c|}{ Patienten } & \multicolumn{2}{|c|}{ Controles } \\
\hline & & $\mathrm{n}$ & 윰 & $\mathrm{n}$ & $q$ & & & $\mathrm{n}$ & 8 & $\mathrm{n}$ & 8 \\
\hline 8.0 & - & 1 & 1,0 & 5 & 2,4 & 36 & - & 0 & 0,0 & 1 & 0,5 \\
\hline 8,5 & - & 5 & 4,8 & 20 & 9,6 & 38 & - & 0 & 0,0 & 1 & 0,5 \\
\hline 9,0 & - & 26 & 25,0 & 58 & 27,9 & 40 & - & 2 & 1.9 & 9 & 4,3 \\
\hline 9,5 & - & 28 & 26,9 & 68 & 32,7 & 42 & - & 8 & 7,7 & 34 & 16,3 \\
\hline 10,0 & - & 23 & 22,1 & 39 & 18,8 & 44 & - & 19 & 18,3 & 63 & 30,3 \\
\hline 10,5 & - & 16 & 15,4 & 16 & 7.7 & 46 & - & 32 & 30,8 & 46 & 22,1 \\
\hline 11,0 & - & 3 & 2,9 & 2 & 1,0 & 48 & - & 19 & 18,3 & 38 & 18,3 \\
\hline \multirow[t]{5}{*}{11,5} & + & 2 & 1,9 & 0 & 0,0 & 50 & - & 17 & 16,3 & 13 & 6,3 \\
\hline & & & & & & 52 & - & 4 & 3,8 & 3 & 1,4 \\
\hline & & & & & & 54 & - & 2 & 1,9 & 0 & 0,0 \\
\hline & & & & & & 56 & + & 1 & 1,0 & 0 & 0,0 \\
\hline & & 104 & 100) & 208 & $(100)$ & & & 104 & $(100)$ & 208 & $(100)$ \\
\hline
\end{tabular}

De hartinfarctpatienten hebben meer gerookt en hadden tevoren cok een hoger cholesterolgehalte dan de controles (tabel 1). Bijna een kwart van de patienten en $6 \%$ van de controles meldden op het voorafgaande APO antihypertensiva te gebruiken. Waarschijnlijk waren deze middelen voorgeschreven door hun huisarts, en dit kan ertoe hebben bijgedragen 
dat tussen de groepen geen verschillen werden gevonden in systolische en diastolische bloeddruk.

In tabell 3 worden de ongecorrigeerde odds ratio"s gegevens van hematocriet en hemoglobine, en van de covariabelen met een odds ratio significant groter dan 1.0, alsmede van de bloeddruk, na dichotomizering op het genidalelde weergegeven. Voor het $\mathrm{Hb}$ (afkappunt $9.7 \mathrm{mmol} / 1$ ) en de Ht (afkappunt 0.46) werden odds ratio's gevonden van respectievelijk 2.1 en 2.7 , significant groter dan 1.0. Zoals verwacht vertonen ook roken en cholesterolgehalte duidelijk positieve relaties met het optreden van een infarct. De odds ratio van de bloeddruk verschilt niet significant van 1.0. Zoals gezegd, kan dit het gevolg zijn van medicatie. Aangezien antihypertensiva met name worden voorgeschreven bil vastgestelde hoge bloeddruk, kan voor hun effect in de analyse niet meer gecorrigeerd worden. Het wekt in dit licht overigens geen verwondering, dat het gebruik van antihypertensiva geassocieerd is met een aanzienlijk verhoogd risico op hartinfarct.

Tabel 3: Ongecorrigeerde Odds Ratio"s voor het risico op myocardinfarct (niet gecorrigeerd voor covariabelen). Continue variabelen gedichotomizeerd op het gemiddelde in "hoog" (hoger dan het gemiddelde) versus "laag" (gelijk aan of lager dan het gemiddelde).

\begin{tabular}{|c|c|c|c|c|c|c|}
\hline \multirow{7}{*}{$\begin{array}{l}\text { Hemoglobine } \\
\text { Hematocriet } \\
\text { Roken (actueel) } \\
\text { Cholesterol } \\
\text { Antihypertensiva gebruik } \\
\text { Bloedaruk * }\end{array}$} & \multirow{2}{*}{$\frac{1}{1}$} & \multirow{2}{*}{$\frac{\mathrm{OR}}{2,10}$} & \multirow{2}{*}{$\frac{1}{1}$} & \multicolumn{3}{|c|}{$95 \% \mathrm{CI}$} \\
\hline & & & & 1,22 & - & 3,61 \\
\hline & 1 & 2,72 & 1 & 1,59 & - & 4,64 \\
\hline & 1 & 4,87 & 1 & 2,56 & - & 9,22 \\
\hline & 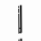 & 2,87 & 1 & 1,64 & - & 4,69 \\
\hline & $\|$ & 5,25 & $\|$ & 2,23 & - & 11,13 \\
\hline & $i$ & 1,12 & $i$ & 0,61 & - & 2,06 \\
\hline
\end{tabular}

* Bloeddruk $=$ diastolische druk +1/3. (systolische - diastolische druk).

Als resultat van de multipele logistische regressie worden de volgende modellen gepresenteerd (tabel 4): alle variabelen zonder interactietermen (1), en de modellen voor de hematocriet (2), het hernoglobine (3) en het erythrocytengetal (4), telkens met andere risicofactoren die een significant effect vertonen en een gevonden interactle tursen de hematologische parameters en de lengte. De hematocriet blijkt een sterk effect te hebben na correctie voor de andere factoren. Het effect van het $H b$ is geringer en niet significant in het volledige 
model. Worden tho en $\mathrm{Ht}$ in aparte modellen ondergebracht, dan zien we dat het effect van het HB significant wordt. Een invloed van het erythrocytengetal kan niet worden aangetoond.

Na de correctie voor andere factoren wordt het risico dat samenhangt het gebruik wan medicatie nog groter, vergeleken met de nuwe odds ratio $\left(e^{2.19}=8.9\right.$, versus 5.3$)$, en blijven de effecten van roken en cholesterol duidelijk aantoonbaar. Verschillen in bloeddruk en $\mathrm{FEV}_{5}$ hebben geen aantoonbare samenhang met het risico. De Pearson correlatiecoëfficiënt tussen lichaamsgewicht en lengte bedroeg 0.58 , maar er was geen gignificant effect van het gewicht aantoonbaar noch was het betrokken in een interactie, ook als lichaamslengte buiten de vergelijking werd gehouden. Interacties werden gevonden tussen lengte en de hematologische parameters. Hoewel niet significant volgens het $5 \%$ criterium is de interactie tussen lengte en erythrocyten in madel (4) opgenomen ter vergelijking met de modellen (2) en (3).

Om een indruk te geven van de effecten van Ht en Hb: de odds ratio voor de vergelijking van een man met een gemiddelde lengte en een Ht van 0.49 ( $=$ gemiddelde + standaarddeviatie) met een overigens vergelijkbare man met een Ht van 0.43 (= gemiddelde - standaarddeviatie) is gelijk aan: $\exp (31.19(0.49-0.43))=6.5$. De odds ratio van een man met een gemiddelde lengte en een $\mathrm{Hb}$ van $10.3 \quad(=$ gemiddelde + standaarddeviatie) ten opzichte van een man met een tho van 9.1 (= gemiddelde standaarddeviatie) is gelijk aan: $\exp (0.91(10.3-9.1))=3.0$.

Discussie.

Onze resultaten wijzen op eer positief verband tussen matig hoge Hten, in mindere mate, Hb-warden enerzijds en het risico op een hartinfarct anderzijds. Hierbil ji werd uitgegaan van Ht- en Hb-bepalingen die reeds vór het infarct verricht waren. De verbanden waren ook duide$1 \mathrm{ijk}$ aantoonbaar na correctie voor roken, cholesterol, bloeddruk, lichaamsgewicht, lichaamslengte en longfunctie. Deze bevindingen zijn in overeensteming met de resultaten van Canplbell et al, hoewel de laatste nog geen gegevens over rookgedrag in de analyse kon betrekken (11). Ondat de APO-gegevens verzameld en geregistreerd waren wóbrat de studie werd verricht, kunnen noch de beantwoording van de vragenlijst, noch het aflezen en coderen van de meetgegevens beinvloed zijn 


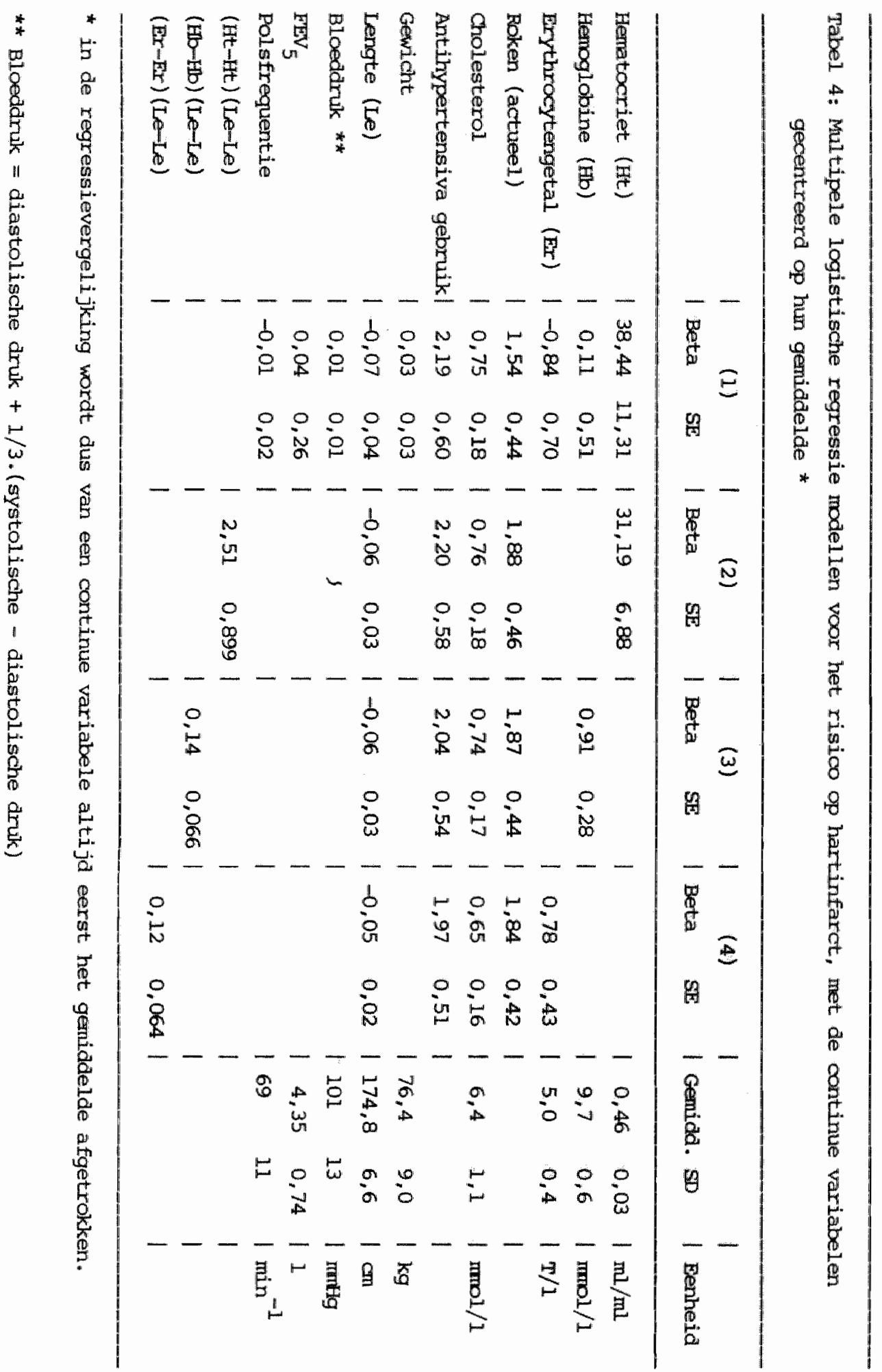


door voorkennis over (het doel van) het onderzoek. Bovendien kan de aarwezigheid van het infarct de gebruikte APO-gegevens over de risicofactoren niet beirvloed hebben amdat deze al vór het optreden van het infarct vastgelegd waren. In ons onderzoek was ook geen vertekening mogelijk door verschilien in hospitalisatie tussen patienten en controlepersonen (18) ondat allen ten tijde van de gebruikte APO-metingen goed gezond en ambulant waren.

Vertekening kan wel veroorzaakt zijn doondat personen met een fataal infarct, of degenen die daarna het APO niet meer bezochten (bijwoorbeeld vanwege invaliditeit), niet in het onderzoek werden betrokken. Dit heeft mogelijk geleid tot een "bias to the null", omdat in cohortstudies julst effecten van $H$ b en Ht ten aanzien van cardiovasculaire mortaliteit zijn gevonden $(9-13)$.

Voor de gevonden verbanden tussen $\mathrm{Ht}$, Ho en hartinfarct komen verschillende verklaringen in aamerking. Waarschijnlijk is, dat de viscositelt van het bloed een rol speelt. De positieve invloed van de hematocriet op de viscositeit is bekend $(19,23)$, evenals het negatieve verband tussen de bloedviscositeit enerzijds en de coronaire doorbloeding (23) respectievelijk cardiale efficiency anderzijals $(24,25)$. Analoge verbanden zijn gevonden tussen de cerebrale doorbloeding en een hoge Ht $(>0.46)(26,27)$. Een hogere Ht is ook geassocieerd met ernstiger graden van coronaire stenose $(20)$ en van cerebrale infarcering (28). Het feit dat wij een duidelijke invlced van de Hit vinden, en niet van het erythrocytengetal, houdt in dat het volume van de rode cel het risico positief beinvloedt.

In postmortale studies is een toegenomen aantal intercoronaire anastomosen gevonden bij anemische patienten, wellicht als compensatie van de minder goede zuurstofbindende capacitelt van het bloed (29). Dit zou anemische patienten kumnen beschermen tegen de gevolgen van coronaire trombose (30). In diverse studies is een negatief verband tussen Ht en bloedingstijd waargenomen. Deze bevinding wordt mogelijk verklaard doordat een hoge Ht de snelheid van de bloedstroom vertraagt en aldus plaatjesaggregatie en trombaseneiging bevordert $(31,32)$. Een hoog gemiddeld celvolume kan ait proces versterken. 
Positieve verbanden zijn gevonden tussen de Ht en het $\mathrm{Hb}$ en bekende risicofactoren zoals roken $(9,18,33,34)$, cholesterol- en tríglycerideconcentratie $(35-37)$, en bloeddruk $(18,38)$.

Wat betreft roken zou er sprake kumen zijn van een compensatie mechanisme voor het hogere Ho-CO gehalte. De effecten van Ht en Ho worden in onze studie echter niet door roken verklaard, comat zij na correctie voor roken blijven bestaan.

Gesuggereerd is dat een toename van de hematocriet, en dus een vermindering van het relatieve plasmavolume, een stijging van het cholesterolgehalte veroorzaakt (35-37). Aldus zou het atherogene effect van cholesterol voor een deel het indirecte gevolg kunnen zijn van een hoge Ht. Wij vonden echter nauwelijks een verband tussen Ht en cholesterolgehalte $(r=0.05)$. Bovendien vercwenen de relaties tussen $H t$, Hb en hartinfarct niet na controle voor het cholesterolgehalte.

De correlatiecoëfficient tussen bloeddruk en Ht was slechts 0.21 , en in ons onderzoek was bloeddruk geen significante risicofactor. Het is dus niet waarschijnlijk dat hogere bloeddruk het risico, dat met een hogere Ht geassocieerd is, verklaart. We moeten hierbij voorzichtig zijn omdat ten aanzien van de relatie bloeddruk-hartinfarct "confounding by indication" wat betreft het voorschrijven van antihypertensiva kan zijin opgetreden. Cok het verband tussen Ht en bloeddruk kan door deze middelen negatief zijn beinvloed. Uitgesloten moet everwel niet worden geacht, dat de predictieve waarde van hoge bloeddruk als risicofactor voor ischemische hartziekten boven de leeftijd van 50 jaar sterk afneemt (39).

Wij vonden wat betreft het risico op een hartinfarct een interactie tussen Ht en Ho enerzijds en lichaamsiengte anderzijds. Of dit een. biologische betekenis heeft is ons niet duidelijk. Voor de beantwoording van deze vraag zou nader onderzoek nodig zijn.

Een helder en aanvaarchaar concept van het mechanisme, verantwoordelijk voor het positieve verband tussen $\mathrm{Ht}$, Hb en hartinfarct, is nog niet uitgekristalliseerd. Een protopathisch effect (40) - een toename van de $\mathrm{Hb}$ synthese als gevolg van langdurende ischemie - kan niet worden uitgesloten. Maar, gezien de negatieve cardiale anarnese én de nilet voor ischenie verdachte electrocardiogramen van onze patienten en controles ten tijde van de bloedbepalingen, is dit geen voor de 
hand liggende verklaring. Mede gegeven de resultaten van de cohortstudie van Campbell et al, wijzend op een constant risico gedurende de follow-up periode (13), 11 kt een causaal verband tussen hoge Ht- en Filo- warden en het optreden van een hartinfarct aannemelijk, al dan niet gesuperponeerd op of gepotenteerd door subklinische ischemie. Beide mechanismen (een protopathisch en een causaal effect) kumnen ook tegelijk bestaan en elkaar versterken.

Gegeven de bevindingen van het biomedisch onderzoek en de nog uiteenlopende resultaten van het epidemiologisch onderzoek, is nader onderzoek naar de precieze aard van het verband tussen hematologische parameters en coronaire hartziekte gewenst, mede met het oog op mogelijke klinische consequenties.

\section{LITERATUUR.}

1. Paul 0 , Lepper MH, Phelan WHi et al. A longitudinal study of coronary heart disease. Circulation 1963; 28: 20-31.

2. Truett J, Cornfield J, Kannel. W. A multivariate analysis of coronary heart disease in Framingham. J Chron Dis 1967; $20: 511-24$.

3. Abu-Zeid HAH. The relation between haemoglobin level and the risk for ischemic heart disease: a prospective study. I Chron Dis 1976; 29 : $395-403$.

4. Yano K, Reed DM, MoGee DL. Ten-year incidence of coronary heart disease in the Honolulu heart program. Relationship to biologic and Iifestyle characteristics. Am J Epldemiol 1984; 119: 653-66.

5. Wilhelmsen L, Wedel H, Tibblin G. Multivariate analysis of risk factors for coronary heart disease. Circulation 1973; 48: 950-58.

6. Takkunen H, Aromaa A. Mortality and anaenia (Letter to the editor). The Lancet 1974; $2: 523-24$.

7. Brand RJ, Rosenman RH, Sholtz RI, Friedman M. Multivariate prediction of coronary heart disease in the Western Collaborative Group study compared to the findings of the Framingham study. Circulation $1976 ; 53: 348-55$.

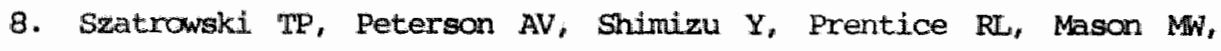
Fukunaga $Y$, Kato Hiroo. Serum Cholesterol, other risk factors and cardiovascular disease in a Japanese cohort. I Chron Dis 1984; 37 : 569-584. 
9. Elwood PC, Waters WE, Benjamin IT, Sweetman PM. Mortality and ariaenu.a in women. The Lancet $1974 ; 2$ : 891-94.

10. Cullen KJ, Stenhouse NS, Wearne KL. Raised haemoglobin and risk of cardiovascular disease. The Lancet 1981; $4: 1288-1289$.

11. Campbell MJ. The analysis using GENSTAT of anaemia, sugar intake and quetelet's Index as prognostic indicators in women. Statistics in Medicine 1983; 2: 223-28.

12. Schatzkin $A$, Cupples $A$, Heeren $T$ et al. Sudden death in the Framingham study. Differences in incidence and risk factors by sex and coronary disease status. Am J Epidemiol 1984; 120: 888-99.

13. Campbell MJ, Elwood PC, Mackean J, Waters WE. Mortality, haemoglobin level and haematocrit in women. J Chron Dis 1985; 38: 881-889.

14. Burch $G E$, De Pasquale NP. The haematocrit in patients with myocardial infarction. JAMA 1962; 180: 63-65.

15. De Pasquale NP, Burch GE. Haematocrit in women with myocardial infarction. JAMA 1963; 183: 142-43.

16. Mayer GA. Haematocrit and coronary heart disease. Canad Med Ass I 1965; $93: 1151-53$.

17. Conley CL, Russell RP, Thomas CB, Tumulty PA. Haematocrit values in coronary artery disease. Arch Intern med 1964; 113: 170-76.

18. McDonough JR, Hames CG, Garrison GE et al. The relationship of haematocrit to cardiovascular states of health in the negro and white population of Evans County, georgia. J Chron Dis 1965; 18: 243-57.

19. Nicolaides $A N$, Bowers $R$, Horbourne $T$ et al. Blood viscosity, redcell flexibility, haematocrit, and plasma-fibrinogen in patients with angina. The Lancet 1977; 2: 943-45.

20. Lowe GDO, Drumond MM, Lorimer et al. Relation between extent of coronary artery disease and blood viscosity. Br Med $J$ 1980; 280: $673-74$.

21. Schlesselman JJ. Case control studies, 9th ed. Oxford University Press 1982.

22. Breslow NE, Day NE. Statistical methods in cancer research. Vol. 1 The analysis of case-control studies. Lyon: LARC Scientific Publications 1980 .

23. Burch GE, De Pasquale NP. Haematocrit, viscosity and coronary blood flow. Diseases of the Chest 1965; $48: 225-30$. 
24. Dintenfass L, Lake B. Blood viscosity factors in evaluation of submaximal work cutput and cardiac activity in men. Angiology $1977 ; 28: 788-98$.

25. Dintenfass L, Lake B. Blood viscosity factors in evaluation of submaximal work output and cardiac activity in patients with myocardial infarction and angina, and in nomals. 9th Europ. Conf. Microcirculation, Antwerp 1976. Bibl Anat no 16: 498-500 (Karger, Basel 1977).

26. Thomas DT, Du Boulay GH, Marshal1 I et al. Effect of haematocrit on cerebral blood-flow in man. The Lancet $1977 ; 2: 941-45$.

27. Grotta J, Ackerman R, Correia J et al. Whole blood viscosity parameters and cerebral flow. Stroke 1982; 13: 296-301.

28. Harrison MJG, Pollock S, Kendall BE, Marshall J. Effect of haematocrit on carotid stenosis and cerebral infarction. The Lancet 1981; 2: 114-5.

29. Zoll PA, Wessler S, Schlesinger J. Interarterial coronary anastomoses in human heart, with particular reference to anemia and relative cardiac anoxia. Circulation 1951; 4: 797-815.

30. Elwood PC. Evaluation of the clinical importance of anemia. The American Journal of Clinical Nutrition 1973; 26:958-64.

31. Turitto VI", Weiss HJ. Red blood cells: their dual role in thrambus formation. Science 1980; 207 : 541-3.

32. Editoria1. The bleeding-time and the haematocrit. The Lancet 1984; 1: 997-8.

33. Abu-Zeid HAH, Chapman JM. The relationship between haemoglobin level and ame risk factors in lischemic heart disease. The Los Angeles Heart Study Circulation 1973; 48 (suppl 4): 9.

34. Dintenfass I. Elevation of blood viscosity, aggregation of red cells, haematocrit values and fibrinogen levels in cigarette smokers. Med J Austr 1975; 1: 617-20.

35. Elwood PC, Mahler $R$, Sweetman P et al. Association between circulating haemoglobin level, serum-cholesterol and blood pressure. The Lancet 1970; 1: 589-90.

36. Böttiger LE, Carlson LA. Relation between cholesterol and triglyceride concentration and haemoglobin values in non-anaemic healthy persons. Br med $J$ 1972; 3: 731-3.

37. BÖttiger LE, Carlson LA. Haemoglobin, plasma lipids, and coronary 
heart disease. Am Heart J 1973; 86: 842-4.

38. Harlan WR, Hull AL, Schmouder RL et al. Blood pressure and nutrition in adults. The national health and Nutrition Examination Survey. Am I Epidemiol 1984; 120: 17-28.

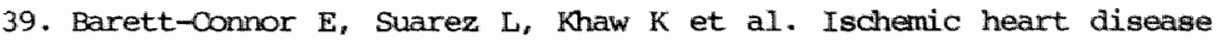
risk factors after age 50. J Chron Dis 1984; 903-8.

40. Feinstein AR. Clinical Epidemiology. The architecture of elinical research. WB Saunders Co., Philadelphia 1985. 

DEEL VI

BESCHOUNING EN SAMENVATTING. 
BESCHOUWING.

\section{Het werkveld van de klinische epidemiologie.}

Als iemand an een bepaalde reden contact heeft gelegd met dokter, dan zijn klachten, symptamen, de resultaten van eventueel verricht diagnostisch onderzoek en de interpretatie van al deze gegevens in hoge mate bepalend voor de verdere 'patiënten carrière'. Daarnaast hebben ook persconskenmerken, zoals de leeftijd van de hulpuragende en de voorgeschiedenis, invloed wat betreft zowel de waarschijnlijkheid van bepaalde diagnosen als de verder te volgen strategie. De laatste bijvoorbeeld vanwege de mate van belastbaarheid van de patiënt ten aanzien van verdere diagnostiek en therapie. Last but not least zijn van betekenis de wensen en de voorkeuren van de patiënt, en ook de opvattingen, voorkeuren en de werksituatie van de arts (1-5).

Een scala van factoren markeert dus de besluitvorming die leidt tot een al dan niet optimal gedoseerde medische aandacht voor onze patiënt. "Optimaal gedoseerd" betekent dan zowel een juiste hoeveelheid als een juiste inhoud van die aandacht, en niet-optimaal zowel te veel als te weinig alsmede niet-adequate medische aandacht.

Wat betreft de interactie arts-patiënt dient gestreefd te worden naar een synthese van het "deskundigheidsmodel" (de arts heeft kennis en vaardigheden tot zijn beschikking) en het 'mondigheids- model" (de patie̊nt heeft het eerste en het laatste woord, en heeft bovendien vragen, ervaringen en ideeën die niet gemist kumnen worden). De voorkeur heeft een benadering waarbij de arts naar aanleiding van de vraag van de patiënt een deskundige beoordeling verricht, en vervolgens $z i j n$ diagnostische overwegingen en conclusies en eventuele beleidsalternatieven aan de patiënt voorlegt, gewogen naar waarschijnlijkheid, ernst, mate van belasting, therapeutische consequenties en prognose. De ingangsvraag dient daarbij dan wel voldoende verhelderd te zijn (6). en de patieint moet over de diverse alternatieven ook kunnen oordelen en beslissen (7).

Wie deze zinnen leest, realiseert zich hoe complex het gebeuren is waarover we spreken. In de eerste plaats leidt dit tot een zekere wetenschappelijke bescheidenheid: de dagtaak van de medicus practicus 
onvat een aaneenschakeling van zulke gebeurtenissen, en deze mbet er mee uit de voeten, hoe onbevredigend ook de stand van de wetenschap is. Tevens is duidelijk, en dit kan ook als geruststellend worden ervaren, dat de individuele menselijke factor altijd een centraal element zal blijven. Tegelijkertija liggen er voor uiteenlopende wetenschappelijke disciplines vele aangrijpingspunten, om een bijarage te leveren aan de verbetering van de voorwaarden op grond waarvan de medische hulpverlening plaatsvindt.

Tot de basisvoorwaarden voor het op zinvolle wijze kumnen bereiken van de genoemde symthese behoren niet alleen het goed onschreven zijn van de deskundigheid van de arts maar ook het valide zijn van het door hem in dat kader gehanteerde pakket aan kennis en vaardigheden. Klinischepidemiologische onderzoekingen en analyses kunnen met name bijdragen aan dit laatstgenoemde "sine qua non". Het betreft dan zowel het toetsen en schonen van reeds in gebruik zijnde medische kennis en inzichten, als het toetsen en (mede-)ontwikkelen van nietwe. Deze bijdrage kan liggen op (1) het niveau van het detail, het concrete, het direct-ambachtelijke, maar kan cok (2) conceptueel van aard zijn en van betekenis voor het ontsluiten van nileuwe denkrichtingen. Een andere belangrijke onderscheiding in deze bijdrage betreft (a) het vergaren en toepasbaar maken van kwantitatieve informatie enerzijds, en (b) kwalitatieve analyse anderzijds. De genoemde elementen kan men in onderlinge samenhang beschouwen, en $\mathrm{zlj}$ leveren dan een schematische indeling op van het werkveld van de klinische epidemiologie (Figuar 1).

In dit proefschrift is, in wisselende mate, ten aanzien van ieder van deze "vier velden van de klinische epldemiologie" materiaal gepresenteerd. Onvemijdelijk was dat bepaalde deelgebieden niet rechtstreeks aan bod kwamen, zoals effectiviteitsonderzoek. Daarop gaan wij elders in $(8)$. 
Eiguur 1: Het werkveld van de klinische epidemiologie, ondergebracht in een viervelden tabel, met voorbeelden.

\begin{tabular}{|c|c|c|}
\hline & conceptueel & I concreet \\
\hline Kwalitatief & $\begin{array}{l}\text { - selectie ten gevolge } \\
\text { van verwijzing } \\
\text { - wat is nomaal } \\
\text { - de beslisboom }\end{array}$ & $\begin{array}{l}\text {. wat is een logisch } \\
\text { gefaseerde en hanteer- } \\
\text { bare strategie bij een } \\
\text { k]ier in de hals }\end{array}$ \\
\hline kwantitatief & $\begin{array}{l}\text { - kwantificeren van } \\
\text { selectiebias } \\
\text { - methoden om het } \\
\text { optimale afkappunt } \\
\text { te bepalen } \\
\text { - sensitiviteitsanalyse }\end{array}$ & $\begin{array}{l}\text { - voorspellende waarde } \\
\text { van bepaalde klachten } \\
\text { wat is de strategie } \\
\text { met de "hoogste ver- } \\
\text { wachte waarde" bij een } \\
\text { klier in de hals } \\
\text { - effectiviteit van } \\
\text { endarterectonie }\end{array}$ \\
\hline
\end{tabular}

2. Selectie en selecteren.

Ten aanzien van de validitelt van het door de medicus gehanteerde kennispakket is veel aandacht besteed aan verschillen tussen de patientenpopulaties in eerste en tweedelijnsgeneeskunde, en de rol die verwijzingspatronen hilerbij spelen (hoofdstukken 2, 3, 12, 13, 14, 21). Aan bod kwamen verschillen in klachten- en morbiditeitspatronen, de voorspellende waarde van klachten, symptomen en andere diagnostische gegevens, en de mate van ontwikkeling van ziektebeelden. Verschillen zijn er ook te verwachten wat betreft het verloop, de prognose en de gevoeligheid voor therapeutische beinvloeding $(8,9)$. Het zich realiseren van deze verschillen is van groot belang. Ten aanzien van de wetenschappelijkke bestudering van het 'kennispakket' is er immers nog een forse achterstand van de hulsartsgeneeskunde ten opzichte van de specialistische geneeskunde. Het is dan voor de huisarts verleidelijk om bijj de specialist 'leentjebuur' te spelen, hetgeen mede bij gebrek aan altematieven - bevorderd wordt in het medisch basiscurriculum en bepaalde vormen van nascholing. Dit schollings- en vormingsproces leidt dan weer tot reming van de eigen ontwikkeling en vergroting van de achterstand. Het geschetste cirkelproces heeft tot gevolg, dat huisartsen dikwijls werken met klinische basiskennis, die nilet op hun positie en 'populatile' is toegesneden. Zij moeten zelf de nodige aanvullingen trachten te creëren, voornamelijk op grond van de 
eigen, weinig gesystematiseerde praktijkervaring. Dit staat in scherp contrast tot de steeds grotere vlucht die de wetenschappelijke onderbouwing van de specialistische geneeskunde neent over een steeds breder terrein met steeds meer subterreinen. De huisarts is door deze gang van zaken steeds minder in staat an een zelfbewuste gesprekspartner te zijn van de specialist, op grond van een krachtilg ontwikkelde eigen discipline.

Een en ander draagt ertoe bij dat het functioneren van de huisarts onder druk staat, wat betreft zowel het eigen algemeen geneeskundig ambacht, als de te vervullen zeeffunctie naar de specialistische zorg. Een stevige, op dit ambacht gerichte wetenschappelijke basis is immers onontbeerlijk, teneinde te komen tot een optimale selectie van patiënten voor de tweede-lijns gezondheldszorg. Bedacht moet worden dat de zeeffunctie van de huisarts in belangrijke mate bepalend is voor de kwaliteit en de kosten van de gezondheidszorg.

Ondanks de genoemde druk bestaat de zeeffunctie van de huisarts nog steeds, en daarmee een belangrijk fundament van de huisartsgeneeskumdige identiteit (hoofidstukken 9, 10, 12). Hier is een opmerkelijke paradox te constateren: naarmate de huisarts sterker (voor) selecteert, $z i j n$ er grotere verschillen tussen huisartsgeneeskundige en specialistische patiëntenpopulaties te verwachten. De huisartsgeneeskunde kan dit - stank voor dank - op haar brood krijgen in de vorm van een zich sterker van haar identiteit vervreemdend onderwijs én onderzoek vanuit de medische faculteiten met als gevolg juist een ondermijning van haar zeeffunctie (wellicht is hiermee een stukje geschiedenis van de relatie medische faculteiten - huisartsgeneeskunde kernachtig beschreven). Indien de huisarts niet, of slechts met behulp van een dobbelsteen, zou selecteren, dan zouden de wezenlijke verschillen tussen belde populaties vervagen en zou alle spraakverwarring wegvallen. Hetzelfide zou dan evenwel het lot zijn van de branche, respectievelijk de professionele identiteit van de huisarts. Een ingebouwde beveliliging tegen een dergelijke ontwikkeling is de blijvende behoefte aan een niet over te dragen en vitaal element van de huisartsgeneeskunde: het all-round-karakter, het overzicht. Per definitie kan géén ander specialisme dit overnemen. Wie zal er voorselecteren er richtingaangeven als de wegwijzer wegvalt? Het zou te gemakkelijk zijn te zeggen dat de 
mondige patiẻnt dit zelf wel zou kunnen. Hoe zou, toevalstreffers daargelaten, bijvoorbeeld de 'patient carrière' eruit zien van de mondige patiënt met onbegrepen moeheidsklachten die na het lezen van de medische encyclopedie besloten heeft on zich als eerste te wenden tot, Iaten we zeggen, de endocrinoloog?

Aantrekkelijker is het on aan te sluiten bij de op dit moment nog intacte onderdelen van de zeeffunctie van de huisarts, en deze grotendeels op ervaringskenis berustende functie van een wetenschappelijke en wetenschappelijk erkende basis te voorzien, met onderkenning van de "kliniek van de huisartsgeneeskunde" (10).

\section{3. "Vage klachten".}

Het selecterend bezig zijn van de arts wordt sterk op de proef gesteld als de patient zich aandient met zogenaamde vage klachten die niet duidelijk op een bepaald organisch of psychosociaal substraat wijzen. Wat diagnostiek betreft, staat hem ten dienste een veelheid aan middelen en een armoede aan houvast. Welke onderzoekingen zijn geindiceerd naar aanleiding van welke klachten? om deze vraag te beantwoorden is het allereerst nodig om te constateren dat de vraag helaas niet in eén keer te beantwoorden is. Men moet stapsgewijs te werk gaan, en zich in eerste instantie beperken tot één of enkele klachten én een beperkt aantal diagnostica. In de hoofdstukken $4 \mathrm{t} / \mathrm{m}$ 8 hebben we dit gedaan. De conclusies lijken dan ook op het eerste gezicht van beperkt belang: hoofdpijnklachten die zodanig ernstig zijn dat men regelmatig hoofdpijrmiddelen moet gebruiken hebben geen relevante betekenis voor het herkenthen van hoge bloeddruk, en vormen dus cok geen speciale indicatie woor (extra) bloeddrukmeting, en: moeheidsklachten in de huisartspraktljk, ook degene waarwoor geen andere verklaring voor de hand ligt, vertonen geen verband met hematologische parameters, noch met het serumferritine gehalte. Bij nadere beschouwing kan men echter inzlen dat het trekken van de praktische consequenties uit deze observaties een groot aantal routinematige handelingen en hulpvragen op losse schroeven zet, alsmede de ermee gepaard gaande medicalisering en financiële kosten. 
Nu zijn er woor het verrichten van handelingen natuurlijk meer redenen dan de overtuliging van de arts dat ze, medisch gezien, zinvol zijn. Vaak is bijvoorbeeld de vraag van de patient doorslaggevend, ook al heeft de dokter twijfels, of zelfs een andere opvatting over wat de beste weg is. Los van de vraag wat in zo'n situatie het juiste besluit is, is het van belang in welke mate de arts kan (en durft) tenug (te) vallen op vakmatige overtuiging. Dit zal eerder gebeuren, naamate ervaringskennis meer wordt ondersteund door gepubliceerde onderzoeksgegevens. Dok voor de patiënt is zo'n onderbouwing een aanvaardbaar houvast. Voorts zullen ook anderen, bijvoorbeeld gebruikersgroeperingen, hun voordeel kunnen doen met dergelijk materiaal.

Een gevolg kan ook zijn, dat klachten meer specifiek worden geanalyseerd, op zoek naar de wél en niet informatieve aspecten ervan, en daamee naar meer gerichte indicatiestellingen voor nadere diagnostiek. Wij hebben getracht wat betreft de klacht moeheid in de huisartspraktijk de "ruis" te elimineren door alle reeds in het eerste consult voor de hand liggende verklaringen uit te sluiten. De overweging hierbij was, dat wij hierbij optimaal zouden aansluiten bij de mede door ervaring gevormde kennis van de huisartsen. Bij het onderzoek naar het verband tussen moeheid en de hematologie van zwangeren kozen we een andere benadering. Specifieke kenmerken van de moeheidsklacht en andere klachten werden expliclet nagevraagd. Hierbij kwam van een aantal klachten (onder andere moeheid, erger dan wós de zwangerschap, hartkloppingen, duizeligheid en kuitkrampen) wel enitg onderscheidend vermogen naar voren ten aanzien van een laag Hb-gehalte. Een mogelijke verklaring hiervoor is, dat bij het lagere Elbgehalte van zwangeren wel een verband met klachten bestaat. Ondat de klachten en het Hib-gehalte in beide studies onafhankelijk van elkaar werden vastgelegd achten wij niet waarschijnlijjk dat het gebruik van andere methoden de verschiliende uitkomsten verklaart. Geconcludeerd kan well worden dat het aan patienten zelf voorleggen van gedetailleerde vragenlijsten het evalueren van verfijnde nuances van klachten mogelijk maakt.

Een algemene conclusie is, dat de vraag naar de zin van bepaalde diagnostiek naar aanleiding van de - zo frequent voorkomende (11) - vage klachten zich goed leent voor klinisch-epldemiologisch onderzoek. 


\section{Medische Besluitworming.}

Het handelen van artsen is zinvol voor zover het kan bijdragen tot een verbetering van de prognose van patiénten, en voor zover de voordelen van dat handelen opwegen tegen de nadelen.

Deze elien gelden al ten aanzien van de eerste fase van de medische betrokkenheid, de diagnostiek. De diagnose is geen doel op zich, maar vindt zijn legitimatie als aangrifpingspunt voor het beleid (12) (hoofdstuk 17). Indien het beleid nilet athangt van het stellen van de bedoelde diagnose, dan kan hierop gericht onderzoek achterwege blijven. Als men met dit principe in het achterhoofd het referentiewaarden-vraagstuk analyseert, dan blijkt dit vraagstuk vloeiend over te gaan in een besliskundige probleemstelling: onder welke onstandigheden is het doen van diagnostiek zinvol, de a priorl kansen op ziekte( $n$ ) en de eventuele consequenties in termen van beleid en gezondheidswinst in aarmerking genomen? En: hoe moet vervolgens een gegeven uitslag geInterpreteerd worden? In het kader van deze probleemstelling blijkt onder andere dat het voor tests met een continue schaal van uitslagen beter is an informatie te hebben over de gehele distributie van testuitslagen voor diverse subpopulaties (met name zieken en niet-zieken), dan alleen over het onderscheidend vermogen bij een bepaald afkappunt (hoofdstuk 20). Het waarden- c.q. utiliteiten-aspect kan men dan desgewenst zelf toevoegen. De afwegingen ten aanzien van het nut van het verrichten van diagnostisch onderzoek of van het volgen van bepaalde strategieẻn kunnen anders uitvallen voor huisarts en specialist (hoofdstuk 13). Dit houdt in dat diagnostische protocollen "echelonspecifiek" moeten worden ontwikkeld en gedoceerd. In het kader van die protocolontwikkeling is ook een kritische houding ten opzichte van het therapeutische aanbod van de tweede lijnsgeneeskunde nodig. Zo zal een protocol-aanbeveling voor het handelen naar aanleiding van het vinden van een carotissouffle sterk vereenvoudigd worden na bestudering van de literatuur over de effectiviteit van carotis operaties (hoofdstuk 18). De vraag doet zich zelfs voor: 'is it safe to auscultate the neck?' (13).

Het objectief bepalen en subjectief schatten van a priori kansen op ziekte zijn belangrijke pijlers van de medische besluitvorming. Gezien 
de verschillen tussen eerste en tweede lljn, die ook doorklinken in subjectieve schattingen (hoofdstuk 15), is dit een belangrijk studieterrein voor huisartsen. Vanwege beperkingen van klachten-en morbiditeits-registraties zal het daarbij vaak nodig zijn om meer gericht en meer gestandaardiseerd onderzoek te verrichten (hoofdstuk 14). Dok onderlinge uitwisseling en bespreking van gehanteerde a priori kansen zijn zinvol als vorm van intercollegiale vergelijking (hoofdstuk 16). Men moet ervoor waken dat de informatie die besloten Iigt in de a priori kans en de informatie welke de testuitslag in zich araagt, niet door elkaar gaan lopen. In dat geval is de test geen onafhankelijke toetssteen meer. Er is in dit verband veel voor te zeggen dat artsen in eerste instantie dié informatie over de patiënt aan een geraadpleegde diagnost verstrekken die nodig is voor een technisch verantwoorde uitvoering van de test, zonder daarbij al te sturen in de richting van de eigen vermoedens. Men kan eventueel afspreken dat wel een differentiaaldiagnose verstrekt wordt, doch in willekeurige volgorde en zondere nadere aanduidingen van waarschijnlijkheid. Het gaat er om, dat testuitslag en klinische interpretatie verschillende zaken zijn. (hoofdstuk 19).

Besliskundige analyses kunnen veel inzicht geven in de mogelijke consequenties van de diverse opties in termen van goede en minder goede uitkomsten (inclusief neveneffecten en complicaties), op grond van de bestaande stand van kennis. Dit kan geschieden (14):

- kwantitatief: als er voldoende getalgmatige data beschijbaar zijn, en als het mogelijk is op redelijke wijze utilitelten te bepalen c.q. hum invloed na te gaan;

- kwalitatief: men beperkt zich dan tot het structureren van het probleem, en kan hieruit vaak al conclusies trekken over de zin en onzin van bepaalde (tussen) stappen.

Deze benaderingen kunnen hur vruchten afwerpen ten aanzien van het onderwijs, de nascholing, de intercolleglale toetsing, en ter ondersteuning van consensusbesprekingen (14). Voor de individuele patiéntenzorg zullen de toepassingmogelijkheden vooralsnog beperkt zijn, omdat te weinilg kwantitatieve gegevens bekend zijn voor bijzondere situaties. De problemen die men ontmoet bij het verrichten van besliskundige analyses, liggen niet zozeer op het gebied van de rekentechnieken, maar betreffen veel meer $(15-19)$ : 
- de structurering van het probleem: het is moeilijk on alle relevante strategieên met een bevredigende mate van detaillering in een beslifiboom weer te geven;

- de kansen: veel data ontbreken, of kunnen slechts worden ontleend aan weinig overtuigende studies. Men met bedacht zijn op diverse vonmen van 'publicatlebias'. Bovendien is een vraag op welke wijze men data die afkomstig $z i j n$ uit verschillende studies op één noemer brengt, respectievelijk kan en mag combineren. Vaak is ook niet bekend in hoeverre diverse kansen van elkaar afhankelijk zijn. Men kan ontbrekende data aanvullen door subjectieve schattingen van deskundigen, maar men moet zich dan goed bewust zijn van de mogelijke bromen van vertekening;

- utiliteiten: voor de vaststeliing van de "waarde' van diverse gezondheidstoestanden bestaan verschillende technieken, waarbij ook de beleving en de voorkeuren van de patiënt geincorporeerd worden (20). Niettemin zijn de resultaten hiervan, zeker als het om kwaliteit van leven gaat, steeds vatbaar voor discussie; en bijvorbeeld afhankelijk van het tijdstip waarop, de toestand waarin, en de techniek waarmee de patiënt ondervraagd wordt (16-18).

Vooral met betrekking tot de huisartsgeneeskunde zijn deze moeilijkheden niet gering: men werkt immers vaak met weinig voargestructureerde problemen, en 'zachte' uitkonsten. Over kansen is zeer weinig bekend. Al deze kanttekeningen kan men echter ook maken ten aanzien van de dagelijkkse gezondheidszorg waar men, zij het impliciet, voortdurend problemen structureert, kansen percipieert en uitkamsten waardieert. Hierbif vindt veel onder- en overschatting van kansen plaats, en de voorkeuren van de patient en de waardering van kwaliteitsaspecten spelen vaak een beschelden rol. Besliskunde onthult de bestaande controversen en onzekerheden en stelt ze expliciet aan de orde, en vervult daarmede wellicht haar belangrijkste functie (21). De besliskunde is dan ook bij uitstek geschikt an hiaten op te sporen, en daarmee aangrijpingspunten te leveren voor nader onderzoek. Tevens noodzaakt $\mathrm{zij}$ telkens tot het expliciteren van vooronderstellingen, in plaats van het routinematig toepassen van eemal geleerde 'clinical rules" (22). 


\section{Aanbevelingen}

Ten aanzien van het klinisch-epidemiologisch onderzoek op het gebied van klachten, symptcomen en diagnostica in de eerste 1 ijn, benadruk Ik de volgende aandachtsvelden:

1. Theorievorming *

Theorievonuing is met name nodig ten aanzien van de methodologie van het huisartsgeneeskundig onderzoek. Enerzijds zullen bruikbare principes en technieken van wetenschapsgebieden met een sterkere onderzoekstraditie (klinische en bicmedische wetenschappen, epidemiologie, gedragswetenschappen) moten worden gemobiliseerd. Anderzijds dienen de specifieke methodologische vraagstukken van het huisartsgeneeskundig onderzoek in kaart te worden gebracht. Gedacht kan hierbij worden aan de bestudering van:

- het probleem van de 'gouden standaard" van de morbiditeit in de eerste 1 ijn;

- uitkamstmaten voor gezondheid, welzijn, ziekte en onwelzijn $(23,24)$;

- mogelijkheden en beperkingen van registratiesystemen in de eerste lijn;

- selectiebias en classificatiebias bij morbiditeitsonderzoek;

- selectiebias ten gevolge van verwijzing. Hierbij komt ook de verhouding tussen de eerste en tweede lijn aan de orde, wat betreft de wederzijdse generaliseerbaarheid van de kennis in beide sectoren;

- methodologische, wetenschapstheoretische en ethische aspecten van de toepassing van besliskunde in de hulgartspraktijk.

2. Empirisch onderzoek.

- onderzoek naar het verband tussen klachten/symtomen en aandoeningen in de eerste lijn, en het op grond van mpirisch anderzoek documenteren van de selectiebias ten gevolge van verwijzing;

- Het bestuderen van de waarde van de anarmese in de hulsartspraktijk voor de diagnostiek; de voorspellende waarde van klachten en symptamen; 
- onderzoek naar de validiteit van (oude en nielwe) diagnostica in de huisartspraktijk. Hierbij dient er speciale aandacht te zijn voor dilagnostica met een "breed screenend" karakter (inspelend op de grote probleemruimte bij de huisarts (25)), diagnostica die eenvoudig toepasbaar (te maken) zijn, en diagnostica die een goed onderscheidend vermogen hebben bij nog weinig ontwikkelde ziektestadia:

- Identificatie van die diagnostische gegevens die voor de huisarts van belang $z i j n$ voor het formuleren van een effectieve therapeutische strategie:

- Het evalueren van cruciale, doch nog onvoldoende getoetste onderdelen van diagnostische protocollen door middel van besliskundige analyse en gericht onderzoek:

- Risicoschatting en prognostiek op grond van epidemiologische onderzoeksresultaten, en de mate waarin, bij gebrek aan objectieve gegevens, subjectieve schattingen en consensus hierop een aanvuling kunnen zijn.

\section{LITERATUUR.}

1. Gerritsma JGM, Smal JA. De werkwijze van huisarts en internist. Bunge, Utrecht 1982 .

2. Es JC van, Gerritsma JGM, Smal JA. Simulatie van patiënten in het onderwijs. Instituut voor Huisartsgeneeskunde, Utrecht, 1977.

3. Eijk JThM van. Verschillen in praktijkvoering van huisartsen. Medisch Contact 1979; 34: 987-991.

4. Lamberts $\mathrm{H}$. Hoe beInvloedbaar is de huisarts? Huisarts en Wetenschap 1981; $24: 371-378$ en $424-430$.

5. Barr DM, Noren DG. Factors influencing clinical decision making by physictans: a conceptual framework and literature review. Office of Community Health Research, Rockford School of Medicine, University of Illinois, College of Medicine, 1978.

6. Holten-Vriesema J, Tampot $C$, van Aalderen $H$ et al. Methodisch werken, over een algemene methode van hulpverlening en de opbouw van een functionele relatie, toegespitst op de huisartspraktijk. Huisarts en Wetenschap 1978; 21 : 322-335. 
7. Knottnerus JA. Democratisering in praktijk, dilenma's voor de hulpverleners. Tijaschrift voor gezondheid en politiek 1983; 1 , december: $6-11$.

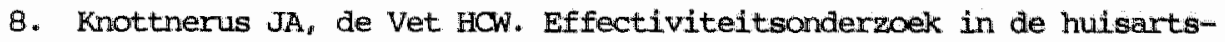
praktijk. Aanvaard voor publicatie in Bivisarts en Wetenschap.

9. Ellenberg $\mathrm{JH}$, Nelson $\mathrm{KB}$. Sample selection and the natural history of diseases: studies of febrile seizures. JAMA 1980; 243 : $1337-1340$.

10. Weel $\mathrm{C}$ van. Alledaagse ziekten en een gezond verstand. Inaugurele rede, Nijmegen 1986. NUHI, Nijmegen 1986.

11. Lamberts $H$. Redenen on naar de hulsarts te gaan. Eerste ervaringen met de Reason for Encounter Classification. Huisarts en Wetenschap $1982 ; 25: 301-310$.

12. Velden HGM van der. Diagnose of prognose; de betekenis van de epidemiologie voor het handelen van de huisarts. Huisarts en Wetenschap 1983; 26: 125-128.

13. Kuller LH, sutton KC. Carotid artery bruit: is it safe and effective to auscultate the neck? Stroke 1984; 15: 944-947.

14. Everdingen JJE van, Touw PPJ, Klazings NS, Casparie AF. Het belang van consensus in de geneeskunde. Ned Tijdschr Geneesk 1985; 129 : 1911-1913.

15. Sichwartz WB, Gorry GA, Kassirer JP, Essig A. Decision Analysis and clinical judgment. Am J Med 1973; 55: 459-472.

16. Zarin DA, Pauker SG. Decision analysis as a basis for medical. decision making: the tree of Hippocrates. J Medicine and Philosophy 1984; 9: 181-213.

17. Elstein AS, Holmer M, Ravitch MM, Rovner DR, Holman GB, Rothert ML. Medical Decisions in perspective: applied regearch in cognitive psychology. Perspectives in Biology and Medicine 1983; 26: 486-499.

18. McNeil BJ, Pauker SG. Decision Analysis for public health: principles and illustrations. Ann Rev Public Health 1984; 5: 135-161.

19. Feinstein. The haze of Bayes, the aerial palaces of decision analysis, and the computerized oija board. Clinical Pharmacology and Therapeutics $1977 ; 21: 482-496$.

20. Weinstein MC, Fineberg HV. Clinical Decision Analysis. WB Saunders Philadelphia 1980. 
21. Sturmans F, Verbeek ALM, van Daal WA. Protocollaire geneeskumde: dictatuur of verantwoord kiezen? In: Het Medisch Jaar 1985. Bohn, Schelteria en Holkema, Utrecht/Antwerpen 1985; p 395-407.

22. Eday DM. Clinical Policies and the quality of clinical practice. Hew Eng J Med 1982; 307: 343-347.

23. Walff HR. Current trends in clinical thinking. Acta Med Scand $1983 ; 213: 3-4$.

24. Donabedian $A$, Wheeler JRC, Wyszewianski $\mathbb{L}$. Quality, Cost and Health: an integrative model. Medical Care 1982; 20: 975-992.

25. Weel $C$ van. Achilles tot hardloper bekeerd. Huisarts en Wetenschap $1981 ; 24: 417-424$. 
SAMENVATTING.

In dit proefschrift wordt op verschillende wijzen en aan de hand van diverse deelonderwerpen de interpretatie van diagnostische informatie bestudeerd, vanuit een epidemiologische invalshoek. Speciale aandacht wordt besteed aan de relatie tussen eerste en tweede lijn.

In deel I worden algemene begrippen besproken, die van nut zijn bij het analyseren van de waarde van diagnostische informatie. Daarbij komt aan de orde, welke gevolgen selectie door middel van verwijzing kan hebben. Hoofdstuk 2 benadrukt dat verschillen in de prevalentie van aandoeningen tussen de huisartsgeneeskundige en de specialistische praktijk consequenties hebben voor de interpretatie van diagnostische gegevens en de te volgen diagnostische strategie. In hoofdstuk 3 wordt gedemonstreerd dat in patientenpopulaties die geselecteend zijn door middel van verwijzing een ander beeld kan ontstaan van verbanden tussen klachten en bevindingen dan in ongeselecteerde populaties. Als men bij het bestuderen van deze verbanden geen adequate vergelijkingsgroepen kiest kunnen schijnverbanden ten onrechte steeds weer bevestigd worden.

Deel II bevat de verslaglegging van een aantal onderzoekingen naar het verband tussen veelvoorkomende klachten en diagnostische bevindingen. Op grond van gegevens uit een bevolkingsonderzoek onder Ansterdammers, waarbij de bloeddnuk werd gemeten en gevraagd werd naar het gebruik van middelen tegen hoofdpijn, werd het verband tussen hoofdpijn en hoge bloeddruk bestudeerd (hoofdstuk 4). Bij personen die wekelijks hoofdpijnmiddelen gebruiken kant een diastolische bloedaruk van 105 mmig of hoger iets vaker voor ( 5 \& versus $3 \%$ ). Tegelijkertija blijkt echter, dat het last hebben van hoofdpijn nauwelijks discrimineert tussen hoge en lagere bloeddrukken. Er zijn, kortam, voor patient en arts weinig argumenten on het meten van de bloeddruk af te laten hangen van hoofdpi jnklachten.

Vervolgens komt een andere "vage" klacht aan de orde: in hoeverre hebben moeheidsklachten, gepresenteerd aan de huisarts, voorspellende betekenis ten aanzien van het hebben van bloedarmoede of ijzer gebrek? Deze vraag is onderzocht door middel van "diagnostisch patient-contro- 
lemonderzoek". Bij patienten die geselecteerd waren via verwijzing naar een diagnostisch centrum werd over het geheel genomen geen verband gevonden tussen moeheid en fb-gehalte. Alleen bij oudere mannen was ex een trend in de verwachte richting (hoofdstuk 5). In een niet door verwijzing geselecteerde populatie kon cok de laatstgenoende trend niet worden teruggevonden. Dit onderzoek richtte zich, ter vermijding van "ruis", op patienten met onverklaarde moeheidsklachten al dan niet in combinatie met andere "anemische" klachten - die door de huilsarts als indicatie werden beschourd voor hematologisch onderzoek (hoofistuk 6). Dok tussen deze klachten en de ijzervoorraad, gemeten door middel van het serunferritine, werd geen relatie gevonden (hoofdstuk 7). Zeer lage flb-waarden kwamen bij deze patienten niet voor. Toch werd, onafhankelijk van klachten en Hb-gehalte, bij 11 \% van de patienten een serumferritine van $12 \mathrm{~g} / 1$ of lager gevonden. andat zwangeren van de zojuist besproken studies waren uitgesloten, en ondat hematologisch onderzoek juist bij hen veel wordt verricht, werd het verband tussen (moeheids- en andere) klachten en hematologische parameters apart bestudeerd bij zwangeren. Gekozen werd voor een screeningsonderzoek rond de dertigste zwangerschapsweek met een vragenlijst en hematologische bepalingen in drie subpopulaties: vrouwen die door perifere verloskundigen werden begeleid, en vrouwen die op een polikliniek verloskunde werden begeleid door verloskundigen respectievelijk gynaecologen. Nu werden wel samenhangen gevonden: met name de klachten "moeheid, erger dan vóbr de zwangerschap", kuitkramper, hartkloppingen en duizeligheid wijzen op een lager Hb en/of Ht. ondat het verband tussen klachten en een laag Hb vooral duidelijk is bij hogere MCV-waarden, zou foliumeuurtekort hierbij een rol kunnen spelen (hoofdistuk B).

Via beschrifvend follow-up onderzoek is nagegaan welke diagnostische eindconclusies de huisarts trok naar aanlelding van een tweetal klachten: onverklaarde moeheid, en klachten op de borst (hoofdstukken 9 en 10). Moeheidsklachten leiden, ok in tweede instantie, meestal niet tot een diagnostische conclusie, en dit gelat vooral voor jongere personen. Bij klachten op de borst is twijfel ten aanzien van een eventuele cardiale corsprong, ook nog na een half jaar, een factor van betekenis. Beide studies schetsen een beeld van de onzekerheden waarmee huisartsen werken, en de mate waarin via verwijzing geselecteerd 
wordt.

Deel III bespreekt en illustreert de medisch besliskundige benadering, wederom met speciale aandacht voor de verhouding tussen eerste en tweede lijnsgeneeskunde. Nadat een orienterend overzicht gegeven is (hoofdstuk 11), wordt benadrukt, dat het voor de beoordeling en (her)waardering van de zeeffunctie van de hulsarts essentieêl is dat men overzicht heeft over "alle vier velden" van de huisartsgeneeskundige betrokkenheid ten aanzien van verwijzing (hoofdstuk 12). Aan de hand van een voorbeeld (de palpabele lymfklier) wordt verduidelijkt dat men er bij het fomuleren van diagnostische protocollen mee rekening moet houden dat de aanbevelingen voor huisartsen en specialisten er geheel anders uit kumnen zien. De a priori kans op ziekte, al dan niet beinvloed door selectie, speelt hierbij een sleutelrol (hoofdstuk 13). Dit brengt ons op de vraag naar de betekenis van het begrip a priori kans in de huisartsgeneeskunde en op de wijze warop hiervan een empirisch onderbouwd beeld kan worden verkregen. Routinematig verzamelde registratilegegevens hebber wat dit betreft beperkingen, afhankelijk van het type aandoening waarin men geinteresseerd is (hoofdstuk 14). Dat subjectieve schattingen van a priori kansen van huisartsen en specialisten kummen verschillen, blijkt uit hoofdistuk 15: naar aanleiding van een papieren patiente met moeheidsklachten nemen internisten vooral anemie en maligniteit in hun differentiaal-diagnose op; Bij huisartsen staat depressie voorop, gevalgd door anemie. Dok zijn er verschillen wat betreft het beleid: internisten doen meer onderzoek dan huisartsen. Cok tússen huisartsen (-in opleiding) kunnen grote verschillen bestaan: voor een patient met klachten van vermagering liepen de schattingen van de kans op kanker uiteen van 10 tot $55 \%$. Het "niletpluis gevoel" hing meer samen met de angst voor scmatische aandoeningen dan met de angst voor meer functionele stoomissen (hoofdstuk 16). Diagnostiek wordt gelegitimeerd door haar belang voor therapeutische beslissingen en de gunstige beinvloeding van de prognose. Als een therapie niet effectief is, is diagnostiek gericht op de indicatiestelling voor die therapie niet zinvol (hoofdstuk 17). In dit verband is de vraag gesteld: moet er naar aanleiding van de bevinding "asymptomatische carotissouffle" nader onderzoek plaatsvinden ter vastste1ling van (de graad van ernst van) een locale stenose en de operabili- 
teit ervan? Bij gebrek aän gerandomiseerd onderzoek moet men zich voor de beantwoording van deze vraag woorlopig baseren op gepubliceerde patientenseries. on deze systematisch te kunnen verwerken, verrichtten wij een besllskundige analyse. De conclusie is dat de literatuur geen ondersteuning biedt voor een op operatle gericht beleid (hoofdstuk 18).

Ter afsiluting van deel III wordt de aandacht gevestigd op de wense11 jkheid van het onderscheiden van "testuitslagen sec" en de interpretatie ervan in het licht van de a priori informatie (hoofastuk 19).

Deel. IV gaat nog wat dieper in op de betekenis van diagnostische tests. Diagnostiek kan met diverse oogmerken worden verricht. Hiermee harigen samen de verschillende betekenissen van de begrippen "normaal" en "afwijkend". Hiervan wordt in hoofdstuk 20 een inventarisatie gegeven. De vraag of een bepaalde test uitslag nu "afwijkend" is of niet is niet in het algemeen te beantwoorden. Uiteindelijk is er sprake van een besliskundige probleemstelling, waarbij de waarden van de mogelijke ultkomsten worden beoordeeld in relatie tot het gestelde doel. Daarbij staat ook het nut van het testen zelf ter discussie. Bij het verstrekken van referentiewaarden is het aan te bevelen de volledige distributies van uitslagen in de referentiepopulaties te geven, en niet slechts de waarden van één of enkele afkappunten.

Het onderscheidend vermogen van test is gevoelig voor selectie door middel van verwijzing (hoofdstuk 21). Niet alleen de prevalentie, maar ook de test-kenuerken worden beinvloed. Temidden van de toename van de belangstelling voor het - vaak als vast gegeven opgevatte - onderscheidend vermogen van diagnostische tests, dient men zich van deze complicaties bewust te zijn en de reikwijdte ervan te onderzoeken.

In deel V worden twee onderzoekingen beschreven naar de prognostische betekeris van uitslagen van diagnostische 1.0. hematologische tests. Middels een cohortstudie werd het verband bestudeerd tussen het $\mathrm{Hb}$ en de hematocriet van zwangeren enerzijds en het later optreden van prematuritas en een laag geboortegewicht anderzijds (hoofdstuk 22). cok na correctie voor andere belangrijke covariaten (roken, pariteit, bloeddruk, gebruik van ijzenmedicatie), blijkt met name een hoge hematocriet positief samen te hangen met een minder gunstige afloop. 
Mede op grond van de eerder beschreven samenhang van een laag $\mathrm{Hb} / \mathrm{Ht}$ met enkele subjectieve klachten, bevelen wij aan tijdens de zwangerschap te streven naar een hematocriet die, na de fysiologische henodilutie, tussen de $32 \%$ en 38 bedraagt.

In hoofdstuk 23 wordt via een patient-controle onderzoek bij mamelijke werknemers nagegaan of er een verband is tussen matig verhoogde Hiben Ht-waarden en de kans op het krijgen van een hartinfarct. Dit. blijkt inderdaad het geval, ook rekening houdend met andere relevante factoren.

Deel VI bevat een afsluitende beschouwing waarin deelonderwerpen in onderling verband worden besproken. In dit verband wondt een indeling voorgesteld van het werkveld van de klinische epidemiologie. Tenslotte worden een aantal aanbevelingen gedaan ten aanzien van het klinischepidemiologisch onderzoek op het gebied van de diagnostiek in de huisartspraktijk. 
SUMMARY.

This thesis deals with the interpretation of diagnostic information, fram a clinical epldemiological point of view. Theoretical backgrounds are discussed and practical examples are presented, with a special interest in the relationship between primary and specialist care.

In part I basic concepts, of importance when analyzing diagrostic information, are introduced. The consequences of selection by referral are stipulated. Chapter 2 explains the impact of different prevalences with respect to the interpretation of diagnostic data and the planning of diagnostic strategies. Chapter 3 demonstrates the changes in the relationship between symptoms and diagnostic findings, that may accur as a result of referral. Pseudo-relationships can be maintained by erroneous comparisons.

Part II contains the results of a number of studies of the relationships between comon complaints and diagnostic findings.

Using data from a population survey in Amsterdam, the relationship between headache and high bloodpressure was investigated (chapter 4). Among subjects who took anticephalalgics weekly, a diastolic pressure of $105 \mathrm{minH}$ or higher is a little more frequent (5\% versus 3\%).

However, suffering headache hardly discriminates between high and low bloodpresisures. Bloodpressure surveillance, guided by headache, is not supported by these results. Fatigue, as an indicator of anenia, is investigated in two "diagnostic case-control studies". Among patients referred to a diagnostic centre no overall relationship between fatigue and hemoglobin level (Hb) was demonstrated. Only in older men a trend in the expected direction was found (chapter 5). Such a trend was not confirmed in a general practice study among patients not preselected by referral. For efficiency reasons, this study focused on "unexplained" fatigue considered to be an indication for hematological evaluation (chapter 6). Also between this complaint and the iron stores, as estimated by the serumferritin level, no relationships were observed. Extremely low Hb-values have not been found among these patients. Yet, 11 of of them had gerumferritin levels of $12 \mathrm{mg} / 1$ or lower (chapter 7 ). 
Pregnant women had been excluded from the studies just mentioned, whereas their hematological status is examined routinely. Therefore, the relationship between symptams and hematologic parameters among pregnant women was studied separately. The women were screened at about 30 weeks of gestation with blood examinations and a questionnaire. This time, moderate relationships were found: increased fatigue, calf cramps, palpitations and dizziness are indicators of low Hb and/or Ht-values. Because the relationship between symptoms and Hblevel is most clear in the presence of a higher Mean Cellular volume (MCV), a possible role of folic acid deficiency is suggested (chapter 8).

In two descriptive studies, the general practitioners' diagnostic conclusions in connection with unexplained fatigue and chestpain are established (chapters 9 and 10). In most cases of fatigue no diagnostic conclusion is reached, and this is the more so in younger patiens. Doubt about a cardiac origin of chestpain is a factor of importance, even half a year after first consultation. Both studies give an impression of the uncertainties general practitioners are dealing with in daily practice, and of the selection by referral.

Part III discusses and illustrates clinical decision analysis, again with a special interest into the relationship between primary care and specialist care. After a general introduction (chapter 11), it is stressed that in order to ( $r$ ) evaluate the selective function of the general practitioner, it is necessary to have a representative overview over the "four fold-table" of his clinical experience (chapter 12). By means of an example (palpable lymph node) it is made clear that optimal protocols may not be the same for general practitioners and specialists. Prior probabilities have a great impact (chapter 13). The significance of prior probabilities in general practice and the methods to estimate then are discussed. Registration systems have Iimitations, depending upon the type of symptom and disease of interest (chapter 14). Subjective estimations of prior probabilities by general practitioners and specialists may differ . Considering exactly the same case, i.c. a fatigue patient, in differential diagnosis internists give much weight to anemia and malignancy. General practitioners however think depression is the most likely diagnosis, 
followed by anemia. Furthermore, internists perform more diagnostic investigations (chapter 15). Also, between general practitioners (residents) considerable differences are observed: for a patient with weight loss the estimated probabilities of malignancy varied from 10 to 55:. Feeling, that scmething is "wrong", appears to be more related wth fear of somatic pathology, than with fear of functional problems (chapter 16 ).

Diagnostics are legitimated by their impact on managenient decisions in order to favour prognosis. Diagnostic investigations to establish the indication for an ineffective therapy are useless and redundant (chapter 17). In this connection we considered the question: is a asymptomatic carotid bruit a reason for further investigations to evaluate operability? Because randomized trials are lacking, the answer must be derived from published patient series. Using their results in a systematic fashion, we performed a clinical decision analysis. We coneluded, that an operative strategy is not supported by literature data (chapter 18 ).

Finally, attention is drawn to the need to distinguish between "testresults sec' and their interpretation in the light of prior information.

In part IV, the interpretation of diagnostic data is discussed more deeply. Different meanings of "normal' and 'abnormal' are associated with the aims of testing. Chapter 20 provides an overview. Bventually, the search for reference values leads to a decision analytic approach, taking into consideration the expected utilities of each possible outcome. Also, the performance of the test itself is included in the decision. In presenting reference values it is recommended to provide the whole distribution of test results in the compared populations, and not only the arbitarily chosen cut-off points. Discrimination of a test is sengitive to selection by referral patterns (chapter 21). Both prevalences and test characteristics are influenced. This notion is important, because the interest in test characteristics is growing presently, and the latter often are supposed to be constants.

Part V describes two studies concerning the prognostic significance of test results, i.c. hematological parameters. In a cohortstudy the 
relationships between $\mathrm{Hl}$ and $\mathrm{Ht}$ in pregmancy, and preterm birth and low birth weight respectively, were investigated (chapter 22). After adjustment for smoking, parity, bloodpressure and iron medication, a high hematocrit especially appears to be associated with an adverse outcome. In connection with the earlier described relationship between low Ht values and subjective symptons, we advise a reference range of the Ht from 32 to $38 \%$ during the hemodilution phase in pregnancy. chapter 23 describes a case-controlstudy in male workers to examine the relationship between moderately high Ho- and Ht-values and the occurrence of myocardial infarction. Positive relationships are found, also after adjustment for covariates.

In part VI the contents of this thesis are discussed in an integrant framework. A simple taxonomy of clinical epidemiologic studies is proposed. Recommendations are made with respect to diagnostic epidemiological research in general practice. 


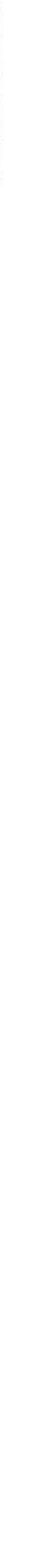


Dankwoord.

Aan de totstandkoming van de diverse onderdelen van dit proefschrift hebben enkele duizenden personen een bijarage geleverd. Daarmee is in de praktijk gebracht, dat epidemiolagie met grote groepen werkt. Dat gold in dit geval niet alleen voor hen die onderzocht werden $(n=5868)$, maar cok voor degenen die het onderzoek verrichtten ( $\geq 58$ ). Ten aanzien van hen allen spreek ik mijn erkentelijkheid ult. Dit dankwoord betreft behalve de medewerking zelf vooral ook de plezierige wijze warap deze gestalte $\mathrm{kreeg}$. Het is niet als afsluiting bedoeld: ik hoop dat er vamuit de opgebouwde contacten en ervaringen nog veel meer tot stand zal komen.

Een aantal personen wil ik op deze plaats in het bijzonder bedanken. om te beginnen, ben ik Prof.dr. Paul Knipschild en Prof.dr. Ferd Sturmans dankbaar voor het vertrouwen dat zij in mij hebben gesteld. Paul knipschild heeft mij geleerd dat het woor het doen van onderzoek nodig is om, sams pijnlijke, reducties aan te brengen, omdat ook hier geldt dat zachte heelmeesters stinkende wonden maken. Zijn wetenschappelijke creativiteit stond garant voor een aantal jaren van boeiende samenwerking. Paul, de wijze waarop je met mij in de theorie en de praktijk rond dit proefschrift bent gedoken, is voor mij van grote betekenis geweest.

Ferd sturmans heeft met zijn inspirerende publicaties mijn belangstelling voor het vak epldemiologie gewekt, reeds lang voordat onze paden elkaar kruisten. Hij heeft mij, en niet alleen mij, gebracht tot het belangrijke inzicht, dat vanuit de epidemiologie algenene begrippen als medicalisering en iatrogenesie geoperationaliseerd en gewogen kunnen worden in het kader van specifieke medische probleemstellingen. Ferd, bedankt voor de onmisbare steun en feed-back die ik van je kreeg.

In én adem met de zojuist genoemden wil ik Ir. Pieter Leffers dankzeggen. Pieter, alleen al door vier jaar je kamergenoot te zijn geweest heb ik zoveel van je opgestoken dat ik verwacht daarult nog gedurende een veelvoud van vier jaren te kunnen putten.

Een speciaal dankwoord wil ik uitgpreken ten aanzien van hen die aan onderdelen van dit proefschrift een bijzondere bijdrage hebben gelevera. 
Dr. Jan van Wersch, Arthur Sijstermanus, Ad Vissers, Richard Stamans en Jos Didderen hebben sleutelrollen vervuld in het onderzoek in Heerlense huisartspraktijken. Edzo Eboens en Phile covaert deden dat in het onderzoek, verricht in het kader van het Registratienet Huisartspraktijken. Van cruciaal belang in deze beide onderzoeken was de actieve deelname van de hulsartsen, waarvoor ik hen zeer erkentelijk ber.

Zonder de inzet van Luis Delgado, Truus Stenkens en Myra Pereboom en de steun van Frans Smits en Gerard Essed was het onderzoek bij zwangeren niet mogelijjk geweest. Speciale vermelding verdienen in dit verband de eersteli.jns-verloskundigen Mevrouw J.W.M. Heuts-verstraten, Zr. Bernardi Kok, Mevrouw A.C.M. Renkens-Gammans, en Mevrouw M. Lamkin. Zij hebben gedurende enkele manden zelfs hun wijze van bloedafname afgestemd op de behoeften van het onderzoek.

Met Gerard Swaen, Jos Slangen, John Durinck en Lex Volovics heb ilk met plezier samengewerkt aan het onderzoek naar de relatie tussen hemoglobinegehalte en myocardinfarct.

Annette Boenink en Paul de Vos wil. ik bedanken voor hun in dit proefschrift geëtaleerde werkzaamheden in het kader van hun student-assistentschap.

Piet Kerkhof heeft de data van het Diagnostisch Centrum Maastricht ter beschikking gesteld en bewerkt. Dr. Jan Broekman, Dr. Jan Lodder en Dr. Herman Muller hebben wezenlijke bijaragen geleverd aan hoofdstukken in dit proefschrift.

Riny Bodifée, Fhia Breevoort en Thum Aarts hebben de totstanakoming van het proefschrift letterlijk begeleid. Dit moet een niet geringe opgave zijn geweest, en an daarvoor te danken schieten woorden te kort.

Hartelijke dank ben ik ook verschuldigd aan Trudie Seegers en Jim Tatipata, die mij in de laatste fase geholpen hebben met de tekstverwerking en zich daarbij niet stoorden aan vreemde tijdstippen en pechduiveltjes.

Tenslotte ben ik Prof.dr. Cees de Geus en Prof.ar. Henk van der Velden zeer erkentelijk voor hun opbouwende commentaar bij de voorbereiding van dit proefschrift. 
Curriculum vitae.

Johamnes Andreas Knottnerus werd op 4 september 1951 geboren te NieuwBeerta. In 1969 behaalde hij het eindexamen gymasium bèta aan het Baarnsch Lyceum, waarna hij geneeskumde studeerde aan de vrije Universiteit te Amsterdam. Na het artsexamen in 1977, volgde hij aan dezelfde instelling de huisartsopleiding. Vervolgens was hij in Amsterdam werkzaam als huisarts en als wetenschappelijk medewerker aan het Huisartsen Instituut van de Vrije Universiteit. Sinds 1982 is hij verbonden aan de Rijksuniversiteit Limburg, aanvankelijk als wetenschappe1ijk medewerker bij de capaciteitsgroep Epidemiologie, en vanaf medio 1986 als universitair docent bij de vakgroep Huisartsgeneeskunde. 